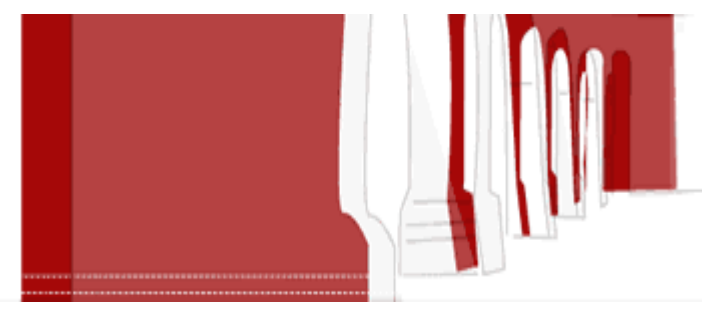

FLÁVIO DA COSTA HIGA

\title{
A PERDA DE UMA CHANCE NO DIREITO DO TRABALHO
}

\author{
DISSERTAÇÃO DE MESTRADO \\ EM DIREITO DO TRABALHO
}

ORIENTADOR PROF. DR. ESTÊVÃO MALLET

UNIVERSIDADE DE SÃO PAULO

FACULDADE DE DIREITO

$$
\text { SÃO PAULO - SP }
$$


Faculdade de Direito

Universidade de São Paulo

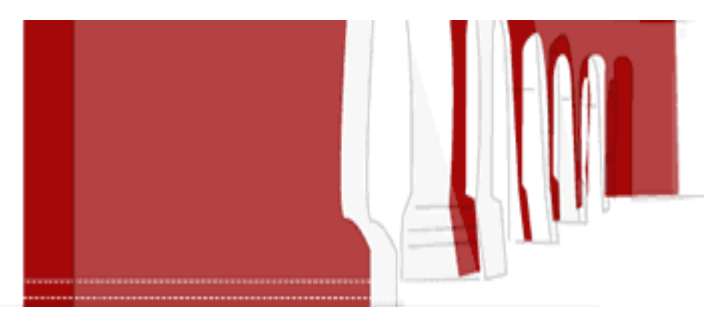

\author{
FLÁVIO DA COSTA HIGA
}

\title{
A PERDA DE UMA CHANCE NO DIREITO DO TRABALHO
}

Dissertação apresentada à

Faculdade de Direito da Universidade de São Paulo para obtenção do título de Mestre em Direito do Trabalho, sob orientação do Professor Estêvão Mallet.

UNIVERSIDADE DE SÃO PAULO

FACULDADE DE DIREITO

SÃO PAULO - SP 
Ao meu filho, Luiz Fernando da Costa Higa, in memoriam, por me consentir um amor genuinamente incondicional, e a eterna saudade por uma partida tão dolorosa... Perder um filho é achar a morte antes de ser achado por ela.

Às crianças do "Lar da Vovó Miloca", pelo regozijo de ser "um pouco pai de muitos", e o espanto diante de pais biológicos que desprezam, desumanizam e seviciam a dádiva da paternidade. 


\section{AGRADECIMENTOS}

Quando comecei a escrever este trabalho, achei que era algo que eu não conseguiria fazer sozinho. Muito antes de terminá-lo, essa impressão já havia se transformado em certeza! Jamais o teria concluído se muitas pessoas não tivessem conspirado para isso. As mais variadas e inesperadas ajudas me socorreram em momentos tão decisivos que, ao recordá-los, agora, sinto uma espécie de catarse pela lembrança do espírito solidário do ser humano.

Cometi vários equívocos durante a pesquisa. $\mathrm{O}$ maior deles, sem dúvida, foi não ter procedido ao fichamento das leituras. Quando escrevia, recordava ter lido nalgum tempo e nalgum lugar, algo que se encaixava perfeitamente àquele contexto, mas contava apenas com reminiscências para tentar resgatá-lo. Essa lembrança me vem à mente, nesse momento, por ter perpetrado idêntica falha em relação às pessoas que passaram pela minha vida para me auxiliar. Deveria ter gravado seus nomes na pedra, para não cometer o pecado da ingratidão.

Sem embargo, mesmo correndo o grave risco de ser traído pela memória, agradeço às seguintes pessoas que, em ordem mais ou menos cronológica, foram fundamentais nesta empreitada:

Ao meu pai, Fernando Shiguenari Higa, por todo legado de valores que me faz ser quem sou.

Ao jurista Júlio César Bebber, grande amigo e incentivador deste projeto, e o primeiro a acreditar e a insistir comigo que ele era viável.

Ao advogado Gustawo Adolpho de Lima Tolentino, por ter me acompanhado no dificílimo momento de realização da primeira prova, e à sua esposa Thaís de Matos Buffa Tolentino, pela compreensão e generosidade. Nos últimos 27 anos, muita coisa mudou em minha vida, mas não essa amizade.

Ao desembargador Amaury Rodrigues Pinto Junior, presidente da Escola Judicial do Egrégio Tribunal Regional do Trabalho da $24^{\mathrm{a}}$ Região, raro entusiasta do sucesso alheio, por ter abraçado a minha causa, desde o início, como se sua fosse.

À acadêmica de direito Maria de Fátima da Silva Sene, por tão bem cuidar da minha casa enquanto luta pela sua entrada no mundo jurídico.

Ao Tribunal Regional do Trabalho da $24^{\text {a }}$ Região, na pessoa dos desembargadores Abdalla Jallad, João de Deus Gomes de Souza, André Luís Moraes de Oliveira, Nicanor de Araújo Lima, Amaury Rodrigues Pinto Junior, Ricardo Geraldo Monteiro Zandona, Marcio Vasques Thibau de Almeida e Francisco das Chagas Lima Filho, por acreditarem no valor da educação e me proporcionarem tão grandiosa oportunidade. O mundo passou e vem passando, com algumas oscilações, de um período de discriminação ao universo acadêmico, para um período de tolerência e, finalmente, de valorização. Nesse ponto, orgulha-me dizer que o Regional de Mato Grosso do Sul compõe a gloriosa vanguarda.

Ao servidor Gilson do Espírito Santo, da Corregedoria do Tribunal Regional do Trabalho da $24^{a}$ Região, pelo apoio e torcida sem alarde, sempre com seu jeito discreto e circunspecto, mas muito persuasivo. 
À Faculdade de Direito da Universidade de São Paulo, por proporcionar e: gratuito e de qualidade a todos os que passam pelo rigoroso crivo das provas e entrev O Brasil é que ainda precisa melhorar para que todos disputem, em condiçõ $\epsilon$ igualdade, o acesso a esse espaço de excelência.

Ao professor Estêvão Mallet, dileto orientador e amigo, de cultura jurídica demasiadamente ululante para que eu diga algo de novo. Estar em sua companhia me proporciona a agradável sensação de estar sempre aprendendo. Do ser humano generoso e solidário talvez o grande público conheça um pouco menos. Desde o início, senti-me recompensado por saber que a uma inteligência tão aguçada unia-se uma alma igualmente boa. E o meu objetivo, como orientando, foi fazer jus à gigantesca oportunidade e escrever algo que não o envergonhasse. O tempo dirá se consegui ou não.

À advogada Olinda Mallet, pessoa doce e afável, de múltiplas habilidades, que tão bem nos recebeu (a mim e a Patrícia) em sua casa e em seu escritório. A ela devo a enorme honraria de "palestrar" sobre o tema em seu escritório, o que foi, sem dúvida, o "pontapé inicial" para os escritos que culminaram nessa dissertação.

À advogada Iasmin Hedel Fayad, assessora jurídica do escritório "Mallet Advogados Associados S/C", pelas preciosas dicas, a interlocução com o Professor e o apoio durante todo o curso, com o mais sincero desejo de sucesso no novo rumo de sua carreira.

Aos advogados do escritório "Mallet Advogados Associados S/C", pelo carinho com que ouviram minhas primeiras impressões sobre o tema, quando tudo não passava de algumas ideias esparsas que germinavam em minha cabeça, bem como pelas sugestões que me deram de forma extremamente polida. Entre eles, destaco o Dr. Marcos Guilherme Cicarino Fantinato, pela calorosa hospitalidade no escritório, e o Dr. Mauricio Pessoa, pelo seu livro, pela "carona" até o Aeroporto de Guarulhos/SP, e por uma frase que até hoje ecoa em minha mente: "Uma obra nunca acaba, apenas vence o prazo de entrega".

Ao juiz Wilson Ricardo Buquetti Pirotta, caro colega de pós-graduação e de orientação, por ter sido o meu guia nos primeiros passos do mestrado. Devo a ele, além de muitas caronas durante um semestre de aulas, os conselhos que me acalmaram em relação à grandiosidade da USP e me ensinaram a compreender como eu seria capaz de enfrentar a missão.

Ao pesquisador Daniel Amaral Carnaúba, pela incomensurável ajuda em toda a pesquisa. Sua contribuição foi uma dessas coisas inacreditáveis que acontecem na vida: nos primeiros dias de aula, descobri que ele havia feito mestrado sobre perda de uma chance na Universidade de Paris I - Panthéon-Sorbonne. Seguiu-se, então, uma sucessão das mais variadas espécies de apoio em pesquisa, cessão de material, interpretação de textos, leitura dos originais e tudo o que eu jamais esperaria que alguém, nessa condição, fizesse por mim.

Ao advogado Vitor Greijal Sardas, o McGiver da pesquisa jurídica, destacado processualista que foi uma espécie de última instância em minhas investigações, teimosia inigualável, sempre encontrando luz onde só se viam trevas.

Ao assessor de ministro Fernando Mil Homens Moreira, pela valiosa ajuda ..... pesquisas e pelo material fornecido.

Ao advogado Luis Fernando Pereira Franchini, por abastecer-me constantemente com decisões e notícias sobre o tema. Graças a ele, descobri, por exemplo, que podia me cadastrar, grauitamente, no site da Corte de Cassação francesa, e receber boletins quinzenais de jurisprudência, além de ter acesso a todo o banco de dados daquela Corte desde 1995.

Ao advogado Jorge Cavalcanti Boucinhas Filho (vulgo Eduardo), pessoa de generosidade ímpar, que me ajudou com acórdãos, textos jornalísticos, dicas e ainda me presenteou com a sua obra, um livro sobre o tema e o seu artigo sobre perda de uma 
chance. De tudo o que ele me fez, o mais marcante foi a elegâcia por eu tê-lo chamado, sabe-se lá porque, durante um semestre inteiro, de "Eduardo", e ele, elegantemente, nunca ter denunciado a minha gafe e ainda ter atendido, solicitamente, pela alcunha que eu o havia rebatizado.

Aos parceiros de luta do "Lar da Vovó Miloca", Antônio João Hugo Rodrigues e Mariléa Abreu de Medeiros, pela gentileza e compreensão na cessão do cobiçado vídeo do "Show do Milhão". No mesmo propósito, aos Srs. Paulo Vander e Jorge Zeraldi, pela edição e direção do material, respectivamente.

Ao professor Bruno Freire e Silva, pela especial atenção dedicada durante o cumprimento dos créditos e pelo seu livro.

Ao procurador do estado Fábio Jun Capucho, pela companhia durante todo o segundo semestre de 2010, a parceria nos seminários e o compartilhamento de material de pesquisa.

À biblioteconomista do TRT da 24a Região Gilza Núria Brandão Marroni, pelo inestimável apoio em toda a pesquisa, principalmente na "aventura" que foi a busca pelas sentenças da Corte de Cassação italiana. Alegra-me saber que o tribunal onde presto jurisdição possui, ao mesmo tempo, ferramentas eletrônicas eficazes e uma servidora competente e sempre disposta a ajudar.

Ao juiz Leonardo Ely, presidente da AMATRA-24, pelo contato com a AMATRA-4, para a localização dos primeiros processos brasileiros sobre o tema.

Ao juiz Marcos Fagundes Salomão, presidente da AMATRA-4, pelo auxílio perante o TJ/RS para a obtenção de acórdãos.

À servidora Luciane Baratto Adolfo, arquivista judicial do Egrégio Tribunal de Justiça do Estado do Rio Grande do Sul, pela eficiência e presteza na localização, digitalização e envio dos primeiros processos de um tribunal brasileiro sobre a perda de uma chance.

Ao assessor de desembargador Fabrício Felini, parte da minha família, pela ajuda na pesquisa de artigos científicos na biblioteca do Tribunal de Justiça do Estado de Mato Grosso do Sul.

À juíza Déa Marisa Brandão Cubel Yules, querida amiga, pela leitura dos originais e as pertinentes críticas e sugestões feitas ao meu trabalho.

Aos servidores da Vara do Trabalho de Coxim/MS: Claudia Gisele Vilela Marques, Diretora de Secretaria; Nildo Jesus de Souza, Adjunto de Diretor; Julieta Pereira Mendes dos Reis, Assistente de Juiz; Marco Antônio Pereira de Lucena, Oficial de Justiça; Cleber Gomes Rosa, Secretário de Audiência; Marlene dos Santos Ferreira, Secretária Especializada; Vitor Anunciação Campos, Secretário Especializado; Silvana de Freitas Aguilar, Secretária Especializada, por formarem uma equipe tão fantástica que funciona muito bem comigo, sem mim ou apesar de mim.

Aos juízes Bóris Luiz Cardozo de Souza e Alcir Kenupp Cunha, por terem momentos distintos, assumido, com destaque, a titularidade da Vara do Trabalh. ... Coxim/MS, o que redobra minha responsabilidade no retorno à jurisdição.

Aos Professores Homero Batista Mateus da Silva e Ari Possidônio Beltran, pelas sugestões de aperfeiçoamento dadas na Banca de Qualificação. Ao Professor Homero, devo, ainda, os vários apontamentos que sucederam à sessão qualificatória, e a proposta, acolhida à unanimidade pelos demais membros da Banca, de uma inigualável distinção para este modesto estudo: a oportunidade de convertê-lo em doutorado direto.

À advogada Biannka Jabrayan Schmidt, pelo incansável auxílio na revisão ortográfica e gramatical, adequação às normas da ABNT, leitura dos originais, sugestões e vasta pesquisa jurisprudencial. 
À servidora Helenrose Coelho, da Seção de Jurisprudência do Tribunal Regional do Trabalho da $24^{a}$ Região, pelo apoio para conseguir decisões sobre o tema em alguns regionais cujos sítios eletrônicos não apontavam resultados.

Ao servidor Carlos Mariano de Sousa Rocha Filho, chefe do setor de Acórdão e Jurisprudência do TRT da $22^{\mathrm{a}}$ Região, pela pesquisa de acórdãos em seu tribunal.

Ao servidor Silas Rodrigues de Lima, do Setor de Documentação do Tribunal Regional do Trabalho da $24^{\mathrm{a}}$ Região, pelo envio de material jurisprudencial. 


\section{RESUMO}

A responsabilidade civil vem sofrendo constante evolução no sentido de aumentar o campo de reparação do dano injusto, o que provocou uma ruptura paradigmática em seus pressupostos, centrando suas preocupações na indenização à vítima. Nesse contexto, vem ganhando relevo a teoria da "perda de uma chance", consistente na possibilidade de reparar o dano causado pela privação da oportunidade de obter um benefício ou de evitar um prejuízo.

Outrora irreparável, por ser considerado um prejuízo meramente hipotético, a chance passou a ser reputada, pela jurisprudência, uma entidade própria, substantiva em si mesma, e dotada de valor econômico. O Direito modificou a maneira de interagir com a álea, antes, repelindo-a, e, agora, absorvendo-a e levando-a em consideração no julgamento.

O trabalho, uma das maiores fontes de afirmação e expressão da cidadania, também merece uma tutela especial, de modo a resguardar os princípios constitucionais da "dignidade da pessoa humana", do "valor social do trabalho" e da "livre iniciativa". Diante disso, não há como o Direito do Trabalho ficar alijado da doutrina das oportunidades perdidas, pois ambos os sujeitos da relação capital e trabalho podem sofrer essa modalidade de ofensa, cuja reparação se impõe como conquista sintomática da evolução social.

Portanto, a análise da imbricação epistemológica entre esses dois fenômenos - a "perda de uma chance" e o "Direito do Trabalho" -, com a explicação dos seus condicionamentos, a sistematização das suas relações, o esclarecimento dos seus vínculos, e a avaliação dos seus resultados e aplicações, constitui o objeto desse estudo, cuja importância se revela, desde logo, a partir do acentuado descompasso entre o atual estado de ebulição jurisprudencial que o tema experimenta e a absoluta escassez de material doutrinário específico.

Palavras-chave: Responsabilidade civil. Perda de uma chance. Direito do Trabalho. Ato ilícito. Dano. Nexo causal. 


\begin{abstract}
Tort liability has been in constant evolution by way of increasing the field of unfair damage recovery, which has caused a paradigmatic breach in its presupposition, centralizing on its concern for the indemnity of the victim. In this context, the "loss-of-achance-doctrine" has been gaining importance. This theory consists of the possibility of repairing the damage caused by the privation of the opportunity to obtain a benefit or avoid a loss.

Formerly irreparable for being considered merely a hypothetical loss, the chance became reputed by jurisprudence, a personal entity, substantive in itself and endowed with economic value. The law changed the way of interacting with the alea, formerly repelling it, and now, absorbing it and taking it into consideration in the trial.

The labor, one of the greatest sources of affirmation and expression of the citizen, also deserves special defense so as to protect the constitutional principles of the "dignity of the human being", " the social value of labor" and "free initiative". Thus, there is no way for the Labor Law to be disabled of the doctrine of lost opportunities, because both subjects of the capital and labor relation can suffer this modality of injury, whose reparation instills itself as a symptomatic conquest of the social evolution.

Therefore, an analysis of the epistemological imbrications between these two phenomena - the "loss-of-a-chance" and the "Labor Law" -, with the explanation of their contingents, and the systemization of their relations, the enlightenment of their bonds, and the evaluation of their results and applications, constitute the objective of this study, whose importance is revealed, as of now, from the accentuated disorder between the current state of ebullient jurisprudence that the theme has been undergoing and the absolute scarcity of specific doctrinal material.
\end{abstract}

Key words: Tort liability. Loss-of-a-chance. Labor law. Tort. Damage. Causation. 


\section{SUMÁRIO}

\section{CAPÍTULO 1 - ESCORÇO HISTÓRICO}

1.1 As primeiras manifestações na França do início do século XX................... 17

1.1.1 O julgamento citado pelos irmãos Mazeaud (1889)................................. 18

1.1.2 O primeiro caso na Corte de Cassação da França (1932).......................... 23

1.2 O leading case no direito britânico (1911) ................................................. 33

1.3 O primeiro caso na Corte de Cassação Italiana (1983) ................................ 35

$1.4 O$ primeiro caso em um Tribunal Brasileiro (1991) .................................. 46

1.4.1 A sinalização ambígua do STJ (1990)................................................. 53

\section{CAPÍTULO 2 - NOÇÕES PROPEDÊUTICAS}

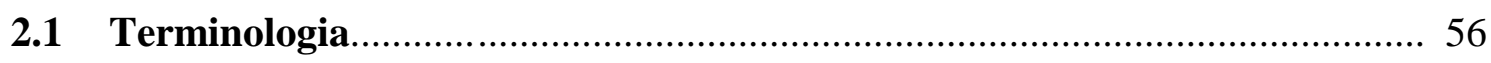

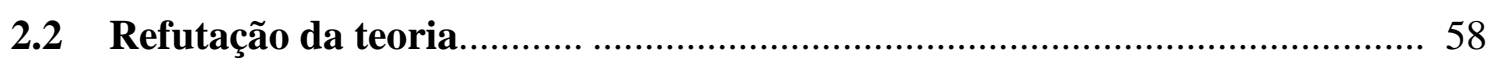

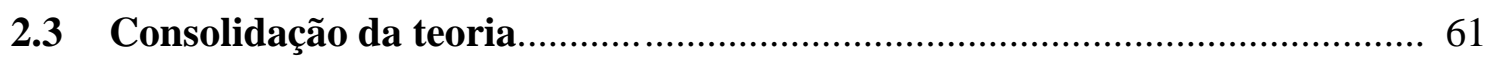

$2.4 O$ paradoxo de direito - “A certeza do incerto".........................................6 64

2.5 Perda de uma chance e figuras afins........................................................6. 67

2.5.1 Distinção entre perda de uma chance e lucros cessantes ......................... 67

2.5.2 Distinção entre perda de uma chance e a condição maliciosamente obstada pela parte a quem desfavorecer ...................................................... 72

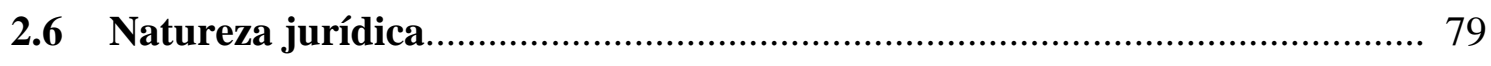

2.7 Requisitos para o reconhecimento de um dano reparável: realidade e

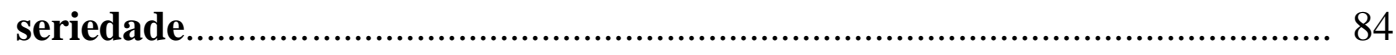

2.7.1 A expressão da seriedade em termos percentuais ................................. 87

2.7.2 A medida da seriedade pela lógica hegeliana ......................................... 92

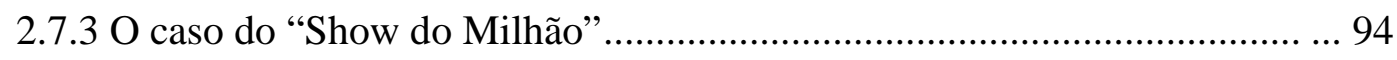

2.8 Fundamento da perda de uma chance...................................................... 105

2.8.1 Perda de uma chance na responsabilidade contratual ............................ 110

2.8.2 Perda de uma chance na responsabilidade extracontratual ..................... 113

2.8.3 Abordagem norte-americana da perda de uma chance.............................115 


\section{CAPÍTULO 3 - DANOS E REPARAÇÃO NA PERDA DE UMA CHANCE}

3.1 Modalidades de danos decorrentes da perda de uma chance.................... 124

3.1.1 Possibilidade de cumulação e/ou isolamento dos danos .......................... 124

3.1.2 O Caso "Vanderlei Cordeiro de Lima" ................................................ 127

3.2 Reparação parcial ou integral?........................................................ 133

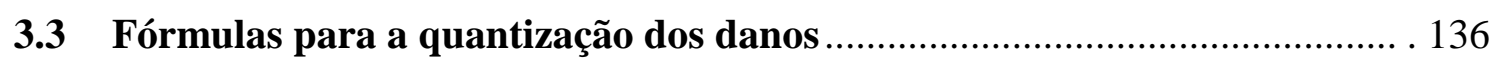

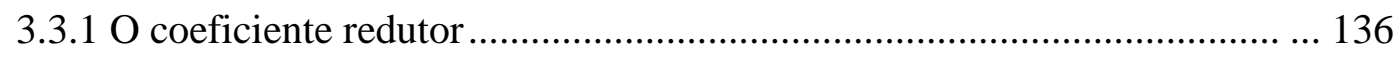

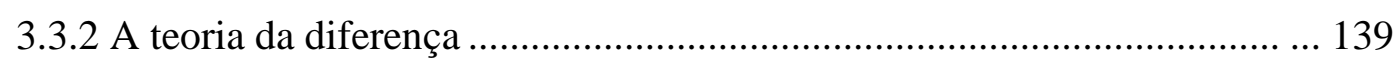

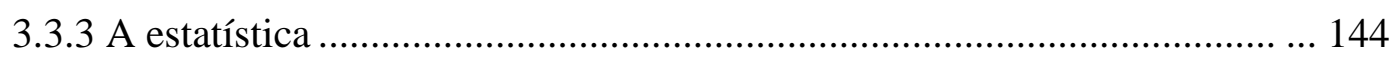

3.3.4 A equidade na acepção aristotélica ................................................. 151

\section{CAPÍTULO 4 - CLASSIFICAÇÕES DA PERDA DE UMA CHANCE}

4.1 As diversas propostas doutrinárias ........................................................ 165

4.2 Perda de uma chance "típica" e "atípica" .............................................. 171

4.3 Ruptura do conceito de causalidade ou uso da causalidade parcial?.......... 179

\section{CAPÍTULO 5 - A PERDA DE UMA CHANCE NO DIREITO DO TRABALHO}

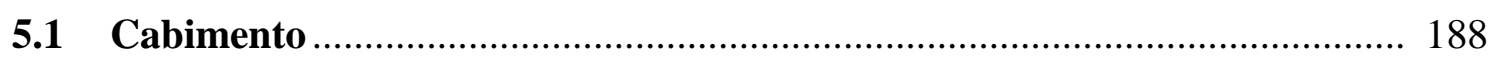

5.2 Omissão e compatibilidade da CLT ….................................................... 192

5.3 A perda de uma chance como "uma via de mão dupla"............................ . 196

5.4 Jurisprudência e Direito do Trabalho …................................................... 203

5.5 Panorama da jurisprudência trabalhista ................................................. 205

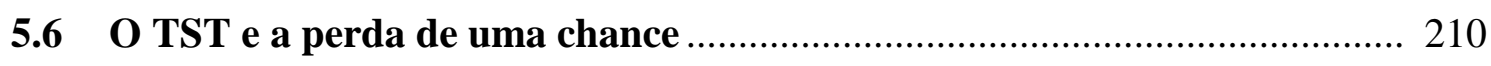

5.7 Perda de uma chance nas diversas fases ............................................... 217

5.7.1 Perda de uma chance pré-contratual................................................... 217

5.7.2 Perda de uma chance contratual ...................................................... 226

5.7.3 Perda de uma chance pós-contratual ................................................. 240 
CONCLUSÃO.

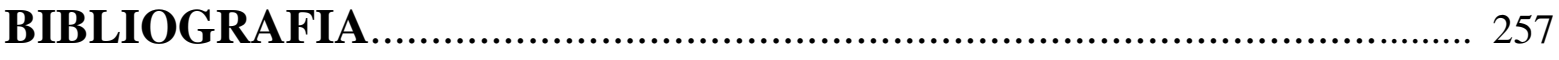

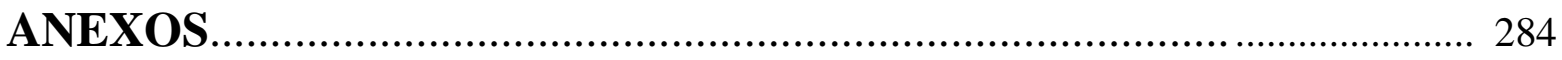




\title{
INTRODUÇÃO
}

\begin{abstract}
"Todo dia é uma chance: De retomar os bons hábitos. De perdoar erros alheios. De absolver suas próprias culpas. De derrubar preconceitos. De ampliar seus valores. De amar sem pudores. De viver sem rancores. De aliviar tantas dores. De esquecer dissabores. De levar conforto a quem sofre. De minimizar misérias alheias. De alimentar bocas famintas. De ouvir amigos infelizes. De ajudar parentes distantes. De levar alegria abundante. Mais rápido que puder sem demora. Para ser mão amiga e bondosa. Que ampara, cura e labora. Para alívio do sofrimento de quem chora" ${ }^{\text {. }}$
\end{abstract}

A idílica visão transcrita no poema acima revela como a vida cotidiana é pródiga em oportunidades de empreender mudanças ou simplesmente manter a ordem das coisas.

Aliás, em nossa cultura judaico-cristã, predomina a ideia de livre arbítrio, referindose principalmente às ações e à vontade humana, e com o significado de que o homem é dotado do poder de, em determinadas circunstâncias, agir sem motivos ou finalidades diferentes da própria ação ${ }^{2}$, ou seja, a vida não segue um curso predeterminado justamente porque o ser humano detém o poder da escolha. A ideia de chance ou oportunidade está, em certo modo, ligada à possibilidade de decidir a própria sorte.

Conta o Livro Sagrado das religiões abraâmicas que Adão e Eva viviam de um modo puramente extrativista no Jardim do Éden, tendo o primeiro, todavia, recebido um comando divinamente emanado, nos seguintes termos: "Coma livremente de qualquer árvore do jardim, mas não coma da árvore do conhecimento do bem e do mal, porque no dia em que dela comer, certamente você morrerá"3.

Portanto, dentro da concepção libertária, na qual está culturalmente inserido o homem desde a criação, Adão e Eva optaram por violar o mandamento que lhes fora imposto, e, com isso, toda a humanidade "perdeu a chance" da vida eterna no paraíso, haja

\footnotetext{
${ }^{1}$ FITTIPALDI, Conceição. Chances. Disponível em <http://poemasencantos.blogspot.com/ 2007/07/chances.html>. Acesso em: 8 set. 2010.

${ }^{2}$ FERREIRA, Aurélio Buarque de Holanda. Novo Dicionário Eletrônico Versão 5.0. Correspondente à 3 ed. $1^{\text {a }}$. impressão da Editora Positivo, rev. e atual. do Aurélio Século XXI, O Dicionário da Língua Portuguesa, 2004. 1 CD-ROM.

${ }^{3}$ GÊNESIS, 1, 16/17. In: Bíblia Sagrada: nova versão internacional. Trad. Sociedade Bíblica Internacional. São Paulo: Vida, 2000, p. 2.
} 
vista uma das sanções aplicadas ter sido, justamente, a expulsão do Jardim do Éden, impossibilitando a ingestão do fruto da vida ${ }^{4}$.

Sob o prisma filosófico do existencialismo ateu, Sartre também foi veemente ao afirmar que a liberdade é condição ontológica do ser humano, ao asserir que: "assim, não teremos nem atrás de nós, nem na nossa frente, no reino luminoso dos valores, nenhuma justificativa e nenhuma desculpa. Estamos sós, sem desculpas. É o que posso expressar dizendo que o homem está condenado a ser livre",5.

Transpondo tal questão para o mundo jurídico, despido de molduras quiméricas ou, ainda, evidentemente, de conteúdo teísta - até porque incompatível com um trabalho científico, elaborado sob a concepção laica de Estado (CF, art. 19, I) ${ }^{6}$-, são diversas as situações da vida em que alguém, "em razão de ato ilícito praticado por outrem, pode ficar privado da oportunidade de obter determinada vantagem ou então, de evitar um prejuízo",7.

Isabelle Vacarie observa que paralelamente à integração da chance no campo jurídico houve uma retração do papel da "vontade" no direito das obrigações, por conta da antinomia entre os conceitos de "chance" e "vontade": a "chance" exclui a "vontade", e a "vontade" marca a fronteira da "chance"

É exatamente aí que o direito atua no campo da responsabilidade civil: quando a atuação omissiva ou comissiva de alguém nos impede de bem cumprir nossa "sentença de liberdade", privando-nos de usufruir nossas escolhas, impedindo-nos de fazê-las ${ }^{9}$ ou, até mesmo, contrariando as que foram feitas.

\footnotetext{
4 "Então disse o SENHOR Deus: 'Agora o homem se tornou como um de nós, conhecendo o bem e o mal. Não se deve, pois, permitir que ele tome também do fruto da árvore da vida e o coma, e viva para sempre.' Por isso o SENHOR Deus o mandou embora do Jardim do Éden para cultivar o solo do qual fora tirado. Depois de expulsar o homem, colocou a leste do Jardim do Éden querubins e uma espada flamejante que se movia, guardando o caminho para a árvore da vida". (Idem, 3, 22/24, p. 3)

${ }^{5}$ SARTRE, Jean-Paul. O existencialismo é um humanismo: a imaginação - questão de método. Seleção de textos de José Américo Motta Pessanha. Trad. Rita Correia Gudes e Luiz Roberto Salinas Forte. 3. ed. São Paulo: Nova Cultura, 1987, p. 9.

${ }^{6}$ BRASIL. Constituição (1988). Constituição da República Federativa do Brasil. 16. ed. São Paulo: RT, 2011.

${ }^{7}$ MELO, Raimundo Simão de. Indenização pela perda de uma chance. Disponível em: < http://www.boletimjuridico.com.br/doutrina/texto.asp?id=1785>. Acesso em: 28 out. 2010.

${ }^{8}$ No original: "Et on observe parallèlement à l'integration de la chance dans le champ juridique un rétrécissement du role de la volonté dans le droit des obligations. Ce mouvement contraire s'explique par l'antinomie de chance et de la volonté: la chance exclut la volonté, la volonté marque la frontière de la chance. Les solutions juridiques traduisent cette opposition". (VACARIE, Isabelle. La perte d'une chance. Revue de la recherche juridique. Droit Prospective, Paris, vol. 3, p. 904-932, 1987, p. 906-907)

${ }^{9}$ Aqui muito bem se encaixaria, dentro da classificação proposta por Fernando Noronha, o que ele denomina de "perda de uma chance por falta de informação": "A segunda modalidade relativa a danos presentes, em que falaremos em perda de uma chance por falta de informação, diz respeito à frustração da oportunidade de
} 
Na proposição trazida à baila, a pessoa fica tolhida de alternativa de otimização das suas possibilidades - realizando vantagens ou evitando prejuízos ${ }^{10}$-, seja porque o curso natural dos acontecimentos foi interrompido por fator externo, alheio à sua vontade, impossibilitando a verificação do evento vantajoso em seu favor; ou, ainda, porque deixou de ser interrompido quando havia uma possibilidade de fazê-lo antes de consumado o evento danoso.

A esse fenômeno, a doutrina pátria atribuiu o nome de "perda de uma chance", fortemente influenciada pelo instituto francês de idêntica nomenclatura ("perte d'une chance”), que, há bastante tempo, vem sendo debatido em domínios alienígenas, mas que, somente nas duas últimas décadas, passou a ser enfrentado no Brasil ${ }^{11}$. Hodiernamente, o tema encontra-se em estágio de verdadeira efervescência.

A toda evidência, o mundo do trabalho, onde as pessoas passam a maior parte do seu tempo, não teria como ficar alijado da ocorrência de privações de oportunidades e de suas consequentes repercussões na seara da responsabilidade civil ${ }^{12}$.

Reforçando esta convicção, Geneviève Viney, já em 1982, foi categórica ao afirmar que, na França, os julgados relacionados à questão profissional eram os mais numerosos, e ainda incluiu outras hipóteses dentro da relação de trabalho lato sensu, que podiam ensejar a aplicação da teoria:

tomar uma decisão esclarecida, devido a ter havido a quebra de um dever de informar, que recaía sobre outra pessoa. Acontece quando alguém sofre um determinado dano por não ter tomado a melhor decisão, que estaria ao seu alcance se outra pessoa tivesse cumprido o dever, que incidia sobre ela, de informar ou aconselhar. São casos em que uma decisão mais esclarecida, a ser tomada pelo próprio lesado, poderia eliminar o risco de este sofrer o dano, ou pelo menos poderia reduzi-lo". (NORONHA, Fernando. Responsabilidade por perda de chances. Revista de Direito Privado, São Paulo, v. 6, n. 23, p. 29-46, jul./set. 2005, p. 32)

${ }^{10}$ Silvia Mota fornece um conceito mais restrito de chance, ligando-a somente à possibilidade de obter um ganho futuro: "A chance é a possibilidade de um benefício futuro provável integrada nas faculdades de atuação do sujeito, considerando um dano ainda quando possa resultar dificultoso estimar seu alcance. Nesta concorrência de fatores passados e futuros, necessários e contingentes, existe uma consequência atual e certa”. (MOTA, Sílvia. Responsabilidade civil decorrente das manipulações genéticas: novo paradigma jurídico ao fulgor do biodireito. 2005. Tese (Doutorado) - Universidade Gama Filho, Rio de Janeiro, 2005)

${ }^{11}$ De acordo com Rafael Peteffi da Silva, o precursor na aplicação da teoria foi o Tribunal de Justiça do Rio Grande do Sul, com alguns julgados da lavra do então desembargador Ruy Rosado de Aguiar Júnior. (SILVA, Rafael Pateffi da. Responsabilidade Civil Pela Perda de Uma Chance. 2. ed. São Paulo: Editora Atlas, 2009, p. 194)

${ }^{12}$ Da doutrina especializada colhe-se: "Sendo certo que o padrão da jornada de trabalho do brasileiro é de oito horas diárias e quarenta e quatro semanais e que se recomenda que os adultos durmam oito horas por dia, devendo as últimas oito horas ser utilizadas para as mais diversas atividades como deslocamento, refeições, lazer e asseio pessoal, resta inquestionável que o que consome a maior parte da vida de um adulto é a sua atividade profissional. É natural, portanto, que inúmeros danos sejam ocasionados no contexto das relações de trabalho". (BOUCINHAS FILHO, Jorge Cavalcanti. Aplicação da Teoria da Responsabilidade Civil por Perda de uma Chance às Relações de Trabalho. Revista Justiça do Trabalho, Porto Alegre, ano 27, n. 318, p. 25-33, jun. 2010, p. 26) 
Mais c'est certainement à propos de la perte d'une chance de réussite professionnelle que les arrêts sont les plus nombreux. Les tribunaux ont en effet eu l'occasion d'affirmer que la perte de la possibilité de se présenter à un examen ou à un concours est un dommage susceptible de réparation ainsi que la perte de l'espoir d'entreprendre une activité rémunérée ou d'embrasser une carrière déterminée. Et de très nombreuses décisions ont admis qu'en cas d'accident la perte d'un espoir de promotion professionnelle ou de la possibilité de prendre un emploi plus lucratif ou d'entendre l'exploitation existante doit entrer dans le calcul de l'indemnisation due à la victime.

Dans la même ligne, on peut encore signaler que la perte de l'espoir de conclure un ou plusiers contrats dont la victime attendait un profit ou un avantage quelconque a été considérée comme susceptible de fonder une action en responsabilité de même que la perte de l'espoir de voir se poursuivre l'exécution d'un contrat lucratif ou de profiter d'un avantage que, par suite d'une fausse information donnée au cours de la période précontractuelle, l'une des parties croyait avoir acquis ${ }^{13}$.

A partir de tais considerações é que se concebe o escopo do presente trabalho: entrelaçar esses dois fenômenos - a "perda de uma chance" e o "Direito do Trabalho", imbricados por questões epistemológicas -, tendo em vista a necessidade de explicar os seus condicionamentos, sistematizar as suas relações, esclarecer os seus vínculos, e avaliar os seus resultados e aplicações.

Há, indubitavelmente, terreno fecundo para que essa semente germine. A doutrina civilista pátria, por meio de precursores como Sérgio Novais Dias, Sérgio Savi e Rafael Peteffi da Silva, entre outros, vem moldando o arcabouço dogmático do qual têm se servido as Cortes ao prestar a tutela jurisdicional. Por sua vez, a jurisprudência trabalhista, ainda que de modo tímido, tem fornecido pistas dos matizes em que a teoria será acolhida no Brasil, mais especificamente no âmbito desta Justiça Especializada.

Assim, num processo contínuo de retroalimentação, a teoria vai sendo dialeticamente revista a partir de julgados que, por seu turno, constroem diretrizes decisórias segundo sólidas bases doutrinárias que são sopesadas à luz das particularidades dos casos concretos,

\footnotetext{
${ }^{13}$ VINEY, Gineviève. Traité de Droit Civil. Sous la direction de Jacques Ghestin. Les obligations. La responsabilité: conditions. Paris : LGDJ, 1982, p. 343-345.
} 
pois "se a jurisprudência é o canteiro de obras da responsabilidade civil, a doutrina é a arquiteta dessa construção. Tão inócua quanto uma doutrina divorciada do direito vivo tecido pelos Tribunais é aquela cingida à utilização dos julgados como 'enfeite', que, não raro, servem só para engordar o volume dos livros ${ }^{14,}$.

Ter-se-á, pois, o que Gustavo Tepedino denominou ser “[...] a rara confluência, da doutrina com a jurisprudência, para a construção do direito civil contemporâneo ${ }^{15, "}$.

${ }^{14}$ MARTINS-COSTA, Judith. Apresentação. In: SILVA, Rafael Peteffi da. Responsabilidade Civil pela Perda de uma Chance. 2 ed. São Paulo: 2009, Editora Atlas, p. XV.

15 TEPEDINO, Gustavo. O tão esperado (e fugaz?) encontro da doutrina com a jurisprudência. Revista trimestral de Direito Civil, Rio de Janeiro, v. 3, 2000, p. 4. 


\section{CAPÍTULO 1 - ESCORÇO HISTÓRICO}

\subsection{As primeiras manifestações na França do início do século XX}

Ao contrário do que deveras se escreveu ${ }^{16} 1718$ e ainda se escreve ${ }^{19}$, a França do final do século XIX era totalmente refratária à reparação das chances perdidas, já que aplicava, sempre, as regras mais estritas de reparação da responsabilidade civil, exigindo, invariavelmente, a prova da certeza do dano (resultado final favorável frustrado), o que, por óbvio, redundava na rejeição dos pleitos dessa estirpe.

Os irmãos Mazeaud, ao relacionarem decisões em que seria possível indenizar as chances perdidas, mencionaram o julgado de 1896, da Corte de Apelação de Limoges ${ }^{20}$, que tratava do pleito indenitário formulado por um proprietário de cavalos contra uma companhia de transportes, pelo fato de o animal não ter chegado a tempo de participar da corrida. O pedido, seguindo a linha do que decidido em primeira instância, fora rechaçado por não haver certeza de que o cavalo venceria o páreo ${ }^{21}$.

Henri Lalou também relacionou uma série de julgados nos quais as oportunidades perdidas deixaram de ser indenizadas ao argumento da incerteza ${ }^{22}$, desde o final do século XIX até a década de 1930. Foi essa, por exemplo, a razão que fez com que o Tribunal de Meaux, em 1920, julgasse improcedente o pedido formulado pelo pai de uma criança, morta em acidente, de reparação concernente ao amparo alimentar que o filho poderia lhe prestar quando atingisse a idade de adentrar ao mercado de trabalho ${ }^{23}$.

\footnotetext{
${ }^{16}$ VINEY, Gineviève; JOURDAIN, Patrice. Traité de Droit Civil. Sous la direction de Jacques Ghestin. Les conditions de la responsabilité. 3. ed. Paris : L.G.D.J, 2006, p. 9

${ }^{17}$ CHARTIER, Yves. La réparation du préjudice dans la responsabilité civile. Paris: Dalloz, 1983, p. 33.

18 BORÉ, Jacques. L'indemnisation pour les chances perdues : une forme d'appreciation quantitative de la causalite d'un fait dommageable. Juris Classeur Périodique - édition générale, Paris, S. I, n. $2620,1974$. Não paginado.

${ }^{19}$ SILVA, Rafael Pateffi da, op. cit., p. 10-11.

${ }^{20}$ MAZEAUD, Henri et Leon; TUNC, André. Traité Théorique et Pratique de la Responsabilité Civile. Délictuelle et Contractuelle. 5.ed. Paris: Éditions Montchrestien, 1958, tome.1, p. 276.

${ }^{21}$ CARNAÚBA. Daniel Amaral. La perte d'une chance. L'aléa et la technique. 2009. 117f. (Master 2 Recherche Droit privé général. Tutrice Mme le Professeur Muriel Fabre-Magnan) - Université de Paris I. Panthéon-Sorbonne. Faculté de Droit. 2009, p. 84-85.

${ }^{22}$ LALOU, Henri. La responsabilité civile: príncipes élémentaires et applications pratiques. 10. ed. Paris: Librairie Dalloz, 1932, p. 78.

${ }^{23}$ FRANÇA. Tribunal de Meaux, 29 jan. 1920. Recueil Dalloz, Paris, v. I, 1920, p. 137.
} 
1.1.1 O julgamento citado pelos irmãos Mazeaud ${ }^{24}(1889)$

Apesar da aversão histórica da jurisprudência francesa (até a década de 1930) ao reconhecimento do valor jurídico do interesse aleatório contido nas chances, há quase um consenso nos textos gauleses, e em parte da doutrina nacional que nela se inspira, que o protótipo da perda de uma chance nos pretórios foi um julgamento da "Chambre de Requêtes”, na França, datado de 17 de julho de 1889.

Em tal julgamento, a Corte, supostamente, teria aceitado conceder indenização a um indivíduo que, em decorrência da negligência profissional de um oficial ministerial $(\text { huissier })^{25}$, teve dizimadas as chances de êxito em uma demanda judicial.

Trata-se de um curioso vezo que se alastra impiedosamente como praga sobre a plantação. Geneviève Viney não só atribui a primogenitura a este julgamento, como também afirma que, a partir dele, a Corte de Cassação, em frequentes ocasiões, aprovou condenações pronunciadas sobre esse fundamento ${ }^{26}$. Yves Chartier seguiu a mesma trilha $^{27}$, a exemplo de Jacques Boré ${ }^{28}$.

No Brasil, Rafael Peteffi da Silva, estudioso da perda de uma chance à luz da doutrina francesa, assentou que, “já no século XIX, precisamente em 17 de julho de 1889, a Corte de Cassação francesa aceitara conferir indenização a um demandante pela atuação culposa de um oficial ministerial que extinguiu todas as possibilidades de a demanda

\footnotetext{
24 A íntegra do acórdão está no "anexo B" do presente trabalho.

25 A palavra "huissier" não possui uma tradução exata para a língua portuguesa, à míngua de função semelhante perante o Poder Judiciário brasileiro. Se, por um lado, ele se assemelha ao oficial de justiça, por deter o monopólio de certos atos oficiais, por outro, ele se parece com o advogado, por ser um profissional liberal contratado diretamente pelas partes, agindo em nome e por conta delas. Dessa peculiaridade decorre que as falhas por ele praticadas são imputadas a quem o contratou, e que, quando lesadas pelo "huissier", as partes têm o direito de pedir reparação diretamente a eles.

${ }^{26}$ Suas precisas palavras foram as seguintes: "L'exemple plus ancien est fourni par un arrêt du 17 juilliet 1889 qui a accepté d'indemniser la perte, provoquée par la faute d'un officier ministériel, de la possibilité de poursuivre une procédure et, par conséquent de gagner un procès. Or, depuis cet arrêt, la Cour de cassation a eu fréquemment l'occasion d'approuver des condamnations prononcées sur ce fondement." (VINEY, Gineviève; JOURDAIN, Patrice, op. cit., p. 91).

${ }^{27}$ Assim o fazendo: “C'est, par excellence, l'hypothèse classique: par la faute d'un de ses conseils ou d'un mandataire, un plaideur n'a pas pu salvegarder ses droits en justice. C'est aussi l'ypothèse la plus ancienne, puisqu'elle a été admise dès 1889 par la Chambre des Requêtes, et dès 1911 par la Chambre civile. Un huissier a signifié un acte d'appel nul, ou bien n'en e pás signifié du tout”. (CHARTIER, Yves, op. cit., p. 33)

28 “Dès 1889 la Chambre des Requêtes, dès 1911 la Chambre civil de la Cour de Cassation admettaient que la privation, par la faute d'un mandataire de justice, du droit d'introduire un recours, constitue un préjudice certain er actuel engageant la responsabilité contractuelle de ce mandataire”. (BORÉ, Jacques. op. cit.)
} 
lograr êxito, mediante o seu normal procedimento ${ }^{29}$ ". E arrematou que "este é o exemplo mais antigo de utilização do conceito de dano pela perda de uma chance encontrado na jurisprudência francesa ${ }^{30,}$.

Ocorre, entretanto, que o relato é inverídico, conforme destacado, de forma pioneira, por Daniel Amaral Carnaúba ${ }^{31}$, razão pela qual se optou por uma breve digressão, a fim de proceder à recuperação histórica do mencionado julgamento.

De proêmio, assinala-se que a "Chambre de Requêtes" sequer tinha competência jurisdicional para a concessão de indenização, dando provimento ao apelo.

Ela não procedia ao julgamento da matéria de fundo, exceto se fosse para desprover o apelo. Deveras, tratava-se de uma antiga divisão da Corte de Cassação Francesa, cuja composição original a dividia em três seções, assim designadas: Câmara Criminal, Câmara de Requerimentos ("Chambre de Requêtes”) e Câmara Civil. Em 1938, foi criada a Câmara Social.

Os recursos criminais, bem como os trabalhistas e, após a guerra, os relativos à seguridade, eram diretamente apresentados, respectivamente, à Câmara Criminal ou à Câmara Social. O mesmo não ocorria com os recursos civis. Eles tinham de ser, primeiramente, examinados pela Câmara de Requerimentos, que dizia se o recurso tinha ou não um bom fundamento. Caso não tivesse, a Câmara podia, desde logo, rejeitá-lo; se, entretanto, a questão permanecesse discutível, o recurso era remetido à Câmara Civil, que decidida com autoridade de coisa julgada.

A lei de 22 de julho de 1947 extinguiu a “Chambre de Requêtes” e promoveu uma nova formatação à Corte de Cassação Francesa, instituindo a Câmara Comercial, que recebia e decidia diretamente os recursos a ela destinados, a exemplo das outras três

\footnotetext{
${ }^{29}$ SILVA, Rafael Pateffi da, op. cit., p. 10-11.

${ }^{30}$ Idem, p. 11.

${ }^{31}$ Que qualificou a imprecisão histórica de "absurda": "Curiosamente, muitos autores consideram que este é o primeiro acórdão em que a Corte de Cassação teria adotado a técnica da reparação de chances. Em nosso ver, tal conclusão é absurda: no caso em questão, a reparação de chances jamais foi aventada por qualquer dos envolvidos; nem pelas partes, nem pelos juízes. De um lado, a Caixa exigia que o huissier a indenizasse 'de todo o valor da condenação'. Demandava, portanto, a reparação da própria vantagem aleatória nãoobtida, e não a reparação das chances de obtê-la. De outro lado, tanto a Corte de Cassação quanto a Corte de Apelação de Limoges buscaram determinar se Rives eram ou não responsável pela perda do processo, estabelecendo qual teria sido o resultado da apelação, caso o huissier não tivesse incorrido em erro. Ou seja, os juízes empregaram o método das presunções, e não o da reparação de chances. Se Rives fosse declarado responsável, ele teria então de reembolsar os 9.000 francos pagos pela Caixa a Sigé. Vê-se, pois, que não era a reparação de chances que estava em jogo, mas a reparação da própria vantagem aleatória desejada". (CARNAÚBA, Daniel Amaral, op. cit., p. 99)
} 
Câmaras remanescentes (Civil, Comercial e Social). A Câmara Comercial foi composta pelos juízes da extinta "Chambre de Requêtes ${ }^{32}$ ".

Portanto, a "Chambre de Requêtes" não poderia ter determinado o pagamento de indenização pela perda de uma chance, diante da restrição de sua competência. Poderia, entretanto, ter rejeitado um recurso contra uma decisão que concedera indenização em tais moldes, por entendê-lo carecedor de fundamento, como deveras o fez em diversas oportunidades.

Mas não foi esse o caso.

Voltando ao julgamento em questão, os irmãos Mazeaud, ao elaborarem diretrizes teóricas sobre a perda de uma chance, enumeraram uma série de casos em que se poderia cogitar da perda de uma chance ${ }^{33}: 1$ - o transportador que não faz o cavalo chegar a tempo de participar da corrida; 2 - um ato de um concorrente ou de um expectador que cause a morte do cavalo; 3 - um editor que deixa de imprimir um manuscrito que poderia obter um prêmio literário; 4 - um advogado negligente no cumprimento do mandato, que faz perder as chances de adquirir uma propriedade; 5 - um oficial ministerial, encarregado de assinar uma apelação, que deixa passar o prazo; ou, que deixa de se garantir contra um devedor de solvabilidade duvidosa, fazendo com que o seu cliente perca a chance de ser reembolsado etc.

\footnotetext{
32 “Ancienne division de la Cour de cassation, la chambre des requêtes n'existe plus depuis la loi du 22 juillet 1947. En effet, la Cour de cassation était à l'origine divisée en trois sections, appelées chambres: la chambre criminelle, la chambre des requêtes et la chambre civile; le décret-loi du 12 novembre 1938 y ajouta une chambre sociale. Lorsqu'un pourvoi portant sur une matière criminelle se présentait, il était directement reçu par la chambre criminelle qui statuait sur lui. La chambre sociale agissait de même à partir des décisions ayant trait au droit du travail et, après la guerre, au droit de la Sécurité sociale. Mais la chambre civile n'acceptait pas directement les pourvois. Les demandes étaient, dans un premier temps, examinées par la chambre des requêtes qui statuait sur leur mal-fondé ou, au contraire, leur bien-fondé. Si la demande paraissait devoir, à l'évidence, se solder par un rejet devant la chambre civile, la chambre des requêtes rejetait le pourvoi. Si, au contraire, la question demeurait discutable, alors elle transmettait la demande à la chambre civile qui, elle, statuait. La chambre des requêtes avait pris une importance considérable: chaque pourvoi était examiné de façon fort approfondie et les attendus de la chambre des requêtes avaient acquis une renommée considérable en jurisprudence. La conséquence en était qu'elle était devenue une véritable chambre civile; certaines affaires avaient donc le privilège d'être examinées par deux "chambres civiles» successives, ce qui créait une inégalité avec celles qui étaient directement rejetées. Mais, surtout, la chambre des requêtes était devenue un véritable goulet d'étranglement pour les pourvois et elle n'arrivait plus à suffire à la tâche. Aussi décida-t-on de la supprimer, et la loi du 22 juillet 1947 procéda à un nouveau découpage de la Cour de cassation. Celle-ci serait désormais à nouveau divisée en quatre chambres : une chambre criminelle, une chambre civile, une chambre sociale et une chambre commerciale. Toutes ces chambres recevraient directement leurs pourvois et statueraient directement. Quant à l'effectif de l'ancienne chambre des requêtes, il fut tout simplement affecté à la nouvelle chambre commerciale". (GREGOGNA, Joel P. Chambre de Requêtes. Disponível em: < $\underline{\text { http://www.universalis.fr/ }}$
} encyclopedie/chambre-des-requetes/>. Acesso em: 15 mar. 2011)

${ }^{33}$ MAZEAUD, Henri et Leon; TUNC, André, op. cit., p. 276-277. 
Do mesmo modo, Planiol, Ripert e Esmein também mencionaram diversos julgamentos com referências jurisprudenciais do século XIX e início do século $\mathrm{XX}^{34}$.

Todos esses casos não haviam sido fabricados pelos Mazeaud ou por Planiol, Ripert e Esmein, eram reais, citados com a indicação precisa das respectivas fontes; porém, não foram abordados pela jurisprudência à luz da teoria da perda de uma chance, embora contivessem essa potencialidade ${ }^{35}$. Em suma, o que os juristas fizeram em suas respectivas obras foi mencionar que os casos poderiam ter sido solucionados de uma maneira mais justa, caso tivessem sido reparadas as chances perdidas.

Observe-se que numa conjuntura bastante similar à do exemplo do oficial ministerial retratado pelos Mazeaud (número 5), julgado em 17 de julho de $1889^{36}$, conquanto também existente, nada falou sobre oportunidades perdidas.

Em verdade, sucedeu o seguinte: a Caixa Comercial de Limoges requeria que o huissier Rives, que atuara em seu favor, fosse condenado a pagar 9.000 francos, a título de reparação de danos, por força do não preenchimento de requisitos formais quando da realização de uma intimação.

A falha cometida pelo Sr. Rives (huissier) havia sido no preenchimento da intimação, pois, na cópia do mandado, não constara a indicação da pessoa com a qual ele o deixara, e esta pessoa permanecera desconhecida, o que gerou a nulidade da apelação ${ }^{37}$.

Diante da nulidade (entre nós, "não conhecimento") do recurso, a Caixa Comercial de Limoges ficou impossibilitada de reverter a condenação de 9.000 francos que lhe fora imposta nas instâncias inferiores. Prevendo essa possibilidade, a Caixa Comercial de Limoges colocou o huissier como uma espécie de "pólo passivo alternativo" da fase

\footnotetext{
${ }^{34}$ PLANIOL, Marcel; RIPERT, Georges; ESMEIN, Paul. Traité pratique de droit civil français, partie 1, Obligations, 2. ed. Paris: LGDJ, 1952, tome VI, p. 747-748.

${ }^{35}$ Em aprofundada pesquisa, Daniel Amaral Carnaúba chegou a esta conclusão: "Os trechos dedicados ao tema são ricos em referências jurisprudenciais, entre as quais se encontram facilmente decisões ou acórdãos proferidos no início do século XX, ou mesmo antes disto. Porém, esta impressão não resiste ao estudo mais atento destes trechos. $\mathrm{Na}$ maioria dos casos, os autores fazem menção a litígios nos quais seria possível reparar as chances perdidas, o que não significa que os juízes tenham efetivamente feito uso da técnica nas decisões citadas. Parece-nos que o objetivo dos juristas não era propriamente o de oferecer precedentes jurisprudenciais aos seus leitores, mas sim demarcar a abrangência do conceito e seu potencial de aplicação". (CARNAÚBA. Daniel Amaral, op. cit., p. 84-85)

${ }^{36}$ FRANÇA. "Chambre de Requêtes”, 17 juil. 1889. Recueil Sirey, 1891, v. 1, p. 399.

37 Trecho correspondente, no julgamento da Corte de Cassação: "Attendu que l'exploit d'appel d $1^{\text {er }}$ juin 1887 porte seulement que l'huissier a dit et declare à Urbain Sigé, à son domicile, ou etant et parlant à..., et que la copie a été donnée parlant comme il est dit; et qu'il y a ainsi, dans l'exploit, omission de l'indication de la personne à laquelle l'huissier a remis le copie, et qu'en le déclarant nul parce que cette personne restait inconnue, l'arrêt attaqué a fait des articles susvises une juste application;” (Idem, p. 400)
} 
recursal (com supressão de instância em relação a ele), pedindo que, caso fosse declarada a nulidade da apelação, que ele, o Sr. Rives, pagasse-lhe os 9.000 francos a que houvera sido condenada, sem oportunidade de prover o apelo a fim de absolver-se. A decisão da Corte de Cassação foi no sentido de negar qualquer reparação à Caixa Comercial de Limoges, ao fundamento de que, ainda que nula não fosse a apelação, caso conhecida e examinado o seu mérito, ela não teria sido exitosa, porque a decisão da instância inferior havia sido proferida em conformidade com a lei ${ }^{38}$.

O entendimento foi energicamente criticado pelos irmãos Mazeaud, que sustentaram ter sido uma má solução, pois as chances não eram “"castelos espanhóis’ de Perrette”, uma metáfora para explicar que as probabilidades eram reais, e não simples devaneios ${ }^{40}$.

\footnotetext{
${ }^{38}$ Trecho correspondente, no julgamento da Corte de Cassação: “Attendu qu'en prevision des cas ou son acte d'appel serait déclaré nul, la Caisse commerciale avait obtenu la mise en cause de l'huissier Rives devant la Cour d'appel; que cette société ne peut être admise à tirer grief de ce que la Cour a statué à sa propré demande, et que, la decision à rendre sur la responsabilité encourue par l'huissier découlant nécessairement $d u$ résultat que l'appel aurait pu amener, la Cour ne pouvait faire autrement que de se livrer à l'examen du mérite de cet appel; qu'il a d'ailleurs été satisfait au voeu de l'art. 7 de la loi du 20 avril 1810, puisque par lequels le tribunal civil de Limoges s'était déterminé, a deplus donné de sa decision une justification détaillée; qu'il résultait de ces motifs, entièrement justifiés, que la perte de 9,000 fr., dont Sigé demandait garantie à la Caísse commerciale, avait eu pour cause une faute lourde imputable en entier à cette société; d'où il suit que l'arrêt attaqué n'a viole aucune des régles invoquées, ni les art. 1382 et 1383 C. civ, pour avoir déclaré qu'il n’y aurait in aucune raison de réformer lá décision du Tribunal de Limoges; (...) Rejette, etc.". (Idem)

${ }^{39}$ Em alusão ao célebre poema de Jean de La Fontaine: "Perrette sur sa tête ayant un pot au lait, Bien posé sur un coussinet, prétendait arriver sans encombre à la ville. Légère et court vêtue elle allait à grands pas; Ayant mis ce jour-là, pour être plus agile, Cotillon simple, et souliers plats. Notre laitière ainsi troussée Comptait déjà dans sa pensée Tout le prix de son lait, en employait l'argent, Achetait un cent d'oeufs, faisait triple couvée; La chose allait à bien par son soin diligent. Il m'est, disait-elle, facile, D'élever des poulets autour de ma maison: Le Renard sera bien habile, S'il ne m'en laisse assez pour avoir un cochon. Le porc à s'engraisser coûtera peu de son; Il était quand je l'eus de grosseur raisonnable: J'aurai le revendant de l'argent bel et bon.

Et qui m'empêchera de mettre en notre étable, vu le prix dont il est, une vache et son veau, Que je verrai sauter au milieu du troupeau? Perrette là-dessus saute aussi, transportée. Le lait tombe; adieu veau, vache, cochon, couvée; La dame de ces biens, quittant d'un oeil marri, Sa fortune ainsi répandue, Va s'excuser à son mari, En grand danger d'être battue. Le récit en farce en fut fait; On l'appela le Pot au lait. Quel esprit ne bat la campagne? Qui ne fait châteaux en Espagne? Picrochole, Pyrrhus, la litière, enfin tous, Autant les sages que les fous? Chacun songe en veillant, il n'est rien de plus doux: Une flatteuse erreur emporte alors nos âmes:

Tout le bien du monde est à nous, Tous les honneurs, toutes les femmes. Quand je suis seul, je fais au plus brave un défi; Je m'écarte, je vais détrôner le Sophi; On m'élit roi, mon peuple m'aime; Les diadèmes vont sur ma tête pleuvant: Quelque accident fait-il que je rentre en moi-même; Je suis gros Jean comme devant. (LA FONTAINE, Jean. La Laitière et le Pot au lait. Disponível em: <http://poesie.webnet.fr/ lesgrandsclassiques/poemes/jean_de la fontaine/la_laitiere_et_le_pot_au_lait.html>Acesso em: 15 mar. 2011)

40 "Le tribunal doit-il alors tenir compte de toutes ces chances de gain ou de perte qui n'ont pu jouer par la faute du défendeur? (...) L'appel ou le pourvoi aurait-il réussi? (...) Les autres persones précédemment citées auraient-elles vu se réaliser leur chance? (...) Nul ne le sait et nul ne saura jamais. Faut-il alors prétendre que, dans toutes ces hypothèses, le dommage dont il est demande réparation est purement hypothétique et que, par suite, le tribunal ne peut en tenir compte? Ce sarait mal raisonner. Les chances qui ont été perdues ne sont pás toujours les 'châteaux en Espagne' de Perrette et son pot au lait. Elles sont parfois réelles". (MAZEAUD, Henri et Leon; TUNC, André, op. cit., p. 278-279)
} 
Todavia, a decisão mencionada passou a ser constantemente citada como sendo o exemplo mais antigo de perda de uma chance na jurisprudência, o que não é verdade.

Sem embargo, tal fato não torna o julgamento anódino. Ele possui vários aspectos pitorescos que demonstram a tendência jurisprudencial da época. Entre eles, destaca-se o de a Corte ter adotado o sistema de presunções para decidir o caso, aplicando a "teoria da diferença", ou seja, a indenização, se houvesse, teria sido medida pela diferença entre a situação hipotética em que a vítima se encontraria, sem o ato do ofensor, e a situação em que ela realmente se encontra, considerando o ato praticado pelo ofensor. Registre-se, por oportuno, que o pedido da Caixa Comercial de Limoges em face do huissier não era de chances perdidas, mas do resultado final que ela buscava com o recurso.

Tendo em vista que a Corte de Cassação seria o tribunal que, por excelência, receberia e julgaria aquela apelação, caso não tivesse sido declarada nula, era-lhe confortável dizer qual seria o resultado do recurso, qual a perda efetiva sofrida pela Caixa Comercial de Limoges, pois lhe bastava um juízo hipotético sobre o mérito do apelo nulificado.

E considerando que a Corte de Cassação estatuiu que, ainda que conhecida, a apelação não teria sido provida, nenhuma indenização foi concedida, porque o resultado da aplicação da equação da "teoria da diferença" foi igual a zero, ou seja, a falha do huissier não causou nenhum prejuízo concreto ao apelante.

\subsubsection{O primeiro caso na Corte de Cassação da França ${ }^{41}$ (1932)}

Dissipada a inexatidão histórica acerca da primazia do julgamento de 17 de julho de 1889, retoma-se o curso histórico da evolução da teoria das chances perdidas.

Conforme mencionado no início do capítulo, a jurisprudência mostrava-se irredutível ao seu acolhimento, decidindo, invariavelmente, pela irreparabilidade do que era, à época, reputado um prejuízo incerto, um dano hipotético. Porém, esse tipo de decisão começou a provocar certo desconforto na doutrina, que considerava não haver a melhor aplicação do direito naquele tipo de ilação. Aliás, o próprio Lalou, em nota na qual comenta o julgamento do Tribunal de Meaux (1920), no qual um pai postulava prestações alimentares

\footnotetext{
${ }^{41}$ A íntegra do acórdão está no "anexo C" do presente trabalho.
} 
em virtude da morte do filho (diante da expectativa de que ele pudesse ampará-lo, financeiramente, quando adentrasse ao mercado de trabalho), dá início à elaboração da teoria da perda de uma chance.

O jurista sustentou que, apesar de ser correto o raciocínio sobre a incerteza do resultado final, ele não era peremptório, pois o ilícito do réu havia privado a vítima de uma chance $^{4243}$.

Em 1932, a obra dos irmãos Mazeaud, que, entre outros méritos, dedicou alguns trechos à perda de uma chance, foi um divisor de águas na responsabilidade civil francesa ${ }^{44}$, fazendo com que a jurisprudência, a partir da década de 1930, passasse a, lentamente, mudar o enfoque dado, até então, ao tema.

Coincidência ou não, no mesmo ano (1932), a Corte de Cassação prolata seu primeiro acórdão concedendo reparação pela perda de chances ${ }^{45}$. Tratava-se do caso em que um notário, Sr. Grimaldi, provocou um duplo prejuízo aos seus então clientes, o casal Marnier, em consequência de suas falhas e de sua conduta dolosa, que fez com que eles perdessem a chance de adquirir o imóvel que desejavam, e, ainda por cima, tivessem de arcar com o pagamento de despesas de diversos atos notariais completamente inúteis. Ante tal quadro, o Tribunal de Aix condenou o Sr. Grimaldi a indenizar os prejuízos do casal Marnier.

Ao apreciar a apelação, o acórdão (da Corte de Cassação) deixou indene de dúvida que, em face das constatações e das declarações, o casal Marnier "tinha perdido toda a chance de adquirir o imóvel que eles tinham em vista”, e que a decisão atacada (da Corte de Apelação) pôde atribuir, de forma correta, a responsabilidade ao Sr. Grimaldi, e, "em seguida, apreciar soberanamente o valor das perdas e danos que deveriam ser alocadas aos consortes Marnier ${ }^{46 "}$. Por tais fundamentos, foi negado provimento ao apelo contra a

\footnotetext{
42 Idem

43 Segundo Daniel Amaral Carnaúba, a nota foi incorporada à primeira edição da obra "La responsabilité Civile”, do mesmo autor, em 1928, sob o nº 146. (CARNAÚBA. Daniel Amaral, op. cit., p. 109)

${ }^{44}$ MAZEAUD, Henri et Leon; TUNC, André, op. cit.

${ }^{45}$ CARNAÚBA. Daniel Amaral, op. cit., p. 110.

${ }^{46}$ Trechos da decisão: "Mais attendu que la Cour d'Aix declare: d'une part, que Grimaldi a manque à ses devoirs professionnels en se livrant à des actes de spéculation à l'occasion de la vente du domaine Apraxine, à laquelle il avait participé comme notaire; de l'autre, que les époux Marnier, acquéreurs d'une partie du domaine, mais gênés pour en payer le prix immédiatement, ayant chargé Grimaldi de leur procurer les fonds, d'obtenir des délais et de conduire toutes procédures susceptibles d'assurer le maintien de la vente, ce dernier n'a pas rempli les obligations qu'il avait assumées et s'est même livre à cette occasion à des agissements qualifiés par l'arrêt de dolosifs, qui ont consisté à bercer les époux Marnier de trompeuses promesses, à inciter le vendeur à porsuivre sans répit la resiliation de la vente et à substituer, en fin de compte à ses mandants, comme acquéreur d'une partie du domaine, la Société d'exploitation immobilière, qui si elle n'est pas son prête-nom, le touche de très près; - Attendu, en ce qui concerne le préjudice et le
} 
decisão de Aix.

Dois anos após, a Corte de Cassação teve a oportunidade de se pronunciar favoravelmente à reparação das chances perdidas, na seara da responsabilidade dos profissionais de justiça, ao rejeitar o recurso contra a decisão do Tribunal de Angers, que condenou um advogado que havia deixado prescrever a pretensão de seu constituinte ${ }^{47}$. E o argumento-chave da Corte de Cassação foi no sentido que existia uma certeza, a de que, até a negligência do réu, a vítima dispunha da chance de obter a vantagem pretendida.

De acordo com os dados do relatório do Tribunal de Angers ${ }^{48}$, no dia 25 de julho de 1926, um advogado havia sido encarregado de solicitar, em proveito do seu constituinte, Sr. Langlais, a renovação de um contrato de locação comercial de um imóvel, pertencente à viúva Chardon, também representada por advogado. Os advogados das partes compareceram perante o presidente da segunda Câmara do Tribunal Civil de Sarthe para a tentativa de conciliação, que restou frustrada pelo fato de a viúva entender que possuía motivos graves e legítimos para recusar a renovação.

Nesse cenário, a lei imperativa de 30 de junho de 1926 determinava um prazo de 15 dias, contados do malogro da composição, para que o locatário notificasse a locadora de uma demanda de indenização pela evicção. Ocorre, entretanto, que o advogado deixou transcorrer in albis tal interstício, vindo a proceder à notificação apenas seis dias depois de expirado o prazo, mas sem advertir o Sr. Langlais da existência dele. Além disso, mesmo sabendo da intempestividade da notificação, o advogado propôs a demanda de indenização por evicção, sem avisar o Sr. Langlais que poderia não ser recebida.

Após decisão interlocutória do Tribunal Civil de Sarthe, a Corte de Angers, em julgamento prolatado em 16 de outubro de 1928, declarou tardia e impossível de ser recebida a apelação, condenando o Sr. Langlais ao pagamento das despesas processuais desde a primeira instância, bem como ao seu imediato despejo.

rapport de causalité entre la faute et le préjudice, que les juges du font déclarent que, par ses manquements professionnels et ses agissements dolosifs, le notaire Grimaldi a occasionné un double préjudice aux époux Marnier, qui ont perdu toute chance d'acquérir le domanie qu'ils avaient en vue, et qui, d'autre part, ont eu à supporter les frais de nombreux actes inutiles; - Attendu que de ces constatations et déclarations, l'arrêt attaqué a pu déduite que la responsabilité de Grimaldi était engagée et apprécier ensuite souverainement l'importance des dommages-intérêts qui devaient être alloués aux consorts Marnier; (...) - Rejette le pourvoi formé contre l'arrêt de la Cour d'Aix du 15 avril 1929, etc" (FRANÇA. "Chambre de Requêtes", 26 mai. 1932. Recueil Sirey, 1932, p. 387-388. Sem grifos no original).

${ }^{47}$ Idem, p. 110-111.

${ }^{48}$ FRANÇA. "Chambre de Requêtes", 19 mai. 1931. Recueil Sirey, 1931, p. 190-191. 
Por essa razão, o Sr. Langlais ajuizou demanda de reparação de danos em desfavor de seu antigo patrono. A Corte de Angers, com bastante propriedade, entendeu inadmissível que o autor de uma falta (no caso, o ex-advogado) sustentasse, a fim de se exonerar da responsabilidade por uma pretensão que ele havia deixado prescrever, que o resultado da ação era incerto, quando era precisamente por obra de sua falha que a existência e a medida dessa vantagem tornaram-se impossíveis de verificação. Ademais, argumentou que, em todo caso, havia uma certeza, e de que, intentada no prazo imposto pela lei, a ação poderia ter um resultado favorável, enquanto que, intentada após o prazo, ela fatalmente resultaria num fracasso ${ }^{49}$.

O caso foi parar na Corte de Cassação, que, em 1934, rejeitou o recurso do advogado, confirmando os fundamentos da Corte de Angers, e dizendo, por outro lado, que a apreciação do montante da indenização estava submissa ao poder soberado dos juízes $a$ $q u o^{50}$. Uma nota anônima de comentário ao julgado alertava que a questão era muito mais delicada no que concernia ao prejuízo, pois, nos casos de erros de avoués ${ }^{51}$ ou de huissiers, a orientação jurisprudencial era no sentido de não conceder indenização por perdas e danos em razão da existência de alguma chance de êxito, em face do princípio da exclusão do dano hipotético. Mas o comentário termina dizendo que é necessário reconhecê-los nas hipóteses em que a Corte de Cassação flexibiliza o rigor do princípio ${ }^{52}$.

49 “Que l'on ne saurait admettre que l'auteur d'une faute soutienne, pour s'exonérer de toute responsabilité, que l'avantage, à procurer par une action que le responsable a laissé prescrire était incertain, alors précisément que, par la faute de ce responsable, l'existence et la mesure de cet avantage se trouvent impossibles à vérifier; qu'en tout cas, une certitude existe, c'est que, intentée dans le délai imparti par la loi, l'action pouvait aboutir à un résultat favorable, alors que, intentée après le délai, elle devait fatalement aboutir à un échec". (Idem, p. 191)

${ }^{50}$ FRANÇA. "Chambre Civile", 22 out. 1934. Gazette du Palais, v. II, 1934, p. 821-822.

51 Os avoués são os advogados que atuam perante a segunda instância na França, onde a capacidade postulatória, nas Cortes de Apelação, Conselho de Estado e Corte de Cassação, não é concedida a qualquer advogado. Há uma reserva de mercado para alguns profissionais em cada uma das Cortes e, o pior, o número é limitado, o cargo é vitalício e o acesso não se dá por concurso público. Para o bem da democracia e do Poder Judiciário francês, o modelo foi revogado, pelo menos em relação à Corte de Cassação, pois as profissões de avoué e avocat fundiram-se numa única, por força da lei 2011-94, de 25 de janeiro de 2011, em vigor a partir de $1^{\circ}$ de janeiro de 2012. Remanesce, porém, o sistema de feudos advocatícios na Corte de Cassação e no Conselho de Estado, nos quais a postulação é restrita aos avocats aux Conseils. (JARIEL, Ludovic. Fusion de la profession d'avocat et d'avoué. Entrevista concedida em 21 févr. 2011. Disponível em: 〈http://www.textes.justice.gouv.fr/zoom-11470/fusion-de-la-profession-davocat-et-davoue-21827.html >. Acesso em: 13 abr. 2011)

${ }^{52}$ Eis o comentário: "La question était beaucoup plus délicate en ce qui concerne le préjudice, car, en matière de procès qui n'ont pu aboutir par suite de nullités de forme causées par la faute des avoués ou des huissiers, la jurisprudence est nettement orientée en ce sens que des dommages-intérêts ne peuvent être dus aux clients de ceux-ci que si l'intéressé avait quelque chance de triompher au fond et d'aboutir ainsi à un résultat tangible. (...) Ce n'est là qu'une application du principe qu'une indemnité ne peut être allouée sans un dommage certain, ce qui exclut le dommage hypothétique. (...) Il est cependant, en pratique, il faut le 
O julgado de 1932, apesar de ter sido o primeiro em que a Corte de Cassação autorizou a reparação das chances perdidas, é pouco conhecido e citado ${ }^{53}$ (o mesmo ocorrendo com o acórdão de 1934). Por isso, optou-se por não o intitular de "leading case, 54 da jurisprudência francesa, porque não teve o condão de servir de guia para as demais decisões, diante da ausência de ampla discussão doutrinária edificada a partir dele, como ocorreu com Chaplin v. Hicks, na Inglaterra, e no caso "Show do Milhão", no Brasil. Aqueles casos, por alguma razão, que se ignora, não tiveram grande repercussão no mundo jurídico.

Há outra curiosidade que, talvez, decorra da baixa popularidade da decisão de 1932: uma parcela significativa da doutrina brasileira diz que a teoria possui aceitação na Corte de Cassação da França desde a década de 1960 (Grácia Maria Moreira do Rosário ${ }^{55}$ e Miguel Kfouri Neto ${ }^{56}$ ). Alguns, em passagens muito semelhantes, sustentam que o ano foi 1965, e o acórdão, também sem referência alguma, teria sido sobre o caso de um médico que emitira diagnóstico equivocado, retirando da vítima as chances de cura da doença que lhe acometia (Glenda Gonçalves Gondim e Cristina Maria N. da Fonseca) ${ }^{57} 58$. Finalmente, em trechos de conteúdo similar, Janaína Rosa Guimarães e José Afonso Dallegrave Neto

reconnaître, des hypothèses dans lesquelles la Cour de cassation a fait fléchir la rigueur du príncipe”. 52 (FRANÇA. "Chambre Civile", 22 out. 1934. Gazette du Palais, v. II, 1934, p. 822.)

${ }^{53}$ CARNAÚBA, Daniel Amaral, op. cit., p. 112.

54 “Um 'leading case' é uma primeira controvérsia submetida à apreciação do Poder Judiciário, normalmente girando em torno de matéria relevante, cuja decisão passa a ser seguida por todos os órgãos judicantes. Trata-se de conceito harmônico com sistemas de 'civil law' e de 'common law', talvez em 'intensidades' diferentes”. (ANDREWS, Neil. O moderno processo civil: formas judiciais e alternativas de resolução de conflitos na Inglaterra. Orientação e revisão da tradução de Tereza Arruda Alvim Wambier. São Paulo: RT, 2009, p. 18.)

55 Nesse sentido, utilizando a expressão “década de 60”, sem citar nenhuma fonte: ROSÁRIO, Grácia Cristina Moreira do. A perda da chance de cura na responsabilidade civil médica. Rio de Janeiro: Lumen Júris, 2009, p. 7

56 Reportando-se ao ano de 1965, também sem mencionar o acórdão: KFOURI NETO, Miguel. Responsabilidade Civil do Médico. São Paulo: RT, 2007, p. 64.

57 Assim falou Gondim: "Foi em 1965, em uma decisão da Corte de Cassação Francesa, que pela primeira vez se utilizou tal conceituação. Tratava-se de um recurso acerca da responsabilidade de um médico que teria proferido diagnóstico equivocado, retirando da vítima suas chances de cura da doença que lhe acometia". GONDIM, Glenda Gonçalves. Responsabilidade civil: teoria da perda de uma chance. Revista dos Tribunais, São Paulo, v. 94, n. 840, p. 11-36, out. 2005, p. 22.

58 "A teoria da responsabilidade pela perda de uma chance teve sua origem na doutrina francesa, no campo da responsabilidade médica e consagrou-se por uma decisão da Corte de Cassação, em 1965, em que o profissional da saúde foi condenado a reparar a perda de uma chance de cura ou sobrevivência de seu paciente (perte d'une chance de guérison ou de survie). A citada decisão examinava um recurso em que se discutia a responsabilidade de um médico que teria conferido um diagnóstico equivocado, subtraindo da vítima suas chances de cura da patologia que lhe acometia". (FONSECA, Cristina Maria N. da. Responsabilidade pela perda de uma chance - compatibilidade com o sistema jurídico brasileiro e aplicabilidade nas relações de trabalho. Revista LTr, São Paulo, v. 73, n. 10, p. 1272-1280 out. 2009 , p. 1272) 
apontam para um acórdão de 1964, em que a indenização pela perda de uma chance, no valor de 65.000 francos, teria sido concedida, na forma de pensão, em razão de falha cometida pelo médico que, contra as técnicas da Medicina, amputou os braços de uma criança a fim de facilitar o parto ${ }^{59} 60$.

Vamos aos fatos: não procede, obviamente, a informação de que o início da aplicação da teoria da perda de uma chance deu-se na década de 1960, diante de tudo o que já foi dito precedentemente, e, em especial, dos comentários e da transcrição dos trechos das decisões de 1932 e 1934. Não se exclui, porém, a possibilidade de alguma pesquisa mais percuciente e correta encontrar precedentes anteriores a 1932; contudo, o asserto de que a teoria começou a ser posta em prática apenas na metade da década de 1960 é desacertado.

Por outro lado, houve, de fato, dois importantes acórdãos publicados em 1966, no “Jurisclasseur Periodique”, também conhecido como "La Semaine Juridique”, que versavam sobre a perda de uma chance, o primeiro de 14 de dezembro de $1965^{61}{ }^{62}$, e o segundo de 10 de março de $1966^{63}$.

O primeiro julgamento reporta o caso do menino Pierre, então com 8 anos de idade, que sofreu uma queda e foi atendido pelo Dr. P., que havia diagnosticado uma fratura da extremidade inferior do úmero direito, sem deslocamento. Diante da manutenção de um

\footnotetext{
59 “A decisão que inaugurou na jurisprudência francesa os fundamentos da teoria adveio da $1^{\mathrm{a}}$ Câmara da Corte de Cassação, por ocasião da reapreciação de caso julgado pela Corte de Apelação de Paris, em julho de 1964. O caso narrou a acusação e posterior condenação de um médico ao pagamento de uma pensão devido à verificação de falta grave contra as técnicas da medicina, considerado desnecessário o procedimento que adotara, consistente em amputar os braços de uma criança para facilitar o parto. Assim, a corte francesa considerou haver um erro de diagnóstico, que redundou em tratamento inadequado. Entendeu-se, logo em sede de $1^{\mathrm{a}}$ instância, que entre o erro do médico e as graves consequências, a ser a invalidez do menor, não se podia estabelecer de modo preciso um nexo de causalidade. A Corte de Cassação assentou que presunções suficientemente graves, precisas e harmônicas podem conduzir à responsabilidade. Tal entendimento foi acatado a partir da avaliação do fato de o médico haver perdido uma chance de agir de modo diverso, condenando-o a uma indenização de 65.000 francos". (GUIMARÃES, Janaína Rosa. Perda de uma chance: considerações acerca de uma teoria. Disponível em: 〈http://jusvi.com/artigos/41209>. Acesso em: 27 mar. 2011.)

60 "O primeiro caso que se tem notícia na adoção da teoria da perda de uma chance ocorreu na França, em 1964, quando a $1^{a}$. Câmara da Corte de Cassação condenou um médico a pagar pensão à família da vítima, 'in casu', uma criança recém-nascida que teve seus braços amputados para facilitar o parto. A atitude precipitada do médico, motivada por um erro de diagnóstico, fez a Corte Francesa declarar que a vítima perdeu a chance (perte d'une chance) de receber atendimento medico diverso que prescindiria da amputação dos membros superiores. A indenização foi de 65.000 francos”. (DALLEGRAVE NETO, José Afonso. Responsabilidade Civil no Direito do Trabalho. 4. ed. São Paulo: LTr, 2010, p. 226)

61 A íntegra do acórdão está no "anexo D" do presente trabalho.

62 FRANÇA. " $1{ }^{\text {ére }}$ Chambre Civile", 14 déc. 1965. Juris Classeur Périodique, v. II, 1966, 14753, note SAVATIER, René.

${ }^{63}$ FRANÇA. "1 ${ }^{\text {ér }}$ Chambre Civile", 10 mars. 1966. Juris Classeur Périodique, v. II, 1966, 14753, note SAVATIER, René.
} 
quadro agudo de algia de Pierre, foi examinado por outros médicos, que detectaram não uma fratura de úmero, mas uma luxação de cotovelo. Pierre teve sequelas de seu acidente, em especial uma invalidez parcial.

Seguindo o parecer de dois peritos, os juízes de primeiro grau atribuíram ao Dr. P. uma falha no método de diagnóstico, bem como erro no tratamento aplicado. Entretanto, o Tribunal de Grande Instância rejeitou o pedido de reparação de danos, ao argumento de que a relação de causalidade, entre as falhas cometidas e o prejuízo severo que atingiu o jovem Pierre, não estava estabelecida de uma maneira certa.

Em sede de apelação, os juízes de segundo grau decidiram que havia presunções suficientemente graves, precisas e concordes para admitir que a invalidez que acometia Pierre era consequência direta da falha perpetrada para com o ofendido. Por esses motivos, a Corte de Apelação de Paris, em 7 de julho de 1964, avaliou soberanamente as chances de cura subtraídas da vítima, e concedeu-lhe, a título de indenização, conglobando todas as causas de pedir, o valor de 65.000 francos ${ }^{64}$.

De sua parte, a Corte de Cassação decidiu, em 14 de dezembro de 1965, que não havia qualquer reparo a ser feito na decisão tomada pela Corte de Apelação de Paris, e que não houve contradição em relação à opinião dos experts, quando estes "emitiram dúvidas sobre os resultados da redução", pois, tendo eles apreciado "as chances de cura" de que foi privada a vítima, puderam, sem se contradizer, acolher parcialmente a demanda ${ }^{65}$.

64 Apesar de não ter sido refeita toda a pesquisa, a coincidência de dados permite lobrigar que o acórdão citado por Janaína Rosa Guimarães e José Afonso Dallegrave Neto não existe, pelo menos, nos termos em que foi mencionado. Houve, deveras, um acórdão relevante sobre responsabilidade civil na seara médica, na França, que versava sobre um recém-nascido que teve os braços amputados para facilitar o parto. Porém, o caso não era de perda de uma chance. Além disso, os dois autores relatam que a indenização foi de 65.000 francos, exatamente o mesmo valor do caso Pierre, e, ambos, asseveram que a decisão foi proferida em julho de 1964, pela Corte de Apelação de Paris, data e local também idênticos a do caso Pierre. Portanto, à míngua de melhores explicações, e não havendo nenhuma citação de fonte para que se pudesse averiguar a informação, acredita-se que os autores podem ter confundido o acórdão a que se referem com o caso Pierre.

${ }^{65}$ A decisão da Corte de Apelação de Paris havia sido de procedência parcial porque o pedido era de indenização correspondente ao total do dano (invalidez) sofrido por Pierre, e não pelas chances subtraídas: "Mais attendu qu'après avoir exactement rapporté les avis formulés par les experts commis, et rappelé que les fautes reprochées au Docteur P... se trouvaient définitivement établies, la Cour d'appel a pu déduire 'des documents 'fournis', dont elle a souverainement apprécié le valeur probante 'qu'il existe des présomptions suffisamment graves 'précises et concordantes pour admettre que l'invalidité dont 'de la faute retenue à l'encontre de l'intimé'; Qu'en se prononçant ainsi, elle ne s'est nullement mise en opposition avec les conclusions des experts, en ce qu'ils ont déclaré 'émettre 'des doutes sur les résultats de la réduction', qu'il est reproche au Docteur P... de ne pas avoir pratiquée; - Et attendu qu'ayant à apprécier 'les 'chances de guérison' dont a été prive le blessé, les juges du second degré ont, sans se contredire, partiellement fait droit à la demande de M...., et souverainement évalué à $65.000 \mathrm{~F}$ la juste réparation du dommage subi, toutes causes de préjudice étant confondues'; Qu'ainsi, le moyen ne saurait être accueilli dans aucune de ses branches; Par ces motifs: - Rejette le pourvoi formé contre l'arrêt rendu le 7 juillet 1964 par le Cour d'appel 
O segundo caso constante do mesmo repertório de jurisprudência era o da Sra. T., que veio a óbito em 4 de abril de 1958, após dar à luz o seu filho C, tendo o seu marido atribuído a morte à insuficiência e à extemporaneidade de cuidados empregados pelo Dr. Y e a Sociedade Clínica Anônima X, para combater uma importante hemorragia uterina ocorrida após o parto.

Os juízes de primeiro grau, embora críticos ao laudo pericial (que, em suas opiniões, reconstituíram cronologicamente os fatos, privilegiando os testemunhos mais favoráveis aos réus), e enumerando uma série de falhas atribuídas ao Dr. Y. e à Clínica X, concluíram que a morte da Sra. T. deveu-se a uma "fibrinólise" ${ }^{66}$, fenômeno raríssimo em partos normais, tratado corretamente pelos réus, de acordo com as técnicas conhecidas em 1958 (injeção de fibrinogênio e transfusões de sangue), e que, àquela época, 15\% a 20\% (quinze a vinte por cento) das doentes faleciam, qualquer que fosse a terapêtica, o que fora o caso da Sra. T.

A Corte de Apelação de Paris enxergou a questão sob outro ponto de vista, bastante sagaz. Em um primeiro momento, indicou as falhas atribuídas ao Dr. Y: saída prematura da clínica, após um exame sumaríssimo de sua cliente; ausência de alerta à equipe para a possibilidade de hemorragia persistente, bem como sobre a necessidade da presença imediata de um médico à disposição; retardamento, após seu retorno à clínica, em proceder ao exame de coagulação sanguínea, de onde se originou uma aplicação tardia de fibrinogênio; que o Dr. Y., na qualidade de obstetra, não poderia ignorar a gravidade de uma fibrinólise, mesmo subsequente a um parto normal, pois esta enfermidade era extremamente grave em 1958, antes de serem descobertos os medicamentos antifibrinolíticos; que o réu não poderia olvidar da possibilidade de um tratamento substitutivo imediato que desse velocidade ao tratamento e, assim, permitisse a cura.

A partir do arrolamento dos erros cometidos pelo médico, a Corte de Apelação estabeleceu que a Sra. T. fora privada dos cuidados que tinha, contratualmente, o direito

de Paris". (FRANÇA. "1 1 ére Chambre Civile”, 14 déc. 1965. Juris Classeur Périodique, v. II, 1966, 14753, note SAVATIER, René. Sem grifos no texto original).

${ }^{66}$ Segundo o professor Rendrik Franco, "Fibrinólise pode ser definida como a degradação da fibrina, mediada pela plasmina. O sistema fibrinolítico ou sistema plasminogênio/plasmina é composto por diversas proteínas (proteases séricas e inibidores), que regulam a geração de plasmina, uma enzima ativa, produzida a partir de uma proenzima inativa (plasminogênio), que tem por função degradar a fibrina e ativar metaloproteinases de matriz extracelular". (FRANCO, Rendrik F. Fisiologia da coagulação, anticoagulação e fibrinólise. Revista da Faculdade de Medicina de Ribeirão Preto e do Hospital das Clínicas da FMRP. Universidade de São Paulo. Ribeirão Preto, v. 34, n. 3/4, p. 229-237, jul./dez. 2001, p. 235. Disponível em: $\langle$ http://www.fmrp.usp.br/revista/2001/vol34n3e4/fisiologia_coagulacao.pdf>. Acesso em: 28 mar. 2011.) 
de receber do profissional em que depositara a sua confiança, enquanto este não exercera uma supervisão médica suficiente, nem recorrera, sem atraso, a uma terapêutica, cujo eventual sucesso dependia, sobretudo, de sua precocidade.

E o enfrentamento do problema do nexo de causalidade foi feito de maneira arguta: se era verdade que não era possível estabelecê-lo de modo peremptório, havia presunções suficientemente graves, precisas e concordes para admitir que o falecimento da Sra. T. era consequência direta dos erros do Dr. $\mathrm{Y}^{67}$.

Isso porque, segundo o entendimento da Corte, seria lícito supor que, caso uma forte infusão de fibrinogênio e uma relevante transfusão de sangue, tivessem sido feitas tempestivamente, a Sra. T. poderia, como quatro quintos das vítimas de fibrinólise (já que as estatísticas apontavam que apenas $15 \%$ a $20 \%$ morriam, independentemente da terapêutica), ter sobrepujado a sua grave doença, pois nada autorizava dizer que a moléstia apresentava um caractere de irreversibilidade.

Desse modo, ao analisar as chances de cura da Sra. T., proveu-se parcialmente o recurso (mais uma vez, porque o referencial era o resultado final), e concedeu-se ao $\mathrm{Sr}$. T., tutor legal do filho da Sra. T, indenização de 30.000 francos $^{68}$.

${ }^{67} \mathrm{O}$ TJ/SP enfrentou problema assemelhado ao decidir que, apesar da incerteza sobre o nexo etiológico do falecimento da criança, havia a certeza de que o comportamento desidioso do médico diminuiu as chances de êxito na gestação. A Corte, de sua parte, optou pela reparação do dano moral pela chance perdida: "RESPONSABILIDADE CIVIL - PERDA DE UMA CHANCE - Óbito de feto no $9^{\circ}$ mês de gestação, dentro do útero da mãe. Autores que pretendem responsabilizar a médica que acompanhou o pré-natal, sob o argumento de que ela errou na previsão da data do parto. Embora não se possa dizer que houve equivoco quanto à estimativa da idade gestacional ou responsabilidade direta da médica na morte da criança, é de se admitir que a adoção de comportamento desidioso colaborou para que a autora sofresse abalo moral com a perda do filho. Paciente que, dias antes do ocorrido, já estava reclamando de fortes dores e não foi adequadamente examinada e nem encaminhada a hospital. Ultrassom atestando o óbito intra-uterino associado à severa redução de líquido amniótico, situação que poderia ter sido averiguada anteriormente, aumentando as chances de a autora ter uma gestação de sucesso. Médica responsável pelo prénatal não forneceu nenhuma explicação para o óbito do feto. Danos materiais indevidos, declarada a compensação pelos efeitos danosos derivados do descaso com o atendimento. Recurso parcialmente provido, para arbitrar indenização por danos morais de R\$ 10.000,00”. (SÃO PAULO. Tribunal de Justiça do Estado de São Paulo, $4^{a}$ Câmara de Direito Privado. Apelação Cível 994.09.322548-8. Casa Branca. Rel. Enio Zuliani. Diário da Justiça eletrônico, 26 jul. 2010, p. 718)

68 “Considerant qu'il est ainsi établi que la danme T... s'est trouvée privée des soins attentifs qu'elle était contractuellement en droit de recevoir du praticien en qui elle avait placé sa confiance, ce praticien n'ayant ni exercé sur sa client une surveillance médicale suffisante, ni recouru sans retard à une thérapeutique dont le succès éventuel dépendait notamment de sa précocité; - Considerant qu'en qui concerne le lien de causalité entre la faute et le dommage, s'il est vrai que le demandeur n'établit pas son existence de façon péremptoire, il n'en existe pas moins en la cause des présomptions suffisamment graves, precises et concordantes pour admettre que le décès de la dame T... est la conséquence directe des fautes commises par le docteur Y...; qu'il est en effet permis de penser, au vu des documents produits, qui si une forte perfusion de fibrinogène et une importante transfusion sanguine avaient été pratiquées avant 20 heures, le dame T...aurait, comme plus des quatre cinquièmes de ceux qui étaient atteints de fibrinolyse en 1958, surmonté la grave maladie dont elle était atteinte et dont rien n'autorise à affirmer qu'elle présentait chez cette malade 
Pois bem, os dois acórdãos mencionados tiveram uma repercussão estrondosa. Tal foi o "eco" que a decisão teve que René Savatier a qualificou de revolucionária ${ }^{69}$, na medida em que modificava a regra do "tudo ou nada" em matéria de responsabilidade civil $^{70}$, e, seguindo as diretrizes decisórias da época, dizia que a reparação concedida era parcial $^{71}$ (o que é um equívoco, conforme se verá no capítulo 3, item 3.2).

Porém, na realidade, a "revolução" propalada por Savatier não se devia ao fato de ser a primeira vez que a Corte de Cassação tratava da perda de uma chance, pois, como visto, o assunto já estava dominado desde o início da década de 1930. A grande novidade estava na ampliação de seu eixo, que passou a abranger aquilo que, no presente estudo, denominaremos de perda de uma chance "atípica” (vide capítulo 4, item 4.2).

Em apertada síntese, essa nova abordagem do instituto desloca topologicamente a álea, ou seja, muda o local do desconhecido, que na perda de uma chance "clássica" (que, aqui, chamaremos de "típica") residia no resultado final (o jóquei ganharia o páreo se houvesse participado?; a miss ganharia o concurso se não fosse obstava de concorrer?), e na "atípica" passa a concernir ao nexo causal (o erro de diagnóstico causou a morte do paciente?; a ação judicial teria sido exitosa caso o advogado tivesse contestado a petição inicial?).

Para se ter uma ideia da dimensão dessa ampliação de paradigma, François Chabas passou a chamar essa nova abordagem de perda de uma chance "falsa"72. Mas a validade

un caractere irréversible; - Considerant que les manquements du docteur Y... à ses obligations de moyens ont ainsi fait perdre d'importances chances de guérison à la dame T...; qu'il convient en conséquence d'infirmer le jugement entrepris et, compte tenu des circonstances de la cause et des documents fournis, de faire partiellement droit à la demande de T..., ès qualitès, en condamnant le docteur Y... à lui payer à titre de réparation du dommage subi la somme de 30.000 F (...). (FRANÇA. "1 1 ére Chambre Civile", 10 mars. 1966. Juris Classeur Périodique, v. II, 1966, 14753, note SAVATIER, René.)

69 "Le deux arrêts rapportés présentent la responsabilité medicale sous un angle nouveau, dont l'importance, s'ils faisaient autorité en jurisprudence, serait 'révolutionnaire', non seulement pour la responsabilité médicale, mais pour toute responsabilité fondée sur une faute”. (Idem)

70 “Jusqu'ici, l'appréciation de l'existence de cette causalité avair paru dépendre indivisiblement de la conviction du juge du fond. Ce dernier était, sans doute, admis à la former d'après de simples présomptions tirées des circonstances pas de composition transactionelle. Il était indivisible. Ou bien, le juge déclarait tirer des circonstances l'intime conviction que l'échec eût été evite en l'absence de la faute reprochée au médecin. Alors, le médecin répondait entièrement de cet échec. Ou bien le juge disait n'avoir pu former cette intime conviction; alors aucune condamnation ne pouvait être prononcée contre le médecin. L'action en responsabilité était soumise à la règle du tout ou rien”. (Idem)

71 “On voit l'étendue de ce que nous avons presente comme 'une révolution' de la responsabilité fondée sur la faute: le doute sur la causalité existant entre la faute et le dommage ne se traduirait plus par le rejet nécessaire de l'action en réparation, mais par une condamnation partielle. Le rôle du juge serait d'établir une sorte de moyenne, résultant de l'impossibilité ou il croit être d'établir son intime conviction sur le lien de causalité réunissant la faute au préjudice!”. (Idem)

${ }^{72} \mathrm{O}$ comentário foi o seguinte: "C'est alors souvent à une véritable déviation de la théorie que l'on assiste, attendu, pour nous en tenir à cet élément essentiel, qu'en ces occurrences, le patient, n'étant pas réduit à de 
epistemológica dessa "revolução" de 1965 será analisada mais adiante (capítulo 4, item 4.2).

\subsection{O leading case no direito britânico ${ }^{73}$ (1911)}

Apesar de ser o leading case do Reino Unido $^{74}$, e servir como referencial de praticamente todos os escritos sobre loss of a chance doctrine na Grã-Bretanha e noutras partes do mundo, o caso Chaplin v. Hicks é muitas vezes citado como se fosse apenas um genuíno concurso de beleza. Esta informação, entretanto, é, no mínimo, incompleta.

Para reconstrução fática, conforme relatado com precisão pelo Lord Walker of Gestingthorpe $^{75}$, o concurso era, sim, para aspirantes a atrizes, inicialmente com 12 prêmios para três anos de contrato como atriz (4 contratos a 5 libras por semana, 4 contratos a 4 libras por semana e 4 contratos a 3 libras por semana).

Originalmente, as 12 vencedoras seriam escolhidas pelo voto dos leitores de um jornal, no qual as fotografias das 24 finalistas, selecionadas pelo Sr. Hicks, com a assessoria de um comitê, seriam publicadas. Porém, o surpreendente número de inscrições (cerca de 6.000), fez com que as regras fossem mudadas. Ficou, então, estabelecido que o comitê iria selecionar 300 candidatas e publicar as respectivas fotos no jornal; que o Reino Unido iria ser divido em dez distritos, e as fotografias das candidatas selecionadas seriam submetidas ao escrutínio dos leitores dos respectivos distritos, que dariam seu voto para aquela que achassem a mais bonita.

simples chances de survie, avait perdu en réalité la vie, mais pour des causes inconnues: au lieu d'avoir perdu, indiscutablement par la faute du médecin, des chances de survie, il y avait des chances pour que ce fût par la faute du médecin qu'il avait perdu la vie. On perçoit qu'il y a une vraie et une false théorie de la perte d'une chance". (CHABAS, François. La perte d'une chance en droit français. In: GUILLOD, Olivier. Développements recents du droit de la responsabilité civile. Zurique: Schultess Polygraphischer Verlag Zürich, p. 131-141, p. 133.)

73 A íntegra do acórdão está no "anexo A" do presente trabalho.

74 De acordo com Daniel Amaral Carnaúba, Chaplin v. Hicks pode, inclusive, ter sido a primeira referência de 'perda de uma chance', pois, refutada a ideia de que o julgamento de 17 de julho de 1889 teria sido o primeiro, e datado de 1932 o primeiro julgamento catalogado na França, não foram encontradas decisões mais antigas sobre o tema. (CARNAÚBA, Daniel Amaral, op. cit., p. 110, nota 290)

${ }^{75}$ GESTINGTORPHE, Lord Walker of. Loss of a Chance and Chance of Loss. The Incorporated Council of Law Reporting for England \& Wales, Londres, p. 1-16, 2009, p. 1. 
Após a conclusão da votação, o Sr. Hicks iria marcar um encontro com as 5 finalistas de cada distrito e, dentre as 50 finalistas, iria selecionar as 12 vencedoras, mediante uma audição ou, pelo menos, uma entrevista.

O nome da Sra. Chaplin apareceu em $1^{\circ}$ lugar no seu distrito. Ela, então, recebeu uma carta para comparecer à fase final de seleção no Aldwich Theatre, em Londres, às $16 \mathrm{~h}$ do dia 06.01.1909. Entretanto, a carta foi remetida para o endereço errado e, posteriormente, encaminhada à Dundee, onde ela estava, porém no próprio dia 06.01.1909, o que impossibilitou seu comparecimento a tempo ${ }^{76}$.

O júri entendeu que o Sr. Hicks não proporcionou meios razoáveis para dar à Sra. Chaplin uma oportunidade de se apresentar à seleção, e avaliou os danos em 100 libras. A Corte de Apelação, por unanimidade, rejeitou a apelação, ao fundamento de que a quebra de contrato pelo Sr. Hicks fez com que a Sra. Chaplin perdesse a chance de concorrer ao prêmio $^{77}$.

\footnotetext{
${ }^{76}$ No Brasil, hipótese semelhante foi enfrentada quando os correios deixaram de entregar a correspondência em tempo hábil para que o candidato participasse do concurso, mas cuja solução encontrada foi conceder reparação a título de danos morais: "CIVIL (RESPONSABILIDADE CIVIL) E PROCESSUAL CIVIL INDENIZAÇÃO POR DANOS MORAIS - INSCRIÇÃO EM CONCURSO PÚBLICO - AGÊNCIA DOS CORREIOS - FALHA OPERACIONAL NO SISTEMA - PERDA DO PRAZO - INSCRIÇÃO NÃO EFETIVADA 4- A frustração decorrente da não participação em concurso público devido a falha no serviço prestado pela instituição recebedora do pagamento da inscrição não se situa no plano dos dissabores insuscetíveis de causarem dano moral. Supera-os, causando abalo psíquico de considerável monta, na medida em que depositadas esperanças na conquista de emprego estável e razoavelmente remunerado, além de despendidos tempo e dinheiro na preparação. 5- Já decidiu esta Turma que "a hipótese é de "perda de uma chance" de realizar concurso (...) é incontroverso que os Correios atrasaram a entrega da correspondência por algumas horas, o que, em tese, foi suficiente para inviabilizar a inscrição no concurso" (AC $\mathrm{n}^{\circ}$ 001996137.2002.4.01.3800/MG, Rel. Desembargador Federal João Batista Moreira). 6- Condenação da ECT ao pagamento da quantia de $\mathrm{R} \$ 10.000,00$ reais a título de danos morais, montante suficiente à reparação do dano e punição pela deficiente prestação do serviço. 7- Apelação provida. Pedido julgado procedente. Honorários advocatícios fixados". (BRASÍLIA. Tribunal Regional Federal da $1^{a}$ Região. Apelação Cível 200441000017172/RO. Relator: Convocado Evaldo de Oliveira Fernandes Filho. Diário da Justiça eletrônico, 08 out. 2010, p. 161)

${ }^{77}$ O relatório da Corte de Apelação não deixa dúvidas do acerto nas observações do Lord Walker: "On November 5, 1908, a letter from the defendant, a well-known actor and theatrical manager, was published in a London daily newspaper, in which he said that, with a view of dealing at once with the numerous applications continually being made to him by young ladies desirous of obtaining engagements as actresses, he was willing that the readers of that newspaper should by their votes select twelve ladies, to whom he would give engagements. On the four following days the offer was published in detail in the newspaper. Ladies were invited to send their photographs to the newspaper by November 24, 1908, together with an application form, in which they were to insert name, address, and general personal description. The defendant, with the assistance of a committee, would then select twenty-four photographs to be published in the newspaper, and the readers of the newspaper would out of those select the twelve winners, to the first four of whom the defendant would give an engagement for three years at 55 a week, to the second four an engagement tor three years at $£ 4$ a week, and to the third four an engagement for three years at £3 a week. On November 10 the plaintiff sent in a signed application to together with her photograph. The response to the defendant's offer was so great that in the issue of December 9 an alteration of the conditions of the competition was announced. It was stated that about six thousand photographs had been sent in, and that from these the defendant or his committee had selected about three hundred, which would be published in the
} 
Além de ter aplicado a perda de uma chance, dentro da esfera contratual, a decisão também é notável por ter utilizado um coeficiente de redução na avaliação dos danos, embora não haja como identificar qualquer base estatística para o valor encontrado ${ }^{78}$, tampouco o uso correto do cálculo de probabilidades ${ }^{79}$.

\subsection{O primeiro caso na Corte de Cassação Italiana $^{80}(1983)$}

De todos os países em que se fez pesquisa jurisprudencial, foi a Itália o que, disparado, trouxe mais dificuldades. Os percalços para se encontrar os primeiros julgados

newspaper in the following way: the United Kingdom would be divided into ten districts, and the photographs of the selected candidates in each district would be submitted to the readers of the newspaper in that district, who were to select by their votes those whom they considered the most beautiful. After the voting was completed the defendant would make an appointment to see the five ladies in each district whose photographs so published obtained the greatest number of votes, and from these fifty the defendant would himself select the twelve who would receive the promised engagements. The plaintiff assented to the alteration in the terms of the competition. The fifty photographs were then published with numbers appended to them in the newspaper, together with a ballot paper on which the reader of the newspaper registered his vote for the particular number which he preferred, and added his signature and address. On January 2, 1909, the poll closed; the plaintiff's name appeared as first in her particular section, and she became one of the fifty eligible for selection by the defendant. On January 4 the defendant's secretary wrote a letter to the plaintiff asking her to call at the Aldwych Theatre at 4 o'clock on Wednesday afternoon [January 6] to see the defendant. This letter was addressed to the plaintiff's London address, which was the only address given by the plaintiff in her application, and was delivered there by the first post on January 5. The plaintiff was at that time fulfilling an engagement at Dundee; the letter was at once re-addressed to Dundee, where it reached the plaintiff on January 6, much too late for her to keep an appointment in London on that afternoon. The other forty-nine ladies kept their appointments, and on January 8 the defendant made his final selection of the twelve, of whom the plaintiff was not one. The plaintiff made attempts, but unsuccessfully, to obtain another appointment with the defendant, and eventually brought the present action to recover damages on the ground that by reason of the defendant's breach of contract she had lost the chance of selection for an engagement. The jury found, in answer to a question put to them by the learned judge, that the defendant did not take reasonable means to give the plaintiff an opportunity of presenting herself for selection, and assessed the damages at £100, for which sum Pickford J., after argument directed judgment to be entered. The defendant appealed. INGLATERRA. Corte de Apelação. Apelação [1911] 2 K. B. 78. Chaplin v. Hicks. Disponível em: 〈http://www.btinternet.com/ akme/chaplin.html〉. Acesso em: 25 nov. 2010).

${ }^{78}$ E a Corte de Apelação, propositadamente, não se imiscuiu na quantificação indenitária feita pelo júri, conforme se vislumbra do voto de Fletcher Moulton, L.J.: "I cannot lay down any rule as to the measure of damages in such a case; this must be left to the good sense of the jury. They must of course give effect to the consideration that the plaintiff's chance is only one out of four and that they cannot tell whether she would have ultimately proved to be the winner. But having considered all this they may well think that it is of considerable pecuniary value to have got into so small a class, and they must assess the damages accordingly.” (Idem).

${ }^{79}$ Nesse sentindo, embora também omitindo os detalhes, John Maynard Keynes afirma que a Corte não teve o requinte na avaliação dos danos, pois, segundo ele, o dano final, sobre o qual se aplicou o coeficiente redutor (25\%), não poderia ter sido estimado em 400 libras: "The jury in assessing the damages at 100, however, cannot have argued so subtly as this; for the average value of a prize (I have omitted the details beating on their value) could not have been fairly estimated so high as £400”. (KEYNES, John Maynard. A

Treatise on Probability. Londres: MacMillan and Co., 1921, p. 27)

80 A íntegra do acórdão está no "anexo E" do presente trabalho. 
referidos nos textos literários são inimagináveis para um estudante que investiga, livremente, as decisões dos mais diversos tribunais brasileiros, sem grandes embaraços ${ }^{81}$, tendo acesso amplo, gratuito e democrático às fontes de manifestação do Poder Judiciário nacional.

$\mathrm{Na}$ Corte de Cassação italiana, entretanto, as coisas são bem diferentes. O sítio eletrônico $^{82}$ tem pouquíssimo conteúdo de utilidade para um operador de Direito. Quando se acessa o link destinado à área reservada ${ }^{83}$, o leitor recebe a informação de que a disponibilidade da legislação, doutrina e jurisprudência subordina-se ao regulamento estipulado por um decreto presidencial de 1981, modificado em $1985^{84}$. E a norma estabelece no artigo 11 que a utilização do serviço é paga, antecipadamente e em parcela única, sem informação alguma sobre o conteúdo ${ }^{85}$.

O comando foi modificado em $2006^{86}$, por um Decreto do Ministério da Justiça, que estabeleceu, em seu artigo $1^{\mathrm{o} 87}$, a concessão de consulta mediante uma espécie de

${ }^{81}$ Excetuando-se, obviamente, os processos que tramitam em segredo de justiça, bem como os processos mais antigos, dos tribunais que ainda não digitalizaram todo o acervo.

${ }^{82}$ Cujo endereço é o seguinte: http://www.cortedicassazione.it/.

${ }^{83}$ CORTE DE CASSAÇÃ̃ ITALIANA. Disponível em: <http://www.cortedicassazione.it/ AreaRiservata/AreaRiservata.asp>.

84 O regulamento é o seguinte: “Decreto Del Presidente Della Repubblica 21 maggio 1981, $n$. 322, modificato dal DPR 759 del 1985. Regolamento per la concessione della utenza del servizio di informatica giuridica del Centro elettronico di documentazione della Corte suprema di cassazione” (ITÁLIA. Decreto presidencial n ${ }^{\circ} 322$, de 21 de maio de 1981. Regulamenta a concessão da utilização do serviço de informática jurídica do Centro de Documentação da Corte de Cassação Italiana)

${ }^{85} \mathrm{Diz}$ o artigo 11 do aludido regulamento: "L'utenza del servizio è concessa dietro il pagamento di un canone annuo e il versamento di una cauzione di pari misura a garanzia degli obblighi derivanti dalla convenzione. L'importo del canone annuo, determinato in misura diversa per ogni singola categoria di utenza di cui all'art. 4, è così stabilito: Lire unmilionetrecentomila per gli utenti della categoria A; Lire unmilionenovecentocinquantamila, per quelli della categoria B; Lire duemilioniseicentomila, per quelli della categoria $C$. Le suddette misure potranno essere revisionate con decreto del Ministro di grazia e giustizia, di concerto con il Ministro del tesoro. L'importo del canone è corrisposto in unica soluzione e anticipatamente, mediante versamento su conto corrente postale intestato alla sezione tesoreria provinciale dello stato competente per territorio, con imputazione all'apposito capo e capitolo dello stato di previsione delle entrate del bilancio dello stato. La cauzione è costituita con le modalità previste dall' art. 54 del regio decreto 23 maggio 1924, n. 827 e successive modificazioni. Le modalità di accesso agli archivi e i parametri relativi al numero dei caratteri in output e dei minuti di collegamento, sono determinati con decreto del Ministro di grazia e giustizia, di concerto con il Ministro del tesoro e possono, in egual forma, essere revisionati in relazione alla variazione accertata dall'ISTAT dell'indice dei prezzi al consumo per le famiglie di operai e impiegati, verificatesi nel biennio precedente. Il Ministro di grazia e giustizia, con proprio decreto, di concerto con il Ministro del tesoro, può stipulare speciali convenzioni con particolari categorie di utenti, anche in deroga alle condizioni stabilite con il provvedimento di cui al precedente quarto comma”. (Idem)

${ }^{86}$ ITÁLIA. Decreto do Ministério da Justiça de 14 de fevereiro de 2006. Institui modalidade e tarifa de acesso ao serviço de informática jurídica do Centro de Documentação da Corte de Cassação Italiana e uso do respectivo serviço. Disponível em: 〈http://www.cortedicassazione.it/Documenti/d7febb_06.html>. Acesso em: 08 abr. 2011.

${ }^{87} \mathrm{O}$ texto do artigo $1^{\circ}$ assim determina: "Art. 1. Abbonamenti e tariffe. 1. Il pagamento del canone di abbonamento al servizio di informatica giuridica del Centro elettronico di documentazione della Corte di cassazione (C.E.D.) consente il collegamento per 1000 minuti l'anno. Per le ricerche compiute in eccedenza 
"assinatura básica" de mil minutos/ano, ao custo, na categoria em que nos encontramos (categoria "C"), de mais de 1.000 euros pelo pacote, com acréscimo de 1,25 euros por minuto excedente, e ágio de $50 \%$ (cinquenta por cento) para as buscas realizadas das $10 \mathrm{~h}$ às $14 \mathrm{~h}$, e deságio de $50 \%$ (cinquenta por cento) para as efetuadas das $20 \mathrm{~h}$ às $10 \mathrm{~h}$.

O quadro para a pesquisa era, então, o seguinte: pagamento de mais de mil euros por um produto cujo conteúdo se ignorava.

A opção foi liminarmente descartada, por motivos óbvios.

Obtivemos, na sequência, a informação ${ }^{88}$ de que para poder acessar os "massimários" da Corte de Cassação italiana seria necessário o cadastro em seu site ${ }^{89}$, e que, para tanto, seria preciso enviar-lhes um email ${ }^{90}$, explicando que se tratava de uma pesquisa científica realizada no Brasil, e postulando um "Códice Utenza".

Assim foi feito. No dia 17 de fevereiro de 2011, às 13h02min, foi enviado um email justificando o interesse na navegação e solicitando o código de utilização ${ }^{91}$. A resposta, encaminhada alguns dias depois, foi que o serviço era pago.

a tale limite, l'utente é tenuto al pagamento: per la categoria A, di Euro 0,50 per ogni minuto di collegamento; per la categoria B, di Euro 1,00 al minuto e, per la categoria $C$, di Euro 1,25 al minuto. 2. Per le concessioni a fatturazione il costo di collegamento é di Euro 1,25 al minuto. 3. I parametri di cui ai commi 1 e 2 sono moltiplicati per 1,5 per le ricerche effettuate tra le ore 10 e le ore 14 e per 0,50 per le ricerche effettuate dalle ore 20 fino alle ore 10. 4. Il tempo di collegamento é dato dall'effettiva occupazione del server del C.E.D., escludendo i tempi intercorrenti tra l'invio della risposta all'utente e la ricezione di una nuova richiesta da parte di quest'ultimo. 5. Le somme dovute ai sensi dei commi precedenti sono versate su conto corrente postale intestato alla Tesoreria provinciale dello Stato, competente per territorio, con imputazione al capo XI - Ministero della giustizia - capitolo 2408, dello stato di previsione delle entrate del bilancio dello Stato. 6. I magistrati della giurisdizione ordinaria, amministrativa, contabile e militare, nonché gli avvocati ed i rocuratori dello Stato, sono ammessi - anche successivamente alla cessazione dal servizio, purché non iscritti in albi professionali - a fruire gratuitamente del collegamento al C.E.D. sia mediante apparecchiature collocate presso gli uffici di appartenenza, sia mediante un collegamento personale compatibile con la rete. 7. La fruizione gratuita del servizio é estesa ai giudici di pace, ai magistrati onorari ed ai magistrati tributari, limitatamente alla durata delle funzioni. 8. Il venir meno dei requisiti che giustificano la fruizione gratuita del servizio deve essere comunicato senza ritardo dall'interessato alla direzione del C.E.D.”. (Idem)

${ }^{88}$ A informação nos foi passada pelo Dr. Fernando Mil Homens Moreira, mestre em direito na Itália e assessor ministerial no Supremo Tribunal Federal.

${ }^{89} \mathrm{O}$ site é o seguinte: http://www.italgiure.giustizia.it/nifuser/index it.htm?lang=it.

90 Ao endereço eletrônico: helpdesk.italgiure@giustizia.it/squirrelmail/src/compose.php?send to=helpdesk. italgiure@giustizia.it

${ }^{91}$ A versão em português do email continha os seguintes dizeres: "Prezados senhores, boa tarde! Meu nome é Flávio da Costa Higa, sou estudante no Brasil, e estou fazendo pesquisas destinadas à apresentação da minha dissertação para a obtenção do título de mestre, pela Universidade de São Paulo, com o tema "A perda de uma chance no Direito do Trabalho", assunto no qual a Itália está bem desenvolvida. Para realizar meu trabalho, preciso pesquisar algumas decisões da Corte de Cassação, já que as primeiras sentenças italianas tratando de perda de uma chance eram vinculadas a assuntos laborais. Todavia, não consegui realizar as pesquisas pelo site. A partir de informações, fiquei sabendo que deveria enviar um email aos senhores, solicitando um "Codice Utenza", para, depois, cadastrar-me no site http://www.italgiure.giustizia.it/nifuser/index_it.htm?lang=it. É esse, então, o próposito do meu contato. Desde já, fico extremamente grato por vossa atenção. Cordialmente. Flávio da Costa Higa”. 
Começava, então, uma saga por todas as obras e bibliotecas a fim de encontrar as intituladas "primeiras sentenças da Corte de Cassação italiana". Numa varredura prefacial, nada de relevante foi encontrado.

Correspondências eletrônicas foram enviadas a praticamente todos os colegas pesquisadores, solicitando auxílio na missão. Por sugestão, pediu-se socorro também ao Consulado Italiano no Brasil (Vice-Consulado de Campo Grande/MS), sem êxito.

Na continuidade da busca, subscrevemos um site pago que se autoproclama "o maior acervo jurisprudencial do mundo", com mais de 62 milhões de documentos de 132 países, disponíveis em 13 idiomas ${ }^{92}$. Somente da Itália, são 2.095.324 documentos, com a jurisprudência da Corte Constitucional, do Conselho de Estado, do Tribunal Administrativo e do Conselho Administrativo para a Região Siciliana... Da Corte de Cassação, porém, nada.

Descobriu-se, na sequência, que as sentenças, supostamente indisponíveis na rede mundial de computadores, haviam sido publicadas em duas revistas italianas: "Foro Italiano" e "Nuona Giurisprudenza della Corte di Cassazione".

Iniciou-se, ato contínuo, e, mais uma vez, mediante ajuda de terceiros, um rastreamento das bibliotecas nacionais em busca do material.

O trabalho parecia alvissareiro. Tanto a biblioteca da Universidade de São Paulo quanto a da Universidade Federal do Rio de Janeiro, notórias pelo acervo clássico, tinham o periódico "Foro Italiano", a última no setor de obras raras. Mas as boas novas não foram assim tão boas: na USP, só havia os volumes até o ano de 1960 e, na UFRJ, até $1965^{93}$. E a sentença procurada, como informa o título deste tópico, é de 1983, e, a seguinte, de 1985. A biblioteca do Tribunal de Justiça do Estado de São Paulo, em reformas, não permitia, naquele momento, a consulta.

Com base no aforismo "Quem tem boca, vai a Roma" (sede, aliás, da Corte de

\footnotetext{
92 Trata-se do site "VLEX". Parece, realmente, ser uma boa fonte de pesquisa a um custo compensador. Porém, pedimos o cancelamento da assinatura, e fomos prontamente atendidos, tão logo constatamos que não havia no banco de dados decisões da Corte de Cassação italiana. (VLEX. Toda a informação jurídica: um único sistema de pesquisa. Disponível em: < http://vlex.com/>. Acesso em: $1^{\circ}$ dez. 2010.)

93 Esse trabalho na ponte-aérea Rio/São Paulo deve ser creditado ao advogado carioca Vitor Greijal Sardas, exímio pesquisador e de perfil inigualavemente recalcitrante na busca por material, que, em seus deslocamentos para o curso de pós-graduação, procedia voluntariamente às buscas nas bibliotecas.

${ }^{94}$ Sobre o qual, aliás, pairam dúvidas sobre o real enunciado, cogitando-se a hipótese de ser "Quem tem boca vaia Roma", numa alusão aos protestos populares (sob a forma de vaias) aos desmandos dos imperadores romanos. Todavia, há argumentos contrários com os supostos equivalentes em espanhol: "Preguntando se
} 
Cassação), os emails, a partir daí, passaram a ser enviados com o provocativo título: "Missão Impossível!", contendo uma súplica de qualquer dica que pudesse levar às decisões procuradas.

Um desses emails foi parar no setor de biblioteca do Tribunal Regional do Trabalho da $24^{\text {a }}$ Região ${ }^{95}$, que, por intermédio de um convênio de rede com diversas bibliotecas e bibliotecários $^{96}$, prontamente conseguiu identificar outra revista que continha a primeira sentença, e localizá-la no cabedal do Supremo Tribunal Federal.

Em relação à segunda sentença, o periódico foi encontrado nas bibliotecas do STF, STJ, Câmara dos Deputados etc., mas não o volume que a contivesse.

Quando já nos contentávamos com o material recolhido, encontramos o desejado julgamento em dois lugares, quase que simultaneamente: na "Rivista di Diritto Commune ${ }^{, 97}$ de 1986; e num link casual com material da Universidade de Roma ${ }^{98}$.

O relato dessa peripécia se presta a dois motivos: 1 - esclarecer que não houve como conferir, um a um, os julgamentos da Corte de Cassação italiana, a fim de atestar a fidedignidade da informação sobre a primazia da decisão de 1983 no tema estudado (portanto, ela se baseia em livros que assim o disseram, e não na bebida direto da fonte, como gostaríamos); 2 - justificar a decisão de incluirmos, anexos, os propalados julgamentos italianos 99 , a fim de que decisões tão "caras" fiquem mais acessíveis aos interessados.

Delimitadas as fronteiras da pesquisa, Sérgio Savi ${ }^{100}$, referindo-se à obra de Patrizia Petrelli em nota de rodapé, afirma que a primeira manifestação da Corte de Cassação italiana sobre a perda de uma chance ocorreu em 19 de novembro de 1983, na sentença

llega a Roma", em italiano: "Chi ha língua arriva a Roma" e em inglês: "All roads lead to Rome". Polêmicas à parte, foi na acepção mais conhecida que se inspirou para prosseguir na pesquisa.

95 Onde o sucesso da busca só foi possível graças ao diligente trabalho da servidora Gilza Núria Brandão Marroni, biblioteconomista do TRT da $24^{\text {a }}$ Região.

96 O convênio permite o contato com: 1- a Rede de Documentação e Informação da Justiça do Trabalho (REDIJT) - composta das bibliotecas de todos os TRT do país; 2 - Grupo Infolegis (600 assinantes, sendo em sua maioria, bibliotecários juridicos) www.infolegis.com.br.

${ }_{97}$ Com crédito, mais uma vez, ao Dr. Vitor Greijal Sardas.

${ }^{98}$ UNIVERSIDADE DE ROMA. Disponível em: <http://www.giur.uniroma3.it/materiale/docenti/ zeno/materiale/3.26.pdf>.

${ }^{99}$ O mesmo será feito com os acórdãos franceses de 1889, 1932 e 1965 (todos cedidos pelo Dr. Daniel Amaral Carnaúba, mestre em Direito pela Universidade de Paris - Panthéon-Sorbonne e Doutorando em Direito pela Universidade de São Paulo e pela Universidade de Paris - Panthéon-Sorbonne), o acórdão inglês de 1911 e o acórdão brasileiro de 1991.

100 SAVI, Sérgio, SAVI, Sérgio. Responsabilidade Civil Por Perda De Uma Chance. São Paulo: Atlas, 2009 , p. 25. 
6.906 da Sessão Trabalhista ${ }^{101}$. Antonio di Rosa também atribui a primazia à mesma sentença ${ }^{102}$, e traz como uma das fontes o mesmo periódico em que a localizamos, a exemplo do que fazem Luca D’ Apollo ${ }^{103}$ e Maria Mangiatordi ${ }^{104}$.

O caso comentado envolvia Cardinale e outros v. STEFER e A.CO.TRA.L., e versava, basicamente, sobre os seguintes fatos: um grupo de trabalhadores, mediante requisição numérica obtida perante uma agência de colocação, havia sido aprovado nos testes iniciais para conquista do emprego de motorista, mas impedido, injustificadamente, de participar das provas subsequentes, de cultura elementar e guia.

O pretor de Roma (juiz de $1^{a}$ instância), em sentença de 27 de março de 1977, declarou o direito à contratação dos trabalhadores, com a condição de serem aprovados nos testes faltantes, e condenou a empresa ao ressarcimento do dano pela procrastinação no procedimento de admissão. $\mathrm{O}$ argumento foi construído a partir de um precedente que dizia que o candidato possuidor de uma requisição numérica era titular do direito subjetivo à realização de todas as provas, o que obrigava o empregador a recrutá-lo, em caso de aprovação, a menos que o empregado já tivesse trabalhado anteriormente para a empresa, e sido dispensado por justa causa ${ }^{105}$.

O Tribunal de Roma, mediante decisão prolatada em 24 de novembro de 1978, rejeitou a demanda relativa à reparação de danos ${ }^{106}$, mas confirmou a obrigação de a

101 ITÁLIA. Corte de Cassação. Sentença 6906. Julgado em 19 de novembro de 1983. Giustizia Civile. Rivista Mensile di Giurisprudenza, Milão, v. I, 1984, p. 1841-1843.

${ }^{102}$ Diz ele na nota 19: "In primis la sentenza emessa dalla Suprema Corte Di Cassazione sezione lavoro nel 19/11/1983 n 6906 pubblicata in Foro it, 1984, I 1830, e in Giustizia Civile, 1984, I 1841”. (ROSA, Antonio de. Il danno da perdita di chance. Disponível em: 〈http://studiogiuridico.it/tesi/chancebreve.htm>. Acesso em: 08 abr. 2011)

${ }^{103}$ D'APOLLO, Luca. Perdita di chance: danno risarcibile, onus probandi e criteri di liquidazione. Disponível em: 〈http://www.altalex.com/index.php?idnot=39075 >. Acesso em: 19 jan. 2011.

${ }^{104}$ MANGIATORDI, Maria. La perdita di chance non è una mera aspettativa. Rivista giuridica telemática, Bari, n. 2, p. 113-127, 2007, p. 120. Disponível em: <http://www.dirittodeilavori.it/n2-07/perditachance.pdf>. Acesso em: 08 abr. 2011.

${ }^{105}$ Conforme nota de Enrico Cappagli: "Nel caso, il pretore di Roma, con sentenza del 27 marzo 1977 (Giust. Civ. Rep. 1978, v. Danni, 72 e, per esteso, Resp. civ. prev. 1978, 304), sul presupposto che il lavoratore avviato dall'ufficio di colocamento in base a richiesta numérica è titolare di un dirrito soggetivo all'asunzione (mentre Pret. Roma 21 ottobre 1976, Foro it. 1976, I, 2630, in un caso símile, ha ritenuto $i$ lavoratori destinatari di una promessa al pubblico e, come tali, aventi diritto a sostenere le ulteriori prove) cui corrisponde l'obbligo del datore di perfezionare il contratto a meno che non si tratti di lavoratori da lui precedentemente licenziati per giusta causa, aveva dichiarato il diritto dei ricorrenti ad essere assunti a condizione del superamento della prova de guida e di cultura elementare ed aveva condannato l'azienda al risarcimento del dano per ritardo nella procedura di assunzione”. (CAPPAGLI, Enrico. Perdita de una chance e risarcibilità del danno per ritardo nella procedura di assunzione. Giustizia Civile. Rivista Mensile di Giurisprudenza, Milão, v. I, p. 1843-1846, 1984, p. 1844.)

${ }^{106}$ De acordo com o relatório da Corte de Cassação, a fundamentação do Tribunal de Roma foi no sentido de haver um dano meramente potencial: "Il tribunale ha sostenuto que non è risarcible il danno che gli appellati avrebbero subito, per non essere stati sottoposti alle ulteriori prove attitudinali propedeutiche 
empresa admitir os trabalhadores. Cinco deles recorreram à Corte de Cassação, insistindo na afirmação do direito ao ressarcimento do dano pelo atraso no procedimento admissional, sustentando que a recusa de a empresa submetê-los às provas ulteriores, necessárias à celebração do contrato, lhes havia privado não de um resultado útil, mas da possibilidade de consegui-lo.

Ao censurar a decisão recorrida, a Corte de Cassação resgatou o argumento do juiz de primeiro grau, acerca da existência de um direito subjetivo dos postulantes às vagas, salvo se já houvessem sido dispensados, daquela empresa, por justa causa. Por isso, tendo os concorrentes sido aprovados no exame de saúde, tinham o direito de fazer as provas de "ditado" e "aritmética", além do teste de "direção". A motivação axiológica desse argumento fundava-se na impessoalidade da contratação, no desejo de subtrair do empregador a escolha arbitrária, garantindo a ocupação precípua dos postos de trabalho pelos trabalhadores mais meritórios, livrando a classe operária da sujeição à discriminação ou aos sistemas de corrupção e clientelismo.

Houve um pronunciamento pontual acerca da mudança da titularidade na exploração da atividade, tendo a Corte estabelecido que, apesar da assunção do serviço de transportes da STEFER pela A.CO.TRA.L, permanecia a responsabilidade concorrente da primeira pelo inadimplemento a ela imputável.

Sobre a perda de uma chance, destacou-se que o conceito de perdas e de ganhos tratado no artigo 1.223 do Código Civil italiano não se referia apenas a uma entidade pecuniária, mas a qualquer entidade economicamente valorável. Naquele caso concreto, constituiu, para os julgadores, uma entidade patrimonial juridicamente tutelável a situação em que havia a probabilidade de se obter um benefício (no caso, o emprego). Quanto ao argumento de contrariedade (incerteza do dano), os juízes entenderam que a situação idônea a produzir apenas um ganho provável, e não um ganho certo, não influenciava na existência do dano, mas, apenas, na sua quantificação ${ }^{107}$.

all'assunzione, trattandosi di un danno meramente potenziale, non sicuramente dimostrato e, come tale, non suscetibile né di valutazione, né di liquidazione equitativa”. (ITÁLIA. Corte de Cassação. Sentença 6906. Julgado em 19 de novembro de 1983. Giustizia Civile. Rivista Mensile di Giurisprudenza, Milão, v. I, 1984, p. 1841-1843.)

${ }^{107}$ Esse ponto foi o destaque da decisão, compondo a ementa, que ficou assim cunhada: “Lavoro (rapporto di) - Collocamento al lavoro - Rifiuto dell'azienda di completare la procedura di assunzione - Perdita, da chance dei lavoratori, della possibilita di essere assunti - Danni - Risarcibilità - Fattispecie. (Cod. Civ., art. 1223, 1226, 1337, 2043). Poiché il concetto di perdita e di guadagno di cui all'art. 1223 c.c. si riferisce a qualsiasi utilità economicamente valutabile, è risarcibile il danno derivante dalla perdita di una chance, 
Outras importantes considerações foram tecidas ao longo do julgado. Acrescentouse que haveria fundamento para alegação de culpa in contrahendo, com violação ao artigo 1337 do Código Civil italiano, segundo o qual as partes devem se comportar conforme a boa-fé, tanto no desenvolvimento das tratativas quanto na formação do contrato $^{108}$. Também foi enfrentada a questão da dificuldade da indenização, com a conclusão de que o juiz deveria se valer da cláusula de estipulação equitativa ${ }^{109}$, prevista no artigo 1226.

Pouco tempo depois, a Corte de Cassação italiana teve a ocasião de confirmar seu posicionamento no caso Baroncini v. Enel, que tinha pontos de comunhão com o primeiro. Em 19 de dezembro de 1985, a Sessão Trabalhista da Suprema Corte assentava, na sentença 6.506, que "a possibilidade, efetiva e congruente, de conseguir certo bem, é considerada um bem patrimonial, econômica e juridicamente valorável, cuja perda produz um dano atual e ressarcível, sempre que ficar demonstrada a sua existência, ainda que segundo um grau de probabilidade ou por presunção, isto é, desde que possa ser demonstrada com certeza, ainda que relativa ${ }^{110}$, e não absoluta, mas, como tal, suficiente ${ }^{111,}$.

già existente nel patrimonio dei dipendenti al momento del comportamento illecito dell'azienda, ed idonea a produre anche solo probabilmente e non con assoluta certezza un determinato reddito (...).( Idem, p. 1841).

${ }^{108}$ Dispositivo bastante assemelhado ao artigo 422 do CCB, verbis: "Art. 422. Os contratantes são obrigados a guardar, assim na conclusão do contrato, como em sua execução, os princípios de probidade e boa-fé" (BRASIL. Código Civil (2002). Código Civil e Constituição Federal. 62. ed. São Paulo: Saraiva, 2011)

${ }^{109} \mathrm{O}$ que Enrico Cappagli observou que deveria redundar, de qualquer modo, em um valor inferior ao do resultado final: "Una volta dimostrata, nel caso di specie, l'esistenza di un danno, restava ancora di risolvere il problema del suo preciso ammontare; la Cassazione, rendendosi conto delle difficoltà, ha ritenuto possibili il ricorso al criterio equitativo 'ex' art. 1226 c.c.; ora è chiaro che, accettando la tesi secondo cui la perdita di una chance va considerata danno emergente in quanto sottrazione di una probabilità esistente nel momento in cui l'evento si è verificato, il risarcimento dovrebbe essere stabilito in mistura direttamente proporzionale al grado di probabilità che i lavoratori avevano di superare la prova; in ogni caso, tale risarcimento dovrebbe essere, di massima, inferiore a quello a cui i lavoratori avrebbero avuto diritto nell'ipotesi in cui loro diritto soggettivo, all'assunzione fosse stato perfetto, cioè non subordinato al superamento di ulteriori prove, altrimenti si arriverebbe alla conclusione contraddittoria di porre sullo stesso piano la situazione di lavoratori titolari di situazioni giuridiche soggettive caratterizzate dalla mera potenzialità del pregiudizio e quella di altri lavoratori che hanno subito la sicura lesione di un diritto soggettivo”.(CAPPAGLI, Enrico, op. cit., p. 1846.)

${ }^{110}$ A expressão "certeza relativa" traz em si contradição terminológica, pois a certeza é a qualidade daquilo que é certo, exato; de modo que toda certeza só pode ser "absoluta" $(a b=$ total + soluta = dissolvida de qualquer vínculo), o que torna sua expressão antônima: "certeza absoluta", um pleonasmo. Portanto, as adetivações feitas pela Suprema Corte ao substantivo "certeza" - absoluta e relativa - conduzem, ao menos na Língua Portuguesa, a armadilhas filológicas: a relativização da certeza a transforma numa incerteza e a absolutização da certeza é um pleonasmo vicioso.

${ }^{111}$ A ementa original ficou assim: "La probabilità, effettiva e congrua, di conseguire un certo bene è anch'essa un bene patrimoniale, economicamente e giuridicamente valutabile, la cui perdita produce un danno atuale e risarcibile qualora ne sia provata la sussistenza anche secondo un calcolo di probabilità o per presunzioni se, cioè, possa essere dimostrata con certezza pur soltanto relativa, e non assoluta, ma come tale sufficiente”. (ITÁLIA. Corte de Cassação. Sentença 6506. Julgado em 19 de dezembro de 1985. Rivista di Diritto Commune, v. II, 1986, p. 207) 
Neste segundo caso $^{112}$, o Sr. Baroncini havia feito, simultaneamente, a solicitação para participar de dois concursos organizados pela instituição: o primeiro, em 1976, concorrendo com o $\mathrm{n}^{\circ}$. 6, cujo vencedor seria enquadrado na categoria "C2" do contrato coletivo de trabalho; o outro, em 1977, com o $\mathrm{n}^{\circ}$. 47, para a função de ajudante de mecânico, lotado na zona de Larderello, enquadrado em uma categoria superior - "C1".

Pois bem, em 18 de dezembro de 1977, depois de ter logrado êxito na prova escrita e oral do concurso que disputava com o $\mathrm{n}^{\circ} .47$ (o de melhor salário), realizou a prova escrita do certame em que competia com o $\mathrm{n}^{\mathrm{o}}$. 6. Em 8 de fevereiro de 1978, foi declarado vencedor do concurso $n^{\circ} .47$, e, dois dias após, aprovado na prova escrita do concurso $n^{\circ}$ 6.

Em 16 de fevereiro de 1978, foi admitido para a categoria "C1" e fixado na região de Larderello. No dia 28 de março subsequente, foi convocado a comparecer ao departamento de pessoal, onde recebeu a notícia de que lhe era proibido participar da prova oral do concurso $\mathrm{n}^{\circ} 6$, prevista para 6 de abril daquele ano, porque já era empregado da Enel.

Ao final, em 27 de abril de 1978, o Sr. Baroncini se demitia do emprego por razões inerentes ao tipo de atribuições que lhe eram confiadas e por conta da distância da região de Larderello em relação à sua residência.

No dia 3 de junho de 1978, ele postulou, perante o pretor de Firenze, que a Enel fosse declarada obrigada a deixá-lo participar da prova oral do concurso $\mathrm{n}^{\circ}$. 6, para ser situado na região de Viza, sustentando a atualidade do seu interesse em participar do concurso e a ilegitimidade do processo de exclusão.

A Enel contestou o pleito, aduzindo que o Sr. Baroncini não tinha interesse jurídico em participar de outro certame, pois já havia vencido o concurso de categoria superior, com maiores estipêndios; além disso, argumentou que tal participação estaria vedada pelo artigo 20 do contrato coletivo da categoria.

O juiz, em sentença promulgada em 2 de agosto de 1978, acolheu a pretensão do autor, reputando ilegítima a sua exclusão da prova oral. Entretanto, o Tribunal de Firenze

\footnotetext{
112 Quem atribui a segunda colocação a esta decisão é Zeno-Zencovich: "La sentenza che si pubblica costituisce - a quanto consta - la seconda della Suprema Corte nella quale viene affrontato 'ex professo' il problema della c.d. perdita di una 'chance'. Essa conferma - sai pure con alcune differenze - il precedente, riconoscendo la risarcibilità del danno consistente nella perdita di una 'chance', qualificandolo come danno emergente”. (ZENO-ZENCOVICH, Vincenzo. Il danno per la perdita della possibilità di una utilità futura. Rivista di Diritto Commune, II, p. 213-219, 1986, p. 213 (nota a Cass. 19 dic. 1985, n. 6506)).
} 
deu provimento ao apelo da Enel, ao fundamento de que o exaurimento do iter do concurso tornava, então, impossível o adimplemento da obrigação de modo específico, mesmo que o comportamento do réu devesse ser considerado ilegal.

Contudo, o Tribunal observou, ainda, que o trabalhador poderia pedir a indenização do dano eventualmente sofrido por força de sua exclusão da prova oral.

Assim fez o Sr. Baroncini: ajuizou nova ação em 15 de novembro de 1983, postulando a condenação da Enel a ressarci-lo do dano sofrido em razão do ilícito praticado no concurso, a ser objeto de liquidação equitativa, sustentando que: em razão de sua ilegítima exclusão, fora privado da oportunidade de conseguir um resultado útil; que o dano era atual à época da prática do ato ilícito; que o dano não consistia na perda do resultado favorável, mas na possibilidade de consegui-lo; que a perda se revestia de indubitável valor econômico, porque ele aspirava aprovação no concurso nº 6 , e tinha interesse em avizinhar-se do emprego, evitando, assim, o desconforto e o maior custo que o impunha a lotação na zona de Larderello.

Mais uma vez, o pretor de Firenze, em julgamento datado de 7 de abril de 1982, acolheu sua reivindicação, condenando a Enel ao pagamento de dois milhões de liras e, do mesmo modo, a decisão foi reformada novamente pelo Tribunal de Firenze, sob a justificativa de que somente se poderia aquilatar que a exclusão trouxera consequências danosas caso o autor produzisse prova de que seria aprovado não fosse a exclusão. E o Tribunal concluiu que tal prova não fora produzida, nem ao menos de forma indireta, pois, dos 91 aprovados na prova escrita, 24 reprovaram na prova oral, o que tornava o dano, segundo a sua ótica, meramente hipotético.

No recurso dessa decisão, a primeira das duras alegações feitas pelo recorrente foi pela imposição de "prova diabólica", haja vista o Tribunal não ter esclarecido por qual meio poderia ele produzi-la, senão realizando o exame cuja participação fora obstada pela Enel $^{113}$. Note-se que a construção de Firenze viola o princípio de que o infrator não pode se beneficiar da própria torpeza, pois, se o fundamento da demanda era justamente o de que interrupção do curso natural dos eventos usurpara a fruição de um interesse aleatório, seria absurda a conclusão de que essa violação tivesse o condão de tornar incerto o dano e, por consequência, impossível a feitura de prova pelo ofendido.

113 ITÁLIA. Corte de Cassação. Sentença 6506. Julgado em 19 de dezembro de 1985. Rivista di Diritto Commune, v. II, 1986, p. 209-210. 
O autor havia, desde o início, pedido a reparação de um dano imediato e certo (a obliteração da chance de ser aprovado), e não um dano futuro e incerto (os benefícios pela vitória no concurso), e, portanto, o pedido e a causa de pedir não lhe impingiam a prova (impossível) da aprovação.

A segunda razão recursal, sobreposta à primeira, foi o Tribunal ter apreciado o pedido do autor como de ressarcimento de dano futuro - lucro cessante consistente na perda de um ganho futuro -, e não como um dano emergente, porque a conduta da Enel, após a superação da primeira prova, de proibir a sua participação nas demais, lesava um direito imediato, já que a chance já compunha o seu patrimônio ${ }^{114}$.

O terceiro fundamento recursal concernia ao montante do dano, pois a incerteza em relação ao quantum não excluía a sua ressarcibilidade, em face da possibilidade de avaliação equitativa, fulcrada em juízos de presunção, elementos indiciários e cálculos de probabilidade.

O quarto, também imbricado ao primeiro, dizia respeito à má fixação dos pontos sobre os quais deveria incidir a prova, cuja decisão era descompassada com o pedido e a causa petendi, na medida em que, se Baroncini não havia alegado que seria aprovado na prova oral, não tinha o ônus de prová-lo.

O último fundamento era meramente acessório, em razão da cominação ao pagamento das despesas processuais dos dois graus de jurisdição.

A Corte de Cassação, implacavelmente, censurou a decisão do Tribunal de Firenze, dizendo que os quatro argumentos eram fundados.

Fixou-se, como premissa inicial, que a base da pretensão ressarcitória se fundava na lesão de um direito subjetivo, o que reduzia à obsolescência o debate sobre se a injustiça do dano deveria residir na lesão de um direito ou se era bastante a lesão a um interesse juridicamente qualificado, pois a jurisprudência já vinha se encaminhando para o alargamento da área de ressarcibilidade.

Posteriormente, várias questões jurídicas foram pontuadas em recepção aos argumentos recursais: que se tratava de uma lesão patrimonial consistente na perda de

\footnotetext{
${ }^{114}$ Esse foi, sem dúvida, um dos pontos altos da decisão, em que, para encontrar a natureza jurídica da perda de uma chance, a Corte de Cassação operou o deslocamento temporal da análise, abandonando a miragem no futuro incerto (aprovação no concurso), e promovendo a análise do passado certo (existência de uma chance concreta).
} 
uma possibilidade e não na perda do resultado; que o dano era certo; que a prova exigível era da existência de um alto grau de probabilidade de êxito; que a natureza dessa "prova" era presuntiva; que a chance era uma entidade patrimonial economicamente dotada de valor; que o dano poderia ser quantificado equitativamente; que, para o cálculo da indenização, deveria ser aplicado um coeficiente de redução equivalente ao grau de probabilidade.

As diretrizes decisórias foram corretas e vanguardistas no contexto do julgado, pois, a par de representarem notório progresso na reparação do dano injusto, equacionavam vários dogmas retrógrados que obstaculizavam a tutela dos direitos dos ofendidos.

É extremamente compreensível, porque bem servia ao caso, que a Suprema Corte tenha estabelecido que "bastava" demonstrar um grau de probabilidade superior a $50 \%$ (cinquenta por cento), pois se partia de uma decisão de segunda instância em que, mesmo com a reprovação de apenas 24 dos 91 candidatos na prova oral (o que equivale a 73,62\% de aprovação, vale dizer, de chance estatística), o dano havia sido considerado hipotético.

Dentro daquela conjuntura histórica, portanto, a pré-fixação de um percentual de chances, em juízo prévio e abstrato, era aceitável e justificável, pois representava um gigantesco avanço se comparado à irreparabilidade de tal fattispecie de dano.

Hoje, todavia, tal exegese é um despropósito (como se verá no item 2.7.1 do capítulo 2).

Idêntica ilação pode ser feita quanto à categorização da perda de uma chance como dano exclusivamente patrimonial. Seu propósito era nitidamente pragmático: escapar da fluidez com que a chance era vislumbrada pela jurisprudência, como algo destituído de valor, mera expectativa de um ganho futuro e contingente. Foi uma verdadeira revolução, naquele cenário nefando, transmudar o ponto de observação, do resultado final, para a chance em si mesma, como integrante do patrimônio, entidade economicamente valorável.

A premissa, em princípio, é válida, até hoje, no que tange à natureza jurídica de dano emergente da perda de uma chance, porque há uma subtração de algo que já pertence à vítima (bem material ou imaterial). Equivocada, porém, é a conclusão de que tal proposição veda a reparação de eventual lesão exclusivamente moral ocasionada pela perda de uma oportunidade, o que será tratado no item 3.1.1 do capítulo 3. 


\subsection{O primeiro caso em um Tribunal Brasileiro (1991)}

Segundo o estudo realizado por Rafael Pettefi da Silva, as primeiras manifestações a respeito da perda de uma chance em domínios brasileiros ocorreram no Rio Grande do Sul, em acórdãos prolatados pelo então desembargador Ruy Rosado de Aguiar Junior. O autor afirma que o pioneirismo gaúcho na "aplicação consciente" da teoria deve-se a uma palestra proferida pelo professor François Chabas, em 23.05.1990, na Universidade Federal do Rio Grande do Sul, intitulada "La perte d'une chance en droit français" ${ }^{115 ” . ~ E ~}$ acrescenta que o jurista paranaense Miguel Kfouri Neto ratificou esse dado ${ }^{116}$.

Ainda de acordo com Silva, o protagonismo do Tribunal de Justiça ocorreu logo no início da década de 1990, e foi expresso por duas decisões, uma delas datada de 12 de

115 'Inquestionável a primazia do Tribunal de Justiça do Rio Grande do Sul na 'aplicação consciente' da teoria da perda de uma chance. Esse pioneirismo deve-se, com certeza, à brilhante palestra 'La perte d'une chance en droit français', proferida pelo professor François Chabas, em 23-5-1990, na Universidade Federal do Rio Grande do Sul, a convite do saudoso professor Clóvis do Couto e Silva. Ratificando o caráter pioneiro do tribunal gaúcho, tem-se a afirmação do magistrado paranaense Miguel Kfouri Neto". (SILVA, Rafael Pettefi da, Op. cit., p. 194, nota 17)

${ }^{116}$ De fato, há no sítio eletrônico do Tribunal de Justiça do Rio Grande do Sul, uma matéria de 07/04/2004, assinada por Marta Zanetti, com o seguinte conteúdo: "Consentimento formado é ponto central da responsabilidade civil médica. Dentre os conceitos que integram a responsabilidade civil médica, o consentimento formado, teoria fundamentada no art. 15 do Código Civil, é considerado o ponto fundamental da relação entre médico e paciente. A análise é do Juiz da $6^{\text {a }}$ Câmara Cível do Tribunal Alçada do Paraná, Miguel Kfouri Neto, em entrevista ao Programa Justiça Gaúcha, exibido ontem. De acordo com esta norma, o médico não pode submeter o paciente a qualquer tratamento que implique risco sem obter o consentimento deste, devendo explicar ao doente os perigos estatisticamente prováveis do procedimento. O ideal é obter do paciente uma autorização por escrito, afirma. Explica que o consentimento formado não serve de salvoconduto para os médicos ou para o hospital. O documento assinado não serve como garantia de que os procedimentos serão exitosos, ou de que o médico está afastado da culpa, diz. É um instrumento que permite um maior entendimento entre o clínico e o enfermo, evitando que um problema de relacionamento se encaminhe ao Judiciário. Em sua obra a 'Culpa médica e o ônus da prova', escrita em 2002, o Juiz Kfouri analisa como os magistrados decidem a responsabilidade do médico por dano causado, se agiu com intenção de provocar o prejuízo ou atuou com negligência, imperícia ou imprudência. Estudando o tema desde 1989, acredita na importância do diálogo entre médico e paciente. 'O médico não precisa dar um curso de medicina ao doente, mas deve dar uma explicação compatível ao grau de instrução dele. Em contrapartida, o paciente deve exigir todas as orientações possíveis, pois o principal sujeito é o paciente'. Segundo o julgador, o TJRS foi pioneiro na aplicação de outra teoria essencial ao campo da responsabilidade civil médica, a da 'perda de uma chance'. A idéia central é explicitar inconvenientes existentes na comprovação dos elementos formadores da responsabilidade subjetiva, enfatizando o resultado lesivo. Nesse sentido, nos casos em que é difícil a comprovação do nexo de causalidade entre o ato ou omissão culposos do médico e o dano experimentado pelo paciente, admite-se que a culpa está na perda de uma chance de cura ou sobrevivência. 'Os Juízes têm concedido uma indenização parcial que não corresponde ao prejuízo pela morte, mas pela chance de vida perdida'. Segundo Kfouri, desde a Constituição Federal de 1988, o brasileiro está cada vez menos condescendente com riscos e com lesões, buscando reparação aos danos causados pelo erro médico". (TRIBUNAL DE JUSTIÇA DO RIO GRANDE DO SUL. Notícias de 7 de abril de 2004. Consentimento formado é ponto central da responsabilidade civil médica. Disponível em: http://www1.tjrs.jus.br/site/ imprensa/noticias/\#../../system/modules/com.br.workroom.tjrs/elements/noticias \%20controller.jsp?acao=ler \&idNoticia $=22609$. Acesso em: 6 abr. 2011) 
junho de $1990^{117}$, em que foram fixados os pressupostos da teoria, mas apenas para rechaçar sua aplicação ao caso concreto, e outra, julgada em 29 de agosto de $1991^{118}$, aí sim, para acolhê-la e conceder a indenização com base nela.

O primeiro caso ${ }^{119}$ foi Leite v. Arroyo, em que a autora (Sra. Leite) se submeteu, em 21 de março de 1987, a uma cirurgia refrativa, denominada "ceratotomia radial", para correção de miopia em grau 4.00 no olho direito, que foi realizada pelo Dr. Arroyo (réu). Tratava-se de uma cirurgia eletiva, cujo objetivo era dispensar o uso de lentes corretivas.

Após a intervenção cirúrgica, a Sra. Leite teve sequela, qual fora uma hipermetropia com grau 2.00 no olho operado, imputando a culpa pelo agourento resultado ao Dr. Arroyo, e postulando o pagamento de indenizações.

Após a contestação do réu, a réplica da autora, a oitiva do perito, do assistente e a inquirição das partes e das testemunhas, o processo foi sentenciado, em 24 de agosto de 1989, pelo juiz Alcindo Gomes Bittencourt, da $3^{\text {a }}$ Vara Cível da Comarca de Porto Alegre/RS, que rejeitou os pedidos formulados pela autora, ao fundamento de ausência de culpa do réu no procedimento realizado.

Asseriu o juiz que "o laudo pericial realizado conclui pela ausência de comprovação de culpa por parte do réu, antes, durante ou depois da cirurgia, dizendo inexistir indícios de que tenha omitido cuidado indispensável recomendado pelas práticas médicas. Não comprovou a autora por outro lado, por alguma outra prova, tivesse o réu agido com culpa no evento". Na sentença, o juiz ainda rechaçou o argumento de responsabilidade objetiva, afirmando-o inaceitável, exceto se o Dr. Arroyo tivesse apregoado a infalibilidade do método (falha no dever de informação), o que não havia acontecido.

A Sra. Leite apelou da decisão, e o feito foi distribuído à $4^{\mathrm{a}}$ Câmara Civil de Porto Alegre/RS, sob a relatoria do então desembargador Ruy Rosado de Aguiar Junior, que abordou a questão sob outra ótica.

\footnotetext{
${ }^{117}$ No site do Tribunal de Justiça do Rio Grande do Sul, encontra-se disponível apenas a ementa do acórdão. (RIO GRANDE DO SUL. Tribunal de Justiça do Estado do Rio Grande do Sul, $5^{\text {a }}$ Câmara Cível. Apelação Cível 589069996. Relator: Ruy Rosado de Aguiar Júnior. Julgado em 12 de junho de 1990. Disponível em: <http://www1.tjrs.jus.br/busca/?tb=jurisnova>. Acesso em: 6 abr. 2011)

118 Do mesmo modo, é possível conseguir apenas a ementa do acórdão no sítio eletrônico do TJ/RS (RIO GRANDE DO SUL. Tribunal de Justiça do Estado do Rio Grande do Sul, 5 a Câmara Cível. Apelação Cível n 591064837. Relator: Ruy Rosado de Aguiar Júnior. Julgado em 29 de agosto de 1991. Disponível em <www.tjrs.jus.br>. Acesso em: 6 abr. 2011).

${ }^{119}$ A cópia dos dois processos nos foi cedida, de forma extremamente gentil e prestimosa, pela Sra. Luciane Baratto Adolfo, Arquivista Judicial do Tribunal de Justiça do Estado do Rio Grande do Sul.
} 
Inicialmente, foram relatadas as lesões funcionais que a Sra. Leite contraíra após a evolução clínica de seu quadro: 1 - névoa diante do olho direito; 2 - "anisometropia" de 6.00 graus (4.00 de miopia no olho esquerdo +2.00 de hipermetropia no olho direito), que é a diferença refratrométrica entre os dois olhos. Por conta desta segunda sequela, a autora não poderia corrigir o seu problema mediante o uso de óculos, pois o grau máximo tolerável para correção através deles é 5.00, já que, acima disso, o paciente passa a sofrer de "aniseiconia"120" (as imagens aparecem com diferenças de tamanhos). No caso específico da Sra. Leite, questões médicas pessoais impediam-na de ter uma boa adaptação às lentes de contato.

Após, transcritos trechos do laudo pericial em que eram fornecidos os elementos que deviam ser levados em conta quando da realização da intervenção: idade da paciente, pressão intra-ocular, curvatura da córnea, número de incisões e a profundidade relacionada ao grau a ser corrigido.

A partir desse quadro é que foi estabelecida a culpa do Sr. Arroyo: pela má avaliação dos dados pré-cirúrgicos, de consideração obrigatória. Isso porque, segundo o acórdão, o número e a profundidade das incisões fora incompatível com a situação da Sra. Leite, notadamente porque o médico sabia do risco de uma hipermetropia, e tinha a informação de que a paciente se contentava em reduzir, apenas, por metade, a miopia, o que obrigava o médico a tomar cautelas para evitar o resultado danoso.

Além disso, o julgado expungiu a tese de que a autora era a culpada pela desventura, por ter abandonado o acompanhamento médico dois meses após a operação, quando seriam necessários três meses para que fossem feitos os ajustes necessários à adequação do procedimento. E o argumento foi deveras sagaz: o relator observou que um resultado mais satisfatório poderia ter sido obtido por medicamentos aplicados para alterar a pressão intraocular e modificar a curvatura corneana. Todavia, o réu parou de ministrar colírios à autora decorridos 20 dias do ato cirúrgico, o que permitia lobrigar que ele não pretendia fazer uso da terapêutica correta para solucionar o problema.

\footnotetext{
${ }^{120}$ Conforme Ilvo Seidenfuz, citando Pickel, a "aniseiconia” é "a geração de uma imagem retiniana maior em um dos olhos devido à diferença no tamanho induzido pelas lentes de potências diferentes. (...)Em graus mais elevados de erro refrativo há a impossibilidade de fusão, advindo daí a visão alternante, na qual cada um dos dois olhos é usado de cada vez, principalmente se um olho for hipermetrópico e outro míope, ou a supressão, quando um olho for portador de uma ametropia mais elevada, tornando-se ambliópico. Pode redundar, também, em estrabismo, como consequiência da não estimulação da fóvea no olho que vê com emborronamento (ABRAMS, 1997)". (SEIDENFUZ, Ilvo. Anisometropia: neutralização dos efeitos com lentes de óculos. Disponível em:< http://www.croosp.org.br/TCC_Ilvo.pdf. $>$. Acesso em: 6 abr. 2011)
} 
O único registro do voto que tratou de perda de uma chance foi para fustigar sua aplicação, por ter ficado comprovado, no caso, o nexo causal entre o comportamento do réu e o dano sofrido pela Sra. Leite, nos seguintes termos:

\begin{abstract}
É preciso esclarecer, para efeito de cálculo da indenização, que não se trata de perda de uma chance, a que em certa passagem se referiu o apelante. Na perda da chance, não há laço de causalidade entre o resultado e a culpa do agente (François Chabas, 'La perte d'une chance en droit français' - palestra na Faculdade de Direito, 23.5.90: 'on remarque, dans ces affaires, les traits communs qui sont les caractéristiques du problème: 1. Une faute de l'agent. 2. Un enjeu total perdu et qui pourrait être le préjudice. 3. Une absence de preuve de lien de causalité entre la perte de cet enjeu et la faute, parce que, par définition, cet enjeu est aléatoire. C'est une caractéristique essentielle de la question'). Aqui houve nexo de causalidade entre o comportamento do réu e o dano sofrido pela paciente ${ }^{121}$.
\end{abstract}

Por esses fundamentos, o relator votou pelo provimento do apelo, para condenar o Sr. Arroyo a pagar a Sra. Leite: 1 - reembolso do valor despendido pela autora na cirurgia realizada pelo réu, e com os tratamentos a que se submeteu na sequência e, em consequência desta; 2 - despesas para operação do olho esquerdo, a fim de reduzir a miopia e, consequentemente, a hipermetropia; 3 - indenização pelo dano à saúde ${ }^{122}$. O voto foi acompanhado pelos desembargadores Lio Cezar Schmitt e Alfredo Guilherme Englert.

Os dados do processo ratificam o acerto da opinião de Rafael Peteffi da Silva ao atribuir o crédito à primeira menção à perda de uma chance à palestra do professor François Chabas: o acórdão foi lavrado em Porto Alegre/RS, mesmo local da palestra; o palestrante foi expressamente citado no acórdão e, finalmente, o julgamento ocorreu em 12 de junho de 1990, menos de um mês após a conferência.

121 RIO GRANDE DO SUL. Tribunal de Justiça do Estado do Rio Grande do Sul, 5ª Câmara Cível. Apelação Cível 589069996. Relator: Ruy Rosado de Aguiar Júnior. Julgado em 12 de junho de 1990.

${ }^{122}$ Em recurso da sentença de liquidação por arbitramento proferida pela juíza Marta Borges Ortiz, os desembargadores da Nona Câmara Civil do TJ/RS negaram provimento a ambos os apelos, e confirmaram a sentença de primeiro grau, que havia fixado em 70 salários mínimos a indenização por dano à saúde. (RIO GRANDE DO SUL, 9 ${ }^{a}$ Câmara Cível. Tribunal de Justiça do Estado do Rio Grande do Sul. Apelação Cível 70002978260. Relator: Paulo de Tarso Vieira Sanseverino. Julgado em 28 de dezembro 2001) 
Correta, também, a asserção de que este não pode ser reconhecido como a primeira manifestação brasileira de acolhimento da teoria, pois, embora assimilados os pressupostos, sua aplicação foi repudiada no caso, à míngua do preenchimento dos requisitos.

A primogenitura da adoção da perda de uma chance por um tribunal brasileiro ocorreu no caso Juchem v. Noé ${ }^{123}$, em que o primeiro, antigo advogado da segunda, havia ajuizado em 14 de agosto de 1975, ação em face do antigo INPS ${ }^{124}$ (hoje INSS), visando obter o benefício de pensão por falecimento de seu cônjuge, nos termos do artigo 67 do antigo regulamento de benefícios da Previdência Social. Não obstante tivesse sido efetivamente proposta, a demanda não foi recebida por nenhuma das Varas Cíveis da Comarca.

Em contestação, o réu alegou que nem sequer conhecia a autora, e que lembrava apenas de ter tentado, junto ao órgão previdenciário, obter esclarecimentos sobre o problema dela.

Todavia, a autora demonstrou documentalmente que a ação havia sido ajuizada e distribuída à $1^{\text {a }}$ Vara Cível da Comarca de Novo Hamburgo/RS. Ademais, restou demonstrado, na instrução processual, que a autora se fizera acompanhar de sua nora quando da outorga do mandato, no escritório do réu, e, passado algum tempo, o advogado foi constantemente procurado por familiares da Sra. Noé para prestar informações, sem êxito. Chegou-se ao cume de até um padre intervir a fim de obter mais esclarecimentos, e, em 1982, a autora buscar informes junto ao próprio Juiz de Direito.

O que ocorrera, de fato, fora o extravio dos autos, sem culpa identificada, porém com a subsequente inércia do advogado, que não informara sua constituinte da situação processual e nem tomara a providência cabível, que era postular a restauração dos autos, na forma da legislação processual civil.

Diante disso, o juiz Pedro Luiz Rodrigues Bossin, do Foro de Novo Hamburgo/RS, condenou o réu a pagar à autora os prejuízos causados, conforme apuração em liquidação de sentença, diante da negligência no exercício do mandato.

\footnotetext{
123 A íntegra do acórdão está no "anexo F" do presente trabalho.

124 INPS é a abreviação para o Instituto Nacional de Previdência Social, atualmente denominado INSS Instituto Nacional de Seguridade Social.
} 
Inconformado com a decisão, o Sr. Juchem recorreu ao Tribunal de Justiça do Estado do Rio Grande do Sul, sendo a apelação distribuída à Quinta Câmara Cível, novamente sob a relatoria do então desembargador Ruy Rosado de Aguiar Júnior. Ele concluiu, a partir das provas produzidas, que houve extravio dos autos e que o réu soube do ocorrido, mas não repassou a informação à cliente, tampouco diligenciou para sanar o problema, o que foi objeto de considerações acerca do descumprimento dos deveres do advogado ${ }^{125}$.

E ao tratar da perda de uma chance, mostrou solidez de fundamentação, ao refutar, com propriedade, os argumentos relativos à incerteza do êxito na demanda, verbis:

Não lhe imputo o fato do extravio, nem asseguro que a autora venceria a demanda, mas tenho por irrecusável que a omissão da informação do extravio e a não restauração dos autos causaram à autora a perda de uma chance e nisso reside o seu prejuízo. Como ensinou o Prof. François Chabas: 'Portanto, o prejuízo não é a perda da aposta (do resultado esperado), mas da chance de tentar alcançá-la ('La perte d'une chance en droit français', conferência na Faculdade de Direito da UFRGS, em 23.5.90). Por isso, não impressiona o argumento longamente expendido nas razões de recurso sobre a impossibilidade jurídica de a autora ver reconhecido seu direito à pensão previdenciária pela morte do marido, uma vez que esse não era segurado do Instituto. $\mathrm{O}$ argumento tem dois defeitos: em primeiro, mostra que o réu está agindo contra os próprios atos, isto é, tendo proposto ação fundada na alegação de um certo direito, não pode justificar sua omissão de informar e de diligenciar, lembrando a inexistência desse mesmo direito. A ninguém é dado 'venire contra factum proprium'; em segundo, porque a álea integra a responsabilidade

\footnotetext{
${ }^{125}$ Nos seguintes termos: "O advogado, na condição de mandatário do cliente para a prática dos atos em juízo, assume uma obrigação de meio, para cujo cumprimento deve dedicar toda a atenção, diligência e cuidado a fim de bem desempenhar o mandato recebido, sem responsabilizar-se, porém, pela obtenção de resultado favorável ao mandante. Para o cumprimento da sua prestação, deve empregar, a favor do cliente, os recursos permitidos pelo sistema jurídico e que estejam ao seu alcance, de acordo com as condições pessoais e as circunstâncias da causa. Entre esses deveres, decorrentes do contrato de mandato, encontram-se o de informar o cliente sobre a sua posição jurídica, possibilidade de êxito, andamento e tramitação do feito, propostas de acordo, resultados decisórios substanciais, oportunidade para recursos e suas expectativas, despesas processuais etc. Nesse contexto, o advogado que propõe uma ação e constata o extravio dos autos entre a distribuição e o cartório para o qual foi destinado, deve, em primeiro lugar, informar a parte do incidente havido e, em seguida, diligenciar para a restauração dos autos, na forma da lei processual civil. Deixando de adotar essas diligências, o advogado cerceou até hoje o direito de a mandante ver apreciado em juízo o seu pedido de pensionamento pelo Instituto Nacional de Previdência Social, direito derivado da morte do marido". (RIO GRANDE DO SUL. Tribunal de Justiça do Estado do Rio Grande do Sul, 5ª Câmara Cível. Apelação Cível 591064837. Relator: Ruy Rosado de Aguiar Júnior. Julgado em 29 de agosto de 1991)
} 
pela perda de uma chance. Se fosse certo o resultado, não haveria a aposta e não caberia invocar este princípio específico da perda da chance, dentro do instituto da responsabilidade civil $^{126}$.

A decisão prosseguiu no caminho da coerência quando, ao negar provimento ao apelo, esclareceu que, na fixação da indenização, deveria ser observado o fato de que o dano correspondia apenas à perda da chance. A decisão foi proclamada unânime, porque o voto do relator foi acompanhado pelos desembargadores Sergio Pilla da Silva e Alfredo Guilherme Englert.

\subsubsection{A sinalização ambígua do STJ (1990)}

De acordo com o histórico traçado no tópico precedente, as primeiras manifestações sobre a perda de uma chance em um tribunal brasileiro ocorreram no início da década de 1990, no Tribunal de Justiça do Estado do Rio Grande do Sul/RS, ambas acolhendo, em abstrato, os fundamentos da teoria, mas, a primeira, afastando sua aplicabilidade, em concreto, porque presentes os pressupostos para que o réu respondesse pela totalidade do dano correspondente ao resultado final, e a segunda, cerca de um ano após, utilizando integralmente os seus critérios para compor o montante indenizatório.

Poder-se-ia opor, contudo, que, nesse intervalo (12 de junho de 1990 e 29 de agosto de 1991), foi prolatada uma decisão abstratamente favorável à aplicação da teoria das oportunidades perdidas no Superior Tribunal de Justiça.

Trata-se de um dado que exige maior reflexão.

Houve, de fato, uma manifestação intersticial sobre o assunto em 10 de outubro de $1990^{127}$. Entretanto, o julgamento carece de precisão científica para que se possa afirmar, de modo categórico, se a Corte, naquele momento, adotaria ou não a teoria da perda de uma chance.

\footnotetext{
${ }^{126}$ Idem.

${ }^{127}$ BRASIL. Superior Tribunal de Justiça, $2^{\text {a }}$ Turma. Agravo Regimental no Agravo 4364/SP (90.057884). Relator: Ministro Ilmar Galvão. Julgado em 10 de outubro de 1990. Disponível em: <https://ww2.stj.jus.br/processo/ita/listarAcordaos?classe=\&num_processo=\&num_registro=199000057884 $\underline{\& d t \_p u b l i c a c a o=29 / 10 / 1990}>$. Acesso em: 10 maio 2010.
} 
O caso versava sobre uma empresa do ramo petrolífero que reclamava haver sido vítima da supressão ilícita da possibilidade de lucro, consistente na ausência de licitação para a implantação de postos de combustíveis ao longo de determinada rodovia, o que lhe extirpara a chance de concorrer no certame licitatório e, eventualmente, sagrar-se vitoriosa e proceder à exploração da atividade naquele nicho de mercado.

O início do voto é desolador. O relator qualifica a chance como "mera expectativa de fato" e aduz que o prejuízo é "meramente hipotético, imaginário, suposto", lembrando as vetustas decisões francesas do final do século XIX e do início do século XX, sinalizando que a Corte iria, às portas do século XXI, repetir um argumento já completamente superado em domínios alienígenas. Confira-se, a propósito, o trecho exordial do arrazoado:

Com efeito, como se viu, sustenta a Agravante que a autorização de implantação de postos de abastecimento ao longo da rodovia haveria de ser precedida de licitação. Admitido, entretanto, que tivesse condições de participar do certame, possuía ela, então, mera expectativa de fato em relação ao lucro produzido pelos postos de serviço em referência, isto é, mera esperança de vir e adquirir um direito, que não rende direito a indenização. O prejuízo indenizável deve ser certo, como o que seria sofrido pela Agravante se já houvesse vencido a licitação. Nas condições descritas nos autos, o alegado prejuízo é meramente hipotético, imaginário, suposto (cf. CUNHA GONÇALVES, Tratado, Vol. XII, Tomo II, pág. 530), não se compreendendo no comando do art. 1.059, do Código Civil.

Parecia, dessa forma, cristalina a convicção do STJ pela irreparabilidade das chances, por nela não vislumbrar uma entidade já componente do patrimônio, dotada de valor econômico. Note-se que a Corte caiu no mesmo equívoco da decisão censurada pela Corte de Cassação italiana em 1985 (capítulo 1, item 1.3), qual fora exigir a produção de "prova diabólica" pela vítima. Ora, se a causa de pedir era justamente a ausência de licitação para a exploração da atividade econômica, é um despautério que a decisão sustente a incerteza do dano, ao argumento de que a certeza só viria com a vitória na licitação que não existiu.

Todavia, de modo contraditório, o voto prossegue, asserindo que a chance pode ter 
valor econômico, verbis:

Por fim, esclareça-se, para melhor entendimento, que, ao aventar o despacho agravado a possibilidade de indenização de mera chance, por si só, quis referir hipótese em que essa chance, por si só, apresenta valor econômico, como é o caso do exercício do direito de ação. Como se sabe, não são raras as cessões de direito de ação, o que se trata de mera chance com valor econômico. Frustrada a chance de vencer, por culpa do advogado, é inegável que remanesce um direito de ressarcimento, que se restringe, entretanto, ao simples valor pago pela cessão, e não pelo resultado da causa. No caso dos autos, conforme se afirmou no despacho em referência, não ficou demonstrado que a mera possibilidade de concorrer na licitação dos postos, caso houvesse sido aberta, possuía algum valor econômico, razão pela qual não se pode sequer falar em indenização do direito de concorrer, o que é o mesmo dizer, em indenização de mera chance.

Assim, de maneira diametralmente oposta, a Corte aparenta reconhecer o valor econômico da chance em si mesma, ilustrando-a com o bom exemplo da cessão do direito de ação e, ainda, corretamente, que a indenização em caso de perda da causa, por culpa do advogado, não poderia ser equivalente ao valor da causa. Contudo, enxerga uma diferença, de todo inexistente, entre a chance de vencer em uma demanda judicial e a chance de vencer em um procedimento licitatório, o que padece de fundamento jurídico ${ }^{128}$.

Diante disso, à míngua de uma coerência interna que permita aquilatar a aquiescência à teoria da perda de uma chance, os registros mais remotos continuam a ser, até que o contrário se prove, os julgados do Tribunal de Justiça do Estado do Rio Grande do Sul.

\footnotetext{
${ }^{128}$ Conforme observado por Rafael Pettefi da Silva, ao comentar a decisão: "Entretanto, parece carecedora de fundamentação a diferenciação entre a chance de vencer uma demanda judicial e a chance de vencer uma licitação, sendo o valor econômico da segunda tão evidente como o da primeira. Aliás, a licitação pública guarda caracterísitcas semelhantes aos concursos públicos, sendo ambos exemplos de processos aleatórios". (SILVA, Rafael Pettefi da, op. cit., p. 197)
} 


\section{CAPÍTULO 2 - NOÇÕES PROPEDÊUTICAS}

\subsection{Terminologia}

Embora extremamente difundida, tanto nos ordenamentos de origem germânicoromana quanto nos anglo-saxônicos, a expressão "perda de uma chance" não desfruta de aprovação unânime entre os doutrinadores, mas, quando muito, resignação por parte de alguns.

Sérgio Savi assevera que seria mais técnico falar em "oportunidade" em vez de “chance", pois “[...] o termo 'chance' utilizado pelos franceses significa, em sentido jurídico, a probabilidade de obter um lucro ou de evitar uma perda. No vernáculo, a melhor tradução para o termo 'chance' seria, em nosso sentir, "oportunidade ${ }^{129, "}$.

No mesmo diapasão, Grácia Cristina Moreira do Rosário aduz que “em França, berço da teoria, a doutrina e a jurisprudência empregam a expressão - perda de uma chance -, e na língua portuguesa a locução exata seria a perda de oportunidade. Todavia, a expressão utilizada nesse trabalho será a usualmente conhecida: a perda da chance de cura ${ }^{130,}$.

Já Sérgio Novais Dias aponta que:

Chance é a palavra de origem francesa que significa entre nós 'ocasião favorável, oportunidade' (cf. Novo Dicionário Aurélio da Língua Portuguesa). Embora raras as manifestações doutrinária e jurisprudencial em derredor desse tema, quando dele se ocupam, utilizam a expressão perda de uma chance para referir-se, no tocante à atividade do advogado, à perda de oportunidade que o cliente sofre, causada por falha daquele profissional, de ver reexaminada em juízo uma pretensão ou de ver reformada em seu favor uma decisão judicial que lhe foi desfavorável e contra a qual cabia recurso. Porque utilizada pelos que cuidam

\footnotetext{
${ }^{129}$ SAVI, Sérgio. Responsabilidade Civil Por Perda De Uma Chance. São Paulo: Atlas, 2009, p. 3.

${ }^{130}$ ROSÁRIO, Grácia Cristina Moreira do, op. cit., p. 7.
} 
especificamente do tema e por identificar, com precisão, a situação jurídica sob exame, adotamos aqui a expressão ${ }^{131}$.

Na Espanha, o termo se popularizou como "pérdida de oportunidades", ao ponto de Mariano Yzquierdo Tolsada criticar o que denomina "galicismo argentino", pelo fato de eles (os argentinos) terem optado pela tradução literal ao empregarem a expressão "pérdida de una chance ${ }^{132, "}$

Nos demais países pesquisados, não foram encontradas resistências à utilização da expressão "perda de uma chance ${ }^{133}$ ", sem embargo do forte apego às tradições léxicas de alguns deles, como os Estados Unidos da América e o Reino Unido, que usam "loss of a chance"; Portugal, que adota quase idêntica expressão à consagrada no Brasil (perda de chance); a Itália, que emprega a expressão "perdita di chance”; e, como mencionado alhures, os próprios argentinos, que adotam o termo "pérdida de una chance".

Apesar da recalcitrância de uma significativa parcela da doutrina brasileira, a utilização da palavra "chance" não implica francesismo, galicismo ou mesmo uma forma menos técnica de se referir à expressão "oportunidade", pois as expressões são sinônimas no vernáculo, conforme denunciam os dicionários da Língua Portuguesa 134135136 .

Até porque o âmbito jurídico-semântico da palavra "chance" remonta ao direito romano, e deriva da expressão latina "cadência", a qual, por sua vez, quer indicar a "queda dos dados", como indicação da álea inerente à boa possibilidade de êxito ${ }^{137}$. No mesmo

${ }^{131}$ DIAS, Sérgio Novais. Responsabilidade civil do advogado: perda de uma chance. São Paulo: LTr, 1999, p. $14-15$.

${ }^{132}$ TOLSADA, Mariano Yzquierdo. Sistema de Responsabilidad Civil, Contractual y Extracontractual. Madri: Dykinson, 2001, p. 152.

${ }^{133}$ Embora, como se verá ao longo deste trabalho, tanto a jurisprudência quanto a doutrina dos países de tradição germânico-romana, por vezes se utilizam também da expressão "perda de oportunidades".

134 “Chance. (Fr.) Substantivo feminino. 1.Ocasião favorável, oportunidade”. (FERREIRA, Aurélio Buarque de Holanda. Novo Dicionário Eletrônico Versão 5.0. Correspondente à 3 ed. $1^{\text {a }}$. impressão da Editora Positivo, rev. e atual. do Aurélio Século XXI, O Dicionário da Língua Portuguesa, 2004. 1 CD-ROM)

135 “Chance. S.f. (pal. fr.). Sorte, acaso./ Oportunidade. (KOOGAN, Abrahão; HOUAISS, Antônio. Enciclopédia e Dicionário Ilustrado. Rio de Janeiro: Edições Delta, 1997, p. 185)

136 "chance. chan.ce. sf. (fr. chance) 1 Acaso favorável. 2 Oportunidade; ensejo. (MICHAELIS. Moderno Dicionário da Língua Portuguesa. São Paulo: Editora Melhoramentos Ltda., 1998-2007. Disponível em: <http://michaelis.uol.com.br/moderno/portugues/index.php?lingua=portugues-portugues\&palavra=chance $>$. Acesso em: 14 fev. 2011)

${ }^{137}$ Como ressalta a doutrina italiana: "L'ambito semantico-giuridico del termine chance, è da ricondurre al diritto romano. La parola chance deriva, etimologicamente, dall'espressione latina cadentia, che sta ad indicare il cadere dei dadi, e significa "buona probabilità di riuscita”. Si tratta, dunque, di una situazione, teleologicamente orientata verso il conseguimento di un'utilità o di un vantaggio e caratterizzata da una possibilità di successo presumibilmente non priva di consistenza”. (D’APOLLO, Luca. Perdita di chance: 
senso, sustentam os franceses que o termo chance, etimologicamente, advém de "choir", que significa cair - também em referência aos dados -, como emblemática do acaso; mas, acrescentam que, no plural, o termo se torna sinônimo de "probabilidades ${ }^{138, "}$

Ademais, a expressão é auto-explicativa, de fácil assimilação e com a vantagem de representar o nomem juris mais consentâneo com a majoritária doutrina e jurisprudência internacionais, o que deveras contribui para a facilidade das pesquisas e estudos no direito comparado.

\subsection{Refutação da teoria}

Malgrado a teoria da "perda de uma chance" goze de boa dose de aceitação em grande parte dos ordenamentos jurídicos ${ }^{139}$, e o debate doutrinário acerca de sua possibilidade possua registros que remontam ao primeiro quarto do século $\mathrm{XX}$, houve, e, de fato, ainda há, alguma resistência nos alfarrábios e até mesmo em obras e decisões mais recentes, cuja importância é fulcral, a fim de aprimorar os estudos no sentido de se chegar a uma correta sistematização do tema.

Colhe-se, da doutrina italiana mais remota, forte oposição à aceitação da perda de uma chance, uma vez que esta provocaria apenas a perda de uma possibilidade, uma mera chance aleatória, impossível de ser indenizada, em face do caráter incerto do dano.

De acordo com o escólio de Giovanni Pacchioni, a possibilidade de atingir um resultado útil apresentava, tão somente, um valor social, ainda que relevante, mas privado da conexão material requerida pelo artigo 1.223 do Código Civil italiano, que exige, para o

\footnotetext{
danno risarcibile, onus probandi e criteri di liquidazione. Disponível em: < http://www.altalex.com/index.php ?idnot=39075>. Acesso em: 19 jan. 2011.)

138 “'Chance' provient de choir, cadere, cadentia: c'est initialement la chute des dés, le nombre de points qu'ils marquent en 'chéant' sur la table. Et le Dictionnaire de l'Académie de 1778 définissait encore la chance comme une sorte de jeu de dés. 'Hasard' aurait, à en croire Guillaume de Tyr, approuvé par Littré, une origine semblable, désignant um jeu de dés invente par les croisés lors du très long siège de la forteresse de Hasart en Syrie. (...) Le mot 'chance' voit en effet sa signification se transformer lorsqu'il est employé au pluriel. Il devient alors l'équivalent de 'probabilité'. Théorie des chances et calcul de probabilités son des expressions synonymes: la probabilité d'un événement, c'est le nombre des chances qu'il a de se produire”. (BÉNABENT, Alain. La chance et le Droit. Paris: LGDJ, 1973, p. 5-7)

139 Boa e, em grande parte, porém, não unânime. De acordo com a pesquisa de Graziano, em pelo menos 12 países europeus o instituto é desconhecido ou foi rejeitado. Ele coloca a Alemanha, a Áustria, a Suíça e a Grécia nesta última categoria. E, dentre os países que ainda não abordaram a perda de uma chance, foram catalogados a Hungria, República Tcheca, Eslovênia, Estônia, Dinamarca, Suécia, Noruega e Finlândia. (GRAZIANO, Kadner. Loss of a chance in European Private Law - "all or nothing" or parcial liability in cases of uncertain causation. European review of private Law, Londres, v. 16, n. 6, 2008, p. 1022)
} 
ressarcimento do dano, um nexo de causalidade certo entre a conduta e o evento. Desse modo, em sua análise, não havia a certeza de que o sujeito, sem o evento danoso, conseguiria o resultado útil desejado, o que evidenciava que a chance não podia ser indenizada, pois ela assumia um caractere de dano prospectivo e incerto ${ }^{140}$.

Francesco Busnelli compartilhava da mesma linha argumentativa, afirmando não ser possível indenizar a perda de uma chance por se tratar de um dano futuro e incerto, sem o nexo causal, exigido pelo artigo 1223 do Código Civil italiano, entre a conduta e o evento danoso. Portanto, segundo ele, era extremamente árduo demonstrar a existência do próprio dano, porque se trata de uma mera expectativa de fato e, consequentemente, não é certo que o evento se verifique, atingindo um resultado útil ${ }^{141}$.

Em Portugal, num contexto muito mais contemporâneo, verifica-se que o Supremo Tribunal de Justiça, apesar de acolher, em tese, a teoria da perda de chance, refuta-a em sua essência. Foi o que sucedeu quando a Corte negou pedido de reparação em face de advogado negligente que interpôs recurso deserto, ao fundamento de ser aleatório o resultado do recurso, conforme se verifica do seguinte acórdão:

8) A perda de chance não se confunde com perda de expectativa, já que aqui há uma esperança de um direito, por se ter percorrido um 'iter' que a ele conduziria com forte probabilidade. Trata-se de situação dogmatizada na responsabilidade pré-contratual. 9) Na perda de chance, ou de oportunidade, verificou-se uma situação omissiva que, a não ter ocorrido, poderia razoavelmente propiciar ao lesado uma situação jurídica vantajosa. 10) Trata-se de imaginar ou prever a situação que ocorreria sem o desvio fortuito não podendo constituir um dano presente

\footnotetext{
140 "La possibilità di raggiungere un risultato utile (rectius la chance) presentava solo un valore sociale magari anche notevole ma essendo priva del collegamento materiale richiesto dall'art. 1223 del cod. civil quale richiede per il risarcimento del danno un collegamento certo tra la condotta e l'evento. In questo modo, non esistendo la certezza che il soggetto, senza l'evento dannoso, avrebbe potuto conseguire il risultato utile. Da ciò, si evince, che la chance, non può essere risarcita proprio perché è priva di detto collegamento espresso dalla norma o meglio non appare dimostrabile che il risultato si sarebbe potuto raggiungere in questo modo la chance assume una prospettiva di danno futuro proprio perché manca la prova che la condotta del soggetto agente, abbia causato la perdita della possibilità di conseguire il risultato utile”. (PACCHIONI, Giovani. Delitti e quasi delitti, in Diritto civile italiano. Padova: Cedam, 1940, v. IV, p. 111)

${ }^{141}$ No original: "Non è possibile risarcire la perdita di chance perché si tratta di un danno futuro ed incerto privo del collegamento richiesto dall'art. 1223 del codice civile tra condotta ed evento dannoso pertanto, è assai arduo dimostrare l'esistenza del danno proprio perché si tratta di una mera aspettativa di fatto futura e quindi non è certo il verificarsi dell'evento inteso come può essere il raggiungimento di un risultato utile”. (BUSNELLI, Francesco Donato. Diritto e Obbligazioni. Torino: 1989, v. III, p. 729).
} 
(imediato ou mediato) nem um dano futuro (por ser eventual ou hipotético) só relevando se provado que o lesado obteria o direito não fora a chance perdida. 11) Se um recurso não foi alegado, e em consequência ficou deserto, não pode afirmar-se ter havido dano de perda de oportunidade, pois não é demonstrada a causalidade já que o resultado do recurso é sempre aleatório por depender das opções jurídicas, doutrinárias e jurisprudenciais dos julgadores chamados a reapreciar a causa ${ }^{142}$.

No Brasil, Carvalho Santos, ao examinar a possibilidade de êxito na ação de indenização movida em face de advogado negligente em seu dever de interpor recurso cabível contra sentença desfavorável, sustenta que "parece duvidoso o direito do constituinte, de poder exigir qualquer indenização, precisamente porque não lhe será possível provar que a sentença seria efetivamente reformada ${ }^{143,}$,

Hoje em dia, porém, o cenário é bastante diverso ${ }^{144}$, com ampla aceitação doutrinária. Cabe registrar, todavia, que, na presente pesquisa, ainda aparece o posicionamento, bastante minoritário, de Rui Stoco, segundo o qual a aplicação da teoria da perda de uma chance, nos casos de responsabilidade civil do advogado, é algo inaceitável $^{145}$, pois, para ele, "admitir a possibilidade de o cliente obter reparação por perda de uma chance é o mesmo que aceitar ou presumir que essa chance de ver a ação julgada conduzirá, obrigatoriamente, a uma decisão favorável a ele ${ }^{146, "}$.

\footnotetext{
${ }^{142}$ PORTUGAL. Supremo Tribunal de Justiça, $1^{\text {a }}$ Seção. Revista 2622/07.0TBPNF.P1.S1. Relator: Sebastião Povoas. Julgado em 29 de abril de 2010. Disponível em: 〈http://www.stj.pt/?idm=546>. Acesso em 8 set. 2010.

${ }^{143}$ CARVAlHO SANTOS, J. M. Código Civil Brasileiro Interpretado. São Paulo: Livraria Freitas Bastos, 1956, v. 21, p. 321-322.

${ }^{144}$ Embora ainda haja alguns focos de resistência. No TJ/SE, v.g., foi negada a indenização pela perda de uma chance pela exclusão ilegal da participação de um policial militar do curso de aperfeiçoamento, porque não havia a "certeza" de que ele seria aprovado no curso: "[...] No caso dos autos, não há que se falar em indenização por danos morais pela perda de uma chance, vez que, apesar de ilegal o ato que excluiu o autor do curso de aperfeiçoamento, ele não teve o condão de gerar a frustração de uma real oportunidade ou de chance vantajosa de algo concretizável, já que havia apenas a expectativa, e não a certeza, de aprovação, além de não restar comprovado que a conclusão do mesmo resultaria em benefício pecuniário para o autor; IV- Recurso conhecido em parte, e, na parte conhecida, parcialmente provido". (SERGIPE. Tribunal de Justiça do Estado de Sergipe, $2^{a}$ Câmara Cível. Apelação Cível 2010203140 - (4015/2010). Relator: Marilza Maynard Salgado de Carvalho. Diário da Justiça eletrônico, 11 maio 2010, p. 47. (Sem grifos no texto original).

${ }^{145}$ STOCO, Rui. Tratado de Responsabilidade Civil. 7. ed. São Paulo: RT, 2007, p. 512.

${ }^{146}$ STOCO, Rui. Responsabilidade civil do advogado à luz das recentes alterações legislativas. In: LEITE, Eduardo de Oliveira (Coord.). Grandes temas da atualidade: responsabilidade civil. Rio de Janeiro: Forense, 2006, v. 6, p. 512.
} 


\subsection{Consolidação da teoria}

Os argumentos que vergastavam o acolhimento da perda de uma chance restaram superados, na medida em que continham equívocos na premissa e no elemento cronológico a ser examinado. Isso porque, quando eles investigaram a propalada "certeza" do prejuízo na perda de uma chance, lançaram seus olhares para um futuro hipotético (v.g.: o êxito no recurso cuja interposição foi negligenciada, a vitória do jóquei no páreo que não pode concorrer etc.), quando deveriam ter operado um deslocamento temporal em suas análises, para mirar um passado certo, no qual constava uma chance que já compunha a esfera de bens - patrimoniais ou extrapatrimoniais - da "vítima", e que poderia ser valorada, sendo, portanto, passível de indenização, ainda que de cunho exclusivamente moral, como se verá mais adiante.

Ninguém questiona o requisito da "certeza" como imperioso à indenização, pois, consoante os dizeres de Lalou, "Le préjudice, avons-nous-dit, doit être non seulement actuel, mais certain. La privation d'une resource à laquelle dans l'avenir ou aurait pu avoir recours ou d'une chance de gain que l'on pouvait courir constitue un préjudice certain $^{147,}$.

Contudo, na perda da chance, o dano consistente no resultado final é, por definição, indemonstrável $^{148}$, porquanto a interrupção do curso normal dos fatos em decorrência de um ato ilícito impede que os acontecimentos cheguem ao seu termo. Mas a obliteração da chance, por ser um ato ilícito, pode gerar dano, seja ele patrimonial ou extrapatrimonial, pois ela possui um valor intrínseco inquestionável.

Indefectível o argumento de Geneviève Viney quando diz que "en effet, à bien des points de vue, le droit reconnaît une valeur certaine à l'existence de la chance.

\footnotetext{
${ }^{147}$ LALOU, Henri, op. cit., p. 78.

${ }^{148}$ Foi o que afirmou, recentemente, a Corte de Cassação Francesa: "Action civile. Préjudice. - Préjudice certain. - Perte d'une chance. - Définition. Dans des poursuites contre deux médecins du chef d'homicide involontaire, la juridiction répressive, qui a relaxé les prévenus au motif que le lien de causalité entre les fautes et le décès n'était pas établi avec certitude, ne peut débouter les parties civiles de leur demande de réparation en application des règles du droit civil au motif que, si les fautes des prévenus ont probablement fait perdre une chance de survie à la victime, il n'existe aucune certitude à cet égard, dès lors que la réalisation d'une chance n'est, par définition, jamais certaine”. (FRANÇA. Corte de Cassação. Crim. - 3 de novembro de 2010. Cassação 09-87.375. CA Versailles, 15 setembro de 2009. Disponível em: <http://www.courdecassation.fr/IMG/pdf/Bicc_737.pdf>. Acesso em 26 fev. 2011)
} 
Notamment, Il n'a jamais été contesté qu'un billet de loterie (qui n'est rien d'autre qu'un titre représentatif d'une chance) peut être vendu contre un prix ${ }^{149, "}$

Ora, se ninguém contesta o valor econômico de um bilhete de loteria, que até o sorteio é mero título representativo de uma chance e, após, ou um título representativo da totalidade do prêmio (no caso de êxito) ou algo absolutamente destituído de valor econômico (na hipótese de insucesso), não há como negar que a destruição da possibilidade de fruir uma determinada vantagem não tenha um caráter de certeza. Certeza em relação à própria chance, e, incerteza, somente em relação ao resultado ou dano final ${ }^{150}$.

Portanto, há certeza de dano sempre que, por força do ato ilícito praticado que interrompeu o curso dos acontecimentos, a vítima fique em situação inferior àquela em que se apresentava anteriormente.

A dificuldade de encontrar parâmetros confiáveis para indenização, que muitas vezes é real e será tratada em tópico específico, jamais pode ser invocada como escusa para deixar de indenizar, sob pena de o instituto da responsabilidade civil retroceder ao tempo em que o dano moral ${ }^{151}$, v.g., não era reparado ao argumento da impossibilidade de precificar a pretium doloris ${ }^{152}$, o que jamais poderá ser feito, pois, conforme preciosa lição de Aguiar Dias, "a condição de impossibilidade matematicamente exata da avaliação só pode ser tomada em benefício da vítima e não em seu prejuízo ${ }^{153}$ ".

\footnotetext{
${ }^{149}$ VINEY, Gineviève; JOURDAIN, Patrice, op. cit., p. 90.

${ }^{150}$ A doutrina argentina também não hesita ao afirmar: "Si bien lo que daría al daño el carácter de eventual sería la probabilidad de obtener la ganancia o de evitar el perjuicio, hay, por otra parte, una circunstancia cierta: la 'oportunidad' de obtener la ganancia o de evitarse el perjuicio, y esa oportunidad cierta se ha perdido por el hecho de un tercero, o a causa de la inejecución de la obligación por el deudor. Si la probabilidad hubiese tenido bastante fundamento, la pérdida de elle debe indemnizarse" (ALSINA, Jorge Bustamante. Teoría General de la Responsabilidad Civil. 9. ed. aum. e atual. Buenos Aires: AbeledoPerrot, 1997, p. 179)

${ }^{151} \mathrm{O}$ entendimento da impossibilidade de indenização do dano moral chegou a ser consolidado pela Suprema Corte brasileira antes da Constituição Federal de 1988. Vide: BRASIL. Supremo Tribunal Federal, $2^{\mathrm{a}}$ Turma. Recurso Extraordinário 29447. Relator: Min. Afrânio Costa. Julgamento em 25 de novembro de 1958. Disponível em: 〈www.stf.jus.br.com.br>. Acesso em: 26 fev. 2011.

${ }^{152}$ Sobre tal aspecto, em particular, o professor Antonio Junqueira de Azevedo comenta os casos em que nem sequer se pode falar em pretium doloris, mas que, indubitavelmente, há dano moral: "Em geral, esse dano moral será um dano de sofrimento, daí se falar em 'pretium doloris', mas algumas vezes haverá também dano moral que foge a essa caracterização, porque se trata de dano - e basta pensar nas pessoas jurídicas, ou nas pessoas físicas que não têm condições de discernimento, ou ainda nos nascituros - que representam algum prejuízo não avaliável economicamente de modo exato. (Observamos entre parêntesis que, se não fosse isso, os velhos argumentos de que o dano moral não deve ser pago em dinheiro e sim, conduzir a uma restauração do status quo anterior ao ato lesivo por meios também morais, não poderiam ser desprezados)". (AZEVEDO, Antonio Junqueira de. Novos Estudos e Pareceres de Direito Privado: por uma nova categoria de dano na responsabilidade civil: o dano social. 1. ed. São Paulo: Saraiva, 2010, p. 378)

${ }^{153}$ AGUIAR DIAS, José de. Da Responsabilidade Civil. 4. ed. Rio de Janeiro: Forense, 1960, v. 2, p. 777.
} 
Finalmente, no que toca aos argumentos de repulsa alinhavados por Rui Stoco, alusivos à inaceitável obrigatoriedade de presunção de êxito na decisão judicial, como pressuposto ao acolhimento da teoria da perda de uma chance, eles, de fato, causam perplexão, por não isolar a perda da "chance" (enquanto prejuízo distinto e suscetível de valoração) da perda do "resultado final”, e também pelo anacronismo.

Ora, ainda que se parta do sofístico argumento de que a indenização pela perda de uma chance implica suposição de triunfo na ação judicial, o que é um grave equívoco, pior é sustentar que isso é impossível em termos hodiernos. Observe-se (vide notas de rodapé 140 e 141) que as argumentações fustigadas foram edificadas em 2006 e 2007, bem posteriores, portanto, à Emenda Constitucional n. 45, de 08 de dezembro de 2004, que, por sua vez, introduziu no ordenamento a súmula de efeito vinculante, com o acréscimo do art. $103-\mathrm{A}^{154}$ ao texto constitucional.

Assim, após a promulgação da aludida Emenda Constitucional, caso o advogado deixe escoar o prazo prescricional para ajuizar determinada ação que tenha como fundamento uma súmula de efeito vinculante, ou, ainda, de recorrer de uma decisão que contrarie expressamente tal súmula, é possível, sim, predizer, com a acepção rigorosamente técnica que se deve empregar a palavra "certeza", que a negligência do advogado ocasionou prejuízo certo ao seu cliente, correspondente ao dano final.

Em tal hipótese, todavia, não será o caso de aplicação da teoria da perda de uma chance para o cálculo da indenização, porquanto não se utilizará do recurso à estatística para o cálculo do percentual probabilístico de vitória, mas, sim, do sistema de presunção de que o dano foi integral, a título de lucros cessantes ${ }^{155}$.

\footnotetext{
154 “Art. 103-A. O Supremo Tribunal Federal poderá, de ofício ou por provocação, mediante decisão de dois terços dos seus membros, após reiteradas decisões sobre matéria constitucional, aprovar súmula que, a partir de sua publicação na imprensa oficial, terá efeito vinculante em relação aos demais órgãos do Poder Judiciário e à administração pública direta e indireta, nas esferas federal, estadual e municipal, bem como proceder à sua revisão ou cancelamento, na forma estabelecida em lei”. BRASIL. Constituição (1988). Constituição da República Federativa do Brasil. 16 ed. São Paulo: RT, 2011).

${ }^{155}$ É como pensa Sérgio Savi: "Contudo, é importante destacar que, com a aprovação da Emenda Constitucional $\mathrm{n}^{\circ} .45$ de 2004, e, consequentemente, a inserção da súmula vinculante em nosso ordenamento jurídico, será possível, em determinados casos concretos de responsabilidade civil de advogados, condená-los ao pagamento de indenização consistente naquilo que o seu constituinte obteria se tivesse vencido a demanda. Ou seja, na vigência do sistema de súmula vinculante será possível, em alguns casos concretos, condenar o advogado, que perde um prazo para a interposição de um recurso, ao pagamento de lucros cessantes, ao invés de condená-lo ao pagamento de indenização pela perda da chance. Isto porque, sabendose de antemão qual é a posição do Supremo Tribunal Federal acerca de determinada matéria e estando o Tribunal de origem vinculado àquele posicionamento, é razoável acreditar que o cliente do advogado negligente obteria uma decisão naquele sentido". (SAVI, Sérgio, op. cit., p. 67).
} 


\subsection{O paradoxo de direito - "A certeza do incerto"}

Um dos mais comezinhos pressupostos para que o prejuízo seja reparável é a certeza. Yves Chartier chega ao ponto de dizer que essa ilação decorre simplesmente do bom senso, pois indenizar um prejuízo eventual seria correr o risco de enriquecer sem causa a vítima $^{156}$. Geneviève Viney aponta que a afirmação sobre a certeza de um dano não significa afirmar uma característica particular do prejuízo, mas apenas constatar que ele deve existir e que o ônus da prova deve ser atribuído ao demandante ${ }^{157}$. Por sua vez, os Mazeaud destacam que pela exigência de que o prejuízo seja certo se deve entender que ele não seja meramente hipotético ${ }^{158}$ ou, ainda, conforme Philippe Le Tourneau, de difícil verificação $^{159}$.

É, portanto, a lesão de um interesse juridicamente protegido ${ }^{160}$, que redunda em um dano certo ${ }^{161}$, que enseja a sua reparação.

Pois bem, a chance, ao avesso, exprime, etimologicamente, a imprevisibilidade ou a incerteza de um evento. $\mathrm{O}$ dano ocasionado fortuitamente caracteriza-se por sua imprevisibilidade; e essa margem aleatória foi, exatamente, o que justificou a não reparação dos danos por oportunidades perdidas durante um longo tempo ${ }^{162}$.

\footnotetext{
156 "Que, pour être réparable, le préjudice doive être certain, relève tout simplement du bons sens. Vouloir indemniser un préjudice éventuel, ce serait prendre le risque d'enrichir sans cause la victime". (CHARTIER, Yves, op. cit., p. 21)

157 "Dire que le dommage doit être 'certain' n'est pás affirmer un caractère particulier du préjudice, mais constater qu'il doit exister et que a preuve doit être apportée par le demandeur". (VINEY, Gineviève; JOURDAIN, Patrice, op. cit., p. 82)

${ }^{158}$ MAZEAUD, Henri et Leon; TUNC, André, op. cit., p. 270.

${ }^{159}$ LE TOURNEAU, Philippe. La responsabilité civile. Paris: PUF, 2003, p. 35.

${ }^{160}$ E não de qualquer interesse, como bem pontua Lindbergh Montenegro: "Para que o dano venha a ser sancionado pelo ordenamento jurídico, vale dizer, autorize, aquele que o sofreu a exigir do responsável uma indenização, indispensável se faz a presença de dois elementos: um de fato e outro de direito. O primeiro se manifesta no prejuízo e o segundo na lesão jurídica. Nem todo prejuízo rende azo à indenização. Preciso é que a vítima demonstre também que o prejuízo constitui um fato violador de um interesse jurídico tutelado do qual seja ela o titular". (MONTENEGRO, Lindbergh C. Ressarcimento de danos. 5 ed. Rio de Janeiro: Lumen Juris, 1998, p. 7)

${ }^{161}$ Martinho Garcez Neto fornece válidos esclarecimentos sobre a certeza do dano: "A certeza do dano é relativa à sua realização, ao fato de que haja realmente ocorrido e não com relação à sua maior ou menor quantia, ou com maior ou menor facilidade para determiná-la ou apreciá-la. Um dano certo quanto à sua existência, embora incerto em relação ao 'quantum', é indenizável. Tão pouco (sic) deixa de sê-lo em razão da maior ou menor dificuldade de ser admitido, justamente porque a certeza do dano diz respeito a sua existência e não a sua prova". (GARCEZ NETO, Martinho. Responsabilidade civil no Direito Comparado. Rio de Janeiro: Renovar, 2000, p. 149)

${ }^{162}$ Nesse sentido, Isabelle Vacarie: "La chance exprime soit l'imprevisibilité soit l'incertitude d'un événement. Le dommage cause fortuitement se caractérise par son imprévisibilité; et c'est d'ailleurs cette imprévisibilité qui a longtemps justifié sa non-réparation”. (VACARIE, Isabelle, op. cit., p. 906)
} 
A situação do juiz torna-se paradoxal, conforme escólio de Daniel Amaral Carnaúba:

\begin{abstract}
Ora, o juiz se encontra assim diante de um paradoxo: ele está legalmente compelido a determinar quais são as consequências concretas da conduta do réu, embora seja precisamente esta conduta que o impeça de traçar qualquer prognóstico. A verdade é que a privação de chances expõe as insuficiências da norma jurídica. Forjada para regular os setores em que a realidade é dominada pela ação humana, a regra jurídica se mostra incapaz de regular o que está além deste controle. Ao criar uma incerteza, a conduta do réu subverte os fundamentos da norma e escapa ao seu campo de aplicação ${ }^{163}$.
\end{abstract}

O ponto de ruptura paradigmática no olhar sobre a perda de uma chance deu-se quando a doutrina e a jurisprudência descobriram que esse binômio - certeza v. incerteza , aparentemente antinômico, integrava a essência do instituto ${ }^{164}$. A contradição jurídica ficou superada ${ }^{165}$ a partir do momento em que se mudou (ou se ampliou) o enfoque exclusivo no futuro incerto - o resultado final cuja experimentação restou expurgada -, para abranger o passado certo, em que havia um interesse jurídico legítimo e merecedor de tutela, consubstanciado na chance, cuja perda acarretava dano.

Concebe-se, assim, que a perda de chances aglutina dois elementos aparentemente incompatíveis, conforme lição de Mariano Yzquierdo Tolsada:

Hablar de pérdida de oportunidades implica, por el contra y por definición, hablar de una situación en la que se da aparentemente

163 CARNAÚBA. Daniel Amaral, op. cit., p. 53.

164 Preciso, no particular, o TJ/MG, ao fixar a seguinte premissa: "A reparação da perda de uma chance repousa em uma probabilidade e uma certeza; Que a chance seria realizada, e que a vantagem perdida resultaria em prejuízo.[...]" (MINAS GERAIS. Tribunal de Justiça do Estado de Minas Gerais, $12^{\mathrm{a}}$ Câmara Cível. Apelação Cível 1.0334.08.014746-8/001. Relator: José Flávio de Almeida. Diário da Justiça eletrônico, 9 nov. 2009)

165 Aliás, a aniquilação dessa contradição, como de todas as outras, era algo inevitável, pois, conforme ensinamentos de Engels, ela pertence a uma categoria meramente especulativa: “A primeira e mais importante das teses sobre as propriedades lógicas fundamentais do ser refere-se à exclusão da contradição. $\mathrm{O}$ contraditório é uma categoria que somente pode ocorrer numa combinação especulativa, mas nunca na realidade. Não existem contradições nas coisas, ou, dito de outro modo, a contradição posta na realidade é o cúmulo do absurdo..." (ENGELS, Friedrich. Anti-Dühring. Parte I. Filosofia. Dialética. Capítulo XII. Quantidade e Qualidade. Disponível em: <http://www.marxists.org/portugues/marx/1877/antiduhring /index.htm>. Acesso em: 07 mar.. 2011) 
contradictoria confluencia de dos elementos: la certeza de que, si no hubiese producido el hecho dañoso, el perjudicado habría mantenido la esperanza en el futuro de obtener una ganancia o evitar una pérdida patrimonial; y la incertidumbre definitiva de lo que habría sucedido si no se hubiera producido el evento ${ }^{166}$.

Em idêntico diapasão, os dizeres de Trigo Represas:

Cuando el daño consiste en la frustración de una esperanza o pérdida de una 'chance', coexisten a la vez un elemento de certeza y otro de incerteza; 'certeza de que no mediar el evento dañoso - trátase de un hecho o acto ilícito o de un incumplimiento contractual -, el damnificado habría mantenido la esperanza' de obtener en el futuro una ganancia o evitar una pérdida patrimonial. Pero, a la par, incertidumbre, definitiva ya, sobre si, 'manteniéndose la situation de hecho o de derecho que era el presupuesto de la 'chance', la ganancia se habría en realidad obtenida, o si la pérdida se habría evitado ${ }^{167}$.

Portanto, "situa-se nesse ponto a característica essencial da perda de uma chance: a certeza da probabilidade ${ }^{168}$ ". No dano decorrente da perda de uma chance, é certa a existência da própria chance ${ }^{169}$, entidade tutelada juridicamente e passível de valoração econômica, mas é incerto se ela iria ou não se concretizar. Por isso, a indenização corresponde à chance (certa) e não ao resultado buscado (incerto) ${ }^{170}$.

\footnotetext{
166 TOLSADA, Mariano Yzquierdo, op. cit., p. 153.

${ }^{167}$ REPRESAS, Félix Alberto Trigo. Pérdida de chance. Buenos Aires: Astrea, 2008, p. 29.

168 SANSEVERINO, Paulo de Tarso Vieira. Princípio da Reparação Integral: indenização no Código Civil. São Paulo: Saraiva, 2010, p. 167.

169 "Embora a realização da chance nunca seja certa, a perda da chance pode ser certa. Por estes motivos, não vemos óbice à aplicação, criteriosa, da teoria. O que o art. 403 afasta é o dano meramente hipotético, mas, se a vítima provar a adequação do nexo causal entre a ação culposa e ilícita do lesante e o dano sofrido (a perda da probabilidade séria e real), configurados estarão os pressupostos do dever de indenizar". MARTINSCOSTA, Judith Hofmeister. Comentários ao Novo Código Civil. Rio de Janeiro: Forense, 2003, v. 5, tomo 2, p. 362)

${ }^{170}$ Nessa linha, incorreu em manifesto equívoco o TJ/MS ao deixar de indenizar a vítima, ao fundamento de que não havia certeza de que o resultado esperado ocorreria: "1- Culpa médica deve ser entendida como desvio ou inobservância dos padrões normais de conduta. 2- Houve erro dos médicos na modalidade culposa, em virtude de sua negligência por omissão quanto a providências aptas, em tese, a impedir a produção do dano. 3- Nexo causal resta evidente na negligência dos médicos, cujo comportamento teve fundamental relevância causal no resultado danoso, por não propiciar ao recém-nascido a chance de vida, mediante
} 


\subsection{Perda de uma chance e figuras afins}

2.5.1 Distinção entre perda de uma chance e lucros cessantes

É sutil a diferença entre a perda de uma chance e os lucros cessantes, pois são conceitos imbricados, cuja confusão traduz perigosa armadilha. Até porque, como a doutrina concernente aos lucros cessantes não é contemporânea à da perda de uma chance, não houve, ainda, preocupação em delinear com precisão os traços distintivos entre as duas figuras e, nas ocasiões em que se debruçou sobre o tema, o resultado não foi dos melhores, como se verá adiante.

Sérgio Cavalieri Filho assevera que o lucro cessante consiste "na perda do ganho esperável, na frustração da expectativa de lucro, na diminuição potencial do patrimônio da vítima"171. Já Pontes de Miranda leciona que "o dano pode consistir em diminuição do patrimônio no momento do fato que o causou, ou em impedimento de elevação do patrimônio; ali, o dano é emergente, 'damnum emergens'; aqui, lucro cessante, 'lucrum cessans $^{172, ",}$.

Concebida a perda de uma chance exclusivamente sob a perspectiva da frustração da probabilidade de obtenção de uma vantagem futura (perspectiva válida, mas não a única), de fato, é preciso alinhavar a dissimilitude entre ela e os lucros cessantes.

Na Itália, Maurizio Bocchiola distinguiu os conceitos pelo critério de certeza e probabilidade, ao mencionar que:

\footnotetext{
prognóstico rápido e eficaz. 4- São devidos danos morais em virtude de morte de pessoa da família, uma vez que o dano decorre do próprio evento danoso. 4- Há de se ressaltar que a indenização fundada na aplicação da la perte d'une chance deverá situar-se no limite percentual de chances perdidas, o que se pondera caso a caso. 5- Adotando-se a teoria da perda de uma chance, não cabe a indenização por danos materiais, uma vez que não se tem a certeza de que efetivamente o resultado esperado ocorreria. 7- A verba honorária, na hipótese, deverá permanecer no patamar de $10 \%$ sobre o valor da condenação, uma vez que observado o disposto no art. 20, $\S 3^{\circ}$, do CPC". (MATO GROSSO DO SUL. Tribunal de Justiça do Estado de Mato Grosso do Sul, $5^{\text {a }}$ Turma Cível. Apelação Cível 2010.016892-5/0000-00. Relator: Sideni Soncini Pimentel. Diário da Justiça eletrônico, 9 set. 2010, p. 41. Sem grifos no texto original).

${ }^{171}$ CAVALIERI FILHO, Sérgio. Programa de Responsabilidade Civil. 8 ed. rev. e aum. São Paulo: Atlas, 2009 , p. 72.

${ }_{172}$ PONTES DE MIRANDA. Tratado de direito privado. Rio de Janeiro: Borsoi, 1955-1972, v. 22, § 2.722 , n. 3, p. 213.
} 
Da un punto di vista teórico, però, le due fattispecie sono abbastanza individualizzabili nesse rispettive caratteristiche. Infatti, propriamente, si deve indicare come lucro cessante solo il caso in cui si avvera la perdita di una possibilità favorevole, che spetterebbe ad un determinato soggeto con una probabilità che representa la certezza; nell'ipotesi di perdita di una chance, il sopraggiungere del risultato utile è per definizione indimostrabile $^{173}$.

$\mathrm{Na}$ Espanha, Mariano Ysquierdo Tolsada vislumbrou semelhante ponto de clivagem ao aduzir que "no se trata del clásico lucro cesante, pues en éste el perjudicado tiene un interés legítimo a la percepción de una ganancia futura, y desde la premisa de la previa existencia de ese título legitimador, viene exigir la ganancia dejada de percibir" ${ }^{174}$.

Glenda Gonçalves Gondim, em recente dissertação sobre a perda de uma chance, também cravou como premissa distintiva que o lucro cessante se baseia numa certeza, enquanto a perda de uma chance tem lastro em mera probabilidade, assim dizendo:

O lucro cessante diz respeito à lesão a um bem jurídico que, comprovadamente, seria incorporado ao patrimônio do ofendido no futuro, acaso a conduta culposa não tivesse ocorrido. A chance representa um resultado almejado certo, mas provável, cuja impossibilidade de acrescer ao patrimônio do ofendido é atual. (...) Portanto, o autor exclui do ressarcimento como lucros cessantes exemplos típicos de perda de uma chance. E outro não poderia ser o entendimento, pois os lucros cessantes dizem respeito ao que efetivamente deixou de ganhar e se não existia a garantia do ganho do prêmio, não há que se falar em tal verba", 175 .

\footnotetext{
${ }^{173}$ BOCCHIOLA, Maurizio. Perdita di una chance e certezza del danno. Rivista Trimestrale di Diritto e Procedura Civile, ano 30, p. 55-101, 1976, p. 74.

${ }^{174}$ TOLSADA, Mariano Yzquierdo, op. cit., p. 153.

175 GONDIM, Glenda Gonçalves. A reparação civil na teoria da perda de uma chance. 2010. 170f. Dissertação (Mestrado em Direito) - Universidade Federal do Paraná - UFPR, Curitiba, p. 123-124. Sem grifos no original.
} 
O critério escolhido não é bom. Aliás, no que tange à afirmação de que o lucro cessante diz respeito ao que o ofendido "comprovadamente" ou "efetivamente" deixou de ganhar, a distinção proposta afronta a literalidade da lei. Deveras, o art. 402 do CCB $^{176}$ é expresso ao dispor que as perdas e danos devidas ao credor abrangem, além do que ele efetivamente perdeu - danos emergentes -, o que razoavelmente deixou de lucrar - lucros cessantes.

A distinção fornecida, portanto, parte de uma premissa falsa, qual seja a de que há certeza de ganho nos lucros cessantes, o que é epistemologicamente impossível, já que quaisquer fatos da vida podem interceder para que o lucro não ocorra. Sérgio Cavalieri Filho aduz que "o nosso Código Civil, no já citado art. 402, consagrou o 'princípio da razoabilidade' ao caracterizar o lucro cessante, dizendo ser aquilo que razoavelmente se deixou de lucrar. Razoável é aquilo que o bom-senso diz que o credor lucraria, apurado segundo um juízo de probabilidade, de acordo com o normal desenrolar dos fatos"177.

Paulo de Tarso Vieira Sanseverino propõe a formulação de um juízo de probabilidade, a partir da imaginação de um processo causal hipotético, que considere o normal desenrolar dos fatos se não tivesse havido o ato ilícito. E prossegue dizendo que “eliminado mentalmente o ato ilícito, as vantangens pretendidas a título de lucros cessantes constituiriam desdobramento normal da vida" ${ }^{178}$.

No mesmo iter, Silvio Neves Baptista ressalta que "o que é fundamental é a probabilidade objetiva que resulta do 'curso normal das coisas' e das 'circunstâncias especiais do caso concreto', levando em conta inclusive o que a pessoa vinha percebendo e o que objetivamente poderia perceber" ${ }^{179}$.

Sérgio Savi também alerta para a fragilidade de tal traço distintivo quando defende que "a maior dificuldade encontrada na aplicação concreta deste critério de distinção decorre do fato de que a certeza no lucro cessante sempre será uma certeza relativa e, por este motivo, o critério de diferenciação proposto se mostraria vago e flutuante ${ }^{180 \text { ", }}$

O Superior Tribunal de Justiça, de sua parte, entendeu que a expressão "o que razoavelmente deixou de lucrar", contida no art. 402, do CCB, indica uma presunção juris

\footnotetext{
${ }^{176}$ BRASIL. Código Civil (2002). Código Civil e Constituição Federal. 62. ed. São Paulo: Saraiva, 2011.

${ }^{177}$ CAVALIERI FILHO, Sérgio, op. cit., p. 73.

${ }^{178}$ SANSEVERINO, Paulo de Tarso Vieira, op. cit., p. 186

179 BAPTISTA, Silvio Neves. Teoria geral do dano: de acordo com o Novo Código Civil Brasileiro. São Paulo: Atlas, 2003, p. 87.

${ }^{180}$ SAVI, Sérgio, op. cit., p. 17.
} 
tantum de que os fatos seguiriam seu curso ordinário, de acordo com as ocorrências pretéritas, pois “[..] deve ser interpretada no sentido de que, até prova em contrário, se admite que o credor haveria de lucrar aquilo que o bom senso diz que lucraria, existindo a presunção de que os fatos se desenrolariam dentro de seu curso normal, tendo em vista os antecedentes $^{181,}$.

O Código Civil Alemão - BGB -, possui em seu $§ 252^{182}$ um conceito mais preciso de lucro cessante, considerando frustrado aquilo que razoavelmente poderia se esperar, atento ao curso normal das coisas ou às circunstâncias especiais do caso concreto.

No aspecto indenitário, a doutrina alemã construiu a "teoria da diferença", segundo a qual "a indenização pecuniária deve ser medida pela diferença entre a situação real em que o ato ilícito deixou o lesado e a situação em que ele se encontraria sem o dano sofrido, atendendo ao curso normal das coisas" ${ }^{\prime 183}$.

Dessa feita, o marco diferencial entre os lucros cessantes e a perda de uma chance, na vertente em que as duas figuras se assemelham, repousa na operação que se faz para chegar ao valor da reparação, no modo como o ordenamento interage com a álea, repelindo-a, no primeiro caso, e assimilando-a, no segundo.

Nos lucros cessantes, o Direito responde ao desconhecido (presente nas duas figuras) obliterando-o pelo sistema de presunções. Ele artificializa o conhecimento no plano técnico, expurgando aquilo que desconhece e dirimindo a dúvida como se soubesse o que aconteceria, com base nos elementos que lhe foram fornecidos. Já na perda de uma chance, o Direito assimila a sua ignorância ontológica perante os fatos que não podem ser conhecidos, e equaciona o problema mediante decisão que absorve ${ }^{184}$ essa ignorância na técnica de decidir, pelo sistema de probabilidades ${ }^{185}$.

\footnotetext{
${ }^{181}$ BRASIL. Superior Tribunal de Justiça. Recurso Especial 61.512-SP, Relator: Min. Sálvio de Figueiredo, Diário da Justiça da União, $1^{\circ}$ dez. 1997.

182 "\$ 252 Entgangener Gewinn. Der zu ersetzende Schaden umfasst auch den entgangenen Gewinn. Als entgangen gilt der Gewinn, welcher nach dem gewöhnlichen Lauf der Dinge oder nach den besonderen Umständen, insbesondere nach den getroffenen Anstalten und Vorkehrungen, mit Wahrscheinlichkeit erwartet werden konnte." ALEMANHA. Código Civil (1896). Código Civil. Disponível em: 〈http://www.gesetze-im-internet.de/bundesrecht/bgb/gesamt.pdf>. Acesso em: 21 jan. 2011). Tradução para o inglês do próprio site do parlamento alemão: "Section 252. Lost profits. The damage to be compensated for also comprises the lost profits. Those profits are considered lost that in the normal course of events or in the special circumstances, particularly due to the measures and precautions taken, could probably be expected. Disponível em: 〈http://www.gesetze-im-internet.de/englisch_bgb/englisch_bgb/>. Acesso em: 26 mar. 2011.

183 CAVALIERI FILHO, Sérgio, op. cit., p. 73.

${ }^{184}$ Caroline Ruellan se refere à perda de uma chance como um dos exemplos em que o acaso é integrado ao campo jurídico: "La perte de chance constitue l'une des nombreuses ilustrations de l'intégration du hasard dans le champ juridique. Erigeant la chance en élément constitutif, elle invite à préciser cette notion et à
} 
Assim sendo, longe de se distinguirem pela aleatoriedade, que antes os aproxima, a perda de uma chance e os lucros cessantes têm seu traço de fragmentação em técnicas diversas de indenização, pois, no primeiro caso, o juízo é de probabilidade, mas não no sentido de se supor qual seria o estado atual da vítima diante da inocorrência do ato ilícito (teoria da diferença), mas de se calcular qual seria a probabilidade de o ofendido obter o resultado final esperado, em termos percentuais.

Já na segunda hipótese, o grau de probabilidade de que os fatos idôneos (pressupostos constitutivos) necessários à percepção da vantagem ocorram é tão grande, por decorrer do andamento normal da vida, que leva o intérprete a presumi-lo ${ }^{186}$, mediante a formulação de um raciocínio hipotético de como os acontecimentos naturais se dariam sem a ocorrência do ilícito. Portanto, o sustentáculo de aferição dos lucros cessantes é informado, nos termos do Código Civil tedesco, pelo que razoavelmente se podia esperar que ocorresse dentro de um determinado padrão, que atenta para um aspecto geral - curso normal das coisas -, e outro especial - circunstâncias peculiares do caso concreto.

déterminer ses rapports avec l'aléa”. (RUELLAN, Caroline. La perte de chance en droit privé. Droit prospectif. Paris: RRJ, 1999, v.3, p. 730)

${ }^{185}$ Sobre essa distinção, expôs de modo inigualável Daniel Amaral Carnaúba: "É por esta razão que o sistema da responsabilidade deve conter regras compatíveis com o acaso, ou seja, regras capazes de responder racionalmente aos dilemas engendrados pela incerteza. E, da mesma forma que o problema se repete, as soluções que lhe são dadas também repercutem a interação entre álea e razão: diante de um evento aleatório, as regras da responsabilidade ora repelem a incerteza, ora a assimilam. Como exemplo da primeira posição, o Direito dispõe notadamente das regras de presunção. Trata-se de um método jurídico de neutralização do desconhecido, o que se deduz de sua própria definição legal: "as presunções”, postula o art. 1349 do Código Civil francês, "são consequências que a lei ou o magistrado extrai de um fato conhecido para um fato desconhecido" Assim, a presunção age como uma espécie de conhecimento artificial, sintetizado no plano da técnica. A partir dos elementos que lhe foram fornecidos, o juiz afasta aquilo que ignora, agindo como se tudo soubesse. Ora, ainda que mero subterfúgio, a presunção expurga a álea da demanda de reparação, permitindo que o julgador decida o conflito ao qual foi chamado a resolver. Por outro lado, o Direito comporta também regras fundadas sobre um método diametralmente oposto. Diante de um evento aleatório, o juiz pode admitir a incerteza que acomete a realidade, proferindo uma decisão que a leve em consideração. A reparação das chances perdidas é um exemplo notável. Segundo uma fórmula diversas vezes empregada pela jurisprudência francesa, a perda de uma chance é reparável "ainda que, por definição, a realização de uma chance jamais seja certa". Aqui, temos uma técnica que, a exemplo do modelo estatístico, assimila o acaso no seio das regras da responsabilidade. Dá-se uma solução ao litígio, mas não à incerteza". (CARNAÚBA. Daniel Amaral, op. cit., p. 13-14)

186 Represas diz, por isso, que a prova dos lucros cessantes se faz pelo meio presuntivo: "No obstante, en general, la prueba del lucro cessante sólo es factible por vía presuncional, por cuanto se refiere a benefícios meramente supuestos o probables. Es decir, el actor debe aportar circunstancias objetivas que permitan inferir que las ganancias se habrían logrado previsiblemente, de no ocurrir el hecho perjudicial, o - em todo caso - que un bien integrante de la actividad productiva há dejado de participar en el processo de rentabilidad al que estaba destinado, por razones ajenas a su idoneidad”. (REPRESAS, Félix Alberto Trigo, op. cit., p. 256) 
É bem verdade que a diferença pode dar margem a dúvidas quando se defronta com situações particulares, como é o caso da Súmula 491 do STF ${ }^{187}{ }^{188}$, que determina a indenização em caso de acidente que cause a morte do filho menor, ainda que não exerça trabalho remunerado ${ }^{189} 190$.

2.5.2 Distinção entre perda de uma chance e a condição maliciosamente obstada pela parte a quem desfavorecer

A outra figura assemelhada à perda de uma chance é a da condição cujo implemento é maliciosamente obstado pela parte a quem ele desfavorece, que tem previsão no artigo 129 do Código Civil Brasileiro, verbis: “Art. 129. Reputa-se verificada, quanto aos efeitos jurídicos, a condição cujo implemento for maliciosamente obstado pela parte a quem desfavorecer, considerando-se, ao contrário, não verificada a condição maliciosamente levada a efeito por aquele a quem aproveita o seu implemento ${ }^{191}$,".

Referido dispositivo não trouxe alvíssaras ao ordenamento jurídico, pois guarda correspondência legislativa com o artigo 120 do Código Civil de $1916^{192}$, tendo, tão somente, aprimorado a técnica de redação, sem alterá-lo em substância.

187 BRASIL. Supremo Tribunal Federal. Súmula nº 491, de 10 de dezembro de 1969. É indenizável o acidente que cause a morte de filho menor, ainda que não exerça trabalho remunerado. Disponível em: $\langle$ http://www.stf.jus.br/portal/cms/verTexto.asp?servico= jurisprudenciaSumula\&pagina=sumula $401 \quad 500$. $>$. Acesso em: 21 jan. 2011.

${ }^{188}$ A Súmula 491 do STF foi aprovada em Sessão Plenária do dia 03.12.1969, no contexto em que a Suprema Corte ainda não contava com o auxílio do STJ para cuidar da maior parte da matéria infra-constitucional, e que o dano moral não era indenizável, ao fundamento de que a dor não tinha preço.

189 “Adianta-se apenas que se está em uma zona limítrofe entre a perda de uma chance, já examinada, e o dano hipotético, o que foi resolvido com sabedoria pela jurisprudência do STF e, após, do STJ, com a concessão de pensão apenas em favor das famílias de baixa renda". (SANSEVERINO, Paulo de Tarso Vieira, op. cit., 187)

${ }^{190}$ Araken de Assis considera o prejuízo indireto e hipotético, reparável por tratar-se de um ilícito absoluto, mas que exije um juízo emanado de dupla presunção: "Diversamente, o dano eventual comporta indenização no ilícito absoluto. Por exemplo, o pagamento de alimentos aos pais pela morte de filho menor de idade, na falta de exercício atual de atividade econômica, indeniza dano hipotético (Súmula 491 do STF). A $3^{\text {a }}$ Turma do STJ estimou que, nas famílias modestas, se afigura razoável presumir o auxílio da vítima menor de idade. Essa espécie de dano necessita, a par da relação de causalidade, a ocorrência de outros fatos, duplamente presumidos no julgado: a necessidade futura de alimentos e a possibilidade de o filho morto prestá-los aos pais. O prejuízo é indireto e hipotético". (ASSIS, Araken de. Liquidação do dano. Revista dos Tribunais, São Paulo, v. 759, ano 88, p. 11-23, jan. 1999, p. 23)

${ }^{191}$ BRASIL. Código Civil (2002). Código Civil e Constituição Federal. 62. ed. São Paulo: Saraiva, 2011.

192 "Art. 120. Reputa-se verificada, quanto aos efeitos jurídicos, a condição, cujo implemento for maliciosamente obstado pela parte, a quem desfavorecer.Considera-se, ao contrário, não verificada a condição maliciosamente levada a efeito por aquele, a quem aproveita o seu implemento" (BRASIL. Código 
No panorama internacional, há dispositivo bastante semelhante no Código Civil alemão ${ }^{193}$, que também reputa satisfeita a condição não verificada em virtude de má-fé da parte cuja verificação traria alguma desvantagem. Portugal apenas inverte o prisma, censurando o inadimplemento da condição por impedimento da parte prejudicada, contra as regras de boa-fé ${ }^{194}$. Do mesmo modo ocorre na França ${ }^{195}$ e na Itália ${ }^{196}$, mas sem menção expressa ao requisito da má-fé ou à violação da boa-fé.

Pois bem, sabe-se que "implementar a condição é dar execução a ela própria, é fazer com que os seus efeitos sejam produzidos por providências concretas"197. Contrario sensu, não implementar uma condição é deixar de lhe dar execução.

É justamente nesse ponto que a figura se aproxima da perda de uma chance (fazendo a jurisprudência, por vezes, claudicar): em ambos os casos, o curso aleatório dos eventos é interrompido, tornando inverificável, empiricamente, a certeza sobre a sua realização. Destarte, tanto na perda de uma chance, quanto na condição cujo implemento é maliciosamente obstado pela parte, a superveniência do ato ilícito obsta que os fatos da vida transcorram do modo normal.

Civil (1916). Código Civil. Disponível em: 〈https://www.planalto.gov.br/ccivil_03/leis/13071.htm>. Acesso em: 21 jan. 2011)

193 "\$ 162 Verhinderung oder Herbeiführung des Bedingungseintritts. (1) Wird der Eintritt der Bedingung von der Partei, zu deren Nachteil er gereichen würde, wider Treu und Glauben verhindert, so gilt die Bedingung als eingetreten. (2) Wird der Eintritt der Bedingung von der Partei, zu deren Vorteil er gereicht, wider Treu und Glauben herbeigeführt, so gilt der Eintritt als nicht erfolgt". (ALEMANHA. Código Civil (1896). Código Civil. Disponível em: 〈http://www.gesetze-im-internet.de/bundesrecht/bgb/gesamt.pdf〉. Acesso em: 28 fev. 2011.) Tradução para o inglês do próprio site do parlamento alemão: "Section 162. Prevention of or bringing about the satisfaction of the condition. (1) If the satisfaction of a condition is prevented in bad faith by the party to whose disadvantage it would be, the condition is deemed to have been satisfied.(2) If the satisfaction of a condition is brought about in bad faith by the party to whose advantage it would be, the condition is deemed not to have been satisfied". Disponível em: <http://www.gesetze-iminternet.de/englisch_bgb/englisch_bgb/>. Acesso em: 28 fev. 2011

194 "Artigo $275^{\circ}$. Verificação e não verificação da condição. 1. A certeza de que a condição se não pode verificar equivale à sua não verificação. 2. Se a verificação da condição for impedida, contra as regras da boa fé, por aquele a quem prejudica, tem-se por verificada; se for provocada, nos mesmos termos, por aquele a quem aproveita, considera-se como não verificada". (PORTUGAL. Código Civil (1966). Código Civil. Disponível em: 〈http://www.stj.pt/nsrepo/geral/ cptlp/Portugal /CodigoCivil.pdf〉. Acesso em: $28 \mathrm{fev}$. 2011)

195 “Article 1.178. La condition est réputée accomplie lorsque c'est le débiteur, obligé sous cette condition, qui en a empêché l'accomplissement". (FRANÇA. Código Civil (1804). Código Civil. Disponível em: $\langle$ http://www.legifrance.gouv.fr >. Acesso em: 28 fev. 2011)

196 "Art.1359. Avveramento della condizione. La condizione si considera avverata qualora sia mancata per causa imputabile alla parte che aveva interesse contrario all'avveramento di essa". (ITÁLIA. Código Civil (1942). Código Civil. Disponível em: 〈http://www.altalex.com/index.php?idnot=36451>. Acesso em: 28 fev. 2011)

${ }^{197}$ ALVIM, Arruda; ALVIM, Thereza (Coord.) et al. Comentários ao Código Civil brasileiro: dos fatos jurídicos (arts. 104 a 232). Rio de Janeiro: Forense, 2008, v.2, p. 418. 
Portanto, sem razão Dallegrave Neto ao estatuir que: "Na perda de uma chance, há certeza quanto à ofensa ao direito de exercitar a chance e uma incerteza quanto ao alcance (ou não) do resultado positivo. No caso do art. 129 do CC há duas certezas, a de que a condição foi maliciosamente obstada pelo devedor da obrigação e a de que, se assim não fosse, o resultado positivo seria inevitável ${ }^{198}$ ".

A condição é a cláusula que, "derivando exclusivamente da vontade das partes, subordina o efeito do negócio jurídico a evento futuro e incerto", de acordo com o artigo 121 do $\mathrm{CCB}^{199}$. Sendo o evento incerto ${ }^{200}$, falar em certeza é afrontar texto expresso de lei.

Maria Helena Diniz, ao estabelecer os requisitos para a configuração de uma condição, alude à "incerteza do acontecimento, pois a condição relaciona-se com um acontecimento incerto, que poderá ocorrer ou não ${ }^{201}$ ". Serpa Lopes sustenta que, na condição, resta fora de dúvida a imprescindibilidade da incerteza ${ }^{202}$. Arnaldo Rizzardo é categórico ao afirmar que a "incerteza, constitui elemento inerente, sob pena de já se definir antecipadamente a validade ou não do negócio. Se a pessoa conhece o resultado, ou subordina a condição de um negócio a uma situação que necessariamente ocorrerá, consistirá a mesma (sic) em um termo, como quando se condiciona o proveito de um bem ao alcançar a pessoa determinada idade ${ }^{203,}$.

Então, o resultado final, tanto na chance perdida quanto na condição obstada, é incerto, variando o grau de probabilidade de ocorrência. As semelhanças cessam por aí.

\footnotetext{
${ }^{198}$ DALLEGRAVE NETO, José Afonso, op. cit., p. 232.

199 BRASIL. Código Civil (2002). Código Civil e Constituição Federal. 62. ed. São Paulo: Saraiva, 2011. Sem grifos no original.

${ }^{200}$ Conforme incisiva lição de Belmonte: "Condição é evento futuro e de ocorrência incerta, incerta no sentido da incerteza da sua verificação: achar petróleo, o acerto dos números do prêmio lotérico, a ocorrência do sinistro previsto em contrato de seguro, a recuperação da capacidade laborativa do empregado aposentado por invalidez etc. No termo incerto, não se pode precisar o momento exato da verificação do evento, o quando, ao passo que na condição não se pode precisar se o próprio evento ocorrerá”. (BELMONTE, Alexandre Agra. Instituições Civis no Direito do Trabalho: curso de Direito Civil aplicado ao Direito do Trabalho. 3. ed. Atual. de acordo com o novo Código Civil e aum. Rio de Janeiro: Renovar, 2004, p. 146147)

${ }^{201}$ DINIZ, Maria Helena. Código Civil Anotado. 5. ed. atual. São Paulo: Saraiva, 1999, p. 132.

${ }^{202}$ Eis as suas palavras: "De qualquer forma, porém, quer prepondere a concepção objetiva ou a subjetiva, ou as várias ramificações outras propostas, o que resta fora de dúvida é a imprescindibilidade do elemento incerteza, para a integração da condição, e o incontestável, sobre a natureza dessa incerteza, é que as normas inerentes à situação de pendência condicional visam a tutelar os interesses dos sujeitos no período em que ainda não se sabe se a relação chegará a existir, tutela essa não só inerente às relações internas dos contraentes, como mesmo às relações externas de terceiros, daqueles que fizeram algum negócio com os contratantes "pendente condictione"”. (SERPA LOPES, Miguel Maria de. Curso de Direito Civil: introdução, parte geral e teoria dos negócios jurídicos. 7. ed. rev. e atual. por José Serpa Santa Maria. Rio de Janeiro: Freitas Bastos, 1989, v.1, p. 433)

${ }^{203}$ RIZZARDO, Arnaldo. Parte Geral do Código Civil. 5. ed. rev. e atual.. Rio de Janeiro: Forense, 2007, 445 .
} 
Vislumbram-se, por outro lado, quatro diferenças entre as figuras ${ }^{204}$ : i) quanto aos requisitos; ii) quanto aos sujeitos; iii) quanto à condição (estado) do ofensor; iv) quanto aos efeitos.

A primeira distinção salta aos olhos da leitura da expressão "maliciosamente", constante do artigo 129 do CCB (referida como "má-fé" no Código Civil alemão e "contrária à boa-fé" no Código Civil português): a exigência do dolo na conduta do ofensor. A regra do artigo 129 do CCB prestigia a probidade do negócio jurídico, estampando um dos corolários do postulado de que o ofensor não pode se beneficiar da sua própria torpeza $^{205}$ (que, por sua vez, é uma ramificação do princípio da boa-fé).

Exigiu o dispositivo em comento o dolo, em toda a sua potencialidade, ou seja, o dolo típico, não sendo bastante a culpa grave 206207 . E o dolo, em geral, não se presume, deve ser provado pelo autor. Tratando-se, todavia, de um elemento psicológico, a sua demonstração poderá ser feita mediante referência aos elementos fáticos que, relacionados às circunstâncias e de acordo com a experiência comum, deponham razoavelmente pela subsistência dos elementos constitutivos do dolo ${ }^{208}$.

\footnotetext{
${ }^{204}$ Dallegrave Neto reduz as diferenças a duas: os requisitos e os efeitos. (Op. cit., p. 231)

205 Oportuno, aqui, o escólio de Nader: "Guiado pelos ditames da boa-fé, o legislador, 'ex vi' do art. 129, impede que o agente se beneficie da própria torpeza. Se, em uma condição suspensiva ou resolutiva, o evento futuro e incerto não se realiza por atitude de malícia daquele a quem desfavorecer, ter-se-á a condição por implementada”. (NADER, Paulo. Curso de Direito Civil. Parte Geral. Rio de Janeiro: Forense, 2003, v. 1, p. 483)

206 Acerca desse requisito, categórica a doutrina: "Estamos, portanto, cuidando do que a doutrina tem denominado 'conditio deficit', isto é, de condição frustrada. Só que essa frustração há de ser dolosa, tendo em vista o artigo 129 exigir que o ato de obstar o implemento da condição há de ser praticado com vontade maliciosa, de má-fé. A malícia, repetimos, é ato revelador de inclinação ou aptidão para fazer o mal, inspirado em ação maldosa e revestida de malignidade. É atitude habilidosa visando enganar, despistar. È prática propositada do mal a realizar, com plena consciência do dano causado a outrem. (...) Deve ser observado que o art. 129 exige a malícia, isto é, o dolo, em toda a sua potencialidade, como requisito preponderante para a sua aplicação. O legislador não se contentou com a culpa em sentido estrito" (ALVIM, Arruda; ALVIM, Thereza (Coord.) et al, op. cit., p. 419)

207 Fica clara, portanto, a ausência de rigor científico no seguinte acórdão: "ESTABILIDADE ACIDENTÁRIA - LEI No 8.213/91 - NÃO FORNECIMENTO DA CAT POR OMISSÃO DO EMPREGADOR - Para a aquisição da estabilidade acidentária prevista no art. 118 da Lei $n^{\circ} 8.213 / 91$, é indispensável o afastamento do trabalho por mais de quinze dias, pelo empregado, e a percepção do auxíliodoença acidentário. Entretanto, se a ausência desses requisitos decorre de culpa exclusiva do empregador, que deixa de enviar a CAT ao órgão previdenciário, têm-se como implementadas tais condições, à luz do disposto no art. 129 do Código Civil de 2002". (PARAÍBA. Tribunal Regional do Trabalho da $13^{\mathrm{a}}$ Região. Recurso Ordinário 28200-82.2007.5.13.0002. Relator: Ana Maria Ferreira Madruga. Diário da Justiça eletrônico, 10 nov. 2010, p. 11. Sem grifos no original).

${ }^{208}$ É a lição de Bianca: "Il dolo in generale non si presume. La prova che l'inadempimento è doloso grava pertanto sul creditore. Trattandosi tuttavia di un elemento psicologico, la sua dimostrazione può essere datta anche mediante il riferimento a quegli elementi di fatto che, in relazione alle circostanze e secondo la comune esperienza, depongono ragionevolmente per la sussistenza degli elementi costitutivi del dolo. (BIANCA, C. Massimo. Diritto Civile. La responsabilità. Milão: Giuffrè, 1994, v. 5, p. 156.)
} 
Já a perda de uma chance prescinde do dolo, ou até mesmo da culpa, para que seja reparável, nas hipóteses em que seja aplicável a responsabilidade objetiva ${ }^{209}$, como, e.g., perda de uma chance decorrente de demanda de consumo (Lei 8.078/90, art. 14) ${ }^{210}$.

O segundo traço contrastivo está nos sujeitos, porque na figura do art. 129 do CCB têm-se, necessariamente, dois pólos de uma relação obrigacional, ou seja, vítima e ofensor se vinculam por meio de um contrato, de um negócio jurídico stricto sensu, o que pode ou não ocorrer na perda de uma chance. Esse leque mais restrito de qualificação dos sujeitos (ofensor e ofendido) dada pelo art. 129 do CCB tem especial relevância no tema que toca ao presente estudo, pois na relação de trabalho as partes estarão envoltas em um contrato $^{211}$, o que exige redobrada atenção ao distinguir as figuras ${ }^{212}$.

A condição é, assim, um elemento incidental de uma obrigação, que submete o início ou fim da eficácia obrigacional, e, por consequência, o dever de prestar que incumbirá ou não ao devedor. Ou seja, a condição pressupõe uma obrigação pré-existente, da qual ela constitui elemento acessório, o que não ocorre na perda de uma chance, em que a álea é um elemento do interesse da vítima. Assim sendo, a condição é a álea que acomete o dever de prestação, ao passo que a chance é a álea do interesse da vítima.

O terceiro ponto de clivagem é um desdobramento do precedente: não basta que ofensor e vítima tenham, entre si, um vínculo obrigacional. É necessário que o primeiro esteja na posição jurídica de suportar uma desvantagem em relação ao segundo ${ }^{213}$, caso a

\footnotetext{
${ }^{209}$ Expressamente admitida por Fernando Noronha: "Essa perda de chance, em si mesma, caracteriza um dano, que será reparável quando estiverem reunidos os demais pressupostos da responsabilidade civil; em especial, será exigida a culpa do agente quando a hipótese for de responsabilidade subjetiva e prescindir-se-á dela qunado a responsabilidade for objetiva". (NORONHA, Fernando, op. cit., p. 28)

${ }^{210}$ BRASIL. Lei $\mathbf{n}^{\mathbf{0}} \mathbf{8 . 0 7 8}$, de 11 de setembro de 1990. Dispõe sobre a proteção do consumidor e dá outras providências Disponível em: 〈http://www.planalto.gov.br/ccivil_03/Leis/L8078.htm>. Acesso em: 24 abr. 2011.

211 Sem olvidar da existência da perda de uma chance 'pré-contratual' e 'pós-contratual' na relação de trabalho.

${ }^{212} \mathrm{O}$ que não ocorreu no seguinte acórdão, que colocou em vala comum os institutos: "Demonstrado nos autos que sua ascensão profissional foi obstada por ato unilateral e ilegal do empregador que impediu sua participação nas avaliações de desempenho necessárias à citada progressão e, sendo incontroverso que isto ocorreu em razão de ato político de perseguição, é certo que voluntariamente impediu a ocorrência de tal condição, razão pela qual se reputa esta verificada, nos termos do art. 129, do atual Código Civil e 120 do diploma de 1916. Aliado a isso, vislumbra-se no caso concreto figura típica da reparação civil em razão da perda de uma chance, que consiste no desaparecimento da "... Probabilidade de um evento que possibilitaria um benefício futuro para a vítima, como progredir na carreira artística ou militar, arrumar um melhor emprego, deixar de recorrer de uma sentença desfavorável pela falha do advogado, e assim por diante..." (BAHIA. Tribunal Regional do Trabalho da $5^{\mathrm{a}}$ Região, $2^{\mathrm{a}}$ Turma. Recurso Ordinário 002480007.2009.5.05.0651. Relator: Luíza Lomba. Diário da Justiça eletrônico, 28 set. 2010).

${ }^{213}$ Daí ser inadequada a menção ao artigo 129 do CCB quando o empregador sonega as guias do segurodesemprego, já que ele não teria ônus algum a suportar caso fornecesse a documentação, na medida em que o benefício é pago pelo Estado: "SEGURO-DESEMPREGO - INDENIZAÇÃO SUBSTITUTIVA - A
} 
condição cujo implemento ele obstou fosse conquistada. É o que ocorre, no Direito do Trabalho, quando o empregador maliciosamente deixa de submeter o empregado à avaliação periódica a que está obrigado pelo Quadro de Carreira, e que, caso resultasse em êxito para o empregado, gerar-lhe-ia o direito a uma promoção, e ao empregador a despesa consequente do aumento de salário ${ }^{214}$.

A quarta e última diferença concerne aos efeitos do ato ilícito: embora tanto na perda de uma chance quanto no artigo 129 do CCB seja incognoscível o resultado final, caso não tivesse ocorrido a interrupção da cadeia causal, o ordenamento atribui-lhes consequências jurídicas distintas. Na perda de uma chance, toma-se o resultado final, e sobre ele aplica-se um percentual correspondente à probabilidade de êxito, e o resultado obtido corresponderá ao valor econômico da chance, para efeitos de indenização.

Já o artigo 129 do CCB estabelece a "ficção do implemento da condição para o caso de o devedor do direito expectativo descumprir o dever de agir com boa-fé, frustrando o implemento da condição ou provocando-a maliciosamente"215. Assim sendo, dentro do escopo de não favorecer o transgressor em seu ardil, o ordenamento considera fictamente

omissão do empregador no fornecimento das guias do seguro-desemprego gera o direito ao pagamento de indenização correspondente, considerando implementadas pelo obreiro as condições legais, porquanto, nos termos do art. 129 do Código Civil de 2002, reputa-se verificada, quanto aos efeitos jurídicos, a condição cujo implemento for obstado pela parte a quem desfavorecer (inteligência do item II da Súmula $n^{\circ} 89$ do TST")". (SANTA CATARINA. Tribunal Regional do Trabalho da $12^{\mathrm{a}}$ Região, $1^{\mathrm{a}}$ Turma. Recurso Ordinário 00094-2008-043-12-00-5. Relator: Viviane Colucci. Diário da Justiça eletrônico, 28 set. 2010).

214 Esta é uma demanda corrente perante o TST, cujo pronunciamento tem sido uníssono no sentido de reputar implementada a condição: "PROMOÇÕES POR DESEMPENHO - AUSÊNCIA DE AVALIAÇÃO - PLANO DE CARGOS E SALÁRIOS - REGULAMENTO DA EMPRESA - DESCUMPRIMENTO - A omissão do empregador em realizar avaliações de desempenho, a fim de garantir a seus empregados a oportunidade de galgar sua escala salarial, por meio de promoções horizontais previstas em norma interna da empresa, tem como efeito reputar-se implementada a condição, nos termos do artigo 129 do Código Civil. Recurso de revista não conhecido". (BRASIL. Tribunal Superior do Trabalho. Recurso de Revista 1446/2000-006-05-00.0. Relator: Min. Guilherme Augusto Caputo Bastos. Diário da Justiça eletrônico, 27 ago. 2010, p. 770)

"PROMOÇÃO POR MERECIMENTO - AVALIAÇÃO PREVISTA EM NORMA INTERNA DA EMPRESA - OMISSÃO DO EMPREGADOR - A omissão do empregador em proceder a avaliações de desempenho, que permitam a seus empregados a oportunidade de galgar níveis na sua escala salarial, por meio de promoções horizontais previstas em norma interna da empresa, tem como efeito reputar-se implementada a condição. Aplicação do artigo 120 do Código Civil de 1916 (artigo 129 do atual Código Civil). Precedentes desta Corte uniformizadora. Recurso de revista a que se dá provimento". (BRASIL. Tribunal Superior do Trabalho. Recurso de Revista 986/2003-004-05-00.7. Relator: Min. Kátia Magalhães Arruda. Diário da Justiça eletrônico, 27 ago. 2010, p. 1195)

"PROMOÇÕES POR MERECIMENTO - AUSÊNCIA DE AVALIAÇÃO - A omissão do empregador em realizar avaliações de desempenho, a fim de garantir a seus empregados a oportunidade de galgar sua escala salarial, por meio de promoções horizontais previstas em norma interna da empresa, tem como efeito reputarse implementada a condição, nos termos do artigo 129 do Código Civil. Recurso de Revista conhecido e provido". (BRASIL. Tribunal Superior do Trabalho. Recurso de Revista 1952/2003-011-05-85.0. Relator: Min. Maria de Assis Calsing. Diário da Justiça eletrônico, $1^{\circ}$ out. 2010, p. 778)

${ }^{215}$ AMARAL, Francisco. Direito Civil: introdução. 6. ed. rev. atual. e aum. de acordo com o novo Código Civil. Rio de Janeiro: Renovar, 2006, p. 491. 
adimplida a condição para todos os efeitos legais, notadamente em relação à desvantagem da qual a parte pretendia se esquivar.

Desde que o juiz entenda que houve malícia no obstáculo posto à conquista da condição, o efeito só pode ser a indenização da totalidade do dano, correspondente àquele que a vítima receberia se não tivesse havido o ilícito reprochado ${ }^{216}$.

É o que as Cortes Trabalhistas têm feito, e.g., quando o empregador dispensa o empregado a fim de impedir a percepção de determinado prêmio ${ }^{217}$, ou, ainda, deixa de emitir a CAT - Comunicação de Acidente de Trabalho ${ }^{218}$, como estratagema para obstar que venha a adquirir a estabilidade provisória por um ano ${ }^{219}$, de que trata o artigo 118 da

${ }^{216}$ Inaceitável, pois, a decisão que concede reparação parcial, mas adota como fundamento o artigo 129 do CCB: "Se a condição para aquisição do direito se concretizava com o labor até dezembro, e tendo o término do vínculo se dado em outubro por iniciativa da empresa, foi ela a responsável pelo não implemento das condições para que o trabalhador fizesse jus à vantagem de forma completa. Considerando-se inclusive o que previsto na norma do art. 129 do Código Civil, o empregado faz jus a 10/12 da vantagem. Recursos desprovidos". (MATO GROSSO DO SUL. Tribunal Regional do Trabalho da $24^{\mathrm{a}}$ Região, $2^{\mathrm{a}}$ Turma. Recurso Ordinário 0117900-66.2008.5.24.0022. Relator: Francisco das C. Lima Filho. Diário da Justiça eletrônico, 25 ago. 2010, p. 64)

217 "PRÊMIO-ASSIDUIDADE - DIREITO OBSTADO - DESPEDIDA SEM JUSTA CAUSA - Gozo do benefício condicionado a ato da empregadora. Prêmio-assiduidade devido em face da despedida sem justa causa. Fato impeditivo da fruição do benefício. Aplicação do art. 120 do Código Civil de 1916, atual art. 129 do novo Código Civil”". (RIO GRANDE DO SUL. Tribunal Regional do Trabalho da $4^{\mathrm{a}}$ Região, $4^{\mathrm{a}}$ Turma. Recurso Ordinário 00423-2004-027-04-00-9. Relator: Ricardo Tavares Gehling. Diário da Justiça eletrônico, 19 abr. 2010).

218 “A concessão do benefício de auxílio-doença previdenciário não constitui requisito para a estabilidade provisória prevista no art. 118 da Lei 8213/91, conforme já pacificado com a Súmula 378, II do C. TST. Ademais, cabe ao empregador comunicar ao INSS a existência de doença profissional, nos termos dos artigos 20 e 22 da Lei 8213/91, não podendo beneficiar-se com a sua omissão (art. 129 do Código Civil). Verificada, em perícia judicial, a existência de moléstia profissional, que tenha nexo causal com o trabalho e cause a incapacidade laborativa, faz jus o trabalhador à estabilidade provisória em questão". (SÃO PAULO. Tribunal Regional do Trabalho da $2^{\mathrm{a}}$ Região, $4^{\mathrm{a}}$ Turma. Recurso Ordinário 01228-2007-083-02-00-8 (20100929030). Relator: Juíza Ivani Contini Bramante. Diário Oficial eletrônico de São Paulo, $1^{\circ}$ out. 2010).

219 Apesar de, tecnicamente, tal ardil ter se tornado inviável com a instituição do NTE - Nexo Técnico Epidemiológico: "De acordo com o Regulamento da Previdência Social (RPS), no art. 336, a empresa deverá comunicar à Previdência Social o acidente de trabalho ocorrido com o segurado empregado, exceto o doméstico, e o trabalhador avulso, até o primeiro dia útil seguinte ao da ocorrência, e, em caso de morte, de imediato, à autoridade competente, sob pena de multa. A comunicação, que pode ser feita pela internet, é a CAT (Comunicação de Acidente de Trabalho). Infelizmente, é comum que muitos empregadores deixem de elaborar este documento, buscando com isso evitar possíveis responsabilizações civis e, ainda, excluir o direito do segurado à estabilidade provisória, quando do retorno (art. 118, da Lei nº 8213/91). De modo a atenuar esta questão, o Ministério da Previdência Social deu importante passo ao criar o Nexo Epidemiológico, que é o vínculo da classificação internacional de doenças (CID), obtida a partir da Perícia Médica, com a atividade desempenhada pelo segurado, reconhecendo-se o benefício como acidentário mesmo sem a CAT. (...) No Regulamento da Previdência Social, o assunto é tratado a partir do art. 337, com redação dada pelo Decreto $n^{\circ}$. 6042/07, que dá nova formatação ao Anexo II do RPS, o qual estabelece Nexo Técnico Epidemiológico entre a atividade da empresa e a entidade mórbida motivadora da incapacidade. Esta presunção de benefício acidentário é válida a partir de abril de 2007 (art. 5o, I, do Decreto n. 6042/07)". (MORAIS, Leonardo Bianchini. O fator acidentário previdenciário (FAP) e o nexo técnico epidemiológico (NTE). Disponível em: <http://jus.uol.com.br/revista/texto/10065/o-fator-acidentarioprevidenciario-fap-e-o-nexo-tecnicoepidemiologico-nte>. Acesso em: 29 abr. 2011) 
Lei 8.213/91 220 (embora, tecnicamente, não se possa falar em "condição", na acepção do artigo 121 do CCB, a emissão da CAT, pois se trata de "condição legal", e não de “condição negocial”, que é a cláusula derivada exclusivamente da vontade das partes).

\subsection{Natureza jurídica}

No que concerne ao estudo da natureza jurídica do instituto, há três vícios epistemológicos que precisam ser escoimados para que a construção da resposta parta de uma correta pedra fundamental: 1 - vincular a avaliação da natureza jurídica ao resultado (dano final) ocasionado; 2 - proceder à análise da natureza jurídica a partir do futuro incerto (caráter aleatório da conquista da vantagem cuja possibilidade foi usurpada) e não do passado certo (chance que a vítima efetivamente tinha); 3 - resolver a questão da natureza jurídica a partir da perspectiva do que seria melhor para a vítima.

Quanto ao primeiro equívoco, trata-se, indubitavelmente, de confusão entre causa e efeito. Ora, uma coisa é a situação lesiva (causa) que faz com que a própria perda da chance exista no mundo dos fatos, outra é o produto ou resultado que desse fenômeno pode decorrer no mundo jurídico, qual seja o dano (efeito), em suas mais diversas modalidades $^{221}$.

Antonio de Rosa, em sua tese de láurea sobre o tema, parece adotar o fustigado critério:

In questa prospettiva il lucro cessante non è nè un'entità, nè è un bene autonomo ma soltanto un vantaggio derivante dalle situazioni giuridiche tutelata dall'ordinamento ed in questo senso, il danno da perdita di chance, rientra nel lucro cessante perché rappresenta la violazione di posizioni giuridiche tutelate da parte dell'ordinamento collegate

\footnotetext{
${ }^{220}$ BRASIL. Lei no 8.213, de 24 de julho de 1991. Dispõe sobre os Planos de Benefícios da Previdência Social e dá outras providências. Disponível em: 〈http://www.planalto.gov.br/ccivil/leis/L8213cons.htm>. Acesso em: 29 abr. 2011.

${ }^{221}$ Nas palavras de Silvio Neves Baptista: "O dano não se confunde com o fato lesivo. Alguns fatos lesivos transfiguram-se em danos, outros não chegam a alcançar essa categoria. O fato lesivo puro e simples é o que não se transforma em dano, ou porque não há previsão normativa, ou porque o ordenamento jurídico préexcluiu a eficácia da responsabilidade civil através de uma das circunstâncias excludentes. O dano é a transfiguração do ato lesivo, por força da previsão da norma, afastadas as circunstâncias excludentes da responsabilidade civil”. (BAPTISTA, Silvio Neves, op. cit., p. 139)
} 


\begin{abstract}
direttamente al danno evento ovvero alla violazione di determinati obblighi come la buona fede contrattuale o la diligenza nell'adempimento dell'obbligazione, senza le quali il danno non si sarebbe prodotto; in questo senso è possibile rilevare il collegamento con il lucro cessante essendo lo stesso soltanto un vantaggio delle posizioni giuridiche tutelate, ed essendo la chance la possibilità di conseguire un vantaggio derivante da determinate situazioni rientra nel lucro cessante $^{222}$.
\end{abstract}

No que concerne ao segundo e terceiro pontos, as palavras de Raimundo Simão de Melo bem ilustram o que, aqui, se pretende demonstrar: "Assim, o enquadramento desse dano não cabe exatamente no dano emergente nem nos lucros cessantes, ante a probabilidade e não certeza de obtenção do resultado aguardado. Entendo que se trata de uma terceira espécie intermediária de dano, entre o dano emergente e o lucro cessante" ${ }^{223}$.

Como se vê, o autor, ao encontrar dificuldades em amoldar o instituto a uma das hipóteses clássicas de perdas e danos - por ter em mira o resultado final, futuro e incerto (segundo equívoco), acaba por criar um terceiro gênero "intermediário", em uma construção nitidamente pragmática (terceiro equívoco) que refoge ao rigor científico necessário, podendo esbarrar em outras dificuldades para encaixá-la ao sistema.

No mesmo iter, Janaína Rosa Guimarães acentua que, no Brasil, "a perda de uma chance surge, atualmente, como uma nova categoria de dano indenizável ${ }^{224} 225$,"

Reiterando o que já foi exposto exaustivamente no item 2.4, a perda de uma chance tem um elemento de certeza (a frustração da oportunidade) e outro aleatório (o resultado final). E o que deve ser indenizado, por integrar o conjunto de bens do lesado, é justamente essa chance.

\footnotetext{
${ }^{222}$ ROSA, Antonio de. Il danno da perdita di chance. Disponível em: $<$ http://www.studiogiuridico.it/tesi.htm>. Acesso em: 28 ago. 2010. Sem grifos no original.

${ }^{223}$ MELO, Raimundo Simão de, op. cit.

${ }^{224}$ GUIMARÃES, Janaína Rosa. Perda de uma chance: considerações acerca de uma teoria. Disponível em: <http://jusvi.com/artigos/41209>. Acesso em: 9. set. 2010.

${ }^{225}$ Registra-se também o pensamento de Paulo Maximilian W. Mendlowicz Schonblun, para quem a perda de uma chance tem natureza jurídica de "danos morais ressarcíveis", inseríveis, contudo, não entre os danos emergentes e os lucros cessantes, mas entre os lucros cessantes e os danos hipotéticos. (SCHONBLUM, Paulo Maximilian Wilhelm. A teoria da perda da chance como solução para o 'se' indenizável. Revista da EMERJ, Rio de Janeiro, v. 12, n. 48, p. 96, p. 87-101, out./dez. 2009)
} 
Confira-se, a propósito, o elucidativo ponto de vista de Patrice Jourdain: "Dans ce type de situation un aléa existe puisque par hypothèse les chances sont aléatories; $\underline{\text { mais il }}$ n'est pas là un obstacle à l'existence d'un préjudice, bien au contraire, puisque c'est la disparition - certaine - de cet aléa, de ces chances de gain, qui constitue le préjudice, lequel ne se confond évidemment pas avec la perte de l'avantage espéré dont l'incertitude interdit toute indemnisation, $^{, 226}$.

A proposta sugerida neste estudo - de olhar para a perda de uma chance com vistas a uma situação pretérita e certa que foi subtraída por conta de ato ilícito - permite lobrigar que a perda de uma chance estaria mais aproximada da figura do dano emergente, na medida em que havia uma pertença antecedente, material ou imaterial, que foi expungida, tornando a situação da vítima pior do que aquela em que estava anteriormente. DosnerDolivet refere-se expressamente ao isolamento da chance como uma espécie de propriedade anterior da vítima que foi, por ela, definitivamente perdida, por ato do réu ${ }^{227}$.

Esse critério, cujo grande mérito é a simplicidade, foi proposto pelos irmãos Mazeaud, ao sustentarem: "Il faut que le juge ait la certitude que le demandeur se serait trouvé dans une situation meilleure si le défendeur n'avait pas accompli l'acte qui lui est reproché 228, .

No direito pátrio, Sérgio Savi foi quem melhor sistematizou a natureza jurídica da perda de uma chance, enquadrando-a como dano emergente, a partir das lições de Adriano de Cupis $^{229}$ :

Ao se inserir a perda de chance no conceito de dano emergente, eliminase o problema da certeza do dano, tendo em vista que, ao contrário de se pretender indenizar o prejuízo decorrente da perda do resultado útil esperado, (a vitória na ação judicial, por exemplo), indeniza-se a perda da

\footnotetext{
${ }^{226}$ JOURDAIN, Patrice. Sur la perte d'une chance. Paris: R.T.D.C., 1992, p. 109. Sem grifos no original.

${ }^{227}$ Nos seguintes termos: "[...] Dans toutes ces hypothèses, pour reprendre une expression de MM. Mazeaud et Tunc, la chance s'isole comme une sorte de proprieté antérieure de la victime et qui est définitivement perdue por elle, par la faute du défendeur”. (DORSNER-DOLIVET, Annick. Paris: Dalloz, 1984, p. 306)

${ }^{228}$ MAZEAUD, Henri et Leon; TUNC, André, op. cit., p. 270.

${ }^{229}$ Foram as seguintes as lições do mestre italiano: "La vittoria è assolutamente incerta, ma la possibilita di vittoria, che il creditori ha inteso garantirsi, già esiste, magari in proporzioni ridotte, al momento in cui si verifica il fatto per effeto del quale resta esclusa: cosicchè è in presenza non già di un danno lucro cessante in ragione dell'impedita futura vittoria, ma di un danno emergente in ragione della frustrata attuale possibilità di vittoria”. (DE CUPIS, Adriano. Il danno: teoria generale della responsabilità civile. 2. ed. Milão: Giuffrè, 1966, v. 2, p. 264)
} 
chance de obter o resultado útil esperado (a possibilidade de ver o recurso examinado por outro órgão de jurisdição capaz de reformar a decisão prejudicial).

Ou seja, não estamos diante de uma hipótese de lucros cessantes em razão da vitória futura que restou frustrada, mas de um dano emergente em razão da atual possibilidade de vitória que deixou de existir.

Assim, não se concede indenização pela vantagem perdida, mas sim pela perda da possibilidade de conseguir essa vantagem. Isto é, faz-se uma distinção entre resultado perdido e chance de consegui-lo. Ao assim proceder, a indenização da perda de uma chance não se afasta da regra da certeza do dano, tendo em vista que a possibilidade perdida, em si considerada, era efetivamente existente: perdida a chance, o dano é, portanto, certo $^{230}$.

O problema que decorre, porém, da vinculação da perda de uma chance a uma dessas duas figuras, de modo inexorável - danos emergentes ou lucros cessantes -, é que elas são vistas, apenas e tão somente, como possíveis desdobramentos do dano patrimonial, o que acarreta, conforme alhures mencionado, uma crise sistêmica, como, por exemplo, a dificuldade de justificar a perda de uma chance quando o evento danoso acarreta prejuízos exclusivamente na esfera imaterial, ou, então, buscar a natureza jurídica a partir do resultado final (primeiro erro apontado neste capítulo).

O estreitamento da classificação do dano emergente e do lucro cessante em, apenas, subespécies de dano patrimonial, é uma restrição de todo inaceitável, pois é possível estendê-las a várias hipóteses de dano moral ${ }^{231}$. Até porque a própria distinção entre dano moral e dano patrimonial, "ao contrário do que parece, não decorre da natureza do direito, bem ou interesse lesado, mas do efeito da lesão, do caráter da sua repercussão sobre o

\footnotetext{
${ }^{230}$ SAVI, Sérgio, op. cit., p. 112.

${ }^{231}$ Sobre o tema, Silvio Neves Baptista foi enfático: "Segundo alguns autores, a classificação do dano em dano emergente e lucro cessante é uma subdivisão dos danos patrimoniais, o que não nos parece correto, uma vez que é perfeitamente possível estendê-la a certas hipóteses de danos morais. No caso, por exemplo, de erro médico cuja lesão incapacita o paciente para o trabalho, o dano não consiste apenas na ofensa corporal (dano emergente), mas também na privação dos ganhos da atividade laboral do ofendido (lucro cessante); o dano estético que impede a atividade profissional de uma atriz deve ser indenizado pela lesão física em si (dano emergente), e pelo prejuízo financeiro que a artista vier sofrer em razão do dano físico". (BAPTISTA, Silvio Neves, op. cit., p. 87)
} 
lesado. De forma que tanto é possível ocorrer dano patrimonial em conseqüência de lesão a um bem não patrimonial como dano moral em resultado de uma ofensa a bem material" ${ }^{232}$.

Por outro lado, há complicações na medida em que a escolha de determinada classificação pode tornar o intérprete refém dela, e estreita a sua capacidade de abstração sobre as hipóteses de aplicação a ponto de não admitir a indenização exclusivamente moral da perda de uma chance.

É bem verdade, todavia, que Sérgio Savi buscou manter a coerência em seu trabalho, dizendo que a perda de uma chance não pode ocasionar um dano exclusivamente moral, por amoldar-se à figura de dano emergente ${ }^{233}$.

Porém, quiçá diante da enxurrada de hipóteses em que a realidade confronta essa premissa, assim elaborou sua contraditória conclusão: “A perda de uma chance, como visto, ao contrário do afirmado por alguns autores, pode, dependendo do caso concreto, dar origem a duas espécies de danos - patrimoniais e extrapatrimoniais -, cumulados ou não. No primeiro caso, o dano decorrente da perda da chance deve ser considerado, em nosso ordenamento, um dano emergente e não lucro cessante" ${ }^{234}$.

Algumas observações merecem destaque: em primeiro lugar, tal entendimento parece vincular a natureza jurídica da perda da chance ao resultado final (modalidade de dano ocasionado), questão por nós já combatida ao longo deste arrazoado; além disso, parece haver uma mistura entre a "perda de uma chance", em si considerada, e o dano que ela pode acarretar.

Gisela Sampaio da Cruz bem se desprendeu da armadilha da vinculação da natureza jurídica da perda de uma chance aos eventuais danos que ela pudesse produzir, ao definir a questão da seguinte maneira:

O dano decorrente da perda de uma chance nem sempre, porém, poderá ser qualificado como dano emergente, porque também pode envolver interesses extrapatrimoniais. Exatamente por isso, ao que parece, a perda de uma chance também não pode ser considerada propriamente, um terceiro gênero, ao lado do dano emergente e do lucro cessante, sendo

\footnotetext{
${ }^{232}$ AGUIAR DIAS, José de, op. cit., p. 772.

${ }^{233}$ Idem, p. 57.

${ }^{234}$ Ibidem, p. 112. Sem grifos no original.
} 
antes uma situação lesiva da qual pode originar um dano patrimonial ou extrapatrimonial, a depender do interesse em jogo ${ }^{235}$.

A perda de uma chance tem característica de "situação lesiva", que pode gerar todas as espécies de reparação por responsabilidade civil previstas no ordenamento, por força do desarmamento ilícito de uma posição jurídica favorável - real e séria.

Assim sendo, afastada a concepção arcaica de que o dano emergente só pode ser patrimonial, ou, mais especificamente, que não contempla a lesão ao patrimônio imaterial, não há dúvidas de que a perda de uma chance estaria encaixada nesta categoria.

\subsection{Requisitos para o acolhimento de um dano reparável: realidade e seriedade}

Não é qualquer "chance" perdida, em sentido vulgar, que dá ensejo a uma indenização. "A chance deve ser 'séria' ou 'real e séria'. É necessário demonstrar a realidade do prejuízo final, que não pode ser evitado - prejuízo cuja quantificação dependerá do grau de probabilidade de que a chance perdida se realizaria" ${ }^{236}$.

Para toda "novidade" do mundo jurídico, faz-se necessário criar mecanismos de blindagem contra abusos. Sob esse enfoque, a exigência do caractere real e sério da chance constitui uma espécie de proteção eficaz contra eventuais distorções do conceito ${ }^{237}$.

Majoritariamente, a doutrina estipula apenas duas exigências para que a chance possa ser juridicamente considerada para efeitos indenitários: realidade e seriedade. Alguns, entretanto, destacam também a atualidade ${ }^{238}$ como um terceiro requisito, embora ela, em

\footnotetext{
${ }^{235}$ SAMPAIO DA CRUZ, Gisela. A reparação dos lucros cessantes no direito brasileiro: do bom senso à incidência do postulado normativo da razoabilidade. 2008. Tese (Doutorado) - Universidade do Estado do Rio de Janeiro - UERJ, Faculdade de Direito, Rio de Janeiro, apud SAVI, Sérgio, op. cit., p. 42-43, nota de rodapé 24.

${ }^{236}$ KFOURI NETO, Miguel, op. cit., p. 65.

${ }^{237}$ É o que atestam Viney e Jourdain: "l'exigence du caractere réel et sérieux de la chance perdue constitue donc un garde-fou assez efficace contre les abus éventuels de la notion”. (VINEY, Gineviève; JOURDAIN, Patrice, op. cit., p. 102)

${ }^{238}$ O professer Yves Chartier definiu assim o "dano atual": "Par dommage 'actuel', on doit naturellement entendre non seulement celui qui se poursuit au moment où le tribunal statue, mais aussi celui qui a cessé. Ce qui caractérise la certitude de ce préjudice, c'est que la victime démontre avoir subi, ou être en train de subir, des atteintes à ses droits ou à ses intérêts. C'est une condition nécessaire, mais suffisante.(...) La certitude n'implique pas que le dommage soit, d'ores et déjà, réalisé (a) : elle suppose en revanche qu'il n'y ait pas, dans le futur, une chance raisonnable que ce préjudice ne se produise pas (b). (CHARTIER, Yves, op. cit., p. 21-23)
} 
verdade, acabe por comprometer a seriedade e a certeza, pois, efetivamente, quanto mais o momento é distante, mais se torna verossímil que as circunstâncias exteriores, de algum modo, impeçam a concretização das chances ${ }^{239}$.

Advirta-se, porém, que tais critérios (seriedade-atualidade) dizem respeito somente à perda de uma chance, porque a linha do tempo conspira em favor do aumento da probabilidade de que outros acontecimentos possam intervir no sentido de evitar que o prejuízo se consume ou a vantagem seja percebida. Foi o que ocorreu, por exemplo, quando a Corte de Cassação negou indenização pela perda de esperança de promoção profissional, excetuados os casos em que a evolução visada era iminente no momento da ocorrência do fato que a impediu ${ }^{240}$.

Desse modo, "enquanto pretensões relacionadas a oportunidades passadas ou projetadas ao futuro próximo possuem maior probabilidade de ser acolhidas, pedidos relativos a chances que poderiam se materializar apenas no futuro distante são menos promissores $^{241}$.

No mesmo sentido, não seria sério que se concedesse indenização a uma criança de oito anos de idade (ou aos seus pais), recém matriculada em uma escolinha de futebol, porque ela sofreu um acidente e isso a impediu de se tornar uma grande atleta profissional e auferir salários milionários, vultosos contratos publicitários etc. ${ }^{242}$.

Diferentemente ocorre na hipótese de lucros cessantes, em que o dano é certo, e o cálculo é feito pelo sistema de presunções legais. Seria o caso, por exemplo, de um trabalhador vítima de um infortúnio que lhe extirpasse a capacidade laboral. É ululante que o dano não se restringe ao presente, mas terá consequências futuras no que tange à percepção de salários. Nesse caso, “du moment que le juge a la certitude que le défendeur

\footnotetext{
${ }^{239}$ Com essa observação, Viney e Jourdain justificam a exigência jurisprudencial do caráter atual ou iminente do dano: "en effet, plus ce moment est éloigné plus il est vraisemblable que des circonstances extérieures l'auraien, de toute façon, empêché de se réaliser. C'est pourquoi la jurisprudence se montre, dans l'ensemble, assez exigeante quant à la preuve du caractere actuel ou imminent de la chance dont le demandeur invoque la disparition”. (VINEY, Gineviève; JOURDAIN, Patrice, op. cit., p. 100)

${ }^{240}$ VINEY, Gineviève; JOURDAIN, Patrice, op. cit., p. 10.

${ }^{241}$ MORAES, Renato Duarte Franco de. A moldura jurídica da "perda de chance”. Valor Econômico, São Paulo, 12 jan. 2011. Legislação \& tributos, Caderno E, p. 2.

${ }^{242}$ Zannoni, ao estatuir as condições para que a vítima esteja apta a vindicar indenização, asseriu que: "debe exigirse que la víctima se encuentre en situación fáctica o jurídica idónea para aspirar a la obtencíon de esas ventajas ao momento del evento dañoso, lo que no existe cuando quien se pretende damnificado, no llegó a emplazerse en la situación idónea para hacer la ganancia o evitar la pérdida”. (ZANNONI, Eduardo A. El daño en la responsabilidad civil. 3. ed. Buenos Aires: Ástrea, 2005, p. 110-111)
} 
subira un préjudice, il serait absurde de le contraindre à rejeter une action qu'il devrait

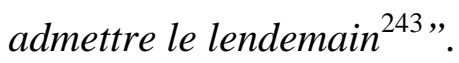

Portanto, "poderá haver indenização de uma futura lesão decorrente de um dano atual. Destaca-se que não é o dano que ocorrerá no futuro, mas sim as repercussões que se prolongam no tempo, como consequências de uma lesão atual ${ }^{244 \text {,. }}$

Outro aspecto relevante é que a realidade da chance deve ser analisada sob o prisma objetivo. Jacques Boré, em feliz ilustração, exemplificou com a hipótese de um doente terminal, vítima de um câncer incurável, que possui a esperança subjetiva, quiçá por motivos religiosos, em sua cura; entretanto, do ponto de vista médico, ele não dispõe de chance real de debelar a doença ${ }^{245}$. Isso significa que, embora a manutenção de expectativas favoráveis possa desempenhar uma importante função sob o aspecto psicológico $^{246}$, para o jurista, a mera esperança subjetiva é um conceito vazio de utilidade prática $^{247}$.

Por outro lado, a seriedade da oportunidade frustrada tem a ver com uma probabilidade palpável, não com algo meramente especulativo ou de possibilidade diminuta $^{248}$. Conjeture-se, v.g, a hipótese de um cidadão que, nos últimos dez anos, todas

\footnotetext{
${ }^{243}$ MAZEAUD, Henri et Leon; TUNC, André, op. cit., p. 272.

244 GONDIM, Glenda Goncalves. Responsabilidade civil: teoria da perda de uma chance. Revista dos Tribunais, São Paulo, v. 94, n. 840, p. 11-36, out. 2005, p. 17.

${ }^{245}$ No original: La chance se distingue d'abord du simple espoir purement subjectif: elle s'apprécie objectivement. Le malade atteint d'un cancer incurable peut conserver l'espoir de guérir ; médicalement cependant, il ne disposera d'alcune chance appréciable de guérison. In: BORÉ, Jacques. Op. cit.

${ }^{246}$ Nessa vertente: "A manutenção de expectativas favoráveis em relação ao futuro apresenta importantes efeitos do ponto de vista psicológico (...). Acland alerta (op. cit., p. 102) que, quando as pessoas não vêem futuro, nada parece importar e aparece a tentação de envolver-se em conflito”. (FIORELLI, José Osmir; FIORELli, Maria Rosa; JUNIOR, Marcos Julio Olivé Malhadas. Psicologia Aplicada ao Direito. São Paulo: LTr, 2006, p. 27)

${ }^{247}$ Conforme lição de Manuel Iglesias Cubria: "Se diferencia de la simples esperanza o mera spes, que puede tener en el campo subjetivo de las motivaciones psicológicas fundamentos muy serios, o, por el contrario, totalmente vanos, hasta el punto de que el sujeto esperanzado pueda hallarse afectado de una auténtica obsesión psicopática por su fe en lo irreal; pero en el campo de la alteridad, la simples esperanza no es más que la interna representación de la idoneidad de un sujeto para ser titular de un derecho hecha acto: subjetiva creencia en la posibilidad de llegar a ser propietario, donatario, heredero, acreedor, etc. Es, en definitiva, una situación subjetiva interna, que puede tener incluso en ocasiones un fundamento objetivo y serio, una manifestación externa - como la del mismo oferente que confiando en la bondad de su oferta, adquiere la esperanza de allegar el precio señalado como contraprestación; la del que se sabe instituido heredero, que confía en llegar a adir la herencia, etc. - pero que el ordenamiento no llega a valorar como digna de protección jurídica individualizada. Ciertamente en sus resultados, la esperanza responde a un concepto que para el jurista carece de utilidad práctica”. (CUBRIA, François. Los derechos patrimoniales e eventuales: estúdio de las situaciones juridicas de pendência. Oviedo: Libreria Ojanguren, 1961, p. 14).

${ }^{248}$ É o que asseriu Fernando Noronha: "A possibilidade poderá ser alta ou reduzida; poderá ser até tão desprezível que nem possa ser tida como correspondendo a um interesse digno de tutela jurídica, se considerar a função social das obrigações". (NORONHA, Fernando. Direito das Obrigações: fundamentos
} 
as quartas-feiras, às $10 \mathrm{~h}$, tem por hábito caminhar até a lotérica próxima de sua casa e fazer um jogo de seis números aleatórios e diferentes na mega-sena. Em determinado dia, quando faz seu percurso até a casa de apostas, é atropelado e vê obstada a possibilidade de concorrer no certame. Considerando que a probabilidade de acerto dos seis números de em concurso é de 1 em $50.063 .860^{249}$, não se pode cogitar da hipótese de "perda de uma chance", sob o conceito cientificista que ora se pretende empregar.

Com esses dois exemplos é possível estabelecer uma escala hierárquica entre os requisitos: a realidade antecede a seriedade, embora somente a conjunção de ambos torne a vítima apta a pedir a reparação do dano. É possível haver uma chance real que não seja séria, mas não é possível cogitar de uma chance séria, que não seja real. Retomando os exemplos anteriores, o enfermo cientificamente condenado não possui uma chance real, logo, ela não é séria; já o possuidor de um bilhete com uma chance em 50 milhões possui uma chance inegavelmente real - tanto assim que adquire o bilhete mediante paga -, mas que, para efeitos jurídicos, não pode ser considerada séria.

2.7.1 A expressão da seriedade em termos percentuais

A asserção de que o proprietário de um bilhete de loteria com uma chance em cinquenta milhões não possui uma chance séria, conduz, ato contínuo, a uma indagação imanente e indissociável: Existe, então, um percentual probabilístico que a pessoa deve ter para que as suas chances possam ser consideradas sérias?

Reitere-se que a seriedade aqui tratada diz respeito à acepção jurídica do termo, pois, conforme já mencionado, existe uma chance real na hipótese tratada, tanto assim que milhões de pessoas pagam para concorrer a essa chance. Ela, de fato, existe.

Todavia, o ordenamento a considera desprezível para efeitos de pretensões indenitárias, embora, do ponto de vista estritamente teórico, seria correto dizer que, em tal hipótese, a vítima perdeu a chance de concorrer ao grande prêmio, que poderia ter sido, v.g., de R \$ 1.000.000,00, e, assim, diante do seu percentual probabilístico de chances (uma

do direito das obrigações: introdução à responsabilidade civil. 2. ed., rev. e atual. São Paulo: Saraiva, 2007 , v. 1, p. 679).

${ }^{249}$ CAIXA ECONÔMICA FEDERAL. Disponível em: <http://www1.caixa.gov.br/loterias/loterias /megasena/probabilidades.asp>. Acesso em: 25 nov. 2010. 
em cinquenta milhões), o valor da oportunidade perdida seria de $\mathrm{R} \$ 0,02$, o que seria um despautério tomar como meritório para efeitos de tutela jurisdicional de chances.

Mas isso ainda não responde à indagação inicial: há um percentual que possa ser prédefinido como sério para os fins a que se colima?

Trata-se de uma pergunta que já foi enfrentada pela doutrina italiana, que chegou a inferir que o percentual deveria ser superior a $50 \%$ (cinquenta por cento), a partir das lições de Bocchiola ${ }^{250}$, e continua a fazê-lo em tempos atuais, por outros escritores:

Procedendo in questa direzione si è giunti ad affermare, come la perdita di chance non è un danno futuro quanto un danno presente perché la chance è perduta nel momento in cui avviene il fatto illecito, tuttavia per aversi certezza del danno da perdita di chance è necessario che le probabilità di conseguire il risultato favorevole siano superiori al $50 \%$. Seguendo tale prospettiva la chance è considerata di per sé risarcibile, rappresentando un bene avente valore economico esistente nel patrimonio del soggetto ${ }^{251}$.

Sérgio Savi perfilhou idêntico pensamento em sua obra, ao sustentar:

Entendemos que somente será possível admitir a indenização da chance perdida quando a vítima demonstrar que a probabilidade de conseguir a vantagem esperada era superior a $50 \%$ (cinquenta por cento). Caso contrário, deve-se considerar não produzida a prova da existência do dano, e o juiz será obrigado o julgar improcedente o pedido de indenização ${ }^{252}$.

Também acompanhou a doutrina italiana Sérgio Cavalieri Filho, ao afirmar que "a perda de uma chance, de acordo com a melhor doutrina, só será indenizável se houver a

\footnotetext{
${ }^{250}$ BOCCHIOLA, Maurizio, op. cit., p. 101.

${ }^{251}$ ROSA, Antonio de, op. cit, p. 98-99.

${ }^{252}$ SAVI, Sérgio, op. cit., p. 112-113.
} 
probabilidade de sucesso superior a cinqüenta por cento, de onde se conclui que nem todos os casos de perda de uma chance são indenizáveis ${ }^{253}$,"

O que há em comum entre os autores citados é a mais completa ausência de fundamento para considerar séria a chance apenas quando ela supera 50\% (cinquenta por cento) de probabilidade, exceto, no caso brasileiro, em que o argumento é a remissão à doutrina italiana. Academicamente, porém, a "autoridade do argumento" deve prevalecer sobre o "argumento de autoridade", de modo que é necessário esquadrinhar sua validade epistemológica.

Ora, afirmar que, para uma chance ter probabilidade maior de se concretizar do que de não se concretizar, é necessário que ela seja maior do que 50\% (cinquenta por cento), soa tão frívolo quanto explicar a diferença entre zero e um. No entanto, confundir essa maior probabilidade com seriedade é um atentado lexicológico dantesco.

Não há como dizer que um candidato a cargo eletivo com $40 \%$ (quarenta por cento) de intenções de voto nas pesquisas não possui uma chance considerável. Impossível sustentar que um paciente que tem à sua disposição um tratamento que lhe confere $30 \%$ de chance de cura, não tem direito a qualquer indenização, se esta oportunidade lhe for expungida. E, para concluir as hipóteses, é um desatino afirmar que, em um jogo de "cara ou coroa", "vermelho ou preto" ou "par ou ímpar", nenhum dos jogadores possui uma chance séria, pois a probabilidade de ambos é “apenas" igual a 50\% (cinquenta por cento), e não superior, como sugerem a doutrina e a jurisprudência italianas ${ }^{254}$ e parte da brasileira.

Mas o critério escolhido é infeliz não apenas por ter estabelecido a seriedade de chance em um percentual superior a 50\% (cinquenta por cento), mas, também, pela própria ideia de "tabelar" o conceito de seriedade, ou seja, ainda que a tarifação tivesse sido estipulada em 10, 20, 30 ou $80 \%$ (dez, vinte, trinta ou oitenta por cento), o resultado seria igualmente nefasto.

${ }^{253}$ CAVALIERI FILHO, Sérgio, op. cit., p. 75.

${ }^{254}$ Convém registrar que a Corte de Cassação Italiana, em alguns pronunciamentos relativamente recentes, afirmou que a chance precisa se materializar em uma probabilidade favorável, mas não necessariamente superior a 50\% (cinquenta por cento): "Nell'ipotesi di inadempimento del datore di lavoro che abbia comportato la perdita della chance di promozione, il danno risarcibile al lavoratore va ragguagliato alla probabilità di conseguire il risultato utile - al qual fine è sufficiente la ragionevole certezza dell'esistenza di una non trascurabile probabilità favorevole (non necessariamente superiore al 50\%)- e può essere determinato applicando al parametro costituito dalle retribuzioni che sarebbero spettate in caso di promozione un coefficiente di riduzione che tenga conto di quella probabilità, oppure, ove questo o altro criterio risulti di difficile utilizzazione, ricorrendo alla valutazione equitativa". (ITÁLIA. Corte de Cassação. Cass. civ., Sez. lav., 22 abr. 1993, n. 4725. In: MANGIATORDI, Maria. La perdita di chance non è una mera aspettativa. Rivista giuridica telemática, Bari, n. 2, p. 113-127, 2007, p.123) 
Epistemologicamente, é inapropriado preestabelecer um determinado conceito jurídico, quando o próprio legislador fez opção clara pela redação a partir de cláusulas gerais $^{255}$. Com efeito, a escolha do legislador foi propositada, e não cabe ao intérprete desvirtuá-la, preenchendo, em juízo prévio e abstrato, conceitos abertos. Destarte, "se o conceito legal é rigoroso e delimitado com precisão, o espaço de atuação do juiz fica mais limitado. (...) Em outros casos, porém, a lei recorre a conceitos menos precisos e mais abertos. São os chamados conceitos jurídicos indeterminados, que se exemplificam com expressões como boa-fé, bons costumes e outras figuras semelhantes ${ }^{256}$,"

Quisesse o legislador conceituar ou delimitar a seriedade da chance, em percentagens de probabilidade, certamente o teria feito, eliminando qualquer tarefa exegética desse jaez. Mas assim não o fez, em patente predileção por deixar uma determinada margem axiológica sob incumbência do intérprete.

Rechaça-se, em caráter proléptico, qualquer argumento no sentido de que não se pode avaliar a mens legis, porque o direito positivo não cuidou especificamente do tema em questão, uma vez que "a lei tira a sua força não tanto da vontade do legislador, que a faz, mas, principalmente, da vontade do legislador que a conserva. Se o legislador atual, podendo revogar a lei, não obstante a conserva, é como se a refizesse cada dia ${ }^{257}$,"

E a eleição da lei pelo critério aberto deu-se justamente pela complexidade da gama de situações no mundo fenomênico que podem fazer com que o percentual de probabilidade para que a chance seja considerada séria não atenda a um padrão rígido, antes experimentando oscilação pendular na materialização do justo, de acordo com as circunstâncias de cada caso, e delegando ao juiz o mister de integrar um dos elementos da $1 \mathrm{ei}^{258}$.

\footnotetext{
${ }^{255}$ Sobre o assunto, explica Pietro Perlingieri: "Ao lado da técnica de legislar com normas regulamentares (ou seja, através de previsões específicas e circunstanciadas), coloca-se a técnica das cláusulas gerais. Legislar por cláusulas gerais significa deixar ao juiz, ao intérprete, uma maior possibilidade de adaptar a norma às situações de fato". (PERLINGIERI, Pietro. Perfis do Direito Civil: introdução ao Direito Civil Constitucional. 3. ed. Rio de Janeiro: Renovar, 2002, p. 27)

${ }^{256}$ MALLET, Estêvão. Antecipação da tutela no processo do trabalho. 2. ed. rev. e amp. São Paulo, LTr, 1999 , p. 90.

${ }^{257}$ CAVALIERI FILHO, Sérgio, op. cit., p. 297.

${ }^{258}$ Sobre o porquê dessa opção, as lições de Estêvão Mallet: "Georges Renard prefere chamá-los de conceitos flexíveis, observando que, se fosse possivel exprimir todas as idéias por meio de números, não haveria tais conceitos, uma vez que 'il n'y a rien de plus inflexible qu'un nombre'. (...) Mas, no campo do direito, isso não é possível em todas as ocasiões, prossegue Renard, porquanto 'le plus grand nombre de nos concepts son qualitatifs, donc porvus d'une certaine élasticité. Por isso o direito apresenta, ao lado de regras precisas e bem delimitadas - como as pertinentes à maioridade, para retomar a hipótese antes figurada - 'd'autres dispositions d'un caractere très générale - obtempera Dabin - n'énonçant qu'un
} 
E essa abertura nos textos legislativos foi a tônica do Código Civil Brasileiro de 2002, que, substituiu os arcaicos dogmas individualistas ${ }^{259}$ do liberalismo predominante no diploma antecedente ${ }^{260}$ e redirecionou o eixo do sistema sob uma concepção solidarista, modificando o paradigma filosófico de se conceber as relações privadas.

Do ponto de vista metodológico, o novo Código teve o intento de criar um sistema aberto, que pudesse recepcionar valores e princípios de outras partes do sistema jurídico e da sociedade, sob a forma intrassistemática (entre dispositivos do próprio Código), interssistemática (entre o Código e outras legislações ou microssistemas) e extrassistemática (fora do próprio sistema jurídico) ${ }^{261}$.

Isso fez com que o legislador inserisse, de modo esparso, cláusulas gerais, cujos dispositivos contêm uma fórmula estrutural que reclama complementação, feita pelo preenchimento dos chamados "conceitos jurídicos abertos"262. Seguiu-se, assim, uma tendência mundial, iniciada na década de 40, de "conjugar à técnica legislativa casuística a introdução de cláusulas gerais, como forma de superar-se o 'fetichismo' da onisciência da lei e, por via transversa, sofrear o envelhecimento precoce das normas" 263 .

Verifica-se, pois, a partir dos pressupostos teóricos de técnica legislativa e hermenêutica, algumas conclusões: i) não se pode predeterminar o preenchimento de um conceito jurídico indeterminado, quando a opção do legislador tiver sido pelo uso de cláusulas gerais; ii) o elemento a ser suprido pelo julgador para emprestar concreção ao

principe ou une directive, dont la détermination est laissée au jugement des parties et des tribunaux selon les particularités del'espèce'. Disposições dessa natureza exprimem aquilo que Herbert Hart chamou de 'textura aberta do direito', correspondendo aos preceitos em que a determinação precisa da conduta a observar-se acaba ficando, por questão de técnica legislativa, a cargo dos tribunais”. (MALLET, Estêvão, op. cit., p. 90-91)

259 "Mas o fato é que, por isso mesmo, por conta dos seus antecedentes, como visto, os códigos do século XIX - aí incluído o Código Civil brasileiro de 1916, já que, como se disse, elaborado o respectivo anteprojeto ao longo do ano de 1899 -, evidenciavam todos um perfil marcadamente individualista e patrimonialista. Ou seja, cuidava-se de legislações postas à tutela das manifestações básicas dos direitos subjetivos, vale dizer, e para utilizar a distribuição dos livros da parte especial do Código Civil de 1916, bem assim a imagem de Miguel Reale e de quem ele considerava serem os protagonistas da lei civil anterior, códigos de tutela do marido, do proprietário, do contratante e do testador". (GODOY, Claudio Luiz Bueno de. Responsabilidade civil pelo risco da atividade. São Paulo: Saraiva, 2009, coleção prof. Agostinho Alvim, p. 10)

${ }^{260}$ Delineou os contornos históricos Orlando Gomes: “Assim, o exame da atividade dos legisladores durante o período de elaboração do Código Civil revela que, a despeito de manifestações entusiásticas do movimento de renovação do Direito, iniciado no fim do século passado, a submissão aos princípios vigentes durante a fase do apogeu do liberalismo foi atitude firmemente mantida pelos codificadores”. (GOMES, Orlando. Raízes históricas e sociológicas do Código Civil brasileiro. São Paulo: Martins Fontes, 2006, p. 34)

${ }^{261}$ AGUIAR, Roger Silva. Responsabilidade Civil Objetiva: do risco à solidariedade. São Paulo: Atlas, 2007 , p. 2.

${ }^{262}$ Idem.

${ }^{263}$ Ibidem, p. 3. 
texto legal deve ser integrado no momento da análise do caso concreto; iii) o Código Civil brasileiro, fundamento genérico da reparação de danos, não estabelece qualquer tarifação para a seriedade da chance, bem como para todas as demais situações lesivas; iv) é necessário, então, traçar diretrizes teóricas para a tarefa de qualificar a chance como reparável.

\subsubsection{A "medida" da seriedade pela lógica hegeliana}

Já se sustentou, no tópico precedente, que a lacuna axiológica relativa à seriedade da chance não pode ser colmatada ex ante, em juízo prévio e abstrato, tampouco a partir de um padrão imutável. Cronologicamente, então, o conceito jurídico aberto deve ganhar contornos mais herméticos apenas ex post, quando, na formulação das inferências de intelecção inerentes ao ato de julgar, o juiz se deparar com uma situação efetivamente séria.

E o conceito de seriedade que ora se propõe, a fim de fornecer os matizes da substantificação do conceito abstrato, deve ser alcançado quando o intérprete vislumbrar a "medida ${ }^{264}$,, o quanto qualitativo, que é o momento, averiguado concretamente, em que a soma de uma determinada quantidade de chances (variável de acordo com as circunstâncias) tem o condão de comutar-se em algo juridicamente tutelável, ou seja, o ponto exato em que as mudanças meramente quantitativas convertem-se em qualitativas.

É do senso comum que a quantidade não altera a qualidade, o que, como regra, pode ser admitido como válido. Assim, tomando-se como exemplo banal objetos como "pregos", pouco importa se há dois, cinquenta ou trezentos deles; serão, sempre, "pregos".

Há, contudo, casos em que uma mera alteração na quantidade implicará mudança na qualidade $^{265}$. Hegel elucida seu raciocínio a partir de exemplos comezinhos ${ }^{266}$, como o da mudança da temperatura em relação ao estado líquido da água. Dentro de determinada

\footnotetext{
${ }^{264}$ Nomenclatura utilizada por HEGEL, Georg Wilhelm Friedrich. Enciclopédia das Ciências Filosóficas em compêndio (1830). Texto completo com os adendos orais. Tradução Paulo Meneses, com a colaboração de José Machado. São Paulo: Loyola, 1995, v. 1, p. 214.

265 “§ 108. Enquanto na medida a quantidade e a qualidade estão só em uma unidade 'imediata', sua diferença nelas ressalta de um modo igualmente imediato. Por isso, o quanto específico é, por uma parte, simples quanto; e o ser-aí é suscetível de um aumento e (de uma) diminuição, sem que a medida, que nisso é uma 'regra', seja suprassumida por esse fato; mas por outra parte a alteração do quanto é também uma alteração da qualidade". (Idem, p. 215)

${ }^{266}$ Ibidem.
} 
margem, pode-se diminuir ou aumentar a temperatura, e tais modificações serem irrelevantes para o estado físico de agregação da água. Todavia, a continuidade de tais mudanças - para baixo ou para cima - gerará, dentro das $\mathrm{CNTP}^{267}$, ao chegar a zero grau centígrado, a mutação de um corpo líquido em um corpo sólido, e, ao atingir os cem graus centígrados, de líquido em gasoso, casos em que, quando do alcance de dois pontos decisivos, uma mera alteração quantitativa provoca alterações qualitativas nos corpos.

No mesmo sentido, Hegel alude aos exemplos dados pelos gregos ${ }^{268}$ para essa aparente antinomia: um grão de trigo sobreposto a outro, faz uma pilha de trigo? Arrancar um pelo da cauda de um cavalo, faz uma cauda sem crina? Se, a respeito da natureza da quantidade, enquanto determinante indiferente e exterior ao ser, o primeiro impulso é o de responder negativamente a essas questões, é preciso conceder um limite à negativa, pois haverá de chegar um momento em que a sobreposição de mais um único grão de trigo gerará uma pilha, ou a retirada de mais um só pelo implicará uma cauda sem crina.

Marx também se apropriou dos conceitos de Hegel para chegar à conclusão de que era a "medida" o que diferenciava a produção de valor da produção de mais-valia ${ }^{269}$, ou seja, o que qualificava a exploração do homem pelo homem como tal, era a quantidade da exploração da mão-de-obra operária, cujo excedente de produção deveria ser suficiente para gerar acúmulo e concentração de riquezas nas mãos da burguesia, e crescentes desigualdades em relação ao proletariado.

Engels, por sua vez, ao sustentar dialeticamente os conceitos de Hegel para explicar a mudança da quantidade em qualidade, a fim de defender as ideias de Karl Marx, cita o ilustrativo exemplo de Napoleão:

\footnotetext{
267 As CNTP - Condições Normais de Temperatura e Pressão (cuja sigla é CNTP no Brasil e PTN em Portugal), são condições experimentais ideais, e referem-se à temperatura e pressão de $273,15 \mathrm{~K}\left(0{ }^{\circ} \mathrm{C}\right) \mathrm{e}$ $101325 \mathrm{~Pa}(101,325 \mathrm{kPa}=1,01325 \mathrm{bar}=1 \mathrm{~atm}=760 \mathrm{mmHg})$, respectivamente. Esta condição é geralmente empregada para medidas de gases em condições atmosféricas (ou de atmosfera padrão). (LUZ, Ana Maria. Condições Normais de Temperatura e Pressão (CNTP).. Disponível em: 〈http://www.infoescola.com/termodinamica/condicoes-normais-de-temperatura-e-pressao-cntp $>$. Acesso em 2 maio 2011)

${ }^{268}$ HEGEL, Georg Wilhelm Friedrich, op. cit., p. 215.

269 "Comparando o processo de produzir valor com o de produzir mais valia, veremos que o segundo só difere do primeiro por se prolongar além de certo ponto. O processo de produzir valor simplesmente dura até o ponto em que o valor da força de trabalho pago pelo capital é substituído por um equivalente. Ultrapassando esse ponto, o processo de produzir valor torna-se processo de produzir mais valia (valor excedente)”. (MARX, Karl. O capital. Volume 1. Capítulo VII. Disponível em: <http://www.marxists.org/portugues/marx/1867/ocapital-v1/vol1cap07.htm\#c7s2>. Acesso em: 07 mar. 2011)
} 
Para terminar este capítulo vamos dar um testemunho final a favor da mudança da quantidade em qualidade: o testemunho de Napoleão. Napoleão descreve o combate travado entre a cavalaria francesa, cujos soldados eram pouco afeitos à equitação, mas que eram, no entanto, disciplinados, e os mamelucos, cuja cavalaria era a melhor do seu tempo para os combates individuais, mas que eram indisciplinados. Eis o que nos diz Napoleão: "Dois mamelucos sobrepujavam, indiscutivelmente, a três franceses; 100 mamelucos faziam frente a 100 franceses; 300 franceses venciam 300 mamelucos e 1.000 franceses derrotavam, inevitavelmente, 1.500 mamelucos $^{270}$.

A quantidade não se altera, sempre, impunemente, sem transgredir a qualidade. "Quando uma variação quantitativa ocorre, isso aparece inicialmente como algo de todo inocente; mas há algo diverso por trás dela, e essa variação - na aparência inocente - do quantitativo, é por assim dizer um ardil, graças ao qual se atinge o qualitativo ${ }^{271 \text { ", }}$

É nesse requinte que o hermeneuta deve investigar a seriedade da chance: do ponto exato em que uma determinada quantidade deixa de ser algo amorfo e destituído de valor, para, transmudando a sua qualidade, transformar-se em algo sério, merecedor de tutela jurisdicional segundo a teoria das chances perdidas.

\subsubsection{O caso do "Show do Milhão"}

No Brasil, pode-se considerar o caso mais célebre ${ }^{272}$ da perda de uma chance em um Tribunal Superior, o caso "Show do Milhão", cuja relevância em se relatar neste tópico decorre do fato de ter sido um acontecimento notório em âmbito nacional, no qual o Superior Tribunal de Justiça considerou a chance séria, para efeitos reparatórios, ainda que a probabilidade de êxito fosse inferior a $50 \%$ (cinquenta por cento), sem se ater, desse modo, ao critério longamente vergastado no tópico precedente.

\footnotetext{
${ }^{270}$ ENGELS, Friedrich, op. cit.

${ }^{271}$ HEGEL, Georg Wilhelm Friedrich, op. cit., p. 216.

272 Porém, reputá-lo o leading case do tema, como faz Sérvio Savi (Op. cit., p. 75), é uma consideração honoris causae, diante da repercussão que o julgamento obteve, e não da primogenitura histórica.
} 
O "Show do Milhão" era um programa televisivo diário, comandado pelo apresentador Silvio Santos, no qual os candidatos respondiam a perguntas sequenciais sobre conhecimentos gerais, em grau supostamente crescente de dificuldade, e, na medida em que acertavam, prosseguiam na competição, amealhando uma premiação cada vez maior. As perguntas eram de múltipla escolha dentre quatro alternativas expressadas pelos números "1" a "4". Os concorrentes contavam com determinados recursos para contribuir com o seu desempenho: tinham a opção de "pular" (furtar-se de responder) até três perguntas; ouvir a opinião de três universitários para uma determinada pergunta; pedir a "ajuda das placas", que eram erguidas por cada um dos outros onze concorrentes (que aguardavam a vez de participar), com as respectivas opiniões; ou, ainda, escolher aleatoriamente dentre quatro cartas, que continham números de zero a três, as quais representavam a quantidade de opções que seriam eliminadas de uma determinada questão escolhida pelo candidato, restando a ele, na sequência, optar entre as alternativas restantes.

O objetivo do certame era conquistar o maior prêmio possível: R $\$ 1.000 .000,00$ (um milhão de reais) em barras de ouro. Para isso, o aspirante a milionário deveria responder corretamente a uma série de 15 perguntas, de acordo com as regras acima mencionadas, até atingir o prêmio de $\mathrm{R} \$ 500.000,00$ (quinhentos mil reais), quando, então, se depararia com a pergunta capital, denominada "pergunta do arrisca tudo".

Para tal indagação, as regras do jogo se modificavam ligeiramente: o concorrente não tinha auxílio algum; após o enunciado da pergunta, aparecia na tela o desenho de uma maleta com barras de ouro, e um cronômetro regressivo de 20 segundos, findo o qual, o candidato dizia se desistia ou respondia à pergunta; exaurido o tempo, e tendo o candidato optado por responder, levaria o prêmio total, desde que acertasse a resposta, ou, caso desse a resposta errada, ficaria apenas com simbólicos $\mathrm{R} \$ 300,00$ (trezentos reais). Havia, ainda, a faculdade de não responder à última pergunta, caso em que o candidato encerraria sua participação auferindo o prêmio até então adquirido, de $\mathrm{R} \$$ 500.000,00 (quinhentos mil reais).

No dia 15 de junho de 2000, a baiana Ana Lúcia Serbeto de Freitas Matos, uma simples dona-de-casa soteropolitana, começou com galhardia sua jornada no famoso quiz show, que provocava alvoroços na televisão brasileira, e a cada dia aumentava a expectativa pelo triunfo do primeiro participante a atingir o patamar de novo 
“milionário ${ }^{273}$ ". Parecia ser o seu dia de sorte. Entre doze convidados a comparecer ao programa como potenciais participantes, Ana Lúcia teve o seu número - o dez - sorteado de pronto, e foi então dar início à sua marcante participação no espetáculo.

Ela exuberou habilidade e perspicácia: respondeu aos questionamentos com aparente serenidade; soube lançar mão dos recursos disponíveis magistralmente; teve bom senso e intuição aguçados ao ouvir a opinião, nem sempre confiável, dos universitários; "pulou" (deixou de responder) no momento certo; não se deixou seduzir pela escassa contribuição das cartas, que só eliminaram uma alternativa, e, assim, seguiu sua trilha, rompendo todas as barreiras até chegar à beira do júbilo, ao mítico grau nunca dantes alcançado, à iminência da consagração pela pergunta final que a tornaria, de súbito, milionária ${ }^{274}$.

Sobreveio, então, o infausto acontecimento: surgiu na tela a seguinte pergunta: “A Constituição reconhece direitos aos índios de quanto do território brasileiro? 1) 22\%; 2) $2 \%$; 3$) 4 \%$; 4) 10\%?". Poderia ser uma pergunta ideal, afinal, Ana Lucia havia declarado durante o programa, nas conversas sobre amenidades com o apresentador, que havia sido acadêmica de Direito, sem concluir o curso. Portanto, ela, que já vinha demonstrando conhecimento em diversos assuntos, poderia ter a chance de responder à pergunta decisiva dentro de uma área que, presumidamente, possuía maior domínio.

\footnotetext{
273 Após muita pesquisa inglória, o material com a participação completa da Sra. Ana Lúcia Serbeto de Freitas Matos nos foi mui gentilmente cedido pela TV Campo Grande/MS, pertencente ao SBT - Sistema Brasileiro de Televisão. (SISTEMA BRASILEIRO DE TELEVISÃO. Direção Jorge Zeraldi. Edição Paulo Vander. Local, 2000, 1 vídeo-disco)

${ }^{274}$ Por mero diletantismo e no afã de saciar a curiosidade do leitor, descreve-se a trajetória da candidata no programa: $1^{\mathrm{a}}$. Pergunta (valor R\$ 1.000,00): O que significa FAB? Força Aérea Brasileira - acerto; $2^{\mathrm{a}}$. Pergunta (valor R \$ 2.000,00): Qual jogador de futebol tinha as pernas tortas? Garrincha - acerto; $3^{\mathrm{a}}$. Pergunta (valor R\$ 3.000,00): O que é flerte? Paquerar - acerto; 4a . Pergunta (valor R\$ 4.000,00): Cavalhada é uma porção de que? Cavalos - acerto; $5^{\mathrm{a}}$. Pergunta (valor R\$ 5.000,00): Linha, isca, anzol, são usados em qual atividade? Pescaria - acerto; $6^{\mathrm{a}}$ pergunta (valor R \$ 10.000,00): Qual presidente do Brasil governou por mais tempo? Getúlio Vargas - acerto; 7 . Pergunta (valor R\$ 20.000,00): Quem é o autor de 'Os escravos'? Castro Alves - "pulou" (não respondeu); 8 a . Pergunta (valor R\$ 20.000,00): Como se chama a arte japonesa de dobraduras em papel? Origami - acerto; $9^{\mathrm{a}}$. Pergunta (valor R \$ 30.000,00): Onde fica a cidade de Ímola? Na Itália - acerto; $10^{\mathrm{a}}$. Pergunta (valor R \$ 40.000,00): Quem foi o segundo governador-geral do Brasil? Duarte da Costa - "pulou" (não respondeu); $11^{\mathrm{a}}$. Pergunta (valor R \$ 40.000,00): O que quer dizer uma ab-rogação? Anulação de uma lei - acerto; $12^{\mathrm{a}}$. Pergunta (valor R\$ 50.000,00): Quem é a filha de D. Pedro I que recebeu o trono de Portugal? Maria da Glória - acerto; $13^{\mathrm{a}}$. Pergunta (valor R\$ 100.000,00): Qual é a árvore símbolo do Líbano? Cedro - acerto; $14^{\mathrm{a}}$. Pergunta (valor R\$ 200.000,00): Quando foi inaugurado o Eurotúnel que liga a França ao Reino Unido? 1994 - pediu as cartas, foi eliminada uma resposta, mas, mesmo assim, "pulou" (não respondeu); $15^{\mathrm{a}}$. Pergunta (valor R\$ 200.000,00): Helianto é o mesmo que...Girassol - acerto; $16^{\mathrm{a}}$. Pergunta (valor R\$ 300.000,00): Qual nome recebe o lugar de culto do Budismo? Pagode - acerto; $17^{\mathrm{a}}$. Pergunta (valor R \$ 400.000,00): Em qual dia se celebra o Halloween? 31 de outubro - acerto; $18^{\mathrm{a}}$. Pergunta (valor R\$ 500.000,00): Qual era o sobrenome de Michelangelo? Buonarrotti - pediu ajuda das placas, sendo que uma ligeira maioria (quatro) deu a resposta certa, e os sete restantes dividiram-se entre as demais respostas; na sequência, pediu auxílio aos universitários, os quais, apesar de bastante pusilânimes, deram a resposta correta, ao que a candidata optou por segui-los. (Idem)
} 
Ocorre, entretanto, que a questão não tinha resposta correta ${ }^{275}$. Os artigos $231^{276} \mathrm{e}$ $232^{277}$ da $\mathrm{CF}$, os únicos no texto constitucional a versarem sobre os índios, não os contemplam com percentual algum. Ana Lúcia não tinha alternativa. Claudicar seria

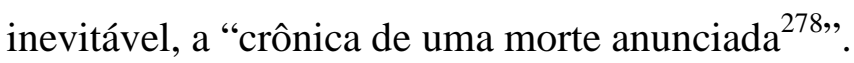

Diante do impasse, a candidata capitulou, recebeu apenas a metade do prêmio, e ajuizou ação perante a $1^{\text {a }}$ Vara Especializada de Defesa do Consumidor de Salvador/BA, alegando a perda da oportunidade de receber o prêmio máximo em razão da conduta do réu, e vindicando, em consequência, a outra metade ( $\mathrm{R} \$ 500.000,00)$, a título de danos materiais, além de reparação de danos morais.

A sentença julgou procedente em parte os pedidos veiculados por Ana Lúcia, rejeitando, tão somente, o pedido de indenização por danos morais, e adotando, como razões de decidir, os fundamentos da teoria da perda de uma chance, mas, paradoxalmente, concedendo à, então, autora, a totalidade do resultado final obstado. Desse modo, apesar de ter reconhecido que não seria possível saber se ela acertaria a derradeira questão, caso

\footnotetext{
${ }^{275}$ Embora, para a produção do programa, constasse do gabarito que a Constituição garante aos índios 10\% (dez por cento) do território nacional.

276 "CAPÍTULO VIII. DOS Í́NDIOS. Art. 231. São reconhecidos aos índios sua organização social, costumes, línguas, crenças e tradições, e os direitos originários sobre as terras que tradicionalmente ocupam, competindo à União demarcá-las, proteger e fazer respeitar todos os seus bens. $\S 1^{\circ}$. São terras tradicionalmente ocupadas pelos índios as por eles habitadas em caráter permanente, as utilizadas para suas atividades produtivas, as imprescindíveis à preservação dos recursos ambientais necessários a seu bem-estar e as necessárias a sua reprodução física e cultural, segundo seus usos, costumes e tradições. $\S 2^{\circ}$. As terras tradicionalmente ocupadas pelos índios destinam-se a sua posse permanente, cabendo-lhes o usufruto exclusivo das riquezas do solo, dos rios e dos lagos nelas existentes. $\S 3^{\circ}$. O aproveitamento dos recursos hídricos, incluídos os potenciais energéticos, a pesquisa e a lavra das riquezas minerais em terras indígenas só podem ser efetivados com autorização do Congresso Nacional, ouvidas as comunidades afetadas, ficandolhes assegurada participação nos resultados da lavra, na forma da lei. $\S 4^{\circ}$. As terras de que trata este artigo são inalienáveis e indisponíveis, e os direitos sobre elas, imprescritíveis. § $5^{\circ}$. É vedada a remoção dos grupos indígenas de suas terras, salvo, ad referendum do Congresso Nacional, em caso de catástrofe ou epidemia que ponha em risco sua população, ou no interesse da soberania do País, após deliberação do Congresso Nacional, garantido, em qualquer hipótese, o retorno imediato logo que cesse o risco. $\S 6^{\circ}$. São nulos e extintos, não produzindo efeitos jurídicos, os atos que tenham por objeto a ocupação, o domínio e a posse das terras a que se refere este artigo, ou a exploração das riquezas naturais do solo, dos rios e dos lagos nelas existentes, ressalvado relevante interesse público da União, segundo o que dispuser lei complementar, não gerando a nulidade e a extinção direito à indenização ou a ações contra a União, salvo, na forma da lei, quanto às benfeitorias derivadas da ocupação de boa fé. $\S 7^{\circ}$. Não se aplica às terras indígenas o disposto no artigo 174, $\S \S 3^{\circ}$ e $4^{\circ}$." (BRASIL. Constituição (1988). Constituição da República Federativa do Brasil. 16. ed. São Paulo: RT, 2011)

277 "Art. 232. Os índios, suas comunidades e organizações são partes legítimas para ingressar em juízo em defesa de seus direitos e interesses, intervindo o Ministério Público em todos os atos do processo". (Idem)

${ }^{278}$ Título do livro de Gabriel García Marquez, publicado em 1981, que tem o formato de reconstrução jornalística, e conta o assassinato de Santiago Nasar pelos irmãos Vicário. O fatídico final é anunciado desde a primeira linha do romance, como uma vingança dos irmãos pela desonra de sua irmã, Ângela, que acusa falsamente Nasar. O mistério da obra está em descobrir a quem Ângela pretende proteger. (GARCÍA MÁRQUEZ, Gabriel. Crônica de uma morte anunciada. Rio de Janeiro: Record, 1981)
} 
houvesse uma resposta, não foi aplicado o corte redutor probabilístico. Inconformado com a decisão, o réu interpôs recurso de apelação ao Tribunal de Justiça da Bahia, que manteve a sentença.

Mais uma vez, o réu interpôs recurso especial ao Superior Tribunal de Justiça, aduzindo violação ao artigo 1.059 do Código Civil de 1916, correspondente ao artigo 402 do Código Civil de 2002, e sustentando que, em caso de manutenção da condenação, o montante deveria ser reduzido ao que a autora efetivamente perdeu, que foi a chance de concorrer aos $\mathrm{R} \$ 500.000,00$ (quinhentos mil reais) remanescentes, cujo valor, de acordo com a lei das probabilidades, correspondia a $25 \%$ da totalidade da condenação.

Em 08 de novembro de 2005, a $4^{\text {a }}$. Turma do Superior Tribunal de Justiça, em voto da lavra do Ministro Fernando Gonçalves, afirmou, com maior propriedade técnica, que embora a candidata/autora tivesse, até então, um desempenho brilhante no concurso, não havia como, dentro de um juízo de probabilidade, afirmar categoricamente que ela acertaria a última resposta. Destarte, como a questão era de múltipla escolha e possuía quatro alternativas, a indenização concedida foi à razão de um quarto do valor do resultado frustrado ( $\mathrm{R} \$ 125.000,00)$, ou seja, no percentual aleatório de probabilidade (chance) aritmética de acerto (25\%). Por sua relevância, transcrevem-se os trechos mais importantes do voto:

Na hipótese dos autos, não há, dentro de um juízo de probabilidade, como se afirmar categoricamente - ainda que a recorrida tenha, até o momento em que surpreendida com uma pergunta, no dizer do acórdão, sem resposta, obtido desempenho brilhante no decorrer do concurso - que, caso fosse o questionamento final do programa formulado dentro de parâmetros regulares, considerando o curso normal dos eventos, seria razoável esperar que ela lograsse responder corretamente à 'pergunta do milhão'. [...] Destarte, não há como concluir, mesmo na esfera da probabilidade, que o normal andamento dos fatos conduziria ao acerto da questão. Falta, assim, pressuposto essencial à condenação da recorrente no pagamento da integralidade do valor que ganharia a recorrida caso obtivesse êxito na pergunta final, qual seja, a certeza - ou a probabilidade objetiva - do acréscimo patrimonial apto a qualificar o lucro cessante. Não obstante, é de se ter em conta que a recorrida, ao se deparar com a 
questão mal formulada, que não comportava resposta efetivamente correta, justamente no momento em que poderia sagrar-se milionária, foi alvo de conduta ensejadora de evidente dano. Resta, em conseqüência, evidente a perda da oportunidade pela recorrida. [...] Quanto ao valor do ressarcimento, a exemplo do que sucede nas indenizações por dano moral, tenho que ao tribunal é permitido analisar com desenvoltura e liberdade o tema, adequando-o aos parâmetros jurídicos utilizados, para não permitir o enriquecimento sem causa de uma parte ou o dano exagerado da outra. A quantia sugerida pela recorrente $(\mathrm{R} \$ 125.000,00)-$ equivalente a um quarto do valor em comento, por ser uma 'probabilidade matemática' de acerto da questão de múltipla escolha com quatro itens, reflete as reais possibilidades de êxito da recorrida ${ }^{279}$.

A decisão faz jus a encômios. Foi precisa quanto à aplicação da teoria e aos critérios adotados. Sem embargo, foi objeto de ressalvas de Rafael Peteffi da Silva em relação ao quantum, extravasadas nos seguintes termos:

Apesar de a decisão ser digna de aplausos, acreditamos que a quantificação do dano poderia sofrer majoração. É forçoso admitir que, no caso em tela, qualquer pessoa, mesmo uma criança em tenra idade ou um amental, teria, matematicamente, ao menos $25 \%$ de chances de acertar a derradeira pergunta do programa televisivo. Como a vítima havia mostrado, durante o próprio programa, impressionante conhecimento enciclopédico, acreditamos que, mesmo levando em conta o elevado grau de complexidade da 'pergunta do milhão', a indenização poderia ter ficado um pouco acima dos $25 \%$ concedidos pelo julgamento final $^{280}$.

A objeção não procede. O fato de haver elementos subjetivos que permitam lobrigar uma maior probabilidade de acerto deve ser contrabalançado com dados objetivos, que

\footnotetext{
${ }^{279}$ BRASIL. Superior Tribunal de Justiça, $4^{\text {a }}$ Turma. Recurso Especial 788459/BA. Relator: Min. Fernando Gonçalves. Diário da Justiça da União, 13 mar. 2006.

${ }^{280}$ SILVA, Rafael Peteffi da, op. cit., p. 202-203.
} 
implicariam reconhecer que, talvez, a maior probabilidade, qualquer que fosse a pergunta formulada, seria a desistência de Ana Lúcia naquele exato momento.

Pondera-se, primeiramente, quanto à privilegiada inteligência da candidata, que influiria no percentual probabilístico de acerto. Ora, se é verdade que Ana Lúcia tinha demonstrado, até aquele momento, um "impressionante conhecimento enciclopédico", deve-se reconhecer que, somente uma pessoa com tal feição poderia chegar àquela fase do concurso, pois o pressuposto era ter passado por 15 questões anteriores. Difícil, senão impossível, imaginar que um inculto pudesse transpô-las ${ }^{281}$. Portanto, ser dotado de um alto grau de conhecimento não seria exclusividade de Ana Lúcia, senão característica inerente a todos que ascendessem àquele patamar.

Por outro lado, também foram expostas vulnerabilidades na expertise de Ana Lúcia, que "pulou" três questões, ou precisou de todo o arsenal remanescente para responder perguntas de dificuldade mediana, como o autor do livro "Os escravos", e o nome de família - chamado no programa de "sobrenome" - de Michelangelo.

Ademais, é esperado que, num programa de perguntas e respostas, cuja premiação aumenta a cada acerto, o nível de complexidade da questão também se eleve em proporção direta à majoração da recompensa.

Destaque-se, ainda, que, na "pergunta do arrisca tudo", Ana Lúcia não contaria com socorro algum: não haveria cartas, nem placas, nem universitários, nem “pulos”. Ela estaria completamente só, abandonada à própria sorte, mercê de seu saber diante do moderno "Enigma da Esfinge ${ }^{282, "}$

\footnotetext{
${ }^{281}$ Muito embora, na ficção, isso tenha ocorrido. No filme britânico "Slumdog Millionaire" (Quem Quer Ser um Milionário? - título no Brasil), 2008, dirigido por Dany Boyle, vencedor de oito Oscars e quatro Globos de Ouro, o jovem Jamil Malik, interpretado por Dev Patel, é um cidadão tosco das favelas de Mumbai/IND que, na ânsia de reencontrar Latika, seu grande amor, se inscreve no programa "Who wants to be a milionaire?", que dá vinte milhões de rúpias àquele que acertar todas as perguntas. Apesar de sua ignorância, Jamal responde às perguntas corretamente, porque todas elas contém respostas em fatos pitorescos de sua dura vida. Entretanto, quando está prestes a se tornar um milionário, ele é preso e torturado por suspeita de fraude, sem nenhuma evidência contra ele, numa ácida crítica ao estamento da sociedade de castas indiana, que não permite e não acredita em ascensão social, ainda que ela ocorra aos olhos de todos. (SLUMDOG Millionaire. Direção Danny Boyle e Loveleen Tandan. Produção Christian Colson. Roteiro Simon Beaufoy. Estados Unidos: Fox Searchlight, 2008. 1 vídeo-disco (120min))

${ }^{282}$ No livro Édipo Rei, de Sófocles, a mitológica figura da esfinge grega pergunta a todos que passam a charada mais famosa de todos os tempos, seguida da ameaça "Decifra-me ou devoro-te": "Que criatura pela manhã tem quatro pés, ao meio-dia tem dois, e à tarde tem três?". E a esfinge estrangulava a todos que não respondiam, até que Édipo decifrou o mistério: "O homem, que engatinha quando bebê, anda sobre os dois pés na idade adulta e precisa de um arrimo na velhice". (SÓFOCLES. Édipo Rei. Trad. Domingos Paschoal Cegalla 3. ed. Rio de Janeiro: DIFEL, 2005.)
} 
Mas o argumento decisivo para se supor que o mais provável seria a desistência, naquele momento, é que a relação custo-benefício na pergunta final revelava não ser compensatório optar pela resposta, salvo se houvesse certeza. Isso porque o programa foi confeccionado de formar a tornar tragédia e comédia vizinhas contíguas, separadas por um muro extremamente tênue. Para elevar o tom dramático do final do show, o candidato que acerta alcança o paraíso, com a glória da conquista mediante a demonstração de conhecimentos gerais; ao revés, o erro representa o pior dos martírios, a inexpugnável derrocada do sonho de se tornar um herói milionário por obra de sua cultura. Sob o prisma subjetivo, perante um risco tão acentuado, é possível que o raciocínio fique comprometido de alguma forma ${ }^{283}$.

E aqui, também, várias inferências podem ser aquilatadas sobre o método de cálculo de probabilidades. A primeira é que, sob o ponto de vista estritamente aleatório, a chance de Ana Lúcia não seria de $25 \%$ (vinte e cinco por cento) sobre os $\mathrm{R} \$ 500.000,00$ (quinhentos mil reais) faltantes, mas $25 \%$ (vinte e cinco por cento) sobre $\mathrm{R} \$ 1.000 .000,00$ (um milhão de reais).

Explico melhor: caso Ana Lúcia assumisse o risco de concorrer à "pergunta do arrisca tudo", ela teria 1/4 de chances de ganhar R \$ 1.000.000,00 (um milhão de reais), e $3 / 4$ de chances de nada ganhar ${ }^{284}$. A "lei das probabilidades", aplicada em sua pureza, seria implacável: as chances meramente aleatórias seriam de R \$ 250.000,00 (duzentos e cinquenta mil reais). Somente a partir deste raciocínio é que se poderia agregar valor aos dotes pessoais da candidata, conforme sugerido por Peteffi.

Mas há uma singularidade que escancara ainda mais a aleatoriedade das chances da candidata no caso particular, senão vejamos: a indagação não era ontológica ou nomologicamente impossível como: “Quantos são os fios de cabelo em sua cabeça?" ou “Quantas são as estrelas no céu?”. A questão tornou-se concretamente irreplicável pela única razão de não ter sido insculpida uma alternativa que contivesse a resposta correta, que seria: "0\% - zero por cento".

\footnotetext{
${ }^{283}$ Não custa lembrar o caso em que, quando parecia haver certa avidez do programa em outorgar a alguém o prêmio milionário, foi formulada uma pergunta facílima, que era: "Quantas letras possui a inscrição da bandeira do Brasil?". Pois o candidato, também brilhante, até então, não conseguiu contar quantas letras existem na frase "Ordem e Progresso". (GOMES, Luan Gerard. Cara erra na ultima pergunta do Show do Milhão fev/2002. Youtube, 7 de julho de 2009. Disponível em: http://www.youtube.com/watch?v=90Um0iqe9zE. Acesso em 2 maio 2011)

${ }^{284}$ Nesse caso, a licença poética permite dizer que $\mathrm{R} \$ 300,00$ equivaliam a nada diante dos valores em jogo.
} 
Porém, é plausível sustentar que Silvio Santos, no diálogo com Ana Lúcia, após a sua desistência, demonstrou que era completamente randômica a possibilidade de acerto da resposta. Assistindo-se à fita, nota-se que o apresentador perguntou à candidata se ela não gostaria de arriscar uma resposta, e ela disse que não, porque não sabia. Encerrada a sua participação, ele ainda indagou: "Se você tivesse que optar por uma das alternativas, qual você escolheria?". E a candidata selecionou uma das hipóteses, aleatoriamente.

Portanto, ficou caracterizado que Ana Lúcia ignorava que a Constituição Federal de 1988 não destina percentual algum de terras aos indígenas, o que implica inferir que, caso a pergunta contivesse a alternativa correta ( $0 \%$ - zero por cento), a chance de Ana Lúcia acertar seria somente de $25 \%$ (vinte e cinco por cento).

Contrario sensu, ninguém questionaria que, caso ela tivesse afirmado, categoricamente, que não responderia por não haver resposta correta, já que a Lei Maior não destina terras aos silvícolas, não haveria oportunidade perdida, mas sim lucro cessante de $\mathrm{R} \$ 500.000,00$.

Entretanto, tais cenários não devem ser conjeturados sem que a candidata tivesse, no momento do programa, a alternativa de uma solução correta, até porque a hipótese acima levantada seria bem mais adequada diante de um concurso de perguntas e respostas que não fosse de múltipla escolha, mas de respostas livres.

Diante dessas reflexões, acredita-se que o STJ agiu bem, no caso, ao desprezar questões subjetivas que pudessem influir no comportamento e no desempenho da candidata, e ater-se, exclusivamente, às probabilidades matemáticas de acerto, até porque, conforme exposto, os fatores positivos e negativos, no máximo, se equivaliam, ou, mais precisamente, não permitiam levá-los em conta para minorar ou majorar o valor da indenização.

Exatamente o mesmo critério foi utilizado no caso Chaplin v. Hicks (ver item 1.2 do capítulo 1), como explica John Maynard Keynes ${ }^{285}$. A Sra. Chaplin perdera a chance de ser

\footnotetext{
${ }^{285}$ Com as seguintes palavras: "The plaintiff had evidently suffered damage, and justice required that she should be compensated. But it was equally evident, that, relative to the completest information available and account being taken of the arbiter's personal taste, the probability could be by no means estimated with numerical precision. Further, it was impossible to say how much weight ought to be attached to the fact that the plaintiff had been head of her district (there were fewer than 50 districts); yet it was plain that it made her chance better than the chances of those of the 50 left in, who were not head of their districts. Let rough justice be done, therefore. Let the case be simplified by ignoring some part of the evidence. The 'doctrine of averages' is then applicable, or, in other words, the plaintiffs loss may be assessed at twelve-fiftieths of the value of the prise”. (KEYNES, John Maynard, op. cit., p. 27)
} 
uma das 12 entre as 50 finalistas, capturadas entre as mais bem votadas em cada um dos 10 distritos. Mas não havia como atribuir um peso extra pelo fato dela ter sido a mais bem votada no seu distrito. Então, à semelhança do que fez o STJ, a Corte inglesa simplificou o caso, ignorando algumas das evidências e restringindo-se ao cálculo das probabilidades, que, coincidentemente, foram avaliadas em $25 \%$ (vinte e cinco por cento).

O outro "reparo" na decisão foi sugerido por Sérgio Savi, em relação à divergência de critérios, porém, fazendo questão de assinalar que não afirmava que a Corte Superior havia se equivocado:

O acórdão é, em nosso sentir, quase impecável e, sem dúvida, merecedor de nossos aplausos pela forma técnica em que elaborado. (...) O único reparo que entendemos cabível e que implicaria a modificação do julgado, diz respeito aos limites para a aplicação da teoria da responsabilidade civil por perda de uma chance. Isto porque, conforme anteriormente exposto, entendemos que a chance, para ser considerada séria, real e, portanto, passível de indenização a título de danos materiais, precisa ser superior a $50 \%$ (cinquenta por cento). (...) Não há como afirmar que o acórdão está equivocado neste ponto. A diferença entre o entendimento esposado pelo STJ no caso do show do milhão e aquele por nós defendido neste livro é, tão somente, em relação ao critério a ser $\operatorname{adotado}^{286}$.

Por todo o exposto ao longo deste capítulo, não há como subscrever a modificação sugerida, que deixaria Ana Lúcia sem indenização.

$\mathrm{O}$ autor, de forma bastante humilde e elegante, destaca todos os predicados do julgamento, mas a ele se opõe, basicamente, por não caber em seu critério. Há, assim, uma clara inversão metodológica: se o julgamento está escorreito, mas não se encaixa no critério, é, então, chegado o momento de rever o critério, e não o julgamento. Se não se erige um único argumento válido para contrapor à tese adotada na decisão, a obstinação, nesse contexto, carece de embasamento científico e empírico ${ }^{287}$.

\footnotetext{
${ }^{286}$ SAVI, Sérgio, op. cit., p. 80.

${ }^{287}$ Longe de querer adentrar no recôndito d'alma, são oportunas as palavras de Schopenhauer: "Muitas vezes, no início, estamos firmemente convencidos da verdade de nossa afirmação; porém, o argumento do
} 
Quando se estabelece um padrão rígido, faz-se como na figura mitológica do "Leito de Procusto" 288 , um salteador que vivia em uma floresta e oferecia pouso aos transeuntes, e os colocava em uma cama de tamanho único, de forma que, caso a pessoa fosse maior do que a cama, ele cortava o excedente com um machado; por outro lado, se a pessoa fosse menor do que a cama, ele esticava a pessoa com cordas. Esta é a metáfora da medida única, da tarifação, de fazer com que os fatos sejam esticados ou cortados até caberem no critério proposto, ao invés de optar por um critério mais justo e equânime.

A qualificação da seriedade da chance por um viés tabelado representa método anacrônico, pois, conforme mencionado na síntese histórica, já na Inglaterra de 1911, no paradigmático caso Chaplin v. Hicks, condenou-se o réu a pagar indenização à autora, à razão de $25 \%$ (vinte e cinco por cento) sobre a totalidade dos prêmios, pois o percentual se traduzia na possibilidade que a autora tinha de ganhar algum prêmio caso não tivesse sido ilicitamente obstada de participar da fase final de um concurso de aspirante a atriz. O caso ficou assim ementado:

\begin{abstract}
Chaplin v. Hicks.
In the Court of Appeal [1911] 2 K. B. 786

Beauty Contestant denied chance to compete - Breach of Contract Measure of Damages - Remoteness - Inassessability

Where by contract a man has a right to belong to a limited class of competitors for a prize, a breach of that contract by reason of which he is prevented from continuing a member of the class and is thereby deprived of his chance of obtaining the prize is a breach in respect of which he may be entitled to recover substantial, and not merely nominal, damages. The existence of a contingency which is dependent on the volition of a third person does not necessarily render the damages for a breach of contract incapable of assessment. Richardson v. Mellish (1824) 2 Bing.
\end{abstract}

adversário parece começar a derrubá-la: logo cedemos à sua causa, mas é comum, depois, acharmos que, na verdade, tínhamos razão; nossa evidência era falsa, mas podia haver uma verdadeira para aquela afirmação: o argumento salvador não nos ocorreu de imediato. Sendo assim, surge, então, em nós, a máxima de continuar a combater o argumento contrário, mesmo quando ele parece correto e decisivo, na crença de que sua própria exatidão seja apenas aparente e que durante a disputa ainda nos ocorrerá outro argumento para derrubar aquele ou confirmar nossa verdade de outra forma[...]” (SCHOPENHAUER, Arthur. A arte de ter razão: exposta em 38 estratagemas. Trad. Alexandre Krug e Eduardo Brandão. São Paulo: Martins Fontes, 2001, p. 5)

${ }^{288}$ Assim descrito por René Ménard: “O bandido Procusto possuía singular mania; queria que todos tivessem a sua altura, e para tanto mandava se deitassem no seu leito os viajantes detidos. Se ultrapassassem a medida do leito, cortavam-se-lhes as extremidades das pernas; se, pelo contrário, fossem demasiadamente pequenos, puxavam-nos mediante cordas, até que atingissem o comprimento exigido. Teseu limpou a região da presença do bandido, e correu depois atrás de Cirão, menos maníaco, mas igualmente mau". (MÉNARD, René. Mitologia Greco-romana. 2. ed. Trad. Aldo Della Nina. São Paulo: Opus, 1991, v. 3p. 272-273) 
229, and Watson v. Ambergate \&c. Railway (1850) 15 Jur. 448, discussed $^{289}$.

É incongruente tal raciocínio, conforme detectado por Vivian de Almeida Sieben Rocha, no sentido de se considerar a perda de uma chance um dano autônomo quando presente a seriedade da chance, mas vedar a sua reparação caso ela não atinja o percentual probabilístico de $50 \%$ (cinquenta por cento). Trata-se de uma interpolação de todo inadequada. Conforme os dizeres da mencionada autora, "se o dano da chance perdida é autônomo e emergente, merece reparação na proporção do prejuízo. Assim, se inferiores a $50 \%$ as probabilidades de ocorrência, mas, mesmo assim, houver uma chance séria e real, deve-se somente minorar o valor da indenização, e não a obstar ${ }^{290}$,.

\subsection{Fundamento da perda de uma chance}

Seja no postulado de não causar dano a outrem ${ }^{291}$, içado à categoria de princípio neminem laedere -, do qual exsurgem como corolários o direito de não ser lesado e, sucessivamente, de ser indenizado, ou, ainda, do inadimplemento de um dever contratual, é plenamente possível cogitar da ocorrência de perda de uma oportunidade reparável. Nesse aspecto, categórica a doutrina italiana ao mencionar que "il danno può sorgere sia da fatto illecito extracontrattuale art. $2043^{292}$ c.c. che da responsabilità contrattuale art. $1218^{293}$ c.c. ${ }^{294, "}$.

O quadro não muda quando se trata das oportundidade perdidas, pois, como salienta Glenda Gonçalves Gondim, "no caso da teoria da perda de uma chance, é importante

\footnotetext{
${ }^{289}$ INGLATERRA. Corte de Apelação. Apelação [1911] 2 K. B. 78. Chaplin v. Hicks. Disponível em: $\langle$ http://www.btinternet.com/ akme/chaplin.html >. Acesso em: 25 nov. 2010.

${ }^{290}$ ROCHA, Vivian de Almeida Sieben. A responsabilidade civil pela perda de uma chance no direito brasileiro. Disponível em: 〈http://www3.pucrs.br/pucrs/files〉 . Acesso em 04 fev. 2011.

${ }^{291}$ GHERSI, Carlos Alberto. Teoría general de la reparación de danos. Buenos Aires: Astrea, 1997, p. 5.

292 "Art. 2043 Risarcimento per fatto illecito. Qualunque fatto doloso o colposo, che cagiona ad altri un danno ingiusto, obbliga colui che ha commesso il fatto a risarcire il danno (Cod. Pen. 185)". (ITÁLIA. Código Civil (1942). Código Civil Disponível em: <http://www.jus.unitn.it/cardozo/ obiter_dictum/codciv/Codciv.htm>. Acesso em 3 fev. 2011)

293 "Art. 1218 Responsabilità del debitore. Il debitore che non esegue esattamente $(1307,1453)$ la prestazione dovuta è tenuto al risarcimento del danno (2740), se non prova $(1673,1681,1693,1784,1787$, 1805-2, 1821) che l'inadempimento o il ritardo è stato determinato da impossibilità della prestazione derivante da causa a lui non imputabile (1256; att. 160)". (Idem)

${ }^{294}$ CHINDEMI, Domenico. Il danno da perdita di chance. 2.ed. Milão: Giuffrè, 2010, p. 9.
} 
salientar que ela pode decorrer tanto de situações contratuais quanto extracontratuais, portanto a violação de um dever primário geral ou contratual ${ }^{295, "}$

As duas espécies de responsabilidade possuem diversos elementos de comunhão, ao ponto de haver uma tradição de tratamento unitário, oriunda de alguns países da Europa Continental $^{296}$. No Brasil, praticamente não se adota o fundamento da responsabilidade contratual, como se a reparação estivesse circunscrita, inexoravelmente, à cláusula geral de responsabilidade delitual ou extracontratual. Na responsabilidade civil por acidente de trabalho, $v . g$., a doutrina é assente ao dispor que o fundamento da indenização enquadra-se na responsabilidade aquiliana, negando, em essência, a existência de uma obrigação contratual implícita de segurança ${ }^{297}$ e incolumidade do empregador para com o empregado $^{298}$.

Isto se deveu - segundo o escólio de Sebastião Geraldo de Oliveira ${ }^{299}$ - à tentativa de facilitar a prova da culpa por parte da vítima, imaginando-se uma evolução da culpa

${ }^{295}$ GONDIM, Glenda Gonçalves. A reparação civil na teoria da perda de uma chance. 2010. $170 \mathrm{f}$. Dissertação (Mestrado em Direito) - Universidade Federal do Paraná - UFPR, Curitiba, p. 29.

${ }^{296}$ Em Portugal, Menezes Cordeiro fez as seguintes considerações sobre o tema: "Colocadas as diferenças nestes termos, as duas responsabilidades, aquiliana e obrigacional, ficariam muito próximas: e isso ao ponto de, no tocante aos pressupostos gerais, haver toda uma tradição de tratamento unitário, com justo relevo para o saudoso Prof. Gomes da Silva. Esta orientação foi retomada por Pessoa Jorge, à luz do Código Vaz Serra, por nós próprios e por Menezes Leitão, constituindo uma tradição da Faculdade de Lisboa. E foi útil: permitiu enriquecer ambas as responsabilidades, com uma intercomunicação de elementos jurídicocientíficos. Hoje, afigura-se-nos, porém, necessário superá-la: por várias razões, que temos vindo a explanar no presente Tratado e que, de seguida, iremos sintetizar”. (CORDEIRO, António Menezes. Tratado de Direito Civil Português. Direito das Obrigações. Gestão de negócios. Enriquecimento sem causa. Responsabilidade civil. Lisboa: Almeida, 2010, v. 2, tomo III, p. 389-390)

297 Antonio Junqueira de Azevedo também assere que a obrigação de segurança está hoje 'descontratualizada', e afirma tal fenômeno como um avanço social: "A obrigação de segurança (segurança de vida e de integridade física e psíquica), durante a segunda metade do século XX, era vista como resultante de uma cláusula contratual, explícita ou implícita. As primeiras considerações vieram a respeito do transporte; o transportador devia garantir a segurança do transportado. Depois, entendeu-se também a obrigação de segurança como existente nos contratos de ensino, de hospedagem, de trabalho, de internação em hospital e assim por diante. Hoje, a obrigação de segurança é autônoma, está 'descontratualizada', de tal forma que, até mesmo sem contrato, qualquer pessoa que tenha algum poder físico sobre outra é responsável por sua segurança, tem dever de cuidado - o que explica a responsabilidade do transportador no transporte totalmente gratuito e em outras situações nas quais absolutamente não há contrato, como o de um visitante que escorrega no saguão de entrada de um prédio de escritório. A segurança, nem é preciso salientar, constitui um valor para qualquer sociedade. Quanto mais segurança, melhor a sociedade, quanto menos, pior". (AZEVEDO, Antonio Junqueira, op. cit., p. 381)

298 “A indenização por acidente do trabalho ou doença ocupacional, em princípio, enquadra-se como responsabilidade extracontratual porque decorre de algum ato ilícito do empregador, por violação dos deveres previstos nas normas gerais de proteção ao trabalhador e ao meio ambiente de trabalho. Essa responsabilidade não tem natureza contratual porque não há cláusula do contrato de trabalho prevendo a garantia de integridade psicobiofísica do empregado ou da sua incolumidade". (OLIVEIRA, Sebastião Geraldo. Indenizações por acidente do trabalho ou doença ocupacional. 4. ed. São Paulo: LTr, 2008, p. 89).

${ }^{299}$ Idem. 
subjetiva para a culpa presumida ${ }^{300}$. Entretanto, conforme a sua avaliação, a teoria objetiva ou teoria do risco mostrou-se mais eficaz à proteção da vítima, por dispensar peremptoriamente o pressuposto da culpa para o dever de indenizar.

Tal desprezo pelo fundamento contratual, até o momento, ainda não atingiu plenamente o desiderato constitucional de melhorar a condição social dos trabalhadores $\left(\mathrm{CF}, \text { art. } 7^{\circ}, \text { caput }\right)^{301}$. Em primeiro lugar, porque a jurisprudência majoritária ainda não se curvou à aplicação da responsabilidade objetiva às ações de indenização por acidente de trabalho $^{302}$. Depois, porque ainda que isso tivesse ocorrido, a leitura do parágrafo único do art. 927 do $\mathrm{CCB}^{303}$ impõe a exegese de que ela não será a regra, mas sim a exceção ou a

\footnotetext{
${ }^{300}$ Que é o que faz o Código Civil italiano ao inverter o ônus da prova, nas ações de reparação de danos, em desfavor daquele que exerce atividade periculosa: "Art. 2050 Responsabilità per l'esercizio di attività pericolose. Chiunque cagiona danno ad altri nello svolgimento di un'attività pericolosa, per sua natura o per la natura dei mezzi adoperati, e tenuto al risarcimento, se non prova di avere adottato tutte le misure idonee a evitare il danno". (ITÁLIA. Código Civil (1942). Código Civil. Disponível em: $\langle$ http://www.jus.unitn.it/cardozo/obiter dictum/codciv/Lib4.htm>. Acesso em: 04 abr. 2011)

${ }^{301}$ BRASIL. Constituição (1988). Constituição da República Federativa do Brasil. 16. ed. São Paulo: RT, 2011.

${ }^{302}$ Embora haja ferrenhas tentativas acadêmicas de transformação do cenário jurisprudencial. Na $1^{\mathrm{a}}$ Jornada de Direito Material e Processual na Justiça do Trabalho, por exemplo, foi aprovado o seguinte Enunciado acerca da responsabilidade civil por acidente de trabalho: "37. RESPONSABILIDADE CIVIL OBJETIVA NO ACIDENTE DE TRABALHO. ATIVIDADE DE RISCO. Aplica-se o art. 927, parágrafo único, do Código Civil nos acidentes do trabalho. $\mathrm{O}$ art. $7^{\circ}$, XXVIII, da Constituição da República, não constitui óbice à aplicação desse dispositivo legal, visto que seu caput garante a inclusão de outros direitos que visem à melhoria da condição social dos trabalhadores". (JORNADA DE DIREITO MATERIAL E PROCESSUAL NA JUSTIÇA DO TRABALHO, 1, 2007, Brasília, Enunciados. Disponível em: 〈http://www.anamatra.org.br/jornada/enunciados/enunciados aprovados.cfm >. Acesso em: 14 out. 2010). Na mesma trilha, o Enunciado 377 da IV Jornada de Direito Civil do Centro de Estudos Judiciários da Justiça Federal: "O art. $7^{\circ}$, inc. XXVIII, da Constituição Federal não é impedimento para a aplicação do disposto no art. 927, parágrafo único, do Código Civil quando se tratar de atividade de risco". (JORNADA DE DIREITO CIVIL DO CENTRO DE ESTUDOS JUDICIÁRIOS DO CONSELHO DA JUSTIÇA FEDERAL, 4, 2006, Brasília, Enunciados. Disponível em: 〈http://daleth.cjf.jus.br/revista/enunciados/IVJornada.pdf〉 $>$. Acesso em: 26 jan. 2011)

303 “Art. 927. Parágrafo único. Haverá obrigação de reparar o dano, independentemente de culpa, nos casos especificados em lei, ou quando a atividade normalmente desenvolvida pelo autor do dano implicar, por sua natureza, risco para os direitos de outrem". (BRASIL. Código Civil (2002). Código Civil e Constituição Federal. 62. ed. São Paulo: Saraiva, 2011)
} 
“cláusula geral das atividades de risco", impondo interpretação restritiva ${ }^{304}$, limitada aos segmentos que representarem risco acima da média da coletividade ${ }^{305}$.

O reconhecimento da existência de uma cláusula contratual implícita de segurança, além de ser tecnicamente mais apropriada, traria modificações substaciais no campo probatório, na medida em que, partindo do postulado de violação de uma obrigação contratual, o corolário inexpugnável seria a presunção de culpa do empregador ${ }^{306}$.

De fato, há diversas disposisões comuns no tratamento da responsabilidade contratual e extracontratual, tais como o prejuízo reparável, o nexo etiológico e até mesmo as causas de exoneração de responsabilidade.

Tanto assim que, na França, o grupo de juristas que se reuniu, sob a coordenação do professor Pierre Catala, para a elaboração do "Anteprojeto de Reforma do Direito das Obrigações e do Direito da Prescrição", divergiu, até o último instante, sobre a disposição ou não das responsabilidades (contratuais e extracontratuais) sob um mesmo título, e só aquiesceu em agrupá-las após terem redigido o conjunto de normas e constatado a

\footnotetext{
${ }^{304}$ Teresa Ancona Lopez explica como interpretar o referido dispositivo: "O dispositivo em tela é composto de um 'caput' e um parágrafo único. Logo, não podemos interpretar corretamente seu parágrafo único sem considerar seu 'caput', pois fazem parte do mesmo artigo. O legislador poderia ter criado um novo texto de lei desvinculando os dois dispositivos do art. 927, fazendo com que a regra geral de seu parágrafo único fosse autônoma. (...) Ora, esse parágrafo tem que ser interpretado restritivamente, pois excepciona o 'caput' e às exceções não se aplica interpretação extensiva. Em outras palavras, a norma do parágrafo único do artigo 927 não tem a sua aplicação automática garantida. Temos que interpretá-la caso a caso, porquanto se trata de cláusula aberta e seu verdadeiro sentido só vai ser dado diante do caso concreto". (LOPEZ, Teresa Ancona. Princípio da Precaução e Evolução da Responsabilidade Civil. São Paulo: Quartier Latin, 2010, p. 164165)

${ }^{305}$ Esse é o teor do Enunciado n ${ }^{\circ} .38$ do Centro de Estudos Judiciários da Justiça Federal: “38 - Art. 927: a responsabilidade fundada no risco da atividade, como prevista na segunda parte do parágrafo único do art. 927 do novo Código Civil, configura-se quando a atividade normalmente desenvolvida pelo autor do dano causar a pessoa determinada um ônus maior do que aos demais membros da coletividade". (JORNADA DE DIREITO CIVIL DO CENTRO DE ESTUDOS JUDICIÁRIOS DO CONSELHO DA JUSTIÇA FEDERAL, 1, 2002, Brasília, Enunciados Disponível em: 〈http://www.cjf.jus.br/revista/enunciados/enunciados.htm>. Acesso em: 15 out. 2010.).

306 “Havendo, entre as partes, uma obrigação específica, cabe ao devedor executar a prestação principal. $O$ dever dele é o bem do credor, atribuído e legitimado pelo ordenamento. Se o devedor não cumpre, é grave: ele está a frustrar, pela sua conduta, precisamente o valor que o Direito atribuía ao credor. Em face do incumprimento, o devedor é automaticamente condenado a indemnizar, isto é: a prosseguir, no plano indemnizatório, o dever de prestar principal que inadimpliu. Mal ficariam quer o Direito quer a Economia que ele tutela quando, depois de ter exigido, do credor, todo o calvário procedimental que desemboca no incumprimento definitivo, ainda se lhe fosse requerer mais do que a prova da obrigação incumprida e a declaração do incumprimento. Perante isso, queda ao devedor: - ou provar o cumprimento: trata-se de um facto extintivo, cujo ónus probatório lhe assiste (342\%/2); - ou provar que tinha qualquer causa de justificação ou de excusa para não cumprir (799\%1). A 'presunção de culpa', referida no artigo 799\%1, retomada dos clássicos civilistas para os quais a culpa era a 'faute' napoleônica é, de facto, uma presunção de culpa e de ilicitude. Quando haja inadimplência, presume-se que esta ocorreu ilicitamente e com culpa (dolo). Caberá logicamente ao devedor demonstrar que tinha a possibilidade legal de não executar a obrigação, provando os competentes factos”. (CORDEIRO, Antonio Menezes, op. cit., p. 391-392).
} 
quantidade de prescrições comuns. Obviamente, entretanto, o fato gerador das responsabilidades foi objeto de disposições distintas e em títulos separados ${ }^{307}$.

Por fim, o anteprojeto não só insculpiu num mesmo artigo, a responsabilidade contratual (caput) e a extracontratual (parágrafo único), como também proibiu, no dispositivo seguinte, a cumulação dos regimes de responsabilidade, com uma exceção deveras importante: nos casos que ocasionarem danos corporais, a vítima tem a faculdade de optar pelas regras que lhe forem mais favoráveis ${ }^{308}$. Os artigos ficaram com a seguinte redação:

Art. 1340. Tout fait illicite ou anormal ayant causé un dommage à autrui oblige celui à qui il est imputable à le réparer.

De même, toute inexécution d'une obligation contractuelle ayant causé

\footnotetext{
307 Geneviève Viney, autora da exposição de motivos no que toca ao subtítulo da responsabilidade civil, assim comentou a passagem: "II.- Le choix d'une construction adaptée à la matière a soulevé d'emblée la question de la place à assigner respectivement aux questions relatives à la responsabilité contractuelle et à la responsabilité extra-contractuelle. Fallait-il maintenir la réglementation de la responsabilité contractuelle dans le titre III à la place que lui avaient assignée les rédacteurs du code civil, en limitant l'objet du titre IV à la responsabilité extracontractuelle? Etait-il, au contraire, préférable de regrouper l'ensemble sous un titre unique intitulé "De la responsabilité" ? Les membres du groupe, divisés sur ce point, ont laissé ce problème en suspens tant que les solutions n'ont pas été arrêtées sur le fond. C'est seulement après avoir rédigé l'ensemble et constaté que les règles communes aux deux branches de la responsabilité l'emportent très largement, qu'ils ont adopté, à la majorité, le second parti 5. Un chapitre intitulé "Dispositions préliminaires" a été placé en exergue du titre IV afin de régler les relations entre les deux branches de la responsabilité. [...] A propos des conditions de la responsabilité (chapitre deux), l'accord s'est fait assez facilement pour reconnaître que le préjudice réparable, le lien de causalité et les causes d'exonération se définissent de la même façon en matière contractuelle et extracontractuelle, ce qui a conduit à les regrouper dans une section 1 intitulée "Dispositions communes aux responsabilités contractuelle et extra-contractuelle". En revanche, le fait générateur de la responsabilité a fait l'objet de dispositions distinctes pour la responsabilité extra-contractuelle, d'une part, la section 2 traitant successivement du "fait personnel", Du "fait des choses", du "fait d'autrui", des "troubles de voisinage" et des "activités dangereuses", et pour la responsabilité contractuelle, d'autre part, la section 3 ne faisant pás cette distinction. (VINEY, Geneviève. De la responsabilite civile. In: AVANT-PROJET DE REFORME DU DROIT DES OBLIGACIONES (ARTICLES 1101 À 1386 DU CODE CIVIL) ET DU DROIT DE LA PRESCRIPTION (ARTICLES 2234 A 2281 DU CODE CIVIL). Relatório encaminhado ao Ministro da Justiça em 22 set. 2005. Disponível em: < http://www.lexisnexis.fr/pdf/DO/RAPPORTCATALA.pdf $>$. Acesso em 14 mar. 2010.)

308 Esta estruturação foi assim explanada por Geneviève Viney: "Traditionnellement, le droit français prohibe ce qu'on appelle le 'cumul' dês régimes de responsabilité, c'est-à-dire en réalité la possibilité, pour la victime d'un dommage contractuel, de choisir de préférence l'application du régime délictuel. Pour justifier cette interdiction, on invoque généralement le fait que les règles relevant de cette branche de la responsabilité risqueraient de déjouer les prévisions des contractants et de tenir en échec les clauses du contrat. Les membres du groupe étaient divisés sur l'opportunité de consacrer dans le code cette 'règle du non-cumul' qui est ignorée par la plupart des droits étrangers. Toutefois, il a été décidé, à la majorité, de l'inscrire à l'article 1341, en lui apportant cependant une exception très importante au profit des victimes de dommages corporels. Il a paru en effet souhaitable de permettre à celles-ci d'opter en faveur du régime qui leur est le plus favorable, à condition toutefois qu'elles soient en mesure d'apporter la preuve dês conditions exigées pour justifier le type de responsabilité qu'elles invoquent. (Idem, p. 144.)
} 
un dommage au créancier oblige le débiteur à en répondre.

Art. 1341. En cas d'inexécution d'une obligation contractuelle, ni le débiteur ni le créancier ne peuvent se soustraire à l'application des dispositions spécifiques à la responsabilité contractuelle pour opter en faveur de la responsabilité extracontractuelle.

Toutefois, lorsque cette inexécution provoque un dommage corporel, le co-contractant peut, pour obtenir réparation de ce dommage, opter en faveur dês règles qui lui sont plus favorables ${ }^{309}$.

A perda de uma chance, por sua vez, também mereceu atenção no anteprojeto, constando da seção de disposições comuns às responsabilidades contratuais e extracontratuais - o que só comprova o que foi sustentado quanto à duplicidade de espécies de responsabilidade que pode gerá-la -, em dispositivo assim cunhado:

Art. 1346 La perte d'une chance constitue un préjudice réparable distinct de l'avantage qu'aurait procuré cette chance si elle s'était réalisée $e^{310}$.

2.8.1 Perda de uma chance na responsabilidade contratual

Diante da feição eminentemente gregária do ser humano, ele, em suas relações interpessoais, acaba por celebrar compromissos com os seus pares, os quais, em sua vasta maioria, vigoram sob a égide de cláusulas que irão determinar o comportamento esperado pelos contratantes, a fim de que os relacionamentos sociais transcorram de maneira harmônica, e os negócios avençados atinjam os fins pretendidos, viabilizando, assim, a convivência pacífica. Quando, entretanto, há conspurcação daquilo que foi pactuado, gerase a responsabilidade contratual.

Jacques Boré explica que, em matéria contratual, a boa execução do avençado é sempre uma das condições para o cumprimento da chance, pois a falha cometida na execução bastará para aniquilar esta chance, interrompendo o curso dos eventos que iriam

${ }^{309}$ Ibidem, p. 152
${ }^{310}$ Ibidem, p. 154 
permitir que ela fosse usufruída. Por isso, a diligência do advogado ou do jóquei será tanto quanto a devoção do médico no tratamento da doença - necessária ao bom exercício dos direitos do litigante ou à exploração da aptidão do cavalo para triunfar na corrida em benefício do seu proprietário ${ }^{311}$.

O mais remoto exemplo de perda de uma chance no direito inglês, o célebre caso Chaplin v. Hicks $(1911)^{312}$, trata exatamente de um caso de quebra de contrato, oriunda da violação do dever de proporcionar meios razoáveis para que a candidata tivesse a oportunidade de se apresentar para a fase final da seleção do "concurso de beleza", que, em verdade, era um contrato de aspirantes a atrizes (vide capítulo item 1.2 do capítulo 1).

Na Itália, por sua vez, a primeira decisão da Suprema Corte de Cassação a respeito de perda de uma chance ${ }^{313}$ teve duas peculiaridades bastante pertinentes a este trabalho: o fato de ser oriunda de responsabilidade pré-contratual; e de ter origem numa relação de trabalho, quando do recrutamento de trabalhadores (vide item 1.3 do capítulo 1). Tratavase do caso de uma empresa que houvera convocado alguns operários para participar de um processo seletivo para a contratação de motoristas de transporte público. Apesar de já terem se submetido a diversos testes para o recrutamento, alguns dos inscritos foram obstados de realizar as provas de cultura elementar e de direção (guia).

A menção na sentença ao artigo 1223 do Código Civil Italiano ${ }^{314}$, que cuida da reparação de danos pelo inadimplemento ou pela mora, não deixa dúvidas de que a abordagem se deu sob o prisma da responsabilidade contratual: "Il concetto di perdita e di guadagno di cui all'art. 1223 cod. civ si riferisce a qualsiasi utilità economicamente valutabile, è risarcibile il danno da perdita di chance, già esistente nel patrimonio dei

\footnotetext{
311 No original: "En matière contractuelle, la bonne exécution du contrat est toujours une des conditions d'épanouissement de la chance, puisque la faute commise dans cette exécution suffira à anéantir cette chance, en arrêtant le cours des événements qui lui auraient permis de s'exercer. Ainsi la diligence et l'habilité de l'avocat ou du jochey seront-ils - tout autant que le dévouement du médicin au malade nécessaires au bon exercise des droits du plaideur ou à l'exploitation de l'aptitude qu'a cheval à gagner la course au bénéfice de son propriétaire”. (BORÉ, Jacques, op. cit.)

312 INGLATERRA. Corte de Apelação. Apelação [1911] 2 K. B. 78. Chaplin v. Hicks. Disponível em: <http://www.btinternet.com/ akme/chaplin.html >. Acesso em: 25 nov. 2010.

313 ITÁLIA. Corte de Cassação. Sentença 6906. Julgado em 19 de novembro de 1983.Giustizia Civile. Rivista Mensile di Giurisprudenza. Milão, v. I, 1984, p. 1841-1843.

314 “Art. 1223 Risarcimento del danno. Il risarcimento del danno per l'inadempimento o per il ritardo deve comprendere così la perdita subita dal creditore come il mancato guadagno, in quanto ne siano conseguenza immediata e diretta”. (ITÁlIA. Código Civil (1942). Código Civil.. Disponível em: <http://www.jus.unitn.it/cardozo/obiter_dictum/codciv/Codciv.htm>. Acesso em 3 fev. 2011.).
} 
dipendenti al momento del comportamento illecito dell'impresa, ed idonea a produrre anche solo probabilmente e non con assoluta certezza un determinato reddito ${ }^{315}$ ".

Por outro lado, a doutrina mais recente destaca que o viés contratual tem sido aquele que tem experimentado a maior expansão na reparação de danos pelas chances perdidas, na qual se admite a reparabilidade, ainda que na ausência da certeza da produção de um dano patrimonial, por força de uma probabilidade qualificada ${ }^{316}$.

No Brasil, a exemplo dos demais países citados, é plenamente possível haver responsabilidade civil contratual pela perda de uma chance, cuja fonte normativa será, genericamente, o art. 389 do Código Civil $^{317}$, que estabelece: "Não cumprida a obrigação, responde o devedor por perdas e danos, mais juros e atualização monetária segundo índices oficiais regularmente estabelecidos, e honorários de advogado".

É o que deveras ocorre, e.g., nas ações de responsabilidade civil pela perda de uma chance em face dos $\operatorname{advogados}^{318}$, cuja natureza jurídica da relação com os clientes (mandantes) é incontestavelmente contratual ${ }^{319}$ pois, uma vez desvirtuado o desempenho do mandato, que impõe ao patrono a defesa escrupulosa dos interesses do constituinte e o minudente aconselhamento profissional, pode ser obrigado a ressarcir eventuais prejuízos $^{320}$.

${ }^{315}$ ITÁLIA. Corte de Cassação. Sentença 6906. Julgado em 19 de novembro de 1983. Giustizia Civile. Rivista Mensile di Giurisprudenza. Milão, v. I, 1984, p. 1841-1843.

316 "Uno dei settori di massima espansione del danno da perdita di chance è quello contrattuale, in cui si ammette la risarcibilità di tale voce di danno, anche in mancanza della certezza del produisi del nocumento patrimoniale, in forza di una probabilità qualificata. (CHINDEMI, Domenico, op. cit., p. 49)

${ }^{317}$ BRASIL. Código Civil (2002). Código Civil e Constituição Federal. 62. ed. São Paulo: Saraiva, 2011.

${ }^{318}$ Sob o rigor técnico, considerando que a natureza jurídica do contrato de advogado é de mandato, o fundamento específico para a reparação de danos é o art. 667, do CCB, cujos termos são os seguintes: "Art. 667. "O mandatário é obrigado a aplicar toda sua diligência habitual na execução do mandato, e a indenizar qualquer prejuízo causado por culpa sua ou daquele a quem substabelecer, sem autorização, poderes que devia exercer pessoalmente". (Idem)

${ }^{319}$ É o que afirma Sérgio Novais Dias (mas sem o fundamento específico do descumprimento do mandato): "A natureza da relação entre o advogado e o cliente é contratual. 'O advogado responde contratualmente perante seus clientes. Havendo inexecução dessa obrigação por parte do advogado, ele responde pelas perdas e danos causados ao cliente, como ocorre com qualquer obrigação contratual, consoante regra geral insculpida no artigo 1.056 do Código Civil brasileiro, 'verbis': 'Não cumprida a obrigação, ou deixando de cumpri-la de modo e no tempo devidos, responde o devedor por perdas e danos". (DIAS, Sérgio Novais, op. cit., p. 30.)

${ }^{320}$ Consoante os dizeres de José Serafim Barbosa: "Em regra, a responsabilidade civil do advogado tem como natureza jurídica o contrato, ou seja, é contratual porque decorrente do mandato que lhe é outorgado. $\mathrm{O}$ fato é que, quando alguém contrata os serviços de determinados profissionais, no caso específico o advogado, o que o cliente espera é que o prestador do serviço tenha conhecimento daquilo que está a oferecer ao contratante, a fim de que o trabalho desenvolvido possa corresponder à expectativa do cliente. A obrigação do mandatário (o advogado) é a de promover a defesa do mandante (cliente) em juízo, bem como aconselhálo profissionalmente. Assim, se não obrar com cautela, desvirtuando o desempenho de seu ofício, o advogado poderá ser obrigado a indenizar o contratante pelos eventuais danos causados, eis que responde pelos erros 
2.8.2 Perda de uma chance na responsabilidade extracontratual

Como já se pode constatar ao longo deste escrito, a perda de uma chance não se trata de uma nova categoria de dano, porém, acarreta um prejuízo distinto do resultado final perseguido, apto a gerar todas as modalidades clássicas de dano reconhecidas pelo ordenamento.

Por isso, o mérito da teoria está em açambarcar um cabedal maior de proteção contra o dano injusto ${ }^{321}$, possibilitando a indenização onde antes não se vislumbrava, em face de uma equivocada incerteza, ou, ainda, obtemperando o rigor do montante indenitário - que poderia corresponder ao resultado final danoso (incerto) -, ao substituí-lo pelo total da chance perdida (certa), evitando-se, destarte, o enriquecimento sem causa da vítima ${ }^{322}$, conforme preconiza o art. 884 do $\mathrm{CCB}^{323}$.

Diante disso, a perda de uma chance é instrumento de tutela dos valores constitucionalmente protegidos, na medida em que irá, em última análise, indenizar, com justiça, a esfera de bens violada, seja ela moral, material ou estética $\left(\mathrm{CF} \text {, art. } 5^{\circ}, \mathrm{V} \text { e } \mathrm{X}\right)^{324}$. Sua reparação prescinde de qualquer prescrição positiva específica, porquanto tem ampla guarida na cláusula geral de responsabilidade civil.

Na França, precursora da teoria, a base normativa é o artigo 1382 do Código Napoleônico ${ }^{325}$, que prevê: "Tout fait quelconque de l'homme, qui cause à autrui un dommage, oblige celui par la faute duquel il est arrivé, à le réparer”. Segundo Savi: “o

de fato e de direito ao desempenhar o mandato". (BARBOSA, José Serafim. Responsabilidade civil do advogado pela perda de uma chance. Disponível em: <http://portal2.unisul.br/content/navitacontent_userFiles/File/cursos.pdf>. Acesso em 4 fev. 2011.)

321 Seguindo, aliás, a tendência mundial, como ressaltam Guido Alpa e Mario Bessone: "La funzione risarcitoria viene per così dire esaltata dall'incremento dei danni che è un connotato tipico della società moderna”. (ALPA, Guido; BESSONE, Mario. Atipicità dell’illecito. Milão: Giuffrè, 1980, parte prima, p. 4).

${ }^{322}$ Nos Estados Unidos da América, Saul Levmore aponta a preocupação com o não enriquecimento ilícito como uma das razões para a utilização da perda de uma chance - e do recurso às probabilidades - na área médica: "There are, however, two reasons why probabilistic innovation has begun in the medical malpractice área. The first has to do with the availability of information, such as the contained in mortality tables, and the second returns us to the possibility that the unjust-enrichment principle could be used as a solution to the problem of recurring misses". (LEVMORE, Saul. Probabilistic recoveries, restitution, recurring wrongs. In: LEVMORE, Saul. Foundations of Tort Law. Nova York: Oxford University, 1994, p. 132.)

${ }^{323}$ BRASIL. Código Civil (2002). Código Civil e Constituição Federal. 62. ed. São Paulo: Saraiva, 2011.

${ }^{324}$ BRASIL. Constituição (1988). Constituição da República Federativa do Brasil. 16. ed. São Paulo: RT, 2011.

${ }^{325}$ FRANÇA. Código Civil (1804). Código Civil. Disponível em: 〈http://www.legifrance.gouv.fr $>$. Acesso em: 4 fev. 2011. 
conceito de dano previsto neste dispositivo é o mais amplo possível, abarcando em sua vasta amplitude todas as espécies de danos, dentre os quais o dano decorrente da perda de uma chance",326.

Por sua vez, Louis Josserand, em obra clássica, avulta o caractere de generalidade do que ele denomina "Código de Sociabilidade Humana":

\begin{abstract}
Aux termes du premier de ces textes, veritable 'Code de la sociabilité humaine', 'tout fait quelconque de l'homme, qui cause à autrui un dommage, oblige celui par la faute duquel il est arrivé, à le réparer'. De l'avis unanime, cette disposition présente le plus grand caractère de généralité; elle pénètre jusque dans le cercle contractuel, puisqu'elle régit certaines fautes comises à l'occasion de la formation ou même de l'exécution des conventions; il faut y voir la charte de la vie en société, l'expression de cette loi suprême d'interdépendance sociale sans l'observation de laquelle il n'y aurait point de communauté humaine de quelque valeur et de quelque durée 327 .
\end{abstract}

Apenas para citar mais alguns exemplos de legislações que adotam a perda de uma chance, o Código Civil Italiano ${ }^{328}$, o Código Civil Português ${ }^{329}$ e o Código Civil Espanhol $^{330}$ contêm "apenas" disposição genérica sobre responsabilidade, e a jurisprudência respectiva a considera bastante para o enfrentamento da questão.

Portanto, a cláusula geral de ato ilícito (CC, art. 186) ${ }^{331}$, com a sua consequente repercussão na obrigação de indenizar $(\mathrm{CC} \text {, art. } 927)^{332}$, constitui fundamento suficiente ao

\footnotetext{
${ }^{326}$ SAVI, Sérgio, op. cit., p. 93.

${ }^{327}$ JOSSERAND, Louis. De l'esprit des droits et de leur relativité: theorie dite de l'abus des droits. 10. ed. Paris: Librairie Dalloz, 1939, p. 326.

328 "Art. 2043. Qualunque fatto doloso o colposo, che cagiona ad altri un danno ingiusto, obbliga colui che ha commesso il fatto a risarcire il danno”. (ITÁLIA. Código Civil (1942). Código Civil. Disponível em: <http://www.jus.unitn.it/cardozo/obiter_dictum/codciv/Codciv.htm>. Acesso em 28 fev. 2011.)

329 "Art. 483". 1. Aquele que, com dolo ou mera culpa, violar ilicitamente o direito de outrem ou qualquer disposição legal estimada a proteger interesses alheios fica obrigado a indemnizar o lesado pelos danos resultantes da violação”. (PORTUGAL. Código Civil (1966). Código Civil. Disponível em <http://www.stj.pt/nsrepo/geral/cptlp/Portugal /CodigoCivil.pdf>. Acesso em: 28 fev. 2011.)

330 "Art. 1.101. Quedan sujetos a la indemnización de los daños y perjuicios causados los que en el cumplimiento de sus obligaciones incurrieren en dolo, negligencia o morosidad, y los que de cualquier modo contravinieren al tenor de aquéllas”. (ESPANHA. Código Civil (1889). Código Civil. Disponível em: <http://www.ucm.es/info/civil/jgstorch/leyes/ccivil.htm>. Acesso em: 28 fev. 2011.)

${ }^{331}$ BRASIL. Código Civil (2002). Código Civil e Constituição Federal. 62. ed. São Paulo: Saraiva, 2011. 332 Idem
} 
acolhimento da teoria da indenização pelas chances perdidas. Corroborando tal entendimento, assevera Dallegrave que "não há como negar que a indenização pela perda de uma chance decorre da aplicação pura dos elementos da responsabilidade civil, quais sejam, o dano, o ato culposo e o nexo causal. Logo, os fundamentos legais são aqueles oriundos dos arts. 186 e 927 do Código Civil 333 334,".

Não se pode olvidar, todavia, da exceção prevista no parágrafo único do art. 927 do $\mathrm{CCB}^{335}$, que contempla as hipóteses de responsabilidade objetiva, nas quais, inquestionavelmente, pode ser enquadrada a perda de uma chance.

2.8.3 Abordagem norte-americana da perda de uma chance

A common law, sistema jurídico no qual se assentam os Estados Unidos da América, tem a sua ordem jurídica composta, predominantemente, não pela lei escrita (statutory law), mas pelos precedentes judicias (precedents), que possuem efeito vinculante ${ }^{336} 337$. Portanto, não faz sentido esquadrinhar o(s) fundamento(s) da perda de uma chance sob a mesma perspectiva que o(s) perquirimos nos países da civil law, buscando edificar, nas normas jurídicas pré-existentes, genéricas ou específicas, uma construção hermenêutica que pudesse agasalhar, ou, ao menos, não repelir, a recepção da teoria pelo ordenamento.

O fundamento, aqui, deve ser apreciado sob uma ótima um pouco diferente: a das razões (rationales) pelas quais as Cortes se curvaram ao acolhimento da teoria da perda de uma chance, com a valorização, muito mais intensa, do argumento aceito pelas jurisdições para a formação de um precedente (causes of action), sem engendrar uma norma escrita que dê guarida à teoria. Embora os fundamentos e estruturas sejam bastante diversos nos EUA, como, em regra, nos ordenamentos de origem anglo-saxônica, pretendem-se apresentar, de modo bastante condensado, os elementos de persuasão que sensibilizaram alguns estados norte-americanos a aplicar a teoria das chances perdidas.

\footnotetext{
${ }^{333}$ DALLEGRAVE NETO, José Afonso, op. cit., p. 227.

${ }^{334}$ Embora correto o raciocínio, o texto despreza tanto o fundamento derivado da responsabilidade contratual, quanto a possibilidade de haver perda de uma chance nos casos de responsabilidade objetiva.

${ }^{335}$ Op. cit.

${ }^{336}$ ANDREWS, Neil, op. cit., p. 17.

${ }^{337}$ O professor Estêvão Mallet discorda dessa asserção e, inclusive, põe em xeque a validade hodierna da distinção entre common law e civil law.
} 
Dois esclarecimentos, entretanto, são necessários: 1 - quando se fala em teoria da perda de uma chance (loss-of-a-chance-doctrine) nos EUA, refere-se, na quase totalidade dos casos, às demandas concernentes aos erros médicos, haja vista a relação médicopaciente ser extremamente judicializada no país, com a prática de uma medicina defensiva, e com a grande maioria dos profissionais coberta pelo gigantesco mercado de seguros; 2 é penosa a tarefa de desenhar um cenário nacional de qualquer assunto jurisdicional nos EUA, justamente pela característica de serem "estados unidos" que confluem numa federação, mas que guardam a marca de entidades territoriais autônomas, com Poder Judiciário próprio, muito mais independente do que nos demais países pesquisados.

A motivação axiológica da aceitação da teoria das chances perdidas na seara médica, em alguns estados, foi o reconhecimento de que o sistema tradicional de ônus da prova da causalidade ("preponderance of evidence"/"more- likely-than-not-rule") fazia com que muitos profissionais escapassem à responsabilidade por sua falha médica ${ }^{338}$, pois as vítimas não tinham possibilidade de demonstrar que o erro médico tinha mais de $50 \%$ (cinquenta por cento) de probabibilidade de ter ocasionado o dano.

Segundo Steven Kock, Herkovits v. Group Health Cooperative Puget Sound é geralmente citado como a primeira decisão em que se adotou a metodologia de perda de uma chance, concedendo reparação parcial em uma circunstância em que o nexo causal entre o dano e a negligência médica contava com uma probalidade inferior a $50 \%$ (cinquenta por cento). Desde então, o precedente passou a ser mencionado em inúmeras decisões subsequentes, e servido de base para a aceitação em mais de 20 estados norte$\operatorname{americanos}^{339}$.

\footnotetext{
338 "Acknowledging that the traditional preponderance of the evidence/more-likely-than-not rule of proving causation would continuously allow certain medical professionals to escape liability for their negligent acts, some courts began recognizing claims in which a plaintiff's odds of recovery were already less than fifty percent prior to a defendant doctor's negligence". (KOCH, Steven. Whose Loss Is It Anyway? Effects os the "Lost-Chance" Doctrine on Civil Litigation and Medical Malpractice Insurance. North Carolina Law Review, v. 88, p. 595-638, 2010, p. 605.)

339 "Courts in the 1980s began applying Dr. King's proportional approach to medical malpractice cases. Herskovits v. Group Health Cooperative of Puget Sound52 is generally cited as the first decision to apply the official lost-chance methodology. Although the Supreme Court of Washington did not expressly apply Dr. King's proportional approach, the decision is significant in that it permitted a plaintiff to recover damages when the evidence in the case indicated that the defendant's negligence was less likely than not the proximate cause of the plaintiff's injury.54 Since Herskovits, Dr. King's proportional approach has been cited in numerous subsequent decisions and has served as a basis for more than twenty states' adoption of the lost chance doctrine". (Idem, p. 605-606)
} 
Outros articulistas corroboram a assertiva de Koch, como, por exemplo, Tory A. Weigand, que, em $2003^{340}$, apontou que a aceitação da teoria continuava a crescer vertiginosamente, e que, o que antes era uma visão restrita, tornara-se majoritária naquelas jurisdições. À época da investigação, dos 50 estados norte-americanos, 24 haviam reconhecido a reparabilidade do dano (além de Porto Rico). De outro bordo, 16 estados rejeitavam a teoria, no âmbito judicial ou legislativo ${ }^{341}$. Nos demais estados a matéria ainda era controvertida ou ainda não havia sido abordada de modo específico.

\footnotetext{
${ }^{340}$ Os estados que aceitavam a teoria, e os respectivos precedentes, são os seguintes: “* Arizona: Thompson v. Sun City Community Hospital, 688 P.2d 605 (Ariz. 1984); * Colorado: Boyria v. Pash, 960 P.2d 123 (Colo. 1998); Sharp v. Kaiser Foundation Health Plan, 710 P.2d 1156 (Colo. App, 1985); * Connecticut: Borkowski v. Sachetti, 682 A.2d 1095 (Conn. App. 1986); Poulin v. Yasner, 781 A.2d 422 (Conn. App. 2001); * Georgia: Richmond County Hospital Authority v. Dickerson, 356 S.E.2d 548 (Ga. App. 1987); Dowling v. Lopez, 440 S.E.2d 205 (Ga. 1993); * Hawaii: McBride v. United States, 462 F.2d 72 (9th Cir. 1972); * Illinois: Holton v. Memorial Hospital, 679 N.E.2d 1202 (Ill. 1997); Reardon v. Bonutti, 737 N.E.2d 309 (III.App. 2000); * Indiana: Cahoon v. Glessie, 734 N.E.2d 535 (Ind. 2000), vacating Cahoon v. Cummings, 715 N.E.2d 1 (Ind.App. 2000); Mayhue v. Sparkman, 653 N.E.2d 1384 (Ind. 1995); Alexander v. Scheid, 726 N.E.2d 272 (Ind. 2000); * Iowa: Wendland v. Sparks, 574 N.W.2d 327 (Iowa 1998); Deburkarte v. Louran, 393 N.W.2d 131 (Iowa 1986); Sanders V. Ghristt, 421 N.W.2d 520 (Iowa 1988); * Kansas: Roberson v. Counselman, 686 P.2d 149 (Kan. 1984); Delaney v. Cade, 873 P.2d 175 (Kan. 1004); Pipe v. Hamilton, 56 P.3d 823 (Kan. 2002); * Louisiana: Hastings v. Baton Rouge General Hospital, 498 So.2d 713 (La. 1986); Smith v. State, 676 So.2d 543 (La. 1996); * Missouri: Soper v. Bopp, 990 S.W.2d 147 (Mo. App. 1999); Wollen v. DePaul Health Center, 828 S.W.2d 681 (Mo. 1992); Holloway v. Cameron County, 18 S.W.3d 417 (Mo.App. 2000); * Montana: Aasheim v. Humberger, 695 P.2d 824 (Mont. 1985); * Nevada: Perez v. Las Vegas Medical Center, 805 P.2d 589 (Nev. 1991); * New Hampshire: Lord v. Lovett, 770 A.2d 1103 (N.H. 2001); * New Jersey: Scalfidi v. Seiler, 574 A.2d 398 (N.J. 1990); * New Mexico: Alberts v. Schultz, 975 P.2d 1279 N.M. 1999); * New York: Kallenberg v. Beth Israel Hospital, 357 N.Y.S.2d 508 (App. Div. 1st Dep't 1974; but see Mortenson v. Memorial Hospital, 483 N.Y.S.2d 264 (App. Div. 1st Dep't 1984); Birbeck v. Central Brooklyn Medical Group, 2001 N.Y. Slip Op. 401330 (N.Y. 2001); * Ohio: Roberts v. Ohio Permanente Medical Group, 668 N.E.2d 480 (Ohio 1996); McMullen v. Ohio State University Hospitals, 725 N.E.2d 1117, 1121 (Ohio 2002); but see Liotta v. Rainey, 2000 Ohio App. Lexis 5475 (Ohio App. 2000); * Oklahoma: McKellips v. Saint Francis Hospital, 741 P.2d 457 (Okla. 1987); * Pennsylvania: Hamil v. Bashline, 392 A.2d 1280 (Pa. 1978); * Puerto Rico: Morales v. United States, 642 F.Supp. 269 (D. P.R. 1986); * Vermont: Short v. United States, 908 F.Supp.2d 227 (D. Vy. 1998); Lockwood v. Lord, 657 A.2d 555 (Vt. 1994); * Washington: Herkovits v. Group Health Co-operative of Puget Sound, 664 P.2d 474 (Wash. 1981); * West Virginia: Thornton v. CAMC, 305 S.E.2d 316 (W.Va. 1983); * Wisconsin: Ehlinger v. Sipes, 454 N.W.2d 754 (Wis. 1990); Fischer v. Ganju, 485 N.W.2d 10 (1992)". (WEIGAND, Tory A. Loss of chance in medical malpractice: a look at recent developments: the growing acceptance of this doctrine raises difficult public policy issues, as well as concerns for the limits of medical professional liability. Disponível em: <http://goliath.ecnext.com/coms2/gi_0199-3026884/Loss-ofchance-in-medical.html >. Acesso em: 16 mar. 2011.)

${ }^{341}$ Os estados que rejeitavam a teoria, e os respectivos precedentes, são os seguintes: "Os estados eram os seguintes: * Alabama: McAffe v. Family Center, 641 So.2d 265 (Ala. ;994); * Alaska: United States v. Crosby, 48 F.Supp.2d 924 (D. Alaska 1999); * Arkansas: Holt v. Wagner, 43 S.W.2d 128 (Ark. 2000); Finn v. Phillips, 2002 Ark. App. Lexis 522; * California: Dumas v. Cooney, 1 Cal.Rptr.2d 584 (Cai.App. 1991); Bromme v. Pavitt, 7 Cal.Rptr.2d 608 (Cal.App. 1992); * Florida: Gooding v. University Hospital Building Inc., 445 So.2d 1015 (Fla. 1984); Swain v. Curry, 595 So.2d 168 (Fla.App. 1992); * Idaho: Manning v. Twin Falls Clinic \& Hospital Inc,, 830 P.2d 1185 (Idaho 1992); * Maryland: Fennell v. Southern Maryland Hospital Center Inc., 580 A.2d 206 (Md. 1990); Chudson v. Rata, 548 A.2d 172 (Md. 1988); * Michigan: Falcon v. Memorial Hospital, 462 N.W.2d 44 (Mich. 1990); Weymers v. Khera, 563 N.W.2d 647 (Mich. 1997); limited by statutory amendment eliminating recovery for loss of chance in wrongful death actions (Michigan Compiled Laws, Section 00 2912(a) (2000)); * Minnesota: Fabio v. Belloma, 504 N.W.2d 758 (Mknn. 1993); * Mississippi: Ladner v. Campbell, 515 So.2d 882 (Miss. 1987); Clayton v. Thompson, 475
} 
O próprio Koch, em 2008, utilizando as informações de Matsuyama e Kemper, apontou para resultados um tanto discrepantes, quiçá pela data da pesquisa. Segundo ele, 22 estados adotaram a doutrina ${ }^{342}, 16$ rechaçaram $^{343}, 6$ adiaram a decisão sobre o tema ${ }^{344}$ e, nos outros 6, a Suprema Corte ainda não havia analisado a questão ${ }^{345}$.

So.2d 430 (Miss. 1985); * South Carolina: Jones v. Owings, 456 S.E.2d 371 (S.C. 1995); Burroughs v. Worsham, 574 S.E.2d 215 (S.C.App. 2002); * South Dakota: Jorgensen v. Vener, 616 N.W.2d 366 (S.D. 2000), further proceedings, 640 N.W.2d 485 (S.D. 2002), abrogated by South Dakota Codified Laws Section 20-9-1; * Tennessee: Kilpatrick v. Bryant, 868 S.W.2d 594 (Tenn. 1991); * Texas: Kramer v. Lewisville Memorial Hospital, 858 S.W.2d 397 (Tex. 1993); Marvelli v. Alston, 100 S.W.3d 460 (Tex.App. 2003); * Utah: Andersen v. Brigham Young University, 1996 U.S.App, Lexis 15543 (10th Cir. 1996); George v. LDS Hospital, 797 P.2d 1117 (Utah App. 1990); Seal v. Gowars, 923 P.2d 1361 (Utah 1006); * Virginia: Murray v. United States, 215 F.3d 460 (4th Cir. 2000); Irby v. Richmond Pediatric Ass'n, 16 Va. Cir. 383 (1995)”. (Idem.)

${ }^{342}$ Aceitaram a teoria os seguintes estados: “Arizona, Thompson v. Sun City Cmty. Hosp., Inc., 688 P.2d 605, 616 (Ariz. 1984) (en banc) ("We hold, therefore, that . . the jury may be allowed to consider the increase in the chance of harm on the issue of causation."); Delaware, United States v. Anderson, 669 A.2d 73, 77 (Del. 1995) ("[T] he loss of a chance of avoiding na adverse consequence . . should be viewed as an injury and be compensable.”); Illinois, Holton v. Mem'l Hosp., 679 N.E.2d 1202, 1213 (Ill. 1997) ("We therefore reject the reasoning ... that plaintiffs may not recover for medical malpractice injuries if they are unable to prove that they would have enjoyed a greater than 50\% chance of survival or recovery absent the alleged malpractice of the defendant."); Indiana, Mayhue v. Sparkman, 653 N.E.2d 1384, 1389 (Ind. 1995) ("While the policy arguments for each position are strong . . . [adopting the lost-chance doctrine] is most consistent with Indiana law . . . "); Iowa, DeBurkarte v. Louvar, 393 N.W.2d 131, 137 (Iowa 1986) ("We believe the better approach is to allow recovery ... for the lost chance of survival.”); Kansas, Roberson v. Counselman, 686 P.2d 149, 160 (Kan. 1984) ("The reasoning of the district court [rejecting the lost-chance doctrine] declares open season on critically ill or injured persons as care providers would be free of liability ... if the patient had only a fifty-fifty chance of surviving the disease or injury even with proper treatment."); Louisiana, Smith v. State Dep't of Health \& Hosps., 95-0038, p.5 (La. 6/25/96), 676 So. 2d 543, 547 ("[I]n a medical malpractice case seeking damages for the loss of a less-than-even chance of survival . . the plaintiff must prove . . that the tortfeasor's action or inaction deprived the victim of all or part of that chance . . . .”); Massachusetts, Matsuyama v. Birnbaum, 890 N.E.2d 819, 838 (Mass. 2008) ("Our method . . remedies the illogical and harsh results of a rule that would permit a person who had a prenegligence chance of survival of $51 \%$ to recover full damages while denying all recovery to the person whose prenegligence chance of survival was 49\%.”); Missouri, Wollen v. DePaul Health Ctr., 828 S.W.2d 681, 685 (Mo. 1992) (en banc) ("[T]his Court chooses to recognize a cause of action for lost chance of recovery in medical malpractice cases."); Montana, Aasheim v. Humberger, 695 P.2d 824, 828 (Mont. 1985) ("We feel that including 'loss of chance' within causality recognizes the realities inherent in medical negligence litigation.”); Nevada, Perez v. Las Vegas Med. Ctr., 805 P.2d 589, 592 (Nev. 1991) ("By defining the injury as the loss of chance of survival, the traditional rule of preponderance is fully satisfied."); New Jersey, Scafidi v. Seiler, 574 A.2d 398, 400 (N.J. 1990) ("We hold [that] plaintiffs' damages will be limited to the value of the lost chance for recovery attributable to defendant's negligence."); New Mexico, Alberts $v$. Schultz, 1999-NMCA-15, II 40, 126 N.M. 807, 816, 975 P.2d 1279, 1288 ("We recognize the legitimacy of the lost-chance concept in New Mexico, as set forth in this opinion.”); New York, Kallenberg v. Beth Israel Hosp., 357 N.Y.S.2d 508, 510-11 (N.Y. App. Div. 1974) (per curiam), aff'd, 37 N.Y.2d 719 (N.Y. 1975) (permitting recovery where plaintiff had only a twenty to forty percent chance of survival prior to defendant's negligence); North Dakota, VanVleet v. Pfeifle, 289 N.W.2d 781, 784 (N.D. 1980) ("We think . . the doctors should not be able to escape liability simply because the cancer would eventually have resulted in [plaintiff's] death even if it were discovered sooner."); Ohio, Roberts v. Ohio Permanente Med. Group, 668 N.E.2d 480, 484 (Ohio 1996) ("[W]e recognize the loss-of-chance theory and follow the [proportional] approach ....”); Oklahoma, McKellips v. St. Francis Hosp., Inc., 741 P.2d 467, 474 (Okla. 1987) ("Today's pronouncement adopts the loss of a chance doctrine in Oklahoma . . . ”); Pennsylvania, Hamil $v$. Bashline, 392 A.2d 1280, 1288 (Pa. 1978) ("We agree with [the lost-chance doctrine] and hold that once a plaintiff has demonstrated that defendant's acts or omissions . . have increased the risk of harm to another, such evidence furnishes a basis for [recovery]."); Washington, Herskovits v. Group Health Coop. of Puget Sound, 664 P.2d 474, 477 (Wash. 1983) (en banc) ("To decide [against the lost-chance doctrine] would be a 
blanket release from liability for doctors and hospitals any time there was less than a 50 percent chance of survival, regardless of how flagrant the negligence."); West Virginia, Mays v. Chang, 579 S.E.2d 561, 566 (W. Va. 2003) (per curiam) ("[A] jury could conclude that the [defendant's] allegedly negligent inactions contributed to [plaintiff's] lost chance of early detection and treatment, and conclude that if the [defendant] had complied with the standard of care, the harm . . would not have occurred."); Wisconsin, Ehlinger by Ehlinger v. Sipes, 454 N.W.2d 754, 763 (Wis. 1990) ("We disagree with the court of appeals' conclusion .. . that in a case of this nature Wisconsin law follows the 'all or nothing' approach.”); Wyoming, McMackin v. Johnson County Healthcare Ctr., 73 P.3d 1094, 1100 (Wyo. 2003) ("We hold that the doctrine of "loss of chance' is cognizable in Wyoming ....”). (KOCH, Steven R, op. cit., p. 606-607.)

${ }^{343}$ Rechaçaram a teoria os seguintes estados: "Alabama, McAfee v. Baptist Med. Ctr., 641 So. $2 d$ 265, 267 (Ala. 1994) ("If, as the defendants suggest, the plaintiffs are in fact asking this Court to abandon Alabama's traditional rules of proximate cause and to recognize the 'loss of chance doctrine,' we decline to do so."); Connecticut, Boone v. William W. Backus Hosp., 864 A.2d 1, 18 (Conn. 2005) ("II]n order to satisfy the elements of a lost chance claim, 'the plaintiff must [first] prove that prior to the defendant's alleged negligence, the [decedent]had a chance of survival of at least 51 percent.' " (quoting Drew v. William W. Backus Hosp., 825 A.2d 810, 815 (Conn. 2003))); Florida, Gooding v. Univ. Hosp. Bldg., Inc., 445 So. $2 d$ 1015, 1020 (Fla. 1984) ("We . . hold that a plaintiff in a medical malpractice action must show more than a decreased chance of survival because of a defendant's conduct.”); Idaho, Manning v. Twin Falls Clinic \& Hosp., Inc., 830 P.2d 1185, 1190 (Idaho 1992) ("Our review of the cases that have considered the rationale of the doctrines of 'increased risk of harm' or 'lost chance' convinces us to reject both doctrines."); Kentucky, Kemper v. Gordon, 272 S.W.3d 146, 148 (Ky. 2008) ("[W]e reject the adoption of the 'lost or diminished chance’ doctrine of recovery.... .”); Maryland, Fennell v. S. Md. Hosp. Ctr., Inc., 580 A.2d 206, 211 (Md. 1990) ("We are unwilling to relax traditional rules of causation and create a new tort allowing full recovery for causing death by causing a loss of less than $50 \%$ chance of survival."); Minnesota, Fabio $v$. Bellomo, 504 N.W.2d 758, 762 (Minn. 1993) ("We have never recognized loss of chance in the context of a medical malpractice action, and we decline to recognize it in this case.”); Mississippi, Clayton v. Thompson, 475 So. 2 d 439, 445 (Miss. 1985) (en banc) ("This Court concludes, therefore, that Mississippi law does not permit recovery of damages because of mere diminishmen of the 'chance of recovery.' "); Nebraska, Steineke v. Share Health Plan of Neb., Inc., 518 N.W.2d 904, 907 (Neb. 1994) ("We decline to adopt the loss of chance doctrine in this case ... .”); New Hampshire, N.H. REV. STAT. ANN. § 507E:2 (2009) (superseding Lord v. Lovett, 770 A.2d 1103, 1106 (N.H. 2001)); Oregon, Joshi v. Providence Health Sys. of Or. Corp., 149 P.3d 1164, 1170 (Or. 2006) ("We cannot accept plaintiff's invitation to adopt [the lostchance] theory in actions brought under [Oregon's wrongful death statute].”); South Carolina, Jones $v$. Owings, 456 S.E.2d 371, 374 (S.C. 1995) ("After a thorough review of the 'loss of chance' doctrine, we decline to adopt the doctrine and maintain our traditional approach.”); South Dakota, S.D. CODIFIED LAWS § 20-9-1.1 (2004) (superseding Jorgenson v. Vener, 2000 SD 87, II 20, 616 N.W.2d 366, 372); Tennessee, Kilpatrick v. Bryant, 868 S.W.2d 594, 603 (Tenn. 1993) ("Accordingly, we hold that a plaintiff who ... more likely than not would have suffered the same harm had proper medical treatment been rendered, is entitled to no recovery for. . . the loss of a chance of obtaining a more favorable medical result."); Texas, Kramer v. Lewisville Mem'l Hosp., 858 S.W.2d 397, 407 (Tex. 1993) ("[W]e do not adopt the loss of chance doctrine as part of the common law of Texas.”); Vermont, Smith v. Parrott, 2003 VT 64, III 12 \& 14, 833 A.2d 843, 848-49, 175 Vt. 375, 381 ("The loss of chance theory of recovery is thus fundamentally at odds with the settled common law standard . . . Accordingly, we hold that the Trial court correctly rejected plaintiff's claim for recovery under the loss of chance doctrine.”). (Idem, p. 607-608.)

${ }^{344}$ Adiaram a decisão sobre o tema: "Alaska, Parson v. Marathon Oil Co., 960 P.2d 615, 620 (Alaska 1998) ("[W]e need not address . . . whether Alaska should adopt the loss-ofchance doctrine.”); Arkansas, Holt ex rel. Holt v. Wagner, 43 S.W.3d 128, 132 (Ark. 2001) ("We recognize that lost chance of survival is a complex legal theory that has taken various shapes and forms in other states. We are not closing the door to the future adoption of one of the versions of lost chance of survival."); Colorado, Kaiser Found. Health Plan of Colo. v. Sharp, 741 P.2d 714, 718 n.5 (Colo. 1987) (en banc) ("[W]e Express no opinion on whether we would apply [the lost-chance doctrine] in a proper case.”); Maine, Phillips v. E. Me. Med. Ctr., 565 A.2d 306, 308 (Me. 1989) ("WW]e conclude that the jury could rationally determine that the plaintiffs satisfied even the more stringent requirement [of more-likely-than-not causation].”); Michigan, Stone v. Williamson, 753 N.W.2d 106, 114-15 (Mich. 2008) (indicating that legislative enactment made in response to the court's earlier adoption of lost-chance doctrine is ambiguous and that, as a result,the status of the doctrine in the state is unclear); Rhode Island, Contois v. Town of W. Warwick, 865 A.2d 1019, 1025 (R.I. 2004) ("Although we may revisit the loss of chance doctrine under an appropriate factual scenario, we hold that for the reasons set forth here the facts presented in this case are inadequate . . . ”). (Idem, p. 608-609). 
O resultado pareceu desparatado aos olhos de Koch, pois, para ele, diante da pontecialidade (da doutrina das chances) de expansão da responsabilidade civil por danos, a tendência lógica seria a assimilação pelos estados mais liberais, e a repulsa pelos mais conservadores. Todavia, não foi o que se observou: Vermont, California, Oregon e Rhode Island, estados marcadamente liberais, repeliram a teoria, ao passo que Oklahoma, Arizona, Wyoming e Kansas, bastante conservadores, adotaram-na. O autor conseguiu, apenas, mapear alguma proximidade geográfica nos locais em que se acolheu a teoria, mas, sem desprezar alguma influência que esse fator possa ter exercido, sustentou que as decisões pareciam, muito mais, baseadas na força e na intensidade do caso do autor, do que na respectiva jurisdição estadual que decidia sobre $\operatorname{ele}^{346}$.

No que tange às premissas para a compensação de danos na perda de uma chance, segundo Tood S. Aagaard, as Cortes adotaram duas abordagens distintas: "causation approach” e “damages approach",347.

Pela primeira, as vítimas recebem indenização na medida em que o cenário factual da perda da chance necessite de um relaxamento do requisito do nexo causal, ou seja, há uma ruptura do método tradicional em que se estabelece a responsabilidade - mediante a demonstração cabal e robusta do nexo entre o ato e o prejuízo - a fim de conceder a justa reparação ${ }^{348}$. Já a segunda concebe a doutrina de modo diferente, não vinculando a causa

\footnotetext{
${ }^{345}$ Sem analise da questão pela Suprema Corte do estado: "California, Bird v. Saenz, 103 Cal. Rptr. 2d 131, 138 n.3 (Cal. Ct. App. 2001), rev'd on other grounds, 51 P.3d 324 (Cal. 2002) ("The California Supreme Court apparently has not yet addressed the lost chance doctrine . . . Inasmuch as the doctrine, in any formulation, has not been approved by our courts, . . . we are loathe to set out to define it."); Georgia, Richmond County Hosp. Auth. v. Dickerson, 356 S.E.2d 548, 550 (Ga. Ct. App. 1987) ("Proximate cause is not eliminated by merely establishing by expert opinion that the patient had less than a fifty percent chance of survival had the negligence not occurred."); Hawaii, Yamane v. Pohlson, 137 P.3d 980, 986 (Haw. 2006) (indicating that plaintiff had filed a lost-chance complaint but not addressing the merits of the doctrine); North Carolina, White v. Hunsinger, 88 N.C. App. 382, 386, 363 S.E.2d 203, 206 (1988) ("Proof of proximate cause in a malpractice case requires more than a showing that a different treatment would have improved the patient's chances of recovery."). But see Shumaker v. United States, 714 F. Supp. 154, 163-64 (M.D.N.C. 1988) ("The statement [in Hunsinger] that proof of proximate causation requires more than a showing that different treatment would have improved the chances of recovery can, but need not, be construed as inconsistent with recognizing lost possibility as a compensable loss.") (citation omitted). Other states include: Utah, Andersen v. Brigham Young Univ., 879 F. Supp. 1124, 1129-30 (D. Utah 1995) ("The Supreme Court of Utah has not directly spoken to loss of chance as a possible separate and new cause of action ... . [T] [Tis Court is not inclined to make an 'eerie guess' that the Supreme Court of Utah will do so."); Virginia, Straus v. McDonald, 67 Va. Cir. 116, 120 (Va. Cir. Ct. 2005) (declining to apply lostchance methodology without prior approval from state supreme court). (Idem, p. 609.)

${ }^{346}$ Idem, p. 609-611.

347 AAGAARD, Tood S. Identifying and Valuing the Injury in Lost Chance Cases. Michigan Law Review, vol. 96, R. 1335, p. 1335-1361, 1997-1998, p. 1337.

348 "Courts employing this causation approach to the loss of chance doctrine award compensation to lost chance plaintiffs on the ground that the lost chance factual scenario necessitates a relaxation of the traditional requirement of proximate causation. In other words, adherents of the causation approach
} 
de pedir a um abrandamento do nexo causal, mas especificando qual o tipo de compensação que é postulada. Por esse viés, o autor vindica, tão somente, os danos sofridos pelas chances perdidas de recuperar a sua condição, e não pelos danos que foram provavelmente, ou, mais provavelmente, ocasionados pelo ato ilícito. Segundo Aagard, essa concepção evita abrir uma exceção ao padrão de reconhecimento do liame causal $^{349}$.

Por outro bordo, Tory A. Weigand desdobra em quatro as possíveis dimensões que as Cortes estaduais podem alcançar para acolher a perda da chance: A - a do aumento do risco de dano; B - a da possibilidade substancial; C - a da combinação dos itens anteriores; D - a da chance pura ${ }^{350}$.

Pelo fundamento do aumento do risco de dano ("increased risk of harm), a responsabilidade é estabelecida quando o testemunho de um expert relata que a conduta profissional, avaliada com um grau razoável de precisão científica, aumentou o risco da ocorrência do mal. Nesse caso, o padrão de probabilidade normalmente requerido para o estabelecimento do vínculo de causalidade é atenuado, e qualquer decréscimo da chance de sobrevivência ou da obtenção de um resultado melhor pode constituir fundamento para a ação, ainda que as chances, anteriormente à negligência, fossem inferiores a 50\% (cinquenta por cento).

De acordo com o critério da possibilidade substancial ("substancial possibility"), a reparação é devida quando resultar numa perda "substancial" das chances de sobrevivência da vítima. O leading case citado por Steven Koch (Herkovits v. Group Health Cooperative Puget Sound), decidido pela Suprema Corte de Washington, enfrentou o problema por esta abordagem. No caso, um médico era acusado de falhar no diagnóstico de um câncer de pulmão, e foi alegado que o atraso de seis meses na diagnose fez com que o paciente perdesse $14 \%$ (catorze por cento) das chances de sobrevivência. A Corte achou que o percentual era "substancial” e, portanto, “compensável”.

sacrifice tort law's usual means of establishing liability - the demonstration of a clear causal nexus between negligent act and harmful result - in order to vindicate fairness values”. (Idem, p. 1340)

349 "An alternative approach to the doctrine, the damages approach, conceives of the loss of chance doctrine differently, and in doing so avoids the need to carve out an exception from the traditional causation standard. According to the damages approach, the loss of chance cause of action does not depend on a relaxation of the causation standard, but on a clarification of the injury for which the plaintiff seeks compensation. Courts adopting tis approach hold that the plaintiff may sue only for the harms specifically attributable to her lost chance of recovering from the condition, and not for the harms that were as likely, or more likely, caused by the condition itself. This separate cognizable injury is distinct from the plaintiff's ultimate failure to recover, for which the preexisting condition is by definition the legal cause in a case involving the loss of chance doctrine”. (Idem, p. 1340-1341.)

${ }^{350}$ WEIGAND, Tory A., op. cit. 
Há também o critério da combinação (“combination”), segundo o qual os dois critérios anteriores são reunidos, com uma ligeira diferença terminológica. A Suprema Corte de Wiscosin decidiu que a omissão de tratamento houvera aumentado o risco de dano; era mais provável do que não, que o tratamento omitido diminuiria ou evitaria a ofensa, de forma que, a negligência alegada era um fator substancial na causação da injúria.

Por último, a abordagem da chance pura ("pure chance”) ou isolamento da ofensa ("separate injury") não atenua o estabelecimento do nexo etiológico, em vez disso, foca-se na ofensa alegada. Segundo esse método, cabe ao autor demonstrar que o erro médico em detectar a doença subjacente reduziu a chance de sobrevivência. Nesse caso, o que se repara é a chance perdida, e não o resultado final ${ }^{351}$.

Entretanto, nenhuma das hipóteses abarcadas pelo direito norte-americano trata-se, genuinamente, de perda de uma chance. As abordagens apresentadas são de criação (ou aumento) de risco, tão somente. Alguns casos podem até vir a ser solucionados pela teoria da perda de uma chance, mas, desde que o risco criado (ou aumentado) venha a se concretizar, conforme preleciona Daniel Amaral Carnaúba: "enquanto o risco não se concretizar, provocando uma efetiva perda à vítima, esta não fará jus à reparação. A solução não deixa de ser a aplicação pura e simples da condição de certeza do prejuízo. $\mathrm{O}$ risco nada mais é do que um prejuízo em potencial, ou seja, um prejuízo eventual e futuro, sendo, portanto, inapto a fundamentar um pedido de indenização ${ }^{352,}$.

Desse modo, proposta a ação antes da concretização do risco, deve ser fustigado o pedido baseado em perda de chances, por padecer da ausência do requisito da certeza do

\footnotetext{
${ }^{351}$ Em Alexander v. Scheid, julgado em 2000, pela Suprema Corte de Indiana, fica patente que a Corte reconhece os critérios alinhavados por Weigand, com exceção do da "combinação", que, na verdade, é uma sutileza terminológica para algo entre o "aumento do risco" e a "possibilidade substancial": "The term "loss of chance" has been applied to a number of related situations. These include: (1) an already ill patient suffers a complete elimination of an insubstantial or substantial probability of recovery from a lifethreatening disease or condition; (2) a patient survives, but has suffered a reduced chance for a better result or for complete recovery; and (3) a person incurs an increased risk of future harm, but has no current illness or injury. The first of these was addressed by this Court in Mayhue. See 653 N.E.2d at 1384. The Alexanders now present the second, which, like the first, typically arises in the context of a claim of negligent health care. The third commonly arises in connection with claims of exposure to toxic substances, where no adverse results have yet emerged". (ESTADOS UNIDOS DA AMÉRICA. Suprema Corte de Indiana. Apelação 49D03-9612-CT-1631. Julgado em 3 de abril 2000. Disponível em: <http://www.in.gov/judiciary/opinions/ archive/04030001.trb.html>. Acesso em: 29 mar. 2011)

${ }^{352}$ CARNAÚB A, Daniel Amaral, op. cit., p. 35.
} 
dano ${ }^{353}$. Sem embargo de, no caso de criação (ou aumento) de risco, existir a possibilidade de haver prejuízos certos que ensejam reparação, desde logo.

Imagine-se, por exemplo, um indivíduo saudável que, após um procedimento cirúrgico seletivo, contrai um risco, da ordem de $50 \%$ (cinquenta por cento), de ficar tetraplégico. Nesse caso, o dano moral pelo temor que ele vai ter de suportar, a todo instante, por força da iminente ameaça de invalidez, é certo, porque experimentado desde quando o risco é criado, e não quando ele for concretizado (embora aumente com a concretização). Na mesma trilha, o dano patrimonial em razão do gasto com consultas, medicamentos, tratamento fisioterapêutico e outras cirurgias, a fim de minimizar o risco, também deve ser reparado imediatamente.

Depois da concretização do risco, caso o nexo causal possa ser firmado, ou afastado, com certeza, então o pedido de reparação de dano será regido pelas regras ordinárias de responsabilidade civil. Contudo, havendo dúvida insanável sobre o nexo causal, mas certeza irrefutável sobre a probabilidade de que o ato ilícito pode ter dado causa ao dano, é justo que a vítima exija reparação, porém limitada à extensão do dano, medido pelo grau de probabilidade que o ato imputável a terceiro possui de ter gerado o resultado lesivo.

\footnotetext{
353 “A regra em comento é a mesma aplicável a outro tipo de incerteza: aquela relativa aos riscos da agravação do prejuízo após o julgamento. Para determinar o montante devido pelo responsável, o juiz deve levar em conta todos os elementos do prejuízo que tenham um caráter certo - ainda que sejam futuros - no momento da prolação da sentença ${ }^{353}$. Os fatores hipotéticos, que podem eventualmente alterar este montante (como, por exemplo, a possível agravação do estado de saúde da vítima de um acidente corporal), não serão considerados nesta avaliação, mas poderão, por outro lado, dar ensejo a uma nova demanda, caso venham a se concretizar". (Idem. p. 35-36)
} 


\section{CAPÍtUlo 3 - DANOS E REPARAÇÃo NA PERDA DE UMA CHANCE}

\subsection{Modalidades de danos decorrentes da perda de uma chance}

\subsubsection{Possibilidade de cumulação e/ou isolamento dos danos}

A partir do postulado de que o acolhimento da teoria da perda de uma chance tem como fundamento aquiliano a cláusula geral de responsabilidade civil (CCB, arts. 186 e $927)^{354}$, a única ilação possível é a de que a indenização pode ter como corolário quaisquer dos bens protegidos constitucionalmente.

Ocorre, entretanto, que é impactante a quantidade de obras e julgados que sustentam, sem, contudo, maior aprofundamento teórico acerca da conclusão, a impossibilidade de o dano da chance perdida ser exclusivamente moral.

Raimundo Simão de Melo, após defender que a perda de uma chance constitui uma terceira espécie, intermediária, de dano, entre o dano emergente e o lucro cessante, acrescenta que "por outro lado, o que não se pode é dizer que a indenização pela perda de uma chance é de natureza moral, apenas"355. Em idêntica trilha, Jorge Cavalcanti Boucinhas Filho diz que "a indenização por perda de uma chance tampouco pode ser confundida com uma indenização de natureza exclusivamente moral, embora seja possível que a perda de uma chance também gere dano desta natureza. A perda de uma

\footnotetext{
354 BRASIL. Código Civil (2002). Código Civil e Constituição Federal. 62. ed. São Paulo: Saraiva, 2011.

${ }^{355}$ MELO, Raimundo Simão de, op. cit.
} 
oportunidade concreta prejudica o próprio patrimônio da vítima e não apenas os seus atributos de personalidade ${ }^{356,}$.

Como se denota das transcrições acima, a conclusão pela impossibilidade da frustração de uma oportunidade gerar dano exclusivamente na órbita extrapatrimonial advém de sua vinculação a um ataque necessariamente patrimonial à vítima. Corrobora essa conclusão a assertiva de que "nesse ensejo, atenta-se que a perda de uma chance, por sua vez, como dano material que é, trata-se da demonstração da perda da oportunidade de se obter uma vantagem ou de se evitar um prejuízo 357, .

Sérgio Savi talvez tenha sido o precursor dessa corrente no Brasil, ao sustentar que “o que não se pode admitir é considerar o dano causado pela perda de chance como sendo um dano exclusivamente moral. Até porque, como visto ao longo deste livro, a frustração de uma oportunidade séria e real de incremento no patrimônio pode causar danos de natureza patrimonial, que se enquadram como uma subespécie de dano emergente" ${ }^{\text {"358 }}$. Até mesmo o Superior Tribunal de Justiça acompanhou a tese acima expendida, conforme se verifica do seguinte acórdão:

O advogado obriga-se a conduzir a causa com toda diligência, não se the impondo o dever de entregar um resultado certo. Ainda que o advogado atue diligentemente, o sucesso no processo judicial depende de outros fatores não sujeitos a seu controle. Daí a dificuldade de estabelecer, para a hipótese, um nexo causal entre a negligência e o dano. Para a solução do impasse, a jurisprudência, sobretudo do direito comparado, e a doutrina passaram a cogitar da teoria da perda da chance. Essa teoria procura dar vazão ao intrincado problema das probabilidades com as quais se depara no dia-a-dia, trazendo para o campo do ilícito aquelas condutas que minam, de forma dolosa ou culposa, as chances, sérias e reais, de sucesso às quais a vítima fazia jus. Há possibilidades e probabilidades diversas e tal fato exige que a teoria seja vista com o devido cuidado. A adoção da teoria da perda da chance exige que o Poder Judiciário bem saiba diferenciar o "improvável" do "quase certo", a

\footnotetext{
${ }^{356}$ BOUCINHAS FILHO, Jorge Cavalcanti, op. cit., 30.

${ }^{357}$ BIONDI, Eduardo Abreu. Teoria da perda de uma chance na responsabilidade civil. Disponível em: $<$ http://www.direitonet.com.br/artigos/exibir/3988/Teoria-da-perda-de-uma-chance-na-responsabilidadecivil>. Acesso em: 9 set. 2010.

${ }^{358}$ SAVI, Sérgio, op. cit., p. 57.
} 


\begin{abstract}
"probabilidade de perda" da "chance do lucro", para atribuir a tais fatos as conseqüências adequadas. Assim, o Tribunal de origem concluiu pela ausência de culpa do advogado e, nesse ponto, não há como extrair daí a responsabilidade nos termos tradicionais e, tampouco, nos termos da teoria da perda da chance. Anotou-se que, em determinados casos, a perda da chance, além de determinar o dano material, poderá ser considerada um agregador do dano moral, o que não se pode admitir é considerar o dano da perda de chance como sendo um dano exclusivamente moral. ${ }^{359}$
\end{abstract}

Todavia, conforme já explanado, se a perda de uma chance é uma situação lesiva que acarreta o dever de indenizar - em sentido amplo -, logo, a reparação pode ser dada nas variadas formas previstas no texto constitucional. O postulado de que a perda de uma chance não pode gerar dano exclusivamente extrapatrimonial nega, sem qualquer lastro de juridicidade, a indenização de uma espécie determinada de dano.

Imagine-se, e.g., o caso de um trabalhador que deseja anular judicialmente uma advertência escrita aplicada pelo seu empregador, sob alegação de "desídia", e recebe uma sentença desfavorável, porém baseada em fundamentos frágeis, cuja probabilidade de reforma seja grande, mas fique totalmente obstada pela interposição de recurso ordinário intempestivo. Ora, não há conteúdo econômico imediato na pretensão do trabalhador, mas a frustração da expectativa de ver reexaminada a sua causa e, por conseguinte, possibilitado o cancelamento da advertência que lhe fora aplicada, gera uma lesão exclusivamente moral.

Geneviève Viney, por sua vez, informa que Corte de Cassação admite que, em caso de morte, as vítimas de dano por ricochete podem se prevalecer de uma indenização por dano moral resultante da perda de uma chance de sobrevida da vítima direta ${ }^{360}$. Observese, neste caso, que desde que os parentes não dependam economicamente do de cujus, a perda de uma chance, decorrente de erro médico, que provoca o falecimento, não acarreta senão um forte abalo moral, indiscutivelmente indenizável. Aliás, abstraindo eventuais

\footnotetext{
${ }^{359}$ BRASIL. Superior Tribunal de Justiça. Recurso Especial 1.079.185-MG, Relator: Min. Nancy Andrighi. Julgado em 11 novembro de 2008. Disponível em: 〈www.stj.jus.br〉. Acesso em 9 set. 2010. Sem grifos no texto original.

${ }^{360}$ No original: "La Cour de cassation admet que les proches victimes par ricochet puissent se prévaloir dun préjudice moral résultant de la perte d'une chance de survie de la victime directe". (VINEY, Geneviève, op. cit., 2001, p. 97.)
} 
pudores do caso, a morte do pai, por exemplo, pode acarretar, até mesmo, aumento patrimonial imediato do filho, em virtude do recebimento de herança.

Outro exemplo de perda de uma chance causadora de dano exclusivamente moral, citado por Rafael Peteffi da Silva ${ }^{361}$, versa sobre uma demanda judicial em que a pretensão do autor era a recuperação da guarda dos filhos, na qual a sentença de improcedência podia verdadeiramente ser reformada, mas o advogado perde o prazo para interpor o recurso de apelação cabível. O mesmo autor fornece exemplo ainda mais contundente, e dessa vez real, em decisão do TJ/RS, na apelação cível no . 70026384438, de relatoria do Des. Alzir Felippe Schmitz, julgado em 18 de dezembro de 2008, cujo voto, na parte que toca ao tema, veio assim ementado ${ }^{362}$ :

\begin{abstract}
APELAÇÃO CÍVEL. AÇÃO INDENIZATÓRIA CONTRA O ESTADO. AUSÊNCIA DE INSCRIÇÃO DO AUTOR NO CADASTRO DE CRIANÇAS DISPONÍVEIS PARA ADOÇÃO. PERDA DE UMA OPORTUNIDADE. Flagrante o dano moral experimentado pela criança cujo encaminhamento para adoção restou suspenso, inexplicavelmente, por mais de oito anos, impedindo a sua chance de ser colocada em família substituta em tenra idade.
\end{abstract}

Portanto, não pode a doutrina negar a realidade, pois o direito foi feito para o homem e não o contrário. A casuística acerca da perda de uma chance vem experimentando um crescimento geométrico, a tal ponto que os casos concretos hão de demonstrar, a cada dia mais, que no infinito mundo de possibilidades fáticas da vida em sociedade, a indenização deve ser aquela correspondente ao bem jurídico violado, seja ele patrimonial ou extrapatrimonial.

\title{
3.1.2 O caso "Vanderlei Cordeiro de Lima" 363
}

\footnotetext{
${ }^{361}$ SILVA, Rafael Peteffi, op. cit., p. 215.

${ }^{362}$ Ibidem, p. 215.

${ }^{363}$ A presente história, reproduzida atualmente em inúmeras obras sobre o tema, foi publicada de forma pioneira pela professora Regina Beatriz Tavares da Silva. (SILVA, Regina Beatriz Tavares. A perda de uma chance. 2 set. 2004. Disponível em: 〈http://www.flaviotartuce.adv.br/secoes/artigosc/Regina_perda.doc $>$. Acesso em: 26 set. 2009)
} 
O cenário é a Grécia, onde, em honra a Zeus, o povo se reunia no Peloponeso, na confluência dos rios Alfeu e Giadeo, local em que se erguia a cidade de Olímpia, que, a partir do ano 776 a.C., cedeu seu nome para aquela que viria a ser a maior competição esportiva em toda a história da humanidade: os Jogos Olímpicos. As Olimpíadas invadiram a era cristã, mantiveram seu espírito esportivo e seu condão mágico de unir homens, fazendo-os disputar desafios e dar trégua às guerras durante as competições, até o ano 394 d.C., quando o imperador Teodósio II ordenou sua interrupção, parecendo, então, condenada ao eterno oblívio, não fosse um idealista francês, o Barão Pierre de Coubertin, ter escolhido novamente o país para sediar, em 1896, os primeiros Jogos Olímpicos da Era Moderna $^{364}$.

Dentro desse panorama, foi criada, já em 1896, a prova da Maratona, a fim de homenagear Feidípedes, um soldado grego que, na Primeira Guerra Médica, entre atenienses e persas, no ano de 490 a.C., na planície de Marathon, foi enviado pelo comandante Milciades para anunciar a surpreendente vitória dos gregos, apesar de estarem em considerável desvantagem numérica. Feidípedes teve que percorrer os 42km195m distância de Marathon até Atenas - em um terreno acidentado, na maior velocidade possível, pois os persas tinham jurado que, caso vencessem a batalha, violentariam as mulheres e sacrificariam os filhos dos atenienses, ao que os gregos ordenaram às suas esposas que, caso não soubessem da notícia da vitória em $24 \mathrm{~h}$, deveriam matar os filhos para, em seguida, suicidarem-se. Feidípedes, preocupado em evitar uma tragédia, chegou esgotado ao seu destino, e teve forças apenas para dizer: "vitória" (Níkn), e depois cair morto $^{365}$.

O palco da odisseia é Atenas. O ano é 2004. O evento é a Maratona: a última e mais tradicional prova dos Jogos Olímpicos e que encerrou as Olimpíadas daquele ano. Um dos

\footnotetext{
${ }^{364}$ (FESTIVAIS de honra a Zeus viram espetáculo moderno. UOL. Disponível em: < http://olimpiadas.uol.com.br/2008/historia/grecia/historia.jhtm. Acesso em: 4 fev. 2011)

${ }^{365}$ Esta é a versão oficial. Porém, na versão de Heródoto, bem menos épica, o que ocorreu foi o seguinte: "O relato mais factível vem do historiador Heródoto. Nascido em 484 AC, portanto 6 anos antes da batalha de Marathon, relata em suas "Histórias" que na verdade Fidipedes (...) correu até Esparta, 233Km, recebeu um sonoro não como resposta, porque os espartanos estavam em pleno festival de Artemis e só concordariam em encarar a briga depois do encerramento, em nove dias, quando chegaria a lua cheia. Lá vai nosso atleta fazendo o caminho de volta no mesmo pique, trazendo a má noticia a seus comandantes. Os atenienses então resolveram partir pro ataque surpresa ao exército persa, ainda próximo a suas embarcações na planície de Marathon, distante $40 \mathrm{Km}$ do local onde as tropas estavam acampadas. Isso fez os persas recuarem. Depois da expulsão dos persas, chegam 2.000 espartanos, e ficaram impressionados com a vitória dos atenienses. Não há menção de mensageiro nem morte de Fidipedes, que supostamente fez os $233 \mathrm{Km}$ até Esparta em um dia. Em 1896, na primeira olimpíada da história, Fidipedes foi homenageado com a criação da maratona, corrida de 40Km, mesma distância de Marathon a Atenas." (HISTÓRIA da maratona. UOL Disponível em: <http://liverun.blogtv.uol.com.br/2007/09/05/ historia-da-maratona>. Acesso em: 4 fev. 2011)
} 
atletas brasileiros, o corredor Vanderlei Cordeiro de Lima, fazia uma prova impecável, e liderava o certame até os $36 \mathrm{~km}$, com 28 segundos de vantagem para o segundo colocado, o italiano Stefano Baldini. Naquele momento, Vanderlei foi atacado e derrubado pelo exsacerdote irlandês Cornelius Horan, e só conseguiu retornar à disputa 8 segundos após graças à providencial intervenção do grego Polyvios Kossivas, um espectador que o ajudou a se desvencilhar do malfadado agressor.

Cerca de três quilômetros após o local do incidente, Vanderlei foi ultrapassado por outros dois corredores, respectivamente, o italiano Stefano Baldini e o norte-americano Mebrahtom Keflezighi, e terminou em terceiro lugar, ganhando a medalha de bronze e a frenética ovação do público presente ao Estádio Panathinaikos, que assistira à confusão pelos telões do Estádio, e presenciara um brasileiro radiante adentrando a pista, abrindo os braços, sorrindo e imitando um “aviãozinho" para comemorar o resultado, como se nada tivesse acontecido.

O Comitê Olímpico Brasileiro - COB, diante do fatídico acontecimento, recorreu imediatamente ao Comitê Olímpico Internacional - COI, solicitando a revisão do resultado ou a anulação da prova. O Júri de Apelação da Associação Internacional das Federações de Atletismo - IAAF rejeitou o recurso. O COB apelou ao Tribunal Esportivo Internacional CAS, mas a apelação também foi negada.

Todavia, por seu espírito esportivo e ideal olímpico, o atleta brasileiro foi agraciado com a medalha Pierre de Coubertin, considerada a maior honraria que pode ser atribuída a um atleta olímpico.

O "caso Vanderlei" deve ser catalogado como um "exemplo de manual”, verdadeira epítome da perda de uma chance típica, pois houve uma interrupção ilícita do curso aleatório dos eventos, de modo a tornar a ciência do resultado final dos fatos idôneos, caso transcorressem dentro da normalidade, algo absolutamente incógnito, ontologicamente indemonstrável, mas de valor intrínseco indiscutível.

Teria Vanderlei vencido a prova sob circunstâncias normais?

O debate em torno do assunto serve apenas ao diletantismo dos amantes do esporte, pois, quanto à verdadeira resposta, qualquer altercação é de manifesta obsolescência. $\mathrm{O}$ imponderável atuou de forma irreversível.

Há, de fato, argumentos favoráveis e contrários a sua vitória. Mediante uma investida 
repentina, o organismo humano entra em "crise metabólica”, uma espécie de colapso de suas funções normais: sofre profundas alterações cardíacas (débito cardíaco, fluxo sanguíneo etc.), no consumo de oxigênio e no equilíbrio hormonal. A retomada da homeóstase demanda tempo e profundo desgaste, pois, quando o cérebro recebe a informação de um ataque iminente, promove uma descarga de adrenalina que faz com que todas as sensações de dor e fadiga venham de súbito. A reação esperada, numa situação como essas, é que o atleta desista da prova ${ }^{366}$. Além disso, não há como olvidar que, no momento da paralisação, faltavam apenas cerca de $7 \mathrm{~km}$ para o final da prova, e a diferença entre o brasileiro e o segundo colocado era de $28 \mathrm{~s}^{367}$.

Dialeticamente, entretanto, pode-se opor que Vanderlei passava por severas dificuldades para manter a primeira colocação no momento em que foi achacado, tanto que, no quilômetro 30, sua vantagem para o italiano Stefano Baldini era de $47 \mathrm{~s}$, e no quilômetro 35, apenas um antes do incidente, já era de apenas $28 \mathrm{~s}^{368}$. Ademais, os especialistas relatam que a expressão de cansaço de Vanderlei contrastava com o semblante tranquilo do segundo e terceiro colocados, "mais inteiros", e que, pelo andar da prova, o mais provável é que ele realmente fosse o terceiro colocado ${ }^{369}$, até mesmo porque a diferença entre Vanderlei e Baldini foi de $1 \mathrm{~m} 16 \mathrm{~s}$ ao final da maratona.

As lucubrações, entretanto, são puramente especulativas.

Do ponto de vista legal, a IAAF e o CAS agiram corretamente em não modificar o resultado da prova (outorgando o ouro a Vanderlei), pois não há certeza de que este teria sido outro, caso o infortúnio não tivesse ocorrido. Nesse sentido (resultado final), o pedido está lastreado em um prejuízo hipotético.

Sob o prisma dos danos, todavia, poderíamos considerar a existência de um dano, exclusivamente moral, para Vanderlei Cordeiro de Lima, pela frustração da chance de sagrar-se vitorioso. Opta-se por não analisar sob tal enfoque, pois, além de já ter sido bastante explorado, pode ser alvo de muitas objeções.

\footnotetext{
${ }^{366}$ RETOMADA cobra caro ao corpo. Folha de São Paulo. São Paulo, 30 ago. 2004. Esportes. Disponível em: <http://www1.folha.uol.com.br/fsp/esporte/fk3008200419.htm〉. Acesso em: 04 fev. 2011.

${ }^{367}$ INTRUSO burla megaesquema e arruína maratona de brasileiro. Folha de São Paulo. São Paulo, 30 ago. 2004. Esportes. Disponível em: 〈http://www1.folha.uol.com.br/fsp/esporte/fk3008200414.htm>. Acesso em: 04 fev. 2011.

${ }^{368}$ Idem.

${ }^{369}$ RETOMADA cobra caro ao corpo. Folha de São Paulo. São Paulo, 30 ago. 2004. Esportes. Disponível em: 〈http://www1.folha.uol.com.br/fsp/esporte/fk3008200419.htm>. Acesso em: 04 fev. 2011.
} 
Isso porque, apesar de os Jogos Olímpicos serem denominados de "A grande festa do esporte amador", é notório que, hoje em dia, o profissionalismo domina a maior parte dos esportes em nível olímpico. Os atletas não raro recebem salários, possuem contratos publicitários com cifras altíssimas e recebem vultosos prêmios pelas vitórias. Desse modo, seria possível sustentar que Vanderlei sofreu, acima de tudo, um prejuízo material, por força das premiações e contratos que deixou de auferir.

Isso não é verídico. Tal foi a comoção popular com o ocorrido e a humildade demonstrada pelo atleta brasileiro, que ele foi coberto de glórias após a prova e, possivelmente, chamou mais a atenção da mídia e conseguiu melhores contratos publicitários do que se tivesse alcançado normalmente o primeiro lugar. No que concerne à premiação, seu patrocinador, o Grupo Pão de Açúcar, fez questão de entregar-lhe, pelas mãos do seu presidente, Sr. Abílio Diniz, o prêmio de R \$ 200.000,00 (duzentos mil reais), prometido somente aos campeões olímpicos - o prêmio para a terceira colocação era de “apenas” R \$ 70.000,00 (setenta mil reais) ${ }^{370}$.

Ainda que o argumento da ausência de dano material seja superado, há quem cogite, de modo tremendamente equivocado, que Vanderlei Cordeiro de Lima também não sofreu prejuízos imateriais, pois alcançou o Olimpo em virtude da sua façanha, tanto assim que

\footnotetext{
370 “Apesar do filho-da-mãe - O brasileiro vencia a prova de 42.195 metros quando o ex-padre católico irlandês Cornelius Horan invadiu a corrida e o empurrou para a calçada. Vanderlei - ajudado por um providencial espectador bigodudo e gordota que ele diz ter sido seu anônimo "anjo da guarda" - voltou para a prova e conquistou a medalha de bronze, a única do atletismo brasileiro na competição, sob aplausos entusiásticos de perto de 20 mil pessoas que lotavam o estádio Panathinaikos. Ganhou também a exclusivíssima medalha Barão de Coubertin, que gratifica gestos nobres do esporte. Sua chegada, apesar de tudo feliz, imitando um "aviãozinho" com os braços abertos, se tornou a imagem-emblema dos Jogos. Sua humilde tolerância em relação ao infortúnio que pode ter lhe roubado o ouro olímpico ganhou o mundo. Vanderlei não sabe se ganharia, mas conhece o peso do prejuízo. 'Numa prova, a parada é programada, você vai amortecendo o impacto. Lá, a interrupção foi brusca como se eu batesse de repente numa parede.' Portanto, ele está certo em considerar no mínimo infeliz a declaração do maratonista italiano Stefano Baldini, que disse que ganharia de qualquer maneira. Mas, sabe, o incidente o alçou à condição única de estrela planetária. 'Me disseram que hoje sou a pessoa mais conhecida do mundo', disse, ainda apressado para embarcar. Além da enorme saudade de Maringá, tinha uma missão importante. 'Preciso chegar lá e levar meu terno para a lavanderia. Na sexta-feira (3) vou ser padrinho de casamento do meu sobrinho Sandro, lá em Cosmópolis (interior de São Paulo).' Pela pressa, esqueceu no carro que o levou ao aeroporto em São Paulo uma mochila que guardava o ramo de oliveira da coroação e o buquê de flores, reservados à mãe, Aurora. Agitado, vasculhou as bolsas e aliviado encontrou a medalha. $O$ cheque de $\mathbf{R} \$ 200$ mil, que acabara de ganhar das mãos do seu Abílio (Diniz, presidente do Conselho Administrativo Grupo Pão de Açúcar), estava salvo no bolso direito do jeans. $O$ valor corresponde ao prêmio pela medalha de ouro que ele deixou de ganhar. A decisão de Diniz foi dar o prêmio integral, já que pelo bronze ele receberia $\mathbf{R} \$ 70$ mil." (VANDERLEI está no céu: Maratonista brasileiro que protagonizou episódio mais marcante da Olimpíada vira estrela planetária. Istoé Brasil. São Paulo, 8 set. 2004. Jogos Olímpicos Atenas 2004. Disponível em: < http://www.istoe.com.br/reportagens/10645 VANDERLEI+ESTA+NO+CEU>. Acesso em: 4 fev. 2011)
} 
fora agraciado com a medalha Pierre de Coubertin. Além do mais, todos os jornais deram conta de que ele deixou Atenas como herói ${ }^{371}$.

É insustentável, porém, a asserção de que um atleta que dedica a vida em busca do ouro olímpico, e é alijado, de modo bizarro, da oportunidade de conquistá-lo, quando está em primeiro lugar e com mais de $85 \%$ (oitenta e cinco por cento) do percurso vencido, possa se contentar com qualquer outra espécie de prêmio de consolação.

Analisa-se o caso, assim, sob uma perspectiva inteiramente diversa: o dano, de ordem exclusivamente moral, sofrido pelo vencedor da prova, o italiano Stefano Baldini, consistente na perda da chance de obter uma vitória incontestável. Parece fora de discussão que o italiano não teve qualquer prejuízo na esfera material, pois se sagrou campeão olímpico e regozijou-se com os louros de sua façanha.

Experimentou, entretanto, o gosto amargo de ter sido ofuscado pelo terceiro colocado, alçado à condição de Semideus por uma questão absolutamente estranha à sua alçada $^{372}$. Além disso, para alguns, tornou-se vilão, sem que nada tivesse feito, além de realizar uma corrida extremamente digna. E a prova incontestável de que o italiano sofreu muito por não ter tido a oportunidade de uma vitória sem intercorrências foi o fato de ele ter dito, pouco diplomaticamente, desde a época do ocorrido ${ }^{373}$ até recentemente, que teria vencido a prova de qualquer maneira ${ }^{374} 375$. E, provavelmente, terá de repetir a afirmação, sob olhares incrédulos, até o seu último suspiro.

\footnotetext{
371 VANDERLEI sai de Atenas como herói. O Estado de São Paulo. São Paulo, 29 abr. 2004. Cidades. Geral. Disponível em: <http://www.estadao.com.br/arquivo/esportes/2004/not20040829p59554.htm>. Acesso em 04 fev. 2011.

${ }^{372}$ VANDERLEI vira astro e ofusca colegas. O Estado de São Paulo. São Paulo, 29 abr. 2004. Cidades. Geral. Disponível em: < http://www.estadao.com.br/arquivo/esportes/2004/not20040829p59556.htm>. Acesso em: 4 fev. 2011.

373 “O italiano, que contou não ter visto o episódio, fez questão de repetir algumas vezes que ganharia a prova com ou sem a entrada de Cornelius Horan. 'Eu estava tirando 20 segundos a cada 3 quilômetros e iria ultrapassá-lo de qualquer jeito', comentou, irritado com o pouco valor dado à conquista. 'Acho que aquilo não interferiu no resultado da prova"'. (COB pede indenização para Vanderlei. O Estado de São Paulo. São Paulo, 29 abr. 2004. Cidades. Geral. Disponível em: <http://www.estadao.com.br/arquivo/esportes/2004/ not20040829p59555.htm>. Acesso em 04 fev. 2011.)

${ }^{374}$ STEFANO diz que ganharia maratona de Atenas mesmo sem padre. O Estado de São Paulo. São Paulo, 02 jan. 2008. Esportes. Disponível em: <http://www.estadao.com.br/noticias/esportes,stefano-diz-queganharia-maratona-de-atenas-mesmo-sem-padre,103428,0.htm>. Acesso em: 04 fev. 2011.

${ }^{375}$ VANDERLEI não venceria, diz rival de 2004. Folha de São Paulo, São Paulo. 03 jan. 2008. Esportes. Disponível em: http://www1.folha.uol.com.br/fsp/esporte/fk0301200810.htm. Acesso em: 04 fev. 2011.
} 


\subsection{Reparação parcial ou integral?}

O princípio reitor da reparação de danos na responsabilidade civil é o da restitutio in integrum, segundo o qual se deve indenizar todo o dano, e nada além do dano, conforme vetusta lição dos franceses ${ }^{376}$.

Tal princípio está positivado na regra do caput do art. 944 do Código Civil, e excepcionado em seu parágrafo único ${ }^{377}$, que tem merecido críticas de alguns juristas ${ }^{378}$, justamente porque, ao romper com o princípio da reparação integral, viola o da inafastabilidade da jurisdição $\left(\mathrm{CF} \text {, art. } 5^{\circ}, \mathrm{XXXV}\right)^{379}$, na medida em que um direito maculado, ao menos em parte, não é reparado, apesar do reconhecimento da injustiça do dano. Registra-se, sem embargo, que tal mitigação encontra-se na legislação codificada de diversos outros países ${ }^{380} 381$ 382, abrangendo, inclusive, outras hipóteses além da desproporção entre culpa e dano ${ }^{383}$, e também possui árduos defensores ${ }^{384}$.

\footnotetext{
376 Nas palavras da doutrina: “Tout le dommage, mais rien que le dommage”. (JOURDAIN, Patrice. Les principles de la responsabilité civile. 7 ed. Paris: Dalloz, 2007, p. 141.)

377 “CCB. Art. 944. A indenização mede-se pela extensão do dano. Parágrafo único. Se houver excessiva desproporção entre a gravidade da culpa e o dano, poderá o juiz reduzir, eqüitativamente, a indenização." (BRASIL. Código Civil (2002). Código Civil e Constituição Federal. 62. ed. São Paulo: Saraiva, 2011)

${ }^{378}$ Nessa linha, o professor Álvaro Villaça de Azevedo: “Assim, se culpa for levíssima, poderá o juiz reduzir o valor indenizatório, o que pode, mesmo desse modo, configurar injustiça irreparável, pois o lesado não terá o dano, que lhe foi causado, devidamente reparado. Desse modo, se houver, por exemplo, o incêndio de um veículo caríssimo, causado por uma simples negligência, poderá não restar o dano coberto integralmente. Seria de perguntar-se: quem pagará a diferença? Um fundo público, o Estado? O CC não responde a essa pergunta". (AZEVEDO, Álvaro Villaça. Teoria Geral das Obrigações e Responsabilidade Civil. 11. ed. São Paulo: Atlas, 2008, p. 278-279)

${ }^{379}$ BRASIL. Constituição (1988). Constituição da República Federativa do Brasil. 16. ed. São Paulo: RT, 2011.

380 “Art. 494․ Limitação da indemnização no caso de mera culpa. Quando a responsabilidade se fundar na mera culpa, poderá a indemnização ser fixada, equitativamente, em montante inferior ao que corresponderia aos danos causados, desde que o grau de culpabilidade do agente, a situação económica deste e do lesado e as demais circunstâncias do caso o justifiquem." (PORTUGAL. Código Civil (1966). Código Civil. Disponível em: < http://www.stj.pt/nsrepo/geral/ cptlp/Portugal /CodigoCivil.pdf>. Acesso em: 23 dez. 2010) 381 “Art.1069.- El daño comprende no sólo el perjuicio efectivamente sufrido, sino también la ganancia de que fue privado el damnificado por el acto ilícito, y que en este Código se designa por las palabras 'pérdidas e intereses'. Los jueces, al fijar las indemnizaciones por daños, podrán considerar la situación patrimonial del deudor, atenuándola si fuere equitativo; pero no será aplicable esta facultad si el daño fuere imputable a dolo del responsable." (ARGENTINA. Código Civil (1869). Código Civil. Disponível em:
} 
Pois bem, no que concerne à indenização pela perda de uma chance, o princípio da reparação integral tem plena incidência para o ressarcimento dos danos experimentados pelo lesado ${ }^{385}$. Há, contudo, quem sustente equivocadamente, como alertam os franceses $^{386}$, que a perda de uma chance dá ensejo a uma reparação parcial.

Tal equívoco decorre de uma falsa percepção, pois o que de fato se indeniza não é o resultado final, mas a chance em si mesma, entidade que compõe o patrimônio - material ou imaterial - da vítima, e à qual se pode atribuir um valor econômico, ainda que meramente para compensar a frustração moral sofrida. A chance, portanto, é substantiva em si mesma, e, indenizável em sua totalidade, consoante a doutrina:

La 'chance' es, pues, sustantiva en si misma, por cuanto la mera probabilidad de obtener una ganancia o ventaja comporta ya, de por sí, implícitamente, un valor económico indiscutible. Es por ello que el resarcimiento sólo puede consistir en la pérdida de la propia 'chance'o posibilidad de éxito, en cuanto daño actual resarcible, valorándosela en

$<$ http://www.infoleg.gov.ar/infolegInternet/anexos/105000-109999/109481/texact.htm>. Acesso em: 23 dez. 2010.)

382 "Art. 1.103. La responsabilidad que proceda de negligencia es igualmente exigible en el cumplimiento de toda clase de obligaciones; pero podrá moderarse por los Tribunales según los casos." (ESPANHA. Código Civil (1889). Código Civil. Disponível em: 〈http://www.ucm.es/info/civil/jgstorch/leyes/ccivil.htm〉. Acesso em: $22 \mathrm{dez} .2010$.)

383 Conforme se verifica das três notas de rodapé precedentes, há uma preocupação nos códigos de outros países em reduzir o montante indenitário não apenas no caso de grau de culpa reduzido, como, principalmente, diante de uma situação econômica muito desfavorecida do devedor, com o claro escopo de se evitar levá-lo à bancarrota por conta de um infortúnio da vida. Não bastasse isso, as leis ainda contêm cláusulas abertas, com conceitos jurídicos indeterminados, concedendo ao juiz larga medida para dosar o valor da reparação segundo as circunstâncias do caso.

384 "Esse texto, com a promulgação do Código Civil de 2002, tornou-se lei, pois hoje é o parágrafo único do art. 944 do novo diploma. Tal solução é de grande sabedoria e restabelecerá a justiça faltante, em muitas hipóteses. De fato, examinado o caso concreto, as circunstâncias pessoais das partes e as materiais que o circundam, o juiz fixará a indenização que entender adequada. Poderá fazê-la variar conforme as posses do agente causador do dano, a existência ou não de seguro, o grau de culpa e outros elementos particulares à hipótese em exame, fugindo de uma decisão ordenada por regra genérica, no geral desatenta das peculiaridades do caso concreto". (RODRIGUES, Silvio. Direito Civil: responsabilidade civil. São Paulo: Saraiva, 2002, v. 4, p. 188-189.)

${ }^{385}$ SANSEVERINO, Paulo de Tarso Vieira, op. cit., p. 172.

386 "On affirme généralement que la perte d'une chance ne donne lieu qu'à une réparation partielle et c'est d'ailleurs ce que disent explicitement certaines décisions. Pourtant, l'indemnisation de la perte d'une chance est soumise au principe de la réparation intégrale, mais, come celui-ci oblige à tenir compte de tous les éléments du dommage, les juges ne peuvent éviter de prendre en considération l'aléa qui affecte la réalisation de la chance perdue. C'est pourquoi l'indemnisation est nécessairement inférieure à celle que aurait été due pour la perte de l'avantage escompté si cette perte était survenue". (VINEY, Gineviève; JOURDAIN, Patrice, op. cit., p. 102.) 
sí misma y con prescindencia del resultado final incierto, y no con relación al eventual beneficio o ganancia frustrada ${ }^{387}$.

François Chabas pontua com precisão a inexistência de diferença na natureza da reparação do dano pela perda de uma chance ${ }^{388}$, a qual, conforme explanado alhures, segue o princípio da reparação integral.

Portanto, sem razão a jurisprudência quando afirma que, pelo fato de a perda da chance implicar a indenização equivalente à oportunidade perdida, e não ao prejuízo final, é parcial a reparação ${ }^{389}$. Trata-se de imprecisão conceitual no raciocínio silogístico, pois a premissa não leva à conclusão alcançada. A reparação é integral, mas como o dano é equivalente à chance (probabilidade), que é sempre menor do que o todo, o valor da indenização (total) da chance é necessariamente inferior a ele ${ }^{390}$.

Contrario sensu, caso o prejuízo esteja inteiramente consumado, ou seja, os eventos aleatórios tenham percorrido o caminho inteiro até o evento danoso, deve ser afastada a teoria da perda de uma chance e indenizado o prejuízo equivalente ao resultado final frustrado ${ }^{391}$.

${ }^{387}$ REPRESAS, Félix Alberto Trigo, op. cit., p. 33.

${ }^{388}$ CHABAS, François, op. cit., p. 142.

389 "Na perda de uma chance, indeniza-se a oportunidade perdida, não o prejuízo final. Por isso, a reparação é parcial" (PARANÁ. Tribunal de Justiça do Estado do Paraná, 6a Camara Civil. Apelação Cível 224.231-1. Relator: Juiz Convocado Sérgio Luiz Patitucci. Julgado em 22 de abril de 2003. Disponível em: $\langle$ http://portal.tjpr.jus.br〉. Acesso em: 16 jan. 2011.)

390 "Aussi, en général, une jurisprudence constante en compte l'aléa inhérent à la chance perdue, et module l'indemnisation selon que cette chance était plus ou moins grande. Le quantum des dommages-intérêts est donc necéssairement inférieur au profit ou à l'absence de perte que la victime aurait connu, si l'espoir legitime qu'elle nourrisait s'était finalement concrétisé. En aucun cas, la réparation ne peut égaler ce profit ou cette perte". (DUCLOS, José. Le régime de la responsabilité du banquier et la décharge des cautions. Juris Classeur Périodique, 1984, II, 20237)

${ }^{391}$ Como fez, em decisão recente, a Corte de Cassação Francesa: "Officiers publics ou ministériels. Notaire. Responsabilité. - Dommage. - Réparation. - Caractérisation du préjudice. - Perte d'une chance. - Exclusion. - Applications diverses. - Redressement fiscal subi par des héritiers du fait du paiement des droits de succession au moyen de fonds remis par un parent. Ne constitue pas une perte de chance mais un préjudice entièrement consommé, sous déduction de l'incidence financière des solutions licites, le préjudice subi par des héritiers du fait du redressement fiscal et des pénalités de retard qu'ils ont du acquitter par suite de la faute commise par le notaire, qui n'avait pas informé le donateur, lequel leur avait consenti une libéralité déguisée en ayant pris en charge et réglé, par l'intermédiaire du notaire, l'intégralité des droits de succession, des solutions fiscales régulières répondant à son intention libérale. 1re Civ. - 9 décembre 2010. (FRANÇA. Corte de Cassação. Cassação 09-16.53. CA Paris, 30 de junho de 2009. Disponível em: $\langle$ http://www.courdecassation.fr/IMG/pdf/Bicc 739.pdf $>$. Acesso em: 05 abr. 2011) 


\subsection{Fórmulas para a quantização dos danos}

\subsubsection{O coeficiente redutor}

É hercúleo o trabalho do magistrado no sentido de encontrar parâmetros confiáveis para a justa composição do dano da perda de uma chance, como, aliás, a reparação exata de qualquer prejuízo. Maria Celina Bodin de Moraes, em capítulo intitulado "o Direito Civil na era das incertezas", pontua três principais circunstâncias responsáveis por esse fenômeno: a primeira é a constatação da impossibilidade de dominar todas as tecnologias, em suas mais amplas dimensões, e que dependerão, de qualquer modo, de opções éticopolítico-jurídicas da sociedade; a segunda é a "explosão da ignorância", pela qual quanto mais cresce o leque de horizontes do saber, mais aumentam as dúvidas, o desconhecimento e a consciência da própria ignorância; a terceira é o fato de a acumulação de profundos conhecimentos sobre o mundo não ter aumentado a sabedoria do mundo, da pessoa em relação a si, aos outros e à natureza, pois a hegemonia do saber científico marginalizou outros saberes $^{392}$.

Porém, conforme já mencionado (item 2.3 do capítulo 2), a dificuldade jamais pode ser interpretada como um obstáculo em desfavor da vítima (Aguiar Dias) ${ }^{393}$, sob pena de afronta ao princípio da inafastabilidade da jurisdição $\left(\mathrm{CF} \text {, art. } 5^{\circ}, \mathrm{XXXV}\right)^{394}$, uma vez que o juiz poderia, no apogeu de um insensível pragmatismo, mesmo "reconhecendo a existência de um direito, negar-lhe tutela apenas por uma dificuldade de ordem prática"395.

Não se pode olvidar que "o direito, considerado como causa final, colocado em meio da engrenagem caótica dos fins, das aspirações, dos interesses humanos, deve

\footnotetext{
392 BODIN DE MORAES, Maria Celina. Danos à pessoa humana: uma leitura Civil-Constitucional dos danos morais. Rio de Janeiro: Renovar, 2007, p. 60-62.

393 AGUIAR DIAS, José de, op. cit., p. 777.

${ }^{394}$ BRASIL. Constituição (1988). Constituição da República Federativa do Brasil. 16. ed. São Paulo: RT, 2011.

395 SILVA, Wilson Melo da. O dano moral e sua reparação. 3. ed. rev. e. ampl. Rio de Janeiro: Forense, 1983, p. 317.
} 
incessantemente ansiar e esforçar-se por encontrar o melhor caminho e, desde que se depare, deve terraplanar toda a resistência que lhe opuser barreiras"396.

O ponto de partida para uma correta quantização do dano consiste em estabelecer, com exatidão, os fundamentos epistemológicos da reparação e, daí em diante, traçar as diretrizes pelas quais o intérprete irá se pautar na fixação do quantum.

Deveras, não obstante a vasta produção doutrinária e jurisprudencial, a temática que envolve, v.g., a quantificação do 'dano moral', experimenta certo menoscabo no mundo acadêmico, não porque perdeu importância, mas, justamente, por ter levado à fadiga os juristas, sem que houvesse aquiescência sobre os fundamentos desse tipo de responsabilidade ${ }^{397}$.

Pois bem, a linha mestra da reparação pela chance perdida é a estrita conformação com o princípio da reparação integral. Não obstante, como a chance nada mais representa do que uma probabilidade (parte) em relação à obtenção do todo, cuja conquista ficou obstaculizada pela superveniência do evento danoso, por óbvio, o valor da indenização será inferior ao do dano final, pois sobre este montante deverá ser aplicado um coeficiente de redução $^{398}$ correspondente ao percentual de chances de êxito que a vítima teria de conseguir o resultado ${ }^{399}$.

\footnotetext{
${ }^{396}$ IHERING, Rudolf Von. A luta pelo direito. Trad. João Vasconcellos. 15. ed. Rio de Janeiro: Forense, 1995 , p. 8.

${ }^{397}$ Foi o que concluiu Antonio Junqueira de Azevedo: "O grande tema, em matéria de responsabilidade civil, na década de noventa, foi o dos danos morais. Apesar, porém, do tempo decorrido, da intensa produção doutrinária e vasta jurisprudência, não se chegou a nenhum critério que pudesse pacificar o debate sobre a sua quantificação. Se essa questão, hoje, parece menos vibrante, isso se deve antes ao cansaço dos contendores que ao fato de terem encontrado uma solução. Certamente uma das grandes dificuldades para essa não conclusão dos juristas brasileiros foi a falta de acordo sobre os exatos fundamentos da responsabilidade pelos danos morais, ou seja, sobre se a indenização constituía somente uma espécie de compensação por sofrimentos psíquicos e lesões a direitos de personalidade, inclusive de pessoas jurídicas, ou se devia incluir um plus, os chamados 'punitive damages'”. (AZEVEDO, Antonio Junqueira de, op. cit., p. 377)

${ }^{398}$ Assim pontuou a jurisprudência trabalhista: "RECURSO DO RECLAMANTE - INDENIZAÇÃO POR PERDA DE UMA CHANCE - O valor da indenização deve ser fixado tomando-se como parâmetro o valor total do resultado esperado e sobre este incidindo um coeficiente de redução proporcional às probabilidades de obtenção do resultado final esperado. Assim como não se pode exigir a prova cabal e inequívoca do dano, mas apenas a demonstração provável da sua ocorrência, a indenização, coerentemente, deve ser proporcional à possibilidade maior ou menor de obtenção do resultado almejado". (ESPÍRITO SANTO. Tribunal Regional do Trabalho da $17^{\text {a }}$ Região. Recurso Ordinário 84400-27.2009.5.17.0003. Relator: Sérgio Moreira de Oliveira. Diário da Justiça eletrônico, 15 out. 2010, p. 46)

${ }^{399}$ É exatamente o que propõe o professor François Chabas ao sistematizar o cálculo da indenização pela perda da chance de cura: "Si le préjudice est la perte de chances de survie, il est normal, pour calculer ce préjudice, que le juge recherche d'abord combien vaut la vie et ensuite applique à ce montant le coefficient de chances". (CHABAS, François, op. cit., p. 143)
} 
Deve-se, pois, formular um juízo de qual seria o resultado final obtido, e minorá-lo conforme a probabilidade dessa hipótese se concretizar ${ }^{400}$. É uma operação singela, a princípio, materializada na equação "PC $=\mathbf{R F} \times \mathbf{P}^{401}$ ", na qual "PC" significa o valor da Perda da Chance, "RF" o Resultado Final esperado e "P" a Probabilidade de concretização do resultado final - que será o coeficiente de redução.

Luca D'Apollo confirma ser este o critério escolhido pela doutrina italiana ao asseverar que "si assume come parametro di riferimento il bene finale cui si aspirava diminuito del coefficiente di riduzione, risultante dal grado di probabilità di conseguirlo in relazione al caso concreto 402 ". E bem ilustra sua asserção ao exemplificar: "trattandosi di un concorso a cui partecipano 10 concorrenti, per un unico posto disponibile, ipotizzando che l'utile economico complessivo perseguibile fosse 1000, il calcolo della chance perduta è dato dalla possibilità di vincere il concorso ovvero $10 \%$ : questo sarà il coefficiente di riduzione da applicare al guadagno sperato $(10 \% \text { di } 1000=100)^{403}$,.

Portanto, a indenização pela perda de uma chance jamais pode ser idêntica ao resultado final que não se conseguiu obter, deverá ser sempre inferior. Se a obliteração de uma chance tiver tal grau de probabilidade de êxito que se possa presumir que ela de fato ocorreria, fica afastada a aplicação da teoria.

Poder-se-ia opor, embora sem nenhuma razão, que há hipóteses em que a aplicação da teoria da perda de uma chance renderia ensejo a um ressarcimento rigorosamente idêntico ao do resultado final. Ocorre, entretanto, que, diante de tal ocorrência, alijar-se-ia a aplicação da teoria das chances perdidas, pois a reparação passaria a ser a título de lucros cessantes, na medida em que o que a vítima razoavelmente deixou de ganhar, de acordo

\footnotetext{
${ }^{400}$ Foi uma das sugestões pontuadas por Alison Grant em artigo específico sobre o problema: "Where the client has lost the chance to bring or defend proceedings then a practice has emerged whereby damages are assessed accordingly to a hypothesis and then scaled down accordingly to the probability that the hypothesis is correct". (GRANT, Alisson. Quantifying lost chances: A look at examples of loss of chance cases arising out of solicitors' negligence and the courts' approach to evaluating the loss. Disponível em: $\langle$ http://www.journalonline.co.uk/Magazine/44-12/1001053.aspx >. Acesso em 28 jan. 2010.)

${ }^{401}$ Sérgio Savi revela que essa é a sintetização da forma de quantificação do prejuízo adotada pela Corte de Cassação italiana, que o autor ilustra com diferentes abreviações: VI $=\mathbf{V R F} \mathbf{x} \mathbf{Y}$, no qual $\mathbf{V I}=$ valor da indenização da chance perdida; $\mathbf{V R F}=$ valor do resultado final e, $\mathbf{Y}=$ percentual de probabilidade de obtenção do resultado final. (SAVI, Sérgio, op. cit., p. 32)

${ }^{402}$ D'APOLLO, Luca. op. cit.

${ }^{403}$ Idem.
} 
com o sistema de presunções adotado pelo art. 402 do $\mathrm{CCB}^{404}$, seria o resultado final esperado $^{405}$.

Há, ainda, que se observar algumas sutilezas na aplicação do coeficiente redutor, para evitar excesso ou privação no valor total da indenização. O coeficiente redutor é um “corte cirúrgico" no montante do dano, que precisa ser realizado no local exato.

O professor Joseph King Jr. exemplifica com a hipótese de um paciente com câncer, morto em virtude de uma overdose de medicamentos. Supondo-se que ele tivesse $40 \%$ (quarenta por cento) de chances de cura, e que, caso ela ocorresse, ele teria uma expectativa de vida de 35 anos, a ilação imediata é que a indenização corresponderia a $40 \%$ (quarenta por cento) do valor que fosse atribuído a esses 35 anos.

Entretanto, uma observação particulariza a hipótese: mesmo que o paciente não obtivesse a cura, caso ele não fosse vítima de uma dose excessiva de medicamentos, teria vivido por mais 6 meses. Portanto, a indenização correta deverá ser equivalente à integralidade do valor desses 6 meses, e 40\% (quarenta por cento) dos 34 anos e 6 meses cuja chance de sobrevida lhe fora subtraída ${ }^{406}$.

\subsubsection{A "teoria da diferença"}

O primeiro padrão para a quantificação dos danos é, por excelência, o da aplicação do coeficiente redutor. Algumas vezes, contudo, ele não será suficiente para se encontrar o

\footnotetext{
${ }^{404}$ BRASIL. Código Civil (2002). Código Civil e Constituição Federal. 62. ed. São Paulo: Saraiva, 2011.

405 "Por outro lado, se a imensa maioria da jurisprudência era favorável à tese judicialmente defendida pela vítima, estando a matéria envolvida sumulada pelo tribunal 'ad quem', a teoria da perda de uma chance não será aplicada, já que a indenização abrangerá o valor total da demanda ( $\mathrm{R} \$ 1.000 .00,00$ - sic), pois este é o valor que a vítima 'razoavelmente deixou de lucrar' (lucros cessantes), tendo em vista a observância do nexo causal entre a conduta do agente e a vantagem esperada pela vítima". (SILVA, Rafael Peteffi da, op. cit., p. 222)

${ }^{406}$ Seus precisos termos: "For example, assume that a cancer patient is megligently kylled by an overdose of medication. Assume further that he had a 40\% chance of recovery and that if he had recovered he would have lived an estimated thirty-five years. Even if he had not recovered from the disease, assume that he would have lived an estimated six months. The plaintiff would claim not only that the decedent was deprived of an opportunity of making a full recovery, but also that he probably lost six months of life even if the disease would have been fatal. Compensation should be calculated in a way that avoids double recovery for the same injury. The plaintiff would be compensated for the full value of the six months by which the decedent's life was probably shortened even if his cancer had been incurable. To this amount would be added the value of the chance of living beyond the six months. Thus, we would add $40 \%$ of the value of thirtyfour and one half years of the decedent's life (thirty five years minus six months already covered by the acceleration damages) to the full value of the loss of six months of life. (KING JR. Joseph H. Causation, Valuation, and Chance in personal injury torts involving Preexisting Conditions and Future Consequences. Yale Law Journal, v. 90. p. 1353-1397, 1981, p. 1382-1383.)
} 
valor da reparação. É bastante intuitivo imaginá-lo quando a oportunidade perdida puder ser facilmente aquilatada a partir de uma singela operação matemática, como no emblemático caso do "Show do Milhão", em que bastou o corte redutor, pois era líquido e certo tanto o resultado final esperado - caso a candidata tivesse respondido a uma pergunta corretamente formulada -, como a probabilidade aleatória de êxito com que ela contava.

Em muitos casos, porém, a tarefa não será fácil, pois um ou mais dados para que se aplique o critério primário estará ausente ou fluido num primeiro momento, demandando uma pesquisa mais aprofundada, subsidiada por outros critérios.

No caso concreto, pode não ser claro qual teria sido o resultado final diante da inocorrência do ato ilícito interruptor do curso aleatório dos eventos; qual o percentual de chances de êxito em alcançar o resultado final, ou a forma de avaliação monetária do resultado perdido.

Tratar-se-á, no presente item, a primeira das barreiras: a ausência de elementos nítidos para se aferir o resultado final.

Em tais casos, propõe a doutrina, como antecedente lógico necessário à aplicação do coeficiente redutor, que o juiz lance mão da "teoria da diferença", cunhada pela doutrina germânica $^{407}$, e comumente utilizada para a apuração dos lucros cessantes (vide item 3.3.2 do capítulo 3). De acordo com essa teoria, "o dano se estabelece mediante o confronto entre o patrimônio realmente existente após o dano e o que possivelmente existiria, se o dano não se tivesse produzido: o dano é expresso pela diferença negativa encontrada nessa operação $^{408,}$.

Tal exercício mental hipotético é balizado pela expressão "razoavelmente", consagrada pelo artigo 402 do $\mathrm{CCB}^{409}$, ou seja, a conjetura sobre a possível situação da vítima é alicerçada no que as possibilidades normais induzem à sua ocorrência, de acordo com o curso esperado dos acontecimentos ou com as especiais circunstâncias do caso

\footnotetext{
${ }^{407}$ Basicamente, é também o que determina o art. 249 do BGB, ao estabelecer que a pessoa responsável pela indenização deve restaurar a posição que existiria se a circunstância que a obriga a indenizar não tivesse ocorrido: "\$249 Art und Umfang des Schadensersatzes (1) Wer zum Schadensersatz verpflichtet ist, hat den Zustand herzustellen, der bestehen würde, wenn der zum Ersatz verpflichtende Umstand nicht eingetreten wäre”. (ALEMANHA. Código Civil (1896). Código Civil. Disponível em: <http://www.gesetze-iminternet.de/bundesrecht/bgb/gesamt.pdf >. Acesso: $1^{\circ}$ maio 2011.) Versão em inglês, também, no sítio do parlamento alemão: "Section 249. Nature and extent of damages (1) A person who is liable in damages must restore the position that would exist if the circumstance obliging him to pay damages had not occurred". Disponível em: 〈http://www.gesetze-im-internet.de/englisch_bgb/englisch_bgb.html\#BGBengl 000P249>. Acesso em: $1^{\circ}$ maio 2011.

${ }^{408}$ AGUIAR DIAS, José de, op. cit., p. 760.

${ }^{409}$ BRASIL. Código Civil (2002). Código Civil e Constituição Federal. 62. ed. São Paulo: Saraiva, 2011.
} 
concreto, conforme critérios fornecidos pelo § 252 do BGB (Código Civil alemão) ${ }^{410}$. Significa, pois, abstrair mentalmente e de modo equilibrado as consequências do ato ilícito, escoimando os exageros dos sonhos das vítimas traduzidos em pretensões hiperbólicas ${ }^{411}$.

Mas, mesmo assim, o juízo será sempre especulativo, pois jamais se terá certeza se outra circunstância também poderia intervir de modo a obstar que os acontecimentos, do modo como previstos pelo julgador a partir da razoabilidade, não se concretizariam daquela maneira. Alison Grant, ao analisar a quantificação das chances nos casos de responsabilidade do advogado, reporta-se ao fato de que as Cortes frequentemente têm que "especular" 412 o que ocorreria se o mandatário cumprisse seu encargo de modo escorreito $^{413}$.

Tory A. Weigand relata que os métodos de cálculo do dano de perda de chance de cura ou sobrevida variam nas Cortes norte-americanas, pois algumas jurisdições avaliam o prejuízo pela multiplicação do total dos danos pela chance que o paciente tinha de sobrevida ao tempo da ausência do diagnóstico (coeficiente redutor), e outras pela diferença do percentual de chances ao tempo em que o diagnóstico deveria ter sido feito, e o percentual de chances com o diagnóstico atual (teoria da diferença) ${ }^{414}$. Steven Kock

\footnotetext{
${ }^{410}$ ALEMANHA. Código Civil (1896). Código Civil. Disponível em: < http://www.gesetze-iminternet.de/bundesrecht/bgb/gesamt.pdf>. Acesso: $1^{\circ}$ maio 2011

${ }^{411}$ Silvio Rodrigues assinala que: "Lucro cessante é aquilo que a vítima do acidente 'razoavelmente' deixou de ganhar. Afastou-se, com o emprego do advérbio 'razoavelmente', usado pelo legislador (art 402 do CC), a idéia de ganhos exagerados presentes mais nos sonhos da vítima do que no quadro da realidade. Na maioria das vezes, esses lucros cessantes são os dias de serviço perdidos pelo empregado, ou a expectativa de ganho do trabalhador autônomo, demonstrada através daquilo que ele vinha ganhando às vésperas do evento danoso, e que, por conseguinte, muito possivelmente continuaria a ganhar não fosse o infeliz acidente". (RODRIGUES, Silvio, op. cit., p. 221-222.)

412 O verbo "especular" não foi empregado no contexto coloquial que modernamente lhe é dado, como assemelhado a qualquer conjetura leviana, mas, sim, no sentido estrito do vernáculo de: "Examinar com atenção; averiguar minuciosamente; observar; indagar; pesquisar". (FERREIRA, Aurélio Buarque de Holanda. Novo Dicionário Eletrônico Versão 5.0. Correspondente à 3 ed. 1 a impressão da Editora Positivo, rev. e atual. do Aurélio Século XXI, O Dicionário da Língua Portuguesa, 2004. 1 CD-ROM.)

413 "It is often necessary for the court to speculate as to what would have happened had the negligent solicitor properly discharged his duty. The court has to compare the position of the pursuer following the solicitors' negligence with what his or her position would have been had there been no negligence”. (GRANT, Alison, op. cit.)

${ }^{414}$ Em suas exatas palavras: "Courts which take a narrower approach view only the loss of chance itself as the harm, and thus allow recovery for "only" the value of the reduction of the chance of survival or better outcome caused by the negligence. The methods of discount vary. Some jurisdictions value the harm resulting from the loss of chance by multiplying full damages by the patient's chance of survival at the time of misdiagnosis 106 or by the difference in chance at the time of misdiagnosis versus the chance at the time of actual diagnosis. 107 A variation of this discounting concept takes the number of years upon which the survival probability is based and divides it by the individual's life expectancy. 108 The full damages are then multiplied by this percentage". (WEIGAND, Tory A. Loss of Chance in Medical Malpractice: the need for caution. Massachusetts Law Review, v. 87, n. 1. 2002. Disponível em:
} <http://www.massbar.org/publications/massachusetts-law-review/ 2002/v87-n1/loss-of-chance-in-medical >. Acesso em: 13 mar. 2011) 
informa que nas cortes norte-americanas é bastante comum a utilização do testemunho de um perito para saber quais as chances de cura sem a negligência do médico, em contraste com as probabilidades de cura apesar do erro médico ${ }^{415}$.

Portanto, quando o juízo prospectivo sobre o resultado final na hipótese de não ocorrência do ato ilícito for incerto, cabe ao julgador, primeiramente, aplicar a "teoria da diferença", a fim de formular um dado hipotético sobre a totalidade da vantagem buscada, para, num segundo momento, aplicar o "coeficiente de redução" correspondente à probabilidade de que aquela chance de obtê-la viesse a se materializar ${ }^{416}$.

O professor Joseph King. Jr. fornece um exemplo que envolve a conjunção dos dois métodos, que ele denomina "expected value" ou "weighted mean": Suponha-se que, em um determinado acidente, a vítima, então com 20 anos de idade, adquira a probabilidade de ficar cega no futuro. De acordo com os prognósticos, há $25 \%$ (vinte e cinco por cento) de chances que a tiflose chegue aos 50 anos, $4 \%$ (quatro por cento) de que chegue aos 40 anos, $1 \%$ (um por cento) de que chegue aos 30 anos e $70 \%$ (setenta por cento) de que ela jamais venha a ocorrer ${ }^{417}$.

No mesmo cenário, imagine-se que a cegueira aos 50 anos implique indenização de cem mil dólares; aos 40 anos, de duzentos mil dólares e, aos 30 anos, de trezentos mil dólares.

Pelo método sugerido, a indenização corresponderia a $25 \%$ (vinte e cinco por cento) de cem mil dólares (vinte e cinco mil dólares), mais 4\% (quatro por cento) de duzentos mil dólares (oito mil dólares), mais $1 \%$ (um por cento) de trezentos mil dólares (três mil dólares), totalizando trinta e seis mil dólares.

\footnotetext{
415 “An expert witness's testimony is typically given in terms of what the plaintiff's odds of recovery would have been in the absence of the defendant doctor's negligence compared to what the plaintiff's odds of recovery actually were in the presence of the doctor's negligence, with both odds being based on similarly situated patients”. (KOCH, Steven R., op. cit., p. 603)

${ }^{416}$ É o que ensina Represas: "El mecanismo para cuantificar una chance perdida, consiste, entonces, en un cálculo sobre lo que habría ocurrido de no existir el evento dañoso. Para que una chance perdida sea resarcible, debe haberse tratado de una muy probable efectivización. Ahora bien, para establecer tal posibilidad, el juez deve realizar un análisis retrospectivo, para remontarse a la situación en que se hallaba el damnificado al ocurrir el hecho dañoso. Una vez situado allí, tendrá que realizar un análisis prospectivo de cómo podría haber evolucionado la situación del perjudicado, de acuerdo con las circunstancias en que se encontraba; es decir, determinar cuál de sus posibilidades era la de más probable realización. Establecido ello, se deberá evaluar, aproximadamente, cuál era la proporción estimativa de esa posibilidad, en comparación com los otros escenarios futuros posibles de la víctima”. (REPRESAS, Félix Alberto Trigo, op. cit., p. 276-277)

${ }^{417}$ KING JR, Joseph H. Causation, Valuation, and Chance in personal injury torts involving Preexisting Conditions and Future Consequences. Yale Law Journal, v. 90. p. 1353-1397, 1981, p. 1384.
} 
Apesar de a fórmula sugerida ter seu valor, no exemplo dado, indubitavelmente, ela indeniza dano hipotético, diante de um caso em que não há espaço sequer para a aplicação da teoria da perda de uma chance ${ }^{418}$, pois o curso aleatório dos eventos não foi interrompido de modo a levar os prognósticos ao campo do indemonstrável.

O paciente em questão, de acordo com o exemplo, está vivo, e, com a continuidade da vida, será possível saber com absoluta precisão se, e, em que momento, ele ficará cego. Não faz nenhum sentido, à luz das premissas adotadas para a teoria proposta, que se indenize hoje, por um dano que poderá ou não ocorrer amanhã, mas, cuja verificação, será plenamente possível de ser feita, e a reparação, concedida ou não, na exatidão do prejuízo experimentado.

O autor confunde perda de uma chance com criação de risco, cuja incerteza, nesta última, será dissipada com o mero desenrolar dos acontecimentos. O pressuposto epistemológico da distinção entre as figuras é que na perda de uma chance o direito admite a incerteza como algo indissolúvel, com ela convive e soluciona a quaestio iuris a partir dela; já na criação do risco, o direito oferece uma resposta cronológica, na medida em que o tempo transmuda a incerteza em certeza: ou o indivíduo ficará cego, aos 30, 40 ou 50 anos de idade, ou jamais ficará ${ }^{419}$.

Em suma, a criação de risco é fato gerador de responsabilidade (que se materializa no dever de indenizar, quando o risco se concretiza), e não espécie de prejuízo ${ }^{420}$.

\footnotetext{
${ }^{418}$ Mutatis mutandis, Daniel Amaral Carnaúba é incisivo ao dizer que a eliminação total das chances da vítima é uma constante de crucial importância para a aplicação da teoria: "É inegável que a não-obtenção da vantagem aleatória constitui um elemento invariável aos casos em que a técnica da reparação de chances é empregada, e esta constante recobra sua importância toda vez que o ato imputável ao terceiro não extinguiu todas as chances do demandante. Em tais casos, a perda de uma chance só poderá ser indenizada com o desfecho do processo aleatório, tornando definitiva a perda da vantagem desejada. Neste sentido, a Corte de Cassação por vezes afirmou que, para que a chance perdida possa ser indenizada, 'é necessário que este elemento tenha um caráter certo no momento da decisão judicial'. A razão de tal exigência é evidente: uma reparação prematura das chances perdidas, concedida antes do desfecho da incerteza, pode se somar à futura obtenção da vantagem desejada, provocando o enriquecimento injustificado do demandante". (CARNAÚBA, Daniel Amaral, op. cit., p. 32-33)

${ }^{419}$ Idem, p. 39-40.

${ }^{420}$ FABRE-MAGNAN, Muriel. De l'obligation d'information dans les contrats - essai d'une théorie. Paris : LGDJ, 1992, n. 626, col. Bibliothèque de droit privé, p. 497.
} 


\subsubsection{A estatística}

A estatística é uma ciência que vive no "banco dos réus" perante a opinião pública, tal a desconfiança com a qual os dados são recebidos pelos seus destinatários. Um bom termômetro do receio que se tem pelo uso de tal instrumento é a quantidade de aforismos, sempre bem humorados, que criticam sua validade: “um homem com um relógio sabe a hora certa, um com dois relógios só sabe a média!”; "torture os seus dados por um tempo suficiente e eles confessarão tudo!"; "está provado que fazer aniversário é saudável; estatísticas mostram que pessoas que fazem mais aniversários vivem mais”; existem três tipos de mentira: mentira, mentira deslavada e estatísticas"; "a estatística é um método sistemático para se ter uma conclusão errada com 95\% de confiança”; "um estatístico é um sujeito que se está com a cabeça num forno e os pés enterrados no gelo, ainda diz que na média a temperatura está ótima”; "estatísticas são iguais a biquínis; o que revelam é sugestivo, mas o que elas escondem é essencial”; "fatos são teimosos, mas estatísticas são flexíveis"; "33\% dos acidentes de trânsito envolvem pessoas embriagadas, portanto 67\% estão sóbrias, logo devemos dirigir bêbados que é mais seguro"; "as estatísticas não mentem, mas existem muitos mentirosos usando estatísticas”; "o estatístico é um sujeito que pode morrer afogado ao cruzar um rio com profundidade média de apenas $50 \mathrm{~cm}^{421}$ ”.

Não obstante o tom jocoso de tais máximas, elas revelam o desvelo que se deve ter no uso da estatística, como de resto, de todas as demais ciências, até para não emprestar uma blindagem pseudocientífica a algo mendaz, que passa a ganhar um status axiomático.

Porém, usada de forma minudente e escrupulosa, a estatística é um ramo eficiente e de extrema utilidade da matemática, cujos métodos têm origem no estudo dos jogos de $\operatorname{azar}^{422}$, em que se investigam os processos de obtenção, organização e análise de dados,

\footnotetext{
${ }^{421}$ PONTIFÍCIA UNIVERSIDADE CATÓLICA DO RIO GRANDE DO SUL. Frases. Disponível em: < http://www.pucrs.br/famat/statweb/outros/frases.htm>. Acesso em: 16 mar. 2011.

${ }^{422}$ Conforme escólio de John E. Freund: "Em face das incertezas, tratamos problemas como esses com métodos estatísticos que têm sua origem nos jogos de azar. Embora o estudo matemático desses jogos remonte ao século XVII, não foi senão no início do século XIX que a teoria foi elaborada para 'cara ou coroa', por exemplo, ou para 'vermelho ou preto', ou para 'par ou ímpar' passou a ser aplicada a situações da vida real, em que os resultados eram 'menino ou menina', 'vida ou morte', 'passar ou rodar' e assim por diante. Assim, a Teoria da Probabilidade foi aplicada a muitos problemas das ciências do comportamento, ciências naturais e ciências sociais, e constitui, atualmente, uma ferramenta importante para a análise de qualquer situação (na ciência, na administração ou na vida diária) que, de alguma forma, envolva um elemento de incerteza, ou chance. Em particular, a Teoria da Probabilidade fornece a base que utilizamos para os métodos quando fazemos generalizações a partir de dados observados, a saber, quando usamos os métodos de inferência estatística". (FREUND, John E. Estatística Aplicada: economia, administração e contabilidade. 11. ed. Porto Alegre: Bookman, 2004, p. 9)
} 
bem como as técnicas para tirar conclusões e fazer ilações com predições baseadas em tais dados.

Na questão que nos concerne, dentro da equação proposta para efetuar a quantização do dano de chance perdida $(\mathrm{PC}=\mathrm{RF} \times \mathrm{P}$ ), ela pode atuar tanto para que se possa deduzir o resultado final $(\mathrm{RF})$, quanto para fins de aferição das probabilidades de um determinado resultado $(\mathrm{P})$. Imagine-se, e.g., a hipótese de um indivíduo que não tenha a sua doença diagnosticada pelos médicos, porém, caso tivesse havido a diagnose e o tratamento precoces, ele teria uma determinada probabilidade de cura, com remissão total dos sintomas, e, assim, viveria normalmente.

Pois bem, se esse indivíduo vem a óbito, a estatística atuará nas duas frentes: em primeiro lugar, porque será preciso aferir qual seria a expectativa de vida, a fim de prognosticar quantos anos lhe foram usurpados, para calcular, no âmbito do dano patrimonial, eventual pensionamento, considerando que o CCB não estabeleceu limite temporal para o seu termo, dispondo que ele deverá levar em conta "a duração provável da vida da vítima"423.

Essa pesquisa da "duração provável da vida da vítima” está, atualmente, consolidada em bases estatísticas seguras, diante da mudança promovida pela Lei 9.876/99, que introduziu o fator previdenciário para o cálculo de aposentadorias, acrescendo dois parágrafos ao artigo 29 da Lei 8.213/91 424 , os quais estabeleceram que a expectativa de sobrevida deve ser obtida a partir da tábua completa de mortalidade ${ }^{425}$ construída pelo IBGE - Instituto Brasilero de Geografia e Estatística -, considerando-se a média nacional única para ambos os sexos ${ }^{426}$.

\footnotetext{
${ }^{423}$ É o que determina o art. 948 do CCB: "Art. 948. No caso de homicídio, a indenização consiste, sem excluir outras reparações: I - no pagamento das despesas com o tratamento da vítima, seu funeral e o luto da família; II - na prestação de alimentos às pessoas a quem o morto os devia, levando-se em conta a duração provável da vida da vítima". (BRASIL. Código Civil (2002). Código Civil e Constituição Federal. 62. ed. São Paulo: Saraiva, 2011. Sem grifos no original).

${ }_{424}$ Foram acrescidos os parágrafos $7^{\circ}$ e $8^{\circ}$ ao artigo 29 da Lei 8.213/91, cujo teor é o seguinte: "§ $7^{\circ} \mathrm{O}$ fator previdenciário será calculado considerando-se a idade, a expectativa de sobrevida e o tempo de contribuição do segurado ao se aposentar, segundo a fórmula constante do Anexo desta Lei. § $8^{\circ}$ Para efeito do disposto no $\S 7^{\circ}$, a expectativa de sobrevida do segurado na idade da aposentadoria será obtida a partir da tábua completa de mortalidade construída pela Fundação Instituto Brasileiro de Geografia e Estatística - IBGE, considerando-se a média nacional única para ambos os sexos". (BRASIL. Lei $\mathbf{n}^{\mathbf{0}} \mathbf{8 . 2 1 3}$, de 24 de julho de 1991. Dispõe sobre os Planos de Benefícios da Previdência Social e dá outras providências. Disponível em: $<$ http://www.planalto.gov.br/ccivil/leis/L8213cons.htm>. Acesso em 16 mar. 2011)

${ }^{425}$ A tábua de mortalidade mais atualizada é a do ano de 2009. (INSTITUTO BRASILEIRO DE GEOGRAFIA E ESTATÍSTICA. Tábuas completas de mortalidade - 2009. Disponível em: http://www.ibge.gov.br/home/estatistica/populacao/tabuadevida/2009/default.shtm. Acesso em: 16 mar. 2011)

${ }^{426}$ Para saber mais sobre o assunto, vide: OLIVEIRA, Sebastião Geraldo, op. cit., p. 254-260.
} 
Obtido o número de anos pelos quais será devido o pensionamento, que seriam, em última análise, uma parte do resultado final (RF) na seara patrimonial, o passo seguinte é determinar o grau de probabilidade (P) com a qual a falha no diagnóstico contribuiu para a morte da vítima, o que também dependerá do uso de estatísticas.

De posse das variáveis, a apuração do dano de chance, no exemplo dado, restrita a essa perspectiva ${ }^{427}$, seria simplória: a pensão perduraria pelos anos de provável sobrevida da vítima, cujo levantamento seria feito através das estatísticas, e o seu valor equivaleria ao salário percebido em vida, reduzido de acordo com o percentual de chances que a vítima tinha de um prognóstico favorável, também calculado estatisticamente.

É bem verdade que não há estatísticas para todos os fatos da vida, o que, às vezes, irá redundar na impossibilidade material de sua utilização. Em alguns casos, por outro lado, não haverá como encaixar os dados numa estatística confiável, pois a singularidade da questão afastará a aplicação da "lei das probabilidades", pela ausência de base amostral de experimentação em quantidade suficiente para a sua consolidação em bases estatísticas. Os norte-americanos, exemplificativamente, repelem o seu uso fora da área médica, por entenderem que não há um cálculo acurado de percentagens confiável em outros campos $^{428}$.

Na Itália, o precursor no uso de estatísticas para o caso de oportunidades perdidas foi Piero Calamandrei ${ }^{429}$, que propôs o seu uso nos casos de demandas judiciais frustradas por conduta negligente do advogado. Seu pioneirismo teve méritos, mas agigantou a convicção

\footnotetext{
${ }^{427}$ Faz-se a ressalva porque o cálculo do pensionamento, a partir de bases salariais, possui outras nuanças, tais como: 1 - a dedução de 1/3 do montante global, por ser, presumidamente, a fração que a vítima gastaria com despesas próprias; 2 - a limitação da pensão aos filhos até 25 anos, por ser, também presumidamente, a idade em que atingiriam a independência financeira; 3 - o direito, ou não, de acrescer, da viúva, em relação à quota dos filhos, quando do atingimento dos 25 anos de idade por estes; 4 - se o novo casamento, concubinato ou união estável do beneficiário faz cessar, ou não, o direito à pensão (CCB, art. 1708); 5 - se a vítima for solteira e os beneficiários forem os pais, a dedução de $1 / 3$ até os 25 anos de idade (despesas pessoais) e, posteriormente, a cessação da pensão, por ser a idade em que, presumidamente, a vítima convolaria núpcias e passaria a gastar exclusivamente consigo e com a nova família, ou, alternativamente, a dedução de 2/3 (despesas pessoais + despesas com a nova família), pois, apesar do gasto com a nova família, persistiria a obrigação constitucional de amparo aos pais (CF, art. 229), principalmente nas famílias de baixa renda (STF, Súmula 491); 6 - a integração, ou não, do $13^{\circ}$ salário, do terço constitucional e do FGTS no valor global da pensão; 7 - a dedução, ou não, do benefício previdenciário do valor da pensal auferida etc. Para discussão detalhada, vide: GONÇALVES, Carlos Roberto. Responsabilidade civil. 8. ed., revista de acordo com o novo Código Civil (Lei n. 10.406, de 10-1-2001). São Paulo: Saraiva, 2003, p. 658-701.

${ }^{428}$ Nesse sentido, a observação de Bryson Moore: "A major problem with extending the doctrine to other fields is the greater difficulty in ascertaining the percentage chance lost. This should concern courts desiring to apply the doctrine to these other fields, but should not keep them from adopting the doctrine in medical malpractice cases, in wich experts can accurately calculate such percentages". (MOORE, Bryson B. South Carolina rejects the lost chance doctrine. South Carolina Law Review, South Carolina, Fall, 1996, p. 214).

${ }^{429}$ Consoante informação de: SAVI, Sérgio, op. cit., p. 20.
} 
sobre a necessidade de critérios científicos sólidos para aventuras em ciências estranhas ao Direito.

A argumentação do jurista foi impecável no sentido que cada sentença é produto de uma quantidade de fatores imponderáveis, muitos dos quais irreproduzíveis fora do ambiente em que a sentença foi prolatada. Disse o autor que somente os leigos, alheios a prática forense ou que observam o fenômeno judiciário in vitro acreditam que os juízes são fornecedores de uma mesma invenção, de modo que para uma mesma causa, dada a dez juízes diferentes, devam ser proferidas dez sentenças iguais.

E prosseguiu, sustentando que cada processo possui uma atmosfera especial, resultante da combinação de elementos deveras variados: a habilidade do advogado, a inteligência do juiz, a opinião pública, o clima etc. Diante disso, concluiu pela possibilidade de ocorrer de um mesmo juiz, colocado em momentos diversos, talvez em um mesmo dia ou noutro, mas, diante da mesma questão, decidir de modo diverso, segundo o seu estado de saúde e o seu humor. E terminou por observar que, por essa razão, alguns ordenamentos medievais determinavam que o juiz sentenciasse no período matutino, antes do almoço ${ }^{430}$.

A despeito desses fatores, Calamandrei sustentou que era possível calcular, segundo o critério estatístico, as possibilidades de um apelo ser acolhido.

Todavia, apesar de ter demonstrado louváveis noções antropológicas, seus conhecimentos estatísticos deixaram a desejar.

Efetivamente, propôs ele que se adotasse a estatística judiciária do índice de provimento dos recursos como um todo, para, assim, subsumir a probabilidade de êxito da vítima de um mandatário negligente. Além disso, a fim de demonstrar uma sofisticação de sua proposta, Calamandrei propugnou que não se adotasse como parâmetro um índice geral

\footnotetext{
${ }^{430}$ Suas palavras exatas foram as seguintes: “Ogni sentenza, ha detto la Corte, è il prodotto di una quantità di fattori imponderabili, molti dei quali sono irreproducibili fuor dell'ambiente in cui la sentenza è pronunciata: solo chi vive estraneo alla pratica forense ed osserva il fenomeno giudiziario 'in vitro', può credere che il giudici siano automi forniti tutti dello stesso congegno, che fanno sempre di sì quando si tocca la stessa molla, in modo che la stessa causa, portata dinanzi a dieci giudici diversi, debba dar luogo necessariamente a dieci sentenze ugualli, simili a dieci positive di una negativa sola. In realtà ogni processo ha la speciale sua atmosfera, resultante dalla combinazione dei più svariati elementi: l'abilità degli avvocati, la intelligenza dei giudici, l'opinioni pubblica, il clima... Può accadere perfino che lo stesso giudice, posto in momenti diversi, magari in diverse ore della stessa giornata, dinanzi alla stessa questione, sia disposto a deciderla in modo diverso, secondo lo stato della sua salute o secondo il suo umore. Non per niente certi statuti mediovali prescrivevano che il giudici dovessero sentenziare sempre nelle ore mattutine, prima di pranzo!” (CALAMANDREI, Piero. Opere Giuridiche. Nápoles: Morano, 1966, v. II, p. 383-384)
} 
de reformas, mas restrito àquela circunscrição, e naquele ano em que se perdeu a chance de reexame da causa ${ }^{431}$.

A proposta é simplesmente desastrosa ${ }^{432}$, porque trata todos os recursos com idêntico peso, sem distinção por assunto ou pelas provas produzidas. Difícil crer que a mesma pessoa que consegue vislumbrar tantas idiossincrasias na figura do juiz, capazes de implicar variações nos critérios e resultados dos julgamentos, não tenha se apercebido das vicissitudes do campo fático, a ponto de colocar em vala comum todas as matérias recursais.

Não é digna de crédito a estatística que, v.g., nivela, em termos probabilísticos, o recurso contra uma decisão que afronta uma súmula de efeito vinculante a um recurso contra uma decisão que perfilha uma súmula de efeito vinculante.

E o refinamento de pesquisa proposto (delimitação da circunscrição e do período) em nada resolve o problema.

Imagine-se, v.g., uma demanda em que se postula o pagamento de verbas rescisórias decorrentes de uma relação de emprego incontroversa, que tramita perante uma Vara do Trabalho com modesta movimentação processual anual.

Pois bem, episodicamente, o juiz não concede as verbas rescisórias, por dar valor a um recibo cuja falsidade da assinatura fora afirmada por testemunhas e corroborada por

\footnotetext{
431 “Facciamo, ad esempio, la ipotesi che la causa, nella quale il procuratore ha lasciato decadere l'appello, avesse per il cliente il valore de 100.000 lire. Si la statistica giudiziaria (e per essere più esatti si potrebbe prendere la statistica concernente la circoscrizione a cui la causa appartenava, e magari la statistica di quello stesso ano in cui l'appelo avrebbe dovuto esser trattato), ci dice, per esempio, che su cento appeli interposti, 40 sono in media accolti, si può ritenere che l'appellante (considerato non como appellante in quella causa, ma preso astrattamente, come unità statistica) avrebbe avuto 40 probabilità su 100 di vincere la causa: gli ha fatto perdere 40 probabilità di vittoria, può essere ragguagliato non al valore intero della causa, ma ai 40/100 di esso, pari a 40.000 lire. E il calcolo si potrebbe anche perfezionare, volendo, com raffinati virtuosismi statistici: si potrebbe, ad esempio, considerare che le cause non finiscono in appello e che essendovi in cassazione 25 su 100 probabilità di accoglimento del ricorso, le probabilità vittoria dell'appellante dovrebbero ancora esser diminuite di um quarto, riducendosi cosi il risarcimento a 3/4 di 40.000 lire, cioè, in definitiva, a 30.000.” (Idem, p. 386-387)

${ }^{432}$ Sérgio Novais Dias também critica durante tal solução: "Contudo, não é difícil perceber que a solução encontrada pelo grande jurista está muito longe de resolver adequadamente o problema, pois Calamandrei deu tratamento igual a todos os recursos. Para ele, todos os recursos, independentemente da matéria, teriam a mesma chance de êxito na instância superior, o que é um erro gritante supor, pois evidentemente que, de acordo com a questão discutida, as chances de êxito são totalmente diferentes. A solução de Calamandrei é injusta para o advogado e para o cliente. Em casos extremos percebe-se isso facilmente, pois, nas hipóteses de amplas possibilidades de êxito do recurso, em sintonia com a jurisprudência uniforme da Corte Suprema e do tribunal para o qual era o recurso dirigido, seria injusto que como indenização o cliente recebesse apenas $25 \%$ do resultado econômico que teria como certo alcançar. Do mesmo modo para o advogado cujo recurso não tivesse praticamente chances de êxito, porque a sentença não recorrida estava em perfeita sintonia com toda a jurisprudência, não seria justo ter de pagar ao cliente $25 \%$ do valor da causa". (DIAS, Sérgio Novais, op. cit., p. 59-60)
} 
laudo pericial, e, ainda por cima, firmada num TRCT que não preenchia os requisitos legais do $\S 1^{\circ}$ do artigo 477 da CLT ${ }^{433}$. O advogado, apesar disso, deixa transcorrer inerte o prazo recursal para insurgência contra tão esdrúxula decisão.

No mesmo ano da sinistra decisão, o Tribunal Regional do Trabalho destinatário de eventual recurso contra a sentença prolatada, recebe uma enxurrada de processos daquela comarca, no qual o mesmo juiz concede o FGTS aos contratados irregularmente, sem concurso público, havendo decisão superveniente do STF estabelecendo a incompetência da Justiça do Trabalho para apreciar tal questão ${ }^{434}$.

$\mathrm{O}$ órgão a quo, em obediência ao preceituado pelo STF, decide, em todos aqueles processos, que respondem por 50\% (cinquenta por cento) da demanda da Vara do Trabalho naquele ano, declinar da competência e determinar a remessa dos autos à Justiça Comum.

Segundo o critério proposto por Calamandrei, a estatística diria que há $50 \%$ (cinquenta por cento) de chances de o TRT dar-se por incompetente para julgar o recurso que não fora interposto. Ademais, mesmo que todas as demais sentenças do aludido juiz fossem reformadas, porque desprovidas de bom fundamento, não se poderia falar em indenização pela perda de uma chance, pois, de acordo com o combatido critério italiano (vide capítulo 2, item 2.7.1), a chance não poderia ser considerada séria, porque não ultrapassaria $50 \%$ (cinquenta por cento).

Por tais motivos, o trabalhador não poderia ser indenizado, diante de uma falha gritante na delimitação ${ }^{435}$ e no método ${ }^{436}$ da pesquisa.

\footnotetext{
433 “Art. 477. § $1^{\circ}$. O pedido de demissão ou recibo de quitação de rescisão do contrato de trabalho, firmado por empregado com mais de 1 (um) ano de serviço, só será válido quando feito com a assistência do respectivo Sindicato ou perante a autoridade do Ministério do Trabalho". (BRASIL. Consolidação das Leis do Trabalho (1943). CLT e Constituição Federal. 38. ed. São Paulo: Saraiva, 2011.)

434 Entre outras decisões, destaca-se: BRASIL. Supremo Tribunal Federal, Tribunal Pleno. Agravo Regimental em reclamação constitucional. Relator: Min. Cármen Lúcia. Diário da Justiça eletrônico $\mathrm{n}$. 222, 21 nov. 2008.

435 "A delimitação da pesquisa é o estabelecimento de limites para a investigação. Esta pode ser delimitada quanto ao assunto (seleciona-se um determinado tema ou parte de conteúdo já previamente limitado); à extensão (limita-se o âmbito de investigação) ou ao número de fatores (delimitação quanto aos meios humanos, econômicos, de tempo, etc.)" (GUSTIN, Miracy Barbosa de Sousa; DIAS, Maria Tereza Fonseca. (Re) Pensando a pesquisa jurídica. 2. ed. rev., amp. e atual. pela NBR 14724, de 30/12/05, da ABNT. Belo Horizonte: Del Rey, 2006, p. 93.)

${ }^{436}$ John E. Freund diz que grande parte das falhas metodológicas de pesquisa decorre de mera falta de bom senso, corroborando sua asserção com dois exemplos: "Exemplo 1.1. Para determinar a reação do público à continuação de certo programa governamental, o pesquisador pergunta: 'Você acha que esse programa esbanjador deve ser continuado?' Explique porque essa pergunta provavelmente não será respondida honestamente, ou objetivamente. Solução: O pesquisador está 'pedindo a resposta' ao sugerir, de fato, que o programa é esbanjador. Exemplo 1.2. Para estudar a reação do consumidor a um novo tipo de alimento congelado, faz-se uma pesquisa de casa em casa durante as manhãs dos dias úteis, sem previsão de retornar
} 
O apanhado de críticas, preocupações e malfadadas experiências não tem o escopo de desencorajar o operador do direito na aplicação de estatísticas, até porque, sua utilização será inexorável no dano de chance, onde o convívio com a álea será inevitável.

Jacques Boré sustenta que as leis aleatórias trazem para a causalidade um modo de determinação técnica indispensável, fundada sobre uma correlação estatística. Na vida cotidiana, a menor das nossas ações é motivada por uma previsão fundada sobre a experiência $^{437}$, uma correlação estatística pré-científica que nos permite agir de determinando modo, porque já houve muitas reprises desse mesmo ato e eles foram executados com sucesso ${ }^{438}$. As empresas também trabalham dessa forma. O mercado de seguros, v.g., é o modelo de um segmento da economia integralmente lastreado em bases estatísticas.

Portanto, a estatística é um método utilizado para que se possa afrontar a álea, mediante técnicas (como, v.g., as equações de probabilidade, as estimativas e as sondagens) que subvertem a estratégia de lidar com o desconhecido. A partir delas, não mais se tenta expungir o desconhecido, no tolo fetichismo da onisciência, mas sim admitir

no caso de ninguém atender. Explique porque essa abordagem pode conduzir a uma informação enganadora. Solução: Essa pesquisa não conseguirá atingir os que mais provavelmente irão usar o produto: pessoas solteiras ou casais em que ambos os cônjuges trabalham fora”. (FREUND, John E, op. cit., p. 16)

${ }^{437}$ Numa rápida digressão filosófica, relembre-se que David Hume chega ao ponto de questionar a própria existência da causalidade, sustentando que só conhecemos as relações de "causa e efeito" pela experiência, e que jamais poderíamos demonstrar uma causa para toda a nova existência ou para uma modificação da existência. Os princípios gerais que associam ideias são a semelhança, a contiguidade e a causalidade, ou seja, quando várias pessoas colocam as mãos sobre o fogo incandescente e, na sequência, têm a sensação quase imediata e calor, a inferência lógica, meramente induzida por semelhança e contiguidade, é que a sensação (calor) é conseqüência do ato (colocar as mãos sobre a fogueira). Sua intrigante especulação foi assim alinhavada: "E como o poder pelo qual um objeto produz outro jamais pode ser descoberto apenas por meio de suas idéias, é evidente que só podemos conhecer as relações de 'causa e efeito' pela experiência, e não por algum raciocínio ou reflexão abstratos. Não há um só fenômeno, por mais simples que seja, que possa ser explicado pelas qualiddes dos objetos, tais como estas aparecem a nós, ou que pudéssemos prever sem a ajuda da nossa memória e experiência. (...) Assim, embora a causalidade seja uma relação filosófica, por implicar contigüidade, sucessão e conjunção constante, é apenas enquanto ela é uma relação natural, produzindo uma união entre nossas idéias, que somos capazes de raciocinar ou fazer qualquer inferência a partir dela". (HUME, David. Tratado da natureza humana: uma tentativa de introduzir o método experimental de raciocínio nos assuntos morais. Trad. Deborah Danowski. São Paulo: UNESP, Imprensa Oficial do Estado, 2001, p. 98-122)

438 A preleção foi a seguinte: "Qu'apporte la loi aléatoire à la causalité? Elle lui apporte un mode de détermination technique indispensable fondé sur une correlation statistique. La teorie des probabilités est en effet indissociable de la statistique. La loi aléatoire nous dit par exemple que sur 100 malades traités avec un certain médicament, 90 ont été guéris, ou bien que 50 seulement l'ont été. Et cette indication a une 'valeur scientifique' si réelle que les entreprises modernes les plus considérables, dans le domaine scientifique, ont été fondées sur de telles données statistiques. La moindre de nos actions est motivée par une prévision fondée sur 'l'expérience', c'est-à-dire sur une correlation statistique pré-scientifique, qui nous permet de dire: 'j'accomplis tel acte, parce 'qu'a plusiers reprises il y a été accompli par moi ou par autrui 'avec le succès escompté'. 'L'aspect statistique de tout phénomène n'est jamais rigouresement absent' (Halbwacks, op. cit. p. 38). Nous avons vu (supra, $\left.n^{\circ} 16\right)$ que la théorie de lá causalité adéquate faisait une place appréciable à cet élément en se référant à 'l'expérience courante'. (BORÉ, Jacques, op. cit.) 
os limites de falibilidade e cognoscibilidade humana e buscar compreensões, a despeito disso. É a assimilação do acaso, pois a partir da ciência (indispensável) de que um ou mais elementos que determinam a resposta são incognoscíveis, busca-se uma resposta provável $^{439}$.

\subsubsection{A equidade na acepção aristotélica}

Preceituou-se nos tópicos anteriores que o método para o cálculo do dano na perda de uma chance é obtido tendo como parâmetro o valor do resultado final esperado, e, sobre ele, aplicado um coeficiente de redução correspondente ao percentual probabilístico de efetivação desse resultado. Trata-se de uma operação bastante trivial, a princípio, que pode ser consolidada a partir da seguinte fórmula: $\mathrm{PC}=\mathrm{RF} \times \mathrm{P}^{440}$.

Viu-se, igualmente, que a apuração pode se tornar um pouco mais complexa quando um dos elementos da fórmula não estiver presente de imediato, pelo que foi sugerida a utilização da "teoria da diferença", para o caso de não se poder determinar, com exatidão, o resultado final $(\mathrm{RF})$, e o recurso à estatística, como apoio à quantização das probabilidades $(\mathrm{P})$.

Todavia, tais recursos não esgotam o manancial de problemas; longe de ter essa pretensão, buscam apenas enriquecer o acervo do intérprete no momento crucial de expressar economicamente uma cifra que corresponda, tanto quanto possível, a mais completa tradução do prejuízo.

Não faltarão, é bem verdade, casos em que um ou mesmo nenhum dos fatores (RF ou P) da fórmula proposta estará presente. Também poderá haver circunstâncias em que a utilização dela, de modo puro, não será possível para dar a medida da justiça perscrutada.

\footnotetext{
${ }^{439}$ É o que explica Daniel Amaral Carnaúba: "É por esta razão que, ao lado da expansão do conhecimento, a razão humana criou para si instrumentos capazes de afrontar a álea, mesmo no seu campo de existência irredutível. O desenvolvimento dos estudos de probabilidade, notadamente a estatística, deu-nos os métodos para este fim: as equações de probabilidade, as estimativas, as sondagens. O lado inovador destas técnicas é que elas subvertem a estratégia de combate à incerteza. Não se trata mais de um esforço para aniquilar o desconhecido, mas o contrário; diante de um problema, o homem admite os limites de sua compreensão e busca obter conclusões a despeito deles. A estatística assimila o acaso. Ela nos permite obter uma resposta provável, visto que um ou mais elementos que determinam tal resposta são desconhecidos". (CARNAÚBA, Daniel Amaral, op. cit., p. 13)

${ }^{440}$ Na qual a abreviação "PC" significa o valor da Perda da Chance, "RF" o Resultado Final esperado e "P" a Probabilidade de concretização do resultado final.
} 
Imagine-se, v.g., uma demanda em que o indivíduo tenha perdido a chance de cura ou sobrevida, por força de um diagnóstico intempestivo de uma determinada moléstia. Ele falece, e os familiares pedem a reparação dos danos materiais e imateriais decorrentes das chances perdidas. Entretanto, não há meios de se avaliar o resultado final, pelo simples fato de ser impossível precificar o valor do bem: "vida".

Não bastasse isso, conjeture-se, ainda, que não haja estatísticas que possam predizer, com grau plausível de fidúcia, em que percentual a extemporaneidade do diagnóstico contribuiu ou pode ter contribuído com o óbito. Agrave o problema acrescentando uma dúvida razoável sobre a causa mortis, tendo em vista a possível existência de concausas, como, e.g., eventual predisposição genética à enfermidade, o que singularizaria de tal modo o episódio experimentado pelo de cujus a não caber em nenhuma estatística confiável.

Já se disse, noutra passagem, que é um caminho espinhoso a ser trilhado. Todavia, o juiz não poderá se esquivar de julgar, diante do princípio da indeclinabilidade da jurisdição (CPC, art. $126^{441}$ e LICC ${ }^{442}$, art. $4^{\circ}$ ), vigente nos ordenamentos modernos de modo bastante destacado, pelo menos desde que o Código Napoleônico proibiu o non liquet ${ }^{443}$, sob pena de o juiz ser processado por denegação de justiça ${ }^{444}$. Ainda que nada possa socorrer o juiz,

${ }^{441}$ BRASIL. Código de Processo Civil (1973). Código de Processo Civil e Constituição Federal. 17. ed. São Paulo: Saraiva, 2011.

${ }^{442}$ Sem olvidar que a LICC - Lei de Introdução ao Código Civil, agora é denominada LINDB - "Lei de Introdução às normas do Direito Brasileiro", conforme Lei 12.376, de 30 de dezembro de 2.010. (BRASIL. Lei $\mathbf{n}^{\mathbf{0}}$ 12.376, de 30 de setembro de 2010. Altera a ementa do Decreto-lei $\mathrm{n}^{\mathbf{0}} 4.657$, de 4 de setembro de 1942. Disponível em: < http://www.planalto.gov.br/ccivil/_Ato2007-2010/2010/Lei/L12376.htm>. Acesso em: 10 mar. 2011)

${ }^{443}$ Conta Bebber que a expressão se deve a Aulo Gélio (125-175 d.C.), um jovem chamado pelos pretores para exercer o cargo de juiz, para o qual passou a estudar avidamente. Não obstante, deparou-se certa feita com uma situação inusitada: uma demanda por dívida movida por um homem notoriamente probo, em desfavor de um réu sabidamente desleal. A sutileza do caso estava no fato de o réu negar a dívida, e o autor não poder prová-la por documentos ou testemunhas. Consumido pela dúvida, Aulo Gélio foi se consultar com seus pares, que o aconselharam a seguir as regras de ônus da prova e, em consequência, absolver o réu. Inconformado, ele procurou um filósofo, Favorino, que lhe disse para dar razão ao honesto em detrimento do pérfido. Porém, ao mesmo tempo em que Aulo Gélio não conseguia dar razão ao ímprobo, também não achava justo condená-lo sem provas. Assim, jurou que o assunto "não estava claro" (non liquet), e livrou-se de sentenciar. (BEBBER, Júlio César. Princípios do Processo do Trabalho. São Paulo: LTr, 1997, p. 244245)

${ }^{444}$ De acordo com o art. $4^{\circ}$ do Código Civil francês, que assim estabelece: "Le juge qui refusera de juger, sous prétexte du silence, de l'obscurité ou de l'insuffisance de la loi, pourra être poursuivi comme coupable de déni de justice”. (FRANÇA. Código Civil (1804). Código Civil. Disponível em: <http://www.legifrance.gouv.fr.>. Açesso em 10 mar. 2011) 
ele terá de julgar, pois, como adverte Carnelutti, o juiz decide não porque sabe, mas como se soubesse ${ }^{445}$.

Entretanto, como consectário da impossibilidade de recusar o julgamento, o ordenamento proveu o juiz com algumas ferramentas ${ }^{446}$ a fim de subsidiar seu penoso ofício. Pretende-se, pois, aludir à equidade, como instrumento de auxílio à entrega da tutela jurisdicional.

Embora praticamente todos os operadores de direito tenham uma noção do significado da palavra equidade, não há consenso a respeito. Segundo Maria Helena Diniz, “isto é assim porque o termo 'eqüidade não é unívoco, pois não se aplica a uma só realidade, nem tampouco equívoco, já que não designa duas ou mais realidade desconexas, mas sim análogo, pois se refere a realidades conexas ou relacionadas entre si ${ }^{447, "}$.

E a sua utilização, tanto nos limites quanto na extensão, também suscita controvérsia. Há quem simplesmente iguale equidade à "justiça do caso concreto", e, no outro extremo, há aqueles que entendem que o julgamento por equidade significa a possibilidade de o juiz julgar como melhor lhe aprouver, em descompromisso com a legalidade.

A legislação, por sua vez, fomenta a quizila. Um processualista civil, v.g., tenderia a restringir ao máximo a utilização da equidade, por equipará-la ao abandono da legalidade estrita, em face do que preconizam os artigos 126 e 127 do Código de Processo Civil ${ }^{448}$, verbis:

Art. 126. O juiz não se exime de sentenciar ou despachar alegando lacuna ou obscuridade da lei. No julgamento da lide caber-lhe-á aplicar as normas legais; não as havendo, recorrerá à analogia, aos costumes e aos princípios gerais de direito.

Art. 127. O juiz só decidirá por eqüidade nos casos previstos em lei.

\footnotetext{
${ }^{445}$ No original: “In giudice decide non perché sa ma como sapesse”. (CARNELUTTI, Francesco. Diritto e Processo. Nápoles: Morano, 1958, p. 256)

${ }^{446}$ Apesar de indiscutível que a equidade seja um recurso de integração, as referências mais explícitas da lei são à analogia, costumes e princípios gerais do direito (LICC ou LINDB, art. $4^{\circ}$ e CPC, art. 126). O artigo $8^{\mathrm{a}}$ da CLT açambarca um rol bem mais extenso de instrumentos de integração e interpretação.

${ }^{447}$ DINIZ, Maria Helena. As lacunas no direito. 4. ed. São Paulo: Saraiva, 1997, p. 241.

448 BRASIL. Código de Processo Civil (1973). Código de Processo Civil e Constituição Federal. 17. ed. São Paulo: Saraiva, 2011.
} 
Conforme se denota, a legislação processual civil relega a equidade à condição de exceção, exigindo previsão legal para a sua adoção e, além disso, inexistência de norma legal específica para reger a matéria. A razão parece assistir aos processualistas, numa primeira análise, mais tópica.

Sem embargo, indaga-se: De onde advém, então, a noção, também bastante impregnada na cultura jurídica, de que equidade é a "justiça no caso concreto"? Ademais, se assim o é, porque o juiz precisa de autorização legal para ser "justo no caso concreto"? É sofístico dizer que, nos casos em que não há autorização, o juiz não deve - ou não pode - ser justo (equitativo)?

Um trabalhista, por sua vez, possivelmente não veria percalços em vislumbrar na equidade a justiça modelar e corretiva, pois sua fonte prima seria o artigo $8^{\circ}$ da CLT, que assim dispõe:

\begin{abstract}
Art. $8^{\circ}$. As autoridades administrativas e a Justiça do Trabalho, na falta de disposições legais ou contratuais, decidirão, conforme o caso, pela jurisprudência, por analogia, por equidade e outros princípios e normas gerais de direito, principalmente do direito do trabalho e, ainda, de acordo com os usos e costumes, o direito comparado, mas sempre de maneira que nenhum interesse de classe ou particular prevaleça sobre o interesse público $^{449}$.
\end{abstract}

A CLT não faz restrição ao uso da equidade, não diz que ela só pode ser utilizada mediante autorização legal. Diante disso, tomando a equidade sob a acepção de decisão marginal à lei (fora da legalidade estrita), estariam os juízes trabalhistas, diferentemente dos demais, autorizados a decidir com discricionariedade, em qualquer caso? Seria essa uma peculiaridade do Direito do Trabalho? Ou a equidade prevista pela CLT tem um significado diferente daquele empregado pelo CPC?

Deveras, no multifacetado conceito que se pode emprestar à palavra, a depender intimamente das convicções jurídico-filosóficas ${ }^{450}$, a equidade pode ganhar contornos bem distintos. Pretende-se, pois, antes de sugerir seu uso como técnica de composição do dano

449 BRASIL. Consolidação das Leis do Trabalho (1943). CLT e Constituição Federal. 38. ed. São Paulo: Saraiva, 2011. Sem grifos no original.

${ }^{450}$ DINIZ, Maria Helena. Op. cit., p. 241. 
da perda de uma chance, traçar, sucintamente, uma distinção entre os dois sentidos mais correntes, a partir da compreensão de suas raízes históricas.

O termo equidade, no Direito Romano, era o aequitas ou aequum et bonum. Segundo Vicente Ráo, “os romanos, que com freqüência ligavam o conceito de eqüidade ao do direito natural, distinguiam, entretanto, a 'aequitas naturalis' da 'aequitas civilis', definindo a primeira como uma forma de justiça absoluta que o direito constituído procura alcançar, e a segunda como parte integrante deste direito, aplicada, em Roma, precipuamente, pelos pretores 'aequitas praetoris 451, ,"

Maria Inês Moura Santos Alves da Cunha também reconhece a exigência moral contida na aequitas, mas diz que “é no 'jus respondendi' dos jurisconsultos e no trabalho dos pretores através dos editos que podiam completar, desenvolver ou modificar a lei que mais se manifesta a aequitas, o mesmo se dizendo das 'formulae', onde se dava proeminência à equiidade, acima do ius civile ${ }^{452, "}$.

Portanto, era enorme a autoridade dos pretores na Roma antiga. "O magistrado tinha maiores poderes, podendo ultrapassar os limites do direito para afastar a aplicação da lei ou para estendê-la para casos não previstos ${ }^{453}$ ". Havia, pois, uma clara função de legiferação na magistratura romana e, sob essa ótima, fica evidente a colisão da equidade com o direito escrito da civil law, e a necessidade de escrupulosa restrição no uso.

Foi essa a noção de equidade que se inseriu no Código de Processo Civil de 1973, de inspiração marcadamente influenciada pela aequitas do Direito Romano. Num código positivista, porém, a regra geral tinha de ser a decisão pela lei (CPC, art. 126) ${ }^{454}$, e a exceção a decisão por equidade $\left(\mathrm{CPC}\right.$, art. 127) ${ }^{455}$, e, mesmo assim, uma decisão que não afrontava a lei, pois decidia fora da lei, porque a lei assim o permitia.

${ }^{451}$ RÁO, Vicente. $\mathrm{O}$ direito e a vida dos direitos. 4. ed. anot. e atual. por Ovídio Rocha Barros Sandoval. Noções Gerais. Direito Positivo. Direito Objetivo. São Paulo: RT, 1997, v. I, p. 84.

${ }^{452}$ CUNHA, Maria Inês Moura Santos Alves da. A equidade e os meios alternativos de solução de conflitos. São Paulo: LTr, 2001, p .28.

${ }^{453}$ Idem, p. 91, nota de rodapé 29.

${ }^{454}$ BRASIL. Código de Processo Civil (1973). Código de Processo Civil e Constituição Federal. 17. ed. São Paulo: Saraiva, 2011.

455 Idem 
A concepção romanista de equidade na qual se inspirou o $\mathrm{CPC}^{456}$ fica ainda mais clara quando se observa o seu antecessor, o artigo 114 do CPC de 1939, que assim determina:

Art. 114. Quando autorizado a decidir por equidade, o juiz aplicará a norma que estabeleceria se fosse legislador ${ }^{457}$.

Observe-se que o diploma processual determina ao juiz que se invista da função de legislador do caso concreto ( 'aequitas praetoris'). Ora, dentro dessa noção extremamente aberta e excepcional de atuação do Poder Judiciário, por óbvio, seu uso deve ser mais limitado, circunscrito à autorização legal. Serpa Lopes leciona que "o artigo 114 do Código de Processo Civil também autoriza o julgamento por eqüidade, limitado, porém, a uma prévia autorização, que outra não pode ser senão a da própria lei, ficando estabelecido, assim, um movimento equilibrado, tendente a coibir o arbítrio judicial ${ }^{458, "}$.

O cuidado da legislação processual em não alargar o poder do juiz nesse sentido fica nítido no contexto do código. Basta ver a hipótese clássica em que o CPC autoriza a decisão por equidade, contida no artigo 1.109 do $\mathrm{CPC}^{459}$, que assim prescreve:

Art. 1109. O juiz decidirá o pedido no prazo de 10 (dez) dias; não é, porém, obrigado a observar critério de legalidade estrita, podendo adotar em cada caso a solução que reputar mais conveniente ou oportuna.

O Código de Processo Civil deixou a equidade romana (aequitas) aos processos de jurisdição voluntária, "em que o juiz apenas realiza gestão pública em torno de interesses

\footnotetext{
456 A inspiração romanista aqui tratada é a nascente mais remota; a fonte mais próxima é o artigo $1^{\circ}$ do Código Civil Suíço, que determina a aplicação do direito costumeiro na falta de disposições legais, e, na falta de um costume, segundo as regras que o juiz estabeleceria se fizesse às vezes de legislador. Assim diz, exatamente, o texto: "Art. $1 .{ }^{2} A$ défaut d'une disposition légale applicable, le juge prononce selon le droit coutumier et, à défaut d'une coutume, selon les règles qu'il établirait s'il avait à faire acte de législateur". (SUÍÇA. Código Civil (1907). Código Civil. Disponível em: 〈http://www.ligiera.com.br/codigos/ cc suico_(em_frances).pdf>. Acesso em: 10 mar. 2011.)

457 BRASIL. Código de Processo Civil (1939). Código de Processo Civil. Disponível em: http://www.planalto.gov.br/ccivil/Decreto-Lei/1937-1946/Del1608.htm. Acesso em: 10 mar. 2011.

458 SERPA LOPES, Miguel Maria de, op. cit., p. 145.

${ }^{459}$ BRASIL. Código de Processo Civil (1973). Código de Processo Civil e Constituição Federal. 17. ed. São Paulo: Saraiva, 2011.
} 
privados [...] Aqui não há lide nem partes, mas apenas um negócio jurídico processual, envolvendo o juiz e os interessados. A função do juiz é, portanto, equivalente ou assemelhada à do tabelião, ou seja, a eficácia do negócio jurídico depende da intervenção pública do magistrado ${ }^{460}$,.

Portanto, o conceito de equidade como liberdade do juiz no julgamento, apesar de correto, prende-se às raízes oriundas do Direito Romano, insculpido no CPC, cuja utilização carece de autorização legal. Essa acepção não se aplica à perda de uma chance, por ausência de autorização legal. Porém, não é a única acepção possível.

Ao lado da aequitas romana, havia a epiqueia grega, ou, mais especificamente, aristotélica, com a ideia de justiça complementar à da lei escrita, a famosa "justiça do caso concreto", decorrente do fato de a norma ser extremamente rígida ou genérica, pois, "no Direito, as lacunas são inevitáveis; e daí ser falso o princípio da plenitude lógica do Direito $^{461,}$.

Aristóteles explica a equidade (epiqueia) com uma analogia à "Régua de Lesbos", instrumento flexível de que se serviam os trabalhadores da Ilha de Lesbos para medir determinados blocos de pedra, a qual, por ser feita de material flexível, podia ajustar-se às irregularidades dos objetos, tal como a lei se adapta aos fatos e às infindáveis ondulações da experiência humana. Pela relevância do texto, segue a transcrição das exatas palavras:

Consequentemente, embora o equitativo seja justo e seja superior a uma espécie de justiça, não é superior à justiça absoluta, mas apenas ao erro devido à expressão absoluta. Esta é a natureza essencial do equitativo, ou seja, é uma retificação da lei onde é lacunar em função de sua generalidade. Com efeito, essa é a razão porque não são todas as coisas determinadas pela lei; pelo fato de haver alguns casos (e situações) em relação aos quais é impossível estabelecer uma lei, é necessária a existência de um decreto especial; pois aquilo que ele próprio indefinido só pode ser medido por um padrão indefinido, como a régua plúmbea usada pelos construtores em Lesbos; tal como essa régua não é rígida,

460 THEODORO JÚNIOR, Humberto. Curso de Direito Processual Civil. 37. ed. Rio de Janeiro: Forense, 2001, v. I, p. 35.

${ }^{461}$ PONTES DE MIRANDA. Fontes e Evolução do Direito Civil Brasileiro. 2. ed. Rio de Janeiro: Forense, 1981, p. 369. 
podendo ser flexibilizada ao formato da pedra, um decreto especial é feito para se ajustar às circunstâncias do caso ${ }^{462}$.

A equidade, exprimida na alegoria da "Régua de Lesbos", é o antônimo da figura mitológica do "Leito de Procusto" (vide capítulo 2.7.3 do capítulo 2), pois, ao invés de recortar ou esticar os fatos até fazê-los caber na medida única da cama da lei - como traduzido à perfeição no brocardo summum ius, summa iniuria ${ }^{463}$-, o que ela procura é emprestar à frieza da lei "calor humano", dando aos fatos "uma roupa sob medida".

No exercício de tal função, a equidade "independe de autorização legal, pois deve ser utilizada para coadjuvar a inteligência do dispositivo interpretado, de acordo com os dados sociológicos que o envolverem e a finalidade que tiver" ${ }^{\text {"464 }}$. Trata-se, antes, de instrumento “di temperare la ridigità della norma escritta. In tali casi, l'equità non è fonte di diritto, è critério di applicazione" ${ }^{465}$.

Por ser mero recurso para aplicação do direito positivo, a equidade com ele não se choca, já que ambos os vetores apontam para uma única direção - a da justiça -, mas sob enfoques diversos: a lei busca a justiça geral e abstrata, atendendo à demanda coletiva, e a equidade procura adaptar a lei ao polimorfismo da realidade, em face das circunstâncias individuais ${ }^{466}$. Diante da necessidade de qualificar todos os fatos, é forçoso que o direito empregue certa dose de artificialismo, abstraindo elementos da realidade para simplificar a regra jurídica, conforme lição da Daniel Amaral Carnaúba:

É necessário ressaltar que a aplicação da regra jurídica exige a prévia abstração dos elementos da realidade, engendrando inevitavelmente sua simplificação. Partindo de seu léxico predeterimando, o Direito é forçado a qualificar juridicamente todos os fatos que lhe são trazidos à análise, o que não pode ser empreendido sem certa dose de artificialismo. Após o jantar, o atendente pergunta à senhora à mesa se ela aceitaria um café.

\footnotetext{
${ }^{462}$ ARISTÓTELES. Ética a Nicômaco. 3. ed. Trad. e notas Edson Bini. São Paulo: Edipro, 2009, p. 173.

${ }^{463}$ Conforme lição Kantiana: "A divisa (dictum) da eqüidade é: 'o direito mais estrito é a maior injustiça (summum ius summa iniuria)". (KANT, Immanuel. Introdução ao Estudo do Direito: doutrina do Direito. 2. ed. Trad., textos adicionais e notas: Edson Bini. Bauru: Edipro, 2007, p. 61)

${ }^{464}$ SERPA LOPES, Miguel Maria de, op. cit., p. 145.

${ }^{465}$ MESSINEO, Francesco. Manuale di Diritto Civile e Commerciale. $7^{\text {a }}$. ed. Milão: Giuffrè, 1947, v. 1, p. 68.

${ }^{466}$ SERPA LOPES, Miguel Maria de, op. cit., p. 144.
} 
Para o Direito, trata-se de uma oferta. Um ônibus para em frente ao ponto, abrindo suas portas. Trata-se de uma oferta. Passando por coincidência no local, o motorista do veículo interrompe sua viagem para socorrer a vítima - inconsciente - de um acidente ocorrido há poucos instantes. Novamente, trata-se de uma oferta. Entre a pobreza dos conceitos jurídicos e a exuberância da realidade, a desproporção é tal que, na passagem desta a aquela, algo será necessariamente perdido ou mal traduzido $^{467}$.

Portanto, na criação da norma jurídica, o processo é de abstração, de simplificação em uma fórmula genérica, que tente compreender todos os casos a que se destina. É uma espécie de "liofilização" dos fatos em uma regra. $\mathrm{Na}$ aplicação ao caso concreto, o processo é o inverso: por meio da equidade, busca-se expandir aquela regra de modo que a interpretação seja feita contemplando todas as particularidades, adaptando-se às infinitas variações da realidade, outrora reduzidas ante a necessidade de um comando mais abrangente.

Vicente Ráo aponta quatro funções para a equidade: a) adaptação da lei a todos os casos que devam incidir em sua disposição; b) a aplicação da lei a todos esses casos, levando-se em conta todos os elementos de fato, pessoais e reais, que particularizam o caso concreto; c) o suprimento de erros, lacunas ou omissões da lei; d) a realização de tais funções com benignidade e humanidade ${ }^{468}$.

Destarte, ainda que na acepção aristotélica de equidade haja determinado espaço para a criatividade do juiz, ela é intrínseca à própria atividade de interpretação judiciária ${ }^{469}$, e, longe de se dar ao bel prazer do julgador, "deve procurar o sistema que presidiu à lei, à própria ideia de lei e mais particularmente ao instituto aplicável ao caso particular, em

\footnotetext{
${ }^{467}$ CARNAÚBA, Daniel Amaral, op. cit., p. 55.

${ }^{468}$ RÁO, Vicente, op. cit., p. 87-88.

${ }^{469}$ Como defende Mauro Cappelletti: “Encontra-se implícito, em outras palavras, o reconhecimento de que na interpretação judiciária do direito legislativo está ínsito certo grau de criatividade. O ponto, de resto, tornou-se explícito pelo próprio Barwick quando escreve que ainda 'a melhor arte de redação das leis, $e$ mesmo o uso da mais simples e precisa linguagem legislativa, sempre deixam, de qualquer modo, lacunas que devam ser preenchidas pelo juiz e sempre permitem ambigüidades e incertezas que, em última análise, devem ser resolvidas pela via judiciária”. (CAPPELLETTI, Mauro. Juízes Legisladores? Trad. Carlos Alberto Alvaro de Oliveira. Porto Alegre: Sergio Antonio Fabris Editor, 1999, p. 20-21)
} 
conformidade com os dados morais, fora das aspirações interiores, nascidas puramente do sentimentalismo do intérprete" ${ }^{470}$.

A epiqueia aristotélica, dessa forma, é critério de justiça ${ }^{471}$ na interpretação de toda e qualquer norma, e de integração das normas genéricas e lacunares, cuja adoção se impõe independentemente de autorização legislativa.

É essa, em caráter apriorístico, a equidade de que trata o artigo $8^{\circ}$ da $\operatorname{CLT}^{472}$, embora não seja incorreto sustentar, mediante interpretação sistemática, que a Justiça do Trabalho também lança mão da equidade aequitas, criando normas jurídicas, como deveras acontece no chamado "poder normativo da Justiça do Trabalho", em que há verdadeira geração do direito pelos Tribunais ${ }^{473}$, com o estabelecimento de novas condições regentes dos contratos individuais de trabalho ${ }^{474}\left(\mathrm{CF}\right.$, art. $114, \S 2^{\mathrm{o} 475} \mathrm{c} / \mathrm{c}$ CLT, art. $\left.868^{476}\right)$.

De outro bordo, a legislação civil (material e processual) também contempla a utilização das duas formas de equidade, embora não haja referência expressa na LICC ou LINDB, mas pode ser explicado até mesmo topologicamente, na técnica de organização legislativa.

${ }^{470}$ SERPA LOPES, Miguel Maria de, op. cit., p. 145.

${ }^{471}$ Sob esse prisma, o artigo $6^{\circ}$ da Convenção Europeia de Direitos Humanos garante o direito de todo cidadão a um processo equitativo (em evidente sinônimo de justo): "Artigo 6. ${ }^{\circ}$ (Direito a um processo equitativo) 1. Qualquer pessoa tem direito a que a sua causa seja examinada, equitativa e publicamente, num prazo razoável por um tribunal independente e imparcial, estabelecido pela lei, o qual decidirá, quer sobre a determinação dos seus direitos e obrigações de carácter civil, quer sobre o fundamento de qualquer acusação em matéria penal dirigida contra ela. $\mathrm{O}$ julgamento deve ser público, mas o acesso à sala de audiências pode ser proibido à imprensa ou ao público durante a totalidade ou parte do processo, quando a bem da moralidade, da ordem pública ou da segurança nacional numa sociedade democrática, quando os interesses de menores ou a protecção da vida privada das partes no processo o exigirem, ou, na medida julgada estritamente necessária pelo tribunal, quando, em circunstâncias especiais, a publicidade pudesse ser prejudicial para os interesses da justiça". (CONVENÇÃO EUROPÉIA DE DIREITOS DO HOMEM. Disponível em: <http://www.gddc.pt/direitos-humanos/textos-internacionais-dh/tidhregionais/conv-tratados04-11-950-ets-5.html >. Acesso em: 08 abr. 2011.)

${ }_{472}$ BRASIL. Consolidação das Leis do Trabalho (1943). CLT e Constituição Federal. 38. ed. São Paulo: Saraiva, 2011.

${ }^{473}$ Conforme lição de Cesarino Júnior: "A competência normativa dos tribunais do trabalho é a faculdade a êles dada pela lei para editar normas gerais, reguladoras das relações de trabalho entre as duas classes, categorias ou grupos em conflito". (CESARINO JÚNIOR. Direito Social Brasileiro. 6. ed. amp. e atual. com a colaboração de Marly A. Cardone. São Paulo: Saraiva, 1970, v. I, p. 213).

${ }^{474}$ Maurício Godinho Delgado também destaca esta função na equidade tratada pela CLT: "Ressalte-se, finalmente, que no Direito do Trabalho brasileiro, à equidade é conferido, ainda, um papel de fonte 'material' do Direito judicialmente produzido (por meio das sentenças normativas). De fato, dispõe a CLT que, nos dissídios de natureza econômica, as sentenças normativas prolatadas (fontes de normas jurídicas, como se sabe) deverão tomar em avaliação a noção de 'salário justo' (art. 766, CLT)". (DELGADO, Mauricio Godinho. Princípios de Direito Individual e Coletivo do Trabalho. 3. ed. São Paulo: LTr, 2010, p. 135.)

475 BRASIL. Constituição (1988). Constituição da República Federativa do Brasil. 16. ed. São Paulo: RT, 2011.

${ }^{476}$ BRASIL. Consolidação das Leis do Trabalho (1943). CLT e Constituição Federal. 38. ed. São Paulo: Saraiva, 2011. 
Conforme já explanado, o art. 126 do $\mathrm{CPC}^{477}$ veda o non liquet, ao mesmo tempo em que determina ao juiz que recorra, na falta de normas legais, à analogia, aos costumes e aos princípios gerais do direito; já no artigo seguinte (127), restringe o uso da equidade aequitas no julgamento à hipótese de consentimento legal.

Observe-se, agora, o que ocorre na LICC ou LINDB: o artigo $4^{\text {o478 }}$ tem redação semelhante à do artigo 126 do $\mathrm{CPC}$, e o artigo subsequente $\left(5^{\circ}\right)$, apesar de não conter referência expressa à equidade epiqueia, revela seu viés interpretativo, ao determinar que "Na aplicação da lei, o juiz atenderá aos fins sociais a que ela se dirige e às exigências do bem comum".

Arnaldo Rizzardo, ao comentar tais dispositivos, esclarece que "há princípios gerais, inseridos nos arts. $4^{\circ}$ e $5^{\circ}$ da Lei de Introdução ao Código Civil, que, embora não refiram expressamente à eqüidade, trazem apoio à determinação do juiz, indicando várias formas e alguns tipos de ações quando omissa a lei ${ }^{479}$,.

Maria Helena Diniz também constata que "a eqüidade está, ainda, ínsita nos arts. $4^{\circ} \mathrm{e}$ $5^{\mathrm{o}}$ da Lei de Introdução ao Código Civil, que estabelecem a obrigação de julgar, por parte do juiz, em caso de omissão ou defeito legal, dentro de certos limites, e a permissão de adequar a lei às novas exigências, oriundas das mutações sociais das instituições ${ }^{480 ", ~}$

Mesmo nos ordenamentos da common law, embora também sem referência expressa à equidade (do mesmo modo como nos arts. $4^{\circ}$ e $5^{\circ}$ da LICC/LINDB), até porque lá a equity tem outras acepções ${ }^{481}$, as justificativas políticas da aceitação da teoria da perda de

${ }^{477}$ BRASIL. Código de Processo Civil (1973). Código de Processo Civil e Constituição Federal. 17. ed. São Paulo: Saraiva, 2011.

478 “Art. $4^{\circ}$. Quando a lei for omissa, o juiz decidirá o caso de acordo com a analogia, os costumes e os princípios gerais de direito”. (BRASIL. Decreto-lei no 4.657, de 4 de setembro de 1942. Lei de Introdução às normas do Direito Brasileiro. Disponível em: 〈http://www.planalto.gov.br/ccivil/Decreto-Lei/Del4657.htm>. Acesso em: 8 abr. 2011)

${ }^{479}$ RIZZARDO, Arnaldo, op. cit., p. 69.

${ }^{480}$ DINIZ, Maria Helena. As lacunas no direito. 4. ed. São Paulo: Saraiva, 1997, p. 250.

${ }^{481}$ Segundo Prof. Pasley, da Cornell University, citado por Carlos Aurélio Mota de Souza, são cinco as acepções da 'equity' norte-americana: “ $1^{o}$ ) A 'equity' é um poder. Nas ações 'in personam' (obrigações de fazer ou não fazer alguma coisa, pena de multa ou prisão), exerce os maiores poderes que qualquer sistema jurídico pode apresentar; $2^{\circ}$ ) A 'equity' não tem caráter imperativo. Uma reparação em 'equity' não constitui um direito pessoal, apenas o tribunal dá forma adequada à reparação. $3^{\circ}$ ) A 'equity' é flexível. Não se obriga a seguir precedentes, pois é adaptável, inventiva e plena de recursos. Satisfaz os interesses de acordo com o momento em que se apresentam (caso concreto). 4 ${ }^{o}$ ) A 'equity' é justa. Funda-se essencialmente em considerações de justiça natural e moralidade: recusa reparação à parte injusta; recusa ao mau gestor os frutos de sua gestão; faz o desonesto restituir proveitos e prestar contas; sobretudo, encontra modo de ressarcir o necessitado, ainda que não the caiba expressamente uma indenização; $5^{\circ}$ ) $A$ 'equity' é criadora e evolutiva. Seja em direito privado como público, não se submete a nenhum sistema, porque é uma evolução; quando se petrifica, deixa de ser 'equity'”. (SOUZA, Carlos Aurélio Mota de. 
uma chance nos casos de erros médicos vêm ao encontro da epiqueia aristotélica, como maneira de corrigir a injustiça de um standard de convencimento muito rígido, pois a tradicional regra do "all or nothing” determina que, caso o paciente tenha mais de $50 \%$ (cinquenta por cento) de chances de cura, deve receber indenização total, ainda que a chance seja de apenas $51 \%$ (cinquenta e um por cento); e, caso tenha menos de 50\% (cinquenta por cento) de chances, não receberá indenização, ainda que possua 49\% (quarenta e nove por cento) de chances de obter um resultado mais favorável ${ }^{482}$.

Há também argumentos axiológicos e sociais na aceitação da teoria da perda de uma chance pelos americanos: i) a preciosidade da vida, pelo que a usurpação de qualquer chance mereceria uma justa compensação; ii) a questão do zelo nas políticas públicas de saúde, pois, sabendo que sairão impunes diante de erros cometidos em pacientes com prognósticos estreitos, os profissionais de saúde podem sentir-se menos inclinados a agir com a máxima eficiência e cautela ${ }^{483}$.

É, pois, dentro desse encadeamento de ideias que se propõe a utilização da equidade, na acepção aristotélica de epiqueia, nunca como espécie de legiferação anômala por parte do magistrado (que exige expressa autorização legal); mas, conforme critérios estabelecidos por Limongi França ${ }^{484}$, que o juiz, diante da inexistência de um texto inflexível; encontrando omissão ou acentuado rigor ou generalidade na lei; após apelar para as formas complementares de expressão do direito e, sem sentimentalismos ou arbitrariedades, elabore uma construção científica, em harmonia com o espírito que rege o

Evolução do Conceito de Eqüidade e sua Influência na Jurisprudência. 1989. Tese (Doutorado em História do Direito) - Faculdade de Direito da Universidade de São Paulo, São Paulo, 1989, p. 50)

${ }^{482}$ Como explica Tory A. Weigand: "The effect of the doctrine is that it alters the traditional "more likely than not" burden of proof. Under loss of chance, claimants are permitted to recover damages even though they have only a 50 percent or less chance of survival or a better outcome prior to the negligence. Absent the special treatment or recognition of "loss" that the loss of chance doctrine affords, plaintiffs otherwise would not be able to meet the traditional burden of proof as to causation (greater than 50 percent) as it is "more likely than not" that the underlying condition or disease caused the harm". (WEIGAND, Tory A. Loss of chance in medical malpractice: a look at recent developments: the growing acceptance of this doctrine raises difficult public policy issues, as well as concerns for the limits of medical professional liability. Disponível em: <http://goliath.ecnext.com/coms2/gi_0199-3026884/Loss-of-chance-in-medical.html>. Acesso em: 16 mar. 2011)

483 "POLICY JUSTIFICATION. The primary justification for recognizing loss of chance, as stated by King, is the notion that life is precious and even the loss of a small chance of cure or better result is deserving of compensation. A similar justification is the argument that acts of negligence as to patients with poor prognoses should not go unredressed and that it is fundamentally unfair to deny or permit recovery based on whether the patient had a 50 percent or greater chance of a better outcome. Proponents also assert that it is unfair to deny recovery where any uncertainty as to outcome was caused by the defendant, another argument made by King. Another common justification is that without loss of chance, healthcare providers may be less inclined to treat ill patients or to perform a full spectrum of testing in less than optimum cases".(Idem.)

${ }^{484}$ LIMONGI FRANÇA, Rubens. Formas e Aplicação do Direito Positivo. São Paulo: RT, 1969, p. 77-78. 
sistema, e que venha a colmatar a lacuna ou complementar a generalidade da lei, fazendo o seu ajuste fino às particularidades do caso.

Humberto Ávila sustenta que o sentido aristotélico de equidade é expressão do "princípio da razoabilidade", que atua na interpretação das regras gerais como decorrência do "princípio da justiça", contido no preâmbulo e no artigo $3^{\circ}$ da $\mathrm{CF}^{485}$.

O Código Civil brasileiro de 2002, que traçou a opção de legislar por meio de cláusulas abertas, fez várias referências à equidade, quando do cálculo do valor de penas, indenizações, prejuízos e método de se evitar a resolução contratual (arts. $413^{486}, 479^{487}$, 738, parágrafo único ${ }^{488}$, art. 928, parágrafo único ${ }^{489}$, 944, parágrafo único ${ }^{490}$ e 953 , parágrafo único ${ }^{491}$ ). Tais alusões, apesar de não implicarem menoscabo à legalidade estrita, são figuras mais próximas da aequitas/equidade romana - embora não tão veementes quanto o exemplo do artigo 1.109 do $\mathrm{CPC}^{492}$-, mas que devem, como em qualquer aplicação de norma jurídica, ser obtemperadas pela epiqueia/equidade grega.

485 O autor comenta que: "Essa concepção de razoabilidade corresponde aos ensinamentos de Aristóteles, para quem a natureza da eqüidade consiste em ser um corretivo da lei quando e onde ela é omissa, por ser geral. Essas considerações levam à conclusão de que a razoabilidade serve de instrumento metodológico para demonstrar que a incidência da norma é condição necessária mas não suficiente para sua aplicação. Para ser aplicável, o caso concreto deve adequar-se à generaralização da norma geral. A razoabilidade atua na interpretação das regras gerais como decorrência do princípio da justiça ('Preâmbulo' a art. $3^{\circ}$. da CF)". (ÁVILA, Humberto. Teoria dos Princípios: da definição à aplicação dos princípios jurídicos. 8. ed., ampl. e atual. São Paulo: Malheiros, 2008, p. 155)

486 “Art. 413. A penalidade deve ser reduzida eqüitativamente pelo juiz se a obrigação principal tiver sido cumprida em parte, ou se o montante da penalidade for manifestamente excessivo, tendo-se em vista a natureza e a finalidade do negócio”. (BRASIL. Código Civil (2002). Código Civil e Constituição Federal. 62. ed. São Paulo: Saraiva, 2011. Sem grifo no original)

487 "Art. 479. A resolução poderá ser evitada, oferecendo-se o réu a modificar eqüitativamente as condições do contrato". (Idem. Sem grifo no original)

488 “Art. 738. A pessoa transportada deve sujeitar-se às normas estabelecidas pelo transportador, constantes no bilhete ou afixadas à vista dos usuários, abstendo-se de quaisquer atos que causem incômodo ou prejuízo aos passageiros, danifiquem o veículo, ou dificultem ou impeçam a execução normal do serviço. Parágrafo único. Se o prejuízo sofrido pela pessoa transportada for atribuível à transgressão de normas e instruções regulamentares, o juiz reduzirá eqüitativamente a indenização, na medida em que a vítima houver concorrido para a ocorrência do dano". (Ibidem. Sem grifo no original)

489 "Art. 928. O incapaz responde pelos prejuízos que causar, se as pessoas por ele responsáveis não tiverem obrigação de fazê-lo ou não dispuserem de meios suficientes. Parágrafo único. A indenização prevista neste artigo, que deverá ser eqüitativa, não terá lugar se privar do necessário o incapaz ou as pessoas que dele dependem". (Ibidem. Sem grifo no original)

490 "Art. 944. A indenização mede-se pela extensão do dano. Parágrafo único. Se houver excessiva desproporção entre a gravidade da culpa e o dano, poderá o juiz reduzir, eqüitativamente, a indenização". (Ibidem. Sem grifo no original)

491 “Art. 953. A indenização por injúria, difamação ou calúnia consistirá na reparação do dano que delas resulte ao ofendido. Parágrafo único. Se o ofendido não puder provar prejuízo material, caberá ao juiz fixar, eqüitativamente, o valor da indenização, na conformidade das circunstâncias do caso". (Ibidem. Sem grifo no original)

492 BRASIL. Código de Processo Civil (1973). Código de Processo Civil e Constituição Federal. 17. ed. São Paulo: Saraiva, 2011. 
Retomando os critérios mencionados ao longo desse trabalho, a equidade servirá sempre como critério de aplicação do direito positivo, e, mais especificamente, na apuração do dano da perda de uma chance, poderá desempenhar importante papel quando da dificuldade de traduzir economicamente o valor de bens imateriais (v.g., o das indenizações por danos morais), para efeitos de aplicação da "teoria da diferença", ou, ainda, no sentido de particularizar o encontro do percentual probabilístico que culminará no coeficiente de redução, quando o recurso à estatística, impessoal e distante das circunstâncias concretas, mostrar-se incipiente na realização do mister ${ }^{493}$.

A doutrina italiana, v.g., com base na cláusula genérica de liquidação equitativa do dano, insculpida no artigo 1.226 do Código Civil italiano ${ }^{494}$, sustenta que a equidade pode ser utilizada subsidiariamente pelo juiz, quando não for possível determinar com exatidão o grau de probabilidade para o cálculo do coeficiente de redução ${ }^{495} 496$.

\footnotetext{
${ }^{493}$ Para uma análise de parâmetros de equidade em um caso concreto, vide capítulo item 5.7.1 do capítulo 5.

494 "Art. 1226 Valutazione equitativa del danno. Se il danno non può essere provato nel suo preciso ammontare, è liquidato dal giudice com valutazione equitativa (2056 e seguenti)”. (ITÁLIA. Código Civil (1942). Código Civil. Disponível em: 〈http://www.ligiera.com.br/codigos/cc italiano_(em italiano).pdf.〉 Acesso em: 15 mar. 2011)

495 "Da tutte queste situazioni può derivare un danno ingiusto tutelabile direttamente dall'ordinamento perché espressione di un interesse protetto dallo stesso ordinamento e per quanto riguarda la sua liquidazione si assume come parametro di riferimento l'utile economico realizzabile diminuito di un coefficiente di riduzione che dipenda dal grado di probabilità di conseguirlo e qualora non sia possibile determinare il danno nel suo preciso ammontare, a norma degli articoli 1226 e 2056 c.c. potrà essere liquidato dal giudice ( anche d'ufficio) equitativamente, ricorrendo a presunzioni ad elementi indiziari e calcolo di probabilità”. (ROSA, Antonio de, op. cit., p. 143)

496 "Recentemente la giurisprudenza ha affermato che nel valutare la chance risarcibile è possibile ricorrere a criteri con cui calcolare il vantaggio economico complessivamente realizzabile dal danneggiato diminuito di un coefficiente di riduzione proporzionato al grado di possibilità di conseguirlo (deducibile, quest'ultimo, caso per caso, dagli elementi costitutivi della situazione giuridica dedotta), ovvero ricorrendo a criteri equitativi ex art. 1226 cod. civ.” (D’APOLLO, Luca, op. cit)
} 


\section{CAPÍTULO 4 - CLASSIFICAÇÕES DA PERDA DE UMA CHANCE}

\subsection{As diversas propostas doutrinárias}

Os primeiros esboços de catalogação das classes e subclasses da perda de uma chance surgiram em domínios alienígenas, que tiveram contato mais precoce com a teoria e, por isso, maior tempo de maturação intelectual para traçar um esquema taxônomico. Não obstante, as classificações apresentadas em outros países não atenderam aos padrões de validade, pois se limitaram a fazer um arrolamento casuístico das hipóteses mais frequentes, ou propuseram um critério ilídimo para separar continentes e conteúdos.

Na França, Yves Chartier relacionou assim as hipóteses de perda de uma chance: a) perda de uma chance relacionada a um direito; b) perda uma chance de cura ou sobrevivência; c) perda de uma chance de ascensão acadêmica ou profissional; d) perda de uma chance de ser socorrido. Afirmou, ainda, que os itens "a" a "d" não esgotavam os casos, extremamente variados, da jurisprudência ${ }^{497}$.

A opção do autor foi por um critério puramente fenomênico, baseado nas hipóteses mais recorrentes nos tribunais daquele país, sem as necessárias correlações de identidade que permitam conferir-lhe um viés cientificista.

Em idêntico diapasão, na Argentina, Félix Alberto Trigo Represas ordenou os casos de oportunidades frustradas a partir dos assuntos que entendia mais relevantes: 1) matrimonial; 2) de êxito ou progresso futuro e de obtenção de maiores benefícios econômicos; 3) pela morte dos filhos menores; 3) de cura, melhora ou sobrevivência, por força de erro médico; 4) de êxito em litígios judiciais frustrados ${ }^{498}$.

Domenico Chindemi, na Itália, sugeriu um método mais elaborado, assim dividindo as hipóteses: i) perda de uma chance como dano patrimonial de natureza contratual; ii) perda de uma chance como dano patrimonial de natureza extracontratual; iii) perda de uma

\footnotetext{
497 Para se fazer justiça ao autor, a leitura de seu texto deixa menos a impressão de que ele tentou confeccionar uma classificação da teoria, e mais a de uma listagem das hipóteses mais frequentes na jurisprudência, e, ainda, com a ressalva de que não se tratava de um rol exaustivo: "Les hypothèses le plus fréquentes - perte d'une chance attachée à un droit (a), perte d'une chance de guérison ou de survie (b), perte d'une chance de réussite scolaire ou professionnelle $(c)$, perte d'une chance d'être secouru $(d)-$ n'épuisent pas l'extrême variété de la jurisprudence (e)". (CHARTIER, Yves, op. cit., p. 32)

${ }^{498}$ REPRESAS, Félix Alberto Trigo, op. cit., p. 81-240.
} 
chance como dano não patrimonial; iv) perda de uma chance em consequência de atividade ilegítima da Administração Pública ${ }^{499}$.

Apesar de a proposição partir de uma linha muito mais correta, que é a de dividir as hipóteses pela origem (contratual e extracontratual) e não pela casuística, os desdobramentos não se justificam. Não há razão de ordem lógica para retirar os danos não patrimoniais de uma gênese contratual ou delitual. No mesmo sentido, não há porque incluir as hipóteses de perda de chance de cura ou sobrevivência na responsabilidade médica apenas no capítulo dos danos extrapatrimoniais, e, ainda por cima, pertencentes a um terceiro gênero, como se existisse uma espécie de responsabilidade que não está nem dentro nem fora do contrato.

Já no Brasil, duas foram as linhas que buscaram sistematizar as espécies de perda de uma chance: a de Rafael Pettefi da Silva e a de Fernando Noronha. Ambas possuem inegáveis méritos por terem conseguido agrupar, de modo conciso e epistemologicamente plausível, as categorias em que se enquadram as possibilidades de ocorrência do fenômeno, facilitando sobremaneira o estudo do tema.

Rafael Pettefi da Silva reduz a duas ${ }^{500}$ as divisões da perda de uma chance: a primeira, como espécie de "dano autônomo", e a segunda, baseada na causalidade parcial, ou seja, no grau de probabilidade que a conduta do réu possui em relação ao dano final ${ }^{501}$.

O traço contrastivo entre as duas figuras, segundo o autor, está no fato de que, na primeira, denominada de "perda de uma chance clássica", o processo aleatório em que se encontra a vítima é interrompido pelo réu, usurpando as chances de ela obter um benefício ou evitar um prejuízo, e fazendo com que a perda de uma chance se isole como propriedade anterior do lesado, incluída em seu patrimônio e totalmente independente do dano final ${ }^{502}$, o que caracterizaria a sua propalada "autonomia".

Já na segunda, a cadeia causal deixa de ser interrompida, acarretando uma diminuição das chances de obter o ganho. Em tais casos, o processo aleatório em que está a

\footnotetext{
499 CHINDEMI, Domenico, op. cit., p. 49-200.

${ }^{500}$ Embora o autor, na sequência, proceda ao enquadramento da teoria das oportunidades perdidas a partir de outra categoria dogmática, qual seja a referência cronológica, dividindo os danos em "presentes" e "futuros". (SILVA, Rafael Pettefi da, op. cit., p. 110-113)

${ }^{501} \mathrm{O}$ arremate de suas ideias deixa clara essa divisão: "Diante do exposto, continua-se a esposar a posição aqui apresentada sobre a sistematização da teoria da perda de uma chance no sentido de existirem duas modalidades: a primeira utilizando um tipo de dano autônomo, representado pelas chances perdidas, e a segunda embasada na causalidade parcial que a conduta do réu apresenta em relação ao dano final'. (Idem, p. 110)

${ }^{502}$ Idem, p. 86.
} 
vítima percorre o iter até os seus ulteriores termos, com a consumação do dano (resultado final), e a noção de "oportunidades perdidas" é utilizada para delimitar em que medida o comportamento ilícito do réu contribuiu para a sua causação. Trata-se de hipótese de utilização do recurso à causalidade parcial, quando não se pode determinar se foi outra causa ou uma conjunção de várias que determinou o resultado final.

Nesta segunda categoria, não se poderia falar em "dano autônomo", porque há a necessidade de que o resultado final seja consumado, quer dizer, de que o paciente, cujo diagnóstico foi negligentemente omitido, venha a falecer ou ficar inválido (de acordo com o interesse aleatório em jogo), ou de que a vítima seja irremediavelmente sucumbente na ação judicial em que houve ausência de contestação pelo seu advogado.

O argumento é extremamente sedutor, pois, de fato, na segunda hipótese alinhavada pelo autor, é forçoso aguardar a concretização do dano equivalente ao resultado final, e esse acontecimento, além de futuro, é incerto. Assim, conforme já explanado alhures (vide item 2.8.3 do capítulo 2), o fato de um médico não fazer a diagnose de uma determinada moléstia, ou de o advogado não contestar a ação, per si, não gera a perda do interesse aleatório buscado (cura ou sobrevivência, no primeiro caso, e êxito na ação, no segundo), mas apenas a criação (ou aumento) do risco de que isso venha a sobrevir.

Ressalvadas as hipóteses de danos gerados pela própria criação do risco, que podem existir, mas pertencem à categoria diversa, só se pode falar em dano de perda de uma chance mediante a verificação da fatídica ocorrência (morte, perda da ação etc.), para, num segundo momento, avaliar o percentual em que a ofensa contribuiu com o prejuízo.

O mesmo não ocorre, em regra, nas hipóteses que o autor denomina de perda de uma chance "clássica". Porém, isso não se deve à propalada "independência" do dano, mas, simplesmente, porque nela, todas as oportunidades da vítima são destruídas desde logo, de forma que, sob esse prisma, a diferença está na desnecessidade de se aguardar por algo que se consolida de imediato, ou seja, na perda de uma chance "clássica", tanto o dano de chance quanto o dano correspondente ao resultado final acontecem simultaneamente, quando da ocorrência do ato ilícito que interrompe o curso dos eventos aleatórios $^{503}$. A perda do resultado final, nesse caso, é um evento presente e certo ${ }^{504}$.

\footnotetext{
${ }^{503} \mathrm{O}$ autor faz exatamente a mesma ilação, mas, paradoxalmente, chega à conclusão diversa: "É verdade que, mesmo quando se trata da aplicação clássica da perda de uma chance, existe a necessidade de ocorrência do dano final. Entretanto, nesses casos, todas as chances são destruídas pelo ato do efensor, restando inexorável o dano final. Destarte, difícil imaginar como um advogado que não apresenta o recurso dentro do prazo pode
} 
Todavia, tal fato não tem o condão de tornar o prejuízo "autônomo", no sentido de se realizar sem a intervenção de forças ou agentes externos ${ }^{505}$, pois, conforme explanação do próprio autor, também existe a necessidade de ocorrência do dano final (vide nota 502). Ora, no caso do "Show do Milhão", houve a perda do prêmio almejado; no páreo em que o jóquei não participou, aconteceu a perda da corrida; no exame a que o trabalhador foi obstado de participar, sucedeu a perda do emprego; no concurso de beleza em que a miss foi impedida de prosseguir nas eliminatórias, ela não foi eleita a mais bela das candidatas. E essa constante (concretização do dano final) era absolutamente necessária ao dano de chance.

A diferença, sob o enfoque pretendido pelo autor, está na aniquilação de ambos os prejuízos (a perda de uma chance e o resultado final) num mesmo momento, o que confere à perda de oportunidade "clássica", em relação ao dano final, contemporaneidade e certeza (em princípio), mas não autonomia.

Fez-se uso, nos parágrafos anteriores, das expressões "em regra" e "em princípio" para sublinhar que, mesmo nos casos de perda de uma chance "clássica", pode ocorrer de o resultado final não vir a se concretizar. Retome-se o exemplo do candidato: ele é aprovado na primeira e impedido de participar da segunda fase do concurso. Neste momento, somem, a um só tempo, a chance e o resultado final. Entretanto, na terceira fase, o certame é anulado por conta de uma irregularidade qualquer, as despesas com as inscrições são restituídas aos participantes e é designado outro concurso, do qual o candidato pode participar, normalmente, de todas as fases.

Nessa circunstância, a anulação posterior e a designação de um novo concurso eliminam o resultado danoso. Mais do que isso, ao expungirem o dano final, acabam, automaticamente, com o dano pela perda de uma chance, por uma razão muito simples: o

vir a ganhá-lo, da mesma forma que o proprietário do cavalo que não dispostou uma competição devido ao atraso do transportador não poderá vir a ganhar o prêmio correspondente. Assim, existe a independência dos prejuízos representados pela perda da vantagem esperada (dano final) e a perda das chances". (Idem, $\mathrm{p}$. 88. Sem grifos no original).

${ }^{504}$ Destaque-se que os elementos cronológicos (presente e futuro) têm como referencial, no caso, a época da ocorrência do dano de chance.

${ }^{505}$ Cf. FERREIRA, Aurélio Buarque de Holanda. Novo Dicionário Eletrônico Versão 5.0. Correspondente à 3 ed. $1^{\text {a }}$. impressão da Editora Positivo, rev. e atual. do Aurélio Século XXI, O Dicionário da Língua Portuguesa, 2004. 1 CD-ROM. 
dano de chances não é "autônomo" em caso algum, ele é totalmente vinculado ao dano final $^{506}$.

Sem abusar do léxico, entretanto, a perda de uma chance rende ensejo a um prejuízo "distinto" 507 (diverso, diferente) do dano final, porém não "autônomo" (independente). Isso tem severas implicações no que concerne à formulação do pedido e da causa de pedir, no ponto em que irá incidir a prova em demandas judiciais e, no campo extrajudicial, no comportamento do mercado de seguros para cobertura desta fattispecie de dano. Esta peculiaridade, sumamente importante, foi observada por Geneviéve Viney, que, ao elaborar o anteprojeto de reforma do Direito das Obrigações e da Prescrição na França (Rapport Catala), assim redigiu o dispositivo sobre a perda de uma chance:

Art. 1346 La perte d'une chance constitue un préjudice réparable distinct de l'avantage qu'aurait procuré cette chance si elle s'était réalisée ${ }^{508}$.

Na proposta taxonômica de Fernando Noronha, por sua vez, a perda de uma chance divide-se em três modalidades: 1 - perda de uma chance de obter uma vantagem futura (perda de uma chance clássica); 2 - perda de uma chance de evitar um prejuízo que aconteceu, que se desdobra em duas situações: de causalidade concorrente e de causalidade alternativa; 3 - perda de uma chance por falta de informação.

A base das duas primeiras proposições se assemelha, quase que integralmente, à proposta de Rafael Pettefi da Silva. A única divergência assinalada por este último, que se

\footnotetext{
${ }^{506}$ O mesmo pode ser dito no exemplo em que o advogado não apresenta recurso da sentença desfavorável, em que Pettefi afirma que fica "difícil imaginar" como ele ganharia. Ora, o "ganhar" aqui deve ser relacionado ao interesse aleatório em jogo, que, no caso, é o de evitar a condenação (no caso do réu) ou consegui-la (no caso do autor). Pois bem, raciocine-se com a hipótese de, apesar da negligência do advogado, a sentença conter algum dos vícios do artigo 485 do CPC. "Ganhar" um recurso não interposto é, de fato, impossível. Porém, considerando que a legislação processual não exige o esgotamento das vias recursais para o manejo da ação rescisória, pode o advogado, após o trânsito em julgado, ajuizar a aludida ação e obter a rescisão da sentença. Isso implicaria na obliteração do resultado final danoso e, consequentemente, no dano pela perda de uma chance. Mais uma vez, demonstra-se que não há autonomia alguma entre os diferentes danos.

${ }^{507}$ O próprio Rafael Pettefi da Silva, quando cita Geneviéve Viney, fala em prejuízo “distinto" e não em prejuízo "autônomo". (SILVA, Rafael Pettefi da, op. cit., p. 109)

${ }_{508}$ VINEY, Geneviève. De la responsabilite civile. In: AVANT-PROJET DE REFORME DU DROIT DES OBLIGACIONES (ARTICLES 1101 À 1386 DU CODE CIVIL) ET DU DROIT DE LA PRESCRIPTION (ARTICLES 2234 A 2281 DU CODE CIVIL). Relatório encaminhado ao Ministro da Justiça em 22 set. 2005Disponível em: 〈http://www.lexisnexis.fr/pdf/DO/RAPPORTCATALA.pdf $>$. Acesso em: 14 mar. 2010, p. 154.
} 
acolhe, é que Fernando Noronha sustenta pesar sobre o réu uma presunção de causação nas hipóteses de perda da oportunidade de evitar um prejuízo consumado ${ }^{509}$.

Ora, se pende sobre o réu tal fardo, as regras de ônus da prova não deixam margem à tergiversação: ou o réu produz provas cabais e robustas, na instrução do processo, capazes de aniquilar a presunção que lhe oprime, e, então, fica exonerado de responsabilidade sobre o ocorrido, ou não consegue elidi-la, e suporta o pagamento da indenização da totalidade do dano ${ }^{510}$.

Quanto à perda de uma chance por falha no dever de informação, trata-se de uma sutileza bem observada pelo autor, mas que, de todo modo, se enquadra nas hipóteses anteriores (perda da chance de obter uma vantagem futura ou de evitar um prejuízo ocorrido). Ela acontece quando alguém sofre um dano por não ter tomado a melhor decisão, que estaria ao seu alcance se a outra pessoa, sobre a qual incidia o dever de informar, tivesse cumprido sua tarefa ${ }^{511}$.

O caráter aleatório a ensejar a aplicação da teoria está na dúvida se a pessoa tomaria ou não uma decisão diversa, caso tivesse sido noticiada da alternativa ou dos perigos. Portanto, em se tratando de uma situação em que, de posse daquele dado, o risco seria totalmente eliminado e, portanto, a escolha se encaminharia num único sentido, deve o ofensor ser responsabilizado pela integralidade do dano sofrido pela vítima. A invocação da técnica das oportunidades perdidas pressupõe, portanto, margem razoável de dúvida sobre a opção que a vítima teria feito se municiada de todo o arsenal de avisos e advertências.

\footnotetext{
${ }^{509}$ As palavras do autor são as seguintes: “A questão do nexo causal, mesmo nos casos de perda de uma chance de evitar um dano que aconteceu, fica resolvida se foi produzida prova suficiente para demonstrar que o fato antijurídico que estiver em questão criou uma séria probabilidade de ocorrência do dano. Se a dúvida que fica subsistindo é apenas porque existe uma outra causa possível, terá de ficar a cargo do indigitado responsável o ônus da prova capaz de destruir a presunção de causação que milita contra ele: provado que o evento atribuído ao indigitado responsável foi uma condição do dano, fica presumido o nexo de causalidade adequada; se ele praticou um fato suscetível de causar o dano, sobre ele deve recair o ônus de provar que, apesar da condicionalidade, não houve adequação entre tal fato e o dano". (NORONHA, Fernando, Responsabilidade por perda de chances. Revista de Direito Privado, São Paulo, v. 6, n.23, p. 29.46, jul./set. 2005 p. 43)

510 Apesar de sustentar a existência de uma presunção em desfavor do ofensor, o autor assevera que a reparação corresponde a uma fração do resultado final, de acordo com o percentual das chances subtraídas. (Idem.)

${ }^{511}$ Ibidem, p. 44.
} 
E o requinte que fez com que o autor categorizasse a hipótese em plano específico está no fato de que, diferentemente das outras, nesta, a realização do dano está ligada a um fato do próprio lesado (tomada ou não da decisão) ${ }^{512}$.

\subsection{Perda de uma chance típica e atípica}

Conforme mencionado alhures, os critérios alinhavados pela doutrina brasileira melhor atendem aos fins colimados pela taxonomia, na medida em que tentam responder aos parâmetros científicos de classificação. Não se pretende, pois, esgotar o tema ou propor sistema diverso com o escopo de "corrigir" os métodos existentes no ordenamento, até porque é possível, validamente, estabelecer diferentes classificações, sob ângulos diversos, e todas elas se apoiarem em escolhas epistemológicas admissíveis.

As divergências pontuais em relação aos doutrinadores brasileiros foram expostas no tópico precedente, e, a partir delas, deseja-se mostrar um enfoque ligeiramente diferente, no anseio de que seja objeto de reflexão e aprimoramento pelos que evoluam no estudo do tema.

A categorização que traçamos parte da mesma síntese organizada por Rafael Peteffi da Silva (nas conclusões de sua obra), nos seguintes termos:

$\mathrm{Na}$ seção 2.3 do Capítulo 2 foi defendido que as hipóteses de responsabilidade pela perda de uma chance deveriam ser sistematizadas em dois grandes grupos. O primeiro seria caracterizado pelos casos nos quais o processo aleatório em que se encontrava a vítima é totalmente interrompido pela conduta do réu, antes de chegar ao seu final, aniquilando com todas as chances daquela. Esses casos apresentariam as chances perdidas pela vítima como uma especificidade do conceito de dano, garantida pela ciência Estatística. Já no segundo grupo, a conduta do réu não interrompe o processo aleatório em que se encontrava a

\footnotetext{
${ }^{512}$ Assim afirma o autor: “As diferenças entre a situação de perda de uma chance pela quebra de um dever de informar e perda de uma chance de evitar um prejuízo efetivamente acontecido, prendem-se com o fato de a chance, na primeira, estar ligada a um fato do próprio lesado, enquanto na segunda está para além dele. Nos casos de que tratamos agora, 'a realização do dano depende da atitude da vítima', como diz Pettefi da Silva, ainda que este jurista não faça a sistematização tripartida aqui proposta”. (Ibidem, p. 45)
} 
vítima, fazendo com que haja apenas uma diminuição das chances de auferir a vantagem esperada. Nesses casos, o processo aleatório foi até o seu momento derradeiro e a ciência Estatística utilizada apenas para medir em que grau a conduta do réu contribuiu para a causação do dano final, fazendo com que as chances perdidas não passem de causas parciais para a perda da vantagem esperada pela vítima. Desse modo, afirma-se que a primeira hipótese de aplicação da teoria da perda de uma chance utiliza um conceito específico de dano, enquanto a segunda hipótese lança mão da causalidade parcial ${ }^{513}$.

A resenha do autor atende ao traço contrastivo que se pretende explanar. De fato, as hipóteses de perda de uma chance podem ser divididas em dois grandes grupos, exatamente na forma por ele exposta. Note-se que o autor utiliza a expressão dano "específico" (em vez de "autônomo"), correta para expressar que a perda de uma chance constitui um prejuízo “distinto" do próprio interesse aleatório perseguido (resultado final).

Pois bem, na primeira hipótese, aqui denominada de perda de uma chance "típica", a cadeia causal de eventos em que se encontra a vítima é interrompida, usurpando-lhe todas as chances de conseguir o resultado final. São os casos do jóquei que não participa da corrida porque o cavalo não é transportado a tempo e do candidato que é obstado de participar da última prova de um concurso.

Desde já, é possível delinear duas características de perda de uma chance "típica": 1 - a vítima só participa do processo aleatório até a prática do ato ilícito (o páreo acontece sem a participação do jóquei, o concurso prossegue sem o candidato); 2 - a obliteração das chances é, em regra, cronologicamente simultânea à do resultado final (no momento em que o jóquei fica privado da chance de correr, perde o páreo; desde quando é vedado ao candidato realizar a prova, ele está reprovado no concurso). Desse modo, na perda de uma chance "típica", a perda do resultado final é um evento presente e certo em relação à oportunidade perdida.

Já na perda de uma chance "atípica", o curso natural dos acontecimentos não é interrompido, o que redunda na diminuição das chances de obter a vantangem ou de evitar o prejuízo. São os casos dos advogados que deixam de contestar a ação, e, de um modo

${ }^{513}$ SILVA, Rafael Pettefi da, op. cit., p. 248. 
geral, dos erros médicos por falha de diagnóstico, conforme apontamentos de Brint e Koehler: "The loss of chance doctrine holds that when a defendant is responsible for reducing a plaintiff's chance of receiving a more favorable outcome, the plaintiff (or his estate) should be compensated by the defendant for that probabilistic loss"

Ao contrário da perda de uma chance "típica", na "atípica" as características são diversas: 1 - a vítima participa do processo aleatório até o seu termo (o réu continua a ser parte no processo judicial apesar da ausência de contestação; o enfermo segue largado à própria sorte no curso da vida, após a omissão do diagnóstico); 2 - a subtração das chances é cronologicamente anterior ao resultado final (o advogado é contumaz e, posteriormente, é provável que advenha uma sentença contrária aos interesses do seu cliente; o doente não é diagnosticado a tempo e, logo depois, há boas chances de que venha a óbito).

Desse modo, na perda de uma chance "atípica", a perda do resultado final é um evento futuro e incerto em relação à oportunidade perdida (não se sabe se a sentença será desfavorável nem se o paciente irá falecer, o que se sabe, de imediato, é que o ato ilícito aumentou as probabilidades de resultados adversos).

Analise-se o seguinte exemplo: uma pessoa contrata um advogado para defendê-la em juízo numa determinada ação de cobrança. Apesar disso, o profissional negligencia em sua obrigação de patrocínio e deixa com que o feito corra à revelia, consumando-se o seu efeito principal, que é a presunção de veracidade dos fatos articulados na petição inicial ficta confessio - (CPC, art. 319) ${ }^{515}$. Sem embargo, o juiz, de ofício, pronuncia a prescrição da pretensão $\left(\mathrm{CPC} \text {, art. 219, } \S 5^{\circ}\right)^{516}$, e, assim, resolve o mérito do processo (CPC, art. 269, IV $)^{517}$. A decisão transita em julgado sem condenação do réu.

Numa segunda hipótese, uma pessoa descobre, com dois anos de atraso, que é portadora de uma moléstia grave, a qual, diagnosticada e tratada precocemente pelos médicos que realizaram os exames de rotina e não a detectaram, teria 30\% (trinta por cento) de chances de cura. Com a intempestividade da diagnose, a probabilidade ficou reduzida a $1 \%$ (um por cento). Todavia, tal pessoa, dotada de uma compleição física

\footnotetext{
514 KOEHLER, Jonathan; BRINT, Arienne P. Psychological aspects of the loss of chance doctrine. In: Conference on Psychology and Economics Centre for Economic Policy Research (CEPR) \& European Center for Advanced Research in Economics and Statistics (ECARES), 2, 2001, Bélgica. Disponível em: $\langle$ http://www.cepr.org/meets/wkcn/3/3509/papers/Koehler.pdf >. Acesso em: 31 ago. 2010.

515 BRASIL. Código de Processo Civil (1973). Código de Processo Civil e Constituição Federal. 17. ed. São Paulo: Saraiva, 2011.

516 Idem

${ }^{517}$ Idem
} 
privilegiada, submetida a um excelente tratamento com outra equipe e contando com uma dose de sorte, fica completamente sã, sem qualquer sequela.

Pois bem, a indagação que se faz em ambos os casos é a seguinte: é possível falar em perda de uma chance, sem aguardar concretização do dano efetivo? E a resposta que parece inexorável é a de que "não", pois os exemplos alinhavados permitem bispar, com absoluta clareza, esta necessidade.

Destarte, admitidas as hipóteses pretéritas como de perda de uma chance, imperioso o rigor taxonômico para classificá-las como "atípicas", na medida em que a ocorrência do dano é um evento futuro e incerto, cuja ocorrência é necessário aguardar, pois a vítima continua participando do processo aleatório após o ilícito que diminuiu suas perspectivas.

O direito britânico possui um precedente bastante emblemático desta situação. Tratase do caso Gregg v. Scott, julgado em sede de apelação pela Câmara dos Lordes em 2005. O Sr. Gregg moveu uma ação por negligência em face do seu médico, Dr. Scott, alegando falha de diagnóstico de um câncer. Quando o Sr. Gregg foi examinado pelo Dr. Scott e reclamou de um caroço na axila esquerda, ele lhe disse que era apenas uma junção de tecidos gordurosos. Esta era a explicação mais provável, porém, infelizmente, era a errada. O Sr. Gregg tinha um linfoma glandular maligno. Isto só foi descoberto cerca de nove meses depois, quando outro clínico geral o enviou a um hospital para exames. Àquele momento, o tumor já havia se espalhado pela região peitoral. Ele sofreu com fortes dores e se submeteu a sessões de alta dose de quimioterapia, particularmente debilitantes. $\mathrm{O}$ tratamento destruiu, temporariamente, o tumor, mas foi seguido de uma recidiva, o que deixou o Sr. Gregg com um prognóstico estreito de sobrevida.

Na ação, o Sr. Gregg alegou que o Dr. Scott deveria, após o exame clínico, tê-lo encaminhado para exames laboratoriais. Sustentou que caso tivesse sido diagnosticado precocemente, teria uma alta probabilidade de cura, o que significa, em termos médicos, uma sobrevida de dez anos com remissão total dos sintomas. Com o ocorrido, a perspectiva de obtenção de cura foi reduzida para menos de $50 \%$ (cinquenta por cento), razão pela qual ele postulou danos pela diminuição (perda) da chance de obter um resultado melhor ${ }^{518}$.

\footnotetext{
${ }^{518}$ O relatório tem como fonte o voto do Lord Hoffmann, cujas palavras exatas foram as seguintes: "The facts. 61. This is an action against a doctor for negligence in failing to recognise that his patient might have cancer. When Mr Gregg showed Dr Scott a lump under his arm, the doctor told him it was a collection of fatty tissues. That was the most likely explanation but unfortunately it was wrong. Mr Gregg had cancer of a lymph gland. This was discovered a year later, when another GP referred him to a hospital for examination. By that time, the tumour had spread into his chest. He suffered a good deal of pain and had to undergo a
} 
Pois bem, como é de rigor nas demandas por perda de uma chance, os peritos recorreram às estatísticas, o que lhes pareceu bastante simples num olhar perfunctório, pois havia índices largamente utilizados como um modelo preditivo para os pacientes com o seu tipo de neoplasia, e isso parecia fornecer bases seguras para estimar o que ocorreria se o tratamento tivesse iniciado no momento em que ele procurou Dr. Scott, antes que as metástases começassem a se espalhar.

A sutileza do caso é que a estatística fornece apenas um dado relativo à média dos pacientes, que de nada serve em relação a um indivíduo em particular, quando é possível avaliá-lo concretamente. O câncer do Sr. Gregg apareceu em Novembro/1994 e não foi diagnosticado. Em Agosto/1995, quando foi a outro médico, ele o encaminhou ao hospital onde, em Janeiro/1996, foi diagnosticado o linfoma debaixo do braço esquerdo, já espalhado pela região peitoral. Foi, então, submetido a 6 sessões de quimioterapia, que, embora tenham dado resposta, não fizeram o tumor desaparecer completamente. $\mathrm{Na}$ sequência, decidiu sujeitar-se a altas doses de quimioterapia e tratamento com a coleta de células-tronco. No início de 1998, sofreu uma recidiva, com um novo tumor, agora na axila direita, o que o deixou com um paupérrimo prognóstico.

O competente perito do Sr. Gregg, Dr. Goldstone, esboçou um modelo que traçava o destino de 100 pacientes com a mesma doença e, a partir dali, firmava-lhe um quadro prospectivo. Segundo a sua demonstração, de 100 pacientes que iniciaram o tratamento quimioterápico, 55 obtiveram remissão completa; 45 não, e desses 45, 41 morreram. Dos 59 que obtiveram remissão $(55+4), 35$ não tiveram recidivas inicialmente, e foram chamados de núcleo de sobreviventes. Destes 35, entretanto, 24 tiveram recidivas posteriores. Destes 24, 12 não responderam ao tratamento e morreram. Os 12 restantes responderam a outros tratamentos, como altas doses de quimioterapia e colheita de célulastronco. Destes 12, outros 6 nunca mais tiveram recidivas e tornaram-se sobreviventes. Dos outros 6, apenas 1 sobreviveu. O Sr. Gregg estaria no grupo que só teve remissão após o tratamento com células-tronco e, apesar disso, teve uma recidiva subsequente. Mesmo

particularly debilitating course of high-dose chemotherapy. The treatment temporarily destroyed the tumour but was followed by a relapse which left Mr Gregg with a poor prospect of survival. The claim. 62. Mr Gregg alleged in his particulars of claim that Dr Scott ought to have referred him to a hospital for examination. His 'particulars of pain and injury' alleged that if he had been diagnosed earlier 'there would have been a very high likelihood of cure'. I shall come back in a moment to what, in this context, was meant by a cure." (INGLATERRA. Câmara dos Lordes, Sessão 2004-5 [2005]. Apelação[2002] EWCA Civ 1471. Disponível em: <http://www.publications.parliament.uk/pa/ld200405/ldjudgmt/jd050127/greg-8.htm>. Acesso em: 27 jan. 2011) 
assim, sobreviveu, o que o tornou, em termos estatísticos, o único sobrevivente daqueles 6 infortunados que tiveram recidivas após os diversos tratamentos. Contudo, quando da recidiva de 1998, o Sr. Gregg tinha, no máximo, de 10\% (dez por cento) a 15\% (quinze por cento) de chance de sobrevivência. Entretanto, ele já havia sobrevivido por 3 anos (2001), e as chances de recidiva diminuíram. Mesmo assim, considerando todo o ocorrido, o perito entendeu que as chances de cura do Sr. Gregg eram inferiores a 50\%, e que ele poderia avaliá-las, naquele estágio, em $20 \%$ (vinte por cento) a 30\% (trinta por cento), na melhor das hipóteses ${ }^{519}$.

Sem embargo, apesar do forte apelo emocional do caso, e da manifesta compaixão dos Lordes pelo sofrimento experimentado pelo Sr. Gregg, a maioria entendeu pela impossibilidade de conceder a reparação de danos, dentro da abordagem feita pelo perito, Sr. Goldstone, de perda (diminuição) de chances de cura ou sobrevida. O placar foi de 3 a 2 pela não concessão de indenização (embora cada um dos votos tenha abordagens singulares).

Com efeito, contrariando todas as probabilidades, o Sr. Gregg, com 10\% (dez por cento) a $15 \%$ (quinze por cento) de chances em 1998, quando da recidiva para a axila direita, estava vivo três anos depois, por ocasião do julgamento em primeira instância, em 2001. Mais impressionante ainda, quando do julgamento da apelação perante a Câmara dos Lordes, em 2005, ele continuava vivo, ou seja, ainda resistia 9 anos após o início do intempestivo tratamento, com chances cada vez mais remotas de uma nova recidiva. Ora, o Sr. Gregg estava perto de ser considerado um sobrevivente, assim definido, alhures, como

\footnotetext{
519 Extraído do voto do Lord Phillips of Worth Matravers: "Of those with initial treatment by CHOP chemotherapy with or without field radiotherapy 55 will achieve complete remission. 45 will not achieve complete remission, and of those 41 will then die. Four who did not achieve complete remission immediately will be brought to achieve it by further treatment of various kinds. Thus of the initial 10059 manage to achieve complete remission. Of those 35 do not relapse. They are described by Professor Goldstone as the core group of survivors. 24, however, do relapse (usually, if they are going to, within two years or so of achieving remission). Of those 24 , half, a further 12 , will not be responsive to further treatment and will die. The remaining 12 will be responsive to further treatment, typically high dose chemotherapy with stem cell harvesting such as the claimant himself went through. Of those 12, half, a further six, will not relapse again and will become survivors. Of the remaining six who do relapse again, only one will survive. The number of survivors from the 100 who started out will therefore be 42. Mr Gregg's disease and treatment has not quite taken this course, since he is probably to be regarded as someone who attained complete remission only after stem cell treatment and high dose chemotherapy. But he is someone who, having received that treatment, subsequently relapsed. He may therefore be regarded as possibly the one survivor [at] the end of the process described in the model. He had after his relapse in early 1998 a 10\% or 15\% chance of survival. However, he has now survived over three years, and as time goes by the chances of relapse diminish. The best that Professor Goldstone can say of it now, however, is that given all that has happened, at present Mr Gregg's chances of survival for five years is less than 50\%, though he put a figure of $20 \%$ to $30 \%$ as the present chance as best as he could assess it". (Idem).
} 
aquele que consegue uma sobrevida assintomática por 10 anos. Tal fato foi decisivo no voto do Lord Phillips of Worth Matravers ${ }^{520}$.

Tais asserções corroboram a premissa de que, na perda de uma chance "atípica", só é possível fazer a abordagem do dano, a partir de tal técnica ${ }^{521}$, quando ele se consuma, e aí, então, as probabilidades de o dano ter sido evitado (ou minorado) podem ser avaliadas para efeitos de indenização. Em tais casos, a perda de uma chance, desde que ocorrido o dano, estaria na usurpação da possibilidade de obter a cura ou a sobrevida ${ }^{522}$, ou o êxito na ação

${ }^{520}$ Conforme se extrai dos seguintes comentários: “133. Mr Gregg is still alive. The claim for lost years has been advanced on the basis of a comparison between Mr Gregg's statistical chance of being a survivor as portrayed by Professor Goldstone's model and his actual chance of being a survivor. While statistics are of assistance in calculating the latter, Mr Gregg's clinical history up to the moment of assessment is of critical significance. At the time of the trial, Mr Gregg had survived about five years from commencement of treatment and, having regard to his clinical history Professor Goldstone estimated his chances of being a survivor as 20-30\%. By the time of the hearing before us, Mr Gregg had survived a further three years, without relapse. This must plainly have resulted in a dramatic improvement in his prospects of being a survivor. It may be that his prospects of being a survivor are better than his statistical prospects would have been had his treatment been commenced timeously. This was not a matter that was raised at the hearing before us, but Mr Havers QC on behalf of Dr Scott now submits that, should the case be remitted to the trial judge for assessment of damages on a loss of a chance basis, he will have to take this into account in order to decide whether Mr Gregg has any claim for lost years. Alternatively he invites us to have regard to the implications of Mr Gregg's survival and to rule that no claim in respect of lost years has been made out. 168. The chance that the delay in commencing his treatment has caused each of these adverse events is not the same. The evidence did not, however, permit the judge to make nice differentiations. He simply addressed himself to assessing the chance that, if Mr Gregg had received prompt treatment, he would have avoided all these adverse events. He concluded that his chance of so doing had been reduced by $20 \%$ as a result of the delay in commencing his treatment. He thus equated Mr Gregg's lost chance of avoiding the adverse events prior to trial with his lost chance of avoiding premature death. 169. It is no longer possible to reach such a conclusion. The closer that Mr Gregg comes to being a survivor the smaller is the likelihood that the delay in commencing his treatment has had any effect on his expectation of life. At the same time, Professor Goldstone's model and his other evidence indicate that if Mr Gregg proves to be a survivor, the odds are high that he would have achieved complete and final remission if treated before his cancer had spread. On balance of probability I suspect that one is now in a position to conclude that the delay in commencing $\mathrm{Mr}$ Gregg's treatment has not affected his prospect of being a survivor but has caused him all the other adverse events which I have set out above. If his claim is to be assessed on the basis of a loss of a chance, some discount will have to be made for the small possibility that, even had he been treated promptly, he would have experienced the same adverse events and some small award may fall to be made for the loss of a chance of living 10 years, unless such an exercise is swept away as being 'de minimis'” (Ibidem).

${ }^{521}$ Pois, sob o prisma da criação ou aumento de risco, conforme já se disse (capítulo 2, item 2.8.3), os danos, materiais ou imateriais, podem ser certos e indenizáveis, desde logo.

${ }^{522}$ Em acórdão sobre a responsabilidade médica no caso de enfermidade com prognóstico estreito, o TJ/RJ enfrentou a questão de modo interessante, vislumbrando não a perda de uma chance de cura, pois o falecimento seria inevitável, mas a perda da oportunidade de um tempo maior de convívio com os familiares: "RESPONSABILIDADE CIVIL DE LABORATORIO ERRO DE DIAGNOSTICO DESCUMPRIMENTO DOS DEVERES PROFISSIONAIS PERDA DE UMA CHANCE REDUCAO DO DANO MORAL APELAÇÃO CÍVEL - RESPONSABILIDADE CIVIL - DIREITO DO CONSUMIDOR LABORATÓRIO DE DIAGNÓSTICOS - DEFEITO NO SERVIÇO CARACTERIZADO PELA AUSÊNCIA DE CONSTATAÇÃO DE CÉLULAS CANCERÍGENAS - POSSÍVEL IMPEDIMENTO DE SOBREVIDA DA ENFERMA - DANO MORAL (...) 4- O quantum indenizatório deve ser fixado com base na chance em si que foi desperdiçada, sem olvidar que, dado o estado avançado da enfermidade apresentado pela paciente em novembro de 2001, o infeliz desfecho seria inevitável, ainda que o laudo realizado em setembro daquele ano tivesse apontado sinais de células cancerígenas. 5- Neste caso, a quantia de $\mathrm{R} \$$ $25.000,00$, fixada pela julgadora de piso a título de dano moral para cada um dos autores, respectivamente 
judicial, e, para estes, o recurso à lei das probabilidades subsidiaria a noção acerca de qual seria, em termos percentuais, a probabilidade de que o dano não ocorresse, caso os fatos idôneos tivessem intercedido a tempo e modo de poupá-lo.

Há, entretanto, outro item fundamental de clivagem entre a perda de uma chance "típica" e "atípica": a localização da álea. Talvez seja este o ponto nevrálgico que melhor confira legitimidade à nomenclatura ora adotada, que é onde reside o elemento incognosível que faz com que o Direito absorva o caráter aleatório de determinado pressuposto da responsabilidade civil, e o leve em consideração no momento de decidir, pautando o montante da indenização de acordo com o grau de probabilidade.

Na perda de uma chance "típica", a álea está no dano (resultado final). Nele reside a ignorância humana sobre os acontecimentos. Sabe-se que a vítima tinha um interesse aleatório; que este foi usurpado pela interrupção do processo aleatório (ato ilícito); que esta interrupção foi a causa da perda do interesse aleatório (nexo causal), mas, como a vítima só participa da cadeia causal até a intervenção interruptiva, não se sabe se a vítima conseguiria ou não o resultado almejado (dano equivalente ao resultado final).

Considerando que a técnica de perda de uma chance está, essencialmente, em absorver o desconhecido, o Direito assume a sua ignorância sobre o dano equivalente ao resultado final (do qual o dano de chance é dependente), por considerá-lo ontologicamente indemonstrável, e arbitra a reparação de acordo com a probabilidade que a vítima possuía de alcançá-lo.

De outro bordo, na perda de uma chance "atípica", a álea está no nexo causal. Nele, habita o desconhecimento sobre os fatos. Sabe-se que a vítima tinha um interesse aleatório; que este foi usurpado pela não interrupção do processo aleatório pelo ofensor (ato ilícito). Como a vítima continuou participando do processo aleatório até o seu fim, também se sabe que ela sofreu o prejuízo ou não obteve o benefício que perseguia (dano equivalente ao resultado final). Porém, não se pode precisar se o ilícito do réu foi o causador do dano (nexo causal), embora haja a "certeza da probabilidade".

filhas e cônjuge da extinta, se revela excessiva, considerando a inevitabilidade do óbito iminente, pelo que deve ser reduzida para $\mathrm{R} \$ 10.000,00$, a qual se revela justa a compensar a frustração da oportunidade de maior convívio dos entes queridos com a falecida". [...]. 7- Provimento parcial do recurso principal. Prejudicada a apelação adesiva”. (RIO DE JANEIRO. Tribunal de Justiça do Estado do Rio de Janeiro, 2a Câmara Cível. Apelação Cível 0001570-44.2002.8.19.0067. Queimados. Relator: Heleno Ribeiro P. Nunes. Diário da Justiça eletrônico, 04 nov. 2010, p. 16) 
Do mesmo modo, o Direito é réu confesso quanto ao seu desconhecimento do nexo causal, mas acolhe essa ignorância no momento de decidir, fixando a indenização de acordo com a probabilidade de o ato ilícito ter sido o causador do resultado final danoso.

\subsection{Ruptura do conceito de causalidade ou uso da causalidade parcial?}

Há, na doutrina, severas críticas ao reconhecimento da existência de perda de uma chance que aqui denominamos "atípica", ao fundamento de que ela rompe com o conceito de causalidade, pois, se o evento danoso já ocorreu, é necessário perquirir, tão somente, se a ação ou omissão ilícita ocasionou o dano, e responsabilizar integralmente o agente, ou, ao revés, concluir pela sua total irresponsabilidade, por não ter sido o causador, não obstante a conduta tenha sido falha.

René Savatier foi um dos maiores recalcitrantes em admitir essa possibilidade,

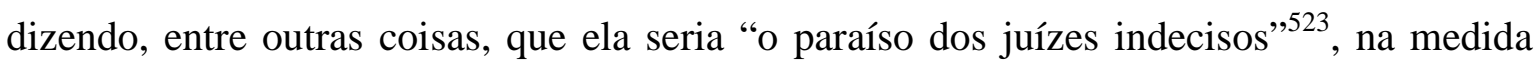
em que possibilitaria uma solução intermediária, sem uma definição clara sobre o causador do dano. Corroborando tal assertiva, Jean Penneau também a considerava uma "extravagância", "porta aberta para indenizações sistemáticas", "acrobacia intelectual" etc. $^{524}$

Em que pese a solidez dos argumentos, eles não são convincentes por, pelo menos, duas razões: a primeira delas, por raciocinar transformando a exceção em regra, guiando o

\footnotetext{
${ }^{523}$ Foram estas as suas palavras: "Mais, ce qui est réparable alors, c'est la perte d'une véritable chance, c'est-à-dire d'une supputation légitime de l'avenir. La chance perdue se place dans le futur. On ne saura jamais, sans une supputation de l'avenir, si elle se serait réalisée. On possède, cependant, sur ce point, de données permettant d'évaluer la chance: ainsi, dans nos examples, les notes justifiant de la préparation du candidat au concours, ou les probabilités qu'aux yeux du juge de la responsabilité, le droit litigieux avait d'être reconnu. Le raisonnement que nous croyons inacceptable situe, au contraire, des chances dans le passé, où se place, déjà, l'événement auquel on les applique. C'est une recherche perimée! Dans les hypothèses retracées plus haut, les chances que l'on prétend faire réparer par le médecin en faute son celles que le patient aurait eues d'éviter la mort ou l'infirmité, dont il souffre définitivement, si le médicin n'avait pas commis l'imprudence ou la négligence qu'on lui reproche. Or le destine a tranché. Par hypothèse, l'infirmité ou la mort sont survenues. Il ne s'agit plus de chances, mais de faits accomplis. Quand la loterie est tirée, le bilets perdues par la faute d'autrui ne représentent plus des chances, mais, selon le cas, de droit acquis, ou de droits inexistants.(...) Cette concepction ouvre au juge tout un éventail. Car nous pensons qu'il est impossible, si l'on admet une réparation fondée sur l'hésitation du juge à reconnaître le rôle causal de la faute dans le dommage, de ne pás déployer en entier cet éventais de sa perplexité. [...] Paradis des juges indécis! C'est bien en cela que la tentation est dangereuse." (SAVATIER, René. Une faute peut-elle engendrer la responsabilité d'un dommage sans l'avoir causé ? Paris: Recueil Dalloz, 1970, chron. XVII, p. 124-125).

${ }_{524}$ PENNEAU, Jean. La responsabilité du medecin. Paris: Dalloz, 1992, p. 32.
} 
pensamento pelo desvio de conduta, pelo teratológico, como se o recurso ao instituto fosse implicar imediato abandono à investigação do nexo de causalidade, e o juiz, pusilânime e inseguro, encontrasse o lenitivo para a ferida de suas angústias no bálsamo da teoria da chance perdida, deixando de diligenciar acerca da real causa do dano.

Ora, nenhuma norma jurídica, princípio ou regra, tem validade a partir da presunção de má-fé dos destinatários.

O segundo desdouro é desconsiderar a própria álea terapêutica e a inexatidão das ciências biológicas e humanas, ou, num aspecto mais amplo, a limitação do conhecimento humano. A Medicina, em geral, assim como a Advocacia, é obrigação de meio, de modo que, nem sempre, é possível precisar em que medida determinada conduta (omissiva ou comissiva) causou o dano. Nesses casos, o recurso à teoria da perda de uma chance representa solução de justiça, que não condena na totalidade do dano sem a "certeza" do nexo causal, mas também não deixa impune o réu que praticou um ato ilícito que contribuiu, com relevante probabilidade, para o evento danoso.

Isabelle Vacarie assim justifica a adoção pelo Judiciário da perda de uma chance em matéria de responsabilidade médica:

En matière de responsabilité médicale, le raisonnement judiciaire est le suivant: s'il ne peut être affirmé qu'une intervention médicale immédiate aurait assuré la survie ou la guérison du patient, néanmoins il y a des chances - plus ou moins grandes selon les cas qu'il en fût ainsi. Cet raisonnement révèle que le recours à la perte d'une chance est dicté par l'aléa thérapeutique. L'acte médical est en effet très généralement consideré comme un acte comportant une part d'aléa. Cet aléa a conduit la Cour de cassation à affirmer que le médecin n'etait tenu qu'à une obligation de moyens : celle de donner des soins consciencieux, attentifs et conformes aux données de la science. La notion de perte d'une chance de survie ou de guérison traduit quant à elle l'influence de l'aléa thérapeutique sur la causalité $e^{525}$.

${ }^{525}$ VACARIE, Isabelle, op. cit., p. 909. 
Caso não se utilize o recurso à perda de uma chance nos casos de incerteza acerca do nexo de causalidade, ao lado da certeza acerca de um ato ilícito que pode ter contribuído para o resultado final, a solução será o "tudo ou nada", dentro de algum standard de convencimento adotado como regra de ônus da prova, o que foi denominado pelo professor Joseph King Jr. como o "pior dos mundos", ao comentar que: "The relaxed proof approach represents the worst of both worlds. It continues the arbitrariness of the 'all-ornothing' rule, but by relaxing the proof requirements, it increases the likelihood that a plaintiff will be able to convince a jury to award full damages

O Lord Nichols of Birkenhead, no caso Gregg v. Scott, também opôs severas críticas ao método "all or nothing", ao asseverar que a sua adoção iria redundar em consequências manifestamente insatisfatórias, pois colocaria em vala comum os bons e maus prognósticos, como se nenhuma diferença existisse, deixando impune a mais gritante das negligências, quando o correto seria avaliar uma soma para o pagamento da justa composição dos danos. Citando o voto do juiz Dore em Herskovits v Group Health Cooperative of Puget Sound (1983) 664 P 2d 474, 477, pontuou que "To decide otherwise would be a blanket release from liability for doctors and hospitals any time there was less than a 50 per cent chance of survival, regardless of how flagrant the negligence, ${ }^{, 527}$.

O fetiche que contamina a noção de onipotência do homem, que se arvora em tudo poder solucionar a partir das relações de causa e efeito, desprezando a sua limitada condição, fá-lo recorrer a soluções iníquas - como as anteriormente apresentadas - a partir de postulados insustentáveis, como a infinitude da sua cognoscibilidade. Friedrich Nietzsche assim descreve o fenômeno:

Enquanto o infortúnio que dormita no seio da cultura teórica começa paulatinamente a angustiar o homem moderno, e ele, inquieto, recorre, tirando-os de suas experiências, a certos meios a fim de desviar do perigo, sem que ele mesmo creia nesses meios; isto é, enquanto esse homem começa a pressentir as suas próprias conseqüências, grandes naturezas, com disposições universais, souberam utilizar com incrível

\footnotetext{
${ }^{526}$ KING JR., Joseph H. "Reduction of likelihood" reformulation and other retrofitting of the loss-of-achance doctrine. Memphis Law Review, winter, 1998. Disponível em: http://findarticles.com/p/articles/ mi_qa3843/is 199801/ai n8788962/. Acesso em: 14 abr. 2011.

527 INGLATERRA. Câmara dos Lordes, Sessão 2004-5 [2005]. Apelação [2002] EWCA Civ. 1471. Disponível em: 〈http://www.publications.parliament.uk/pa/ld200405/ldjudgmt/jd050127/greg-8.htm>. Acesso em: 27 jan. 2011.
} 
sensatez o instrumento da própria ciência, a fim de expor os limites e condicionamentos do conhecer em geral e, com isso, negar definitivamente a pretensão da ciência à validade universal e a metas universais: prova mediante a qual, pela primeira vez, foi reconhecida como tal aquela idéia ilusória que, pela mão da causalidade, se arroga o poder de sondar o ser mais íntimo das coisas ${ }^{528}$.

O "calcanhar de Aquiles" dos que repudiam a aplicação da teoria da perda de uma chance "atípica" está no desconhecimento do extraordinário valor da ignorância, e, mais, no de seu reconhecimento pelos seres humanos. Há uma passagem contada por Platão bastante ilustrativa deste argumento: o dilema de Sócrates perante o Oráculo de Delfos.

A história é a seguinte: na Grégia antiga, os Oráculos eram locais sagrados onde habitavam os deuses, e onde os mortais se consultavam e recebiam explicações que eram consideradas verdades absolutas. O Oráculo de Delfos era um local especialmente consagrado ao Deus Apolo. No julgamento de Sócrates, uma das acusações que pesava contra ele era a de arrogar-se o mais sábio dos homens, o que havia despertado o ódio e a vaidade de muitos políticos, poetas e intelectuais da época.

Ele dizia ter refutado tal condição, mas enfrentado uma situação embaraçosa, pois o Oráculo de Delfos havia dito a Xenofonte, seu primo, que não havia homem mais sábio do que Sócrates, e, se era verdadeira a sua ignorância, igualmente verídica era a premissa da infalibidade das respostas oraculares ${ }^{529}$.

Diante de tão intrincada questão, Sócrates respondeu com maestria ao conformar a sua ignorância à sapiência, assim destrinchando a arguciosa resposta do Oráculo: sua

\footnotetext{
${ }^{528}$ NIETZSCHE, Friedrich. O nascimento da tragédia ou Helenismo e Pessimismo. Trad., notas e posfácio de J. Guinsburg. São Paulo: Companhia das Letras, 1992, p. 110.

${ }_{529}$ A passagem ficou assim registrada: "Apresento-vos, de fato, o deus de Delfos como testemunha de minha sabedoria, se eu a tivesse, e qualquer que fosse. Conheceis bem Xenofonte. Era meu amigo desde jovem, também amigo do vosso partido democrático, e participou de vosso exílio e convosco repatriou-se. E sabeis também como era Xenofonte, veemente em tudo aquilo que empreendesse. Uma vez, de fato, indo a Delfos, ousou interrogar o oráculo a respeito disso e - não façais rumor, por isso que digo - perguntou-lhe, pois, se havia alguém mais sábio que eu. Ora, a pitonisa respondeu que não havia ninguém mais sábio. E a testemunha disso é seu irmão, que aqui está". (PLATÃO. Apologia de Sócrates: primeira parte: sócrates apresenta a sua defesa. Trad. Maria Lacerda de Souza. Cultvox. Disponível em: $\langle$ http://www.dominiopublico.gov.br/ download/texto/cv000065.pdf $>$. Acesso em: 18 abr. 2011)
} 
superioridade intelectual residia na consciência de sua ignorância, em não acreditar saber aquilo que não sabia ${ }^{530}$.

Talvez seja esse, também, o grande mérito da perda de uma chance "atípica": romper com a realidade mítica da onisciência da causalidade e, absorvendo a possibilidade da ignorância sobre o nexo causal em determinadas situações, levá-lo em conta na decisão. Não há como negar que a base estrutural da responsabilidade civil esteja fincada na determinação da etiologia, do mesmo modo como não se pode rechaçar a finitude do nosso saber sobre ela. Levá-las (ambas) em conta é demonstrar o saber socrático na decisão.

A escolha de excelência será sempre a determinação do nexo causal, em todas as vezes que for possível, de algum modo, firmá-lo com segurança. Porém, nas situações de ontológica dúvida, o "tudo ou nada” não é uma boa solução.

Fica evidente que "a teoria da perda de uma chance, nos casos em que o processo foi até o seu final, sempre deveria constituir-se em uma opção subsidiária, utilizada somente após esgotar as possibilidades de utilização ortodoxa do nexo causal" ${ }^{531}$, jamais pelo critério da maior facilidade ou simplicidade de seu estabelecimento ${ }^{532}$.

A doutrina italiana é profusa ao sustentar que a "perda de uma chance" é instrumento de facilitação de prova do nexo causal ${ }^{533} 534$, o que é um grave equívoco, que pode levar à rejeição da teoria, na medida em que implica erosão do sistema de responsabilidade civil.

\footnotetext{
${ }^{530}$ Conforme o testemunho de Platão, Sócrates teria dito: "Em verdade, ouvindo isso, pensei: que queria dizer o deus e qual é o sentido de suas palavras obscuras? Sei bem que não sou sábio, nem muito nem pouco: o que quer dizer, pois, afirmando que sou o mais sábio? Certo não mente, não é possível. E fiquei por muito tempo em dúvida sobre o que pudesse dizer; depois de grande fadiga resolvi buscar a significação do seguinte modo: Fui a um daqueles detentores da sabedoria, com a intenção de refutar, por meio dele, sem dúvida, o oráculo, e, com tais provas, opor-lhe a minha resposta: Este é mais sábio que eu, enquanto tu dizias que eu sou o mais sábio. Examinando esse tal: - não importa o nome, mas era, cidadãos atenienses, um dos políticos, este de quem eu experimentava essa impressão. - e falando com ele, afigurou-se-me que esse homem parecia sábio a muitos outros e principalmente a si mesmo, mas não era sábio. Procurei demonstrar-lhe que ele parecia sábio sem o ser. Daí me veio o ódio dele e de muitos dos presentes. Então, pus-me a considerar, de mim para mim, que eu sou mais sábio do que esse homem, pois que, ao contrário, nenhum de nós sabe nada de belo e bom, mas aquele homem acredita saber alguma coisa, sem sabê-la, enquanto eu, como não sei nada, também estou certo de não saber. Parece, pois, que eu seja mais sábio do que ele nisso, ainda que seja pouca coisa: não acredito saber aquilo que não sei”. (Idem)

${ }^{531}$ SILVA, Rafael Peteffi, op. cit., p. 251.

${ }^{532}$ Como, aparentemente, sugeriu Renato Duarte Franco Moraes: "Mais simples do que tentar estabelecer relação direta entre a conduta dos ofensores e o resultado final danoso é vincular o comportamento ilícito à perda da chance de se obter um benefício ou evitar um prejuízo. Ao invés de realizar a difícil tarefa de suscitar conexão entre a negligência do profissional com a perda da ação judicial ou com a ausência de cura, é melhor vincular a conduta ilícita com a perda da chance de se obter o resultado positivo ou de se evitar o negativo". (MORAES, Renato Duarte Franco de. A moldura jurídica da "perda de chance". Valor Econômico, São Paulo, 12 jan. 2011. Legislação \& tributos, Caderno E, p. 2)

533 “(...) la chance viene utilizzata per facilitare la prova del nesso causale tra condota (inadimpiente o ilecita) e danno (perdita del bene giurido finale), alleggerendo l'onere probatorio del danneggiato nei casi
} 
Na perda de uma chance "típica", o liame causal é estabelecido à perfeição entre o ato ilícito e o dano da usurpação da oportunidade. Já na perda de uma chance "atípica", dissipadas todas as possibilidades de se resolver a questão por meio da determinação do nexo etiológico e, sabendo que o ato ilícito pode ter contribuído para a causação, procurase reparar o dano a partir da fixação do percentual de probabilidades que o ato do ofensor concorreu para a ocorrência do prejuízo.

Esta é a principal razão da escolha da nomenclatura: na perda de uma chance "típica", a álea é ontológica (jamais se pode saber se o jóquei venceria o páreo do qual foi obstado de participar), ao passo que na atípica ela é circunstancial (no caso, é impossível estabelecer o nexo causal entre o erro de diagnóstico e a morte do paciente).

Mais uma vez, o direito inglês possui um exemplo interessante, qual seja, o caso Hotson v. East Berkshire Area Health Authority [1987] AC 750, em que o garoto Hotson quebrou os quadris quando caiu de uma árvore. A junta dos quadris estava irremediavelmente danificada pela perda de sangue em sua cartilagem. O juiz descobriu que a ruptura de vasos sanguíneos causada pela queda provavelmente tornou o dano inevitável, mas que havia uma chance de $25 \%$ (vinte e cinco por cento) de que vasos sanguíneos suficientes tivessem permanecido intactos, a fim de evitar a necrose, desde que a fratura fosse diagnosticada a tempo. A Corte de Apelação concedeu danos pela perda da chance de $25 \%$ (vinte e cinco por cento) de obter um resultado melhor.

A Câmara dos Lordes, entretanto, unanimemente reverteu a decisão porque, na instrução do processo, descobriu-se que nada poderia ter sido feito para salvá-lo, ou seja, ele não perdeu chance alguma ${ }^{535}$. No caso concreto, o resultado foi determinado pelo que

in cui questo risulti di difficile raggiungimento". (GUALANO, Tommaso. Perdita di chance. In: VETOORI, Giuseppe (Org.). Il danno risarcible. Milão: Cedam, 2004, v. 1, p. 124).

534 "Altra dottrina di recente sostiene che 'la chance perduta costituisce in definitiva un escamotage, di cui si avvale l'interprete per più facilmente individuare e graduare il quantum risarcitorio da infliggere a chi col suo comportamento non si è uniformato ai principi della correttezza e della lealtà e che per questo deve essere sanzionato'” . (D'APOLLO, Luca, op. cit.)

${ }^{535}$ Tony Weir, em seu comentário, deixa claro que a decisão da Câmara dos Lordes se baseou no fato de que não restaram, após a queda, vasos sanguíneos intactos suficientes para a recuperação. Portanto, não foi considerada a questão da chance inferior a $50 \%$, pois o garoto Hotson não perdera chance alguma com o atraso no diagnóstico: "On appeal by the defendants to the House of Lords, the decision was unanimously reversed. Does this mean that the House disagreed with the view of the Court of Appeal that the loss of a less-than-even chance of recovery was harm sufficient to establhish a cause of action in negligence? Not on the face of it. The House said that the question did not arise at all. 'Much of the judgement of the Court of Appeal Will remain for consideration in the future'. The only question was one of fact, whether there were enough blood vessels intact at the time of the first visit to the hospital immediately after the accident. They found the judge to have concluded that there were not, as he said in terms that thought it was possible that there were not. Accordingly, the plaintiff had no chance of recovery at that time, no chance to lose, therefore 
ocorreu quando ele caiu da árvore. Nessa situação, em que é possível, em tese, determinar a existência ou não do liame de causalidade, recorrer à perda de uma chance é um erro imperdoável.

Helen Reece explica a diferença entre Chaplin (ver item 1.2 do capítulo 1) e Hotson a partir do conceito de eventos determinísticos e indeterminísticos, chegando à conclusão de que Hotson era determinístico, pois houvera, no passado, um tempo em que seria humanamente possível determinar a causa da necrose (logo após a queda da árvore $)^{536}$. Por tal razão, na ocasião do julgamento a causa podia ser incerta, mas esta incerteza não era epistemologicamente objetiva ${ }^{537}$.

Deve-se aquiescer, com ressalvas, a explanação de Helen Reece. Primeiramente, esclareça-se que a divisão entre eventos determinísticos e indeterminísticos pertence a uma categoria que só cabe no mundo abstrato. No mundo fenomênico, todo evento é, por natureza, certo ou determinado, ele acontecerá ou não acontecerá, existiu ou não existiu ${ }^{538}$.

no chance lost throughthe defendants misdiagnosis". (WEIR, Tony. Loss of a chance - Compensable in tort? The common law. In: GUILLOD, Olivier. Développements recents du droit de la responsabilité civile. Zurique: Schultess Polygraphischer Verlag Zürich, p. 118-119)

${ }^{536}$ Foram estas as suas asserções para justificar que Hotson era um caso determinístico: “That Hotson was a deterministic case becomes clear when we look at the medical facts a little more closely. Avascular necrosis develops if and only if insufficient blood vessels are left intact to keep the epiphysis alive. The trial judge found that it was likely (to a degree of 75 per cent) that insufficient vessels were left intact after the fall, so that necrosis would have been bound to develop; but that if, on the contrary, there were enough vessels left, then the delay would have made the onset of necrosis inevitable, because the pressure caused by the bruising (haematoma) or bleeding (haematosis) of ruptured blood vessels would have compressed and blocked the intact vessels, rendering them ineffective. The evidence was that necrosis could only have been caused in one of these two ways.34 Therefore, there was a time in the past when the cause of the necrosis could have been determined. If the blood vessels had been examined after the fall, then it would have been humanly possible to decide whether or not the plaintiff would develop necrosis even if he were treated. At the time of the trial the cause was uncertain, but the uncertainty was epistemological not objective. If Hotson is a case where the necrosis was fully determined by the events which occurred, then any expressions of probability must be of epistemological degrees of belief in the proposition that the failure to treat caused the necrosis".(REECE, Helen. Losses of chance in the Law. The modern Law review, Oxford, v. 59, n. 2, p. 188-206, mar. 1996, p. 195-196)

${ }^{537} \mathrm{O}$ artigo de Helen Reece tem como mote os casos Chaplin e Hotson porque, a partir deles, a autora busca justificar a suposta "incoerência" no fato de a Câmara dos Lordes ter concedido indenização à primeira, embora tivesse apenas $25 \%$ (vinte e cinco por cento) de chances de vencer o concurso, e não ter concedido ao segundo, embora houvesse a crença de que as chances de cura eram as mesmas. Embora não caiba alongar-se na explicação feita pela autora, diante do corte metodológico a que se propôs neste trabalho, salienta-se, apenas, que ela parte da distinção entre eventos determinísticos e indeterminísticos (com o que se concorda, com restrições), para justificar, em seguida, a razão de a Corte ter exigido ter seguido trilhas distintas nos casos Hotson e Chaplin. (Idem)

${ }^{538}$ Esta é a firme objeção que Joseph King Jr. fez ao voto do Lord Ackner quando, ao distinguir Chaplin v. Hicks (vide item 1.2 do capítulo 1) de Hotson v. v East Berkshire Area Health Authority, adotou a distinção entre eventos determinados e indeterminados, para dizer que, a rigor, todas as situações são, essencialmente, determináveis: "Presumably, if one accepts predestination or determinism, the outcome in both situations was preordained. The problem in both instances is one of imperfect or limited knowledge. As leading historical figures in mathematics have maintained, '[P]robabilities measure human ignorance, not genuine chance'.Thus, probabilities have been characterized as 'states of mind rather than states of the world, the 
O que qualificamos de incerto nada mais é do que a finitude do nosso conhecimento, ou, segundo os dizeres de Jules Henri Poincaré, “a medida de nossa ignorância”" 539.

São duas as espécies de incógnitos em que a álea atua: a primeira, quando a ignorância atinge a cadeia causal que tem como consequência o efeito, ou seja, o desconhecido reside no saber nomológico, ou seja, sobre as leis da natureza que regem o evento (v.g., a probabilidade de chuva em determinado dia e local); a segunda, pertecente ao saber ontológico, por conta de uma ignorância fática sobre um ou mais dados da realidade, apesar da possibilidade tecnológica de conhecer todos eles (v.g., a probabilidade de uma equipe, desclassificada de uma competição esportiva, tê-la vencido, não fosse a desqualificação) ${ }^{540}$.

Dessa feita, a sistematização dos eventos em "determinísticos" e "indeterminísticos" deve ser acatada sob a compreensão de que são diferenças concernentes apenas à imperfeição do conhecimento humano, que devem, na medida do possível, ser superadas, com a busca exaustiva de elementos cognoscíveis, para, somente na impossibilidade, dar azo aos critérios jurídicos ora expostos para o enfrentamento da aleatoriedade.

Em Gregg v. Scott, a Baronesa Hale of Richmond fez uma analogia interessante com o jogo de "cara ou coroa", para sustentar o porquê de se optar, no caso concreto, pela investigação da existência de algum nexo etiológico. Disse ela que, quando as partes fazem as apostas e a moeda é arremessada ao ar, há uma probabilidade de 50\% de que o resultado seja um ou outro. Porém, a partir do momento em que a moeda cai, não há subterfúgios: deu cara, ou coroa. O juiz que opta por não olhar para a moeda, tendo condições de fazê-lo, comete um ato de injustiça. Mas a própria Baronesa afirma que deve haver muitos casos

makeshift tools of intellects too feeble to penetrate immediately to the real nature of things. 'According to this deterministic view, 'necessary causes, however hidden, govern (...) all events.'” (KING JR., Joseph H. "Reduction of likelihood" reformulation and other retrofitting of the loss-of-a-chance doctrine. Memphis Law Review, winter, 1998. Disponível em: <http://findarticles.com/p/articles/mi_qa3843/is 199801/ ai_n8788962/>. Acesso em: 14 abr. 2011.)

${ }^{539}$ POINCARÉ, Henri Jules. Calcul des Probabilités. 2. ed. Paris: Gauthier-Villars, 1987, p. 3.

${ }^{540}$ É o que afirma Daniel Amaral Carnaúba: "São duas as espécies de incógnito que podem dar ensejo à aleatoriedade: em alguns casos, a ignorância atinge uma ou mais regras causais que determinam o evento em questão, hipótese na qual o incógnito é algo inerente ao estado da ciência. Trata-se de uma lacuna do saber nomológico, relativo ao conhecimento das leis da natureza que regem aquele fato judicioso. Em outros casos, a álea é fruto de uma ignorância fática. Não obstante a aptidão tecnológica para compreender todas as leis causais que regem uma determinada situação, a aplicação de tais regras ao caso concreto mostra-se impossível, pois um ou mais dados da realidade são ignorados. Nesta segunda hipótese, o desconhecido atinge o saber ontológico, tornando imperfeita a descrição do fenômeno analisado". (CARNAÚBA, Daniel Amaral, op. cit., p. 7) 
em que a moeda ainda está no ar e é retirada antes que seja possível saber qualquer seria o resultado. Para todos estes, a perda de uma chance pode ser uma solução ${ }^{541}$.

Portanto, não se pode desprezar tão valioso recurso, mesmo na perda de uma chance "atípica", pois ela parte de uma realidade ontológica inexorável, que é a limitação do conhecimento humano.

${ }^{541}$ Suas precisas palavras foram as seguintes: "211. The House of Lords treated this as a case in which the die was already cast by the time the claimant got to the hospital (or at least the claimant could not prove otherwise). The defendant had not even caused the loss of the chance of saving the situation, because by the time the claimant got to them there was no chance. The coin had already been tossed, and had come down heads or tails. But there must be many cases in which that is not so. The coin is in the air. The claimant does have a chance of a favorable outcome which chance is wiped out or significantly reduced by the negligence. The coin is whipped out of the air before it has been able to land." (INGLATERRA. Câmara dos Lordes, Sessão 2004-5 [2005]. Apelação [2002] EWCA. Civ. 1471. Disponível em: <http://www.publications.parliament.uk/pa/ld200405/ldjudgmt/jd050127/greg-8.htm〉. Acesso em: 27 jan. 2011.) 


\section{CAPÍtUlO 5 - A PERDA DE UMA CHANCE NO DIREITO DO TRABALHO}

\subsection{Cabimento}

Do ponto de vista fenomênico, a relação de trabalho constitui um dos ramos mais propícios à ocorrência de perda de chances, em suas diversas facetas. Há dados históricos a comprovar essa assertiva. A França e a Itália, provavelmente os países de tradição germânico-romana mais destacados na aplicação da teoria, reconhecem a sua importância na consolidação da teoria das oportunidades perdidas, o que reforça a vocação expansionista do Direito do Trabalho ${ }^{542}$.

De acordo com o que se consignou na introdução deste estudo, Geneviève Viney já constatara, no início da década de $1980^{543}$, que eram os acórdãos sobre a perda de uma chance de obter vantagens profissionais os mais numerosos, e que os tribunais proferiram, na época, decisões favoráveis à indenização em casos de perda da oportunidade de se apresentar em um concurso, assim como de perda da esperança de empreender uma atividade remunerada, iniciar uma carreira profissional ou de obter um emprego com melhores salários.

Na Itália, atribui-se à jurisprudência trabalhista o mérito de, hoje, depois de várias hesitações protelatórias, a perda de uma chance encontrar plena afirmação no mundo jurídico e, em particular, no âmbito da tutela reparatória ${ }^{544}$. Aliás, pode-se afirmar que, conforme relatado na parte histórica, o protagonismo na aplicação da teoria na Corte de Cassação italiana deu-se em demandas trabalhistas, na fase pré-contratual, em que

\footnotetext{
542 Acerca dessa vocação, leciona Maria do Rosário Palma Ramalho: "Pela sua vocação protectiva tradicional, o Direito do Trabalho é ainda de caracterizar como uma área jurídica de vocação expansionista, porque sempre procurou estender o âmbito de sua tutela para além das suas fronteiras originárias, porque exportou alguns dos seus institutos para outras áreas jurídicas e, finalmente, porque influenciou o próprio Direito Civil, que constituiu o seu berço originário”. (RAMALHO, Maria do Rosário Palma. Direito do Trabalho: parte I - dogmática Geral. 2. ed. Actualizada ao Código do Trabalho de 2009. v. I, Coimbra: Almedina, 2009, p. 123)

${ }^{543}$ VINEY, Gineviève. Traité de Droit Civil. Sous la direction de Jacques Ghestin. Les obligations. La responsabilité: conditions. Paris: L.G.D.J: 1982, p. 343-345.

544 "É merito soprattutto della giurisprudenza giuslavoristica se oggi, dopo vari tentennamenti protrattisi nel tempo, la perdita di chance ha trovato piena cittadinanza nel mondo giuridico $e$, in particolare, nell'ambito della tutela risarcitoria”. (MANGIATORDI, Maria. La perdita di chance non è una mera aspettativa. Rivista giuridica telemática di Diritto dei Lavori, Bari, n. 2, p. 113-127, 2007, p. 120. Disponível em: <http://www.dirittodeilavori.it/n2-07/perdita-chance.pdf> Acesso em: 08 abr. 2011)
} 
determinados candidatos à vaga de motorista de uma empresa, após aprovados nos exames preliminares, foram obstados de participar das fases subsequentes do concurso (provas de cultura elementar e direção).

No Brasil, a doutrina aponta para o pioneirismo gaúcho na aplicação da teoria, e especula que o motivo pode ter sido uma conferência ocorrida nos pampas riograndenses no início da década de 1990, proferida pelo professor François Chabas.

A doutrina pátria, especializada no ramo trabalhista, logo passou, ainda que de maneira tímida, a vislumbrar a aplicação da teoria da perda de uma chance na seara laboral. Raimundo Simão de Melo vaticinou que "nas relações de trabalho, a teoria da responsabilidade pela perda de chances encontra campo fértil, assim como vem ocorrendo no tocante às indenizações por dano moral 'lato sensu'",545.

Como visto ao longo de todo este arrazoado, a perda de uma chance constitui importante ferramenta da responsabilidade civil, capaz de aprimorar as formas de reparação do dano injusto ${ }^{546} \mathrm{e}$, com isso, requintar também a relação entre capital e trabalho, de modo a fomentar a "melhoria da condição social do trabalhador" 547548 (CF, art. $7^{\circ}$, caput $)^{549}$, realçando o princípio constitucional da "dignidade da pessoa humana" $\left(\mathrm{CF}, \text { art. } 1^{\circ}, \mathrm{III}\right)^{550551}$, considerado o "epicentro de todo o ordenamento jurídico"

\footnotetext{
${ }^{545}$ MELO, Raimundo Simão de, op. cit..

546 “O direito brasileiro, neste início do terceiro milênio, tem a vocação para a imposição da obrigação de indenizar, reparar ou compensar os danos injustos causados a bem material ou imaterial de pessoa inocente, que não deu causa ao fato, com ou sem culpa provada, conforme relata o direito positivo vigente". (SILVA, Roberto de Abreu e. A teoria da perda de uma chance em sede de responsabilidade civil. Revista da EMERJ, Rio de Janeiro, v. 9, n. 36, p. 24, p. 24-49, out./dez. 2006).

${ }^{547}$ Considerado o valor teleologicamente essencial ao Direito do Trabalho, consoante a doutrina: "De fato, o ramo 'justrabalhista' incorpora, no conjunto de suas regras, princípios e institutos um valor finalístico essencial, que marca a direção de todo o sistema jurídico que compõe. Este valor - e a consequente direção teleológica imprimida a este ramo jurídico especializado - consiste na 'melhoria das condições de pactuação da força de trabalho' na ordem socioeconômica. Sem tal valor e direção finalística, o Direito do Trabalho sequer se compreenderia, historicamente, e sequer se justificaria, socialmente, deixando, pois, de cumprir sua função principal na sociedade contemporânea". (DELGADO, Mauricio Godinho. Princípios de Direito Individual e Coletivo do Trabalho. 3. ed. São Paulo: LTr, 2010, p. 58)

${ }^{548}$ Sem descurar que, conforme se verá ao longo deste capítulo, a perda de uma chance no Direito do Trabalho é uma "via de mão dúplice", embora a realidade jurisprudencial confirme que a hipótese de o empregado fazer o empregador perder oportunidades seja bem mais rara, porém, longe de ser impossível.

549 BRASIL. Constituição (1988). Constituição da República Federativa do Brasil. 16. ed. São Paulo: RT, 2011.

${ }^{550}$ Idem.

${ }^{551}$ Nessa linha de raciocínio, sustenta Roberto de Abreu e Silva: “A teoria da perda de uma chance no direito brasileiro é de aplicação na solução justa da demanda à luz do princípio democrático do direito e de respeito à dignidade da pessoa humana e de seus bens protegidos pela ordem jurídica. Essa teoria afigura-se inteligível em seus próprios termos". (Op. cit, p. 37)

${ }^{552}$ FLÓREZ-VALDÉZ, Joaquim Arce y. Los princípios generales del derecho y su formulación constitucional. Madri: Civitas, 1990, p. 149.
} 
Dignidade esta que, conforme assentado pelo Tribunal Constitucional da Espanha, está intimamente relacionada ao próprio direito à vida, como o germe de todos os que lhe são inerentes, pois os direitos fundamentais são componentes estruturais básicos que traduzem a expressão jurídica de um sistema de valores que, por decisão do legislador constituinte, informam o conjunto de organização jurídica e política, e constituem o fundamento da ordem jurídica e da paz social ${ }^{553} 554$.

Esses "direitos fundamentais" irradiam reflexos para a relação de trabalho, inexoravelmente, até porque não haveria como blindá-la do contexto das relações sociais, como se, ao adentrar na fábrica, o trabalhador perdesse sua condição, ontologicamente irrefragável, de destinatário de um feixe de garantias que constituem o patamar mínimo civilizatório. Sobre o tema, o incisivo escólio de Marly A. Cardone ${ }^{555}$ :

Nas relações que as pessoas travam na vida, elas podem, voluntariamente ou não, causar prejuízos às outras. A relação humana e jurídica que liga empregado e empregador não é suscetível de escapar desta contingência. Isto é tão irrefutável quanto dizer que o ser humano é passível de errar. Por isso, causa espanto que alguns queiram isolar empregado e empregador deste círculo no qual está inserida toda a prática de atos ilícitos. A relação de emprego tem uma disciplina jurídica para a troca

\footnotetext{
${ }^{553}$ Salientando o valor da dignidade, a sentença do Tribunal Constitucional da Espanha: “1. El derecho a la vida, reconocido y garantizado en su doble significación física y moral por el art. 15 de la C.E. es la proyección de un valor superior del ordenamiento jurídico constitucional -la vida humana- y constituye el derecho fundamental esencial y troncal en cuanto es el supuesto ontológico sin el que los restantes derechos no tendrían existencia posible. 2. Indisolublemente relacionado con el derecho a la vida en su dimensión humana se encuentra el valor jurídico fundamental de la dignidad de la persona, reconocido en el art. 10 como germen o núcleo de unos derechos «que le son inherentes». 3. Los derechos fundamentales no incluyen solamente derechos subjetivos de defensa de los individuos frente al Estado y garantías institucionales, sino también deberes positivos por parte de éste (véanse al respecto arts. 9.2, 17.4, 18.1 y 4; 20.3 y 27 de la Constitución). 4. Los derechos fundamentales son los componentes estructurales básicos, tanto del conjunto del orden jurídico objetivo como de cada una de las ramas que lo integran, en razón de que son la expresión jurídica de un sistema de valores que, por decisión del constituyente, ha de informar el conjunto de la organización jurídica y política; son, como dice el art. 10 de la C.E., el «fundamento del orden jurídico y de la paz social" " [...]. (ESPANHA. Tribunal Constitucional, Pleno. Recurso prévio de inconstitucionalidade. Sentença 53/1985. Publicado em 18 de maio de 1985. Disponível em: < http://www.boe.es/aeboe/consultas/bases_datos/doc.php?coleccion=tc\&id=SENTENCIA-1985-0053>.

Acesso em: 4 abr. 2011. Sem grifo no original)

${ }^{554}$ No mesmo diapasão, consta do início do preâmbulo da Declaração dos Direitos Universais do Homem a seguinte consideração: "Considerando que o reconhecimento da dignidade inerente a todos os membros da família humana e de seus direitos iguais e inalienáveis é o fundamento da liberdade, da justiça e da paz no mundo [...];”. (DECLARAÇÃO DOS DIREITOS UNIVERSAIS DO HOMEM. Disponível em: $<$ http://www.onu-brasil.org.br/documentos direitoshumanos.php >. Acesso em: 03 abr. 2011.)

${ }^{555}$ CARDONE, Marly A. A Responsabilidade Civil no Direito do Trabalho. Repertório IOB de Jurisprudência, p. 322, Set.1993.
} 
trabalho x remuneração, mas seus sujeitos não estão excluídos da órbita do Direito Civil quando praticam atos ou fatos da natureza civil na específica situação de empregado e empregador.

E não haveria espaço para ser diferente, pois o artigo VI da Declaração dos Direitos Universais do Homem estabelece que: "Todo ser humano tem o direito de ser, em todos os lugares, reconhecido como pessoa perante a lei ${ }^{556 ”}$. E, mais à frente, o emblemático documento destaca que o trabalho remunerado com justiça constitui um dos componentes da dignidade humana ${ }^{557}$.

Irani Ferrari e Melchíades Rodrigues Martins chegam ao ponto de denominar "sagrados" os direitos fundamentais dos trabalhadores, e apontar, como consequência, a repulsa às linhas de conduta aptas a ofender diversos desses direitos ${ }^{558}$.

Mauricio Godinho Delgado, por sua vez, assinala que a ideia de dignidade não mais se restringe ao âmbito particular dos valores imanentes à personalidade e que não se projetam socialmente, mas sim na afirmação social do ser humano, para a qual desponta a necessidade do trabalho juridicamente tutelado sob a forma de emprego ${ }^{559}$.

\footnotetext{
${ }^{556}$ DECLARAÇÃO DOS DIREITOS UNIVERSAIS DO HOMEM. Disponível em: < http://www.onubrasil.org.br/documentos_direitoshumanos.php>. Acesso em: 3 abr. 2011.

557 “Artigo XXIII. 3. Todo ser humano que trabalha tem direito a uma remuneração justa e satisfatória, que lhe assegure, assim como à sua família, uma existência compatível com a dignidade humana e a que se acrescentarão, se necessário, outros meios de proteção social". (Idem)

558 O comentário é assim desenvolvido: "Voltados esses direitos para o trabalhador, têm-se que, na atualidade, ele não é mais um simples operário que oferece o seu labor sem qualquer proteção quanto a sua dignidade e seus direitos ligados à personalidade. Ao contrário, quando passa à condição de trabalhador, a sua dignidade e os seus direitos personalíssimos são protegidos pela ordem jurídica ante a possibilidade de uma reparação pelo ofensor em caso de lesão a tão sagrados direitos. É importante assinalar que o trabalhador é, acima de tudo, uma pessoa, não perdendo essa qualidade por entrar na porta da empresa e, nessa medida, o direito à dignidade que é inerente à pessoa humana acompanha-o onde quer que se encontre e, portanto, também quando está a trabalhar. Esta concepção tem como consequência direta o repúdio por linhas de conduta aptas a ofenderem diversos direitos, avultando entre eles o direito à dignidade e o direito à integridade física e moral, particularmente quando é patente que o sujeito passivo se encontra numa situação de vulnerabilidade, desde logo porque inserido numa organização alheia”. (FERRARI, Irani; MARTINS, Melchíades Rodrigues. Dano moral: múltiplos aspectos nas relações de trabalho. 4. ed. São Paulo: LTr, 2011, p. 17)

${ }^{559}$ É dele o seguinte argumento: "Tudo isso significa que a ideia de dignidade não se reduz, hoje, a uma dimensão estritamente particular, atada a valores imanentes à personalidade e que não se projetam socialmente. Ao contrário, o que se concebe inerente à dignidade da pessoa humana também, ao lado dessa dimensão estritamente privada de valores, é a 'afirmação social do ser humano'. Conforme já dito, a dignidade da pessoa fica, pois, lesada caso ela se encontre em uma situação de completa privação de instrumentos de mínima afirmação social. Isso porque na qualidade de ser necessariamente integrante de uma comunidade, o indivíduo tem assegurado por este princípio não apenas a intangibilidade de valores individuais básicos, como também um mínimo de possibilidade de afirmação no plano social circundante. Na medida desta afirmação social é que desponta o 'trabalho', notadamente o 'trabalho regulado', em sua modalidade mais bem elaborada, o "emprego"”. (DELGADO, Mauricio Godinho, op. cit., p. 40)
} 
Portanto, a teoria da perda de uma chance vem ao encontro da predestinação teleológica da legislação trabalhista, que é de oferecer maior tutela aos trabalhadores subordinados, ou seja, a doutrina coaduna-se com a vocação finalisticamente determinada de intervenção legislativa em prol do pólo mais frágil da relação laboral ${ }^{560}$.

\subsection{Omissão e compatibilidade da CLT}

Hodiernamente, é quase consensual, no meio acadêmico, a autonomia científica do "Direito do Trabalho" "561 - enquanto "parte" do "todo" orgânico que é o Direito -, patamar adquirido por ser uma disciplina suficientemente ampla para merecer um estudo peculiar, conter doutrinas homogêneas dominadas por conceitos gerais comuns e, finalmente, por possuir metodologia própria ${ }^{562}$.

Contudo, essa propalada "autonomia" não significa independência, tampouco ruptura com o restante do organismo jurídico, até mesmo diante da impossibilidade de separá-lo em "compartimentos estanques". Naturalmente, a "seiva comum" que abastece todas as ramificações da ciência jurídica provém da mesma fonte ${ }^{563}$, embora cada uma delas possa,

\footnotetext{
560 No direito português, essa é a conclusão de Maria do Rosário Palma Ramalho: “Animada pela necessidade de fazer face à 'questão social', a intervenção normativa dos Estados no domínio laboral, em qualquer das suas áreas regulativas, é bastante pragmática: trata-se, por um lado, de uma intervenção assumidamente em favor do trabalhador, reconhecido como parte mais fraca do vínculo laboral; e trata-se, de outra parte, de uma intervenção em moldes imperativos, única forma de coartar efectivamente a liberdade do empregador na fixação do conteúdo do contrato de trabalho. (...) Perante o quadro exposto e em face dos valores em jogo, ressalta, como traço unificador de todo o Direito do Trabalho, desde a sua origem, o 'objectivo de tutela dos trabalhadores subordinados' - neste sentido, pode-se dizer que o Direito Laboral é um ramo jurídico finalisticamente determinado. Por outro lado, este determinismo inicial torna compreensível a tradicional fisionomia classista desta área jurídica: dito de outra forma, na sua origem, o Direito do Trabalho foi, sobretudo, o 'direito dos trabalhadores'. Esta fisionomia classista da área jurídica é, aliás, expressamente reconhecida na doutrina, logo na designação do novo ramo jurídico como 'direito dos trabalhadores' ou 'direito do operariado'”. (RAMALHO, Maria do Rosário Palma, op. cit., p. 51-52)

${ }^{561}$ MORAES FILHO, Evaristo de; MORAES, Antonio Carlos Flores de. Introdução ao Direito do Trabalho. 7. ed. rev. e atual. São Paulo: LTr, 1995, p. 89.

${ }^{562}$ SÜSSEKIND, Arnaldo; MARANHÃO, Délio; VIANNA, Segadas. Participação de João de Lima Teixeira Filho. Instituições de Direito do Trabalho. 13. ed. São Paulo: LTr, 1993, v. I, p. 134-135.

${ }^{563}$ É esse o ensinamento de Evaristo Moraes Filho: "Em primeiro lugar, autonomia não quer significar, de modo algum, separação estanque, rompimento com o restante do corpo jurídico. Exprime meramente a mesma relação que existe entre autonomia dos Estados, com suas Constituições próprias, e a soberania da União. Embora o direito constitua uma ciência unitária, não há negar que um ramo jurídico consegue alcançar a sua autonomia quando atinge a maturidade, passando a gozar da liberdade de poder orientar-se por princípios próprios, com características de direito especial. Porque constituído para um fim especial, também especiais são os seus princípios, a sua doutrina, os seus desígnios, os seus métodos. A seiva comum vem da mesma fonte, mas cada ramo dirige-se para caminhos diferentes do espaço social, alcançando nova realidade, regulando certos tipos de relações, voltando, por isso mesmo, mais enriquecida ao tronco comum, ao qual
} 
a um só tempo, guardar orientação epistemológica que a distinga, e manter uma relação dialógica com as demais, propiciando a evolução conjunta do Direito.

Alexandre Agra Belmonte assevera que "autonomia de um ramo do Direito não significa desvinculação dentro de um sistema jurídico. O Direito do Trabalho tem por fim regular as relações jurídicas derivadas da prestação pessoal, subordinada, não eventual e assalariada de serviços, mas nem por isto deixa de se servir das normas gerais compatíveis do Direito Civil, subsidiariamente aplicáveis à Consolidação das Leis do Trabalho, quando omissa" ${ }^{, 564}$.

Já Arnaldo Süssekind aduz que, sem embargo do desprendimento do Direito Laboral em relação ao Direito Civil, "essa separação não pode ser absoluta por força da própria unidade orgânica do Direito. Demais disto, a importância indesmedível do Direito Civil e a amplitude do campo de ação que constitui o objeto de suas normas, tornam bastante fortes suas relações com todos os outros setores da enciclopédia jurídica ${ }^{565, "}$.

Desse modo, permanecem extremamente sólidas as relações entre o Direito do Trabalho e o Direito Civil, originariamente, de ordem histórica ${ }^{566}$, por ter o primeiro provindo do segundo ${ }^{567}$; e, atualmente, de imbricação reforçada diante dos princípios da eticidade, operabilidade e socialidade ${ }^{568}$, que informam o Código Civil brasileiro de 2002.

ajuda a alimentar-se e a manter-se vivo". (MORAES FILHO, Evaristo de; MORAES, Antonio Carlos Flores de, op. cit., p. 89)

${ }^{564}$ BELMONTE, Alexandre Agra, op. cit., VII.

565 SÜSSEKIND, Arnaldo; MARANHÃO, Délio; VIANNA, Segadas. Participação de João de Lima Teixeira Filho. op. cit., p. 141.

${ }^{566}$ Como ensinam Gomes e Gottschalk: "Com o Direito Civil está a nova disciplina vinculada, desde o berço, pela razão óbvia de que foi, através de uma longa evolução, a 'locatio operarum' romana que deu origem histórica ao moderno contrato de trabalho. Os Códigos Civis, que seguiram a orientação do Código de Napoleão assimilaram a noção romanística da 'locatio' com o instituto da locação de serviços. O nosso Código Civil, de 1916, abriu um capítulo sobre a locação de serviços, tratando-a segundo as regras tradicionais. Foi no Direito Civil, malgrado às modificações introduzidas no conceito da locação de serviço, que o novo direito se abeberou para haurir as noções fundamentais da teoria geral das obrigações, as regras sobre a capacidade das pessoas, as nulidades, os vícios de consentimento, a vigência da lei no tempo e no espaço, a interpretação e a aplicação da lei, entre outras". (GOMES, Orlando; GOTTSCHALK, Élson. Curso de Direito do Trabalho. 14. ed. rev. e atual. Rio de Janeiro: Forense, 1997, p. 28)

567 Amauri Mascaro Nascimento arrola outros desdobramentos das relações entre as duas ciências: "As relações entre o direito do trabalho e o direito civil são inicialmente, de ordem 'histórica', pois o direito do trabalho provém do direito civil; depois de ordem 'doutrinária', porque não são poucas as teses e as figuras do direito civil desenvolvidas e adaptadas pelo direito do trabalho, como ocorre na parte geral, nas obrigações, nas coisas etc.; a seguir de ordem 'legislativa', porque o direito civil é fonte subsidiária do direito do trabalho, existindo no Brasil, inclusive, expressa determinação nesse sentido". (NASCIMENTO, Amauri Mascaro. Curso de Direito do Trabalho. 15. ed., rev. e atual. São Paulo: Saraiva, 1998, 168)

${ }^{568}$ REALE, Miguel. O projeto do novo Código Civil. 2. ed. reform. e atual. São Paulo: Saraiva, 1999. 
E o legislador celetista, preocupado com a constante interseção entre o Direito do Trabalho e suas fontes, criou regra de Direito Hermenêutico ${ }^{569}$, ao estabelecer, no artigo $8^{\circ}$ da $\mathrm{CLT}^{570}$, um comando extremamente elástico de diálogo com os demais mananciais de integração da norma jurídica. Homero Batista Mateus da Silva, ao comentar a abertura contida no artigo $8^{\circ}$ da CLT (embora, especificamente, em alusão ao direito comparado), afirmou que "a autorização do art. $8^{\circ}$ da CLT representa um bálsamo para o direito do trabalho, uma espécie de canal permanente de comunicação com os demais ordenamentos preocupados com a disciplina, sem o constrangimento de o julgado parecer uma carta de princípios ou um postulado de solução legislativa ${ }^{571 "}$ "

Já o parágrafo único do art. $8^{\circ}$ da CLT $^{572}$ delega ao direito comum um caráter supletivo $^{573}$, a ser utilizado somente naquilo que não for incompatível com os princípios fundamentais de Direito do Trabalho.

Mauricio Godinho Delgado assinala que o Direito Civil é aplicado em situações de lacuna nas fontes principais do ordenamento jurídico ${ }^{574}$, o que se justifica plenamente, pois “o próprio legislador celetista, sabedor da incompletude intrínseca de seu texto, nele insculpiu cláusula de abertura à utilização do direito comum - dentre outros instrumentos como fonte subsidiária, de modo à colmatar suas eventuais lacunas (CLT, art. $\left.8^{\circ}\right)^{575,}$.

\footnotetext{
${ }^{569}$ Consoante os dizeres de Russomano: "Se atentarmos para a legislação brasileira sobre fontes secundárias do Direito do Trabalho, encontraremos um dispositivo que chama a atenção por sua admirável (quiçá excessiva) amplitude, no sentido de nele abarcar - como não ocorreu em nenhum outro momento legislativo, em nosso país - quase todas as modalidades de fontes formais indiretas. Referimo-nos ao art. $8^{\circ}$, da Consolidação. Em sua estrutura mais profunda, esse dispositivo estabelece norma de Direito Hermenêutico, fixando critério para a conduta do Juiz do Trabalho e, inclusive, das autoridades administrativas encarregadas de assuntos trabalhistas". (RUSSOMANO, Mozart Victor. Curso de Direito do Trabalho. 9. ed. rev. e atual. Curitiba: Juruá, 2003, p. 57)

570 "Art. $8^{\circ}$. As autoridades administrativas e a Justiça do Trabalho, na falta de disposições legais ou contratuais, decidirão, conforme o caso, pela jurisprudência, por analogia, por equidade e outros princípios e normas gerais de direito, principalmente do direito do trabalho e, ainda, de acordo com os usos e costumes, o direito comparado, mas sempre de maneira que nenhum interesse de classe ou particular prevaleça sobre o interesse público". (BRASIL. Consolidação das Leis do Trabalho (1943). CLT e Constituição Federal. 38. ed. São Paulo: Saraiva, 2011)

571 SILVA, Homero Mateus Batista da. Curso de Direito do Trabalho Aplicado: parte geral. Rio de Janeiro: Elsevier, 2009, v. 1, p. 217.

572 “Art. $8^{\circ}$. Parágrafo único. O direito comum será fonte subsidiária do direito do trabalho, naquilo em que não for incompatível com os princípios fundamentais deste”. (Idem)

${ }^{573}$ Consoante as lições de Gomes e Gottschalk: "O particularismo do Direito do Trabalho conduz o intérprte a deixar ao direito comum, apenas um lugar secundário, ou, como se expressa a Consolidação, naquilo em que não for incompatível com os princípios fundamentais deste". (GOMES, Orlando; GOTTSCHALK, Elson, op. cit., p. 33)

${ }^{574}$ DELGADO, Mauricio Godinho. Curso de Direito do Trabalho. 8. ed. São Paulo: LTr, 2009, p. 75.

575 HIGA, Flávio da Costa. Abuso do Direito na Relação de Emprego: uma visão teórico-sistêmica. Revista Científica Virtual da ESA/OAB-SP. Direito e Processo do Trabalho, São Paulo, ano 2, n. 4, Out.2010.
} 
Octávio Bueno Magano oferece outro ponto de vista, acenando para a referência histórica ao Direito Comum como um símbolo da recusa à ideia de "cavar um fosso impeditivo" da utilização dos conceitos individualistas do vetusto Código Civil de $1916^{576}$.

De qualquer forma, há uma fenda no ordenamento trabalhista que autoriza a aplicação do Direito Comum para a solução de litígios trabalhistas, o que permite afirmar, sem hesitação, a inclusão das demandas reparatórias lato sensu (nelas incluídas, portanto, as de danos pela perda de uma chance), pois, conforme adverte Alice Monteiro de Barros, "a responsabilidade civil se aplica não só ao âmbito da respectiva disciplina, mas de todas as que derivam desse ramo, inclusive do Direito do Trabalho ${ }^{577,}$.

Entretanto, como já se pode observar, essa autorização não é irrestrita, exigindo, segundo a doutrina, omissão da norma especial e compatibilidade de princípios ${ }^{578}$. Disso decorre que "a aplicação do instituto da responsabilidade civil no Direito do Trabalho distingue-se de sua congênere do Direito Civil. Ao contrário das relações civilistas, lastreadas na presunção de igualdade entre as partes, o Direito do Trabalho nasce e desenvolve-se com o escopo de reequilibrar a posição de igualdade inerente à relação de emprego 579 ,

Considerando que a doutrina da perda de uma chance concilia-se com os princípios do Direito Laboral, pois a ampliação do leque de reparação do dano injusto é harmônica ao ideal de melhoria da condição social do trabalhador, e, por outro lado, também valoriza a livre iniciativa, na medida em que o empregador também pode se valer do instituto para se

Disponível em: http://www2.oabsp.org.br/asp/esa/comunicacao/revista/revista04/fluidbook/index2.html. Acesso em 26 nov. 2010.

576 Segundo ele, "a referência do texto ao direito comum significa repúdio à idéia, defendida por alguns juristas extremados, de que entre o Direito do Trabalho e os demais ramos do direito dever-se-ia cavar um fosso impeditivo da utilização, na área do primeiro, de caráter nitidamente social, dos conceitos individualistas dos últimos. 'Durante muito tempo - assinalou Evaristo Moraes Filho - viveram os especialistas do Direito do Trabalho excessivamente dedicados a cavar cada vez mais fundo o fosso que os separava dos outros ramos jurídicos, preocupados com a sua autonomia científica e receosos de serem absorvidos pelas manifestações mais antigas do Direito". (MAGANO, Octávio Bueno. Manual de Direito do Trabalho: parte geral. São Paulo: LTr, p. 108)

${ }^{577}$ BARROS, Alice Monteiro de. Curso de Direito do Trabalho. São Paulo: LTr, 2005, p. 603-604.

578 Nas palavras de Arnaldo Süssekind: "Releva ponderar, entretanto, como adverte Alejandro Unsain, que 'as leis do trabalho estão à margem do Direito comum, se movem em outro plano, respondem a outras necessidades bem diversas e têm objetivos distintos. Por isto mesmo, o apelo a normas do Direito Civil deve restringir-se aos casos em que houver omissão do sistema especial e a regra civil invocada for compatível com os princípios caracterizadores do Direito do Trabalho". (SÜSSEKIND, Arnaldo; MARANHÃO, Délio; VIANNA, Segadas. Participação de João de Lima Teixeira Filho, op. cit., p. 141)

${ }^{579}$ BRASIL. Tribunal Superior do Trabalho, $3^{\text {a }}$ Turma. Recurso de Revista 930/2001-010-08-00-6, Relator: Min. Maria Cristina I. Peduzzi. Publicação em 19 de março de 2004. Disponível em 〈wwww.tst.jus.br〉. Acesso em: 26 nov. 2010. 
ressarcir de eventuais oportunidades perdidas, não há empecilhos legais à adoção da teoria pelo Direito do Trabalho brasileiro.

\subsection{A perda de uma chance como "via de mão dupla"}

Em que pese o exame da compatibilidade da teoria da perda de uma chance com o Direito do Trabalho ter sido feito a partir de princípios, conforme determina o parágrafo único do artigo $8^{\circ}$ da CLT $^{580}$, em especial os da "dignidade da pessoa humana" e da "melhoria da condição do trabalhador", tal análise não pode dar lugar a interpretações sectárias ou maniqueístas, como se a doutrina se encaixasse na relação de trabalho com o único e exclusivo fito de proteger o empregado.

Isso, efetivamente, seria um grave equívoco. Mesmo os princípios peculiares ao Direito do Trabalho que, em sua gênese, foram teleologicamente destinados à proteção do trabalhador, tiveram seu leque tuitivo aumentado para alcançar os dois pólos do liame empregatício, pois seria epistemologicamente injustificável que o empregador, pela mera condição ontológica de "parte mais forte da relação de trabalho", não pudesse se valer de alguns pressupostos basilares às relações humanas, como, por exemplo, a "primazia da realidade", a "boa-fé" e a "razoabilidade" 581.

Do mesmo modo, a "dignidade da pessoa humana", a exemplo dos demais direitos e garantias fundamentais, são extensíveis a todas as pessoas, físicas e jurídicas ${ }^{582}$, desde que

\footnotetext{
${ }^{580}$ BRASIL. Consolidação das Leis do Trabalho (1943). CLT e Constituição Federal. 38. ed. São Paulo: Saraiva, 2011.

${ }^{581}$ É o que nos ensina Plá-Rodriguez: "Cumpre formular a seguinte pergunta: os princípios do Direito do Trabalho só podem ser invocados pelos trabalhadores?, ou também pelos empregadores? Uma primeira resposta diria que, como os princípios do Direito do Trabalho atendem à razão de ser do Direito do Trabalho e como este surgiu para defender os trabalhadores, esses princípios só podem ser invocados pelos trabalhadores. Mas uma reflexão um pouco mais demorada sobre a questão impõe uma resposta mais matizada e complexa. (...) Isto se explica pela própria natureza dos princípios de que se trata. Na busca da verdade real - que inspira o princípio da primazia da realidade - qualquer das partes pode invocar a verdade verdadeira diante dos aspectos formais que a desfigurem. O trabalhador não poderá invocar o formal argumento para contestar o argumento derivado da verdade dos fatos. Ou melhor, se vier a fazê-lo, o empregador poderá invocar esse princípio da primazia da realidade sobre a aparência, o formalismo ou a ficção. No caso dos princípios da razoabilidade e de boa-fé, por sua própria significação, amparam, protegem e podem ser validamente utilizados por qualquer das duas partes". (PLÁ-RODRIGUES, Américo. Princípios de Direito do Trabalho. 3. ed. atual. São Paulo: LTr, 2002, p. 424)

${ }^{582}$ Sem olvidar, por óbvio, que o empregador também pode ser pessoa física, conforme artigo $2^{\circ}$, caput da CLT, artigo $1^{\circ}$ da Lei 5.859/72, artigo $3^{\circ}$ da Lei. 5.889/73 etc.
} 
a natureza do direito assim o permita ${ }^{583}$, conforme expresso no artigo 19.3 da Constituição Alemã $\tilde{a}^{584}$. É essa amplitude que explica, por exemplo, o STJ reconhecer a possibilidade de a pessoa jurídica ser reparada dos danos morais sofridos ${ }^{585}$ e, o STF, lhes assegurar o direito à justiça gratuita ${ }^{586}$. Portanto, a "dignidade da pessoa humana" coexiste com a legislação trabalhista, já que, conforme explanação de Ruprecht ${ }^{587}$, ela eleva o status daquele que presta serviços ao mesmo patamar do que utiliza tais serviços.

Nesse contexto, avulta-se o caractere bilateral da aplicação da perda de uma chance, verdadeira "via de mão dupla na estrada do Direito do Trabalho". Essa ambivalência foi assinalada por Jorge Cavalcanti Boucinhas Filho:

É preciso ter em conta também a possibilidade de o empregado ser condenado a indenizar o empregador pela perda de uma chance. Seria a situação, bem menos provável, mas hipoteticamente relevante, de determinado trabalhador detentor de conhecimento exclusivo abandonar a empresa ou pedir demissão sem cumprir aviso prévio ou cláusula de permanência previamente pactuada justamente quando a empresa necessitava de suas habilidades para participar de concorrência ou incrementar seus ganhos. Os mesmos motivos que justificam o dever de o empregador ressarcir o empregado pela perda de uma chance em concurso público ou de recolocação no mercado de trabalho justificam que este indenize aquele pela perda de um importante contrato ou de bons

\footnotetext{
${ }^{583}$ É o que defende Alexandre de Moraes: "Igualmente, as pessoas jurídicas são beneficiárias dos direitos e garantias individuais, pois reconhece-se às associações o direito à existência, o que de nada adiantaria se fosse possível excluí-las de todos os seus demais direitos. Dessa forma, os direitos enunciados e garantidos pela constituição são de brasileiros, pessoas físicas ou jurídicas. Assim, o regime das liberdades públicas protege tanto as pessoas naturais, brasileiros ou estrangeiros no território nacional, como as pessoas jurídicas, pois têm direito à existência, à segurança, à propriedade, à proteção tributária e aos remédios constitucionais". (MORAES, Alexandre de. Direito Constitucional. 17. ed. Atual. com a Reforma do Judiciário (EC nº. 45/04). São Paulo: Atlas, 2005, p. 30)

${ }^{584}$ Texto disponível em alemão, e traduzido para o francês, no site do planalto: “Artikel 19 [Einschränkung von Grundrechten]. (3) Die Grundrechte gelten auch für inländische juristische Personen, soweit sie ihrem Wesen nach auf diese anwendbar sind. Versão em francês: Article 19 [Restrictions apportées aux droits fondamentaux]. (3) Les droits fondamentaux s'appliquent également aux personnes morales nationales lorsque leur nature le permet. (ALEMANHA. Código Civil (1896). Código Civil. Disponível em: <http://archiv.jura.uni-saarland.de/BIJUS/grundgesetz/>. Acesso em: 13 abr. 2011.)

${ }^{585}$ BRASIL. Superior Tribunal de Justiça. Súmula $\mathrm{n}^{\circ} 227$, de 8 de outubro de 1999. A pessoa jurídica pode sofrer dano moral. Disponível em: < http://www.stj.jus.br/SCON/pesquisar.jsp>. Acesso em: 13 abr. 2011.

586 BRASIL, Supremo Tribunal Federal, Pleno. Reclamação AgR-ED n. 1.905/SP, Relator: Min. Marco Aurélio. Julgado em 15 de agosto de 2002. Disponível em: 〈www.stf.jus.br〉. Acesso em: 13 abr. 2011)

${ }^{587}$ RUPRECHT, Alfredo J. Os princípios do Direito do Trabalho. Trad. de Edilson Alkmin Cunha. São Paulo: LTr, 1995, p. 106.
} 
negócios em razão da interrupção abrupta e irresponsável do contrato de trabalho. ${ }^{588}$

A observação é bastante pertinente, porém o cenário é mais amplo do que o vislumbrado. Num primeiro plano, porque a própria bipolaridade da aplicação da perda de uma chance também deve ser enxergada por dois ângulos: o da possibilidade de o empregador vindicar do empregado a indenização pela chance perdida, anteriormente delineada, mas, também, a de poder arguir, com supedâneo no princípio da eventualidade (CPC, art. 300) ${ }^{589}$, uma tese eventual (ou subsidiária) de defesa.

Ora, a perda de uma chance não só aumenta o manancial de reparação do dano injusto, como também o torna mais equitativo, pois o juiz, que, até então, perante tal fattispecie, deveria optar entre duas injustiças (conceder indenização correspondente à totalidade do benefício perseguido ou nenhuma indenização), passa a ter a possibilidade de reparar o dano na medida de sua extensão (CCB, art. 944) ${ }^{590}$, de acordo com o grau de probabilidade de concretização da chance. No célebre caso do "Show do Milhão", por exemplo, a utilização de teoria das oportunidades perdidas veio a acolher a tese eventual da defesa, reduzindo o montante indenitário a $25 \%$ (vinte e cinco por cento) do valor da condenação atribuído pelas instâncias inferiores (vide item 2.7.3 do capítulo 2).

Em relação ao empregado causar ao empregador a perda de chances, embora a hipótese seja menos recorrente, nem de longe se restringe a exemplos cerebrinos, de interesse meramente acadêmico. Para ilustrar tal asserção, tome-se como exemplo uma hipótese pertencente ao cotidiano das lides na Justiça do Trabalho: a ausência do preposto em audiência.

A lei exige o comparecimento das partes em audiência, mas faculta ao empregador fazer-se substituir por preposto com conhecimento dos fatos, e cujas declarações lhe obrigam, nos termos do artigo 843, caput e parágrafo primeiro, da CLT. E a consequência

\footnotetext{
${ }^{588}$ BOUCINHAS FILHO, Jorge Cavalcanti, op. cit., p. 32.

${ }^{589}$ BRASIL. Código de Processo Civil (1973). Código de Processo Civil e Constituição Federal. 17. ed. São Paulo: Saraiva, 2011.

${ }^{590}$ BRASIL. Código Civil (2002). Código Civil e Constituição Federal. 62. ed. São Paulo: Saraiva, 2011
} 
para o não comparecimento do reclamado (geralmente, o empregador), é a revelia, e o seu efeito é a confissão ficta quanto à matéria de fato (CLT, art. 844, caput $)^{591}$.

Depois de acirrada cizânia doutrinária e jurisprudencial sobre quem poderia ostentar a condição de preposto, o Tribunal Superior do Trabalho pacificou a celeuma, estabelecendo que deva ser, necessariamente, um empregado do reclamado, exceto nas reclamações de empregado doméstico ou em face de micro ou pequenas empresas ${ }^{592}$.

Assim, caso o preposto falte injustificadamente à audiência, tem-se configurada a possibilidade de dano causado pelo empregado ao seu empregador, consistente na perda da chance de evitar um prejuízo, por força da impossibilidade de se defender, ao menos, adequadamente, na ação movida pelo reclamante.

Não se pode falar que o dano seja correspondente ao valor das pretensões veiculadas, porque não há certeza de que, em decorrência da revelia e confissão, o pronunciamento jurisdicional será pela procedência ${ }^{593}$, com o acolhimento de todos os pedidos ${ }^{594}$. As mais

591 (BRASIL. Consolidação das Leis do Trabalho (1943). CLT e Constituição Federal. 38. ed. São Paulo: Saraiva, 2011). O exemplo também se aplica, mutatis mutandis, aos processos perante os Juizados Especiais Cíveis, a teor do que dispõem os artigos $9^{\circ}, \S 4^{\circ}$ c/c 20 da Lei 9.099, de 26 de setembro de 1995, verbis: “Art. $9^{\circ}$. Nas causas de valor até vinte salários mínimos, as partes comparecerão pessoalmente, podendo ser assistidas por advogado; nas de valor superior, a assistência é obrigatória. $4^{\circ}$. O réu, sendo pessoa jurídica ou titular de firma individual, poderá ser representado por preposto credenciado, munido de carta de preposição com poderes para transigir, sem haver necessidade de vínculo empregatício. Art. 20. Não comparecendo o demandado à sessão de conciliação ou à audiência de instrução e julgamento, reputar-se-ão verdadeiros os fatos alegados no pedido inicial, salvo se o contrário resultar da convicção do Juiz". (BRASIL. Lei no 9.099, de 26 de setembro de 1995. Dispõe sobre Juizados Especiais Cíveis e Criminais e dá outras providências. Disponível em: < http://www.planalto.gov.br/ccivil/leis/L9099.htm>. Acesso em: 13 abr. 2011)

592 BRASIL. Tribunal Superior do Trabalho. Súmula $n^{\circ}$ 377, de 24 abr. 2008. Exceto quanto à reclamação de empregado doméstico, ou contra micro ou pequeno empresário, o preposto deve ser necessariamente empregado do reclamado. Inteligência do art. 843, $\S 1^{\circ}$, da CLT e do art. 54 da Lei Complementar $\mathrm{n}^{\circ} 123$, de 14 de dezembro de $2006 . \quad$ Disponível em: http://www.tst.gov.br/jurisprudencia/Livro_Jurisprud/livro_html_atual.html\#Sumulas>. Acesso em 13 abr. 2011)

593 Assim vaticina Wagner D. Giglio: "Na prática, nem sempre se acolhe integralmente o pedido inicial no procedimento à revelia do reclamado, seja porque dos fatos narrados não decorrem todos os direitos pleiteados, seja porque, como acontece freqüentemente, a confissão ficta é destruída por outros elementos de prova tais como a confissão real do reclamante, já examinada, os documentos, depoimentos de testemunhas etc.”. (GIGLIO, Wagner D. Direito Processual do Trabalho. 9. ed. rev. amp. e adaptada à Constituição Federal de 1988. São Paulo: LTr, 1995, p. 223)

${ }^{594}$ Em sentido contrário, e completamente atécnico, o posicionamento de Antonio Lamarca (que, ao menos, excepciona as hipóteses do artigo 320 do CPC): "Ausente o reclamado - desde que regularmente citado considera-se o mesmo revel e confesso quanto à matéria de fato. Quem não comparece evidentemente não responde à ação; por isso é revel e reputam-se verdadeiros os fatos afirmados pelo autor (CPC, art. 319). (...) Tudo isso implica, desde logo, na procedência da reclamação, exceto, é óbvio, discussão recursal em torno de matéria de direito ou possível elisão de revelia". (LAMARCA, Antônio. Processo do Trabalho Comentado: (artigos 643 a 910 da CLT). São Paulo: RT, 1982, p. 378-379). Pela procedência, sem ressalvas, Isis de Almeida: “A revelia implica a extinção do processo com julgamento do mérito. A sentença é da Junta (ou do Juiz de Direito). Dá pela procedência do pedido, classificada, portanto, como definitiva, desafiando o recurso ordinário, salvo se se tratar de reclamação de alçada. Aí, os recursos trabalhistas só caberão se houver matéria constitucional a ser discutida". (ALMEIDA, Isis de. Manual de Direito Processual do Trabalho: processo 
diversas hipóteses podem levar à elisão do efeito principal da revelia (ficta confessio), ou, mesmo diante da consumação do efeito, conduzir a um julgamento de extinção sem apreciação meritória, ou, apenas, de procedência parcial ou de improcedência: 1 - quando houver pluralidade de réus e um deles contestar a ação (CPC, art. 320, I) ${ }^{595} ; 2$ - quando o litígio versar sobre direitos indisponíveis (CPC, art. 320, II); 3 - quando a petição inicial não estiver acompanhada de instrumento público que a lei considere indispensável (CPC, art. 320, III c/c art. $366^{596}$ ); 4 - quando houver provas pré-constituídas que confrontem seu valor (TST, Súmula 74, II) ${ }^{597} ; 5$ - quando o pedido impuser a produção de prova técnica $\left(\mathrm{CLT} \text {, art. } 195, \S 2^{\mathrm{o}}\right)^{598}{ }^{599} ; 6$ - quando as pretensões veiculadas forem completamente inverossímeis $^{600} ; 7$ - quando, além do preposto, o reclamante também deixar de

de conhecimento e processo de execução trabalhista.. 3. ed. atual. amp. de acordo com a Constituição de 1988. São Paulo: LTr: 1991, v. 2, p. 48)

595 BRASIL. Código de Processo Civil (1973). Código de Processo Civil e Constituição Federal. 17. ed. São Paulo: Saraiva, 2011.

596 Idem

${ }^{597}$ BRASIL. Tribunal Superior do Trabalho. Súmula $\mathrm{n}^{\mathrm{o}} 74$, de 25 de abril de 2005. A prova pré-constituída nos autos pode ser levada em conta para confronto com a confissão ficta (art. 400, I, CPC), não implicando cerceamento de defesa o indeferimento de provas posteriores. Disponível em: < http://www.tst.gov.br/jurisprudencia/Livro_Jurisprud/livro_html_atual.html\#Sumulas>. Acesso em: 13 abr. 2011)

${ }^{598}$ BRASIL. Consolidação das Leis do Trabalho (1943). CLT e Constituição Federal. 38. ed. São Paulo: Saraiva, 2011.

${ }^{599}$ É o que afirma Coqueijo Costa: "Manda a CLT que se proceda à perícia técnica para se classificar e caracterizar, qualitativa e quantitativamente, a insalubridade e a periculosidade, assim sejam estas argüidas em juízo. O CPC impõe também a perícia indispensável em certos tipos de ação. Deduz-se daí que, versando o pedido sobre qualquer dos dois adicionais referidos, o Juiz do Trabalho há de verificar que o efeito da revelia não se produz, pois impossível a confissão ficta de fato para o qual a lei estabelece prova técnica indispensável e insubstituível por outro qualquer meio de prova”. (COSTA, Coqueijo. Direito Processual do Trabalho. 4 ed. rev., atual. e adaptada à Constituição de 1988 por Washington Luiz da Trindade. Rio de Janeiro: Forense, 1995, p. 265)

${ }^{600}$ Sobre a questão, a famosa sentença de Marcos Neves Fava, quando, por ocasião de uma revelia, em que o autor alegava trabalhar $24 \mathrm{~h}$ por dia, todos os dias da semana, durante quatro anos, julgou improcedente o pedido de horas extras: "Alega o reclamante que laborava das 0:00 às 24:00 horas, sem intervalo de refeição e sem qualquer folga, entre 2001 e 2005. Alertado por mim, em instrução, de que, à vista da experiência deste Juiz de mais de 11 anos de magistratura na área do trabalho, era pouco plausível, para dizer o mínimo, o trabalho continuado, sem dormir, nem comer, por mais de quatro anos, insistiu em reafirmar a jornada. Cedeu, apenas, para dizer que entre 12 e 13 horas, dormia um cochilo de 60 minutos. Em que pese a revelia da reclamada, pondero que a sentença judicial tem caráter e função públicos, não se prestando a ratificar absurdos. Mentirosa a alegação da inicial. Com efeito, ainda que laborasse, por exemplo, 20 horas por dia carga já elevadíssima - mister que se alimentasse, no mínimo, uma vez por dia. Negar sono - uma hora por dia, nos mais de 4 anos da avença - e negar parada para qualquer intervalo - nunca gozou de folgas - é mentir, deslavadamente, em Juízo.

E quem mente acintosamente, não tem limites para continuar inventado. A revelia não confirmaria que o reclamante trabalhava voando por sobre o telhado da empresa, como também não confirmaria que ele recepcionava extraterrestres, quando das visitas regulares dos marcianos à Terra. Não obstante a confissão da reclamada, por sua revelia, não vejo possibilidade de concessão dos títulos postulados. O processo não é um jogo de pega-pega, é instrumento de distribuição da justiça e de fixação dos parâmetros da cidadania e isto está acima do interesse privado de defesa do reclamado. Não pode o Judiciário reconhecer o impossível, sob pena de desrespeito à sociedade. Por estas razões, julgo improcedente a pretensão exordial". (SÃO PAULO. Tribunal Regional do Trabalho da $2^{a}$ Região. Reclamação Trabalhista no 04454/2006-089-02-008, 89 ${ }^{\text {a }}$ Vara 
comparecer à audiência, ocasionando arquivamento da reclamatória $\left(\right.$ CLT, art. 844) ${ }^{601} ; 8$ quando o juiz pronunciar, de ofício, a prescrição (CPC, art. $\left.219, \S 5^{\circ}\right)^{602} ; 9$ - quando o juiz reconhecer, de ofício $\left(\mathrm{CPC} \text {, art. } 267, \S 3^{\circ} \text { e CPC, art. } 301, \S 4^{\circ}\right)^{603}$, quaisquer das matérias de ordem pública arroladas na legislação processual; 10 - quando a audiência se realizar no prazo em que o reclamante deva estar cumprindo a penalidade dos artigos 731 e 732 da $\mathrm{CLT}^{604} ; 11$ - quando o autor desistir (CPC, art. 267, VIII) ${ }^{605}$ ou renunciar ao direito no qual se funda a ação (CPC, art. 269, V) ${ }^{606} ; 12$ - quando não houver subsunção do fato alegado pelo autor à norma jurídica que lhe ampare, levando à rejeição do pedido (CPC, art. 269, I) ${ }^{607}$ etc.

Por outro lado, não há como dizer que com a presença do preposto, a possibilitar a apresentação de defesa, o resultado da ação seria, indiscutivelmente, melhor do que sem a presença dele, pois: 1 - do depoimento do preposto poderia advir confissão real (CPC, art. $348)^{608} ; 2$ - a defesa poderia conter impugnação genérica, levando ao mesmo efeito da ausência do preposto (CPC, art. 302) ${ }^{609} ; 3$ - a defesa poderia conter o reconhecimento da procedência do pedido (CPC, art. 269, II $)^{610} ; 4$ - além do preposto, pode não comparecer o advogado, que deveria apresentar a defesa e os documentos; 5 - a tese da contestação que seria apresentada poderia ser incapaz de evitar a condenação; 6 - apesar de a defesa ser suficiente para escapar da condenação, o reclamado pode não ter testemunhas para comprovar as alegações cujo ônus de provar detém etc.

Há, ainda, uma sutileza na questão. É comum, em muitos lugares, que a audiência trabalhista seja fracionada em várias etapas, e, com o desmembramento, a primeira audiência destina-se à tentativa de conciliação, a qual, frustrada, prossegue com a

do Trabalho de São Paulo/SP. Juiz Marcos Neves Fava. Julgamento em 23 de março de 2007. Disponível em: <www.trt2.jus.br>. Acesso em: 13 abr. 2011)

${ }^{601}$ BRASIL. Consolidação das Leis do Trabalho (1943). CLT e Constituição Federal. 38. ed. São Paulo: Saraiva, 2011.

${ }^{602}$ BRASIL. Código de Processo Civil (1973). Código de Processo Civil e Constituição Federal. 17. ed. São Paulo: Saraiva, 2011.

603 Idem

${ }^{604}$ BRASIL. Consolidação das Leis do Trabalho (1943). CLT e Constituição Federal. 38. ed. São Paulo: Saraiva, 2011.

${ }^{605}$ BRASIL. Código de Processo Civil (1973). Código de Processo Civil e Constituição Federal. 17. ed. São Paulo: Saraiva, 2011.

${ }^{606}$ Idem

${ }^{607}$ Ibidem.

${ }^{608}$ Ibidem

${ }^{609}$ Ibidem

${ }^{610}$ Ibidem 
apresentação de defesa e juntada de documentos, sendo a segunda destinada à oitiva das partes e testemunhas, e ainda uma terceira, apenas para a prolação da sentença ${ }^{611}$.

Tal circunstância faz com que a ausência do preposto tenha consequências distintas, de acordo com a audiência em que ele não se faz presente: i) na primeira audiência, sua ausência redunda na revelia e confissão, ainda que presente o advogado, munido de procuração (conforme o texto da Orientação Jurisprudencial $n^{\circ} .184$ da SBDI-1/TST, incorporada pela Súmula 74 do TST) ${ }^{612}$; ii) na segunda audiência, o não comparecimento acarreta apenas confissão, desde que tenha sido intimado a comparecer para depor, sob expressa cominação de confissão (TST, Súmula 74, I), permitindo sejam avaliadas as provas pré-constituídas (TST, Súmula 74, II) ${ }^{613}$; iii) na audiência de julgamento, nenhum efeito $^{614}$.

Trata-se, pois, de clara hipótese de "perda de uma chance atípica”, conforme taxonomia proposta (vide item 4.2 do capítulo 4), pois o ato ilícito está na não interrupção do curso aleatório dos eventos (que ocorreria mediante a presença do preposto), e, ademais, para a constatação da existência do prejuízo, é necessário que a cadeia causal percorra seu iter até o trâmite final da demanda, na qual se verificará, ou não, a ocorrência de dano.

Portanto, o dano causado pelo preposto/empregado ao empregador não está no resultado final perseguido (absolvição ou redução da condenação, presumidamente), mas na chance de obtê-lo. A indenização deverá obedecer aos parâmetros fornecidos ao longo do trabalho (vide item 3.3 do capítulo 3), e calculada de acordo com o grau de probabilidade de evitar ou diminuir a condenação efetivamente sofrida.

\footnotetext{
${ }^{611}$ É o que explica César P. S. Machado Jr.: "Tornou-se comum a realização da audiência trabalhista em várias etapas, embora a previsão legal no processo do trabalho seja a realização de uma única audiência. (...) A primeira audiência ficou resumida na tentativa de conciliação e a apresentação da defesa, com a juntada de todos os documentos necessários. Uma segunda audiência é designada apenas para a realização da prova oral ou testemunhal, ou seja, para a oitiva das partes, testemunhas e peritos, e tentativa final de conciliação. E, finalmente, uma terceira audiência para o julgamento do processo". (MACHADO JUNIOR, César Pereira da Silva. O ônus da prova no processo do trabalho. 3. ed. rev. e atual. São Paulo: LTr, 2001, p. 101-102)

612 BRASIL. Tribunal Superior do Trabalho. Súmula no 74, de 25 de abril de 2005. Confissão. Disponível em: 〈http://www.tst.gov.br/jurisprudencia/Livro_Jurisprud/livro_html atual.html\#Sumulas〉. Acesso em: 13 abr. 2011.

${ }^{613}$ Francisco Antônio de Oliveira assim resume a diferença: "A confissão imposta à parte após a defesa é relativa e poderá ser ilidida por outras provas (depoimento pessoal da parte contrária, testemunhas, documentos etc.). A confissão conseqüente da revelia é absoluta". (OLIVEIRA, Francisco Antonio de. Comentários aos Enunciados do TST. 4. ed., rev. e atual. São Paulo: RT, 1997, p. 197)

${ }^{614}$ Ainda que o juiz tenha intimado as partes da data do julgamento, a consequência é apenas que o prazo começa o contar da data designada, na forma do artigo 775 da CLT, independentemente da presença ou não dos litigantes (TST, Súmula 197), aplicando-se o brocardo "dies interpellat pro homine".
} 


\subsection{Jurisprudência e Direito do Trabalho}

Diante da constante e progressiva transformação dos fatos sociais no mundo do trabalho, em discrepância com o vagar das modificações legislativas, sobressai o papel fundamental da jurisprudência, na medida em que aproxima o Direito do Trabalho do escopo que lhe é atávico, equacionando, mediante técnicas de interpretação e integração, as mais diversas formas de conflito que lhe são postas ao enfrentamento.

Nesse sentido, a jurisprudência cria ou sistematiza ${ }^{615}$ regras não previstas no ordenamento jurídico $^{616}$, e, assim, desempenha importante tarefa na regulamentação das relações trabalhistas. Segundo $\operatorname{Saad}^{617}$, “a jurisprudência é um 'jus novum' porque a iteração das decisões dos tribunais se converte num direito costumeiro, num direito novo", que pode ser fonte do Direito quando a lei for lacunosa.

A complexidade das relações empregatícias, portanto, demanda constante posicionamento dos Tribunais, pois "a riqueza das relações de trabalho e a multiplicidade imensurável de situações e pequenos detalhes que alteram profundamente o enquadramento legal forçaram os tribunais a marcarem posição sobre temas tão diversos quanto o cálculo das horas extras, fixação da jornada noturna e até a forma correta de se proceder à baixa da Carteira de Trabalho"618.

A matriz hermenêutica do Direito Laboral, o artigo $8^{\circ}$ da $\mathrm{CLT}^{619}$, dá à jurisprudência um lugar de destaque não alcançado nos demais diplomas ${ }^{620}$. A explicação histórico-

\footnotetext{
${ }^{615}$ Exemplo do que se está a expor é o regime de terceirização, cuja disciplina está assentada, em linhas gerais, na Súmula 331 do Tribunal Superior do Trabalho. (BRASIL. Tribunal Superior do Trabalho. Súmula n 331, de 23 de novembro de 2003. Contrato de Prestação de Serviços. Legalidade. Disponível em: < http://www.tst.gov.br/jurisprudencia/Livro_Jurisprud/livro_html_atual.html>. Acesso em 13 abr. 2011.)

${ }^{616}$ De acordo com Magano: "A verdade é que a jurisprudência cria regras não previstas no ordenamento jurídico, alterando mesmo o alcance das existentes. Foi, por exemplo, o que aconteceu em matéria de responsabilidade civil. O Código Civil só responsabilizava o patrão, amo ou comitente, por atos de seus prepostos, quando ficasse provada a culpa indireta daqueles 'in eligendo' ou 'in vigilando'. Dado o aumento do número de acidentes, fenômeno típico da época moderna e decorrente do progresso técnico e da multiplicação de coisas perigosas, os juízes foram verificando que a aplicação rigorosa da regra do Código Civil deixaria muitos sem a possibilidade de haver compensação por danos sofridos. Em conseqüência disso, alteraram o alcance da aludida regra, tranqüilizando-se a jurisprudência no sentido de que a responsabilidade do amo, patrão ou comitente não depende mais da prova de sua culpa, sendo objetiva. Na área trabalhista, o maior exemplo da força criadora da jurisprudência encontra-se na chamada estabilidade provisória, que já era assegurada ao dirigente sindical, mesmo antes de sua transposição para a lei”. (MAGANO, Octávio Bueno, op. cit., p. 88)

${ }^{617}$ SAAD, Eduardo Gabriel. CLT Comentada. 34. ed. São Paulo: LTr, 2001, p. 43.

${ }^{618}$ SILVA, Homero Mateus Batista da, op. cit., p. 200.

${ }^{619}$ BRASIL. Consolidação das Leis do Trabalho (1943). CLT e Constituição Federal. 38. ed. São Paulo: Saraiva, 2011.
} 
sistemática mais provável para isso está no fato de a redação original do artigo 902 da $\mathrm{CLT}^{621}$, muito antes das súmulas de efeito vinculante trazidas pela Emenda Constitucional 45/2004 $4^{622}$, autorizar o antigo “Tribunal Nacional do Trabalho" (atualmente Tribunal Superior do Trabalho) a expedir pré-julgados, cujo conteúdo obrigava os juízes das instâncias inferiores ${ }^{623}$.

Apesar de tal dispositivo não estar mais em vigor desde 1982, a jurisprudência continua a ser uma das formas mais importantes de exteriorização do Direito do Trabalho, cujo estudo é de crucial importância para se analisar o modo como a teoria da perda de uma chance será abordada em domínios juslaborais.

Eis a razão de se esquadrinhar a jurisprudência trabalhista nos tópicos que se seguem, sem se ater, obviamente, a um mero relato dos acórdãos já prolatados, mas com o propósito de avaliar e interpretar até mesmo a mais clara das decisões ${ }^{624}$, a fim de traçar um perfil dos pretórios trabalhistas em sua interação com o tema, verificando a conformação ou não dos postulados dogmáticos alinhavados na parte geral à praxis forense.

\footnotetext{
${ }^{620}$ Refere-se aqui, em especial, aos artigos $4^{\circ}$ da LINDB (LICC) e 126 do CPC.

621 "Art. 902. É facultado ao Tribunal Nacional do Trabalho estabelecer prejulgados, na forma que prescrever o seu regimento interno. $\S 1^{\circ}$ Uma vez estabelecido o prejulgado, aos Conselhos Regionais do Trabalho, as Juntas de Conciliação e Julgamento e o Juizes de Direito investidos da jurisdição a Justiça do trabalho ficarão obrigados a respeitá-lo". (BRASIL. Consolidação das Leis do Trabalho (1943). CLT e Constituição Federal. 38. ed. São Paulo: Saraiva, 2011. Sem grifo no original)

${ }^{622}$ BRASIL. Emenda constitucional $\mathbf{n}^{\circ} \mathbf{4 5}$, de 30 de dezembro de 2004. Altera dispositivos da Constituição Federal e acrescenta os arts. 103-A, 103-B, 111-A, 130-A e dá outras providências. Disponível em: < http://www.planalto.gov.br/ccivil_03/constituicao/emendas/emc/emc45.htm>. Acesso em 13 abr. 2011.

${ }^{623}$ É o que conta Amauri Mascaro do Nascimento: "Até 1982, o Tribunal Superior do Trabalho podia, com base no disposto no art. 902 da CLT, expedir prejulgados com força obrigatória para os demais tribunais e juízes. No entanto, em decorrência da Lei n. 7.033, de 5.10.82, foi revogado o referido dispositivo legal, bem como outros que previam os prejulgados. (...) Com essa revogação, a Justiça do Trabalho não pode mais expedir prejulgados, prevalecendo, assim, a tese segundo a qual esses atos ferem a autonomia do juiz, atritando-se com a liberdade de julgar segundo a livre convicção, princípio fundamental da organização jurisdicional". (NASCIMENTO, Amauri Mascaro. Iniciação ao Direito do Trabalho. 25. ed. rev. e atual. São Paulo: LTr, 1999, p. 97)

${ }^{624}$ Consoante escólio de Mallet: "Hoje não se leva mais a sério a máxima 'in claris cessat interpretatio', que Paulo Batista ainda repetiu. Na verdade, para concluir que o enunciado é claro mostra-se impostergável, antes de qualquer outra coisa, interpretá-lo. Daí porque até as mais cristalinas decisões judiciais, como as mais claras disposições legais, sujeitam-se a interpretação. Já se dizia, no Digesto: 'Quamvis sit manifestissimum edictum praetoris, attamen non est neglegenda interpretatio eius', ou seja, ainda que claríssimo o edito do pretor, não se deve descurar de sua interpretação". (MALLET, Estêvão. Ensaio sobre A Interpretação das Decisões Judiciais. São Paulo: LTr, 2009, 17)
} 


\subsection{Panorama da jurisprudência trabalhista}

No período compreendido entre 02 de abril de 2011 a 25 de abril de 2011, foi realizada uma pesquisa da jurisprudência nacional, tendo como principal ferramenta o sítio eletrônico dos 24 Tribunais Regionais do Trabalho e o do Tribunal Superior do Trabalho (abrangendo suas 8 turmas, a SBDI-1, SBDI-2 e SDC), a saber: www.trt1.jus.br;

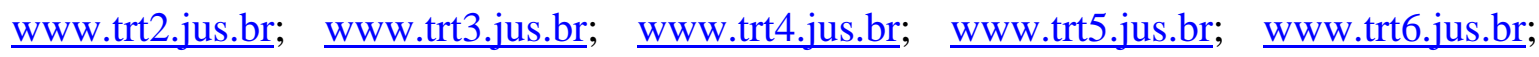
$\underline{\text { www.trt7.jus.br; }}$ www.trt8.jus.br; www.trt9.jus.br; www.trt10.jus.br; $\underline{\text { www.trt11.jus.br; }}$ $\underline{w w w . t r t 12 . j u s . b r} ; \underline{w w w . t r t 13 . j u s . b r} ; \underline{w w w . t r t 14 . j u s . b r} ; \underline{w w w . t r t 15 . j u s . b r} ; \underline{w w w . t r t 16 . j u s . b r} ;$

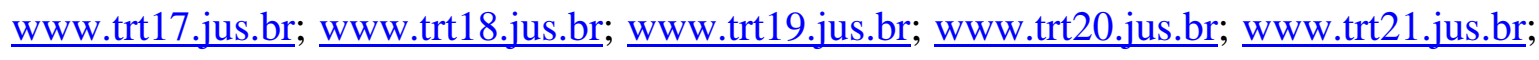

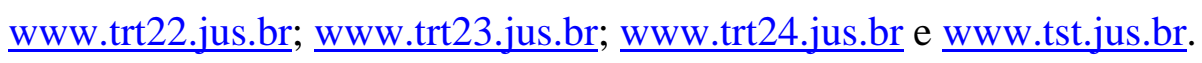

Utilizou-se, ainda, como instrumento de busca o "Juris Síntese DVD IOB n 86", atualizado até 07 de dezembro de 2010, e do auxílio do Serviço de Jurisprudência do Tribunal Regional do Trabalho da $24^{\mathrm{a}}$ Região, especialmente em razão de alguns entraves no manejo dos recursos disponibilizados pelo sítio eletrônico de determinados tribunais regionais. À guisa de complementação, foram usados acórdãos mencionados em artigos científicos versando sobre o tema. Nos dois casos, o procedimento foi o de refazer a busca nos sites dos respectivos tribunais a partir do número dos processos.

Quatro foram os argumentos de busca inseridos inicialmente, a saber: "perda de uma chance"; "perda de chance"; "perda de uma oportunidade" e "perda de oportunidade". Já no sítio eletrônico do Tribunal Superior do Trabalho, a busca foi limitada pelos dois primeiros argumentos, uma vez que, a partir dos dois últimos, considerando o uso comum e recorrente das expressões, foram encontradas, em média, mais de 100 referências por órgão colegiado, sem pertinência alguma com o assunto. Nos Tribunais menores, por sua vez, em que não havia decisões ou eram muito escassas, a pesquisa foi refinada a partir de um único argumento, como "chance", "perda" ou "oportunidade", a fim de agregar valor à investigação. 
Apesar dos esforços empreendidos e não obstante a velocidade com que se caminha em direção ao processo virtual, a pesquisa eletrônica ainda trouxe algumas dificuldades ${ }^{625}$ 626627628629630 , que, por certo, serão solucionadas.

Por questão de corte metodológico, a perquirição restringiu-se aos julgados que conheceram dos pedidos de indenização de chances perdidas, seja para acolhê-los ou rejeitá-los, bem como, aos que a ela fizeram referência ao arrostarem outras pretensões.

Não foram aproveitados, por outro lado, para fins de estatística e compreensão do cenário jurisprudencial trabalhista sobre o instituto, os julgados: i) que não conheceram do pedido recursal; ii) que pronunciaram a prescrição da pretensão reparatória; iii) que

${ }^{625}$ O sítio do TRT/1 ${ }^{\text {a }}$ Região é o de maior complexidade. Dos dois acórdãos encontrados na pesquisa realizada nesse regional, um deles foi obtido em artigo de autoria de Raimundo Simão de Melo e Cristina Maria N. da Fonseca. Já o outro, embora localizado pela ferramenta de busca do sítio eletrônico do tribunal, não pôde ser inserido na estatística parcial (assunto x tribunal), uma vez que não foi possível, no mesmo sítio, encontrar a integralidade da decisão, e a ementa, por sua vez, não permite identificar a causa de pedir. (RIO DE JANEIRO. Tribunal Regional do Trabalho da $1^{\mathrm{a}}$ Região, $8^{\mathrm{a}}$ Turma, Recurso Ordinário 03119-2006-34201-00-9. Publicação em 14 de julho de 2008. Relator: Marcelo Augusto Souto de Oliveira. Disponível em: <www.trt1.jus.br>. Acesso em: 13 abr. 2011)

${ }^{626}$ O TRT da $2^{a}$ Região está em processo de digitalização do seu acervo, e oferece, eletronicamente, para fim de pesquisa temática, apenas acórdãos publicados a partir de 01 jul.2010.

${ }^{627}$ Um acórdão da $3^{\text {a }}$ Região foi encontrado somente no "Juris Síntese". (MINAS GERAIS. Tribunal Regional do Trabalho da $3^{\text {a }}$ Região, $1^{\text {a }}$ Turma, Recurso Ordinário 831/2008-043-03-00.9. Publicação em 18 de dezembro de 2009. Relator: Manuel Candido Rodrigues. Disponível em: 〈www.trt3.jus.br〉. Acesso em: 6 abr. 2011)

${ }^{628}$ Nenhum acórdão da $11^{\text {a }}$ Região foi encontrado a partir da indexação de argumentos no sítio eletrônico. Os dois únicos apontados na presente pesquisa foram localizados pelo "Juris Síntese" (AMAZONAS. Tribunal Regional do Trabalho da 11 a Região. Recurso Ordinário 0122500-69.2009.5.11.0051, Relator: Vera Lúcia Câmara de Sá Peixoto, Diário da Justiça eletrônico, 19 ago. 2010) e (AMAZONAS. Tribunal Regional do Trabalho da $11^{\text {a }}$ Região. Recurso Ordinário 01612/2008-018-11-00.3, Relator: Antônio Carlos Marinho Bezerra, Diário da Justiça eletrônico, 24 maio 2010, p. 16)

${ }^{629}$ Dois acórdãos da $9^{\mathrm{a}}$ Região (PARANÁ. Tribunal Regional do Trabalho da $9^{\mathrm{a}}$ Região, $4^{\mathrm{a}}$ Turma. Recurso Ordinário 0734-2008-242-09-00-3. Julgado em 17 de junho de 2009. Relator: Luiz Celso Napp. Disponível em: 〈www.trt9.jus.br〉. Acesso em: 8 abr. 2011) e (PARANÁ. Tribunal Regional do Trabalho da 9a Região, $3^{a}$ Turma. Recurso Ordinário 02128-2009-594-09-00-7. Julgado em 23 de junho de 2010. Relator: Altino Pedrozo dos Santos. Disponível em: 〈www.trt9.jus.br〉. Acesso em: 8 abr. 2011), apesar de não referidos nos resultados da pesquisa jurisprudencial levada a efeito no sítio eletrônico do tribunal respectivo, foram identificados na investigação realizada no sítio do Tribunal Superior do Trabalho (BRASIL. Tribunal Superior do Trabalho, $6^{\text {a }}$ Turma. Recurso de Revista 73400-48.2008.5.09.0242. Publicação em 28 de maio de 2010. Relator: Min. Aloysio Corrêa da Veiga. Disponível em: 〈www.tst.jus.br〉. Acesso em: 19 abr. 2011) e (BRASIL. Tribunal Superior do Trabalho, 6 ${ }^{\mathbf{a}}$ Turma. Recurso de Revista 212800-54.2009.5.09.0594. Publicação em 4 de fevereiro de 2011. Relator: Min. Maurício Godinho Delgado. Disponível em: <www.tst.jus.br>. Acesso em: 19 abr. 2011).

${ }^{630} \mathrm{O}$ único julgado da $14^{\mathrm{a}}$ Região (RONDÔNIA. Tribunal Regional do Trabalho da $14^{\mathrm{a}}$ Região. Recurso Ordinário 00219.2006.001.14.00-2. Julgado em 07 de maio de 2008. Relator: Vânia Maria da Rocha Abensur. Disponível em: 〈www.trt14.jus.br>. Acesso em: 12 abr. 2011), foi localizado, por via transversa, mediante o julgado do TST (BRASIL. Tribunal Superior do Trabalho, $3^{\text {a }}$ Turma. Recurso de Revista 2194096.2006.5.14.0001. Publicação em 23 de outubro de 2009. Relator: Min. Alberto Luiz Bresciani de Fontan Pereira. Disponível em: 〈wwww.tst.jus.br>. Acesso em: 19 abr. 2011). Mesmo após a localização, pelos dados numéricos também não encontramos a decisão disponibilizada no sítio do Regional, o que só foi possível pelo envio, pela Sra. Helenrose Coelho, do Setor de Jurisprudência do Tribunal Regional do Trabalho da $24^{\mathrm{a}}$ Região, do inteiro teor do acórdão. 
declararam a incompetência da Justiça do Trabalho; iv) em que os argumentos se apresentavam em seu sentido vulgar - sem relação com a teoria -; v) em que os argumentos representavam somente referência a obras literárias ou artigos doutrinários, contudo, sem enfrentamento da tese.

No âmbito do TST, contudo, o critério foi excepcionado algumas vezes, sendo computadas as decisões que não conheciam dos recursos, mas, ainda assim, pelo modo peculiar de fazer o juízo de admissibilidade, analisavam tese pertinente ao tema pesquisado. Nesta Corte, somente não foram aproveitados julgados em que a teoria estava limitada à transcrição da decisão regional, sem, todavia, relação alguma com o objeto do apelo, bem como, decisões sem abordagem da tese, como as que negam provimento a agravo de instrumento.

O resultado da investigação, segundo os parâmetros indicados, revelou 275 decisões, no conjunto dos 24 tribunais regionais, e 4 julgados no Tribunal Superior do Trabalho, totalizando 279 , assim distribuídas:

\begin{tabular}{|c|c|c|c|c|c|c|c|c|c|c|c|}
\hline & \multicolumn{11}{|c|}{ PERÍODO } \\
\hline TRIBUNAIS & 2002 & 2003 & 2004 & 2005 & 2006 & 2007 & 2008 & 2009 & 2010 & 2011 & \\
\hline TST & & & & & & & & & 4 & & 4 \\
\hline $\mathbf{1}^{\mathrm{a}}$ & & & & & & & 2 & & & & 2 \\
\hline $2^{a}$ & & & & & & & & & 13 & 1 & 14 \\
\hline $3^{\mathbf{a}}$ & & 1 & & & & 1 & 4 & 5 & 5 & 2 & 18 \\
\hline $4^{a}$ & 1 & & 1 & 1 & & 1 & 16 & 19 & 34 & 4 & 77 \\
\hline $5^{a}$ & & & & & & 5 & 11 & 18 & 14 & 4 & 52 \\
\hline $\mathbf{6}^{\mathbf{a}}$ & & & & & & & 3 & 2 & 1 & 1 & 7 \\
\hline $7^{a}$ & & & & & & & 1 & & & & 1 \\
\hline $9^{a}$ & & & & & & 1 & & 1 & 3 & & 5 \\
\hline $10^{\mathrm{a}}$ & & & & & 1 & & & 2 & 1 & & 4 \\
\hline $11^{a}$ & & & & & & & 1 & & 1 & & 2 \\
\hline $12^{\mathrm{a}}$ & & & & & & 1 & 1 & 2 & 9 & 2 & 15 \\
\hline $14^{\mathrm{a}}$ & & & & & & & $\mathbf{1}$ & & & & 1 \\
\hline $15^{\mathrm{a}}$ & 1 & & & & & 2 & 3 & 9 & 10 & 5 & 30 \\
\hline $16^{\mathrm{a}}$ & & & & & & & 1 & & 2 & & 3 \\
\hline $17^{\mathrm{a}}$ & & & & 1 & 1 & & $\mathbf{1}$ & 3 & $\mathbf{1 0}$ & 8 & 24 \\
\hline $18^{a}$ & & & & & & 2 & & 2 & 1 & & 5 \\
\hline $19^{a}$ & & & & & & & & & 1 & & 1 \\
\hline $20^{a}$ & & & & & & 1 & 1 & 2 & & & 4 \\
\hline $21^{a}$ & & & & & & & & 1 & & & 1 \\
\hline $23^{a}$ & & & & & & 2 & 1 & 2 & 1 & 1 & 7 \\
\hline $24^{a}$ & & & & & & & 1 & & 1 & & 2 \\
\hline TOTAL & 2 & 1 & 1 & 2 & 2 & 16 & 48 & 68 & 111 & 28 & 279 \\
\hline
\end{tabular}


Apesar de o espaço amostral ser ainda restrito para uma análise mais sólida, pode-se afirmar, desde logo, que as demandas abrangeram todas as fases contratuais, da seguinte forma:

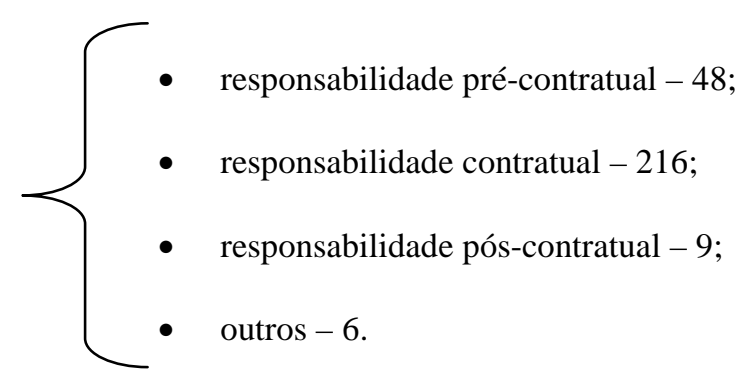

Optou-se pela denominação "outros" para os processos em que não foi possível identificar a causa de pedir (2), bem como os processos em que trabalhadores ou empregadores demandavam em face de seus ex-advogados pela perda de uma chance decorrente de má atuação profissional (4), assunto que, além de não inserido na relação de emprego stricto sensu, tende, atualmente, a ser absorvida pela Justiça Comum, em face do entendimento consolidado do $\mathrm{STJ}^{631}$ e majoritário do $\mathrm{TST}^{632}$.

Todavia, em se considerando a ação como decorrente da relação de trabalho lato sensu, incluindo-a na competência da Justiça do Trabalho, e mudando-se a perspectiva do

${ }^{631}$ BRASIL. Superior Tribunal de Justiça. Súmula no 363, de 3 de novembro de 2008. Compete à Justiça estadual processar e julgar a ação de cobrança ajuizada por profissional liberal contra cliente. Disponível em: $<$ http://www.stj.jus.br/SCON/pesquisar.jsp >. Acesso em 13 abr. 2011.

632 "RECURSO DE REVISTA - AÇÃO DE COBRANÇA DE HONORÁRIOS ADVOCATÍCIOS INCOMPETÊNCIA DA JUSTIÇA DO TRABALHO - Não há que se falar em competência da Justiça do Trabalho para processar e julgar a ação de cobrança de honorários advocatícios, tendo em vista que a prestação de serviços fundada em contrato de mandato e representação se trata de liame obrigacional decorrente de contrato firmado sob a égide do direito civil, não possuindo, portanto, o pedido e a causa de pedir qualquer natureza trabalhista. Recurso de revista conhecido e desprovido". (BRASIL. Tribunal Superior do Trabalho, $2^{a}$ Turma. Recurso de Revista 1878/2007-004-18-00.4. Relator: Min. Renato de Lacerda Paiva. Diário da Justiça eletrônico, $1^{\circ}$ out. 2010, p. 421); "INCOMPETÊNCIA DA JUSTIÇA DO TRABALHO - AÇÃO DE COBRANÇA - HONORÁRIOS ADVOCATÍCIOS - Não tem competência a Justiça do Trabalho para apreciar a lide entre cliente e advogado em ação de cobrança de honorários. De acordo com a Súmula no 363 do Superior Tribunal de Justiça, compete à Justiça estadual processar e julgar a ação de cobrança ajuizada por profissional liberal contra cliente. Recurso de revista a que se nega provimento". (BRASIL. Tribunal Superior do Trabalho, 5a Turma. Recurso de Revista 1821/2007-013-1800.6. Relator: Min. Kátia Magalhães Arruda. Diário da Justiça eletrônico, $1^{\circ}$ out. 2010, p. 944); "RECURSO DE REVISTA - AÇÃO SOBRE A COBRANÇA DE HONORÁRIOS ADVOCATÍCIOS INCOMPETÊNCIA DA JUSTIÇA DO TRABALHO - A jurisprudência do Eg. TST se orienta no sentido de que, se a ação de cobrança objetiva o pagamento de honorários de sucumbência, em razão de vínculo contratual, a competência para processar e julgar a causa é da Justiça Comum Estadual. Precedentes. Recurso

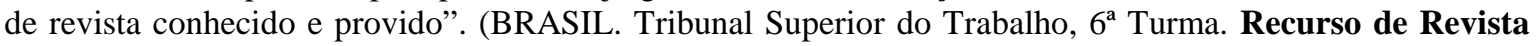
1283/2008-041-03-40.6. Relator: Min. Mauricio Godinho Delgado. Diário da Justiça eletrônico, $1^{\circ}$ out. 2010, p. 1098). 
(extinto) contrato de emprego para o contrato de mandato, tais demandas seriam classificadas como danos contratuais.

No que concerne aos assuntos julgados sob a ótica das chances perdidas, os mais recorrentes foram os seguintes: acidente de trabalho (80); ruptura contratual (58); contratação frustrada (42), retenção de CTPS (29) informação desabonadora (9) $e$ concurso público (8).

Porém, verifica-se que até o ano de 2006 o assunto era praticamente desconhecido na seara laboral, com um ou dois acórdãos por ano, exceções que confirmavam a regra. Embora não se tenha dados explicativos do crescimento constante e regular a partir de $2007^{633}$, especula-se que importantes acontecimentos doutrinários e jurisprudenciais devam ter contribuído significativamente para tal ocorrência.

Em 2005/2006, Sérgio Savi lançou sua obra "Responsabilidade Civil por perda de uma chance ${ }^{634, "}$. Já em 2007, Rafael Pettefi da Silva apresenta a sua obra "Responsabilidade Civil pela Perda de uma Chance ${ }^{635 "}$. Foram as duas primeiras obras brasileiras específicas sobre o tema, com densa pesquisa doutrinária e jurisprudencial. Em 13 de março de 2006, foi publicado no Diário de Justiça da União o acórdão do alardeado caso "Show do Milhão" (vide item 2.7.3 do capítulo 2), da lavra do Ministro Fernando Gonçalves. Todos esses acontecimentos fizeram com que, a partir de 2007, ainda que timidamente, a Justiça do Trabalho despertasse para o tema.

A liderança do ranking está com o Rio Grande do Sul (TRT 4 ${ }^{a}$ ), quiçá impulsionado pelos efeitos, ainda que tardios, da palestra do Professor François Chabas na UFRGS, 23 de maio de 1990, e, mais provavelmente, pela significativa obra do gaúcho Rafael Pettefi da Silva. A Bahia (TRT 5a) ocupa o segundo lugar, e dois fatores não podem ser desprezados em relação a isso: o primeiro foi o lançamento, em 1999, da obra "Responsabilidade Civil do Advogado - perda de uma chance ${ }^{636 ", ~ p e l o ~ b a i a n o ~ S e ́ r g i o ~}$ Novais Dias. O segundo é a soteropolitana Ana Lúcia Serbeto de Freitas Matos ter sido a vítima da pergunta sem resposta no "Show do Milhão", o que fez com que sua demanda

\footnotetext{
${ }^{633} \mathrm{O}$ ano de 2011 ainda não pode ser considerado para efeitos comparativos de crescimento da quantidade de processos, pois a pesquisa não abrangeu, sequer, o primeiro quadrimestre do corrente ano.

${ }^{634}$ SAVI, Sérgio. Responsabilidade Civil por perda de uma chance. São Paulo: Atlas, 2005.

${ }^{635}$ SILVA. Rafael Peteffi da. Responsabilidade Civil pela Perda de uma Chance. São Paulo: Atlas, 2007.

${ }^{636}$ DIAS, Sérgio Novais. Responsabilidade Civil do Advogado: perda de uma chance. São Paulo: LTr, 1999.
} 
tramitasse em primeira instância e em grau de apelação em terras baianas, aumentando, muito provavelmente, a notoriedade do caso naquelas bandas.

Mas a regra ainda é o desconhecimento do assunto. Dos 24 tribunais regionais visitados, em 12 deles foram encontradas apenas de uma a cinco decisões nos últimos dez anos. Nos tribunais da $8^{\mathrm{a}}, 13^{\mathrm{a}}$ e $22^{\mathrm{a}}$ Regiões $^{637}$, nenhum resultado foi obtido para os argumentos selecionados. São 15, de 24 tribunais, com número inexpressivo de decisões. Se considerarmos o total de casos catalogados (275) para os 10 anos abrangidos pela pesquisa, e uma média de pouco mais de 2 milhões de processos trabalhistas por ano ${ }^{638}$, constatar-se-á que, apesar do crescimento vertiginoso, o tema ainda é pouquíssimo explorado.

\subsection{O TST e a perda de uma chance}

Seria precipitada, no momento, a tentativa de emitir uma opinião mais idônea acerca da forma como a Corte Superior Trabalhista irá enfrentar a temática das oportunidades perdidas. Conforme se pode vislubrar da tabela alhures, a assunto era praticamente um "tabu" na Justiça do Trabalho até o ano de 2006, nos 24 Tribunais Regionais do Trabalho. Com o crescimento exponencial das demandas a partir do ano de 2007, e os trâmites naturais de um processo, os próximos anos poderão ser decisivos à fixação das premissas dogmáticas nas quais o Tribunal Superior do Trabalho balizará seu entendimento.

No momento, o material é relativamente escasso para sugerir grandes ilações. Sem embargo, o esquadrinhamento dos quatro acórdãos ${ }^{639} 640641$ em que o TST abordou a tese

\footnotetext{
${ }^{637}$ Para ratificar a informação, foram enviados emails aos Tribunais que não disponibilizavam decisões sobre o tema. O TRT da $22^{a}$ Região respondeu, gentilmente, confirmando a ausência de acórdãos, em pesquisa realizada pelo servidor Carlos Mariano de Sousa Rocha Filho, chefe do setor de Acórdão e Jurisprudência.

638 CONSELHO NACIONAL DE JUSTIÇA. Disponível em: < http://www.cnj.jus.br/images /programas/justica-em-numeros/2009/rel-justica-trabalho.pdf>. Acesso em: 22 abr. 2011.

${ }^{639}$ Alguns acórdãos não integraram a estatística. Nesse sentido, foram encontrados dois acórdãos ementados com referência à teoria, sem, todavia, enfrentamento da tese, pois a discussão esteve restrita ao quantum arbitrado para compensação do dano moral. Foram eles: (BRASIL. Tribunal Superior do Trabalho, $6^{\mathrm{a}}$ Turma. Recurso de Revista 122500-69.2009.5.11.0051. Publicação em 18 de fevereiro de 2011. Relator: Min. Aloysio Corrêa da Veiga. Disponível em: 〈www.tst.jus.br〉. Acesso em: 19 abr. 2011) e (BRASIL. Tribunal Superior do Trabalho, $8^{\text {a }}$ Turma. Recurso de Revista 128840-03.2007.5.04.0404. Publicação em 30 de abril de 2010. Relator: Min. Maria Cristina Irigoyen Peduzzi. Disponível em: 〈www.tst.jus.br〉. Acesso em: 19 abr. 2011).

${ }^{640}$ Também não compôs a estatística um acórdão em cujo teor há menção à teoria da perda de uma chance, contudo, restrita à transcrição da decisão regional, sem enfrentamento pela Corte Superior, que, ao reconhecer a licitude da ruptura contratual, não prosseguiu no exame do prejuízo. (BRASIL. Tribunal
} 
permite lobrigar que a Corte, provavelmente, não oporá restrições à compatibilidade do instituto com o Direito do Trabalho e, apesar de claudicante em alguns momentos, demonstra naturalidade no modo como aborda o tema e aplica as diretrizes teóricas ao caso concreto.

O caso mais emblemático, por enquanto, diz respeito a uma trabalhadora que vindicava indenização pela perda de uma chance, ao fundamento de que o atraso no pagamento das verbas rescisórias a fez perder a oportunidade de auferir lucro com a aplicação do respectivo numerário no mercado de capitais. Ao analisar o tema, assim decidiu o TST:

\begin{abstract}
Ora, não houve prova, nos autos, de que a reclamante tivesse o costume de fazer aplicações no mercado de capitais, ou de que tivesse a intenção de aplicar aquele valor específico para este fim, e não para a compra de um bem material, por exemplo. Também não restou provado que a possível aplicação no mercado de capitais rendesse lucro, uma vez que, se escolhesse a bolsa de valores, por exemplo, poderia obter prejuízo ${ }^{642}$.
\end{abstract}

O acórdão merece ser cirurgicamente recortado em dois períodos. Quando a Corte sustenta que "não houve prova, nos autos, de que a reclamante tivesse o costume de fazer

Superior do Trabalho, $2^{\mathrm{a}}$ Turma. Recurso de Revista 166100-48.2002.5.05.0021. Publicação em 28 de junho de 2010. Relator: Convocado Roberto Pessoa. Disponível em: 〈www.tst.jus.br〉. Acesso em: 19 abr. 2011).

${ }^{641}$ Finalmente, não foram incluídos cinco acórdãos que, nada obstante apontarem como precedente o julgado da $2^{\text {a }}$ Turma da Corte (BRASIL. Tribunal Superior do Traballho, $2^{\text {a }}$ Turma. Recurso de Revista 14454094.2006.5.02.0085. Relator: Min. Renato de Lacerda Paiva. Diário eletrônico da Justiça do Trabalho, 9 abr. 2010), que indubitavelmente trata do assunto, examinaram a questão sob perspectiva diversa, porquanto, nessas hipóteses, a alegação é de frutos percebidos na posse de má-fé, com violação do art. 1216 do CCB. Foram eles: (BRASIL. Tribunal Superior do Trabalho, $8^{\mathrm{a}}$ Turma. Agravo de Instrumento 4104019.2006.5.02.0018. Publicação em 06 de abr. 2011. Relator: Min. Dora Maria da Costa. Disponível em: <www.tst.jus.br>. Acesso em: 19 abr. 2011); (BRASIL. Tribunal Superior do Trabalho, $8^{\text {a }}$ Turma. Recurso de Revista 205100-60.2002.5.02.0014. Publicação em 13 de outubro de 2010. Relator: Min. Dora Maria da Costa. Disponível em: 〈www.tst.jus.br>. Acesso em: 19 abr. 2011); (BRASIL. Tribunal Superior do Trabalho, $8^{\mathrm{a}}$ Turma. Recurso de Revista 201100-57.2007.5.12.0048. Publicação em $1^{\circ}$ de abril de 2011. Relator: Min. Dora Maria da Costa. Disponível em: 〈wwww.tst.jus.br〉. Acesso em: 19 abr. 2011); (BRASIL. Tribunal Superior do Trabalho, $2^{\text {a }}$ Turma. Recurso de Revista 160440-43.2006.5.02.0045. Publicação em 08 de abril de 2011. Relator: Min. Guilherme Augusto Caputo Bastos. Disponível em: 〈www.tst.jus.br〉. Acesso em: 19 abr. 2011) e (BRASIL. Tribunal Superior do Trabalho, $4^{\text {a }}$ Turma. Recurso de Revista 5790084.2007.5.02.0075. Publicação em 25 de março de 2011. Relator: Min. Maria de Assis Calsing. Disponível em: 〈www.tst.jus.br〉. Acesso em: 19 abr. 2011).

${ }^{642}$ BRASIL. Tribunal Superior do Traballho, $2^{\text {a }}$ Turma. Recurso de Revista 144540-94.2006.5.02.0085. Relator: Min. Renato de Lacerda Paiva. Diário eletrônico da Justiça do Trabalho, 9 abr. 2010. 
aplicações no mercado de capitais, ou de que tivesse a intenção de aplicar aquele valor específico para este fim" percorre uma trilha digna de encômios, na medida em que busca frear abusos e distorções na aplicação da teoria.

Ora, como já se teve a oportunidade de afirmar (item 2.7 do capítulo 2), o instituto visa a reparar chances reais e sérias, e não danos meramente hipotéticos, fruto de quimeras ou conjeturas totalmente desconectadas com a realidade. Deveras, deve-se exigir, em tais casos, prova de que o ofendido perseguia um interesse aleatório daquele jaez, de cuja suposta usurpação se intitula vítima. E tal prova poderia ter sido realizada, conforme deixou transparecer o voto, pela demonstração de que era costume da reclamante investir no mercado financeiro.

Não fosse essa exigência, muito bem observada pelo TST, o instituto poderia ser levado ao paroxismo, dando margem a todo tipo de demanda especulativa, com indivíduos postulando, por força da ausência do pagamento de verbas rescisórias, a perda da chance de ganhar na loteria, de realizar o melhor e mais lucrativo investimento do mercado de capitais, de comprar imóveis que posteriormente renderam lucros astronômicos etc.

Todavia, na continuidade do acórdão, quando assevera que "também não restou provado que a possível aplicação no mercado de capitais rendesse lucro, uma vez que, se escolhesse a bolsa de valores, por exemplo, poderia obter prejuízo", a Corte torna, na prática, absolutamente inviável a indenização pela perda de uma chance.

Isso porque, na perda de uma chance "típica", a experimentação do resultado final pela vítima é ontologicamente indemonstrável, porquanto o ato interruptivo do curso aleatório dos eventos a retira da cadeia causal. Ora, não há como o jóquei provar que ganharia o páreo que foi impedido de correr, não há como o candidato provar que teria êxito em um concurso do qual foi excluído das provas posteriores etc.

Caroline Ruellan é absolutamente categórica ao afirmar que o prejuízo final é essencialmente eventual, pois ninguém pode prever com exatidão um evento somente provável e que, definitivamente, não será realizado com a presença da vítima ${ }^{643}$.

\footnotetext{
${ }^{643}$ Seu comentário exato foi o seguinte: “Le préjudice final, futur, est par essence éventuel puisque personne ne peut augurer d'un événement seulement probable qui n'est définitivement plus en mesure de se réaliser, et qui ne saurait donc être pris en compte par le droit. Le préjudice intermédiaire, constitué par la disparition de la situation en devenir, est saisi par le droit à travers la qualification de perte de chance”. (RUELLAN, Caroline, op. cit., p. 738)
} 
Sob tal enfoque, a decisão analisada incorre em dois desdouros: o primeiro, de permitir que o infrator se beneficie da própria torpeza, pois a autora teria sido, em tese, obstada de investir no mercado de capitais por força do ato ilícito do réu (sonegação das verbas rescisórias), e foi justamente este ilícito que a impediu de provar que obteria ganho na aplicação.

Sendo a chance uma entidade substantiva em si mesma e dotada de valor econômico, cabia à autora provar a "chance" (real e séria) e não o "ganho" (prova impossível).

O segundo deslustre é a exigência de "prova diabólica". Determinar que a autora demonstrasse a concretização de um resultado final aleatório de que não pode fazer parte é tornar o instituto natimorto. A colocação: "se escolhesse a bolsa de valores, por exemplo, poderia obter prejuízo" é um disparate, pois é da essência do mercado financeiro o risco, o caráter aleatório das aplicações. Investir em ações é um jogo randômico, por excelência, de modo que qualquer escolha (e não apenas a bolsa de valores) pode redundar prejuízo.

A Corte de Cassação italiana, em 1985, no caso Baroncini v. Enel (vide item 1.3 do capítulo 1), enfrentou com galhardia a questão da "prova diabólica", ao censurar a decisão do Tribunal de Firenze, que rechaçara uma demanda de oportunidade perdida de ser aprovado num concurso e obter um emprego, sustentando que o Sr. Baroncini não demonstrara que seria aprovado na prova oral da qual fora excluído pela empresa ${ }^{644}$.

A Suprema Corte italiana disse que a demonstração poderia ser feita pela via presuntiva, a partir de um razoável grau de probabilidade de êxito na conquista da chance obliterada $^{645} 646$.

\footnotetext{
${ }^{644}$ No original: "Il Tribunale non spiega per quale motivo o attraverso quale configurazione dei fatti il Baroncini avrebbe dovuto fornire la prova, davvero diabolica, per cui 'partecipando a quell'esame avrebbe potuto superarlo. (...) Si deduce con il quarto mezzo che erroneamente, e in violazione dell'art. 2697 c.c., il Tribunale ha ritenuto inadimpiuto l'onere probatorio da parte del Baroncini. Il 'petitum' e la 'causa petendi' della sua domanda non li imponevano affato di dimostrare che 'partecipando a quell'esame avrebbe potuto superarlo'”. (ITÁLIA. Corte de Cassação. Sentença 6506. Julgado em 19 de dezembro de 1985. Rivista di Diritto Commune, v. II, 1986, p. 209-210)

${ }^{645}$ Nos seguintes termos: "Dunque, ove il Baroncini avesse potuto partecipare a detta prova, avrebbe avuto una rilevante probabilità di superarla, secondo quanto è dato desumere dagli accertamenti effettuati dalla stessa sentenza impugnata. E tanto poteva consentire di ritenere sussistente il danno, senza che egli dovesse dimostrare, come invece richiesto dalla impugnata sentenza, che avrebbe superato l'esame, bastando la prova, anche presuntiva, che avesse una ragionevole e giuridicamente rilevante possibilità di superarlo". (Idem)

${ }^{646}$ Embora esse mesmo raciocínio tenha levado a Corte italiana à desastrosa ilação de que o grau de probabilidade deveria ser superior a 50\% (cinquenta por cento), afirmação zurzida com veemência ao longo deste trabalho (vide itens 3.7.1. a 3.7.3 do capítulo 3).
} 
Porém, a parte final do acórdão do TST deixa entrever, de soslaio, "uma luz no fim do túnel”, pois possibilita a interpretação de que a autora poderia fazer a prova, não só da aposta no mercado de capitais, mas também do ganho na aposta, a partir de um razoável grau de probabilidade, ao assim concluir: "Assim, não restaria caracterizada a perda da chance, ante a ausência do razoável grau de probabilidade de que o valor não recebido fosse aplicado no mercado de capitais, e de que a aplicação rendesse lucro, e, portanto, não seria devida a indenização para compensá-la" ${ }^{647}$.

O segundo caso, originário do TRT da $9^{\text {a }}$ Região, versava sobre a frustração da contratação imediata de um trabalhador por uma determinada empresa, pelo fato de, no emprego anterior, ter cometido infrações de trânsito que culminaram com lançamento de pontos em sua CNH - Carteira Nacional de Habilitação, o que o motivara a reclamar danos pela perda de uma chance de ser imediatamente admitido pelo outro empregador.

O Regional, ao negar o pedido de reparação, já havia decidido de forma escorreita, ao fundamentar que, se perda de oportunidade houvesse, teria sido por ato imputável ao próprio reclamante, ou seja, o TRT bem decidiu segundo as excludentes ordinárias da responsabilidade civil, mais especificamente, o fato exclusivo da vítima. Observou corretamente também que, se ilícito houvesse, não ocasionara perda de chance alguma (no máximo criação de risco - vide item 4.2 do capítulo 4), pois o trabalhador foi rapidamente contratado por outra empresa. A decisão do TRT teve o seguinte teor:

\footnotetext{
No caso, a não contratação imediata na empresa ALL, supostamente decorrente dos pontos lançados na sua Carteira de Habilitação, ocorreu por ato do próprio Autor, único responsável pela conduta imprudente de avançar o semáforo quando este encontrava-se fechado, colocando em risco também a segurança da coletividade. Acrescenta-se, por fim, que o Reclamante foi contratado pela ALL cerca de 45/60 dias após a entrevista, como freteiro, e posteriormente como empregado, cerca de 6 meses após a $1^{\mathrm{a}}$ entrevista, não havendo a alegada perda de uma chance, mesmo porque não preenchidos seus requisitos, eis que os prejuízos
}

${ }^{647}$ BRASIL. Tribunal Superior do Traballho, $2^{\text {a }}$ Turma. Recurso de Revista 144540-94.2006.5.02.0085. Relator: Min. Renato de Lacerda Paiva. Diário eletrônico da Justiça do Trabalho, 9 abr. 2010. 
advindos de suposta perda de imediata contratação decorreu de sua própria conduta, e não da empresa. Não provejo $^{648}$.

Ao ponderar sobre o tema, o TST, além de confirmar, sucintamente, os fundamentos do Regional, ainda estabeleceu as diretrizes do "paradoxo de direito" ${ }^{649}$ (vide item 2.4 do capítulo 2), ao mencionar que a reparação necessitava de prova da certeza da existência da "chance" e da probabilidade (incerteza) de sua conquista ${ }^{650}$, assim o fazendo:

A reparação pela pert d'une chance somente seria possível se houvesse sido provado nos autos a existência de uma probabilidade de que o autor teria um ganho, bem como a certeza de que ele teve um prejuízo pela vantagem perdida. Infere-se da v. decisão regional que não restou demonstrada a existência de qualquer dano sofrido pelo autor nem de qualquer conduta ilícita da reclamada, de forma que indevido o pagamento de indenização por danos morais ${ }^{651}$.

Noutro acórdão sobre o tema, o TST repeliu uma demanda relativamente recorrente no TRT da $4^{\text {a }}$ Região, em que uma professora postulava a perda de uma chance de prosseguir no emprego ou de arrumar uma nova colocação, por ter sido dispensada durante o período letivo. No caso, a rejeição do pedido se deu pela ausência de um dos pressupostos da responsabilidade civil, qual fora o ato ilícito, pois, como oportunamente

\footnotetext{
${ }^{648}$ PARANÁ. Tribunal Regional do Trabalho da $9^{\text {a }}$ Região, $4^{\text {a }}$ Turma. Recurso Ordinário 0734-2008-24209-00-3. Julgado em 17 de junho de 2009. Relator: Luiz Celso Napp. Disponível em: <www.trt9.jus.br>. Acesso em: 8 abr. 2011

${ }^{649}$ A doutrina francesa ressalta que a Corte de Cassação frequentemente cristaliza a complexidade desta difícil operação intelectual: "La formule de la Cour de cassation, souvent reproduit, cristallise la complexité de cette opération intellectuelle. Lorsqu'elle affirme qu'il y a perte de chance 'chaque fois qu'est constatée la disparition, par l'effet du délit, de la probabilité d'un événement favorable, encore que, par définition, la réalisation d'une chance ne soit jamais certaine". (RUELLAN, Caroline, op. cit., p. 737)

${ }^{650}$ O que, aparentemente, está bem consolidado no Paraná: "A teoria da responsabilidade civil por perda de uma chance ('pert d'une chance'), desenvolvida pela doutrina e jurisprudência francesa, fundamenta-se simultaneamente em uma probabilidade e em uma certeza: a probabilidade de ocorrência de ganho e a certeza de que a perda indevida da vantagem resultou um prejuízo". (PARANÁ. Tribunal Regional do Trabalho da 9a Região, $1^{a}$ Turma. Recurso Ordinário 00601-2006-094-09-00-8. Publicação em 04 de agosto de 2007. Relator: Ubirajara Carlos Mendes. Disponível em: 〈www.trt9.jus.br〉. Acesso em: 8 abr. 2011).

${ }^{651}$ BRASIL. Tribunal Superior do Trabalho, $6^{\text {a }}$ Turma. Recurso de Revista 73400-48.2008.5.09.0242. Publicação em 28 de maio de 2010. Relator: Min. Aloysio Corrêa da Veiga. Sem grifos no original. Disponível em: <www.tst.jus.br $>$. Acesso em: 19 abr. 2011.
} 
registrado, a tese criaria a figura jurídica da estabilidade provisória para os docentes, que só poderiam ser dispensados ao término do período de aulas ${ }^{652}$.

Na última decisão encontrada, também não houve grande possibilidade de o TST examinar minuciosamente os pressupostos da teoria, pois se tratava de suposta perda de chance sofrida pelo advogado, em face do levantamento do alvará judicial pelo cliente sem a sua ciência, o que lhe impediu de impugnar os cálculos de liquidação e, dessa forma, majorar o valor do crédito e, consequentemente, o de seus honorários.

A decisão foi no sentido de a atuação do advogado ser na condição de mandatário, não lhe competindo impor limites ao interesse da parte, de modo que, a despeito de cláusulas contratuais em sentido diverso, era inválida qualquer pactuação que obrigasse o cliente a litigar ou a permanecer em litígio ${ }^{653}$.

Destarte, o TST ainda carece de provocação jurisdicional eficaz e suficiente para emanar seu posicionamento acerca de todas as nuanças do tema. Várias pistas já foram dadas sobre os matizes com os quais a Corte Superior irá desenhar o cenário da perda de uma chance, boa parte delas já com a herança madura do acúmulo de discussão de mais de um século em parte da Europa ocidental.

Todavia, não houve um único caso em que um recurso de revista sobre o tema acolhesse a indenização pela perda de uma chance, de forma que caberá aos próximos que

\footnotetext{
652 "Com efeito, a tese desenvolvida pela decisão recorrida, cria uma figura jurídica nova, qual seja, a da estabilidade provisória para os docentes. De acordo com esta tese, as demissões dos professores só deveriam ocorrer ao final do período de aulas, ou seja, os docentes teriam direito à estabilidade nos períodos compreendidos entre o final do semestre letivo e o início do novo semestre. Contudo, a ausência de previsão legal não confere respaldo ao entendimento expresso na sentença recorrida”. E o acórdão ficou assim ementado: "INDENIZAÇÃO POR DANOS MORAIS, LUCROS CESSANTES E INDENIZAÇÃO PELA PERDA DE UMA CHANCE. Mostram-se incólumes os arts. 186, 187 e 927 do Código Civil e 5o, incisos Ve $X$, da Constituição Federal, diante do fundamento exarado no v. acórdão regional no sentido de que a despedida de empregado sem justa causa encontra-se dentro do poder potestativo do empregador, não caracterizando ato ilícito ou abuso de direito a justificar a condenação da reclamada no pagamento de indenização por danos materiais e morais. E acrescentou que, no momento da sua despedida, a autora não se enquadrava em nenhuma das hipóteses de estabilidade provisória a impedir a sua despedida”. (BRASIL. Tribunal Superior do Trabalho, 6 a Turma. Recurso de Revista 53900-70.2007.5.04.0403. Publicação em 07 de maio de 2010. Relator: Min. Aloysio Corrêa da Veiga. Disponível em: 〈www.tst.jus.br〉. Acesso em: 19 abr. 2011).

${ }^{653}$ Os precisos fundamentos foram os seguintes: “Com efeito, o advogado representa peça fundamental no processo, uma vez que se encontra na condição de defensor dos direitos do cliente, e não dos seus. Assim, os seus honorários destinam-se a compensar pelos serviços prestados e não para obtenção de vantagem pecuniária para o profissional. No caso, o interesse no prosseguimento do feito quando o processo já se encontrava em liquidação era do titular do direito, ou seja, o empregado, de forma que a alegada perda de uma chance nada mais representou do que a nítida intenção de aumentar o valor dos honorários advocatícios". (BRASIL. Tribunal Superior do Trabalho, $7^{\text {a }}$ Turma. Recurso de Revista 31970188.2007.5.12.0026. Publicação em 27 de agosto de 2010. Relator: Min. Maria Doralice Novaes. Disponível em: 〈www.tst.jus.br〉. Acesso em: 19 abr. 2011).
} 
se debruçarem sobre o assunto avaliar em que circunstâncias se deferiu a reparação, no âmbito do Tribunal Superior do Trabalho, tendo como fundamento a teoria das oportunidades perdidas.

\subsection{Perda de uma chance nas diversas fases}

\subsubsection{Perda de uma chance pré-contratual}

Por sua característica de situação lesiva lato sensu, a aplicação da teoria da perda de uma chance à relação de trabalho deve açambarcar, além da execução do contrato, as fases pré e pós-contratuais. De outro bordo, considerando que a doutrina das oportunidades perdidas pode ter fundamento contratual ou extracontratual (vide item 2.8 do capítulo 2), é possível abstrair a discussão sobre a topologia dos danos marginais ao contrato, acatandose, em princípio, a tese tradicionalista de que tanto a responsabilidade pré quanto a póscontratual se enquadram na responsabilidade civil delitual ou aquiliana, pois, na primeira, o vínculo jurídico não se formou, e, na segunda, já se exauriu ${ }^{654}$.

Isso porque tanto a doutrina quanto a jurisprudência ${ }^{655}$ têm constantemente batido na tecla de que as lesões ocorridas na fase pré-contratual atentam contra o "princípio da boa-

\footnotetext{
${ }^{654}$ SILVA, Hebe Mara Sá. Dano moral na fase pré-contratual das relações individuais trabalhistas. Disponível em: 〈http://www.conpedi.org.br/manaus/arquivos/anais/salvador/hebe_mara_sa_silva.pdf $>$. Acesso em: 26 abr. 2011.

${ }^{65}$ Como bem observou o TRT baiano ao reprimir a conduta do empregador que frustra expectativas reais de contratação do empregado: "PROCESSO SELETIVO. BOA-FÉ OBJETIVA. PERDA DE UMA CHANCE. DANO MORAL. CONFIGURAÇÃO. O empregador tem o dever de agir com lealdade, lisura, respeito e consideração com o empregado, sobretudo ante o seu estado de necessidade econômica e a sua condição de hipossuficiente, de modo que o fomento a uma expectativa de direito ao contrato de trabalho causa prejuízos não apenas financeiros, mas também afeta a moral de permanecer na situação de desemprego e faz emergir o dever de reparação baseado na perda de uma chance”. (BAHIA. Tribunal Regional do Trabalho da $5^{\text {a }}$ Região, $2^{\mathrm{a}}$ Turma. Recurso Ordinário 0058100-92.2009.5.05.0122. Publicação em 11 de dezembro de 2009. Relator: Cláudio Mascarenhas Brandão. Disponível em: 〈www.trt5.jus.br>. Acesso em: 6 abr. 2011), e também o TRT paulista ao condenar empregador que submeteu o empregado a três exames admissionais para rechaçar sua contratação: "DANO PRE-CONTRATUAL. PROCESSO SELETIVO. EXAME MÉDICO ADMISSISIONAL DE INAPTIDÃO. SEGUNDA CHANCE DE EXAME MÉDICO ADMISSIONAL COM RESULTADO DE APTIDÃO. CONFIANÇA NA CONTRATAÇÃO. ABALO DA CONFIANÇA PELA DETERMINAÇÃO POTESTATIVA DE TERCEIRO EXAME MÉDICO ADMISSIONAL COM RESULTADO DE INAPTIDÃO. RESPONSABIILIDADE PRÉ-CONTRATUAL. PRINCÍPIO DA BOAFÉ OBJETIVA. DEVER DE INDENIZAR. INTELIGENCIA DO ARTIGO 422 DO CODIGO CIVIL". (SÃO PAULO. Tribunal Regional do Trabalho da $2^{\mathrm{a}}$ Região, $4^{\mathrm{a}}$ Turma. Recurso Ordinário 01325.2008.463.02.00-0. Publicação em 21 de janeiro de 2011. Relator: Ivani Contini Bramante. Disponível em: 〈www.trt2.jus.br〉. Acesso em: 6 abr. 2011).
} 
fé” ${ }^{656}$, agora expresso no artigo 422 do $\mathrm{CCB}^{657}$, razão e fundamento da responsabilidade pré-contratual ${ }^{658}$, pois, embora a legislação codificada não tenha oferecido parâmetros para uma especificação de seu conteúdo, trata-se da cláusula geral que orienta o "princípio da eticidade", da tutela da fidúcia negocial na postura dos negociantes ${ }^{659}$.

$\mathrm{Na}$ sentença que inaugurou o tema da perda de uma chance na Suprema Corte italiana - o caso Cardinale e outros v. Stefer (vide item 1.3 do capítulo 1) -, um conflito tipicamente pré-contratual trabalhista -, a Corte de Cassação consignou que o contrato deveria ser interpretado e seguido de acordo com os ditames da boa-fé. Por isso, a empresa que, com o seu comportamento, havia dado fundadas razões ao trabalhador para confiar na conclusão do contrato e, posteriomente, interrompido o processo de admissão, incorria em culpa in contrahendo $^{660}$, com a consequente obrigação de reparar o dano ${ }^{661}$.

${ }^{656}$ De atuação marcante no Direito do Trabalho, conforme Plá-Rodriguez: "Porém o mais importante a assinalar é que este princípio de boa-fé tem no Direito do Trabalho um sentido muito especial, em virtude do componente pessoal que existe neste ramo jurídico. O contrato de trabalho não cria somente direitos e obrigações de ordem exclusivamente patrimonial, mas também pessoal. Cria, de outro lado, uma relação estável e continuada, na qual se exige a confiança recíproca em múltiplos planos, em direções opostas e, sobretudo, por um período prolongado de tempo. Para o devido cumprimento dessas obrigações e a adequada manutenção dessas relações, torna-se importantíssimo que ambas as partes atuem de boa-fé. Por isso dizemos que a justificação e a aplicação deste princípio tem um significado, uma duração e uma necessidade muito superiores às que podem ter em contratos que se esgotam em um intercâmbio único de prestações ou em uma simples correspondência de prestações materiais". (PLÁ-RODRIGUES, Américo, op. cit., p. 424)

657 "Art. 422. Os contratantes são obrigados a guardar, assim na conclusão do contrato, como em sua execução, os princípios de probidade e boa-fé”. (BRASIL. Código Civil (2002). Código Civil e Constituição Federal. 62. ed. São Paulo: Saraiva, 2011)

${ }^{658}$ Afirma Coelho que: "a boa-fé é o fundamento e a razão da responsabilidade pré-contratual. Todas as obras que procuram explicar a origem e as bases do instituto analisam o princípio da confiança e os deveres laterais. O Código Civil de 2002 não ofereceu parâmetros para uma especificação do conteúdo da cláusula e a Lei de Introdução ao Código Civil já admitia o recurso aos princípios gerais para a colmatação de lacunas, juntamente com a analogia e o costume. (...) É possível, entretanto, afirmar que a referência à boa-fé na lei civil brasileira evidencia uma elevação de status, de um pressuposto hermenêutico referido a um dado de fato a uma condição de princípio? A resposta ainda é dada por Reale, quando esclarece sobre os três princípios fundamentais do novo Código Civil: a eticidade, a socialidade e a operabilidade. A referência à boa-fé, no contexto do referido pronunciamento perante a Academia Paulista, leva a concluir que ela aparece no texto codificado como cláusula geral que normatiza o princípio da eticidade." (COELHO, Luciano Augusto de. Responsabilidade civil pré-contratual em Direito do Trabalho. São Paulo: LTr, 2008, p. 78-79)

${ }^{659}$ Segundo Dallegrave: "O fundamento para a responsabilidade civil pré-contratual é a tutela da confiança negocial que propugna pela harmonia do comportamento das partes, solucionando eventual conflito entre a vontade e a declaração manifestada". (DALLEGRAVE NETO, José Afonso, op. cit., p. 144)

${ }^{660}$ Conceituada assim por Dallegrave: “Assim, a chamada 'culpa in contrahendo', como o próprio nome sugere, baseia-se numa conduta ilícita do contratante; num agir pautado na culpa ou no dolo do agente que deixa de informar eventual vício ou qualidade essencial no conteúdo do contrato ou mesmo desiste, injustificadamente, de ultimar a negociação preliminar após ter gerado forte expectativa no contratante adverso". (Idem)

${ }^{661}$ Tal motivação foi extravazada nos seguintes moldes: "In contratto va interpretato ed eseguito secondo buona fede. L'attività delle parti in causa per giungere al contrato di lavoro si è arrestata nella fase preparatoria, senza da luogo ad una stipulazione vincolativa, per l'inosservanza del dovere di comportarsi secondo buona fede da parte dell'azienda, che avendo dato, col suo originario contegno alle controparti fondata ragione di fare affidamento sulla conclusione del contrato, ha interrotto senza giusto motivo il proseguimento della procedura di assunzione, dando luogo a responsabilità per c.d. 'culpa in contrahendo' 
E o fundamento legal utilizado na condenação foi exatamente o artigo 1.337 do Código Civil italiano ${ }^{662}$, que, a exemplo da legislação brasileira, exige o respeito à boa-fé nas tratativas e na formação do contrato ${ }^{663} 664$.

Na pesquisa sobre as demandas trabalhistas concernentes à perda de uma chance no estágio pré-contratual, os julgados encontrados versaram, quase que exclusivamente, sobre a frustração da contratação (42), com esparsas reclamações sobre danos pelo retardamento na posse em concurso público (3) e retenção de CTPS (3), conforme tabela abaixo:

\begin{tabular}{|c|c|c|c|c|c|c|c|c|c|c|c|c|c|c|c|c|c|}
\hline $\begin{array}{l}\text { Assunto/ } \\
\text { TRT }\end{array}$ & $2^{\mathrm{a}}$ & $3^{\mathrm{a}}$ & $4^{\mathrm{a}}$ & $5^{a}$ & $6^{a}$ & $7^{\mathrm{a}}$ & $9^{a}$ & $10^{a}$ & $11^{\mathrm{a}}$ & $12^{\mathrm{a}}$ & $15^{\mathrm{a}}$ & $19^{\mathrm{a}}$ & $20^{\mathrm{a}}$ & $21^{\mathrm{a}}$ & $23^{a}$ & $24^{\mathrm{a}}$ & TOTAL \\
\hline $\begin{array}{l}\text { Contratação } \\
\text { Frustrada }\end{array}$ & 3 & 5 & 7 & 4 & 3 & 1 & 1 & 1 & & 4 & 10 & & 1 & 1 & 1 & & 42 \\
\hline $\begin{array}{l}\text { Concurso } \\
\text { público } \\
\text { (posse } \\
\text { tardia) }\end{array}$ & & & 2 & & & & & & 1 & & & & & & & & 3 \\
\hline $\begin{array}{l}\text { Retenção de } \\
\text { CTPS }\end{array}$ & & & & 1 & & & & & & & 1 & 1 & & & & & 3 \\
\hline TOTAL & 3 & 5 & 9 & 5 & 3 & 1 & 1 & 1 & 1 & 4 & 11 & 1 & 1 & 1 & 1 & & 48 \\
\hline
\end{tabular}

Além de se basearem na violação do dever de boa-fé, alguns acórdãos também enfrentaram a questão sob a ótica do abuso de direito ${ }^{665}$ e da função social do contrato ${ }^{666}$.

con consequente obbligo di risarcire il danno derivante ai lavoratori dal fato di aver perduto l'eccezione reale di concludere con altri, lo stesso contrato mandato a monte". (ITÁLIA. Corte de Cassação. Sentença 6906. Julgado em 19 de novembro de 1983. Giustizia Civile. Rivista Mensile di Giurisprudenza, Milão, I, 1984, p. 1841-1843)

${ }_{662}$ Cuja redação é a seguinte: “Art. 1337 Trattative e responsabilità precontrattuale. Le parti, nello svolgimento delle trattative e nella formazione del contratto, devono comportarsi secondo buona fede (1366,1375, 2208). (ITÁLIA. Código Civil (1942). Código Civil. Disponível em: <http://www.jus.unitn.it/cardozo/obiter_dictum/codciv/Lib4.htm>. Acesso em: 26 abr. 2011)

663 A cláusula geral de boa-fé contratual no Código Civil italiano está, em verdade, no artigo 1375: "Art. 1375 Esecuzione di buona fede Il contratto deve essere eseguito secondo buona fede". (Idem)

${ }^{664} \mathrm{O}$ Código Civil português também possui dispositivo que assegura a boa-fé na fase de formação e de conclusão do contrato: "Artigo $227^{\circ}$ (Culpa na formação dos contratos). 1. Quem negoceia com outrem para conclusão de um contrato deve, tanto nos preliminares como na formação dele, proceder segundo as regras da boa fé, sob pena de responder pelos danos que culposamente causar à outra parte". ((PORTUGAL. Código Civil (1966). Código Civil. Disponível em: <http://www.stj.pt/nsrepo/geral/cptlp/ Portugal/CodigoCivil.pdf>. Acesso em: 26 abr. 2011)

665 “[...] A lei impõe aos contratantes a obrigação de guardar na elaboração, execução e conclusão do contrato os princípios da probidade e da boa-fé (Código Civil, art. 422). Assim, toda conduta do proponente do contrato que desviar deste propósito configura a ruptura às figuras parcelares da boa-fé objetiva (teoria dos atos próprios), notadamente do 'venire contra factum proprium', que veda atos contraditórios dos sujeitos nas negociações, como forma de coibir o abuso de direito, e a ofensa íntima e moral à dignidade da pessoa humana. Recurso Ordinário da ré a que se nega provimento". (CAMPINAS. Tribunal Regional do Trabalho da $15^{a}$ Região, $5^{\text {a }}$ Turma. Recurso Ordinário 0255000-65.2008.5.15.0070. Publicação em 27 de agosto de 2010. Relator: José Antônio Pancotti. Disponível em: 〈www.trt15.jus.br〉. Acesso em: 12 abr. 2011)

666 "A reclamada tem liberdade de contratar quem quiser como empregado, contudo, a liberdade de contratar é limitada pela função social do contrato (art. 421 do Código Civil). Ao contratar outra pessoa para a vaga, após criar real e efetiva expectativa de contratação na pessoa do reclamante, a reclamada abusou do seu 
Porém, as decisões sobre esse estágio contratual trazem muito mais informações e desenvolvimento doutrinário sobre o pré-contrato do que sobre a perda de uma chance.

Os Regionais têm sido escrupulosos quando procedem à distinção entre os meros atos iniciais no contexto de um processo seletivo (entre os quais se incluem a análise de currículo, verificação da experiência profissional $^{667}$ e aplicação de testes de aptidão ${ }^{668}$ ), que decorrem do direito à liberdade de escolha do empregador, e cuja não conclusão do contrato é inapta a gerar danos, e as hipóteses em que o comportamento da empresa confere ao empregado a certeza da contratação ${ }^{669}$.

direito de livre escolha de quem contratar como empregado, cometendo, assim, ato ilícito, nos termos do art. 187 do Código Civil. Diante do ato ilícito praticado pela reclamada ("Teoria da Perda da Chance"), devida ao reclamante a indenização por dano material pela perda de uma chance de emprego de professor na reclamada, na forma de perdas e danos (danos emergentes e lucros cessantes), conforme o disposto nos artigos 946 e 402 do Código Civil. Além da indenização por danos materiais, também é devida a indenização por danos morais, ante o inescusável abalo psicológico sofrido pelo reclamante, que teve que reformular sua vida profissional, ao pedir demissão do emprego anterior e se dedicar à proposta de emprego na reclamada, que escolheu como a mais conveniente e que lhe gerou maior expectativa de contratação, em detrimento de outras existentes ou prováveis propostas de emprego de professor". (MINAS GERAIS. Tribunal Regional do Trabalho da $3^{\mathrm{a}}$ Região, 9a Turma. Recurso Ordinário 0000734-51.2010.5.03.0014. Publicação em 14 de janeiro de 2011. Relator: Convocado Rodrigo Ribeiro Bueno. Disponível em: 〈www.trt3.jus.br $\rangle$. Acesso em: 6 abr. 2011)

${ }^{667}$ "FASE PRÉ-CONTRATUAL. NÃO EFETIVAÇÃO DA CONTRATAÇÃO. DANO MORAL. NÃO CONFIGURAÇÃO. A análise de currículo e verificação da experiência profissional de candidatos a emprego são atitudes legítimas tomadas pelas empresas, que não gera o direito à contratação. Efetivamente, não existe no ordenamento nacional dispositivo que imponha a contratação de candidatos a emprego. Não se está com isso a desconhecer que existem situações pré-contratuais que, embora legalmente não esteja o empregador obrigado a efetivar a contratação, moral e eticamente fica compelido a materializá-la, sob pena de acarretar danos, morais e materiais. Contudo, esta não é a hipótese dos autos. Correta a sentença que indeferiu a indenização pleiteada. Recurso negado". (PERNAMBUCO. Tribunal Regional do Trabalho da $6^{\mathrm{a}}$ Região, $3^{\mathrm{a}}$ Turma. Recurso Ordinário 00174.2008.010.06.00.2. Julgado em 17 de setembro de 2008. Relator: Ana Catarina Cisneiros Barbosa de Araújo. Disponível em: 〈www.trt6.jus.br〉. Acesso em: 8 abr. 2011)

668“،INDENIZAÇÃO POR DANOS MORAIS. PERDA DE CHANCE. FASE PRÉ-CONTRATUAL. TESTE DE APTIDÃO. INEXISTÊNCIA DE ATO ILÍCITO. A indenização por perda de uma chance é devida quando o lesado, por ato ilícito do responsável, tem frustrada uma vantagem futura e certa, ocasionando-se aqueles danos ao patrimônio jurídico, de ordem material ou moral. Na forma da lei, é inerente ao poder empresarial exigir dos candidatos a emprego em seus quadros de pessoal a satisfação de condições objetivas mínimas, o que se justifica pela busca constante de qualidade na execução dos objetivos empresariais, com o máximo de eficiência, vedada qualquer forma de discriminação. Não comete ato ilícito, a rejeição de candidato ao emprego que não atende as condições exigidas para o cargo, não sendo por isto devidas indenizações por danos materiais e morais, decorrentes da fase de pré-contratação, ainda mais, quando, no caso, o empregado não faz qualquer prova de ter perdido chance de nova colação profissional”. (MINAS GERAIS. Tribunal Regional do Trabalho da $3^{\mathrm{a}}$ Região, $5^{\mathrm{a}}$ Turma. Recurso Ordinário 000080678.2010.5.03.0033. Publicação em 14 de março de 2011. Relator: Convocado Maurílio Brasil. Disponível em: 〈www.trt3.jus.br〉. Acesso em: 6 abr. 2011)

${ }_{669}$ "INDENIZAÇÕES POR DANOS MATERIAIS E MORAL. RESPONSABILIDADE PRÉCONTRATUAL. A instituição de critérios e de fases atinentes a processo seletivo de trabalhador, inclusive quanto à verificação da aptidão física do candidato para a função a ser desempenhada, está inserida no poder de gestão do empregador. Hipótese dos autos em que o conjunto probatório indica, todavia, ter adotado a reclamada conduta imprudente, conferindo ao reclamante a certeza da sua contratação, a qual, uma vez frustrada, resultou em inegáveis prejuízos de ordem material e moral ao trabalhador. Recurso do reclamante provido no aspecto para condenar a reclamada ao pagamento das indenizações respectivas". (RIO GRANDE DO SUL. Tribunal Regional do Trabalho da $4^{\mathrm{a}}$ Região, $8^{\mathrm{a}}$ Turma. Recurso Ordinário 0000001- 
Há, contudo, importante diferença a ser traçada entre negociações prévias e précontrato ou contrato preliminar. Estes últimos têm natureza jurídica contratual, na medida em que contêm uma obrigação de fazer, qual seja a celebração do contrato definitivo ${ }^{670}$. Reúnem todos os elementos essenciais do negócio jurídico ${ }^{671}$, mas dispensam forma especial, com o escopo de dinamizar os negócios jurídicos e reduzir custos. "Já as negociações preliminares são constituídas de fatos e tratativas em fase incipiente que objetivam fixar as condições e objeto de um contrato ou um pré-contrato" ${ }^{672}$.

Embora seja simples traçar as distinções doutrinárias, as figuras podem se confundir na prática, mormente quando as atitudes do empregador acenam, objetivamente ${ }^{673}$, para a concretização do contrato de trabalho, como, por exemplo, quando é realizado o exame admissional, aberta a conta-salário e procedida à entrega de documentos etc. ${ }^{674}$, caso em que a jurisprudência tem considerado tais atitudes como equivalentes a um pré-contrato.

Do cotejo das decisões acerca da perda de uma chance pela frustração da contratação, infere-se que a grande dificuldade, ou, pelo menos, a maior heterogeneidade

96.2010.5.04.0551. Julgado em 05 de agosto de 2010. Relator: Wilson Carvalho Dias. Disponível em: <www.trt4.jus.br>. Acesso em: 6 abr. 2011)

${ }^{670}$ De acordo com o que leciona Venosa: "Terminológica e tecnicamente, o contrato preliminar objetiva a conclusão de um contrato principal e definitivo. Possui todas as características de contrato, tratando-se de modalidade autônoma em sua classificação geral. No contrato preliminar, pré-contrato ou promessa de contratar já existem todos os requisitos de um contrato. Por isso, não se confunde com as chamadas negociações preliminares. Essa fase preliminar de negociação ou pontuação, como regra geral, não gera direitos. Pode dela decorrer uma responsabilidade pré-contratual sob determinadas condições, situada fora da relação contratual (...)”. (VENOSA, Sílvio de Salvo. Compromisso de compra e venda com Eficácia Real: direito do promitente comprador. Disponível em: <http://www.professorsimao.com.br/artigos_convidados venosa.htm>. Acesso em: 27 abr. 2011)

671 "CCB. Art. 462. O contrato preliminar, exceto quanto à forma, deve conter todos os requisitos essenciais ao contrato a ser celebrado”. (BRASIL. Código Civil (2002). Código Civil e Constituição Federal. 62. ed. São Paulo: Saraiva, 2011)

${ }^{672}$ DALLEGRAVE NETO, José Afonso, op. cit., p. 145.

${ }^{673}$ Já que a frustração puramente psicológica da expectativa de contratação não interessa ao Direito, porque não se trata de chance real e séria, como bem decidido pelo TRT da $15^{\text {a }}$ Região: "Pré-contratação. Indenização. Desde a primeira entrevista o empregado está engajado à concretização do emprego. Suas expectativas positivas transcendem à razão. $\mathrm{O}$ fracasso não faz parte de seu universo, naquele momento. Assim, o sentimento de frustração pela perda daquela oportunidade não é elemento suficiente à ensejar reparação moral ou material, pois ausente o elemento culpa por parte do empregador". (CAMPINAS. Tribunal Regional do Trabalho da $15^{\mathrm{a}}$ Região, $6^{\mathrm{a}}$ Turma. Recurso Ordinário 0032500-85.2008.5.15.0135. Publicação em 21 de agosto de 2009. Relator: Nora Magnólia Costa Rotondaro. Disponível em: <www.trt15.jus.br>. Acesso em: 12 abr. 2011)

674" PROMESSA DE CONTRATAÇÃO FRUSTRADA. FASE PRÉ-CONTRATUAL. DANO MORAL. Tendo havido entrevista, exame admissional, abertura de conta para recebimento de salário e entrega da documentação, há a formação de um pré-contrato, fase em que também as partes devem respeitar o princípio da boa-fé objetiva consagrado no art. 422 do Código Civil. A promessa de contratação frustrada por parte da reclamada caracteriza a afronta à boa-fé, gerando a obrigação de indenizar o empregado pela falsa expectativa criada. Recurso da reclamada a que se nega provimento". (RIO GRANDE DO SUL. Tribunal Regional do Trabalho da $4^{\mathrm{a}}$ Região, $4^{\mathrm{a}}$ Turma. Recurso Ordinário 0000305-60.2010.5.04.0304. Julgado em 28 de outubro de 2010. Relator: Hugo Carlos Scheuermann. Disponível em: 〈www.trt4.jus.br〉. Acesso em: 6 abr. 2011) 
nas decisões situa-se na liquidação do dano. Nesse aspecto, as decisões tomam caminhos variados, mas, raramente, enfrentam de forma minudente o problema da quantização, questão que, inexoravelmente, passa pelo correto enquadramento do instituto.

Alguns julgados enquadram a perda de uma chance como uma "terceira modalidade de dano" ${ }^{\text {,675 }}$, questão por nós veementemente fustigada (vide item 2.6 do capítulo 2), pois ela é a situação lesiva (causa) que pode gerar dano moral, material ou estético (efeitos), e não uma "terceira" (ou quarta) espécie de dano.

Há também diversas decisões que optam por conceder a indenização a título de danos morais. Sem compulsar os respectivos autos, seria leviano afirmar se tal postura advém de um método mais cômodo de arbitrar o valor do dano, ou, propriamente, das limitações impostas pelo "princípio da demanda" e pelos limites objetivos da litiscontestatio (CPC, arts. $2^{\circ}, 128$ e 460$)^{676}$. Sem embargo, eventual transmudação da modalidade da ofensa causada para efeitos de facilitação ou de viabilização da condenação é algo proscrito do ordenamento hodierno.

Mas já foi algo positivado até recentemente.

Com efeito, o vetusto artigo 1.547 do CCB de 1916 dispunha que: "a indenização por injúria ou calúnia consistirá na reparação do dano que delas resulte ao ofendido”, ou seja, que a indenização do dano material seria medida pela sua extensão (o que, hoje, tem regra geral no artigo 944 do $\mathrm{CCB}$ ). Porém, em seu parágrafo único estabelecia que "Se este não puder provar prejuízo material, pagar-lhe-á o ofensor o dobro da multa no grau máximo de pena criminal respectiva”.

Tratava-se, pois, de uma opção do legislador de tarifar um valor a título de dano moral, quando não fosse possível provar o dano material nos crimes contra a honra. $\mathrm{O}$ valor podia chegar a 10.800 salários mínimos, pelo seguinte motivo: o artigo 49 do Código

\footnotetext{
675 “Conforme já consta da r. sentença recorrida, além dos danos morais e dos danos materiais, como espécie de dano originalmente regulado pelo ordenamento jurídico, vem se aceitando, uma terceira modalidade de dano, na qual se enquadra a indenização pela perda de uma chance, em que a vítima vem a ser privada da oportunidade de obter determinada vantagem, em razão de ato ilícito praticado por terceiro, verificando-se daí um prejuízo material indenizável, mas, a fim de que haja essa responsabilidade indenizatória, impõe-se o concurso da ação ou omissão, dolosa ou culposa, por parte do agente, efetivo prejuízo para a vítima e nexo causal entre o evento e o dano". (CAMPINAS. Tribunal Regional do Trabalho da $15^{\mathrm{a}}$ Região, $6^{\mathrm{a}}$ Turma. Recurso Ordinário 0161200-60.2009.5.15.0033. Publicação em 12 de novembro de 2010. Relator: Maria Cristina Mattioli. Disponível em: 〈www.trt15.jus.br〉. Acesso em: 12 abr. 2011)

${ }^{676}$ BRASIL. Código de Processo Civil (1973). Código de Processo Civil e Constituição Federal. 17. ed. São Paulo: Saraiva, 2011.
} 
Penal fixa a quantidade máxima de dias-multa em $360^{677}$, e o maior valor do dia-multa, conforme o parágrafo único, é de 5 salários mínimos ${ }^{678}$. Logo, a pena criminal máxima é 1.800 salários mínimos ( 360 X 5), e o seu dobro é 3.600 salários mínimos. Todavia, como o $\S 1^{\circ}$ do artigo 60 do Código Penal ${ }^{679}$ permite triplicar o valor diante da situação econômica do réu, chega-se ao valor de 10.800 salários mínimos ${ }^{680}$.

Tal escolha foi modificada, pois o legislador, no parágrafo único do artigo 953 do $\mathrm{CCB}^{681}$, determinou que "Se o ofendido não puder provar prejuízo material, caberá ao juiz fixar, eqüitativamente, o valor da indenização, na conformidade das circunstâncias do caso.” Portanto, a opção da lei, que vincula e impede escolhas do intérprete, é a adoção da equidade (vide item 3.3.4 do capítulo 3) na fixação dos danos.

Cabe, pois, estabelecer, no caso concreto, os parâmetros equitativos para o arbitramento da indenização por danos patrimoniais decorrentes da frustração na contratação, utilizando-se critérios claros e particularmente justos em cada situação, como, por exemplo:

A) para fixação do salário, caso não haja importância ajustada ou prova dela, deve-se socorrer do critério do artigo 460 da $\mathrm{CLT}^{682}$, que determina; "Na falta de estipulação do salário ou não havendo prova sobre a importância ajustada, o empregado terá direito a

\footnotetext{
677 “CP. Art. 49. A pena de multa consiste no pagamento ao fundo penitenciário da quantia fixada na sentença e calculada em dias-multas. Será, no mínimo, de 10 (dez) e, no máximo, de 360 (trezentos e sessenta) diasmulta". (BRASIL. Código Penal (1940). Código Penal. Disponível em: < http://www.planalto.gov.br/ccivil/decreto-lei/Del2848.htm>. Acesso em: 27 abr. 2011)

678 "§ $1^{\circ}$. O valor do dia-multa será fixado pelo juiz não podendo ser inferior a um trigésimo do maior salário mínimo mensal vigente ao tempo do fato, nem superior a 5 (cinco) vezes esse salário". (Idem)

679 "CP. Art. 60. Na fixação da pena de multa o juiz deve atender, principalmente, à situação econômica do réu. $\S 1^{\circ}$. A multa pode ser aumentada até o triplo, se o juiz considerar que, em virtude da situação econômica do réu, é ineficaz, embora aplicada no máximo". (Idem)

${ }^{680}$ Foi a conclusão de Galeno Lacerda, citado por Araken de Assis: "Seja como for, demonstrou GALENO LACERDA que a mudança do valor da pena criminal de multa, prevista como meio de liquidar o dano no parágrafo único do art. 1.547, provocou radical transformação no panorama, autorizando, em casos que tais, uma indenização de até 10.800 salários mínimos, atualmente a expressiva quantia de $\mathrm{R} \$ 1.209 .600,00$. O art. 49 do Cód. Penal reza que a pena máxima de multa corresponderá a 360 dias-multa, e, segundo seu $\S 1^{\circ}$, o valor do dia-multa é de cinco salários mínimos. Logo, 360 x $5=1.800$ salários mínimos. E tal multa, consoante o art. $60, \S 1^{\circ}$, do Cód. Penal, poderá ser triplicada, em virtude da condição econômica do réu. Assim, o valor máximo da pena criminal de multa é de 5.400 salários mínimos e, permitindo o art. 1.547, parágrafo único, do Cód. Civil a aplicação de seu dobro, chega-se àquele valor espantoso". (ASSIS, Araken de, op. cit., p.18)

${ }^{681}$ BRASIL. Código de Processo Civil (1973). Código de Processo Civil e Constituição Federal. 17. ed. São Paulo: Saraiva, 2011.

${ }^{682}$ BRASIL. Consolidação das Leis do Trabalho (1943). CLT e Constituição Federal. 38. ed. São Paulo: Saraiva, 2011.
} 
perceber salário igual ao daquele que, na mesma empresa, fizer serviço equivalente, ou do que for habitualmente pago para serviço semelhante";

B) para a fixação do tempo de serviço frustrado na empresa em que a vítima perdeu a oportunidade de se colocar, pode-se utilizar de dados estatísticos genéricos sobre o período de permanência de um trabalhador (da indústria, do comércio, dos serviços, do campo ou doméstico) no emprego, ou dados mais específicos sobre o grau de rotatividade na própria empresa em que restou malograda a admissão;

C) pode-se, ainda, como método de refinamento da equidade, confrontar os dados gerais e pessoais de empregabilidade da empresa (item "B") com os do próprio trabalhador, analisando-se a média de tempo que ele permaneceu em cada emprego anterior;

D) no mesmo sentido, pode-se verificar se o recrutamento seria mediante contrato de experiência, por prazo determinado ou indeterminado. Nos dois primeiros casos, pode-se analisar o percentual de trabalhadores que eram efetivados após o contrato de experiência ou o contrato por prazo determinado, obtemperando tal informação com a condição econômica que ostentava a empresa em cuja oportunidade se frustrou.

Para apuração do montante devido a título de dano moral, podem ser observados os seguintes fatores: i) se houve dolo ou culpa da empresa; ii) se a empresa é reincidente na prática; iii) até que fase foram as tratativas negociais; iv) se o empregado foi obrigado a se desligar de outro emprego; v) se o empregado foi obrigado a mudar de domicílio; vi) quanto tempo o empregado permaneceu desempregado; vii) se o empregado é responsável pelo sustento próprio e/ou de sua família, e se o seu salário é a única fonte de renda da família; viii) se há alguma justificativa econômica, técnica ou financeira para a não contratação.

Enfim, há muitas nuanças que permitem ao juiz ser equitativo, na acepção aristotélica do termo, arbitrando a indenização a partir de matizes palpáveis ${ }^{683}$, que desçam

\footnotetext{
${ }^{683}$ Sob esse aspecto, merece destaque a seguinte decisão: "No entanto, aplicando-se, de forma analógica, a teoria francesa relativa à perda de uma chance, que, resumidamente, reconhece a existência de danos que ficam equidistantes das modalidades previstas no artigo 402 do Código Civil, reputo que o obreiro deverá ser indenizado, pela metade, em montante que representa a soma dos salários devidos no período de 04/04/2008 a $03 / 09 / 2008(\mathrm{R} \$ 1.636,30)$ com as férias enriquecidas com um terço $(\mathrm{R} \$ 181,81)$, salários trezenos $(136,35)$ e FGTS (R\$ 141,81) desse mesmo período, utilizando-se, nos cálculos, o valor do salário mensal que recebia do antigo empregador, R\$ 654,52”. (CAMPINAS. Tribunal Regional do Trabalho da $15^{\mathrm{a}}$ Região, $6^{\mathrm{a}}$ Turma. Recurso Ordinário 0179500-62.2008.5.15.0144. Relator: Eurico Cruz Neto. Publicação em 25 de setembro de 2009. Disponível em: 〈www.trt15.jus.br〉. Acesso em: 12 abr. 2011).
} 
às minúcias de cada situação, e não promovam, meramente, a reprodução artificializada de velhos chavões, absolutamente idênticos para todos os casos, que só servem para encobrir as autênticas razões da decisão, ou maquilar uma sentença despudoradamente sem fundamento.

A dissimulação reinante por trás da perniciosa máscara da (des)motivação por meio de autotextos que desembocam no alçapão do vazio léxico, na erosão da dialética e no niilismo retórico, esconde o arbítrio do magistrado que se vislumbra em panteão narcisóide, e coloca-se na posição de paradigma da humanidade, medindo o mundo com a sua própria régua e decidindo segundo suas convicções mais íntimas ${ }^{684}$, como se o Direito pudesse pertencer ao ramo das ciências ocultas.

É imperioso permitir aos litigantes conhecer as razões de convencimento do juiz, garantindo-lhes, assim, além de uma decisão mais justa e fundamentada (CF, art. 93, IX $)^{685}$, a proteção aos direitos constitucionais de um devido processo legal, com possibilidade do contraditório efetivo e da ampla defesa (CF, art. $5^{\circ}$, LIV e LV) ${ }^{686}$.

\subsubsection{Perda de uma chance contratual}

Diferentemente do estágio preambular, em que a temática é quase como um "samba de uma nota só" pautado na frustração da contratação, o desenrolar da relação de trabalho oferece maior e mais variada gama de assuntos, conforme os dados consolidados:

\footnotetext{
${ }^{684}$ Confira-se, a propósito, as lições de Décio Antônio Erpen: "Aí minha insurgência ante o extremo subjetivismo que sustenta a estimativa do dano e da indenização correspondente, preponderando, por óbvio, a postura axiológica do juiz. Este risco calculado deve, no mínimo ser proclamamado e dado à publicidade, para que a sociedade o assuma. (...) Quando afirmo que há omissão do legislador, não pretendo esvaziar a jurisdição. Apenas pretendo delimitá-la para que reine sobranceiro o primado do Direito, segundo um sistema. Sei que a jurisprudência é, igualmente, fonte de Direito. Talvez a mais viçosa. Não olvido, por óbvio, que o termo 'jurisprudência' é a 'prudência do direito'. Todavia, o vetor da cidadania é a lei. É ela que torna necessária a presença do Juiz-mediador, dentro dos limites que ela mesmo consente. A aferição do fato há que se dar pelo magistrado, porquanto opera sobre o plano executivo. Todavia, a segurança jurídica do cidadão está na lei e não na direção dos julgados, ou sentimentos dos Juízes, ou inclinações dos magistrados porque nem sempre elas são antecipadamente conhecidas. O magistrado deve ser o mediador entre a lei e o fato, e não a norma de conduta recôndita em seu íntimo. Do conrário geraria um estado de insegurança. A jurisdição tem como escopo a justiça, no caso concreto; a lei, objetiva outorgar a segurança, daí porque se proclama que "um direito inseguro é um direito eminentemente injusto". (ERPEN, Décio Antônio. O dano moral e a desagregação social. Revista dos Tribunais, São Paulo, ano 87, n. 758, seção 3, p. 44-52, dez. 1998, p. 47)

${ }^{685}$ BRASIL. Constituição (1988). Constituição da República Federativa do Brasil. 16. ed. São Paulo: RT, 2011.

${ }^{686}$ Idem
} 


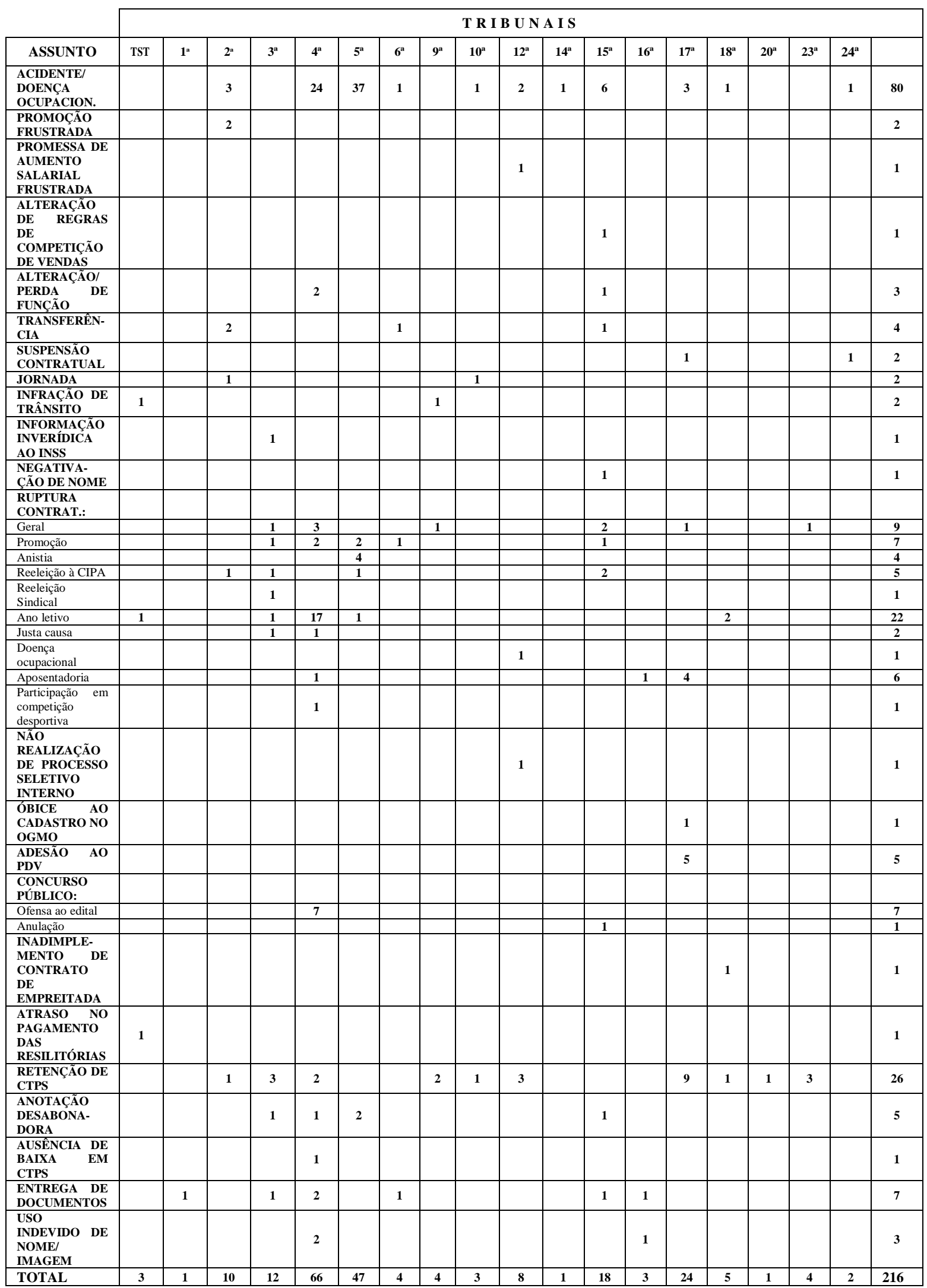

Estatisticamente, porém, a exemplo do que ocorreu nos domínios internacionais, é no campo da infortunística que a jurisprudência mais deu azo às demandas de oportunidades 
perdidas na Justiça do Trabalho, haja vista as diversas possibilidades de subtração de chances que um acidente de trabalho ou uma doença profissional podem ocasionar.

Essa tendência de uma quantidade vultosa de infortúnios é herança das modificações introduzidas pela Revolução Industrial, cujo berço foi a Inglaterra do século XVIII, que encetou uma profunda transformação no modo de produção, fazendo com que a lida diária com novas máquinas e instrumentos, ao mesmo tempo extremamente eficientes, sob o prisma da produtividade, e altamente perigosos, sob o ângulo da higidez física e mental, fizesse aflorar um desenvolvimento da responsabilidade civil por danos corporais, pois quanto menor era a segurança jurídica, mais se demandava por segurança material ${ }^{687} 688$.

O quadro mais recente não parece muito confortável, já que "de acordo com levantamento da OIT divulgado em 1985, a cada três minutos um trabalhador perdia a vida no mundo em consequência de acidente do trabalho ou de doença profissional, e a cada segundo, pelo menos, quatro trabalhadores sofriam algum tipo de lesão" ${ }^{689}$.

Também em nossas fronteiras, o problema acidentário é grave e mobiliza todos os atores sociais, pois além de provocar a perda ou a mutilação de seres humanos, ainda acarreta elevado custo para a Previdência Social, sem olvidar que os expressivos números de acidentes de trabalho constantes das estatísticas oficiais representam, apenas, 50\% (cinquenta por cento) dos sinistros efetivamente acontecidos, notadamente porque a introdução no ordenamento da estabilidade provisória às vítimas de acidente de trabalho estimula a subnotificação das ocorrências ${ }^{690} 691$.

Há, porém, outra circunstância que eleva sobremaneira o recurso à teoria da perda de uma chance em matéria de acidentes de trabalho: a nítida confusão do instituto com os lucros cessantes (vide item 2.5.1 do capítulo 2).

\footnotetext{
${ }^{687}$ Este foi o cenário descrito por Josserand: "O século do caminho de ferro, do automóvel, do avião, da grande indústria e do maquinismo, o século dos transportes e da mecanização universal, não será precisamente o da segurança material: fiéis à recomendação de Nietzsche, vivemos perigosamente, cada vez mais intensamente, como nos aconselhava o presidente Teodoro Roosevelt. E então, acontece muito naturalmente que, desprovidos de segurança material, aspiramos mais e mais à segurança jurídica". (JOSSERAND, Louis. Evolução da responsabilidade civil. Revista Forense, v. 86, n. 454, 1941, p. 549)

688 Em harmonia com esta conclusão, Antonio Pedrotti sublinha o avanço da legislação infortunística brasileira ao equiparar as doenças ocupacionais aos acidentes de trabalho, nos termos do artigo 20, da Lei 8.213/91. (PEDROTTI, Irineu Antonio. Doenças profissionais ou do trabalho. 2. ed. São Paulo: Universitária de Direito, 1998, p. 63). E tal dado, em arremate ao sustentado, é sintomático de o Brasil ter ostentado, durante a década de 70, o título de "campeão mundial de acidentes de trabalho".

${ }^{689}$ OLIVEIRA, Sebastião Geraldo, op. cit., p. 29-30.

${ }^{690}$ BRANDÃO, Cláudio. Acidente de trabalho e responsabilidade civil do empregador. São Paulo: LTr, 2006, p. 28-29.

${ }^{691}$ Embora a instituição do Nexo Técnico Epidemiológico - NTE (vide capítulo II, item 5.2) tenha ajudado a diminuir as fraudes nas notificações de acidentes de trabalho.
} 
Repise-se que a distinção entre ambos não repousa no fato de o último basear-se em uma "certeza" e o primeiro em uma "probabilidade", pois o caráter randômico compõe a essência de ambos. A diferença está no modo como o Direito interatua com a álea: nos lucros cessantes, ele a repugna, artificializando o conhecimento e agindo como se tudo soubesse, a partir de decisões pautadas pelo sistema de "presunções". Já na perda de uma chance o Direito a assimila, admite o desconhecimento e o toma em consideração no momento de decidir, com base em juízos de "probabilidade".

Pois bem, o Código Civil brasileiro estampa algumas regras de reparação de ofensas corporais $^{692} 693$, naturalmente aplicáveis nos casos de acidente de trabalho, as quais, por opção do legislador, são determináveis pela via presuncional, pois, diante de um elevado grau de probabilidade de que aquele fosse o curso natural das coisas, a lei aceita decidir como se assim fosse. Mas nenhuma certeza há de que a vítima viveria até aquela data, permaneceria no emprego ou mesmo prestaria alimentos aos dependentes ${ }^{694}$.

Daí a razão de ser um erro grave afirmar que o pensionamento é "apenas uma indenização pela perda de uma chance" ${ }^{695}$. E o equívoco transcende o mero capricho taxonômico, pois a confusão entre os institutos pode implicar prejuízo na reparação do dano injusto, por exemplo, quando se sustenta que a concessão de indenização pela perda de uma chance cumulada com lucros cessantes seria bis in idem ${ }^{696}$.

692 “CCB. Art. 948. No caso de homicídio, a indenização consiste, sem excluir outras reparações: I - no pagamento das despesas com o tratamento da vítima, seu funeral e o luto da família; I - no pagamento das despesas com o tratamento da vítima, seu funeral e o luto da família; II - na prestação de alimentos às pessoas a quem o morto os devia, levando-se em conta a duração provável da vida da vítima”. (BRASIL. Código Civil (2002). Código Civil e Constituição Federal. 62. ed. São Paulo: Saraiva, 2011)

693 “CCB. Art. 950. Se da ofensa resultar defeito pelo qual o ofendido não possa exercer o seu ofício ou profissão, ou se lhe diminua a capacidade de trabalho, a indenização, além das despesas do tratamento e lucros cessantes até ao fim da convalescença, incluirá pensão correspondente à importância do trabalho para que se inabilitou, ou da depreciação que ele sofreu. Parágrafo único. O prejudicado, se preferir, poderá exigir que a indenização seja arbitrada e paga de uma só vez". (Idem)

${ }^{694}$ Para esta hipótese, basta imaginar a situação do ex-cônjuge que presta alimentos ao outro, até que este passe a exercer atividade remunerada e prescinda da prestação, ou, que ele venha a convolar novas núpcias, fazendo cessar o direito à pensão.

${ }^{695}$ Como asseverado na seguinte decisão: "Quanto à fixação do valor da pensão mensal, entende-se que a decisão não está adequada, merecendo reforma para determinar que a pensão deva ser paga no percentual de $100 \%$ do salário percebido, na medida em que o pensionamento é apenas uma indenização pela perda de uma chance". (RIO GRANDE DO SUL. Tribunal Regional do Trabalho da $4^{\mathrm{a}}$ Região, $6^{\mathrm{a}}$ Turma. Recurso Ordinário 0010300-51.2007.5.04.0030. Julgado em 14 de abril de 2010. Relator: Maria Madalena Telesca. Disponível em: 〈www.trt4.jus.br〉 . Acesso em: 6 abr. 2011)

${ }^{696}$ Nesse sentido: "Com efeito, dá-se provimento ao recurso para condenar a reclamada ao pagamento de indenização a título de lucros cessantes no valor de $\mathrm{R} \$ 10.000,00$, bem assim ao pagamento de indenização por dano moral no valor de $\mathrm{R} \$ 20.000,00$. No tocante ao pedido de indenização por perda de uma chance, indefere-se, porquanto caracterizaria bis in idem, uma vez que deferido o pedido de indenização por lucros cessantes". (RIO GRANDE DO SUL. Tribunal Regional do Trabalho da $4^{\mathrm{a}}$ Região, $3^{\mathrm{a}}$ Turma. Recurso 
Exploro a questão a partir do corriqueiro exemplo de um acidente de trabalho que provoca a morte do empregado, ensejando a condenação ao pagamento de pensão, como vertente dos lucros cessantes. Pois bem, a renda deverá ser apurada segundo os efetivos rendimentos do de cujus, computando-se o valor do seu último salário, acrescido da média de variáveis percebidas habitualmente, utilidades concedidas pelo serviço, $13^{\circ}$ salário e o terço constitucional de férias, ambos pelo duodécimo etc ${ }^{697}$.

O cálculo do benefício, com o acréscimo das rubricas salariais e remuneratórias arroladas, além de parcelas da contratualidde, é orientado a partir do critério de presunções, considerando-se aquilo que, razoavelmente, poderia supor-se que a vítima auferiria, caso estivesse viva e trabalhando.

Uma circunstância, todavia, pode intrigar em relação ao assunto: a existência de pessoal organizado em Quadro de Carreira ${ }^{698}$, devidamente homologado pelo Ministério do Trabalho e Emprego ${ }^{699}$, no qual as promoções são alternadas, por antiguidade e merecimento. Em tais casos, é forçoso debater se as majorações salariais decorrentes de tais promoções (futuras e incertas) devem ser agregadas no cálculo do salário, e a que título.

Pois bem, considerando que a apuração do montante parte do pressuposto de que o trabalhador continuaria prestando serviços até a sua provável expectativa de sobrevida, é

Ordinário 0191400-78.2007.5.04.0404. Julgado em 12 de novembro de 2008. Relator: Luiz Alberto de Vargas. Disponível em: 〈www.trt4.jus.br〉. Acesso em: 6 abr. 2011).

${ }^{697}$ É o que ensina Sebastião Geraldo de Oliveira: "Pelo princípio da 'restitutio in integrum' que orienta o cálculo da indenização, deve-se apurar os rendimentos efetivos da vítima, computando-se o valor do seu último salário, mais a média das parcelas variáveis habitualmente recebidas, tais como: horas extras, adicional noturno, insalubridade, periculosidade, acréscimos previstos em convenções coletivas etc. [...] Compõem, ainda, o cálculo da remuneração os valores correspondentes às utilidades fornecidas habitualmente pelo empregador, tais como: alimentação, habitação, vestuário e outras prestações 'in natura', salvo as exceções mencionadas (art. 458 da CLT). Além das parcelas mencionadas da remuneração, o valor relativo ao $13^{\circ}$ salário deve ser acrescido, pelo seu duodécimo ou então determinar que no mês de dezembro de cada ano haja uma prestação adicional equivalente a tal vantagem. [...] É razoável, todavia, computar o acréscimo correspondente ao adicional de $1 / 3$ sobre as férias, também pelo seu duodécimo, porquanto esse valor compunha o conjunto de rendimentos ao longo do ano". (OLIVEIRA, Sebastião Geraldo, op. cit., p. 243-244)

${ }^{698}$ Como prevê o $§ 2^{\circ}$ do artigo 461 da CLT: “\$ $2^{\circ}$. Os dispositivos deste artigo não prevalecerão quando o empregador tiver pessoal organizado em quadro de carreira, hipótese em que as promoções deverão obedecer aos critérios de antigüidade e merecimento". (BRASIL. Consolidação das Leis do Trabalho (1943). CLT e Constituição Federal. 38. ed. São Paulo: Saraiva, 2011)

${ }^{699}$ Condição de validade estipulada pela Súmula 6, I do TST. (BRASIL. Tribunal Superior do Trabalho. Súmula $\mathrm{n}^{\circ}$ 6, de 23 de novembro de 2010. Para os fins previstos no $\S 2^{\circ}$ do art. 461 da CLT, só é válido o quadro de pessoal organizado em carreira quando homologado pelo Ministério do Trabalho, excluindo-se, apenas, dessa exigência o quadro de carreira das entidades de direito público da administração direta, autárquica e fundacional aprovado por ato administrativo da autoridade competente. Disponível em: <http://www.tst.gov.br/jurisprudencia/Livro_Jurisprud/livro_html_atual.html〉. Acesso em: 20 abr. 2011) 
lógico presumir que, na medida em que forem completados os interstícios necessários às promoções por antiguidade, os reajustamentos salariais delas decorrentes devem compor o valor da pensão, a título de lucros cessantes.

Intelecção diversa se exige no que concerne às promoções por merecimento. Rechaçá-las por não haver "certeza" da conquista das promoções é resolver mal o problema, pois, igualmente, não há "certeza" do fracasso em sua busca. A ilação palmar é a de que o trabalhador, normalmente, persegue o interesse aleatório de ascensão profissional. E o que se tem de concreto é que todo empregado de uma empresa que possui Plano de Carreira possui a chance de galgar degraus mais elevados, e que o sinistro que lhe provoca invalidez ou óbito exirpa-lhe esta oportunidade.

Assim, preenchidos os pressupostos teóricos, o pensionamento pode embutir não apenas os aumentos encontrados a título de lucros cessantes (promoções por antiguidade), baseados em juízos de presunção, mas também a importância correspondente às oportunidades perdidas $^{700}$, calculadas, na hipótese apresentada, de acordo com o grau de probabilidade que a vítima teria de obter as promoções por merecimento.

Observou-se, ainda, certa hesitação no momento de distinguir a perda de uma chance da condição maliciosamente obstada pela parte cujo implemento desfavorecer (vide item 2.5.2 do capítulo 2), cuja confusão pode transcender à mera adequação no emprego dos vocábulos e expressões jurídicas. Analise-se o teor da seguinte ementa:

O ato injustificável do empregador que limita o empregado de executar o contrato em sua plenitude, de modo a impedir o ganho de parcela salarial até então percebida, constitui-se naquilo que doutrinariamente se chama de perda de uma chance. Tipifica a dita rescisão indireta e tem-se a responsabilidade civil do empregador. A indenização, nesse caso, visa compensar a perda da possibilidade de ganho, de modo que a média da

\footnotetext{
${ }^{700}$ Sutileza bem observada no seguinte acórdão: “ACIDENTE DE TRABALHO. REPARAÇÃO POR DANOS MATERIAIS, MORAIS E ESTÉTICOS. É da responsabilidade do empregador a direção de sua atividade empresarial, cabendo-lhe zelar pela segurança de seus empregados. Provado o sinistro de que resultou amputação de parte do membro superior do trabalhador, o prejuízo é direto e imediato, cabendo, também, a análise do prejuízo futuro dentro do juízo de probabilidade, do que a doutrina denomina de análise pela perda de oportunidade, perda de chance da vítima. Logo, devida a reparação pelo empregador dos danos morais, materiais e estéticos em face do sinistro sofrido pelo trabalhador". (ESPÍRITO SANTO. Tribunal Regional do Trabalho da $17^{\mathrm{a}}$ Região. Recurso Ordinário 00651.2005.002.17.00.2. Publicação em 28 de novembro de 2006. Relator: Lucy de Fátima Cruz Lago. Disponível em: 〈www.trt17.jus.br〉. Acesso em: 12 abr. 2011).
} 
parcela salarial paga até então e injustificadamente suprimida, guarda proporcionalidade com o dano material experimentado pelo empregado. É razoável, pois, que a indenização em foco tenha por base a referida média salarial suprimida ${ }^{701}$.

Foram delineadas, no tópico pertinente, quatro possíveis diferenças entre a perda de uma chance e a condição maliciosamente obstada pelas partes. Duas delas, no caso, não permitem fazer a distinção: as partes estavam insertas numa relação jurídica contratual stricto sensu e o empregador na situação de suportar uma desvantagem (pagamento das comissões e seus consectários) caso a condição fosse implementada pelo trabalhador (realização das vendas), circunstâncias possíveis em ambas as hipóteses.

Porém, quando a decisão assere que "o ato injustificável do empregador que limita o empregado de executar o contrato em sua plenitude, de modo a impedir o ganho de parcela salarial até então percebida [...]" ${ }^{702}$, revela a existência de dolo por parte do ofensor, algo bastante característico da figura do artigo 129 do $\mathrm{CCB}^{703}$.

E apesar do equívoco em relação à nomenclatura, a decisão acerta em cheio quanto ao efeito, pois, na prática, considera conquistada a condição, haja vista reputar, fictamente, para efeitos indenizatórios, realizadas as vendas impedidas pelo empregador. Mais do que isso, em vez de utilizar de juízos de probabilidade, próprios à perda de uma chance, o julgamento segue a via presuncional, avaliando as perdas e danos de acordo com a média salarial paga até o momento anterior à injustificada supressão.

No exame do tratamento jurídico dispensado pelos Regionais à teoria da perda de uma chance, chamou bastante atenção o indeferimento da reparação das chances perdidas ao fundamento de ser um "dano futuro" e, portanto, sem haver comprovação de sua ocorrência, como se observa do seguinte acórdão ${ }^{704}$ :

\footnotetext{
${ }^{701}$ MATO GROSSO DO SUL. Tribunal Regional do Trabalho da $24^{\mathrm{a}}$ Região, $2^{\mathrm{a}}$ Turma. Recurso Ordinário 1111/2006-002-24-00-9. Julgado em 23 de abril de 2008. Relator: Convocado João Marcelo Balsanelli. Disponível em: <www.trt24.jus.br〉. Acesso em: 19 abr. 2011.

702 Idem.

${ }^{703}$ BRASIL. Código Civil (2002). Código Civil e Constituição Federal. 62. ed. São Paulo: Saraiva, 2011.

704 PERNAMBUCO. Tribunal Regional do Trabalho da $6^{a}$ Região, $2^{\mathrm{a}}$ Turma. Recurso Ordinário 011382007-003-06-00-7. Julgado em 14 de outubro de 2009. Relator: Maria Helena Guedes Soares de Pinho Maciel. Disponível em: <www.trt6.jus.br>. Acesso em: 8 abr. 2011.
} 
Danos materiais e morais. Perda de chance. O pleito em comento não pode ser deferido, tendo em vista que condicionado a evento futuro (perda de promoção para o cargo de diretor), encontrando vedação no parágrafo único do art. 460, do CPC, segundo o qual 'A sentença deve ser certa, ainda quando decida relação jurídica condicional'. Para ser reconhecida a perda de chance, é indispensável a comprovação efetiva dos danos sofridos, não se podendo basear em alegações hipotéticas.

Isso porque é absolutamente incontroversa a reparabilidade dos danos futuros ${ }^{705}$. E o que é mais grave: todo dano futuro é, em maior ou menor grau, ontologicamente destituído de certeza ${ }^{706}$. Ninguém, em sã consciência, pode atestar a certeza de um ato jurídico futuro. O juízo é, inexoravelmente, de probabilidade ou previsibilidade ${ }^{707}$. Rechaçar a indenização pelo simples fato de o dano ser futuro varre do ordenamento, de uma só vez, não só hipóteses de perda de uma chance, mas boa parte dos lucros cessantes e alguma dos danos emergentes ${ }^{708}$.

Também desperta contrariedade o fato de se sustentar que eventual decisão contemplativa de danos futuros viola a condição de certeza da sentença ${ }^{709}$, de que trata o

705 De acordo com o escólio de Bianca: "Il creditore e la vitima dell'illecito civile possono chiedere il risarcimento dei danni futuri. Danni futuri sono quei danni di cui si prevede con ragionevole certezza in un tempo successivo alla domanda di risarcimento o alla scadenza. Tipica ipotesi di danno futuro è il danno che i congiunti della persona uccisa risentiranno nel corso del tempo per il mancato apporto dei contributi assistenziali da parte della vitima". (BIANCA, C. Massimo. Diritto Civile. La responsabilità. Milão: Giuffrè, 1994, v. 5, p. 160)

${ }^{706}$ E reconhecê-lo foi um grande passo da responsabilidade civil, como afirma Represas: "§ 11 . La indemnizabilidad del daño futuro. - La resarcibilidad de un daño futuro constituye un nuevo paso en la ya mencionada relativización del recaudo de la 'certeza' del daño. Cuando se trata de un hecho ya acontecido, pero cuyas consecuencias dañosas no han completado aún todo su ciclo, y se sabe, de acuerdo con el curso natural e ordinario de los acontecimientos, que en el futuro aumentarán sus repercusiones perjudiciales, esas consecuencias futuras de tal hecho ya ocurrido habrán de ser también indemnizables; porque, bien se ha dicho, 'la mirada del juez debe 'extenderse' también a las posibilidades del porvenir". (REPRESAS, Felix Alberto Trigo, op. cit., p. 19-20)

707 "Previsibilidade" é a expressão adotada pelo Código Civil português ao tratar dos danos futuros: "Artigo 564". (Cálculo da indemnização). 2. Na fixação da indemnização pode o tribunal atender aos danos futuros, desde que sejam previsíveis; se não forem determináveis, a fixação da indemnização correspondente será remetida para decisão ulterior”. (PORTUGAL. Código Civil (1966). Código Civil. Disponível em: <http://www.stj.pt/nsrepo/geral/ cptlp/Portugal /CodigoCivil.pdf>. Acesso em: 30 abr. 2011)

${ }^{708}$ Assim esclarece Sanseverino: "Os prejuízos futuros englobam aqueles ainda não materializados à época da sentença, mas que já surgem como objetivamente previsíveis de acordo com as circunstâncias do caso e as experiências da vida, podendo ocorrer danos emergentes futuros (v.g., continuação do tratamento médico com gastos com medicamentos e fisioterapia), como também lucros cessantes (v.g. incapacidade laborativa da vítima direta - total ou parcial), conforme analisado no tópico anterior". (SANSEVERINO, Paulo de Tarso Vieira, op. cit., p. 187)

${ }^{709} \mathrm{Na}$ França, em que há um princípio que determina a avaliação do dano no dia em que se decide sobre ele, impõe-se ao juiz que também leve em consideração o que já é normalmente previsível, como explica 
parágrafo único do artigo 460 do $\mathrm{CPC}^{710}$, pois denota desconhecimento sistêmico, na medida em que ignora a possibilidade de formulação de pedidos genéricos ${ }^{711}$ e a própria existência da liquidação por artigos ${ }^{712} 713$, sendo o segundo uma das consequências do primeiro $^{714}$.

Porém, todos esses desvios técnicos não se aplicam à doutrina das oportunidades perdidas, pois, sob a perspectiva analisada na decisão, ela representa um dano presente. Há uma deformação no campo de análise, pois na perda de uma chance não se indeniza o prejuízo pela perda da promoção futura (e incerta), mas pela obliteração da chance atual (e certa) de concorrer a ela ${ }^{715}$.

Geneviéve Viney: "Le príncipe de l'évaluation du dommage au jour de la décision définitive qui statue sur l'indemnité est donc bien acquis et il n'oblige pas seulement le juge à tenir compte des faits et événements qui ont d'ores et déjà affecté soit la consistance du dommage soit son expression monétaire. Il lui impose également de prendre en considération ceux qui sont normalement prévisibles au jour ou il statue. Or cette prévision est particuliérement importante pour les dommages dont les manifestations doivent se poursuivre dans l'avenir, notamment pour les troubles de voisinage, les atteintes à l'environnement et les séquelles des atteintes à l'intégrité corporelle". (VINEY, Gineviève; JOURDAIN, Patrice, op. cit., p. 143-144)

${ }_{710}$ BRASIL. Código de Processo Civil (1973). Código de Processo Civil e Constituição Federal. 17. ed. São Paulo: Saraiva, 2011.

711 "CPC. Art. 286. O pedido deve ser certo ou determinado. É lícito, porém, formular pedido genérico: - nas ações universais, se não puder o autor individuar na petição os bens demandados; II - quando não for possível determinar, de modo definitivo, as conseqüências do ato ou do fato ilícito; III - quando a determinação do valor da condenação depender de ato que deva ser praticado pelo réu". (sem grifos no original). (Idem)

712 "CPC. Art. 475-E. Far-se-á a liquidação por artigos, quando, para determinar o valor da condenação, houver necessidade de alegar e provar fato novo". (Ibidem)

${ }^{713} \mathrm{E}$ o exemplo fornecido pela doutrina para a liquidação por artigos é justamente o do réu condenado a indenizar a vítima que sofreu danos à saúde: "Exemplos de liquidação que deve ser feita por artigos. a) Sentença que condena o réu a indenizar os danos decorrentes de acidente, com todas as suas consequências passadas, presentes e futuras. Caso a vítima tenha de submeter-se a nova cirurgia, não descrita na petição inicial (...), deverá ser alegada e comprovada em liquidação de sentença, para que seu valor possa integrar o título executivo. Isso não alterará o julgado (...), porque a sentença já declarou a existência do acidente e o réu já foi condenado a indenizar os danos dele decorrentes. O que se prova na liquidação é o fato novo, isto é, que essa cirurgia superveniente é um dos danos de que fala a sentença. b) O réu é condenado a indenizar o dano causado à saúde da vítima. Diz o CC 949 (...). O pagamento das despesas até a total convalescença que pode ocorrer depois de haver sentença proferida - é obrigação ex lege, que decorre expressamente de lei. Como a fonte dessa obrigação é a própria lei, o ofensor tem de arcar com esse pagamento, ainda que não conste expressamente da sentença condenatória. Os fatos novos que o ofendido precisa comprovar na liquidação por artigos são as despesas que teve até a sua convalescença". (NERY JUNIOR, Nelson; NERY, Rosa Maria de Andrade. Código de Processo Civil Comentado e legislação extravagante. 9. ed. rev., atual. e ampl. São Paulo: RT, 2006, p. 636)

${ }^{714}$ Como informam Nelson e Rosa Maria de Andrade Nery: "O pedido pode ser genérico nas ações de indenização, quando não se puder, desde logo, determinar as consequências do ato ou fato ilícito. Nesse caso, o juiz poderá levar em consideração fatos novos ocorridos depois da propositura da ação, para que possa proferir sentença. Uma das consequiências da exceção prevista no CPC 286 II é a possibilidade de fazer-se liquidação de sentença por artigos, quando houver de provar-se fato novo, superveniente à sentença". (Idem, p. 484)

${ }_{715} \mathrm{O}$ que foi corretamente observado na seguinte decisão, na qual o quadro fático, por sua vez, era bem mais favorável ao autor, que já havia sido aprovado em processo seletivo interno: "A teoria da responsabilidade civil pela perda de uma chance torna indenizável a probabilidade séria de obtenção de um resultado legitimamente esperado que é obstado por ato ilícito praticado pelo agente ofensor. Se o reclamante tinha como justa e real a probabilidade de um ganho salarial decorrente de sua promoção ao cargo de supervisor de 
Não se questiona que o resultado do julgamento poderia ter sido exatamente o mesmo, desde que baseado na ausência de seriedade da chance (vide item 2.7 do capítulo 2), no fato de a aspiração do reclamante estar ligada a uma expectativa psicológica dissociada de dados da realidade ${ }^{716}$, de elementos que permitissem lobrigar um grau considerável de probabilidade da suposta promoção frustrada. No entanto, rejeitar o pedido ao fundamento de o dano ser futuro, de haver vedação na legislação processual e de não haver prova ou certeza do resultado final é desconstruir todo o sistema de responsabilidade civil.

Mais uma vez deve ser ressaltado o valor da boa-fé, orientado pelas práticas $\operatorname{costumeiras~}^{717}$, pelas regras máximas da experiência comum ${ }^{718}$. Negar reparação a um trabalhador que perdeu a oportunidade de ser promovido, independentemente do quão adiantadas estavam as tratativas na persecução e na conquista do interesse aleatório, ao argumento da incerteza da promoção, é dizer, de modo subliminar, que o direito material à "chance" não é tutelável juridicamente ${ }^{719}$.

vendas da reclamada, porque aprovado em processo seletivo interno da empresa, mas viu perdida a chance de conquistar esse resultado em razão de ato ilícito praticado pelo empregador, quando da sua dispensa, manifestamente abusiva e ilícita, faz jus à reparação patrimonial decorrente deste ilícito. E aqui, independentemente dos ganhos perdidos, o que se indeniza é o prejuízo consistente na perda dessa oportunidade, a perda da chance real de alcançar a promoção legitimamente esperada”. (MINAS GERAIS. Tribunal Regional do Trabalho da $3^{\mathrm{a}}$ Região, 7 ${ }^{\mathrm{a}}$ Turma. Recurso Ordinário 01533-2007-112-03-00-5. Publicação em 02 de outubro de 2008. Relator: Emerson José Alves Lage. Disponível em: <www.trt3.jus.br>. Acesso em: 6 abr. 2011)

${ }^{716} \mathrm{O}$ dano puramente hipotético, baseado em esperanças subjetivas, não é indenizável, como bem assentado no seguinte julgado: "Não bastasse isso, a pretensão do autor está afeta ao campo do desejo, da aspiração, da possibilidade, mas não há razoáveis elementos nos autos de que a possibilidade de ganho futuro do requerente seria de fato superior ao que auferia sem o mencionado curso". (GOIÁS. Tribunal Regional do Trabalho da 18ª Região. Recurso Ordinário 00825-2006-001-18-00-6. Publicação em 24 de janeiro de 2007. Relator: Khatia Maria Bomtempo de Albuquerque. Disponível em: 〈www.trt18.jus.br〉. Acesso em: 19 abr. 2011)

${ }^{717}$ É o que orienta o artigo 242 do Código Civil alemão - BGB: “\$ 242 Leistung nach Treu und Glauben Der Schuldner ist verpflichtet, die Leistung so zu bewirken, wie Treu und Glauben mit Rücksicht auf die Verkehrssitte es erfordern”. (ALEMANHA. Código Civil (1896). Código Civil. Disponível em: <http://www.gesetze-im-internet.de/bgb/ 242.html>. Acesso: $1^{\circ}$ maio 2011). Versão em inglês, também no sítio do parlamento alemão: "Section 242. Performance in good faith. An obligor has a duty to perform according to the requirements of good faith, taking customary practice into consideration". Disponível em: <http://www.gesetze-im-internet.de/englisch_bgb /englisch_bgb.html\#BGBengl_000P242>. Acesso em: $1^{\circ}$ maio 2011.

${ }^{718}$ Nesse campo, a orientação vem do artigo 335 do CPC: “Art. 335. Em falta de normas jurídicas particulares, o juiz aplicará as regras de experiência comum subministradas pela observação do que ordinariamente acontece e ainda as regras da experiência técnica, ressalvado, quanto a esta, o exame pericial”. (BRASIL. Código de Processo Civil (1973). Código de Processo Civil e Constituição Federal. 17. ed. São Paulo: Saraiva, 2011)

${ }^{719}$ Pois, como já se disse por diversas vezes, só se tem certeza da promoção depois que se é promovido, ou seja, a prova é diabólica. Além disso, a premissa permite ao infrator tirar proveito de sua infração, pois a incerteza provém exatamente do seu ilícito, que retirou a vítima do curso aleatório dos acontecimentos, impedindo que se saiba se ela seria ou não agraciada com a concretização do interesse usurpado. 
Aliás, a exigência da propalada "certeza" tem sido, no âmbito dos Tribunais Regionais do Trabalho, a maior empecilho à indenização pela perda de uma chance. Não por ser errado exigir “certeza”, pois todo dano deve ser certo, mas pela notória dificuldade em distinguir a chance, como entidade distinta e tutelável, do resultado final buscado ${ }^{720} 721$, o que faz com que as Cortes não saibam sobre o quê, exatamente, deve-se exigir a "certeza".

Em determinadas hipóteses, parece escapar à compreensão nas decisões o valor intrínseco da chance (vide item 2.3 do capítulo 2) e a certeza da probabilidade, cuja usurpação constitui um dano atual, na medida em que a situação da vítima fica pior do que anteriormente ao ato ilícito, já que a oportunidade compunha o seu patrimônio e era dotada de valor $^{722} 723$.

${ }^{720} \mathrm{O}$ acórdão seguinte, mesmo descaracterizando a dispensa por justa causa, e reconhecendo que a reclamante estava frequentando curso para a função de Supervisora Regional, rejeitou o pedido de perda de uma chance porque não havia certeza da promoção: "Por fim, pretende a Reclamante lhe seja deferida indenização por danos materiais, em face da despedida irregular por justa causa, por prática de ato de improbidade, quando estava na iminência de ser promovida ao cargo de Supervisora Regional. Trata-se da reparação do dano causado em virtude da perda de uma chance. Ora, tratando-se de pedido de danos materiais, é imprescindível a demonstração inequívoca do prejuízo causado, que, segundo alega, está baseado na supressão do lucro ou vantagem concretamente aguardada, em função de promoção em curso. Na verdade, o fato de as testemunhas (segunda da Reclamante e primeira da Reclamada) reconhecerem a realização de curso de treinamento preparatório para Supervisão Regional, não conduz à certeza da promoção, até mesmo porque deveria haver aprovação em tal curso e existir a vaga. Também não houve prova da retribuição financeira que iria auferir". (BAHIA. Tribunal Regional do Trabalho da $5^{\mathrm{a}}$ Região, $2^{\mathrm{a}}$ Turma. Recurso Ordinário 0097400-58.2008.5.05.0005. Publicação em 08 de outubro de 2009. Relator: Cláudio Mascarenhas Brandão. Disponível em: 〈www.trt5.jus.br〉. Acesso em: 6 abr. 2011)

${ }^{721}$ No mesmo sentido, o julgado reconhece que a vítima perseguia um interesse aleatório, pois frequentava o curso para gerente, mas rejeita a indenização porque a promoção não era certa: "Não se deve indenizar pela "perda de uma chance" se a própria oportunidade era incerta. $\mathrm{O}$ fato do reclamante ter sido despedido quando supostamente freqüentava treinamento para o cargo de gerente não dá a ele a certeza de que seria promovido, até porque não detinha nenhuma modalidade estabilitária". (BAHIA. Tribunal Regional do Trabalho da $5^{\mathrm{a}}$ Região, $2^{\mathrm{a}}$ Turma. Recurso Ordinário 0121300-61.2008.5.05.0008. Publicação em 11 de dezembro de 2009. Relator: Renato Mário Borges Simões. Disponível em: 〈www.trt5.jus.br〉. Acesso em: 6 abr. 2011)

${ }^{722}$ Consoante o escólio doutrinário: "Entender sin más que este tipo de daños es meramente hipotético y que no puede ser tenido en cuenta por los Tribunales me parece equivocado, pues no siempre se tratará de recordatorios del cuento de la lechera. Hay incertidumbre en el perjuicio, pero certidumbre de probabilidad. 'Es bien distinto - dice VICENTE DOMINGO - hablar de valoración del daño futuro e incierto, postura un tanto arriesgada porque implicaría una extensión ilimitada del sistema de reparación, que decir que la própria 'chance' tiene un valor, porque su desaparición es un daño actual y cierto, ya que aquella, efectivamente existia en el patrimonio del sujeto antes de que sufriera la lesión'. Me parece claro que si la víctima se encontraba en una situación fáctica o jurídica idónea para aspirar a convertir en hechos essas ‘chances', el juez debe valorarlo”. (TOLSADA, Mariano Yzquierdo, op. cit., 153)

${ }^{723}$ Sob esse aspecto, feliz a decisão que vislumbrou a perda da chance do autor concluir o curso de aprendizagem no SENAI e, com isso, ter, também, perdido a oportunidade de uma melhor colocação profissional: "O autor cursou por mais de um ano as aulas do Programa de Aprendizagem ministradas pelo SENAI, faltando apenas seis meses para a sua conclusão, e não pôde, por culpa exclusiva da Ré, receber (ao menos ter a chance de receber) o certificado de qualificação profissional. Houve, sim, um dano material, que foi a perda da possibilidade de qualificação profissional, que daria ao Autor uma chance maior de colocação no mercado de trabalho. O menor terá de iniciar novamente o curso de aprendizado (se conseguir ser novamente contratado na modalidade de aprendizagem) para poder se qualificar profissionalmente da forma 
Noutras, porém, ela parece ser vista com clareza. As decisões que analisaram as chances perdidas por um trabalhador que perdeu a oportunidade de se eleger membro da CIPA - Comissão Interna de Prevenção de Acidentes de Trabalho, em sua maioria, absorveram com naturalidade a existência do caráter aleatório do evento, e indenizaram levando em conta a redução probabilística no montante indenizatório ${ }^{724}$.

E tal entendimento está em perfeita consonância com o pensamento do STJ. Em aliciante caso de um candidato a vereador que deixou de ser eleito por apenas oito votos, depois de ter sido vítima de uma notícia falsa veiculada pelas rádios do local, que davam conta da cassação de sua candidatura ${ }^{725}$, a Corte Superior confirmou a decisão estadual que havia deferido indenização correspondente aos proventos que a vítima deixou de receber pela não assunção da função pública, mas de forma proporcional à probabilidade de sua eleição ${ }^{726}$.

Há outros méritos a serem destacados na atuação da Justiça do Trabalho. Em particular, destaca-se o bom caminho trilhado ao exigir o caractere real e sério da chance, expurgando os litígios puramentes especulativos ${ }^{727}$.

como o teria feito se não houvesse a extinção de seu contrato de emprego pela Ré”. (ESPÍRITO SANTO. Tribunal Regional do Trabalho da $17^{\mathrm{a}}$ Região, $1^{\mathrm{a}}$ Turma. Recurso Ordinário 00765.2007.005.17.00.3. Publicação em 26 de fevereiro de 2008. Relator: Sérgio Moreira de Oliveira. Disponível em: <www.trt17.jus.br>. Acesso em: 12 abr. 2011)

724 "Tratando-se de situação hipotética de perda de uma chance, relacionada a fato futuro e incerto, a reparação não deve corresponder aos salários e demais direitos abrangendo o período de 01/12/08 a 30/11/2010, quando exaurida a estabilidade como membro eleito da CIPA. Assim, lançando mão do princípio da razoabilidade, dou parcial provimento ao apelo da reclamada para reduzir a indenização pela perda chance arbitrada em $\mathrm{R} \$ 31.051,93$ para $\mathrm{R} \$ 10.000,00$, valor que entendo mais compatível com a peculiar situação dos autos". (MINAS GERAIS. Tribunal Regional do Trabalho da $3^{\mathrm{a}}$ Região, $8^{\mathrm{a}}$ Turma. Recurso Ordinário 01405-2008-077-03-00-0. Publicação em 25 de maio de 2009. Relator: Cleube de Freitas Pereira. Disponível em: 〈www.trt3.jus.br〉. Acesso em: 6 abr. 2011)

${ }^{725} \mathrm{O}$ mais interessante da história é que não se pode afirmar que houve malícia da mídia local, pois havia um candidato homônimo (mesmo prenome) da vítima cuja candidatura fora cassada, e que, ainda por cima, pertencia ao mesmo partido político.

${ }^{726}$ Transcrevem-se os trechos pertinentes da ementa: “[...] III - Aplica-se a teoria da perda de uma chance ao caso de candidato a Vereador que deixa de ser eleito por reduzida diferença de oito votos após atingido por notícia falsa publicada por jornal, resultando, por isso, a obrigação de indenizar. IV.- Tendo o Acórdão recorrido concluído, com base no firmado pelas provas dos autos, no sentido de que era objetivamente provável que o recorrido seria eleito vereador da Comarca de Carangola, e que esse resultado foi frustrado em razão de conduta ilícita das rádios recorrentes, essa conclusão não pode ser revista sem o revolvimento do conteúdo fático-probatório dos autos, procedimento vedado em sede de Recurso Especial, nos termos da Súmula 7 desta Corte. V.- Recurso Especial improvido”. (BRASIL. Superior Tribunal de Justiça, $3^{a}$ Turma. Recurso Especial 821004-MG (2006/0035112-2). Relator: Min. Sidnei Beneti. Julgado em 19 de agosto de 2010. Disponível em: 〈www.stj.jus.br〉. Acesso em: 13 abr. 2011))

${ }^{727}$ Como fez o TRT da $23^{\text {a }}$ Região, ao rejeitar pedido de reparação pela não efetivação após o contrato de experiência: “APELO OBREIRO. INDENIZAÇÃO PELA PERDA DE UMA CHANCE. CONTRATO DE EXPERIÊNCIA. A reparação civil pela perda de uma chance é devida quando provados os seguintes requisitos: conduta (ação ou omissão); dano, caracterizado pela perda da oportunidade de obter uma vantagem ou de evitar um prejuízo; e nexo de causalidade entre a conduta e o dano. No caso dos autos, o 
No mesmo diapasão, correta a censura às demandas em que a perda de uma chance decorre de um ato espontâneo do trabalhador, como, por exemplo, pela não adesão ao Plano de Demissão Voluntária (PDV) 728729730 , já que, como falado na introdução do trabalho, o preço da liberdade ontológica do ser humano é suportar os ônus de suas escolhas.

Merece destaque, também, a importante decisão que reconheceu a possibilidade de a perda de uma chance causar lesão exclusivamente moral (vide item 3.1.1 do capítulo 3), pelo fato de a retenção da CTPS ter provocado constrangimento e desconforto no trabalhador que se viu impedido da oportunidade de buscar uma imediata recolocação no mercado de trabalho ${ }^{731}$.

mencionado dano não se verificou, muito embora o Obreiro tenha se submetido a concorrido concurso público, porquanto houve apenas a extinção do contrato de experiência, que atendeu uma de suas finalidades, qual seja, avaliar as aptidões do Reclamante. Como o Obreiro, por sua própria culpa, não atendeu às expectativas patronais, por óbvio, não tem qualquer direito à reparação civil no particular. Apelo obreiro improvido". (MATO GROSSO. Tribunal Regional do Trabalho da $23^{\mathrm{a}}$ Região, $2^{\mathrm{a}}$ Turma. Recurso Ordinário 01196.2007.001.23.00-5, Relator: Luiz Alcântara. Publicação em 06 de junho de 2008. Disponível em: <www.trt23.jus.br〉. Acesso em: 19 abr. 2011).

${ }^{728}$ Neste julgado, o empregado optou por ocupar o cargo de gerente, mas posteriormente vindicou a perda da chance de aderir ao PDV: "Não obstante o reclamante tenha exercido o cargo de gerência pelo período de aproximadamente seis meses, não há como se conceber a alegação de que deveria ser indenizado pela perda da oportunidade de adesão ao referido plano de desligamento, já que o mesmo sabia dos riscos que estaria correndo ao desistir da adesão para assumir o cargo de confiança que lhe foi oferecido, o qual, por sua própria natureza, é atribuído a título precário". (CAMPINAS. Tribunal Regional do Trabalho da $15^{\text {a }}$ Região, $1^{a}$ Turma. Recurso Ordinário 0083900-27.2000.5.15.0101. Publicação em 13 de maio de 2002. Relator: Eliane de Carvalho Costa Ribeiro. Disponível em: 〈www.trt15.jus.br〉. Acesso em: 12 abr. 2011)

${ }^{729}$ Em situação peculiar ocorrida em território capixaba, o trabalhador aderia ao PDV (no caso, denominado Plano Antecipado de Afastamento Voluntário - PAVV), e depois alegava ter perdido a chance de trabalhar por mais tempo e majorar a complementação de aposentadoria. A presensão era apropriadamente fulminada, nos seguintes termos: "“Não prevalece a tese de "perda de uma chance" ao preenchimento de requisitos mais favoráveis à complementação de aposentadoria, se o empregado adere espontaneamente a plano de demissão incentivada, o que atrai a presunção de aquiescência às regras estabelecidas para sua implementação". (ESPÍRITO SANTO. Tribunal Regional do Trabalho da $17^{\mathrm{a}}$ Região, $1^{\mathrm{a}}$ Turma. Recurso Ordinário 01399.2009.002.17.00.2. Publicação em 08 de outubro de 2010. Relator: Gerson Fernando da Sylveira Novais. Disponível em: 〈www.trt17.jus.br〉. Acesso em: 12 abr. 2011)

${ }^{730}$ E o entendimento foi solidicado por outras diversas decisões: (ESPÍRITO SANTO. Tribunal Regional do Trabalho da $17^{\mathrm{a}}$ Região, $3^{\mathrm{a}}$ Turma. Recurso Ordinário 01092.2009.005.17.00.0. Publicação em 31 de janeiro de 2011. Relator: Carmem Vilma Garisto. Disponível em: 〈www.trt17.jus.br〉. Acesso em: 12 abr. 2011); (ESPÍRITO SANTO. Tribunal Regional do Trabalho da $17^{\mathrm{a}}$ Região, $1^{\mathrm{a}}$ Turma. Recurso Ordinário 00491.2010.008.17.00.7. Publicação em 21 de fevereiro de 2011. Relator: Gerson Fernando da Sylveira Novais. Disponível em: 〈www.trt17.jus.br〉. Acesso em: 12 abr. 2011)

731 "RECURSO ADESIVO DA RECLAMANTE. DANOS MORAIS. RETENÇÃO DA CTPS. A reparabilidade do dano moral, após o advento da Constituição de 1988, tornou-se inegável, estando expressamente prevista em seu artigo $5^{\circ}$, incisos $\mathrm{V}$ e X, como garantia do indivíduo. Inexistem, portanto, dúvidas quanto à indenização do dano puramente moral. In casu, restou comprovado que a ré reteve a CTPS da obreira por cerca de um mês. Embora não tenha a obreira comprovado que perdeu uma proposta de emprego em virtude da posse indevida de sua CTPS pela primeira reclamada, entende-se que o dano moral restou indiscutível, uma vez que o fato ocorrido leva o indivíduo comum a um estado de constrangimento e desconforto natural, vez que a retenção da CTPS impede que a funcionária busque uma nova contratação, mormente quando acaba de ser dispensada". (ESPÍRITO SANTO. Tribunal Regional do Trabalho da $17^{\mathrm{a}}$ 
Finalmente, embora a maior deficiência nos julgados tenha sido percebida na apuração dos danos, notadamente quanto à fluidez, vagueza ou mesmo ausência absoluta de critérios objetivos de quantização, há pistas que indicam parâmetros mais sólidos, como, por exemplo, a explicitação do coeficiente redutor (vide item 3.3.1 do capítulo 3) como fórmula matricial de excelência na aferição do montante indenizatório ${ }^{732}$.

Digna de registro, ainda, a decisão carioca $^{733}$ que demonstrou, na prática, preocupação no uso da epiqueia aristotélica (vide item 3.3.4 do capítulo 3), requintando a quantização dos danos a partir de fundamentos bem explicitados e que possibilitaram às partes conhecer das razões do arbitramento, não obstante o emaranhado de probabilidades do caso concreto tornasse impossível prever, com exatidão, o que iria ocorrer.

O caso versava sobre um atleta profissional de futebol, vítima de retenção dolosa de seu atestado liberatório pelo clube, que o fez perder a oportunidade de se transferir para o clube Olímpia, do Paraguai, e fechar um contrato em moldes bastante vantajosos. A sentença arbitrara a indenização em R $\$ 350.000,00^{734}$.

Região, $1^{\text {a }}$ Turma. Recurso Ordinário 00806.2009.002.17.00.4. Publicação em 13 de outubro de 2010. Relator: José Carlos Rizk. Disponível em: <www.trt17.jus.br>. Acesso em: 12 abr. 2011).

732 É o que confirma o seguinte aresto: "RECURSO DO RECLAMANTE. INDENIZAÇÃO POR PERDA DE UMA CHANCE. O valor da indenização deve ser fixado tomando-se como parâmetro o valor total do resultado esperado e sobre este incidindo um coeficiente de redução proporcional às probabilidades de obtenção do resultado final esperado. Assim como não se pode exigir a prova cabal e inequívoca do dano, mas apenas a demonstração provável da sua ocorrência, a indenização, coerentemente, deve ser proporcional à possibilidade maior ou menor de obtenção do resultado almejado". (ESPÍRITO SANTO. Tribunal Regional do Trabalho da $17^{\mathrm{a}}$ Região, $1^{\mathrm{a}}$ Turma. Recurso Ordinário 00844.2009.003.17.00.3. Publicação em 15 de outubro de 2010. Relator: Sérgio Moreira de Oliveira. Disponível em: 〈www.trt17.jus.br〉. Acesso em: 12 abr. 2011).

${ }^{733}$ Cuja ementa teve o seguinte teor: "RECURSO ORDINÁRIO. INDENIZAÇÃO POR PERDA DE UMA CHANCE. Segundo moderna tendência doutrinária e jurisprudencial, é cabível indenização por perda de uma chance desde que, além dos elementos comuns a toda espécie de responsabilidade civil, quais sejam, a) a prática de um ato ilícito; b) o dano causado por este ato ilícito e c) o nexo de causa e efeito entre o ato e o dano, também se verifique a ocorrência de: 1) uma alta probabilidade de realização do bem perdido, 2) que a chance esteja irremediavelmente perdida, não sendo mais possível ao ofendido alcançar o bem que lhe havia sido oportunizado. Todavia, a indenização deve ressarcir a perda da chance e não o próprio bem que seria obtido se a chance fosse aproveitada, já que é da essência do próprio conceito de chance o ser aleatório, de modo que nunca se irá saber se, agindo o ofensor de outro modo, o bem teria sido efetivamente alcançado". (RIO DE JANEIRO. Tribunal Regional do Trabalho da $1^{\text {a }}$ Região, $8^{a}$ Turma. Recurso Ordinário 031192006-342-01-00-9. Publicação em 14 de julho de 2008. Relator: Marcelo Augusto Souto de Oliveira. Disponível em: 〈www.trt1.jus.br〉. Acesso em: 13 abr. 2011).

${ }^{734}$ A decisão de $1^{a}$ instância foi igualmente rica em fundamentos: a) discorreu fartamente sobre a teoria; b) a partir da verificação dos efeitos do artigo 302 do CPC, tomou por incontroverso: i - que o reclamante era uma grande promessa, como jogador de futebol; ii - que o valor mensalmente recebido por atletas do reclamado correspondia a $\mathrm{R} \$ 1.000,00$, mensais; iii - que a retenção do passe do reclamante acarretou-lhe uma perda de um possível contrato de $\mathrm{R} \$ 700.000,00$; c) utilizou as máximas da experiência (CPC, art. 305), para tecer considerações sobre a transferência de jogadores para o exterior; d) considerou o dano final (R $\$ 700.000,00)$, e aplicou o coeficiente redutor, arbitrando a probabilidade em 50\%. (RIO DE JANEIRO. Tribunal Regional do Trabalho da $1^{\text {a }}$ Região, $2^{\text {a }}$ Vara do Trabalho de Volta Redonda/RJ. Reclamação Trabalhista 03119-2006- 
Ao reexaminar a causa, a decisão explicitou, em sua inteireza, os motivos da reforma da decisão no tocante ao valor: a) que o contrato poderia não ter se concretizado por motivos alheios ao clube-réu, como, e.g., eventual contusão do jogador-autor (absorção da álea na técnica de decidir); b) que os 60 meses, constantes da "Lei Pelé" (Lei 9.615/98), não seriam aplicáveis, porque o contrato seria celebrado no estrangeiro; c) o salário arbitrado ( $\mathrm{R} \$ 11.666,66)$ não era compatível com o que se pagava a um atleta recém saído das categorias de base; d) o Paraguai era um país de economia inferior a do Brasil e que, presumidamente, praticava salários inferiores.

A partir de tais diretrizes, foi arbitrado um salário-base de $\mathrm{R} \$ 6.000,00$, e considerada a duração de 15 meses para o contrato, totalizando $\mathrm{R} \$ 90.000,00$, a título de indenização pelas oportunidades perdidas ${ }^{735}$.

Concordar ou não com os parâmetros eleitos é uma questão secundária. Deveras, há muitas maneiras de se efetuar cálculos probabilísticos no caso comentado. Louva-se, porém, a política judiciária de transparência da decisão, de modo a permitir à sociedade, em geral, e aos jurisdicionados, em particular, saber as exatas razões do convencimento, e, ao Poder Judiciário, submeter-se às críticas próprias ao Estado Democrático de Direito.

342-01-00-9. Juiz Prolator: Leandro Nascimento Soares. Julgado em abril de 2007. Disponível em: <www.trt1.jus.br>. Acesso em: 13 abr. 2011)

${ }^{735}$ Seguem os trechos mais relevantes da decisão sobre o quantum debeatur: "Todavia, quanto ao valor da indenização, merece reparos a sentença. É que a estipulação da indenização no valor equivalente à metade de um suposto contrato de 60 (sessenta) meses afigura-se exagerada. Primeiro, porque a contratação poderia, por motivos alheios ao clube-réu, não ter se concretizado. Como já dito, a chance dependia de eventos futuros. $\mathrm{O}$ autor, por exemplo, poderia ter se acidentado, não necessariamente jogando, ficando impossibilitado de praticar o futebol. Segundo, porque não se sabe por quanto tempo o clube Olimpia contrataria o autor. O contrato poderia ser por uma experiência de seis meses, por exemplo. Destaque-se sequer fazer sentido a utilização da Lei Pelé (Lei no 9.615/98) como parâmetro para um possível contrato pelo período máximo de 60 (sessenta) meses, já que o autor pretendia um contrato com clube estrangeiro, onde a referida lei não é aplicável. Enfim, são diversas as variáveis envolvidas quando se discute um evento apenas provável. Nesse sentido, parece razoável a indenização sugerida no recurso, equivalente a quinze meses de salário, que é um tempo relativamente longo e com certeza, se não chega a ressarcir os valores totais que seriam recebidos num suposto contrato com o clube paraguaio, e que, como já esclarecido, não é o objetivo da indenização por perda de chance, é com certeza suficiente para indenizar a possibilidade que se perdeu e apagar a dúvida que permaneceu. Tampouco parece condizente com a realidade a presunção de que um jogador iniciante, saído das categorias de base, iria alcançar um rendimento mensal de $\mathrm{R} \$ 11.666,66$. No que toca ao Brasil, sabe-se que, mesmo em grandes clubes, não são todos os jogadores de futebol que recebem altos salários. Os iniciantes, aqueles que normalmente sequer integram o banco de reservas, em geral recebem salários bem inferiores aos dos "craques", por vezes até simbólicos. Presume-se que no Paraguai, de economia inferior ao de muitos Estados brasileiros, a situação seja ainda pior. Portanto, arbitra-se para o cálculo da indenização um salário mensal de $\mathrm{R} \$ 6.000,00$ (seis mil reais). Dá-se parcial provimento ao recurso para reduzir a indenização pela chance perdida ao valor total de $\mathrm{R} \$ 90.000,00$ (noventa mil reais), a ser atualizada a partir do ajuizamento da ação". (RIO DE JANEIRO. Tribunal Regional do Trabalho da $1^{a}$ Região, $8^{\text {a }}$ Turma. Recurso Ordinário 03119-2006-342-01-00-9. Publicação em 14 de julho de 2008. Relator: Marcelo Augusto Souto de Oliveira. Disponível em: <www.trt1.jus.br〉. Acesso em: 13 abr. 2011). 
5.7.3 Perda de uma chance pós-contratual

Para tecer considerações analíticas sobre o tema também denominado "culpa post pactum finitum", é necessário, primeiramente, dirimir a cizânia doutrinária acerca do conceito de "obrigações pós-contratuais", distinguindo-as de figuras assemelhadas, a fim de imprimir o rigor taxonômico que o trabalho exige, para, num segundo momento, esclarecer os matizes pelos quais se propôs catalogar as espécies de perda de uma chance, aqui apresentadas, como pertencentes às obrigações pós-contratuais.

Historicamente, foi o direito germânico da década de 1920 o precursor na atribuição da responsabilidade pós-contratual. Em 1925, a jurisprudência tedesca atribuiu a culpa post pactum finitum a um vendedor que persuadiu o comprador a efetuar a transação, ao argumento de que o imóvel possuía uma vista belíssima, e, indevassável, de acordo com o plano diretor da cidade. Concluída a negociação, o vendedor logrou obter, junto ao órgão municipal, a modificação do plano diretor, e, após, adquirir o terreno vizinho e construir uma edificação que obstruía a visão da alardeada paisagem ${ }^{736} 737$.

A jurisprudência brasileira, todavia, ainda é bastante tímida no que concerne ao reconhecimento explícito da responsabilidade pós-contratual ${ }^{738}$. Cogita-se, dentre os motivos, o fato de o artigo 422 do $\mathrm{CCB}^{739} 740$ não dispor expressamente sobre ela.

\footnotetext{
${ }^{736}$ DONNINI, Rogério Ferraz. Responsabilidade pós-contratual no novo Código Civil e no Código de defesa do consumidor. São Paulo: Saraiva, 2004, p. 86.

${ }^{737}$ Menezes Cordeiro cita outros exemplos em que a jurisprudência alemã consolidou a doutrina: “Mas, em 26 de setembro de 1925, ao decidir que, depois de consumada uma cessão de créditos, o cedente continuava obrigado a não tolher a condição do cessionário, o 'Reichsgericht' dá a base à nova doutrina, reforçando-a a 3 de fevereiro de 1926, com nova sentença pela qual, expirado um contrato de edição, o titular do direito de publicação fica obrigado a não fazer concorrência com o editor, procedendo à feitura de novas edições, antes de esgotadas as anteriores". (CORDEIRO, António Menezes. Da pós-eficácia das obrigações: estudos de Direito Civil. Coimbra: Almedina, 1984, p. 147-148)

${ }^{738}$ Todavia, o TJ/RS possui um precedente interessante: “COMPRA E VENDA. RESOLUCAO. CULPA POST PACTUM FINITUM. O VENDEDOR QUE IMEDIATAMENTE APOS A VENDA TORNA INVIAVEL A COMPRADORA DISPOR DO BEM, AMEACANDO-A DE MORTE E A ESCORRACANDO DO LUGAR, PARA APROVEITAR-SE DISSO E VENDER A CASA PARA OUTREM, DESCUMPRE UMA OBRIGACAO SECUNDARIA DO CONTRATO E DÁ MOTIVO A RESOLUCAO. PRINCIPIO DA BOA FE. PRELIMINAR DE NULIDADE REJEITADA. APELO PROVIDO EM PARTE, APENAS PARA SUSPENDER EXIGIBILIDADE DOS ONUS DA SUCUMBENCIA”. (RIO GRANDE DO SUL. Tribunal de Justiça do Estado do Rio Grande do Sul. Apelação Cível no 588042580, Quinta Câmara Cível, Relator: Ruy Rosado de Aguiar Júnior, Julgado em 16 de agosto de 1988). O sítio eletrônico (http://www1.tjrs.jus.br/busca/?tb=proc) do tribunal não permite a visualização do inteiro teor do acórdão.

739 "Art. 422. Os contratantes são obrigados a guardar, assim na conclusão do contrato, como em sua execução, os princípios de probidade e boa-fé”. (BRASIL. Código Civil (2002). Código Civil e Constituição Federal. 62. ed. São Paulo: Saraiva, 2011)
} 
Abstraindo-se a discussão acerca das razões pelas quais há pouco acolhimento desta fattispecie de obrigação pelos pretórios, notadamente por não compor o objeto do presente estudo, constata-se que é, epistemologicamente, impossível dividir a responsabilidade por fases (antes, durante e depois) sem saber quando começa e quando termina o contrato ${ }^{741}$.

No afã de delimitar tais fronteiras, ou, aqui, mais especificamente, demarcar o ponto extremo do contrato, é fundamental conhecer as variadas classificações que se aproximam da responsabilidade pós-contratual, mas que com ela não se confundem, como as hipóteses de: a) pós-eficácia negocial aparente; b) pós-eficácia negocial virtual e c) pós-eficácia negocial continuada.

A pós-eficácia negocial aparente é aquela em que, embora a obrigação seja nitidamente contratual, a responsabilização se dá após a extinção do pacto principal, porquanto a execução de determinadas cláusulas, forçosamente, ocorre após o exaurimento do contrato, em sentido estrito. É o que ocorre, por exemplo, na compra e venda de um automóvel, em que o negócio jurídico se aperfeiçoa com a tradição de coisa e preço, mas a garantia de fábrica do bem, por determinado período, sucede essa transação ${ }^{742}$.

No âmbito trabalhista, é o caso do trabalhador que assina cláusula de nãoconcorrência ${ }^{743}$, cujos efeitos, naturalmente, protraem-se no tempo, para gerar deveres ulteriores à cessação do liame empregatício. Malgrado o silêncio absoluto da legislação nacional, muitos dos países da Europa continental nos quais o Brasil se referencia, tais

\footnotetext{
${ }^{740}$ Por esse razão, o Projeto de Lei n. 6.960/2002, batizado de "Projeto Fiúza", propôs a alteração da redação do comentado dispositivo, de modo a abarcar, textualmente, todas as fases do contrato, nos seguintes termos: “Art. 422. Os contratantes são obrigados a guardar, assim nas negociações preliminares e conclusão do contrato, como em sua execução e fase pós-contratual, os princípios da probidade e boa-fé e tudo mais que resulte da natureza do contrato, da lei, dos usos e das exigências da razão e da eqüidade”. (BRASIL. Projeto de lei no 6.960, de 12 de junho de 2002. Disponível em: <http://www.camara.gov.br/sileg/ Prop Detalhe.asp?id=56549>. Acesso em: 06 maio 2011. Sem grifos no original). Esse Projeto foi arquivado pela Mesa Diretora da Câmara dos Deputados em 31 jan. 2007.

741 Tolsada elabora a seguinte indagação: "Da la impresión de que al hablar de la cuestión del comienzo y fin del contrato nos encontramos ante uno de los aspectos más resbaladizos y que mejor aconsejan un trataminento jurídico unitario de la responsabilidad civil. Mientras no haya contrato y desde el instante en que ya no haya contrato, los problemas de responsabilidad que se originen com ocasión de un contrato futuro o pasado son problemas extracontractuales. Pero ?cuándo comienzan y terminan los contratos? (TOLSADA, Mariano Yzquierdo, op. cit., p. 90)

${ }^{742}$ É o exemplo mencionado por Lissandra de Ávila Lopes: “A pós-eficácia aparente é aquela em que uma das partes poderá responsabilizar a outra parte em decorrência de previsão expressa da lei, mesmo após a extinção do contrato. É o que ocorre, por exemplo, quando há, na compra-e-venda, o dever de garantia do produto, ou seja, quando o vendedor continua com o compromisso de garantir o bom funcionamento do produto vendido mesmo após o cumprimento do contrato devido à regulamentação do Código de Defesa do Consumidor". (LOPES, Lissandra de Ávila. A responsabilidade pós-contratual no Direito Civil. Revista Eletrônica do Curso de Direito da UFSM, v. I, n. 3, Nov. 1996, p. 47. Disponível em: <http://www.ufsm.br/revistadireito/eds/v1n3/a4.pdf >. Acesso em: 6 de maio de 2011)

${ }^{743}$ No Brasil, popularmente chamada de "cláusula de quarentena".
} 
como Portugal $^{744}$, Itália ${ }^{745}$ e Espanha ${ }^{746}$, possuem dispositivos que validam tal estipulação, mediante determinadas condições, como forma solene (escrita), delimitação de tempo, espaço e objeto, e contraprestação equipolente em favor do empregado. Tal fator motiva a doutrina pátria, com supedâneo na autorização do artigo $8^{\circ}$ da $\mathrm{CLT}^{747}$, a adotar o direito estrangeiro como fonte subsidiária, e admitir tal avença com algumas restrições ${ }^{748}$.

Ademais, mesmo que não haja cláusula expressa de "quarentena", a doutrina entende que, caso o empregado, detentor de informações confidenciais obtidas perante o ex-

${ }^{744}$ Conforme disposto no artigo 136 da Lei 7, de 12 de fevereiro de 2009, que aprovou o novo Código do Trabalho: "Artigo $136 .^{\circ}$ Pacto de não concorrência. 2 - É lícita a limitação da actividade do trabalhador durante o período máximo de dois anos subsequente à cessação do contrato de trabalho, nas seguintes condições:a) Constar de acordo escrito, nomeadamente de contrato de trabalho ou de revogação deste; b) Tratar -se de actividade cujo exercício possa causar prejuízo ao empregador; c) Atribuir ao trabalhador, durante o período de limitação da actividade, uma compensação que pode ser reduzida equitativamente quando o empregador tiver realizado despesas avultadas com a sua formação profissional”. (PORTUGAL. Lei $\mathbf{n}^{\mathbf{0}}$ 7, de 12 de fevereiro de 2009. Aprova revisão do Código do Trabalho. Disponível em: <http://dre.pt/pdf1sdip/2009/02/03000/0092601029.pdf>. Acesso em: 5 maio 2011)

$74 \overline{5}$ A disposição está no próprio Código Civil italiano: "Art. 2125 Patto di non concorrenza. Il patto con il quale si limita lo svolgimento dell'attività del prestatore di lavoro, per il tempo successivo alla cessazione del contratto, è nullo se non risulta da atto scritto (2725), se non è pattuito un corrispettivo a favore del prestatore di lavoro e se il vincolo non è contenuto entro determinati limiti di oggetto, di tempo e di luogo.La durata del vincolo non può essere superiore a cinque anni, se si tratta di dirigenti, e a tre anni negli altri casi. Se è pattuita una durata maggiore, essa si riduce nella misura suindicata (2557, 2596; att. 198)”. (ITÁliA. Código Civil (1942). Código Civil. Disponível em: <http://www.jus.unitn.it/cardozo /obiter_dictum/codciv/Lib5.htm>. Acesso em: 5 de maio 2011)

${ }^{746}$ Conforme estabelecido pelo artigo 21 da Lei do Estatuto dos Trabalhadores (Real Decreto Legislativo 1, de 24 de março de 1995): "Artículo 21. Pacto de no concurrencia y de permanencia en la empresa. 2. El pacto de no competencia para después de extinguido el contrato de trabajo, que no podrá tener una duración superior a dos años para los técnicos y de seis meses para los demás trabajadores, sólo será válido si concurren los requisitos siguientes: a) Que el empresario tenga un efectivo interés industrial o comercial en ello, y b) Que se satisfaga al trabajador una compensación económica adecuada.” (ESPANHA. Real decreto legislativo $\mathbf{n}^{\mathbf{0}} \mathbf{1}$, de 24 de março de 1995. Estatuto dos Trabalhadores. Disponível em: <http://www.ugt.es/DatoBasico/estatutodelostrabajadoresactualizado.pdf>. Acesso em: 5 maio 2011)

747 BRASIL. Consolidação das Leis do Trabalho (1943). CLT e Constituição Federal. 38. ed. São Paulo: Saraiva, 2011.

${ }^{748}$ É o que pensa Alice Monteiro de Barros: "Após o término da relação de emprego, a persistência dessa cláusula só se justifica em casos excepcionais, isto é, quando necessária à proteção dos interesses do empregador, e ainda assim, por um determinado período, durante o qual dever-se-á assegurar ao trabalhador uma indenização. Não cremos, tampouco, possa a referida cláusula, nessas condições, cercear a liberdade de exercício de qualquer trabalho, ofício ou profissão constante do art. $5^{\circ}$, XIII, da Constituição de 1988, pois a inserção da cláusula deverá permitir ao empregado a possibilidade de exercer a atividade que lhe é própria,considerando sua experiência e formação, desde que junto a estabelecimentos empresariais insuscetíveis de ocasionar concorrência danosa ao ex-empregador. Percebe-se que a doutrina brasileira, cujo ponto de vista aderimos, tende a aceitar a aplicação da cláusula de não concorrência ao contrato de trabalho, por aplicação subsidiária da legislação estrangeira, como autoriza o art. $8^{\circ}$ da CLT, em situações excepcionais, sendo ideal a previsão em convenção coletiva, com limitações relativas ao objeto, tempo e espaço. A inserção dessa cláusula nos contratos de trabalho deverá ser analisada dentro de um contexto de razoabilidade, em face dos interesses e liberdade que estão em jogo". (BARROS, Alice Monteiro de. Contatos e Regulamentações Especiais de Trabalho: peculiaridades, aspectos controvertidos e tendências. 2. ed. rev., atual. e ampl. São Paulo: LTr, 2002, p. 478) 
empregador, desligue-se do emprego para trabalhar na empresa concorrente, viola o dever de boa-fé, cuja obrigação transborda a fronteira do extinto vínculo de emprego ${ }^{749}$.

Já a pós-eficácia negocial virtual diz respeito ao cumprimento de deveres secundários, ou seja, complementares à prestação principal, cujo descumprimento importa adimplemento parcial ou cumprimento imperfeito da obrigação. O exemplo clássico é o do contrato de locação: findo o contrato, o locatário tem o dever de entregar o imóvel (obrigação principal) em perfeitas condições (obrigações secundárias relativas à desinsetização, limpeza, pintura etc.).

Transposta para a seara laboral, ela abrange, por exemplo, o dever do empregador, após a extinção do vínculo de emprego, proceder à baixa na CTPS, e restitui-la ao empregado em 48 horas ${ }^{750}$, ou, do empregado rural, de desocupar o imóvel cedido pelo empregador, em 30 (trinta) dias ${ }^{751}$.

Finalmente, a pós-eficácia negocial continuada concerne às obrigações de execução repetida, como, por exemplo, o pagamento de prestações (v.g., na mencionada compra do automóvel) ou de comissões vencidas após a cessação do contrato de trabalho ${ }^{752}$.

Todas essas hipóteses de pós-eficácia lato sensu não se confundem com as situações em que se pode adotar a teoria da responsabilidade pós-contratual propriamente

\footnotetext{
${ }^{749}$ É o exemplo dado por Luiz Marcelo Figueira de Góis: "Finalmente, seguindo o mesmo raciocínio, mesmo após a extinção do contrato de trabalho subsistem às partes obrigações, conferindo-lhe a nova ordem, também, pós-eficácia. Nesse sentido, é razoável que se entenda que o ex-empregado que detinha dados empresariais confidenciais viola o art. 422 do CC/2002, caso comece a trabalhar para empresa concorrente imediatamente após o término de seu contrato de trabalho. É como se o contrato de trabalho extinto deixasse seu tronco para trás, estendendo, contudo, alguns tentáculos para frente na linha do tempo". (GÓIS, Luiz Marcelo Figueira de. A eficácia do contrato de trabalho à luz do novo Código Civil. Revista Síntese Trabalhista, São Paulo, n. 168, jun. 2003, p. 40)

${ }^{750}$ Como determina o artigo 29 da CLT: "Art. 29. A Carteira de Trabalho e Previdência Social será obrigatoriamente apresentada, contra recibo, pelo trabalhador ao empregador que o admitir, o qual terá o prazo de 48 (quarenta e oito) horas para nela anotar, especificamente, a data de admissão, a remuneração e as condições especiais, se houver, sendo facultada a adoção de sistema manual, mecânico ou eletrônico, conforme instruções a serem expedidas pelo Ministério do Trabalho. $\S 2^{\circ}$. As anotações na Carteira de Trabalho e Previdência Social serão feitas: a) na data-base; b) a qualquer tempo, por solicitação do trabalhador; c) no caso de rescisão contratual; ou d) necessidade de comprovação perante a Previdência Social". (BRASIL. Consolidação das Leis do Trabalho (1943). CLT e Constituição Federal. 38. ed. São Paulo: Saraiva, 2011. Sem grifos no original).

751 "Lei 5.889/73. Art. $9^{\circ} . \S 3^{\circ}$. Rescindido ou findo o contrato de trabalho, o empregado será obrigado a desocupar a casa dentro de trinta dias". (BRASIL. Lei $\mathbf{n}^{\mathbf{0}} \mathbf{5 . 5 8 9}$, de 8 de junho de 1973. Estatui normas reguladoras do trabalho rural. Disponível em: < http://www.planalto.gov.br/ccivil_03/Leis/L5889.htm>. Acesso em: 7 maio 2011)

752 Cujo recebimento é assegurado pelo $\S 2^{\circ}$ do artigo 466 da CLT: "§ $2^{\circ}$. A cessação das relações de trabalho não prejudica a percepção das comissões e percentagens devidas na forma estabelecida por este artigo". (BRASIL. Consolidação das Leis do Trabalho (1943). CLT e Constituição Federal. 38. ed. São Paulo: Saraiva, 2011. Sem grifos no original).
} 
dita, pois, nesta, não há uma obrigação legal ou contratual específica que determine a observância de uma determinada regra ${ }^{753}$.

Portanto, a chamada culpa post pactum finitum só pode ser invocada quando os deveres acessórios de lealdade, proteção e informação tiverem de ser cumpridos após o encerramento do vínculo contratual, e sem que haja comando legal ou cláusula contratual desse jaez. Desta característica decorre a consequência de que a boa-fé objetiva acaba por ser o principal fundamento dos deveres secundários ${ }^{754}$ e da responsabilidade póscontratual, já que tal cláusula transcende os limites temporais do contrato e autonomiza-se em relação à prestação principal, a fim de assegurar sua correta execução ${ }^{755}$.

É essa, tecnicamente, a definição de obrigação ou de responsabilidade póscontratual (post pactum finitum), e, para manter a coerência em relação ao trabalho, é a opção que nos pareceu inexorável quando da classificação da casuística. A escolha taxonômica pautou-se pela origem da responsabilidade, e não pelo momento cronológico da ocorrência do ato ilícito ou da perda de uma chance (dano).

\footnotetext{
${ }^{753}$ É o que sustenta Ademir de Oliveira Costa Júnior: “Algumas hipóteses de pós-eficácia têm um sentido amplo e não representam situações em que se possa adotar a teoria da culpa post factum finitum, tendo em vista que não está ligado a deveres impostos por norma jurídica (pós-eficácia aparente), a efeitos da prestação secundária que aparecem após o efetivo cumprimento da prestação principal (pós-eficácia virtual) ou a vínculos acessórios numa obrigação duradoura (pós-eficácia continuada). Para que se caracterize a póseficácia em sentido estrito, não há que se falar em deveres expressamente previstos em lei, contrato, ou em deveres que estejam à mercê das partes, ou seja, que não são disponíveis. São, na realidade, os deveres acessórios. Embora nada pró́ba que os deveres acessórios venham expressos em lei, a aplicação da teoria da culpa post factum finitum se dá somente quando tais deveres acessórios não sejam previstos em lei. Caso venha disposto em contrato o dever acessório, sua violação implicará no dever de reparar o prejuízo, mas a responsabilidade, nesse caso, seria contratual e não pós-contratual”. (COSTA JÚNIOR, Ademir de Oliveira. A responsabilidade "post factum finitum" no direito civil e do consumidor. Disponível em: <http://jus.uol.com.br/revista/texto/9434/a-responsabilidade-post-factum-finitum-no-direito-civil-e-doconsumidor>. Acesso em: 5 maio 2011)

${ }^{754}$ Consoante as lições de Antônio Junqueira de Azevedo: "Como regra de conduta, a boa-fé serve como fonte de deveres que não estão necessariamente expressos no contrato, nem encontram previsão legal específica. Neste sentido, afirmei em outra ocasião: 'A cláusula de boa-fé - sempre comentada por todos os tratadistas - cria deveres anexos ao vínculo principal. Existe, no contrato, aquilo a que as partes expressamente se referiram, seu objeto principal expresso, e, depois, há os deveres colocados ao lado, ora ditos secundários, ora anexos, especialmente o dever de informar e, mais um dever negativo, o de manter sigilo sobre alguma coisa que um contratante soube de outra parte, ou também deveres ditos positivos, como o de procurar colaborar com a outra parte [...]". (AZEVEDO, Antonio Junqueira de, op. cit., p. 128)

${ }^{755}$ De acordo com o que preconiza Maurício Jorge Mota: "Os deveres laterais de conduta inerentes à boa-fé são deveres funcionalizados ao fim do contrato e, como tal, surgem e se superam no desenvolvimento da situação contratual como uma totalidade, autonomizando-se em relação ao dever de prestação principal para assegurarem o correto implemento do escopo do contrato. Assim, podem subsistir deveres pós-eficazes ao término do adimplemento do contrato, no interesse da correta consecução deste”. (MOTA, Maurício Jorge. A pós-eficácia das obrigações. TEPEDINO, Gustavo (Coord.). Problemas de direito civil-constitucional. Rio de Janeiro: Renovar, 2000, p. 238)
} 
Destarte, em que pese a possibilidade de causar alguma estranheza aos menos familiarizados com o tema, assuntos como a ausência de baixa ${ }^{756}$ ou a retenção indevida da CTPS $^{757}$ após o final do contrato de emprego, apesar de terem causado danos topograficamente localizados após a cessação do liame empregatício, tiveram sua gênese na violação de um dever legal ou contratual, e, por essa razão, foram catalogados em tal fase.

A partir de tais premissas, verifica-se do quadro a seguir que, da mesma forma como nas demais espécies de contratos em geral, a perda de uma chance "pós-contratual" foi a que teve menor incidência no contrato de trabalho, senão vejamos:

\begin{tabular}{|l|l|l|l|l|l|l|l|}
\hline \multicolumn{1}{|c|}{ ASSUNTO/ TRT } & $\mathbf{2}^{\mathbf{a}}$ & $\mathbf{3}^{\mathrm{a}}$ & $\mathbf{4}^{\mathrm{a}}$ & $\mathbf{1 2}^{\mathrm{a}}$ & $\mathbf{1 5}^{\mathbf{a}}$ & $\mathbf{2 0}^{\mathbf{a}}$ & Total \\
\hline $\begin{array}{l}\text { Informação } \\
\text { Desabonadora }\end{array}$ & $\mathbf{1}$ & $\mathbf{1}$ & $\mathbf{2}$ & $\mathbf{2}$ & $\mathbf{1}$ & $\mathbf{2}$ & $\mathbf{9}$ \\
\hline TOTAL & $\mathbf{1}$ & $\mathbf{1}$ & $\mathbf{2}$ & $\mathbf{2}$ & $\mathbf{1}$ & $\mathbf{2}$ & $\mathbf{9}$ \\
\hline
\end{tabular}

A oportunidade perdida em ambas as margens do contrato diz respeito, basicamente, à frustração da contratação: na fase pré-contratual, alguma violação do empregador faz com que o empregado perca uma chance real e séria de ser admitido; na fase póscontratual, determinado embaraço criado pelo empregador aniquila as perspectivas do empregado dispensado de recolocar-se no mercado de trabalho.

Observa-se, do conjunto das decisões, que não há menção expressa à responsabilidade pós-contratual, embora também não haja repúdio. Sem embargo, os acórdãos seguem a trilha da boa-fé objetiva, cujos efeitos se projetam para além do término

756 “ANOTAÇÃO DA BAIXA NA CARTEIRA PROFISSIONAL. RETENÇÃO DA CTPS. DANO MORAL. INOCORRÊNCIA”. (MATO GROSSO. Tribunal Regional do Trabalho da $23^{\mathrm{a}}$ Região, $2^{\mathrm{a}}$ Turma. Recurso Ordinário 00526.2007.009.23.00-6. Publicação em 26 de fevereiro de 2009. Relator: Paulo Barrionuevo. Disponível em: 〈www.trt23.jus.br〉. Acesso em: 19 abr. 2011).

757 "INDENIZAÇÃO POR DANOS MORAIS - AUSÊNCIA DE DEVOLUÇÃO DA CTPS INDEFERIMENTO - IMODIFICABILIDADE DO DECISUM” (SERGIPE. Tribunal Regional do Trabalho da 20a Região, Recurso Ordinário 00031-2008-006-20-00-5. Publicação em 03 de setembro de 2008. Relator: Augusto César Leite Carvalho. Disponível em: 〈wwww.trt20.jus.br〉. Acesso em: 19 abr. 2011) 
do contrato de trabalho ${ }^{758}$, o que implica, indubitavelmente, na admissão da culpa post pactum finitum.

Ante tal quadro, a perda de uma chance derivada de ilícito pós-contratual é matéria que não conta com material jurisprudencial significativo capaz de ensejar maiores reflexões sobre o tema.

${ }^{758}$ Como se vislumbra no seguinte julgamento: "INFORMAÇÃO DESABONADORA. AJUIZAMENTO DE AÇÃO PELO EMPREGADO. Do ponto de vista do ex-empregador, que presta informações desabonadoras, a conduta representa inegável descumprimento de obrigações derivadas da cláusula geral de boa-fé, que acompanham todo o desenvolvimento da relação jurídica contratual, projetando-se para além do término do contrato de trabalho. No caso em exame, restou comprovado que o proprietário da empresa ré afirmara expressamente a terceiro que lhe pedira informações sobre a reclamante que a ex-empregada havia dado um problema e que este somente se resolvera na Justiça, de forma flagrantemente desabonadora em relação à imagem e à dignidade da trabalhadora, caracterizando a chamada "lista negra" e dificultando injustamente a obtenção de novo emprego pela autora. Configurada a prática de conduta antijurídica apta a ensejar, no caso em apreço, a reparação ao dano moral pleiteada pela autora, nos moldes dos artigos $186 \mathrm{e}$ 927 do Código Civil Brasileiro. Recurso provido". (MINAS GERAIS. Tribunal Regional do Trabalho da $3^{\text {a }}$ Região, Turma Recursal de Juiz de Fora. Recurso Ordinário 0056900-74.2009.5.03.0132. Publicação em 24 de fevereiro de 2010. Relator: Heriberto de Castro. Disponível em: 〈www.trt3.jus.br〉. Acesso em: 6 abr. 2011. Sem grifos no original). 


\section{CONCLUSÃO}

O estudo teve por intento traçar um esboço sobre a teoria da "perda de uma chance", fenômeno que ocorre quando alguém, por força de ato praticado por outrem, fica tolhido da oportunidade de obter um benefício ou de evitar um malefício. Já na apresentação da obra, procurou-se demonstrar que a subtração da oportunidade oblitera a possibilidade de fazer escolhas ou seguir em frente nelas, algo ontologicamente intrínseco à condição humana, conforme se tentou justificar por argumentos culturais e filosóficos.

Ainda no prelúdio, afirmou-se a origem doutrinariamente francesa do instituto, que se consolidou através da expressão "perte d'une chance”, fazendo-se remissões às primeiras manifestações, em apertada síntese.

Finalizando a parte introdutória, sustentou-se a imbricação epistemológica entre a perda de uma chance e a relação de trabalho, com a proposta de desenvolvimento do estudo mediante a explicação dos seus condicionamentos, a sistematização das suas relações, o esclarecimento dos seus vínculos e a avaliação dos seus resultados e aplicações.

No espaço destinado ao escorço histórico (capítulo 1), concluiu-se pelo equívoco da doutrina francesa ao asseverar que, naquele país, a Corte de Cassação admitira a reparação das chances desde o final do século XIX, demonstrando-se, a partir da análise dos julgados mencionados, que a Suprema Corte Francesa, até a década de 1930, era refratária ao reconhecimento da indenização das chances perdidas. Em relação à França, provou-se, outrossim, o desacerto de uma parte da doutrina brasileira ao afirmar que o primeiro julgamento de perda de uma chance ocorrera na década de 1960.

Aludiu-se ao caso Chaplin v. Hicks, de 1911, na Inglaterra, como o precedente mais antigo por nós encontrado sobre o tema. Falou-se, ainda, sobre o início do reconhecimento jurisprudencial do instituto na Itália e no Brasil, baseando-se em fontes indiretas.

$\mathrm{Na}$ sequência, discutiram-se, com o necessário rigor científico, as noções propedêuticas sobre o tema (capítulo 2), iniciando-se pela questão terminológica, haja vista algum dissenso doutrinário e jurisprudencial na aplicação das expressões "chance" e "oportunidade". A partir do contraste da nomenclatura adotada pelo direito estrangeiro com a do direito pátrio, aliado a uma reflexão filológica, entendeu-se que a expressão consagrada - perda de uma chance - preserva o casticismo vernacular, a par de contemplar 
a vantagem de ser auto-explicativa, de fácil assimilação e representar o nomem juris mais utilizado.

Posteriormente, problematizou-se sobre a refutação e a consolidação da teoria, recuperando-se, historicamente, o argumento repelente, no sentido de que a sua ocorrência provocaria apenas a perda de uma possibilidade, mera chance aleatória e impossível de ser indenizada, em face do caráter incerto do dano.

Procurou-se, incontinente, demonstrar o equívoco na metodologia cronológica de análise da teoria, cujo fulcro da investigação sobre a propalada "certeza" do prejuízo estava em mirar o futuro hipotético (incerto), quando se deveria operar um deslocamento temporal para o passado (certo), no qual constava uma chance, que já compunha a esfera de bens da "vítima" - patrimoniais ou extrapatrimoniais -, e que poderia ser valorada, sendo, portanto, passível de indenização.

Sustentou-se, mediante exemplos comezinhos, como o do bilhete de loteria, que a chance, em si mesma, já possui um valor intrínseco.

Acenou-se com a existência de um aparente paradoxo na figura da perda de uma chance, consistente na "certeza do incerto", pois, nela, as duas categorias (certeza e incerteza) convivem de modo harmônico, além de comporem sua essência, já que a ressarcibilidade da chance repousava na certeza da existência da própria chance, entidade tutelada juridicamente e passível de valoração econômica, e na incerteza sobre a sua concretização. Destarte, a perda de uma chance assenta-se na certeza da probabilidade.

Investigaram-se, na continuidade do trabalho, as diferenças entre a perda de uma chance e as figuras mais aproximadas, eleitas pelo critério de um ou mais pontos de contato que pudessem gerar uma espécie de "zona cinzenta" na demarcação dos traços distintivos.

Dentro desse objetivo, perquiriu-se a diferença entre a perda de uma chance e os lucros cessantes, opondo-se, de maneira ferrenha, à corrente doutrinária que apregoa que a distinção reside no fato de que na primeira (perda de uma chance) existe incerteza em relação ao resultado final e no segundo (lucros cessantes) há certeza, porquanto a incerteza é uma constante em ambos os casos.

A desigualdade entre os institutos situa-se no modo como o Direito interage com a álea: nos lucros cessantes, ele a repele, artificializando o conhecimento, e agindo como se 
tudo soubesse, a partir de juízos presuntivos; na perda de uma chance, o Direito absorve a álea, admite a sua ignorância, e a leva em conta no momento de decidir, obtemperando o montante indenitário de acordo com juízos de probabilidade.

De igual modo, no estabelecimento da diferença entre a perda de uma chance e a condição maliciosamente obstada pela parte cujo adimplemento desfavorecer (CCB, art. 129), também se contrariou a tese de que haveria a certeza do adimplemento da condição, não fosse o ato ilícito, porque tal asserção macula o próprio conceito de condição, enquanto cláusula que subordina a eficácia de um negócio jurídico a evento futuro e incerto (CCB, art. 121).

Por outro lado, partindo-se da semelhança existente entre as figuras, que era a interrupção da cadeia aleatória de acontecimentos, foram estabelecidas quatro dessemelhanças: i) quanto aos requisitos, pois o artigo 129 do CCB exige o dolo, de que prescinde a perda de uma chance; ii) quanto aos sujeitos, já que no art. 129 do CCB têmse, necessariamente, dois pólos de uma relação obrigacional, ou seja, vítima e ofensor se vinculam por meio de um contrato, de um negócio jurídico stricto sensu, o que pode ou não ocorrer na perda de uma chance; iii) quanto à condição (estado) do ofensor, porquanto no artigo 129 do CCB o ofensor deve estar na posição jurídica de suportar uma desvantagem em relação ao ofendido, caso a condição cujo implemento ele obstou fosse conquistada; iv) quanto aos efeitos, porque o ordenamento atribui desdobramentos distintos em face da ocorrência do ato ilícito, utilizando um juízo de probabilidade na perda de uma chance, e a ficção do adimplemento da condição na hipótese do artigo 129 do CCB.

A natureza jurídica foi largamente debatida no tópico seguinte, em que foram alinhavados os seguintes desacertos nos métodos tradicionais para o seu estabelecimento: 1 - a vinculação da avaliação da natureza jurídica ao resultado (dano final) ocasionado; 2 - o procedimento da análise da natureza jurídica a partir do futuro incerto (caráter aleatório da conquista da vantagem cuja possibilidade fora arrebatada) e não do passado certo (chance que a vítima efetivamente tinha); 3 - a resolução da questão da natureza jurídica a partir da perspectiva do que é melhor para a vítima.

Escoimados tais vícios, afirmou-se que a perda de uma chance tem característica de "situação lesiva", que pode gerar todas as espécies de reparação por responsabilidade civil previstas no ordenamento, por força do desarmamento de uma posição jurídica favorável - 
real e séria. Ademais, asseverou-se que, expurgada a concepção errônea de que o dano emergente só pode ser patrimonial, a perda de uma chance se encaixa nesta categoria, pois antes do evento lesivo, havia uma propriedade, material ou imaterial, que foi expungida, tornando a situação da vítima pior do que aquela em que ela se encontrava anteriormente.

Como requisitos para o acolhimento do pleito de indenização, foram adotados os critérios da realidade e seriedade, com destaque também para a atualidade da oportunidade perdida, sendo esta última englobada pela seriedade. Foi estabelecida a necessária anteriorização cronológica e hierarquização dos requisitos, afirmando-se que a realidade precede a seriedade, na medida em que a primeira situa-se no plano da própria existência da chance, ao passo que a segunda encontra-se na seara da eficácia, da relevância jurídica apta a reclamar tutela jurisdicional. A fixação de condições de responsabilidade teve por escopo coibir abusos da noção do instituto, para que a probabilidade indenizável se constitua em algo palpável, sob o enfoque objetivo, e não meramente especulativo ou de possibilidade deveras diminuta.

Todavia, objetou-se veementemente quanto ao estabelecimento, em juízo prévio e abstrato, de tarifações rígidas de percentuais mínimos para que a chance fosse considerada séria, ao fundamento de que a seriedade constitui um conceito jurídico indeterminado, verdadeira opção legislativa por cláusula aberta, cuja lacuna deve ser colmatada ex post, de acordo com as peculiaridades do caso concreto. Criticou-se, em especial, a tendência da doutrina italiana, acatada por parte da brasileira, de fixar como sérias somente as chances com conteúdo probabilístico superior a 50\% (cinquenta por cento), pela absoluta ausência de cientificidade.

Sugeriu-se, como técnica de aplicação e integração da norma jurídica no preenchimento do conceito de seriedade, que o intérprete buscasse a "medida", de acordo com a lógica de Hegel, ou seja, o momento em que a quantidade (de chances) tivesse o condão de transmudar a qualidade (de meramente hipotética em séria).

Exemplificou-se a inconveniência do "tabelamento prévio" do conceito de chance séria com o relato, detalhado, do caso do "Show do Milhão", o mais célebre da jurisprudência nacional.

Para descobrir o fundamento da reparação do dano de chances perdidas, estabeleceuse, como premissa, que ela pode fundar-se tanto no postulado de não causar dano a outrem, expresso no princípio “neminem laedere”, quanto no inadimplemento de um dever 
contratual. A partir daí, inferiu-se, no que concerne à responsabilidade extracontratual ou aquiliana, que ela prescinde de qualquer prescrição positiva específica para ser concedida, porquanto tem respaldo na cláusula geral de responsabilidade civil, tal qual ocorre em diversos países da Europa Continental que lhe dão guarida.

Abriu-se, no tópico, uma brecha para a abordagem norte-americana da perda de uma chance, pois se concluiu pela inadequação de encaixar os fundamentos de admissibilidade do assunto nos Estados Unidos da América em compartimentos contratuais ou extracontratuais, dadas as diferenças de sistemas. No tópico, descobriu-se que os norteamericanos lançam mão da doutrina, quase que de modo exclusivo, nas ações relativas à perda de uma chance de cura ou sobrevivência, em questões médicas. Além disso, notou-se que, na maior parte dos casos, as decisões conferem indenizações não pela ocorrência genuína de perda de uma chance, mas em hipóteses de criação ou aumento de risco, em que não há necessidade da concretização do evento danoso, apenas o surgimento ou a elevação da probabilidade de sua ocorrência.

No que diz respeito às espécies de dano que a perda de uma chance pode provocar (capítulo 3), argumentou-se, a partir do postulado de que ela tem como fundamento a cláusula geral de responsabilidade civil, que a única ilação possível é a de que a indenização pode ter como corolário quaisquer dos bens protegidos constitucionalmente, sejam eles morais, materiais ou estéticos (isolados ou cumulados).

Nesse ponto, fustigou-se, em particular, a construção doutrinária e jurisprudencial de que a perda de uma chance não pode dar lugar, apenas, a uma indenização por dano moral. Mais uma vez, houve a utilização do recurso a um exemplo ilustre a fim de reforçar o argumento sustentado, qual fora o caso "Vanderlei Cordeiro de Lima", porém, sob uma ótica diversa daquela normalmente analisada, qual fora o do vencedor da prova, o italiano Stefano Baldini, que perdeu a chance de uma vitória incontestável.

Quanto ao caráter da reparação das chances perdidas, sustentou-se que ela respeita ao princípio da restitutio in integrum, repudiando-se todas as construções no sentido de que haveria reparação parcial do dano. Não obstante, como a chance, em si considerada, representa apenas uma probabilidade (parte) em relação ao todo, o valor da indenização deve ser, necessariamente, inferior ao do dano final.

A preocupação subsequente ao estabelecimento do postulado de que a perda de uma chance conformava-se ao princípio da reparação integral foi a de estabelecer os parâmetros 
para a quantificação dos danos.

Como standard de excelência na quantização, foi aclarado que a primeira técnica deve ser a aplicação de um "coeficiente redutor", correspondente ao grau (percentual) de probabilidade de êxito que a vítima teria de conseguir o resultado final obstaculizado, seja o de obter um benefício ou de evitar um prejuízo. O método foi traduzido numa fórmula matemática representada pela seguinte operação: "PC = RF x P", na qual "PC" significa o valor da Perda da Chance, "RF" o Resultado Final esperado e "P" a Probabilidade de concretização do resultado final - que é o coeficiente de redução.

Problematizou-se, na continuidade do trabalho, com os casos em que a ferramenta sugerida não puder ser utilizada de imediato, ou seja, quando um ou ambos os fatores da equação não estiverem claros desde logo, seja pela dificuldade em vislumbrar qual seria o resultado final $(\mathrm{RF})$ na ausência do ato ilícito, ou diante de empecilhos à obtenção do percentual de probabilidade $(\mathrm{P})$ de alcance do interesse aleatório.

Para dirimir tais obstáculos, apontou-se, como primeiro subsídio, para o critério da "teoria da diferença", inspirado no Código Civil alemão, e comumente utilizado na aferição dos lucros cessantes. De acordo com essa técnica, o juiz deve formular um juízo hipotético sobre qual seria o estado da vítima caso fossem extirpadas as consequências do ato ilícito, para, em seguida, contrastá-lo com o seu estado atual, indenizando-a pelo valor da diferença apurada.

Um segundo instrumento aventado para municiar o magistrado com informações acerca do possível resultado final e da probabilidade de alcançá-lo foi a "estatística", tendo sido feitas algumas advertências sobre as cautelas a serem tomadas no seu emprego, com ênfase à delimitação do método e do objeto de estudo.

O último utensílio apresentado para contribuir com a apuração do dano foi a “equidade”, na acepção aristotélica. Para tanto, fez-se uma breve digressão sobre as origens históricas do termo, concentrando-se nas duas vertentes mais comuns, a epiqueia grega e a aequitas romana, com um enfrentamento sobre a abordagem do instituto nos textos legislativos pátrios e a perquirição acerca de qual dos significados seria o empregado pelo CPC e pela LINDB (LICC) e qual o adotado pela CLT.

Após a delimitação do sentido e do alcance da palavra, alvitrou-se seu uso na acepção aristotélica de epiqueia, nunca como espécie de legiferação anômala por parte do magistrado, mas, que o juiz, diante da inexistência de um texto inflexível, 
encontrando omissão ou acentuado rigor ou generalidade na lei, após apelar para as formas complementares de expressão do direito e sem sentimentalismos ou arbitrariedades, elabore uma construção científica, em harmonia com o espírito que rege o sistema, e que venha a complementar a lei, fazendo o seu ajuste fino às particularidades do caso.

Em consequência, na apuração do dano pelas chances perdidas, a equidade pode desempenhar relevante papel diante da dificuldade de traduzir economicamente o valor de bens imateriais (v.g., o das indenizações por danos morais), para efeitos de aplicação da "teoria da diferença", ou, ainda, no sentido de refinar o encontro do percentual probabilístico que culminará no coeficiente redutor, quando o recurso à estatística, impessoal e distante das circunstâncias concretas, for insuficiente para a realização da tarefa. Lembrou-se, a propósito, que a Itália, com base na cláusula geral de equidade de seu Código Civil (artigo 1226), usa frequentemente tal critério quando da complexidade de se aferir o valor por outros meios.

$\mathrm{Na}$ fase seguinte (capítulo 4), alinhavaram-se as diversas propostas doutrinárias de classificar a perda de uma chance. No plano internacional, constatou-se que, apesar da anterioridade no estudo em relação ao Brasil, as esquematizações não obedecem a critérios científicos para separação de conteúdo e continente. Por outro lado, as classificações nacionais de maior relevo, propostas por Rafael Pettefi da Silva e Fernando Noronha, são meritórias, na medida em que promoviam o agrupamento das classes e sub-classes de perda de uma chance de acordo com métodos epistemologicamente razoáveis.

Considerando que, apesar de melhor organizadas, foram encontradas algumas imperfeições nas fórmulas de estruturação confeccionadas na doutrina pátria, propôs-se, a fim de aprimorar o rigor taxonômico, a classificação da perda de uma chance em dois grupos: "típica" e "atípica", partindo do que já havia sido edificado.

Na primeira espécie, por nós denominada de "típica", o curso aleatório dos eventos em que se encontra a vítima é interrompido, anulando as possibilidades de ela usufruir o benefício ou evitar o prejuízo. Nesta hipótese, a vítima não participa da cadeia causal até o fim, e o dano de chance, em regra, é um evento contemporâneo e certo em relação ao dano de resultado final (interesse aleatório perseguido).

Em face da simultaneidade dos danos (perda de chance e resultado final), e da retirada da vítima da cadeia causal antes do fim, há outra peculiaridade da perda de uma chance "típica": a álea está no dano equivalente ao resultado final, que é ontologicamente 
indemonstrável, na medida em que não é possível saber se a vítima conseguiria ou não alcançá-lo, não fosse a sua saída da sucessão de eventos, e o Direito acolhe a álea e a considera no momento de decidir, fixando indenização de acordo com a probabilidade de alcance do resultado frustrado.

Contrario sensu, na perda de uma chance "atípica" o processo aleatório vai até os seus ulteriores termos sem interrupção, havendo necessidade de se aguardar a concretização do resultado final, já que o dano equivalente ao resultado final é um evento futuro e incerto em relação ao dano da perda de uma chance. Argumentou-se, nesse sentido, com o exemplo de um advogado que deixa de contestar uma ação, ou um médico que, negligentemente, omite um diagnóstico importante na cura de uma doença, mas, em ambos os casos, nenhum dano resulta aos ofendidos além da criação/aumento do risco, pois a demanda é rejeitada em juízo, ou a pessoa se recupera, mesmo com um prognóstico estreito. Em tal tipo de situação, só é possível falar em "perda de uma chance" caso o resultado danoso se concretize.

E como a vítima participa do curso aleatório dos eventos até o fim, na perda de uma chance "atípica" a álea está no nexo causal, pois o que se desconhece é se o ato do ofensor (omissão do diagnóstico, ausência de contestação etc.) acarretou a perda do interesse aleatório. O método de solução também consiste na absorção da álea pelo Direito, que assume a sua ignorância perante o nexo causal, e a considera ao proferir o julgamento, utilizando da Estatística e de outros recursos a fim de estabelecer o percentual em que o ato ilícito pode ter ocasionado o dano.

Ao cabo do capítulo, discutiu-se a possibilidade de a perda de uma chance "atípica" representar ruptura com o conceito de causalidade ou utilização da causalidade parcial, concluindo-se que, em tais casos, as soluções ordinárias de responsabilidade civil devem prevalecer, com a investigação minudente e escrupulosa sobre o nexo causal. Entretanto, não sendo possível estabelecê-lo de modo preciso, diante da limitação da ignorância humana, mas, de outra parte, restando incontroversa a probabilidade de que o ilícito pode ter sido o causador do dano, a perda de uma chance representa opção subsidiária de extrema valia, que promove a justiça no caso concreto, aniquilando o padrão "tudo ou nada", em que, diante de um standard de convencimento mais ou menos rígido, a vítima pode ficar sem indenização alguma, mesmo diante de um ilícito com probabilidade de haver causado o prejuízo, ou, o ofensor pode ter de reparar a integralidade do prejuízo, 
mesmo que haja outra causa também provável para a ocorrência do dano.

No arremate das ideias (capítulo 5), asseverou-se que a perda de uma chance constitui importante ferramenta da responsabilidade civil, capaz de aprimorar as formas de reparação do dano injusto e, com isso, requintar também a relação entre capital e trabalho, de modo a fomentar a melhoria da condição social do trabalhador, atendendo ao princípio da dignidade da pessoa humana. Por isso, sustentou-se o cabimento, apriorístico, da teoria da perda de uma chance às relações de trabalho.

Numa análise mais minuciosa da legislação, chegou-se a idêntica conclusão, haja vista o instituto passar incólume ao crivo do artigo $8^{\circ}$ da CLT, por ser o diploma trabalhista omisso em relação à reparação das chances, bem como por haver compatibilidade de princípios. Assim, a perda de uma chance, a exemplo de todas as demais figuras da responsabilidade civil, deve ser aplicada ao Direito do Trabalho com a observância da peculiaridade de que o Direito Civil se baseia em relações ou contratos paritários, ao passo que o Direito do Trabalho visa à correção das desigualdades próprias à relação de emprego.

Advertiu-se, oportunamente, que malgrado as hipóteses de perda de uma chance por parte do empregado sejam as mais comuns, não se exclui, por óbvio, a possibilidade de o empregado fazer com que o empregador perca oportunidades, o que expressa ser a teoria da perda de uma chance uma "via de mão dupla" na estrada do Direito do Trabalho. Reforçou-se tal argumento com um exemplo bastante recorrente no cotidiano da relação de emprego: o do preposto, necessariamente empregado (TST, Súmula 377), que falta em audiência, fazendo com que o empregador perca a chance de se defender adequadamente em uma demanda trabalhista, diante do efeito da confissão ficta (CLT, art. 844).

Traçado o esboço dogmático da perda de uma chance no Direito do Trabalho, desenhou-se um panorama da jurisprudência nos Tribunais Regionais do Trabalho e no Tribunal Superior do Trabalho, com um mapeamento dos acórdãos por região, discriminando-se as Cortes que ainda não tiveram a ocasião de enfrentar o tema e, entre as que já o fizeram, como foi feito. Asseriu-se a possibilidade de a perda de uma chance ocorrer tanto na fase pré-contratual, quanto na fase contratual e na pós-contratual, apontando-se exemplos teóricos e casos efetivamente vivenciados pela jurisprudência.

Foram analisados, ainda, os acertos e desacertos na aplicação da técnica ao Direito do Trabalho, concluindo-se que o tema ainda se encontra sub-explorado no país, e que ainda 
há algumas deficiências de embasamento a serem corrigidas para que se possa haurir uma teoria bem consolidada na seara laboral. Sem embargo, apontou-se para uma tendência de crescimento nas demandas dessa estirpe, do mesmo modo como de um refinamento técnico-científico em sua aplicação, o que, esperamos, irá provocar uma fusão entre a juris-ciência e a juris-prudência, cada uma delas desempenhando o seu importante papel na construção de uma sociedade mais justa e solidária. 


\section{BIBLIOGRAFIA}

AAGAARD, Tood S. Identifying and Valuing the Injury in Lost Chance Cases. Michigan Law Review, vol. 96, p. 1335-1361, 1997-1998.

AGUIAR DIAS, José de. Da Responsabilidade Civil. 4. ed. Rio de Janeiro: Forense, 1960, v.2.

AGUIAR, Roger Silva. Responsabilidade Civil Objetiva: do risco à solidariedade. São Paulo: Atlas, 2007.

ALMEIDA, Isis de. Manual de Direito Processual do Trabalho: processo de conhecimento e processo de execução trabalhista.. 3. ed. atual. amp. de acordo com a Constituição de 1988. São Paulo: LTr: 1991, v. 2.

ALPA, Guido; BESSONE, Mario. Atipicità dell’illecito. Milão: Giuffrè, 1980, parte prima.

ALSINA, Jorge Bustamante. Teoría General de la Responsabilidad Civil. 9. ed. aum. e atual. Buenos Aires: Abeledo-Perrot, 1997.

ALVIM, Arruda; ALVIM, Thereza (Coord.) et al. Comentários ao Código Civil brasileiro: dos fatos jurídicos (arts. 104 a 232). Rio de Janeiro: Forense, 2008, v.2.

AMARAL, Francisco. Direito Civil: introdução. 6. ed. rev. atual. e aum. de acordo com o novo Código Civil. Rio de Janeiro: Renovar, 2006.

ANDREWS, Neil. O moderno processo civil: formas judiciais e alternativas de resolução de conflitos na Inglaterra. Orientação e revisão da tradução de Tereza Arruda Alvim Wambier. São Paulo: RT, 2009.

ARISTÓTELES. Ética a Nicômaco. 3. ed. Trad. e notas Edson Bini. São Paulo: Edipro, 2009.

ASSIS, Araken de. Liquidação do dano. Revista dos Tribunais, São Paulo, v. 759, ano 88, p. 11-23, jan. 1999.

ÁVILA, Humberto. Teoria dos Princípios: da definição à aplicação dos princípios jurídicos. 8. ed., ampl. e atual. São Paulo: Malheiros, 2008.

AZEVEDO, Álvaro Villaça. Teoria Geral das Obrigações e Responsabilidade Civil. 11. ed. São Paulo: Atlas, 2008.

AZEVEDO, Antonio Junqueira de. Novos Estudos e Pareceres de Direito Privado: por uma nova categoria de dano na responsabilidade civil: o dano social. 1. ed. São Paulo: Saraiva, 2010.

BAPTISTA, Silvio Neves. Teoria geral do dano: de acordo com o Novo Código Civil Brasileiro. São Paulo: Atlas, 2003. 
BARBOSA, José Serafim. Responsabilidade civil do advogado pela perda de uma chance. Disponível em: <http://portal2.unisul.br/content/navitacontent_userFiles/ File/ cursos.pdf $>$. Acesso em 4 fev. 2011.

BARROS, Alice Monteiro de. Curso de Direito do Trabalho. São Paulo: LTr, 2005.

Contatos e Regulamentações Especiais de Trabalho: peculiaridades, aspectos controvertidos e tendências. 2. ed. rev., atual. e ampl. São Paulo: LTr, 2002.

BEBBER, Júlio César. Princípios do Processo do Trabalho. São Paulo: LTr, 1997.

BELMONTE, Alexandre Agra. Instituições Civis no Direito do Trabalho: curso de Direito Civil aplicado ao Direito do Trabalho. 3. ed. Atual. de acordo com o novo Código Civil e aum. Rio de Janeiro: Renovar, 2004.

BÉNABENT, Alain. La chance et le Droit. Paris: LGDJ, 1973.

BIANCA, C. Massimo. Diritto Civile. La responsabilità. Milão: Giuffrè, 1994, v. 5.

BIONDI, Eduardo Abreu. Teoria da perda de uma chance na responsabilidade civil. Disponível em: <http://www.direitonet.com.br/artigos/exibir/3988/Teoria-da-perda-deuma-chance-na-responsabilidade-civil>. Acesso em: 9 set. 2010.

BOCCHIOLA, Maurizio. Perdita di una chance e certezza del danno. Rivista Trimestrale di Diritto e Procedura Civile, ano 30, p. 55-101, 1976.

BODIN DE MORAES, Maria Celina. Danos à pessoa humana: uma leitura CivilConstitucional dos danos morais. Rio de Janeiro: Renovar, 2007.

BORÉ, Jacques. L'indemnisation pour les chances perdues : une forme d'appreciation quantitative de la causalite d'un fait dommageable. Juris Classeur Périodique - édition générale, Paris, S. I, n. 2620, 1974. Não paginado.

BOUCINHAS FILHO, Jorge Cavalcanti Boucinhas. Aplicação da Teoria da Responsabilidade Civil por Perda de uma Chance às Relações de Trabalho. Revista Justiça do Trabalho, Porto Alegre, ano 27, n. 318, p. 25-33, jun. 2010.

BRANDÃO, Cláudio. Acidente de trabalho e responsabilidade civil do empregador. São Paulo: LTr, 2006.

BUSNELLI, Francesco Donato. Diritto e Obbligazioni. Torino: 1989, v. III.

CAIXA ECONÔMICA FEDERAL. Disponível em: <http://www1.caixa.gov.br/ loterias/loterias /megasena/probabilidades.asp>. Acesso em: 25 nov. 2010.

CALAMANDREI, Piero. Opere Giuridiche. Nápoles: Morano, 1966, v. II.

CAPPAGLI, Enrico. Perdita de una chance e risarcibilità del danno per ritardo nella procedura di assunzione: Giustizia Civile. Rivista Mensile di Giurisprudenza, Milão, v. 
I, p.1843-1846, 1984.

CAPPELLETTI, Mauro. Juízes Legisladores? Trad. Carlos Alberto Alvaro de Oliveira. Porto Alegre: Sergio Antonio Fabris Editor, 1999.

CARDONE, Marly A. A Responsabilidade Civil no Direito do Trabalho. Repertório IOB de Jurisprudência, p. 322, Set.1993.

CARNAÚBA. Daniel Amaral. La perte d'une chance. L'aléa et la technique. 2009. 177 f. (Master 2 Recherche Droit privé général. Tutrice Mme le Professeur Muriel FabreMagnan) - Université de Paris I. Panthéon-Sorbonne. Faculté de Droit. 2009.

CARNELUTTI, Francesco. Diritto e Processo. Nápoles: Morano, 1958.

CARVALHO SANTOS, J. M. Código Civil Brasileiro Interpretado. São Paulo: Livraria Freitas Bastos, 1956, v. 21.

CAVAliERI FILHO, Sérgio. Programa de Responsabilidade Civil. 8 ed. rev. e aum. São Paulo: Atlas, 2009.

CESARINO JÚNIOR. Direito Social Brasileiro. 6. ed. amp. e atual. com a colaboração de Marly A. Cardone. São Paulo: Saraiva, 1970, v. I.

CHABAS, François. La perte d'une chance en droit français. In: GUILLOD, Olivier. Développements recents du droit de la responsabilité civile. Zurique: Schultess Polygraphischer Verlag Zürich, p. 131-143.

CHARTIER, Yves. La réparation du préjudice dans la responsabilité civile. Paris: Dalloz, 1983.

CHINDEMI, Domenico. Il danno da perdita di chance. 2.ed. Milão: Giuffrè, 2010.

COB pede indenização para Vanderlei. O Estado de São Paulo. São Paulo, 29 abr. 2004. Cidades. Geral. Disponível em: <http://www.estadao.com.br/arquivo/ esportes/2004/ not20040829p59555.htm>. Acesso em 04 fev. 2011.

COELHO, Luciano Augusto de. Responsabilidade civil pré-contratual em Direito do Trabalho. São Paulo: LTr, 2008.

CONSELHO NACIONAL DE JUSTIÇA. Disponível em: 〈http://www.cnj.jus.br/images /programas/justica-em-numeros/2009/rel-justica-trabalho.pdf>. Acesso em: 22 abr. 2011.

CORDEIRO, António Menezes. Da pós-eficácia das obrigações: estudos de Direito Civil. Coimbra: Almedina, 1984.

Tratado de Direito Civil Português. Direito das obrigações. Gestão de negócios. Enriquecimento sem causa. Responsabilidade civil. Lisboa: Almeida, 2010. v. 2, tomo III.

CORTE DE CASSAÇÃO ITALIANA. Disponível em: <http://www.cortedicassazione.it/ 


\section{AreaRiservata/AreaRiservata.asp>.}

COSTA, Coqueijo. Direito Processual do Trabalho. 4 ed. rev., atual. e adaptada à Constituição de 1988 por Washington Luiz da Trindade. Rio de Janeiro: Forense, 1995.

COSTA JÚNIOR, Ademir de Oliveira. A responsabilidade "post factum finitum" no direito civil e do consumidor. Disponível em: <http://jus.uol.com.br/revista/texto/9434/aresponsabilidade-post-factum-finitum-no-direito-civil-e-do-consumidor $>$. Acesso em: 5 maio 2011.

CUBRIA, François. Los derechos patrimoniales e eventuales: estúdio de las situaciones juridicas de pendência. Oviedo: Libreria Ojanguren, 1961.

CUNHA, Maria Inês Moura Santos Alves da. A equidade e os meios alternativos de solução de conflitos. São Paulo: LTr, 2001.

DALleGRAVE neto, José Afonso. Responsabilidade Civil no Direito do Trabalho. 4. ed. São Paulo: LTr, 2010.

D'APOLlO, Luca. Perdita di chance: danno risarcibile, onus probandi e criteri di liquidazione. Disponível em: 〈http://www.altalex.com/index.php?idnot=39075 >. Acesso em: 19 jan. 2011.

DELGADO, Mauricio Godinho. Curso de Direito do Trabalho. 8. ed. São Paulo: LTr, 2009. LTr, 2010.

Princípios de Direito Individual e Coletivo do Trabalho. 3. ed. São Paulo:

DE CUPIS, Adriano. Il danno: teoria generale della responsabilità civile. 2. ed. Milão: Giuffrè, 1966, v. 2.

DIAS, Sérgio Novais. Responsabilidade civil do advogado: perda de uma chance. São Paulo: LTr, 1999.

DINIZ, Maria Helena. As lacunas no direito. 4. ed. São Paulo: Saraiva, 1997.

Código Civil Anotado. 5. ed. atual. São Paulo: Saraiva, 1999.

DORSNER-DOLIVET, Annick. Paris: Dalloz, 1984, p. 306.

DONNINI, Rogério Ferraz. Responsabilidade pós-contratual no novo Código Civil e no Código de defesa do consumidor. São Paulo: Saraiva, 2004, p. 86.

DUCLOS, José. Le régime de la responsabilité du banquier et la décharge des cautions. Juris Classeur Périodique, 1984, II, 20237.

ENGELS, Friedrich. Anti-Dühring. Parte I. Filosofia. Dialética. Capítulo XII. Quantidade e Qualidade. Disponível em: <http://www.marxists.org/portugues/marx/1877/antiduhring lindex.htm>. Acesso em: 07 mar.. 2011. 
ERPEN, Décio Antônio. O dano moral e a desagregação social. Revista dos Tribunais, São Paulo, ano 87, n. 758, seção 3, p. 44-52, dez. 1998.

FABRE-MAGNAN, Muriel. De l'obligation d'information dans les contrats - essai d'une théorie. Paris : LGDJ, 1992, n. 626, col. Bibliothèque de droit privé.

FERRARI, Irani; MARTINS, Melchíades Rodrigues. Dano moral: múltiplos aspectos nas relações de trabalho. 4. ed. São Paulo: LTr, 2011.

FERREIRA, Aurélio Buarque de Holanda. Novo Dicionário Eletrônico Versão 5.0. Correspondente à 3 ed. $1^{\text {a }}$. impressão da Editora Positivo, rev. e atual. do Aurélio Século XXI, O Dicionário da Língua Portuguesa, 2004. 1 CD-ROM.

FESTIVAIS de honra a Zeus viram espetáculo moderno. UOL. Disponível em: < http://olimpiadas.uol.com.br/2008/historia/grecia/historia.jhtm>. Acesso em: 4 fev. 2011.

FIORELLI, José Osmir; FIORELLI, Maria Rosa; JUNIOR, Marcos Julio Olivé Malhadas. Psicologia Aplicada ao Direito. São Paulo: LTr, 2006.

FITTIPALDI, Conceição. Chances. Disponível em < $\underline{\text { http://poemasencantos.blogspot.com/ }}$ 2007/07/chances.html>. Acesso em: 8 set. 2010.

FLÓREZ-VALDÉZ, Joaquim Arce y. Los princípios generales del derecho y su formulación constitucional. Madri: Civitas, 1990.

FONSECA, Cristina Maria N. da. Responsabilidade pela perda de uma chance compatibilidade com o sistema jurídico brasileiro e aplicabilidade nas relações de trabalho. Revista LTr, São Paulo, v. 73, n. 10, p. 1272-1280, out. 2009.

FRANCO, Rendrik F. Fisiologia da coagulação, anticoagulação e fibrinólise. Revista da Faculdade de Medicina de Ribeirão Preto e do Hospital das Clínicas da FMRP. Universidade de São Paulo. Ribeirão Preto, v. 34, n. 3/4, p. 229-237, jul./dez. 2001, p. 235. Disponível em: <http://www.fmrp.usp.br/revista/2001/vol34n3e4/ fisiologia_coagulacao.pdf $>$. Acesso em: 28 mar. 2011.

FREUND, John E. Estatística Aplicada: economia, administração e contabilidade. 11. ed. Porto Alegre: Bookman, 2004.

GARCEZ NETO, Martinho. Responsabilidade civil no Direito Comparado. Rio de Janeiro: Renovar, 2000.

GARCÍA MÁRQUEZ, Gabriel. Crônica de uma morte anunciada. Rio de Janeiro: Record, 1981.

GÊNESIS, 1, 16/17. In: Bíblia Sagrada: nova versão internacional. Trad. Sociedade Bíblica Internacional. São Paulo: Vida, 2000.

GESTINGTORPHE, Lord Walker of. Loss of a Chance and Chance of Loss. The Incorporated Council of Law Reporting for England \& Wales, Londres, 2009, p. 1-16. 
GHERSI, Carlos Alberto. Teoría general de la reparación de danos. Buenos Aires: Astrea, 1997.

GIGLIO, Wagner D. Direito Processual do Trabalho. 9. ed. rev. amp. e adaptada à Constituição Federal de 1988. São Paulo: LTr, 1995.

GODOY, Claudio Luiz Bueno de. Responsabilidade civil pelo risco da atividade. São Paulo: Saraiva, 2009, coleção prof. Agostinho Alvim.

GÓIS, Luiz Marcelo Figueira de. A eficácia do contrato de trabalho à luz do novo Código Civil. Revista Síntese Trabalhista, São Paulo, n. 168, jun. 2003.

GOMES, Orlando. Raízes históricas e sociológicas do Código Civil brasileiro. São Paulo: Martins Fontes, 2006.

; GOTTSCHALK, Élson. Curso de Direito do Trabalho. 14. ed. rev. e atual. Rio de Janeiro: Forense, 1997.

GOMES, Luan Gerard. Cara erra na ultima pergunta do Show do Milhão fev/2002. Youtube, 7 de julho de 2009. Disponível em: http://www.youtube.com/watch? v=90Um0iqe9zE. Acesso em 2 maio 2011.

GONÇALVES, Carlos Roberto. Responsabilidade civil. 8. ed., revista de acordo com o novo Código Civil (Lei n. 10.406, de 10-1-2001). São Paulo: Saraiva, 2003.

GONDIM, Glenda Gonçalves. Responsabilidade civil: teoria da perda de uma chance. Revista dos Tribunais, São Paulo, v. 94, n. 840, p. 11-36, out. 2005.

GONDIM, Glenda Gonçalves. A reparação civil na teoria da perda de uma chance. 2010. 170f. Dissertação (Mestrado em Direito) - Universidade Federal do Paraná - UFPR, Curitiba, 2010.

GRANT, Alisson. Quantifying lost chances: A look at examples of loss of chance cases arising out of solicitors' negligence and the courts' approach to evaluating the loss. Disponível em: 〈http://www.journalonline.co.uk/Magazine/44-12/1001053.aspx >. Acesso em 28 jan. 2010.

GRAZIANO, Kadner. Loss of a chance in European Private Law - "all or nothing" or parcial liability in cases of uncertain causation. European review of private Law, Londres, v. 16, n. 6, 2008.

GREGOGNA, Joel P. Chambre de Requêtes. Disponível em : <http://www.universalis.fr/ encyclopedie/chambre-des-requetes/>. Acesso em: 15 mar. 2011.

GUALANO, Tommaso. Perdita di chance. In: VETOORI, Giuseppe (Org.). Il danno risarcible. Milão: Cedam, 2004, v. 1.

GUIMARÃES, Janaína Rosa. Perda de uma chance: considerações acerca de uma teoria. Disponível em: http://jusvi.com/artigos/41209. Acesso em: 27 mar. 2011. 
GUSTIN, Miracy Barbosa de Sousa; DIAS, Maria Tereza Fonseca. (Re) Pensando a pesquisa jurídica. 2. ed. rev., amp. e atual. pela NBR 14724, de 30/12/05, da ABNT. Belo Horizonte: Del Rey, 2006.

HEGEL, Georg Wilhelm Friedrich. Enciclopédia das Ciências Filosóficas em compêndio (1830). Texto completo com os adendos orais. Tradução Paulo Meneses, com a colaboração de José Machado. São Paulo: Loyola, 1995, vol. I.

HIGA, Flávio da Costa. Abuso do Direito na Relação de Emprego: uma visão teóricosistêmica. Revista Científica Virtual da ESA/OAB-SP. Direito e Processo do Trabalho, São Paulo, ano 2, n. 4, Out.2010. Disponível em: http://www2.oabsp.org.br/asp/esa/ comunicacao/revista/revista04/fluidbook/index2.html. Acesso em 26 nov. 2010.

HISTÓRIA da maratona. UOL Disponível em: <http://liverun.blogtv.uol.com.br/ 2007/09/05/ historia-da-maratona>. Acesso em: 4 fev. 2011.

HUME, David. Tratado da natureza humana: uma tentativa de introduzir o método experimental de raciocínio nos assuntos morais. Trad. Deborah Danowski. São Paulo: UNESP, Imprensa Oficial do Estado, 2001.

IHERING, Rudolf Von. A luta pelo direito. Trad. João Vasconcellos. 15. ed. Rio de Janeiro: Forense, 1995.

INSTITUTO BRASILEIRO DE GEOGRAFIA E ESTATÍSTICA. Tábuas completas de mortalidade - 2009. Disponível em: http://www.ibge.gov.br/home/estatistica/ populacao/tabuadevida/2009/default.shtm. Acesso em: 16 mar. 2011.

INTRUSO burla megaesquema e arruína maratona de brasileiro. Folha de São Paulo. São Paulo, 30 ago. 2004. Esportes. Disponível em: <http://www1.folha.uol.com.br/ fsp/esporte/fk3008200414.htm>. Acesso em: 04 fev. 2011.

JARIEL, Ludovic. Fusion de la profession d'avocat et d'avoué. Entrevista concedida em 21 févr. 2011. Disponível em: <http://www.textes.justice.gouv.fr/zoom-11470/fusion-dela-profession-davocat-et-davoue-21827.html >. Acesso em: 13 abr. 2011.

JOURDAIN, Patrice. Les principles de la responsabilité civile. 7 ed. Paris: Dalloz, 2007.

JOURDAIN, Patrice. Sur la perte d'une chance. Paris: R.T.D.C., 1992.

JORNADA DE DIREITO CIVIL DO CENTRO DE ESTUDOS JUDICIÁRIOS DO CONSELHO DA JUSTIÇA FEDERAL, 1, 2002, Brasília, Enunciados Disponível em: <http://www.cjf.jus.br/revista/enunciados/enunciados.htm>. Acesso em: 15 out. 2010.

JORNADA DE DIREITO CIVIL DO CENTRO DE ESTUDOS JUDICIÁRIOS DO CONSELHO DA JUSTIÇA FEDERAL, 4, 2006, Brasília, Enunciados. Disponível em: 〈http://daleth.cjf.jus.br/revista/enunciados/IVJornada.pdf〉. Acesso em: 26 jan. 2011.

JORNADA DE DIREITO MATERIAL E PROCESSUAL NA JUSTIÇA DO TRABALHO, 1, 2007, Brasília, Enunciados. Disponível em: < 
http://www.anamatra.org.br/jornada/enunciados/enunciados_aprovados.cfm $>$. Acesso em: 14 out. 2010.

JOSSERAND, Louis. De l'esprit des droits et de leur relativité: theorie dite de l'abus des droits. 10. ed. Paris: Librairie Dalloz, 1939.

Evolução da responsabilidade civil. Revista Forense, v. 86, n. 454, 1941.

KANT, Immanuel. Introdução ao Estudo do Direito: doutrina do Direito. 2. ed. Trad., textos adicionais e notas: Edson Bini. Bauru: Edipro, 2007.

KEYNES, John Maynard. A Treatise on Probability. Londres: MacMillan and Co., 1921.

KING JR. Joseph H. Causation, Valuation, and Chance in personal injury torts involving Preexisting Conditions and Future Consequences. Yale Law Journal, v. 90, p. 1353-1397, 1981.

. "Reduction of likelihood" reformulation and other retrofitting of the loss-of-a-

chance doctrine. Memphis Law Review, winter, 1998. Disponível em: http://findarticles.com/p/articles/ mi_qa3843/is_199801/ai_n8788962/. Acesso em: 14 abr. 2011.

KOCH, Steven R. Whose Loss Is It Anyway? Effects os the "Lost-Chance" Doctrine on Civil Litigation and Medical Malpractice Insurance. North Carolina Law Review, v. 88, p. 595-638, 2010.

KOEHLER, Jonathan; BRINT, Arienne P. Psychological aspects of the loss of chance doctrine. In: Conference on Psychology and Economics Centre for Economic Policy Research (CEPR) \& European Center for Advanced Research in Economics and Statistics (ECARES), 2, 2001, Bélgica. Disponível em: <http://www.cepr.org/meets/ wkcn/3/3509/papers/Koehler.pdf>. Acesso em: 31 ago. 2010.

KFOURI NETO, Miguel. Responsabilidade Civil do Médico. São Paulo: RT, 2007.

KOOGAN, Abrahão et HOUAISS, Antônio. Enciclopédia e Dicionário Ilustrado. Rio de Janeiro: Edições Delta, 1997.

LA FONTAINE, Jean. La Laitière et le Pot au lait. Disponível em: http://poesie.webnet.fr/lesgrandsclassiques/poemes/jean_de_la_fontaine/la_laitiere_et_le_p ot_au_lait.html. Acesso em: 15 mar. 2011.

LALOU, Henri. La responsabilité civile: príncipes élémentaires et applications pratiques. 10. ed. Paris: Librairie Dalloz, 1932.

LAMARCA, Antônio. Processo do Trabalho Comentado: (artigos 643 a 910 da CLT). São Paulo: RT, 1982.

LE TOURNEAU, Philippe. La responsabilité civile. Paris: PUF, 2003.

LEVMORE, Saul. Probabilistic recoveries, restitution, recurring wrongs. In: LEVMORE, 
Saul. Foundations of Tort Law. Nova York: Oxford University, 1994.

LIMONGI FRANÇA, Rubens. Formas e Aplicação do Direito Positivo. São Paulo: RT, 1969.

LOPES, Lissandra de Ávila. A responsabilidade pós-contratual no Direito Civil. Revista Eletrônica do Curso de Direito da UFSM, v. I, n. 3, Nov. 1996, p. 47. Disponível em: <http://www.ufsm.br/revistadireito/eds/v1n3/a4.pdf>. Acesso em: 06 de maio de 2011.

LOPEZ, Teresa Ancona. Princípio da Precaução e Evolução da Responsabilidade Civil. São Paulo: Quartier Latin, 2010.

LUZ, Ana Maria. Condições Normais de Temperatura e Pressão (CNTP). Disponível em: $\quad\langle$ http://www.infoescola.com/termodinamica/condicoes-normais-de-temperatura-epressao-cntp >. Acesso em: 2 maio 2011.

MACHADO JUNIOR, César Pereira da Silva. O ônus da prova no processo do trabalho. 3. ed. re. e atual. São Paulo: LTr, 2001.

MAGANO, Octávio Bueno. Manual de Direito do Trabalho: parte geral. São Paulo: LTr.

MALLET, Estêvão. Antecipação da tutela no processo do trabalho. 2. ed. rev. e amp. São Paulo, LTr, 1999.

Ensaio sobre A Interpretação das Decisões Judiciais. São Paulo: LTr, 2009.

MANGIATORDI, Maria. La perdita di chance non è una mera aspettativa. Rivista giuridica telemática, $\quad$ n. 2 , p. 113-127, 200. Disponível em: http://www.dirittodeilavori.it/n2-07/perdita-chance.pdf. Acesso em: 08 abr. 2011.

MARTINS-COSTA, Judith Hofmeister. Apresentação. In: SILVA, Rafael Peteffi da. Responsabilidade Civil pela Perda de uma Chance. 2 ed. São Paulo: 2009, Editora Atlas.

2.

. Comentários ao Novo Código Civil. Rio de Janeiro: Forense, 2003, v. 5, tomo

MARX, Karl. O capital. Volume 1. Capítulo VII. Disponível em: http://www.marxists.org/portugues/marx/1867/ocapital-v1/vol1cap07.htm\#c7s2. Acesso em: 07 mar. 2011.

MAZEAUD, Henri et Leon; TUNC, André. Traité Théorique et Pratique de la Responsabilité Civile. Délictuelle et Contractuelle. 5.ed. Paris: Éditions Montchrestien, 1958, tome.1.

MELO, Raimundo Simão de. Indenização pela perda de uma chance. Disponível em: http://www.boletimjuridico.com.br/doutrina/texto.asp?id=1785. Acesso em: 28 out. 2010.

MÉNARD, René. Mitologia Greco-romana. 2. ed. Trad. Aldo Della Nina. São Paulo: Opus, 1991, V. 3. 
MESSINEO, Francesco. Manuale di Diritto Civile e Commerciale. $7^{a}$. ed. Milão: Giuffrè, 1947, v. 1.

MICHAELIS. Moderno Dicionário da Língua Portuguesa. São Paulo: Editora Melhoramentos Ltda., 1998-2007. Disponível em: http://michaelis.uol.com.br/ moderno/portugues/index.php?lingua=portugues-portugues\&palavra=chance. Acesso em: 14 fev. 2011.

MONTENEGRO, Lindbergh C. Ressarcimento de danos. 5 ed. Rio de Janeiro: Lumen Juris, 1998.

MOORE, Bryson B. South Carolina rejects the lost chance doctrine. South Carolina Law Review, South Carolina, Fall, 1996.

MORAES, Alexandre de. Direito Constitucional. 17. ed. Atual. com a Reforma do Judiciário (EC nº. 45/04). São Paulo: Atlas, 2005.

MORAES FILHO, Evaristo de; MORAES, Antonio Carlos Flores de. Introdução ao Direito do Trabalho. 7. ed. rev. e atual. São Paulo: LTr, 1995.

MORAES, Renato Duarte Franco de. A moldura jurídica da "perda de chance". Valor Econômico, São Paulo, 12 jan. 2011. Legislação \& tributos, Caderno E.

MORAIS, Leonardo Bianchini. O fator acidentário previdenciário (FAP) e o nexo técnico epidemiológico (NTE). Disponível em: http://jus.uol.com.br/revista/texto/ 10065/o-fator-acidentario-previdenciario-fap-e-o-nexo-tecnicoepidemiologico-nte. Acesso em: 29 abr. 2011.

MOTA, Maurício Jorge. A pós-eficácia das obrigações. TEPEDINO, Gustavo (Coord.). Problemas de direito civil-constitucional. Rio de Janeiro: Renovar, 2000.

MOTA, Sílvia. Responsabilidade civil decorrente das manipulações genéticas: novo paradigma jurídico ao fulgor do biodireito. 2005. Tese (Doutorado). Universidade Gama Filho, Rio de Janeiro, 2005.

NADER, Paulo. Curso de Direito Civil. Parte Geral. Rio de Janeiro: Forense, 2003, v. 1.

NASCIMENTO, Amauri Mascaro. Curso de Direito do Trabalho. 15. ed., rev. e atual. São Paulo: Saraiva, 1998.

Iniciação ao Direito do Trabalho. 25. ed. rev. e atual. São Paulo: LTr, 1999.

NERY JUNIOR, Nelson; NERY, Rosa Maria de Andrade. Código de Processo Civil Comentado e legislação extravagante. 9. ed. rev., atual. e ampl. São Paulo: RT, 2006.

NIETZSCHE, Friedrich. O nascimento da tragédia ou Helenismo e Pessimismo. Trad., notas e posfácio de J. Guinsburg. São Paulo: Companhia das Letras, 1992.

NORONHA, Fernando. Direito das Obrigações: fundamentos do direito das obrigações: 
introdução à responsabilidade civil. 2a . ed., rev. e atual. São Paulo: Saraiva, 2007, v. 1.

Responsabilidade por perda de chances. Revista de Direito Privado, São Paulo, v. 6, n. 23, p. 29-46, jul./set. 2005.

OLIVEIRA, Francisco Antonio de. Comentários aos Enunciados do TST. 4. ed., rev. e atual. São Paulo: RT, 1997.

OLIVEIRA, Sebastião Geraldo. Indenizações por acidente do trabalho ou doença ocupacional. 4. ed. São Paulo: LTr, 2008.

PACCHIONI, Giovani. Delitti e quasi delitti, in Diritto civile italiano. Padova: Cedam, 1940, v. IV.

PEDROTTI, Irineu Antonio. Doenças profissionais ou do trabalho. 2. ed. São Paulo: Universitária de Direito, 1998.

PENNEAU, Jean. La responsabilité du medecin. Paris: Dalloz, 1992.

PERLINGIERI, Pietro. Perfis do Direito Civil: introdução ao Direito Civil Constitucional. 3. ed. Rio de Janeiro: Renovar, 2002.

PLANIOL, Marcel; RIPERT, Georges; ESMEIN, Paul. Traité pratique de droit civil français, partie 1, Obligations, 2. ed. Paris: LGDJ, 1952, tome VI.

PLÁ-RODRIGUES, Américo. Princípios de Direito do Trabalho. 3. ed. atual. São Paulo: LTr, 2002.

PLATÃO. Apologia de Sócrates: primeira parte: sócrates apresenta a sua defesa. Trad. Maria Lacerda de Souza. Cultvox. Disponível em: <http://www.dominiopublico.gov.br/ download/texto/cv000065.pdf>. Acesso em: 18 abr. 2011.

POINCARÉ, Henri Jules. Calcul des Probabilités. 2. ed. Paris: Gauthier-Villars, 1987.

PONTES DE MIRANDA. Fontes e Evolução do Direito Civil Brasileiro. 2. ed. Rio de Janeiro: Forense, 1981.

n. 3 .

Tratado de direito privado. Rio de Janeiro: Borsoi, 1955-1972, v. 22, § 2.722,

PONTIFÍCIA UNIVERSIDADE CATÓLICA DO RIO GRANDE DO SUL. Frases. Disponível em: < http://www.pucrs.br/famat/statweb/outros/frases.htm>. Acesso em: 16 mar. 2011.

RAMALHO, Maria do Rosário Palma. Direito do Trabalho: parte I - dogmática Geral. 2. ed. Actualizada ao Código do Trabalho de 2009. v. I, Coimbra: Almedina, 2009.

RÁO, Vicente. O direito e a vida dos direitos. 4. ed. anot. e atual. por Ovídio Rocha Barros Sandoval. Noções Gerais. Direito Positivo. Direito Objetivo. São Paulo: RT, 1997, v. I. 
REALE, Miguel. O projeto do novo Código Civil. 2. ed. reform. e atual. São Paulo: Saraiva, 1999.

REECE, Helen. Losses of chance in the Law. The modern Law review, Oxford, v. 59, n. 2, p. 188-206, mar. 1996.

REPRESAS, Félix Alberto Trigo. Pérdida de chance. Buenos Aires: Astrea, 2008.

RETOMADA cobra caro ao corpo. Folha de São Paulo. São Paulo, 30 ago. 2004. Esportes. Disponível em: 〈http://www1.folha.uol.com.br/fsp/esporte/fk3008200419.htm〉. Acesso em: 04 fev. 2011.

RIZZARDO, Arnaldo. Parte Geral do Código Civil. 5. ed. rev. e atual.. Rio de Janeiro: Forense, 2007.

ROCHA, Vivian de Almeida Sieben. A responsabilidade civil pela perda de uma chance no direito brasileiro. Disponível em: http://www3.pucrs.br/pucrs/files . Acesso em 04 fev. 2011.

RODRIGUES, Silvio. Direito Civil: responsabilidade civil. São Paulo: Saraiva, 2002, v. 4.

ROSA, Antonio de. Il danno da perdita di chance. Disponível em: http://studiogiuridico.it/tesi/chancebreve.htm. Acesso em: 08 abr. 2011.

ROSÁRIO, Grácia Cristina Moreira do. A perda da chance de cura na responsabilidade civil médica. Rio de Janeiro: Lumen Júris, 2009.

RUELLAN, Caroline. La perte de chance en droit privé. Droit prospectif. Paris: RRJ, 1999, v.3.

RUPRECHT, Alfredo J. Os princípios do Direito do Trabalho. Trad. de Edilson Alkmin Cunha. São Paulo: LTr, 1995.

RUSSOMAnO, Mozart Victor. Curso de Direito do Trabalho. 9. ed. rev. e atual. Curitiba: Juruá, 2003.

SAAD, Eduardo Gabriel. CLT Comentada. 34. ed. São Paulo: LTr, 2001.

SANSEVERINO, Paulo de Tarso Vieira. Princípio da Reparação Integral: indenização no Código Civil. São Paulo: Saraiva, 2010.

SARTRE, Jean-Paul. O existencialismo é um humanismo: a imaginação - questão de método. Seleção de textos de José Américo Motta Pessanha. Trad. Rita Correia Gudes e Luiz Roberto Salinas Forte. 3. ed. São Paulo: Nova Cultura, 1987.

SAVATIER, René. Une faute peut-elle engendrer la responsabilité d'un dommage sans l'avoir causé? Paris : Recueil Dalloz, 1970, chron. XVII.

SAVI, Sérgio. Responsabilidade Civil Por Perda De Uma Chance. São Paulo: Atlas, 
2009.

SCHONBLUM, Paulo Maximilian Wilhelm. A teoria da perda da chance como solução para o 'se' indenizável. Revista da EMERJ, Rio de Janeiro, v. 12, n. 48, p. 87-101, out./dez. 2009.

SCHOPENHAUER, Arthur. A arte de ter razão: exposta em 38 estratagemas. Trad. Alexandre Krug e Eduardo Brandão. São Paulo: Martins Fontes, 2001.

SEIDENFUZ, Ilvo. Anisometropia: neutralização dos efeitos com lentes de óculos. Disponível em: http://www.croosp.org.br/TCC_Ilvo.pdf. Acesso em: 6 abr. 2011.

SERPA LOPES, Miguel Maria de. Curso de Direito Civil: introdução, parte geral e teoria dos negócios jurídicos. 7. ed. rev. e atual. por José Serpa Santa Maria. Rio de Janeiro: Freitas Bastos, 1989, v.1.

SILVA, Hebe Mara Sá. Dano moral na fase pré-contratual das relações individuais trabalhistas. Disponível em: <http://www.conpedi.org.br/manaus/arquivos/anais /salvador/hebe_mara_sa_silva.pdf $>$. Acesso em: 26 abr. 2011.

SILVA, Homero Mateus Batista da. Curso de Direito do Trabalho Aplicado: parte geral. Rio de Janeiro: Elsevier, 2009, v. 1.

SILVA, Rafael Peteffi da. Responsabilidade Civil Pela Perda de Uma Chance. 2. ed. São Paulo: Editora Atlas, 2009.

SILVA, Regina Beatriz Tavares. A perda de uma chance. 2 set. 2004. Disponível em: <http://www.flaviotartuce.adv.br/secoes/artigosc/Regina_perda.doc $>$. Acesso em: 26 set. 2009.

SILVA, Roberto de Abreu e. A teoria da perda de uma chance em sede de responsabilidade civil. Revista da EMERJ, Rio de Janeiro, v. 9, n. 36, p. 24-49, out./dez. 2006

SILVA, Wilson Melo da. O dano moral e sua reparação. 3. ed. rev. e. ampl. Rio de Janeiro: Forense, 1983.

SLUMDOG Millionaire. Direção Danny Boyle e Loveleen Tandan. Produção Christian Colson. Roteiro Simon Beaufoy. Estados Unidos: Fox Searchlight, 2008. 1 vídeo-disco (120min).

SISTEMA BRASILEIRO DE TELEVISÃO. Direção Jorge Zeraldi. Edição Paulo Vander. Local, 2000, 1 vídeo-disco.

SÓFOCLES. Édipo Rei. Trad. Domingos Paschoal Cegalla 3. ed. Rio de Janeiro: DIFEL, 2005.

SOUZA, Carlos Aurélio Mota de. Evolução do Conceito de Eqüidade e sua Influência na Jurisprudência. Tese (Doutorado em História do Direito) - Faculdade de Direito da Universidade de São Paulo, São Paulo, 1989. 
STEFANO diz que ganharia maratona de Atenas mesmo sem padre. O Estado de São Paulo. São Paulo, 02 jan. 2008. Esportes. Disponível em: <http://www.estadao.com.br/ noticias/esportes,stefano-diz-que-ganharia-maratona-de-atenas-mesmo-sem padre, 103428,0.htm>. Acesso em: 04 fev. 2011.

STOCO, Rui. Responsabilidade civil do advogado à luz das recentes alterações legislativas. In: LEITE, Eduardo de Oliveira (Coord.). Grandes temas da atualidade: responsabilidade civil. Rio de Janeiro: Forense, 2006, v. 6.

STOCO, Rui. Tratado de Responsabilidade Civil. 7. ed. São Paulo: RT, 2007.

SÜSSEKIND, Arnaldo; MARANHÃO, Délio; VIANNA, Segadas. Participação de João de Lima Teixeira Filho. Instituições de Direito do Trabalho. 13. ed. São Paulo: LTr, 1993, v. I.

TEPEDINO, Gustavo. O tão esperado (e fugaz?) encontro da doutrina com a jurisprudência. Revista trimestral de direito civil, Rio de Janeiro: Padma, v. 3, 2000.

THEODORO JÚNIOR, Humberto. Curso de Direito Processual Civil. 37. ed. Rio de Janeiro: Forense, 2001, v. I.

TOLSADA, Mariano Yzquierdo. Sistema de Responsabilidad Civil, Contractual y Extracontractual. Madri: Dykinson, 2001.

TRIBUNAL DE JUSTIÇA DO RIO GRANDE DO SUL. Notícias de 7 de abril de 2004. Consentimento formado é ponto central da responsabilidade civil médica. Disponível em: http://www1.tjrs.jus.br/site/imprensa/noticias/\#../../system/modules/com.br.workroom. tjrs/elements/noticias_\%20controller.jsp?acao=ler\&idNoticia=22609. Acesso em: 6 abr. 2011.

UNIVERSIDADE DE ROMA. Disponível em: <http://www.giur.uniroma3.it/materiale/ docenti/zeno/materiale/3.26.pdf>.

VACARIE, Isabelle. La perte d'une chance. Revue de la recherche juridique. Droit Prospective, Paris, vol. 3, p. 904-932, 1987.

VANDERLEI está no céu: Maratonista brasileiro que protagonizou episódio mais marcante da Olimpíada vira estrela planetária. Istoé Brasil. São Paulo, 8 set. 2004. Jogos Olímpicos Atenas 2004. Disponível em: < http://www.istoe.com.br/reportagens/ 10645_VANDERLEI+ESTA+NO+CEU>. Acesso em: 4 fev. 2011.

VANDERLEI não venceria, diz rival de 2004. Folha de São Paulo, São Paulo. 03 jan. 2008. Esportes. Disponível em: <http://www1.folha.uol.com.br/fsp/esporte/ fk0301200810.htm>. Acesso em: 04 fev. 2011.

VANDERLEI sai de Atenas como herói. O Estado de São Paulo. São Paulo, 29 abr. 2004. Cidades. Geral. Disponível em: <http://www.estadao.com.br/arquivo/esportes/2004/ not20040829p59554.htm>. Acesso em 04 fev. 2011.

VANDERLEI vira astro e ofusca colegas. O Estado de São Paulo. São Paulo, 29 abr. 
2004. Cidades. Geral. Disponível em: <http://www.estadao.com.br/arquivo/esportes/ 2004/not20040829p59556.htm>. Acesso em 04 fev. 2011.

VENOSA, Sílvio de Salvo. Compromisso de compra e venda com Eficácia Real: direito do promitente comprador. Disponível em: <http://www.professorsimao.com.br/artigos _convidados_venosa.htm>. Acesso em: 27 abr. 2011.

VINEY, Gineviève. Traité de Droit Civil. Sous la direction de Jacques Ghestin. Les obligations. La responsabilité: conditions. Paris : LGDJ, 1982.

; JOURDAIN, Patrice. Traité de Droit Civil. Sous la direction de Jacques Ghestin. Les conditions de la responsabilité. 2. ed. Paris : L.G.D.J, 2001.

; _ Traité de Droit Civil. Sous la direction de Jacques Ghestin. Les conditions de la responsabilité. 3. ed. Paris : L.G.D.J, 2006.

De la responsabilite civile. In: AVANT-PROJET DE REFORME DU DROIT DES OBLIGACIONES (ARTICLES 1101 À 1386 DU CODE CIVIL) ET DU DROIT DE LA PRESCRIPTION (ARTICLES 2234 A 2281 DU CODE CIVIL). Relatório encaminhado ao Ministro da Justiça em 22 set. 2005. Disponível em: < http://www.lexisnexis.fr/pdf/DO/RAPPORTCATALA.pdf>. Acesso em 14 mar. 2010.

VLEX. Toda a informação jurídica: um único sistema de pesquisa. Disponível em: http://vlex.com/. Acesso em: $1^{\circ}$ dez. 2010.

WEIGAND, Tory A. Loss of chance in medical malpractice: a look at recent developments: the growing acceptance of this doctrine raises difficult public policy issues, as well as concerns for the limits of medical professional liability. Disponível em: <http://goliath.ecnext.com/coms2/gi_0199-3026884/Loss-of-chance-in-medical.html>.

Acesso em: 16 mar. 2011.

WEIGAND, Tory A. Loss of Chance in Medical Malpractice: the need for caution. Massachusetts Law Review, v. 87, n. 1. 2002. Disponível em: <http://www.massbar.org/ publications/massachusetts-law-review/2002/v87-n1/loss-of-chance-in-medical >. Acesso em: 13 mar. 2011.

WEIR, Tony. Loss of a chance - Compensable in tort? The common law. In: GUILLOD, Olivier. Développements recents du droit de la responsabilité civile. Zurique: Schultess Polygraphischer Verlag Zürich.

ZANNONI, Eduardo A. EI daño en la responsabilidad civil. 3. ed. Buenos Aires: Ástrea, 2005 .

ZENO-ZENCOVICH, Vincenzo. Il danno per la perdita della possibilità di una utilità futura. Rivista di Diritto Commune, II, p. 213-219, 1986. 


\section{LEGISLAÇÃO}

ALEMANHA. Código Civil (1896). Código Civil: Disponível em: <http://archiv.jura.unisaarland.de/BIJUS/grundgesetz/>. Acesso em: 13 abr. 2011.

ALEMANHA. Código Civil (1896). Código Civil. Disponível em: <http://www.gesetzeim-internet.de/bundesrecht/bgb/gesamt.pdf>. Acesso em: 21 jan. 2011.

ARGENTINA. Código Civil (1869). Código Civil. Disponível em: <http://www.infoleg.gov.ar/infolegInternet/anexos/105000-109999/109481/texact.htm>.

Acesso em: 23 dez. 2010.

BRASIL. Constituição (1988). Constituição da República Federativa do Brasil. 16. ed. São Paulo: RT, 2011.

BRASIL. Emenda constitucional $\mathbf{n}^{\mathbf{0}}$ 45, de 30 de dezembro de 2004. Altera dispositivos da Constituição Federal e acrescenta os arts. 103-A, 103-B, 111-A, 130-A e dá outras providências. Disponível em: < http://www.planalto.gov.br/ccivil_03/ constituicao/emendas/emc/emc45.htm>. Acesso em 13 abr. 2011.

BRASIL. Código Civil (2002). Código Civil e Constituição Federal. 62. ed. São Paulo: Saraiva, 2011.

BRASIL. Código de Processo Civil (1973). Código de Processo Civil e Constituição Federal. 17. ed. São Paulo: Saraiva, 2011.

BRASIL. Consolidação das Leis do Trabalho (1943). CLT e Constituição Federal. 38. ed. São Paulo: Saraiva, 2011.

BRASIL. Código Civil (1916). Código Civil. Disponível em: <https://www.planalto.gov.br/ccivil_03/leis/13071.htm>. Acesso em: 21 jan. 2011.

BRASIL. Código Penal (1940). Código Penal. Disponível em: < http://www.planalto.gov.br/ccivil/decreto-lei/Del2848.htm>. Acesso em: 27 abr. 2011.

BRASIL. Código de Processo Civil (1939). Código de Processo Civil. Disponível em: <http://www.planalto.gov.br/ccivil/Decreto-Lei/1937-1946/Del1608.htm>. Acesso em: 10 mar. 2011.

BRASIL. Lei $\mathbf{n}^{\mathbf{0}}$ 12.376, de 30 de setembro de 2010. Altera a ementa do Decreto-lei $\mathrm{n}^{\mathbf{o}}$ 4.657, de 4 de setembro de 1942. Disponível em: < http://www.planalto.gov.br/ccivil/_Ato2007-2010/2010/Lei/L12376.htm>. Acesso em: 10 mar. 2011.

BRASIL. Lei no 9.099, de 26 de setembro de 1995. Dispõe sobre Juizados Especiais Cíveis e Criminais e dá outras providências. Disponível em: < http://www.planalto.gov.br/ccivil/leis/L9099.htm>. Acesso em: 13 abr. 2011. 
BRASIL. Lei $\mathbf{n}^{\mathbf{0}}$ 8.213, de 24 de julho de 1991. Dispõe sobre os Planos de Benefícios da Previdência Social e dá outras providências. Disponível em: <http://www.planalto.gov.br/ccivil/leis/L8213cons.htm>. Acesso em: 29 abr. 2011.

BRASIL. Lei $\mathbf{n}^{\circ} \mathbf{8 . 0 7 8}$, de 11 de setembro de 1990. Dispõe sobre a proteção do consumidor e dá outras providências Disponível em: <http://www.planalto.gov.br/ccivil_03/Leis/L8078.htm>. Acesso em: 24 abr. 2011.

BRASIL. Lei $\mathbf{n}^{\mathbf{0}}$ 5.589, de 8 de junho de 1973. Estatui normas reguladoras do trabalho rural. Disponível em: < http://www.planalto.gov.br/ccivil_03/Leis/L5889.htm>. Acesso em: 7 maio 2011.

BRASIL. Decreto-lei no 4.657, de 4 de setembro de 1942. Lei de introdução às normas do Direito Brasileiro. Disponível em: <http://www.planalto.gov.br/ccivil/DecretoLei/Del4657.htm>. Acesso em: 8 abr. 2011.

BRASIL. Projeto de lei $\mathbf{n}^{\mathbf{6}} \mathbf{6 . 9 6 0}$, de 12 de junho de 2002. Disponível em: <http://www.camara.gov.br/sileg/Prop_Detalhe.asp?id=56549>. Acesso em: 06 maio 2011.

CONVENÇÃO EUROPÉIA DE DIREITOS DO HOMEM. Disponível em: <http://www.gddc.pt/direitos-humanos/textos-internacionais-dh/tidhregionais/convtratados-04-11-950-ets-5.html>. Acesso em: 08 abr. 2011.

DECLARAÇÃO DOS DIREITOS UNIVERSAIS DO HOMEM. Disponível em: <http://www.onu-brasil.org.br/documentos_direitoshumanos.php>. Acesso em: 03 abr. 2011.

ESPANHA. Código Civil (1889). Código Civil. Disponível em: <http://www.ucm.es/info/civil/jgstorch/leyes/ccivil.htm>. Acesso em: 28 fev. 2011.

ESPANHA. Real decreto legislativo 1, de 24 de março de 1995. Estatuto dos Trabalhadores. Disponível em: estatutodelostrabajadoresactualizado.pdf>. Acesso em: 05 maio 2011.

FRANÇA. Código Civil (1804). Código Civil. Disponível em: http://www.legifrance.gouv.fr. Acesso em: 28 fev. 2011.

ITÁLIA. Código Civil (1942). Código Civil. Disponível em: http://www.altalex.com/ index.php?idnot=36451. Acesso em: 28 fev.2011.

ITÁliA. Código Civil (1942). Código Civil. Disponível em: $<$ http://www.ligiera.com.br/codigos/cc_italiano_(em_italiano).pdf. $>$ Acesso em: 15 mar. 2011.

ITÁlIA. Código Civil (1942). Código Civil. Disponível em: <http://www.jus.unitn.it/cardozo/obiter_dictum/codciv/Codciv.htm>. Acesso em 3 fev. 2011.

ITÁLIA. Decreto presidencial no 322, de 21 de maio de 1981. Regulamenta a concessão da utilização do serviço de informática jurídica do Centro de Documentação da Corte de 
Cassação Italiana.

ITÁLIA. Decreto do Ministério da Justiça de 14 de fevereiro de 2006. Institui modalidade e tarifa de acesso ao serviço de informática jurídica do Centro de Documentação da Corte de Cassação Italiana e uso do respectivo serviço. Disponível em: http://www.cortedicassazione.it/Documenti/d7febb_06.html. Acesso em: 08 abr. 2011

PORTUGAL. Código Civil (1966). Código Civil. Disponível em: 〈http://www.stj.pt/nsrepo/geral/ cptlp/Portugal /CodigoCivil.pdf >. Acesso em: $28 \mathrm{fev}$. 2011.

PORTUGAL. Lei $\mathbf{n}^{\mathbf{0}}$ 7, de 12 de fevereiro de 2009. Aprova revisão do Código do Trabalho. Disponível em: 〈http://dre.pt/pdf1sdip/2009/02/03000/0092601029.pdf>. Acesso em: 5 maio 2011.

SUÍÇA. Código Civil (1907). Código Civil. Disponível em: http://www.ligiera.com.br/codigos /cc_suico_(em_frances).pdf. Acesso em: 10/03/2011.

\section{SÚMULAS DE JURISPRUDÊNCIA}

BRASIL. Supremo Tribunal Federal. Súmula no 491, de 10 de dezembro de 1969. É indenizável o acidente que cause a morte de filho menor, ainda que não exerça trabalho remunerado. Disponível em: <http://www.stf.jus.br/portal/cms/verTexto.asp?servico= jurisprudenciaSumula\&pagina=sumula_401_500>. Acesso em: 21 jan. 2011.

BRASIL. Superior Tribunal de Justiça. Súmula $n^{\circ}$ 363, de 3 de novembro de 2008. Compete à Justiça estadual processar e julgar a ação de cobrança ajuizada por profissional liberal contra cliente. Disponível em: < http://www.stj.jus.br/SCON/ pesquisar.jsp>. Acesso em 13 abr. 2011.

BRASIL. Superior Tribunal de Justiça. Súmula no 227, de 8 de outubro de 1999. A pessoa jurídica pode sofrer dano moral. Disponível em: < http://www.stj.jus.br/SCON/pesquisar.jsp>. Acesso em: 13 abr. 2011

BRASIL. Tribunal Superior do Trabalho. Súmula nº 377, de 24 abr. 2008. Exceto quanto à reclamação de empregado doméstico, ou contra micro ou pequeno empresário, o preposto deve ser necessariamente empregado do reclamado. Inteligência do art. $843, \S 1^{\circ}$, da CLT e do art. 54 da Lei Complementar $\mathrm{n}^{\mathrm{o}}$ 123, de 14 de dezembro de 2006. Disponível em: < http://www.tst.gov.br/jurisprudencia/Livro_Jurisprud/ livro_html_atual.html\#Sumulas>. Acesso em: 13 abr. 2011.

BRASIL. Tribunal Superior do Trabalho. Súmula $n^{\circ}$ 331, de 23 de novembro de 2003. Contrato de Prestação de Serviços. Legalidade. Disponível em: < http://www.tst.gov.br/jurisprudencia/Livro_Jurisprud/livro_html_atual.html>. Acesso em 13 abr. 2011.)

BRASIL. Tribunal Superior do Trabalho. Súmula $\mathrm{n}^{\circ} 74$, de 25 de abril de 2005. A prova 
pré-constituída nos autos pode ser levada em conta para confronto com a confissão ficta (art. 400, I, CPC), não implicando cerceamento de defesa o indeferimento de provas posteriores. Disponível em: < http://www.tst.gov.br/jurisprudencia/Livro_Jurisprud/ livro_html_atual.html\#Sumulas $>$. Acesso em: 13 abr. 2011.

BRASIL. Tribunal Superior do Trabalho. Súmula no 6, de 23 de novembro de 2010. Para os fins previstos no $\S 2^{\circ}$ do art. 461 da CLT, só é válido o quadro de pessoal organizado em carreira quando homologado pelo Ministério do Trabalho, excluindo-se, apenas, dessa exigência o quadro de carreira das entidades de direito público da administração direta, autárquica e fundacional aprovado por ato administrativo da autoridade competente. Disponível em: <http://www.tst.gov.br/jurisprudencia/ Livro_Jurisprud/livro_html_atual.html>. Acesso em: 20 abr. 2011.

\section{JULGADOS BRASILEIROS}

AMAZONAS. Tribunal Regional do Trabalho da $11^{\text {a }}$ Região. Recurso Ordinário 0122500-69.2009.5.11.0051, Relator: Vera Lúcia Câmara de Sá Peixoto, Diário da Justiça eletrônico, 19 ago. 2010, p. 6.

AMAZONAS. Tribunal Regional do Trabalho da $11^{\mathrm{a}}$ Região. Recurso Ordinário 01612/2008-018-11-00.3, Relator: Antônio Carlos Marinho Bezerra, Diário da Justiça eletrônico, 24 maio 2010, p. 16.

BAHIA. Tribunal Regional do Trabalho da $5^{\mathrm{a}}$ Região, $2^{\mathrm{a}}$ Turma. Recurso Ordinário 0024800-07.2009.5.05.0651. Relator: Luíza Lomba. Diário da Justiça eletrônico, 28 set. 2010.

BAHIA. Tribunal Regional do Trabalho da $5^{\text {a }}$ Região, $2^{\text {a }}$ Turma. Recurso Ordinário 0097400-58.2008.5.05.0005. Publicação em 08 de outubro de 2009. Relator: Cláudio Mascarenhas Brandão. Disponível em: 〈wwww.trt5.jus.br〉. Acesso em 6 abr. 2011.

BAHIA. Tribunal Regional do Trabalho da $5^{\mathrm{a}}$ Região, $2^{\mathrm{a}}$ Turma. Recurso Ordinário 0121300-61.2008.5.05.0008. Publicação em 11 de de dezembro de 2009. Relator: Renato Mário Borges Simões. Disponível em: 〈wwww.trt5.jus.br〉. Acesso em 6 abr. 2011.

BAHIA. Tribunal Regional do Trabalho da $5^{\text {a }}$ Região, $2^{\text {a }}$ Turma. Recurso Ordinário 0058100-92.2009.5.05.0122. Publicação em 11 de dezembro de 2009. Relator: Cláudio Mascarenhas Brandão. Disponível em: 〈wwww.trt5.jus.br〉. Acesso em 6 abr. 2011.

BRASIL, Supremo Tribunal Federal, Pleno. Reclamação AgR-ED n. 1.905/SP, Relator: Min. Marco Aurélio. Julgado em 15 de agosto de 2002. Disponível em: 〈www.stf.jus.br〉. Acesso em: 13 abr. 2011.

BRASIL. Supremo Tribunal Federal. $2^{\text {a }}$ Turma. Recurso Extraordinário 29447. Relator: Min. Afrânio Costa. Julgado em 25 de novembro de 1958. Disponível em: <www.stf.jus.br.com.br>. Acesso em: 26 fev. 2011.

BRASIL. Supremo Tribunal Federal, Tribunal Pleno. Agravo Regimental em reclamação constitucional. Relator: Min. Cármen Lúcia. Diário da Justiça eletrônico n. 222, 21 nov. 2008. 


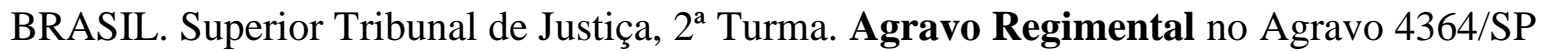
(90.057884). Relator: Ministro Ilmar Galvão. Julgado em 10 de outubro de 1990. Disponível

em: <https://ww2.stj.jus.br/processo/ita/listarAcordaos?classe=\&num_processo=\&num_registr

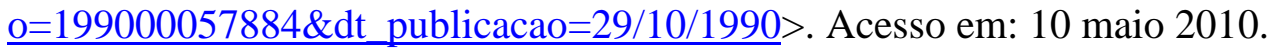

BRASIL. Superior Tribunal de Justiça, $3^{\text {a }}$ Turma. Recurso Especial 821004-MG (2006/0035112-2). Relator: Min. Sidnei Beneti. Julgado em 19 de agosto de 2010. Disponível em: 〈www.stj.jus.br〉. Acesso em: 13 abr. 2011.

BRASIL. Superior Tribunal de Justiça. Recurso Especial 61.512-SP, Relator: Min. Sálvio de Figueiredo, Diário da Justiça da União, $1^{\circ}$ dez.1997.

BRASIL. Superior Tribunal de Justiça. Recurso Especial 1.079.185-MG, Relator: Min. Nancy Andrighi. Julgado em 11 novembro 2008. Disponível em: 〈www.stj.jus.br〉. Acesso em 9 set. 2010.

BRASIL. Superior Tribunal de Justiça, $4^{a}$ Turma. Recurso Especial 788459/BA. Relator: Min. Fernando Gonçalves. Diário da Justiça da União, 13 mar. 2006.

BRASIL. Tribunal Superior do Trabalho. Recurso de Revista 1446/2000-006-05-00.0. Relator: Min. Guilherme Augusto Caputo Bastos. Diário da Justiça eletrônico, 27 ago. 2010, p. 770

BRASIL. Tribunal Superior do Trabalho. Recurso de Revista 986/2003-004-05-00.7. Relator: Min. Kátia Magalhães Arruda. Diário da Justiça eletrônico, 27 ago. 2010, p. 1195

BRASIL. Tribunal Superior do Trabalho. Recurso de Revista 1952/2003-011-05-85.0. Relator: Min. Maria de Assis Calsing. Diário da Justiça eletrônico, $1^{\circ}$ out. 2010, p. 778

BRASIL. Tribunal Superior do Trabalho, $3^{\text {a }}$ Turma. Recurso de Revista 930/2001-01008-00-6, Relator: Min. Maria Cristina I. Peduzzi. Publicação em 19 de março de 2004. Disponível em 〈www.tst.jus.br〉. Acesso em: 26 nov. 2010.

BRASIL. Tribunal Superior do Trabalho, $6^{\mathrm{a}}$ Turma. Recurso de Revista 7340048.2008.5.09.0242. Publicação em 28 de maio de 2010. Relator: Min. Aloysio Corrêa da Veiga. Disponível em <www.tst.jus.br>. Acesso em: 19 abr. 2011.

BRASIL. Tribunal Superior do Trabalho, $6^{\text {a }}$ Turma. Recurso de Revista 5390070.2007.5.04.0403. Publicação em 07 de maio de 2010. Relator: Min. Aloysio Corrêa da Veiga. Disponível em <www.tst.jus.br〉. Acesso em: 19 abr. 2011.

BRASIL. Tribunal Superior do Trabalho, $7^{\text {a }}$ Turma. Recurso de Revista 31970188.2007.5.12.0026. Publicação em 27 de agosto de 2010. Relator: Min. Maria Doralice Novaes. Disponível em <www.tst.jus.br〉. Acesso em: 19 abr. 2011.

BRASIL. Tribunal Superior do Trabalho, $6^{\text {a }}$ Turma. Recurso de Revista 12250069.2009.5.11.0051. Publicação em 18 de fevereiro de 2011. Relator: Min. Aloysio Corrêa da Veiga. Disponível em <www.tst.jus.br . Acesso em: 19 abr. 2011. 
BRASIL. Tribunal Superior do Trabalho, $8^{\mathrm{a}}$ Turma. Recurso de Revista 12884003.2007.5.04.0404. Publicação em 30 de abril de 2010. Relator: Min. Maria Cristina Irigoyen Peduzzi. Disponível em <www.tst.jus.br〉 . Acesso em: 19 abr. 2011.

BRASIL. Tribunal Superior do Trabalho, $2^{\mathrm{a}}$ Turma. Recurso de Revista 16610048.2002.5.05.0021. Publicação em 28 de junho de 2010. Relator: Convocado Roberto Pessoa. Disponível em 〈www.tst.jus.br $>$. Acesso em: 19 abr. 2011.

BRASIL. Tribunal Superior do Traballho, $2^{\text {a }}$ Turma. Recurso de Revista 14454094.2006.5.02.0085. Relator: Min. Renato de Lacerda Paiva. Diário eletrônico da Justiça do Trabalho, 9 abr. 2010.

BRASIL. Tribunal Superior do Trabalho, $8^{\text {a }}$ Turma. Agravo de Instrumento 4104019.2006.5.02.0018. Publicação em 06 de abr. 2011. Relator: Min. Dora Maria da Costa. Disponível em 〈www.tst.jus.br〉. Acesso em: 19 abr. 2011.

BRASIL. Tribunal Superior do Trabalho, $8^{\text {a }}$ Turma. Recurso de Revista 20510060.2002.5.02.0014. Publicação em 13 de outubro de 2010. Relator: Min. Dora Maria da Costa. Disponível em <www.tst.jus.br>. Acesso em: 19 abr. 2011.

BRASIL. Tribunal Superior do Trabalho, $8^{\text {a }}$ Turma. Recurso de Revista 20110057.2007.5.12.0048. Publicação em $1^{\circ}$ de abril de 2011. Relator: Min. Dora Maria da Costa. Disponível em 〈www.tst.jus.br〉. Acesso em: 19 abr. 2011.

BRASIL. Tribunal Superior do Trabalho, $2^{\mathrm{a}}$ Turma. Recurso de Revista 16044043.2006.5.02.0045. Publicação em 08 de abril de 2011. Relator: Min. Guilherme Augusto Caputo Bastos. Disponível em <www.tst.jus.br>. Acesso em: 19 abr. 2011.

BRASIL. Tribunal Superior do Trabalho, $6^{\text {a }}$ Turma. Recurso de Revista 21280054.2009.5.09.0594. Publicação em 4 de fevereiro de 2011. Relator: Min. Maurício Godinho Delgado. Disponível em 〈www.tst.jus.br〉. Acesso em: 19 abr. 2011.

BRASIL. Tribunal Superior do Trabalho, $3^{\text {a }}$ Turma. Recurso de Revista 2194096.2006.5.14.0001. Publicação em 23 de outubro de 2009. Relator: Min. Alberto Luiz Bresciani de Fontan Pereira. Disponível em <www.tst.jus.br〉. Acesso em: 19 abr. 2011.

BRASIL. Tribunal Superior do Trabalho, $4^{\text {a }}$ Turma. Recurso de Revista 5790084.2007.5.02.0075. Publicação em 25 de março de 2011. Relator: Min. Maria de Assis Calsing. Disponível em <www.tst.jus.br>. Acesso em: 19 abr. 2011.

BRASIL. Tribunal Superior do Trabalho, $2^{\text {a }}$ Turma. Recurso de Revista 1878/2007-00418-00.4. Relator: Min. Renato de Lacerda Paiva. Diário da Justiça eletrônico, $1^{\text {o }}$ out. 2010, p. 421.

BRASIL. Tribunal Superior do Trabalho, $5^{\text {a }}$ Turma. Recurso de Revista 1821/2007-01318-00.6. Relator: Min. Kátia Magalhães Arruda. Diário da Justiça eletrônico, $1^{\circ}$ out. 2010, p. 944.

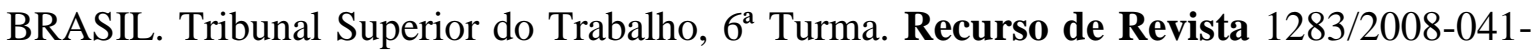


03-40.6. Relator: Min. Mauricio Godinho Delgado. Diário da Justiça eletrônico, $1^{\circ}$ out. 2010, p. 1098.

BRASÍLIA. Tribunal Regional Federal da $1^{\mathrm{a}}$ Região. Apelação Cível 200441000017172/RO. Relator: Convocado Evaldo de Oliveira Fernandes Filho. Diário da Justiça eletrônico, 08 out. 2010, p. 161.

CAMPINAS. Tribunal Regional do Trabalho da $15^{\mathrm{a}}$ Região, $5^{\mathrm{a}}$ Turma. Recurso Ordinário 0255000-56.2008.5.15.0070. Publicação em 27 de agosto de 2010. Relator: José Antônio Pancotti. Disponível em <www.trt15.jus.br〉. Acesso em: 12 abr. 2011.

CAMPINAS. Tribunal Regional do Trabalho da $15^{\mathrm{a}}$ Região, $6^{\mathrm{a}}$ Turma. Recurso Ordinário 0032500-85.2008.5.15.0135. Publicação em 21 de agosto de 2009. Relator: Nora Magnólia Costa Rotondaro. Disponível em 〈www.trt15.jus.br〉. Acesso em: 12 abr. 2011.

CAMPINAS. Tribunal Regional do Trabalho da $15^{\mathrm{a}}$ Região, $6^{\mathrm{a}}$ Turma. Recurso Ordinário 0161200-60.2009.5.15.0033. Publicação em 12 de novembro de.2010. Relator: Maria Cristina Mattioli. Disponível em <www.trt15.jus.br>. Acesso em: 12 abr. 2011.

CAMPINAS. Tribunal Regional do Trabalho da $15^{\mathrm{a}}$ Região, $6^{\mathrm{a}}$ Turma. Recurso Ordinário 0179500-62.2008.5.15.0144. Relator: Eurico Cruz Neto. Publicação em 25 de setembro de 2009. Disponível em 〈www.trt15.jus.br〉 . Acesso em: 12 abr. 2011.

CAMPINAS. Tribunal Regional do Trabalho da $15^{\text {a }}$ Região, $1^{\text {a }}$ Turma. Recurso Ordinário 0083900-27.2000.5.15.0101. Publicação em 13 de maio de 2002. Relator: Eliane de Carvalho Costa Ribeiro. Disponível em 〈www.trt15.jus.br $>$. Acesso em: 12 abr. 2011.

ESPÍRITO SANTO. Tribunal Regional do Trabalho da $17^{\mathrm{a}}$ Região, $1^{\mathrm{a}}$ Turma. Recurso Ordinário 00844.2009.003.17.00.3. Publicação em 15 de outubro de 2010. Relator: Sérgio Moreira de Oliveira. Disponível em <www.trt17.jus.br $>$. Acesso em: 12 abr. 2011.

ESPÍRITO SANTO. Tribunal Regional do Trabalho da $17^{\mathrm{a}}$ Região. Recurso Ordinário 00651.2005.002.17.00.2. Publicação em 28 de novembro de 2006. Relator: Lucy de Fátima Cruz Lago. Disponível em <www.trt17.jus.br〉 . Acesso em: 12 abr. 2011.

ESPÍRITO SANTO. Tribunal Regional do Trabalho da $17^{\mathrm{a}}$ Região, $1^{\mathrm{a}}$ Turma. Recurso Ordinário 00765.2007.005.17.00.3. Publicação em 26 de fevereiro de 2008. Relator: Sérgio Moreira de Oliveira. Disponível em <www.trt17.jus.br>. Acesso em: 12 abr. 2011.

ESPÍRITO SANTO. Tribunal Regional do Trabalho da $17^{\mathrm{a}}$ Região, $1^{\mathrm{a}}$ Turma. Recurso Ordinário 01399.2009.002.17.00.2. Publicação em 08 de outubro de 2010. Relator: Gerson Fernando da Sylveira Novais. Disponível em <www.trt17.jus.br $>$. Acesso em: 12 abr. 2011.

ESPÍRITO SANTO. Tribunal Regional do Trabalho da $17^{\mathrm{a}}$ Região, $3^{\mathrm{a}}$ Turma. Recurso Ordinário 01092.2009.005.17.00.0. Publicação em 31 de janeiro de 2011. Relator: Carmem Vilma Garisto. Disponível em <www.trt17.jus.br〉. Acesso em: 12 abr. 2011. 
ESPÍRITO SANTO. Tribunal Regional do Trabalho da $17^{\mathrm{a}}$ Região, $1^{\mathrm{a}}$ Turma. Recurso Ordinário 00491.2010.008.17.00.7. Publicação em 21 de fevereiro de 2011. Relator: Gerson Fernando da Sylveira Novais. Disponível em <www.trt17.jus.br〉. Acesso em: 12 abr. 2011.

ESPÍRITO SANTO. Tribunal Regional do Trabalho da $17^{\mathrm{a}}$ Região, $1^{\mathrm{a}}$ Turma. Recurso Ordinário 00806.2009.002.17.00.4. Publicação em 13 de outubro de 2010. Relator: José Carlos Rizk. Disponível em <www.trt17.jus.br> . Acesso em: 12 abr. 2011.

GOIÁS. Tribunal Regional do Trabalho da $18^{\mathrm{a}}$ Região. Recurso Ordinário 00825-2006001-18-00-6. Publicação em 24 de janeiro de 2007. Relator: Khatia Maria Bomtempo de Albuquerque. Disponível em <www.trt18.jus.br>. Acesso em: 19 abr. 2011.

MATO GROSSO. Tribunal Regional do Trabalho da $23^{\mathrm{a}}$ Região, $2^{\mathrm{a}}$ Turma. Recurso Ordinário 01196.2007.001.23.00-5, Relator: Luiz Alcântara. Publicação em 06 de junho de 2008. Disponível em <www.trt23.jus.br>. Acesso em: 19 abr. 2011.

MATO GROSSO. Tribunal Regional do Trabalho da 23 ${ }^{\mathrm{a}}$ Região, $2^{\mathrm{a}}$ Turma. Recurso Ordinário 00526.2007.009.23.00-6. Publicação em 26 de fevereiro de 2009. Relator: Paulo Barrionuevo. Disponível em <www.trt23.jus.br〉. Acesso em: 19 abr. 2011.

MATO GROSSO DO SUL. Tribunal de Justiça do Estado de Mato Grosso do Sul, $5^{\text {a }}$ Turma Cível. Apelação Cível 2010.016892-5/0000-00. Relator: Sideni Soncini Pimentel. Diário da Justiça eletrônico, 9 set. 2010, p. 41.

MATO GROSSO DO SUL. Tribunal Regional do Trabalho da $24^{\mathrm{a}}$ Região, $2^{\mathrm{a}}$ Turma. Recurso Ordinário 0117900-66.2008.5.24.0022. Relator: Francisco das C. Lima Filho. Diário da Justiça eletrônico, 25 ago. 2010, p. 64

MATO GROSSO DO SUL. Tribunal Regional do Trabalho da $24^{a}$ Região, $2^{a}$ Turma. Recurso Ordinário 1111/2006-002-24-00-9. Julgado em 23 de abril de 2008. Relator: Convocado João Marcelo Balsanelli. Disponível em 〈www.trt24.jus.br〉. Acesso em: 19 abr. 2011.

MINAS GERAIS. Tribunal de Justiça do Estado de Minas Gerais, 12a Câmara Cível. Apelação Cível 1.0334.08.014746-8/001. Relator: José Flávio de Almeida. Diário da Justiça eletrônico, 9 nov. 2009

MINAS GERAIS. Tribunal Regional do Trabalho da $3^{\text {a }}$ Região, $1^{\text {a }}$ Turma, Recurso Ordinário 831/2008-043-03-00.9. Publicação em 18 de dezembro de 2009. Relator: Manuel Candido Rodrigues. Disponível em <www.trt3.jus.br>. Acesso em: 6 abr. 2011.

MINAS GERAIS. Tribunal Regional do Trabalho da $3^{\mathrm{a}}$ Região, 9 ${ }^{\mathrm{a}}$ Turma. Recurso Ordinário 0000734-51.2010.5.03.0014. Publicação em 14 de janeiro de 2011. Relator:

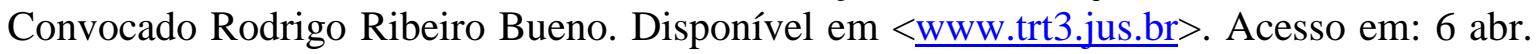
2011.

MINAS GERAIS. Tribunal Regional do Trabalho da $3^{\mathrm{a}}$ Região, $8^{\mathrm{a}}$ Turma. Recurso Ordinário 01405-2008-077-03-00-0. Publicação em 25 de maio de 2009. Relator: Cleube de Freitas Pereira. Disponível em <www.trt3.jus.br>. Acesso em: 6 abr. 2011. 
MINAS GERAIS. Tribunal Regional do Trabalho da $3^{\mathrm{a}}$ Região, $5^{\mathrm{a}}$ Turma. Recurso Ordinário 0000806-78.2010.5.03.0033. Publicação em 14 de março de 2011. Relator: Convocado Maurílio Brasil. Disponível em 〈www.trt3.jus.br〉. Acesso em: 6 abr. 2011.

MINAS GERAIS. Tribunal Regional do Trabalho da $3^{a}$ Região, $7^{a}$ Turma. Recurso Ordinário 01533-2007-112-03-00-5. Publicação em 02 de outubro de 2008. Relator: Emerson José Alves Lage. Disponível em <www.trt3.jus.br>. Acesso em: 6 abr. 2011.

MINAS GERAIS. Tribunal Regional do Trabalho da $3^{\text {a }}$ Região, Turma Recursal de Juiz de Fora. Recurso Ordinário 0056900-74.2009.5.03.0132. Publicação em 24 de fevereiro de 2010. Relator: Heriberto de Castro. Sem grifos no original. Disponível em <www.trt3.jus.br>. Acesso em: 6 abr. 2011.

PARAÍBA. Tribunal Regional do Trabalho da $13^{\mathrm{a}}$ Região. Recurso Ordinário 2820082.2007.5.13.0002. Relator: Ana Maria Ferreira Madruga. Diário da Justiça eletrônico, 10 nov. 2010, p. 11. Sem grifos no original

PARANÁ. Tribunal de Justiça do Estado do Paraná, 6 ${ }^{\mathbf{a}}$ Câmara Civil. Apelação Cível 224.231-1. Relator: Juiz Convocado Sérgio Luiz Patitucci. Julgado em 22 de abril de 2003. Disponível em: <http://portal.tjpr.jus.br>. Acesso em: 16 jan. 2011.

PARANÁ. Tribunal Regional do Trabalho da $9^{\mathrm{a}}$ Região, $4^{\mathrm{a}}$ Turma. Recurso Ordinário 0734-2008-242-09-00-3. Julgado em 17 de junho de 2009. Relator: Luiz Celso Napp. Disponível em <www.trt9.jus.br>. Acesso em: 8 abr. 2011.

PARANÁ. Tribunal Regional do Trabalho da $9^{a}$ Região, $3^{\text {a }}$ Turma. Recurso Ordinário 02128-2009-594-09-00-7. Julgado em 23 de junho de 2010. Relator: Altino Pedrozo dos Santos. Disponível em <www.trt9.jus.br>. Acesso em: 8 abr. 2011.

PARANÁ. Tribunal Regional do Trabalho da $9^{\mathrm{a}}$ Região, $1^{\mathrm{a}}$ Turma. Recurso Ordinário 00601-2006-094-09-00-8. Publicação em 04 de agosto de 2007. Relator: Ubirajara Carlos Mendes. Disponível em <www.trt9.jus.br>. Acesso em: 8 abr. 2011.

PERNAMBUCO. Tribunal Regional do Trabalho da $6^{a}$ Região, $3^{\mathbf{a}}$ Turma. Recurso Ordinário 00174.2008.010.06.00.2. Julgado em 17 de setembro de 2008. Relator: Ana Catarina Cisneiros Barbosa de Araújo. Disponível em <www.trt6.jus.br>. Acesso em: 8 abr. 2011.

PERNAMBUCO. Tribunal Regional do Trabalho da $6^{a}$ Região, $2^{a}$ Turma. Recurso Ordinário 01138-2007-003-06-00-7. Julgado em 14 de outubro de 2009. Relator: Maria Helena Guedes Soares de Pinho Maciel. Disponível em <www.trt6.jus.br>. Acesso em: 8 abr. 2011.

RIO DE JANEIRO. Tribunal de Justiça do Estado do Rio de Janeiro, $2^{\text {a }}$ Câmara Cível. Apelação Cível 0001570-44.2002.8.19.0067. Queimados. Relator: Heleno Ribeiro P. Nunes. Diário da Justiça eletrônico, 04 nov. 2010, p. 16

RIO DE JANEIRO. Tribunal Regional do Trabalho da $1^{\text {a }}$ Região, $8^{\text {a }}$ Turma. Recurso Ordinário 03119-2006-342-01-00-9. Publicação em 14 de julho de 2008. Relator: Marcelo 
Augusto Souto de Oliveira. Disponível em <www.trt1.jus.br>. Acesso em: 13 abr. 2011.

RIO DE JANEIRO. Tribunal Regional do Trabalho da $1^{\text {a }}$ Região, $2^{\mathrm{a}}$ Vara do Trabalho de Volta Redonda/RJ. Reclamação Trabalhista 03119-2006-342-01-00-9. Juiz Prolator: Leandro Nascimento Soares. Julgado em abril de 2007. Disponível em 〈www.trt1.jus.br〉. Acesso em: 13 abr. 2011.

RIO GRANDE DO SUL. Tribunal de Justiça do Estado do Rio Grande do Sul, $5^{\text {a }}$ Câmara Cível. Apelação Cível 589069996. Relator: Ruy Rosado de Aguiar Júnior. Julgado em 12 de junho de 1990.

RIO GRANDE DO SUL. Tribunal de Justiça do Estado do Rio Grande do Sul, $5^{\text {a }}$ Câmara Cível. Apelação Cível 591064837. Relator: Ruy Rosado de Aguiar Júnior. Julgado em 29 de agosto de 1991.

RIO GRANDE DO SUL, 9a Câmara Cível. Tribunal de Justiça do Estado do Rio Grande do Sul. Apelação Cível 70002978260. Relator: Paulo de Tarso Vieira Sanseverino. Julgado em 28 de dezembro 2001.

RIO GRANDE DO SUL. Tribunal Regional do Trabalho da $4^{\mathrm{a}}$ Região, $8^{\mathrm{a}}$ Turma. Recurso Ordinário 0000001-96.2010.5.04.0551. Julgado em 05 de agosto de 2010. Relator: Wilson Carvalho Dias. Disponível em <www.trt4.jus.br>. Acesso em: 6 abr. 2011.

RIO GRANDE DO SUL. Tribunal Regional do Trabalho da $4^{\mathrm{a}}$ Região, $4^{\mathrm{a}}$ Turma. Recurso Ordinário 0000305-60.2010.5.04.0304. Julgado em 28 de outubro de 2010. Relator: Hugo Carlos Scheuermann. Disponível em <www.trt4.jus.br〉. Acesso em: 6 abr. 2011.

RIO GRANDE DO SUL. Tribunal Regional do Trabalho da $4^{\mathrm{a}}$ Região, $4^{\mathrm{a}}$ Turma. Recurso Ordinário 00423-2004-027-04-00-9. Relator: Ricardo Tavares Gehling. Diário da Justiça eletrônico, 19 abr. 2010. Disponível em 〈www.trt4.jus.br〉. Acesso em: 6 abr. 2011.

RIO GRANDE DO SUL. Tribunal Regional do Trabalho da $4^{\text {a }}$ Região, $6^{\text {a }}$ Turma. Recurso Ordinário 0010300-51.2007.5.04.0030. Julgado em 14 de abril de 2010. Relator: Maria Madalena Telesca. Disponível em <www.trt4.jus.br>. Acesso em: 6 abr. 2011.

RIO GRANDE DO SUL. Tribunal Regional do Trabalho da $4^{\mathrm{a}}$ Região, $3^{\mathrm{a}}$ Turma. Recurso Ordinário 0191400-78.2007.5.04.0404. Julgado em 12 de novembro de 2008. Relator: Luiz Alberto de Vargas. Disponível em <www.trt4.jus.br>. Acesso em: 6 abr. 2011.

RONDÔNIA. Tribunal Regional do Trabalho da $14^{\text {a }}$ Região. Recurso Ordinário 00219.2006.001.14.00-2. Julgado em 07 de maio de 2008. Relator: Vânia Maria da Rocha Abensur. Disponível em 〈www.trt14.jus.br〉. Acesso em: 12 abr. 2011.

SANTA CATARINA. Tribunal Regional do Trabalho da $12^{\mathrm{a}}$ Região, $1^{\mathrm{a}}$ Turma. Recurso Ordinário 00094-2008-043-12-00-5. Relator: Viviane Colucci. Diário da Justiça eletrônico, 28 set. 2010.

SÃO PAULO. Tribunal de Justiça do Estado de São Paulo, $4^{a}$ Câmara de Direito Privado. Apelação Cível 994.09.322548-8. Casa Branca.. Rel. Enio Zuliani. Diário da Justiça eletrônico, 26 jul. 2010, p. 718. 
SÃO PAULO. Tribunal Regional do Trabalho da $2^{\mathrm{a}}$ Região, $4^{\mathrm{a}}$ Turma. Recurso Ordinário 01228-2007-083-02-00-8 - (20100929030). Relator: Juíza Ivani Contini Bramante. Diário Oficial eletrônico de São Paulo, $1^{\circ}$ out. 2010.

SÃO PAULO. Tribunal Regional do Trabalho da $2^{\mathrm{a}}$ Região, $4^{\mathrm{a}}$ Turma. Recurso Ordinário 01325.2008.463.02.00-0. Publicação em 21 de janeiro de 2011. Relator: Ivani Contini Bramante. Disponível em <www.trt2.jus.br>. Acesso em: 6 abr. 2011.

SÃO PAULO. Tribunal Regional do Trabalho da $2^{\mathrm{a}}$ Região. Reclamação Trabalhista $\mathrm{n}^{\mathrm{o}}$ 04454/2006-089-02-008, 89 ${ }^{\text {a }}$ Vara do Trabalho de São Paulo/SP. Juiz Marcos Neves Fava. Julgamento em 23 de março de 2007. Disponível em: 〈www.trt2.jus.br〉. Acesso em: 13 abr. 2011.

SERGIPE. Tribunal de Justiça do Estado de Sergipe, $2^{\text {a }}$ Câmara Cível. Apelação Cível 2010203140 - (4015/2010). Relator: Marilza Maynard Salgado de Carvalho. Diário da Justiça eletrônico, 11 maio 2010, p. 47.

SERGIPE. Tribunal Regional do Trabalho da 20a Região, Recurso Ordinário 000312008-006-20-00-5. Publicação em 03 de setembro de 2008. Relator: Augusto César Leite Carvalho. Disponível em: 〈www.trt20.jus.br〉. Acesso em: 19 abr. 2011.

\section{JULGADOS ESTRANGEIROS}

ESPANHA. Tribunal Constitucional, Pleno. Recurso prévio de inconstitucionalidade. Sentença 53/1985. Publicado em 18 de maio de 1985. Disponível em: < http://www.boe.es/aeboe/consultas/bases_datos/doc.php?coleccion=tc\&id=SENTENCIA1985-0053 >. Acesso em: 4 abr. 2011. Sem grifo no original.

ESTADOS UNIDOS DA AMÉRICA. Suprema Corte de Indiana. Apelação 49D03-9612CT-1631. Julgado em 3 de abril 2000. Disponível em: <http://www.in.gov/judiciary/opinions/ archive/04030001.trb.htmll>. Acesso em: 29 mar. 2011

FRANÇA. “Chambre de Requêtes”, 17 juil. 1889. In: Recueil Sirey, 1891, v. 1, p. 399

FRANÇA. Tribunal de Meaux, 29 jan. 1920. In: Recueil Dalloz, Paris, v. I, 1920, p. 137.

FRANÇA. "Chambre de Requêtes", 19 mai. 1931. Recueil Sirey, 1931, p. 190-191.

FRANÇA. "Chambre de Requêtes", 26 mai. 1932. Recueil Sirey, 1932, p. 387-388.

FRANÇA. "Chambre Civile”, 22 out. 1934. Gazette du Palais, v. II, 1934, p. 821-822.

FRANÇA. " 1 ére Chambre Civile”, 14 déc. 1965. Juris Classeur Périodique, v. II, 1966, 14753, note SAVATIER, René.

FRANÇA. " $1{ }^{\text {ere }}$ Chambre Civile”, 10 mars. 1966. Juris Classeur Périodique, v. II, 1966, 
14753, note SAVATIER, René.

FRANÇA. Corte de Cassação. Crim. - 3 de novembro de 2010. Cassação 09-87.375. CA Versailles, 15 setembro de $2009 . \quad$ Disponível em: <http://www.courdecassation.fr/IMG/pdf/Bicc_737.pdf>. Acesso em 26 fev. 2011.

FRANÇA. Corte de Cassação. Cassação 09-16.53. CA Paris, 30 de junho de 2009. Disponível em: 〈http://www.courdecassation.fr/IMG/pdf/Bicc_739.pdf>. Acesso em: 05 abr. 2011

INGLATERRA. Corte de Apelação. Apelação [1911] 2 K. B. 78. Chaplin v. Hicks. Disponível em: <http://www.btinternet.com/ akme/chaplin.html>. Acesso em: 25 nov. 2010.

INGLATERRA. Câmara dos Lordes, Sessão 2004-5 [2005]. Apelação [2002] EWCA. Civ. 1471. Disponível em: <http://www.publications.parliament.uk /pa/ld200405/ldjudgmt/jd050127/greg-8.htm>. Acesso em: 27 jan. 2011.

ITÁliA. Corte de Cassação. Sentença 6906. Julgado em 19 de novembro de 1983. Giustizia Civile. Rivista Mensile di Giurisprudenza, Milão, I, 1984, p. 1841-1843

ITÁLIA. Corte de Cassação. Sentença 6506. Julgado em 19 de dezembro de 1985. Rivista di Diritto Commune, v. II, p. 207.

ITÁliA. Corte de Cassação. Cass. civ., Sez. lav., 22 abr. 1993, n. 4725. In: MANGIATORDI, Maria. La perdita di chance non è una mera aspettativa. Rivista giuridica telemática, Bari, n. 2, 2007, p.123

PORTUGAL. Supremo Tribunal de Justiça, 1a Seção. Revista 2622/07.0TBPNF.P1.S1. Relator: Sebastião Povoas. Julgado em 29 de abril de 2010. Disponível em: <http://www.stj.pt/?idm=546>. Acesso em 8 set. 2010. 


\title{
ANEXO A - Chaplin v. Hicks - Inglaterra (1911)
}

\author{
In the Court of Appeal [1911] 2 K. B. 786
}

\section{Beauty Contestant denied chance to compete - Breach of Contract - Measure of Damages - Remoteness - Inassessability}

Where by contract a man has a right to belong to a limited class of competitors for a prize, a breach of that contract by reason of which he is prevented from continuing a member of the class and is thereby deprived of his chance of obtaining the prize is a breach in respect of which he may be entitled to recover substantial, and not merely nominal, damages. The existence of a contingency which is dependent on the volition of a third person does not necessarily render the damages for a breach of contract incapable of assessment. Richardson v. Mellish (1824) 2 Bing. 229, and Watson v. Ambergate \&c. Railway (1850) 15 Jur. 448, discussed.

APPLICATION Of the defendant for judgment or a new trial in an action tried by Pickford J. and a common jury.

On November 5, 1908, a letter from the defendant, a well-known actor and theatrical manager, was published in a London daily newspaper, in which he said that, with a view of dealing at once with the numerous applications continually being made to him by young ladies desirous of obtaining engagements as actresses, he was willing that the readers of that newspaper should by their votes select twelve ladies, to whom he would give engagements. On the four following days the offer was published in detail in the newspaper. Ladies were invited to send their photographs to the newspaper by November 24, 1908, together with an application form, in which they were to insert name, address, and general personal description. The defendant, with the assistance of a committee, would then select twenty-four photographs to be published in the newspaper, and the readers of the newspaper would out of those select the twelve winners, to the first four of whom the defendant would give an engagement for three years at $£ 5$ a week, to the second four an engagement tor three years at $£ 4$ a week, and to the third four an engagement for three years at $£ 3$ a week. On November 10 the plaintiff sent in a signed application to together with her photograph. The response to the defendant's offer was so great that in the issue of December 9 an alteration of the conditions of the competition was announced. It was stated that about six thousand photographs had been sent in, and that from these the defendant or his committee had selected about three hundred, which would be published in the newspaper in the following way: the United Kingdom would be divided into ten districts, and the photographs of the selected candidates in each district would be submitted to the readers of the newspaper in that district, who were to select by their votes those whom they considered the most beautiful. After the voting was completed the defendant would make an appointment to see the five ladies in each district whose photographs so published obtained the greatest number of votes, and from these fifty the defendant would himself select the twelve who would receive the promised engagements. The plaintiff assented to the alteration in the terms of the competition. The fifty photographs were then published with numbers appended to them in the newspaper, together with a ballot paper on which the reader of the newspaper registered his vote for the particular number which he preferred, and added his signature and address. On January 2, 1909 , the poll closed; the plaintiff's name appeared as first in her particular section, and she became one of the fifty eligible for selection by the defendant. On January 4 the defendant's secretary wrote a letter to the plaintiff asking her to call at the Aldwych Theatre at 4 o'clock on Wednesday afternoon [January 6] to see the defendant. This letter was addressed to the plaintiff's London address, which was the only address given by the plaintiff in her application, and was delivered there by the first post on January 5. The plaintiff was at that time fulfilling an engagement at Dundee; the letter was at once re-addressed to Dundee, where it reached the plaintiff on January 6 , much too late for her to keep an appointment in London on that afternoon. The other forty-nine ladies kept their appointments, and on January 8 the defendant made his final selection of the twelve, of whom the plaintiff was not one. The plaintiff made attempts, but unsuccessfully, to 
obtain another appointment with the defendant, and eventually brought the present action to recover damages on the ground that by reason of the defendant's breach of contract she had lost the chance of selection for an engagement. The jury found, in answer to a question put to them by the learned judge, that the defendant did not take reasonable means to give the plaintiff an opportunity of presenting herself for selection, and assessed the damages at $£ 100$, for which sum Pickford J., after argument directed judgment to be entered. The defendant appealed.

\section{McCardie (A. R. Churchill with him), for the defendant.}

Assuming a breach of contract, the plaintiff is not entitled to substantial damages, but to nominal damages only. Either the damages do not flow directly from the breach and are too remote, or they are so contingent as to be incapable of assessment. The question has been discussed in actions against carriers for damages for loss or delay in the carriage of goods. In Watson v. Ambergate \&c., Railway 15 Jur. 448, which was decided at a time when the rule as to notice of the purpose for which the goods were required affecting the damages for their loss had not been authoritatively formulated, the question arose of the damages recoverable for the loss of a plan and model of a machine for loading colliers from barges, the plan and model being intended to be used in a competition for prizes; the Court seems to have decided that the measure of damages for loss of the plan and model was the value of the plan and model, and that the loss of the chance of obtaining the prize was not capable of assessment; there was, however, a difference of opinion, Patteson J, thinking that damages might be given for the loss of the chance, Erle J. thinking that they could not. In Mayne on Damages, 8th ed., p. 70, it is suggested that the view of Erle J. was correct, and the author puts the question thus: "Was the plaintiff's chance of winning the prize a matter of such an ascertainable value at the time of entering into the contract of carriage, as to have been capable of contemplation by both parties?" In Simpson v. London and North Western Railway (1876) Q.B.D. 274, where the defendants had notice of the purpose for which the samples delivered to them for carriage were required, loss of profit was held to be a natural and probable result of failure to deliver them in time. But substantial damages cannot be recovered where the claim is merely for the loss of a benefit which might or might not have accrued to the plaintiff; they certainly cannot be recovered where, in ordinary language, the odds are against the plaintiff ever deriving any benefit from his contract; that is not a mere question for the jury in assessing the amount of damages.

[FLETCHER MOULTON L.J. Take the.case of a tontine of a hundred persons, of whom only three are left; if one of the three were improperly struck out, would he not be entitled to substantial damages?]

It is submitted that he would be entitled to nominal damages only; if he were held to be entitled to substantial damages, it would only be because a member of a tontine has an acknowledged right in property. It is clear that the law recognizes the existence of a liability which is incapable of being estimated. Such cases were directly provided for by s.81 of the Bankruptcy Act, 1869, where a future and contingent liability, declared by an order of the Court to be incapable of being fairly estimated, was declared to be not provable in bankruptcy: see Hardy v. Fothergill (1888) 13 App. Cas. 351. The recent decision of Jelf J. in Sapwell v. Bass [1910] 2 K.B. 486 is a clear authority in favour of the defendant. The cases in which damages have been given for the loss of a probability such as Frost v. Knight (1872) L. R. 7 Ex. 111 are not in point; a probability is very different from a chance, which is a non-assessible possibility.

[FARWELL L.J. referred to Richardson v. Mellish 2 Bing. 229]

That is the only case in which the question of a contingency or of the approval of a third person has arisen in respect of an assessment of damages, and it does not conflict with the general rule that the existence of a contingency which is dependent on the volition of a third person renders the damages for a breach of contract incapable of assessment. [He also cited Horne v. Midland Railway (1873) L. R. 8 C. P. 131; Walker v. Goe (1859) 4 H. \& N. 350; Maw v. Jones (1890) 25 Q.B.D.107; Addis v. Gramophone Co. [1909] A.C. 488 Lagunas Nitrate Co. v. Lagunas Syndicate [1899] 2 Ch. 392]

G. A. Scott, for the plaintiff, was not called upon.

VAUGHAN WILLIAMS L.J. I am of opinion that this appeal should be dismissed. The plaintiff relies upon a contract alleged to have been made with the defendant, a contract under which she 
asserts that she obtained the opportunity of appearing in a competition in which considerable prizes were offered. I need not discuss the facts in any detail; so far as the contract and its breach are concerned, even if neither of them is admitted on the pleadings, the matter has been discussed by Mr. McCardie in his able argument upon the basis that there was a contract and that there was a breach of that contract. It is contended, however, that the breach of contract was such that the damages (if any) obtainable in respect of it could only be nominal. The argument for the defendant was based upon two propositions, first, that the damages were remote, and, secondly, that they were unassessable, and we have to deal with both those contentions.

As regards remoteness, the test that is generally applied is to see whether the damages sought to be recovered follow so naturally or by express declaration from the terms of the contract that they can be said to be the result of the breach. This generally resolves itself into the question whether the damages flowing from a breach of contract were such as must have been contemplated by the parties as a possible result of the breach. Now, the moment it is admitted that the contract was in effect one which gave the plaintiff a right to present herself and to take her chance of getting a prize, and the moment the jury find that she did not have a reasonable opportunity of presenting herself on the particular day, we have a breach attended by neglect of the defendant to give her a later opportunity; and when we get a breach of that sort and a claim for loss sustained in consequence of the failure to give the plaintiff an opportunity of taking part in the competition, it is impossible to say that such a result and such damages were not within the contemplation of the parties as the possible direct outcome of the breach of contract. I cannot think these damages are too remote, and I need say no more on the question of remoteness.

Then came the point that was more strenuously argued, that the damages were of such a nature as to be impossible of assessment. It was said that the plaintiff's chance of winning a prize turned on such a number of contingencies that it was impossible for any one, even after arriving at the conclusion that the plaintiff had lost her opportunity by the breach, to say that there was any assessable value of that loss. It is said that in a case which involves so many contingencies it is impossible to say what was the plaintiff's pecuniary loss. I am unable to agree with that contention. I agree that the presence of all the contingencies upon which the gaining of the prize might depend makes the calculation not only difficult but incapable of being carried out with certainty or precision. The proposition is that, whenever the contingencies on which the result depends are numerous and difficult to deal with, it is impossible to recover any damages for the loss of the chance or opportunity of winning the prize. In the present case I understand that there were fifty selected competitors, of whom the plaintiff was one, and twelve prizes, so that the average chance of each competitor was about one in four. Then it is said that the questions which might arise in the minds of the judges are so numerous that it is impossible to say that the case is one in which it is possible to apply the doctrine of averages at all. I do not agree with the contention that, if certainty is impossible of attainment, the damages for a breach of contract are unassessable. I agree, however, that damages might be so unassessable that the doctrine of averages would be inapplicable because the necessary figures for working upon would not be forthcoming; there are several decisions, which I need not deal with, to that effect. I only wish to deny with emphasis that, because precision cannot be arrived at, the jury has no function in the assessment of damages.

In early days when it was necessary to assess damages, no rules were laid down by the Courts to guide juries in the assessment of damages for breach of contract; it was left to the jury absolutely. But in course of time judges began to give advice to juries as the stress of commerce increased, let us say between the reigns of Queen Elizabeth and Queen Victoria, rule after rule was suggested by way of advice to juries by the judges when damages for breach of contract had to be assessed. But from first to last there were, as there are now, many cases in which it was difficult to apply definite rules. In the case of a breach of a contract for the delivery of goods the damages are usually supplied by the fact of there being a market in which similar goods can be immediately bought, and the difference between the contract price and the price given for the substituted goods in the open market is the measure of damages; that rule has been always recognised. Sometimes, however, there is no market for the particular class of goods; but no one has ever suggested that, because there is no market, there are no damages. In such a case the jury must do the best they can, and it 
may be that the amount of their verdict will really be a matter of guesswork. But the fact that damages cannot be assessed with certainty does not relieve the wrongdoer of the necessity of paying damages for his breach of contract. I do not wish to lay down any such rule as that a judge can in every case leave it to the jury to assess damages for a breach of contract. There are cases, no doubt, where the loss is so dependent on the mere unrestricted volition of another that it is impossible to say that there is any assessable loss resulting from the breach. In the present case there is no such difficulty. It is true that no market can be said to exist. None of the fifty competitors could have gone into the market and sold her right; her right was a personal right and incapable of transfer. But a jury might well take the view that such a right, if it could have been transferred, could have been of such a value that every one would recognise that a good price could be obtained for it. My view is that under such circumstances as those in this case the assessment of damages was unquestionably for the jury. The jury came to the conclusion that the taking away from the plaintiff of the opportunity of competition, as one of a body of fifty, when twelve prizes were to be distributed, deprived the plaintiff of something which had a monetary value. I think that they were right and that this appeal fails.

FLETCHER MOULTON L.J. I have come to the same conclusion. The contract was made when the plaintiff, in answer to the defendant's announcement, sent up her photograph as one to be submitted to the committee by whom the selection was to be made. About six thousand photographs in all were sent in, and three hundred, of which the plaintiff's was one, were selected; these appear to have been voted upon by the readers of the newspaper, and the plaintiff was the first of the group or district to which, for the purposes of the competition, she belonged; by the conditions of the offer fifty altogether were in the end to come before the defendant, and twelve appointments were to be given to twelve members of that body of fifty. The jury have found that the defendant did not keep his engagement with the plaintiff; she was afforded no reasonable opportunity of submitting herself to the judgment of the tribunal that awarded the prizes, but was excluded from the limited competition for which by the terms of the contract she had become eligible and had therefore no chance of winning a prize.

Mr. McCardie does not deny that there is a contract, nor that its terms are as the plaintiff alleges them to be, nor that it is enforceable, but he contends that the plaintiff can only recover nominal damages, say one shilling. To start with, he puts it thus: where the expectation of the plaintiff depends on a contingency, only nominal damages are recoverable. Upon examination, this principle is obviously much too wide; everything that can happen in the future depends on a contingency, and such a principle would deprive a plaintiff of anything beyond nominal damages for a breach of contract where the damages could not be assessed with mathematical accuracy. The learned counsel admitted that it was very difficult to formulate his proposition, but he ultimately said that where the volition of another comes between the competitor and what he hopes to get under the contract, no damages can, as a matter of law, be given. I can find no authority for that proposition; in fact, the decision in Richardson v. Mellish 2 Bing. 229 is obviously in the teeth of it. I do not rely, however, on that or on any other authority; I would rather consider what is the right of a plaintiff as regards damages for breach of a contract, and regarding it as a matter of broad general principle, I do not think that any such distinction as that suggested by Mr. McCardie can be drawn. The Common Law Courts never enforced contracts specifically, as was done in equity; if a contract was broken, the common law held that an adequate solatium was to be found in a pecuniary sum, that is, in the damages assessed by a jury. But there is no other universal principle as to the amount of damages than that it is the aim of the law to ensure that a person whose contract has been broken shall be placed as near as possible in the same position as if it had not. The assessment is sometimes a matter of great difficulty. It is impossible in many cases to regard the damage that has followed the breach as that for which the plaintiff is to be compensated, for the injury to the plaintiff may depend on matters which have nothing to do with the defendant. For example, an innkeeper furnishes a chaise to a son to drive to see his dying father; the chaise breaks down; the son arrives too late to see his father, who has cut him out of his will in his disappointment at his not coming to see him; in such a case it is obvious that the actual damage to the plaintiff has nothing to do with the contract to supply the chaise. Therefore at an early stage the limitation was imposed that damages for breach of a contract must be such as might naturally be supposed to be in the 
contemplation of the parties at the time the contract was entered into; damages, in order to be recoverable, must be such as arise out of the contract and are not extraneous to it. This limitation has been appealed to here. It has been contended in the present case that the damages are too remote; that they are not the natural consequences of a breach with regard to which the parties intended to contract. To my mind the contention that they are too remote is unjustifiable. The very object and scope of the contract were to give the plaintiff the chance of being selected as a prizewinner, and the refusal of that chance is the breach of contract complained of and in respect of which damages are claimed as compensation for the exclusion of the plaintiff from the limited class of competitors. In my judgment nothing more directly flowing from the contract and the intentions of the parties can well be found.

Then the learned counsel takes up a more hopeful position. He says that the damages are difficult to assess, because it is impossible to say that the plaintiff would have obtained any prize. This is the only point of importance left for our consideration. Is expulsion from a limited class of competitors an injury? To my mind there can be only one answer to that question; it is an injury and may be a very substantial one. Therefore the plaintiff starts with an unchallengeable case of injury, and the damages given in respect of it should be equivalent to the loss. But it is said that the damages cannot be arrived at because it is impossible to estimate the quantum of the reasonable probability of the plaintiff's being a prize-winner. I think that, where it is clear that there hes been actual loss resulting from the breach of contract, which it is difficult to estimate in money, it is for the jury to do their best to estimate; it is not necessary that there should be an absolute measure of damages in each case. There are no doubt well-settled rules as to the measure of damages in certain cases, but such accepted rules are only applicable where the breach is one that frequently occurs. In such cases the Court weighs the pros and cons and gives advice, and I may almost say directions, to the jury as regards the measure of damages. This is especially the case in actions relating to the sale of goods of a class for which there is an active and ready market. But in most cases it may be said that there is no recognised measure of damages, and that the jury must give what they think to be an adequate solatium under all the circumstances of the case. Is there any such rule as that, where the result of a contract depends on the volition of an independent party, the law shuts its eyes to the wrong and says that there are no damages? Such a rule, if it existed, would work great wrong. Let us take the case of a man under a contract of service to serve as a second-class clerk for five years at a salary of $£ 200$ a year, which expressly provides that, at the end of that period, out of every five second-class clerks two first-class clerks will be chosen at a salary of $£ 500$ a year. If such a clause is embodied in the contract, it is clear that a person thinking of applying for the position would reckon that he would have the advantage of being one of five persons from whom the two firstclass clerks must be chosen, and that that might be a very substantial portion of the consideration for his appointment. If, after he has taken the post and worked under the contract of service, the employers repudiate the obligation, is he to have no remedy? He has sustained a very real loss, and there can be no possible reason why the law should not leave it to the jury to estimate the value of that of which he has been deprived. Where by contract a man has a right to belong to a limited class of competitors, he is possessed of something of value, and it is the duty of the jury to estimate the pecuniary value of that advantage if it is taken from him. The present case is a typical one. From a body of six thousand, who sent in their photographs, a smaller body of fifty was formed, of which the plaintiff was one, and among that smaller body twelve prizes were allotted for distribution; by reason of the defendant's breach of contract she has lost all the advantage of being in the limited competition, and she is entitled to have her.loss estimated. I cannot lay down any rule as to the measure of damages in such a case; this must be left to the good sense of the jury. They must of course give effect to the consideration that the plaintiff's chance is only one out of four and that they cannot tell whether she would have ultimately proved to be the winner. But having considered all this they may well think that it is of considerable pecuniary value to have got into so small a class, and they must assess the damages accordingly.

This consideration decides the case, but I wish to refer to the decision of Jelf J. in Sapwell v. Bass [1910] 2 K.B. 486. That decision was, in my opinion, right on the facts of the particular case. The plaintiff had acquired by contract a right to send a mare during the following year to a renowned stallion belonging to the defendant, and the defendant broke his contract. The right to send the mare 
was coupled with the payment of a fee of 800 guineas. Jelf $\mathrm{J}$. held that for the breach of contract the plaintiff was only entitled to nominal damages. The ground of the decision was that there was no evidence to shew that the right was worth more to the plaintiff than the 800 guineas which he would have had to pay for the services of the stallion, and that there was therefore no evidence that the damages were more than nominal. If, however, the learned judge meant to hold that there were no damages for breach of an undertaking to serve the mare, there is, in my opinion, no justification for such a view. The contract gave the plaintiff a right of considerable value, one for which many people would give money; therefore to hold that the plaintiff was entitled to no damages for being deprived of such a right because the final result depended on a contingency or chance would have been a misdirection. This appeal must be dismissed.

FARWELL L.J. I agree. The fallacy of Mr. McCardie's argument consists, in my opinion, in his failing to distinguish between the remoteness of the damage claimed and its assessment; the question of remoteness is for the judge; the assessment of damages is for the jury. I agree in thinking that the contention that the damages in the present case are too remote is unarguable; the case could not have been withdrawn from the jury, for damage might result not only from the loss of the opportunity of winning a prize but also from the slur upon the plaintiff in her professional capacity, which might result in a diminution of the value of her services as an actress when she applied for an engagement. In Maw v, Jones 26 Q.B.D. 107, which raised the question of the measure of damages in an action for the wrongful dismissal of an apprentice, Lord Coleridge C.J. said: "The plaintiff was entitled to recover for all the damage flowing naturally from the breach, and in considering what that would include the jury might take into account the difficulty that the plaintiff as a discharged apprentice would have in obtaining employment elsewhere." The jury may well have considered the difficulty which the plaintiff, after being passed over in this fashion by the defendant, would have in obtaining as good an appointment as before. I think, therefore, that the question of remoteness of damage does not arise here.

Then comes the question as to the ascertainment of the amount. In actions for unliquidated damages this is ordinarily for the jury, and to my mind it is not correct to say that the present is an exceptional case. It is contended that the amount of the plaintiff's loss is so entirely a matter of pure chance as to be incapable of assessment. I cannot for this purpose draw any distinction between a chance and a probability. In the Oxford English Dictionary one of the definitions of "chance" is "a possibility or probability of anything happening, as distinct from a certainty," and a citation is given from Reid's Intellectual Powers, "The doctrine of chances is a branch of mathematics little more than an hundred years old." The two words "chance" and "probability" may be treated as being practically interchangeable, though it may be that the one is somewhat less definite than the other. The necessary ingredients of such an action are all present; the defendant has committed a breach of his contract, the damages claimed are a reasonable and probable consequence of that breach, and loss has accrued to the plaintiff at the time of action. It is obvious, of course, that the chance or probability may in a given case be so slender that a jury could not properly give more than nominal damages, say one shilling; if they had done so in the present case, it would have been entirely a question for them, and this Court could not have interfered. But in the present competition we find chance upon chance, two of which the plaintiff had succeeded in passing; from being one of six thousand she had become a member of a class of fifty, and, as I understand it, was first in her particular division by the votes of readers of the paper; out of those fifty there were to be selected twelve prize-winners; it is obvious that her chances were then far greater and more easily assessable than when she was only one of the original six thousand. If the plaintiff had never been selected at all, the case would have been very different; but that was not the case. In my opinion the existence of a contingency, which is dependent on the volition of a third person, is not enough to justify us in saying that the damages are incapable of assessment. The case of Richardson $v$. Mellish 2 Bing. 229 affords a very good illustration on this point. There the question was raised whether in an action for breach of contract the jury could give damages for the loss of two voyages as captain of an East Indiaman, though the second had not been accomplished at the time of action, and in his judgment Best C.J. said (p.239): "It is clear that the plaintiff could only be appointed for one voyage, for the appointment of master is renewed every voyage. But though that is the case, may not parties look to that which is the practice of the East India Company, that though they 
renew the appointment, they renew it in the same person? If that practice be legal, may I not say, if you had appointed me for the first voyage, I should have continued for the second? You have deprived me of the profits I should have made not only on the first voyage, but on the second also. It requires no legal head to decide this: common sense says, you are not to be paid for consequences which might not turn up in your favour; but the plaintiff is entitled to have a compensation for being deprived of that which almost to a certainty happens in these cases." Now, the expression "almost to a certainty" means that the contemplated event is very probable, and the fact that it is very probable only increases the amount of damages which a jury would give. It is obvious that if the East India Company were in the habit of appointing the same man master for the next voyage, the chance of appointment of the plaintiff in that case was a very good one, and the jury assessed the damages accordingly. It is clear upon the authorities that damage resulting from the loss of a chance of winning in a competition is assessable. In Ex parte Waters, In re Hoyle (1873) L. R. 8 Ch. 562, at p. 567, Mellish L.J. said: "It is difficult to imagine any kind of contract (I speak of business contracts) in respect of which, if broken before, or put an end to by, the bankruptcy, a jury could not point out a fair way of estimating the damages under the direction of the judge." I agree with Mr. McCardie that the principles on which the Bankruptcy Court acts are wider and more extensive than those applicable to cases of mere breach of contract, for the effect of bankruptcy proceedings is to make a clean sweep of contractual relations; but it makes no difference whether the proceedings are taken for closing a bankrupt's estate or for payment of compensation to a plaintiff who has been injured by breach of a contract. I see no difficulty in the assessment of damage in the present case. It was a question for the jury, and, that being so, this Court is not entitled to interfere with their finding. The case of Watson v. Ambergate, \&c., Railway 15 Jur. 448 affords us no assistance at all. That decision is discussed by the learned author of Sedgwick on Damages 7th ed., i. 128, who says: "The question of damages was not necessarily involved in this decision. In a similar case in Pennsylvania, the opinion expressed in it was disapproved, the Court holding that the value of the opportunity to compete for the premium furnished the measure of the plaintiff's damages. If the company were informed of the object of the transmission, the loss of the privilege of the competition was in view of both parties when they entered into the contract; and if not, the loss was still the result of the carrier's negligent breach. But it appearing from the evidence of one of the committee by whom the prizes were awarded, that the plaintiff must at any rate have failed to obtain the prize, he was held entitled to nominal damages only: Adams Express Co. v. Egbert. (1860) 36 Pa. 360." To a great extent that expresses my own view; where a railway company has no notice of the special purpose for which goods are to be carried, it is not possible to hold them liable for the special damages resulting from their loss. I need only refer shortly to Sapwell v. Bass $[1910] 2$ K.B. 486. In that case there was no jury, and Jelf J., exercising the functions of a jury, did not see his way towards assessing the damages at a larger sum than one shilling; if there had been a jury, and the learned judge had withdrawn the case from them on the question of the amount of damages, I think he would have been wrong. And in the present case, if the jury had given only a shilling, we could not have interfered. I agree that the appeal must be dismissed.

Appeal dismissed.

Solicitors for plaintiff: Chas. Anderson \& Co.

Solicitors for defendant : J. D. Langton \& Passmore.

W. J. B. 


\title{
ANEXO B - Caisse commerciale de Limoges v. Rives - França (1889)
}

\author{
CASS. - Req. 17 juillet 1889 \\ $1^{\circ}$ et $4^{\circ}$ EXPLOIT, ACTE D'APPEL, PARLANT A, OMISSION, NULLITÉ, JUGEMENT, \\ SIGNIFICATION, SOCIÉTÉ ANONYME, DIRECTEUR, SIÈGE SOCIAL, DOMICILE PRIVE. \\ $-2^{\circ}$ EXCEPTION, NULLITÉ D'EXPLOIT, CONSTITUTION D'AVOUÉ $-3^{\circ}$ HUISSIER, \\ ACTE D'APPEL, NULLITÉ, RESPONSABILITÉ, COUR D'APPEL, MISE EN CAUSE. \\ $1^{\circ}$ Est nul l'exploit, et spécialement l'acte d'appel, dans lequel il y a omission de l'indication de la \\ personne à laquelle l'huissier a remis la copie et qui demeure ainsi inconnue (1) (C. proc., 61, 68, \\ $70,456)$.
}

$2^{\circ}$ La nullité d'un acte d'appel, pour omission du parlant à..., n'est pas couverte par le fait d'une constitution d'avoué sans réserves, un tel acte étant nécessaire pour permettre de proposer la nullité de l'exploit et n'impliquant en conséquence aucune renonciation à la faire valoir $(2)(C$. proc., 173).

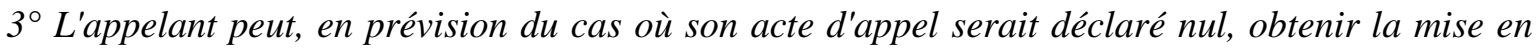
cause devant la Cour d'appel de l'huissier instrumentaire qu'il entend rendre responsable de cette nullité (3) (G. civ., 1382, 1383; C. proc, 71, 1031). - Sol. implic.

Et, la décision à rendre sur la responsabilité encourue par cet huissier découlant nécessairement du résultat que l'appel aurait pu amener, la Cour ne peut faire autrement que d'examiner le mérite de cet appel (4) (Id.).

$4^{\circ}$ La signification de jugement à une société anonyme, faite non au siège social, mais au domicile et à la personne même de son directeur qui a qualité pour la représenter en justice, est valable et suffisante pour faire courir les délais de l'appel (5).(C. proc, 68, 69, 70, 443, 449, 1029).

(Caisse commerciale de Limoges C. C. Sigé).

Le tribunal de Limoges ayant, le 23 déc 1886, rendu au profit de M. Sigé un jugement contre la Caisse commerciale de Limoges, société anonyme représentée par son directeur, M. Loze, M. Sigé a fait signifier ce jugement à M. Loze, qui a interjeté appel par un exploit de M. Rives, huissier. M. Sigé a demandé la nullité de l'acte d'appel, et M. Loze a mis l'huissier en cause. M. Loze a d'ailleurs réitéré son appel. Le 10 févr. 1888, arrêt de la Cour de Limoges, ainsi conçu : — « La Cour; — Sur la nullité de l'acte d'appel du $1^{\text {er }}$ juin 1887 : - Considérant que l'art. 456, C. proc, exige à peine de nullité que l'acte d'appel soit signifié à personne ou domicile, et que l'art. 68 du même Code dispose que tous exploits seront faits à personne ou domicile, en notifiant l'acte aux parents ou serviteurs de la partie, si elle n'est pas elle-même trouvée à son domicile; que ledit art. 68 oblige l'huissier à mentionner toutes ces prescriptions tant sur l'original que sur la copie ; - Considérant que la copie de l'acte d'appel du $1^{\text {er }}$ juin 1887, signifiée par Rives, huissier à Carcassonne, porte ces mots : «Dit et déclare à M. Aubin Sigé, négociant, demeurant à Carcassonne (Aude), à son domicile, où étant et parlant à... », et que ladite copie se termine par ces mots : "Et j'ai donné cette copie audit sieur Sigé, ainsi et parlant comme il est dit »; - Considérant que de cette double mention il résulte que la personne à laquelle l'huissier a parlé et remis copie est inconnue, puisque la copie a été remise à la personne à qui il a été parlé, et que, pour connaître celle-ci, il faut se reporter à la désignation qui devait se trouver au parlant à..., mais qui y manque absolument, d'où il suit qu'il est impossible de savoir quel est, de la partie, de ses parents ou de ses serviteurs, celui à qui l'huissier a parlé; Considérant qu'à la vérité, Rives soutient que c'est l'art. 61, C. proc, relatif à l'ajournement, qui doit s'appliquer avec l'art. 456; mais que, dans ce système, l'acte ne remplirait pas une condition exigée par l'art. 61 à peine de nullité, à savoir la mention de la personne à laquelle copie de l'exploit a été laissée, personne qui, ainsi qu'il vient d'être établi, est absolument inconnue dans la copie donnée à Sigé ; 
«Sur la nullité de l'acte d'appel du 24 déc. 1887 : - Considérant que le jugement dont est appel a été rendu contradictoirement le 23 déc 1886; qu'il a été signifié le 4 mai, 1887, et que l'acte d'appel qu'il s'agit d'examiner a été notifié le 24 déc 1887; que, plus de deux mois s'étant écoulés entre la signification du jugement et l'appel, ce dernier est nul conformément à l'art. 453, C. proc., si la signitication du jugement est régulière;

- Considérant que cette signification est parfaitement régulière; qu'en effet, elle a été faite au directeur de la Caisse commerciale en parlant à sa personne, ainsi qualifié, en son domicile privé, et que, par conséquent, elle est conforme aux règles des exploits en général prescrites par l'art. 68, C. proc., dans lesquels rentre la signification des jugements; que l'appelant invoque à tort l'art. 69, C. proc., lequel n'est relatif qu'aux assignations, pour prétendre que la signification aurait dû être faite au siège social de la Caisse commerciale;

« Sur la garantie demandée contre Rives, huissier : - Considérant que Rives, en entachant de nullité l'acte d'appel du $1^{\text {er }}$ juin 1887, a causé à Loze par sa faute un dommage qu'il est tenu, aux termes de l'art. 1382, C. civ., de réparer dans les conditions qui vont être déterminées : - Sur le chef de conclusions de Loze, directeur de la Caisse commerciale de Limoges, tendant à ce que Rives le relève indemne de toute condamnation prononcée contre lui en principal et accessoires; Considérant que, pour résoudre cetie question, il y a lieu de rechercher si, sur un appel valable, le jugement eût été ou non confirmé, parce qu'en cas d'affirmative, Rives devrait l'indemnité réclamée, et qu'en cas de négative, il ne la devrait pas; - Considérant que les motifs des premiers juges (qui avaient condamné la Caisse commerciale) sont bien fondés, et qu'il est juste de les adopter.... ; - Par ces motifs, etc. ».

Pourvoi en cassation par la Caisse commerciale. $-1^{\text {er }}$ Moyen. Fausse application et violation des art. 443 et 444, C. proc.; violation des règles de la compétence et du décret du 14 juin 1813, art. 78, ainsi que des principes en matière de garantie; violation des art. 1382 et 1383, C. civ., et de l'art. 7 de la loi du 20 avril 1810, en ce que, sans donner de motifs suffisants : $1^{\circ}$ l'arrêt attaqué a cru pouvoir, malgré la déchéance d'ordre public résultant d'un appel qu'il déclare tardif, examiner l'affaire au fond et statuer, en adoptant les motifs des premiers juges, sur un prétendu recours en garantie dont la Cour n'était saisie qu'accessoirement à la demande principale; $2^{\circ}$ en ce que l'arrêt attaqué a fait peser, en définitive, la responsabilité totale du dommage sur la demanderesse en cassation, alors que, la faute ayant été tout au moins commune, la responsabilité devait être partagée.

$2^{\mathrm{e}}$ Moyen. Violation par fausse application des art. 61 et 456, C. proc; violation des art. 173 et 1030 du même Code, et 7 de la loi du 20 avril 1810, en ce que l'arrêt attaqué a déclaré irrecevable l'appel formé par la demanderesse en cassation, sous le prétexte que la copie de l'acte d'appel ne portait pas l'indication de la personne à qui elle avait été remise, alors que: $1^{\circ}$ la remise de l'acte à l'intimé luimême résultait des autres mentions de l'exploit, et que $2^{\circ}$ la nullité, si elle avait existé, eût été couverte par la constitution d'avoué signifiée sans réserves à la requête de l'intimé.

$3^{\mathrm{e}}$ Moyen. Violation des art. 69, 70 et 1029, C. proc., fausse application des art. 443 et $444 \mathrm{du}$ même Code, et violation de l'art. 7 de la loi du 20 avril 1810, en ce que l'arrêt attaqué a déclaré valable une signification de jugement faite au domicile personnel du directeur d'une société, alors que, la société ayant un siège social, cette signification devait être faite à ce siège social, et déclaré ainsi irrecevable, comme tardif, un appel régulièrement formé, cette significaiion nulle n'ayant pu faire courir le délai d'appel.

\section{ARRÊT.}

LA COUR ; - Sur le second moyen d'abord, qui est pris de la violation par fausse application des art. 61 et 456, C. proc, de la violation des art. 173 et 1030 du même Code, et 7 de la loi du 20 avril 1810 : - Attendu qu'il résulte des art. 61, 68, 70, 456, C. proc, que les exploits, et spécialement les exploits d'appel, doivent contenir mention de la personne, à qui la copie de l'exploit serait laissée; - Attendu que l'exploit d'appel du $1^{\text {er }}$ juin 1887 porte seulement que l'huissier a dit et déclaré à Urbain Sigé, à son domicile, où étant et parlant à..., et que la copie a été donnée parlant comme 
il est dit; et qu'il y a ainsi, dans l'exploit, omission de l'indication de la personne à laquelle l'huissier a remis la copie, et qu'en le déclarant nul parce que cette personne restait inconnue, l'arrêt attaqué a fait des articles susvisés une juste application; que vainement il est prétendu que cette nullité aurait été couverte par le fait d'une constitution d'avoué sans réserves, un tel acte étant nécessaire pour permettre de proposer la nullité de l'exploit, et n'impliquant, en conséquence, aucune renonciation à la faire valoir;

Sur le premier moyen, dans ses deux branches, fondées sur la fausse application et violation des art. 443 et 444,C. proc, violation des règles de la compétence et du décret du 14 juin 1813, art. 73, ainsi que des principes en matière de garantie; violation des art. 1382 et 1383, C. civ., et de l'art. 7 de la loi du 20 avril 1810 : - Attendu qu'en prévision des cas où son acte d'appel serait déclaré nul, la Caisse commerciale avait obtenu la mise en cause de l'huissier Rives devant la Cour d'appel; que cette société ne peut être admise à tirer grief de ce que la Cour a statué à sa propre demande, et que, la décision à rendre sur la responsabilité encourue par l'huissier découlant nécessairement du résultat que l'appel aurait pu amener, la Cour ne pouvait faire autrement que de se livrer à l'examen du mérite de cet appel ; qu'il a d'ailleurs été satisfait au voeu de l'art. 7 de la loi du 20 avril 1810, puisque l'arrêt, après avoir reconnu fondés les motifs par lesquels le tribunal civil de Limoges s'était déterminé, a déplus donné de sa décision une justification détaillée; qu'il résultait de ces motifs, entièrement justifiés, que la perte de 9,000 fr., dont Sigé demandait garantie à la Caisse commerciale, avait eu pour cause une faute lourde imputable en entier à cette société; d'où il suit que l'arrêt attaqué n'a viole aucune des régles invoquées, ni les art. 1382 et $1383 \mathrm{C}$. civ, pour avoir déclaré qu'il n'y aurait in aucune raison de réformer lá décision du Tribunal de Limoges;

Sur le troisième moyen, pris de la violation des art. 69, 70, 1029, C. proc, fausse application des art. 443 et 444 du même Code, et violation de l'art. 7 de la loi du 20 avril 1810! - Attendu qu'il a été soutenu par la Caisse commerciale que l'acte du 24déc 1887, par lequel elle avait réitéré son appel, devait avoir effet, parce que, la signification du jugement ayant été faite au domicile particulier de son directeur, au lieu de l'être au siège social, n'avait pu faire courir les délais de l'appel; Attendu, en fait, que la signification dont il s'agit a été délivrée au domicile et à la personne même du directeur de la Caisse commerciale, qui avait qualité pour la représenter en justice ; que la nullité de cet exploit ne pouvait donc être prononcée et que par suite, c'est à bon droit que l'appel interjeté plus de deux mois après cette signification a été déclaré irrecevable comme tardif; Rejette, etc.

Du 17 juill. 1889. —Ch. req.-MM. Bédar-rides, prés.; Denis, rapp.; Chévrier, av. gén. (concl. conf.) ; Perrin, av. 


\section{ANEXO C - Grimaldi v. Marnier - França (1932)}

1o NOTAIRE, RESPONSABILITÉ, MANQUEMENT PROFESSIONNEL, VENTE D'IMMEUBLES, ACTE DE SPECULATION, OBLIGATION DE PROCURER LES FONDS A L'ACQUÉREUR, MANQUEMENT A L'OBLIGATION, MANOEUVRES DOLOSIVES, FAUTE, PRÉJUDICE, DOMMAGES-INTÉRÊTS, APPRÉCIATION SOUVERAINE (Rép. $\mathbf{v}^{\circ}$ Notaire, n. 2657 et s., 2685 et s., 2729 et s., 2749 et s.; Pand. Rép., eod. verb., n. 2360 et s., 3693 et s.) $-2^{\circ}$ DEPENS, PARTIE PERDANTE, DÉPENS EXPOSÉS DANS UNE AUTRE INSTANCE, CONDAMNATION A TITRE DE DOMMAGES-INTERETS (Rép., $\mathbf{v}^{\circ}$ Dépens, $\mathbf{n}$. 1772 et s.; Pand. Rép., $\mathbf{v}^{\circ}$ Frais et dépens, n. 619 et s.).

10. "L'arrêt qui déclare, d'une part, qu'un notaire a manqué à ses devoirs professionnels en se livrant à des actes de spéculation à l'occasion de la vente d'un domaine à laquelle il avait participé comme notaire, et, d'autre part, que les acquéreurs d'une partie du domaine, ayant chargé ledit notaire de leur procurer les fonds nécessaires au paiement, ce dernier n'a pas rempli les obligations qu'il avait assumées et s'est même livré à cette occasion à des agissements qu'il qualifie de dolosifs, décide à bon droit que ce notaire a commis une faute dont il est responsable (4) (C. civ., 1382).

Et, en ce qui concerne le préjudice et le rapport, de causalité entre la faute et le préjudice, les juges qui déclarent que, par ses manquements professionnels et ses agissements dolosifs, le notaire a occasionné un double préjudice à ses clients, qui ont perdu toute chance d'acquérir le domaine qu'ils avaient en vue et qui, d'autre part, ont eu à supporter les frais de nombreux actes inutiles, a $p u$, à bon droit, déduire de ces constatations et déclarations que la responsabilité du notaire était engagée et apprécier ensuite souverainement l'importance des dommages-intérêts qui devaient être alloués (5) (Id.).

$2^{\circ}$ Justifie légalement sa décision l'arrêt qui met l'ensemble des dépens à la charge du perdant, en y comprenant' les dépens exposés dans une autre instance à laquelle celui-ci avait été étranger, en déclarant que les entiers dépens sont mis à la charge du perdant à titre de dommages-intérêts (6) (C. proc, art. 130).

\section{(Grimaldi C. Epoux Marnier-Lapostolle). — ARRÊT}

LA COUR; - Sur le premier moven, pris de la violation des art. 1382 et s., 1146 et s., C. civ., de la loi de vent, an XI et 7 de la loi du 20 avril 1810 : - Attendu que le pourvoi reproche à l'arrêt attaqué d'avoir condamné le notaire Grimaldi à payer à ses clients, les époux Marnier, la somme de 25.000 fr., à titre de dommages-intérêts, sans avoir relevé une faute, un préjudice et un rapport de cause entre la faute et le préjudice; Mais attendu que la Cour d'Aix declare: d'une part, que Grimaldi a manque à ses devoirs professionnels en se livrant à des actes de spéculation à l'occasion de la vente du domaine Apraxine, à laquelle il avait participé comme notaire; de l'autre, que les époux Marnier, acquéreurs d'une partie du domaine, mais gênés pour en payer le prix immédiatement, ayant chargé Grimaldi de leur procurer les fonds, d'obtenir des délais et de conduire toutes procédures susceptibles d'assurer le maintien de la vente, ce dernier n'a pas rempli les obligations qu'il avait assumées et s'est même livre à cette occasion à des agissements qualifiés par l'arrêt de dolosifs, qui ont consisté à bercer les époux Marnier de trompeuses promesses, à inciter le vendeur à porsuivre sans répit la resiliation de la vente et à substituer, en fin de compte à ses mandants, comme acquéreur d'une partie du domaine, la Société d'exploitation immobilière, qui si elle n'est pas son prête-nom, le touche de très près; - Attendu, en ce qui concerne le préjudice et le rapport de causalité entre la faute et le préjudice, que les juges du font déclarent que, par ses manquements professionnels et ses agissements dolosifs, le notaire Grimaldi a occasionné un double préjudice aux époux Marnier, qui ont perdu toute chance d'acquérir le domanie qu'ils avaient en vue, et qui, d'autre part, ont eu à supporter les frais de nombreux actes inutiles; Attendu que de ces constatations et déclarations, l'arrêt attaqué a pu déduite que la responsabilité de Grimaldi était engagée et apprécier ensuite souverainement l'importance des dommages-intérêts 
qui devaient être alloués aux consorts Marnier;

Sur le deuxième moyen, pris de la violation de l'art. 130, C. proc. civ., et 7 de la loi du 20 avril 1810 , pour défaut de motifs, en ce que l'arrêt attaqué a mis l'ensemble des dépens à la charge de Grimaldi, en y comprenant les dépens exposés sur l'instance existant entre les consorts Marnier et la Société d'exploitation immobilière, alors que l'exposant a été étranger à cette procédure; - Mais attendu qu'en déclarant que les entiers dépens étaient mis à la charge de Grimaldi à titre de dommages-intérêts, la Cour d'Aix a légalement justifié sa décision et n'a, par suite, violé aucun des textes visés au moyen; - Rejette le pourvoi formé contre l'arrêt de la Cour d'Aix du 15 avril 1929, etc.

Du 26 mai 1932, — Ch. req. - MM. Paul Boulloche, prés.; Castets, rapp.; Durand, av. gén.; Labbé, av. 


\title{
ANEXO D - Docteur P. v. Pierre M. - França (1965)
} RESPONSABILITE CIVILE. $-1^{\circ}$ Médecins. Action de la victime. Preuve. Objet. Faute
médicale faisant perdre des chances de guérison. Responsabilité médicale partielle ; $2^{\circ}$ Lien
de causalité. Faute médicale restreignant les chances de guérison. Responsabilité partielle (1 ${ }^{\circ}$
Cass. civ. $1^{\mathrm{TM}}, 14$ déc. 1965, Dr P... c. M... et Dr B...).

\author{
$1^{\text {ere }}$ espèce: Cass. civ. $1^{\text {ere }}, 14$ décembre 1965.
}

La Cour; - Sur le moyen unique, pris en ses deux branches: - Attendu que des énonciations de l'arrêt infirmatif attaqué il résulte que, le 5 octobre 1957, Pierre M..., alors âgé de 8 ans, ayant fait une chute, a été soigné par le Docteur P..., qui avait diagnostiqué une fracture de l'extrémité inférieure de l'humérus droit, sans déplacement; que par la suite, l'enfant, éprouvant toujours une grande gêne dans les mouvements du coude, fut examiné par d'autres médecins qui décelèrent non une fracture de l'humérus, mais une luxation du coude; qu'à la suite de deux expertises, les premiers juges ont retenu à la charge du Docteur P... « une faute initiale dans la méthode « de recherche du diagnostic, ayant entraîné l'erreur du praticien et aussi l'erreur dans le traitement à appliquer»; Que le Tribunal de grande instance a cependant débouté M..., agissant en qualité de représentant légal de son fil mineur, de son action en paiement de dommages-intérêts, estimant «que la relation de causalité entre les fautes caractérisées du Docteur P... et le préjudice sérieux dont reste atteint le « jeune M... n'est pas établie d'une façon certaine »; Que sur le seul appel de M..., les juges du second degré ont décidé qu'il existait « des présomptions suffisamment graves, précises et concordantes, pour admettre que l'invalidité dont est aujourd'hui atteint Pierre M... est la conséquence directe de la faute retenue à l'encontre de l'intimé »; Qu'il est fait grief à la Cour d'appel d'avoir ainsi statué, alors que, d'une part, le Docteur P... ne pouvait être condamné que si une preuve certaine d'un lien de causalité entre le dommage et la faute était rapportée, sans que les juges du fond puissent se contenter de présomptions dont le caractère hypothétique avait été relevé par les experts; que, d'autre part, selon le pourvoi, l'arrêt attaqué ne pouvait, sans se contredire, décider que les erreurs commises par le Docteur P... avait eu pour effet de priver l'enfant « des chances de guérison », et condamner le praticien à réparer, en totalité, les conséquences de l'invalidité invoquée ; - Mais attendu qu'après avoir exactement rapporté les avis formulés par les experts commis, et rappelé que les fautes reprochées au Docteur P... se trouvaient définitivement établies, la Cour d'appel a pu déduire "des documents fournis », dont elle a souverainement apprécié la valeur probante «qu'il existe des présomptions suffisamment graves, précises et concordantes pour admettre que l'invalidité dont est aujourd'hui atteint Pierre M... est la conséquence directe de la faute retenue à l'encontre de l'intimé»; Qu'en se prononçant ainsi, elle ne s'est nullement mise en opposition avec les conclusions des experts, en ce qu'ils ont déclaré "émettre des doutes sur les résultats de la réduction », qu'il est reproché au Docteur P... de ne pas avoir pratiquée ;--"Et attendu qu'ayant à apprécier les «chances de guérison» dont a été privé le blessé, les juges du second degré ont, sans se contredire, partiellement fait droit à la demande de M..., et souverainement évalué à $65.000 \mathrm{~F}$ la juste réparation du dommage subi, toutes causes de préjudice étant confondues »; Qu'ainsi, le moyen ne saurait être accueilli dans aucune de ses branches;

Par ces motifs ; - Rejette le pourvoi formé contre l'arrêt rendu le 7 juillet 1964 par la Cour d'appel de Paris.

MM. Blin, prés.; Ausset, rapp. ; Lindon, av. gén. ; $\mathrm{M}^{\mathrm{es}}$ Fortunet, Cail et Rouvière, av. 


\title{
ANEXO E - Cardinali ed. altri v. STEFER e A.CO.TRA.L - Itália (1983)
}

\author{
CORTE DI CASSAZIONE - Sez. lav. - 19 novembre 1983 n. 6906 - Pres. ed est. Santilli \\ - P. M. Pandolfelli (conci, conf.) - Cardinale ed altri (aw. Barone e Zammit) c. STEFER \\ S.p.a. e A.CO.TRA.L. (aw. Giannetto e Nicola Cavasola).
}

(Cassa Trib. Roma 24 novembre 1978).

Lavoro (rapporto di) - Collocamento al lavoro - Rifiuto dell'azienda di completare la procedura di assunzione - Perdita, da parte dei lavoratori, della possibilità di essere assunti Danni - Risarcibilità - Fattispecie. (Cod. civ., art. 1223, 1226, 1337, 2043).

Poiché il concetto di perdita e di guadagno di cui all'art. 1223 ce. si riferisce a qualsiasi utilità economicamente valutabile, è risarcibile il danno derivante dalla perdita di una chance, già esistente nel patrimonio dei dipendenti al momento del comportamento illecito dell'azienda, ed idonea a produrre anche solo probabilmente e non con assoluta certezza un determinato reddito. (Nella specie, l'azienda, non sottoponendo gli autisti, avviati dall'ufficio di collocamento in base a richiesta numerica, alle rimanenti prove di cultura elementare e dì guida, aveva sottratto loro la possibilità di conseguire il risultato utile consistente nell'assunzione; la Corte ha cassato la pronuncia del tribunale che aveva aprioristicamente negato le possibilità di risarcimento).

L'unica questione che questo Supremo Collegio è chiarato a decidere è quella della risarcibilità del danno per il ritardo nell'adempimento degli obblighi cui l'azienda era tenuta, di completare la procedura di assunzione rispettando l'ordine di avviamento al lavoro.

Il tribunale ha sostenuto che non è risarcibile il danno che gli appellati avrebbero subito, per non essere stati sottoposti alle ulteriori prove attitudinali propedeutiche all'assunzione, trattandosi di un danno meramente potenziale, non sicuramente dimostrato e, come tale, non suscettibile né di valutazione, né di liquidazione equitativa.

Sul punto i ricorrenti, con unico mezzo deducono violazione degli art. 1223, 1226, 2043 ce. in relazione all'art. 360 n. 3 e 5 c.p.c. affermando che il giudice di appello: $a$ ) ha ignorato i rilievi da essi svolti a sostegno della tesi della risarcibilità del danno da perdita di chances accolta dalla dottrina italiana alla stregua di un attento esame delle norme di diritto positivo; $b$ ) su tale, unico argomento decisivo, ha quasi completamente omesso la motivazione.

La censura è fondata.

Con la richiesta numerica all'ufficio di collocamento, il datore di lavoro si obbliga ad assumere i lavoratori avviati dal collocatore, i quali superati gli esami e le prove prescritte, acquistano il diritto soggettivo ad essere assunti, come questa Suprema Corte ha statuito, posto che, per l'art. 15 della legge n. 264 del 1949 (« il datore di lavoro può rifiutare di assumere lavoratori avviati dall'ufficio competente, i quali siano stati precedentemente da lui licenziati per giusta causa ») il datore non può rifiutarsi di assumere, quindi, è obbligato ad assumere, i lavoratori avviati che non siano stati da lui licenziati, in precedenza, per giusta causa.

Gli attuali ricorrenti avevano superato l'esame sanitario (cioè il secondo esame; non risulta, né è stato dedotto dalle aziende che una qualunque norma regolamentare impedisse alla commissione medica di consentire la ripetizione della visita psicotecnica e di considerare valido il risultato del secondo esame) e avevano diritto di sostenere le ulteriori prove, quali gli esami di guida, di dettato e di aritmetica. 
La STEFER era obbligata a sottoporli a tali prove e avendo violato tale obbligo, glinteressati possono chiedere, come hanno chiesto, l'accertamento, l'adempimento e, in ogni caso il risarcimento del danno. Gli obblighi della STEFER si sono trasferiti al-l'A.CO.TRA.L. subentrata il 6 novembre 1976 nella gestione dei servizi di trasporto e in tutti i rapporti alla stessa collegati; rimanendo salva la concorrente responsabilità della STEFER per l'inadempimento a lei imputabile.

Hanno sostenuto le aziende che la richiesta numerica e il conseguente avviamento non limitano la libertà del datore di lavoro di perfezionare, o meno, il contratto: la sua autonomia incontra un limite solo per quanto attiene alla scelta del lavoratore da assumere.

Senonché questa tesi (in sostanza, sostengono le attuali controricorrenti che la libertà di assumere non si consuma con l'esercizio della stessa, mediante l'avviamento, ma perdura anche dopo che tale atto ha prodotto il suo effetto) contrasta, sia con l'art. 15 legge n. 264 del 1949 citato, che con le finalità della disciplina legislativa del collocamento, diretta a sottrarre al datore di lavoro la scelta del lavoratore da assumere onde garantire l'occupazione prima ai lavoratori più meritevoli (in base a criteri obiettivi) e liberare la classe operaia dalla soggezione a discriminazioni o sistemi di corruzione e clientelismo.

Tutto ciò posto, va considerato, ai fini della sussistenza e della determinazione del danno risarcibile (conseguente al ritardo della STEFER e dell'A.CO.TRA.L. nell'adempimento degli obblighi suddetti) che il concetto di perdita e di guadagno di cui all'art. 1223 ce. non si riferisce solo ad entità pecuniaria, ma a qualsiasi utilità economicamente valutabile. In concreto, costituisce un'entità patrimoniale anche una situazione cui è collegato un reddito probabile: il valore economico è offerto dall'entità di questo reddito e dal grado di probabilità che il reddito sia effettivamente prodotto; il fatto che la situazione sia idonea - come nella fattispecie - a produrre solo probabilmente e non con assoluta certezza il reddito ad essa rannodato, influisce non sull'esistenza, ma sulla valutazione di un danno risarcibile.

È stata, in proposito richiamata, specialmente in dottrina, la risarcibilità del danno rappresentato dalla perdita di avviamento, del danno per riduzione della capacità lavorativa, del danno degli artisti per legittima lesione nel loro interesse alla notorietà.

Nel caso, ai lavoratori è stata sottratta una situazione (ammissione a sostenere le ulteriori prove il cui superamento avrebbe determinato l'assunzione) di cui avevano diritto di usufruire; il risarcimento si riferisce non alla perdita di un risultato favorevole, bensì alla perdita della possibilità di conseguire un risultato utile, possibilità esistente nei loro patrimoni al momento in cui hanno subito il comportamento illecito dell'azienda e la lesione del diritto. La perdita di chance, così intesa, è fenomeno che può essere assimilato alla cennata perdita dell'avviamento commerciale (la cui risarcibilità è pacifica in giurisprudenza e in dottrina) ed il riconoscimento della risarcibilità, trova razionale e logica giustificazione nella peculiare situazione soggettiva (vedi Cass. 25 giugno 1981 n. 4137; 4 maggio 1982 n. 2765), di potenzialità del pregiudizio.

La Corte Suprema in sezioni unite, nella sentenza 2 novembre 1979 n. 5688 ha ritenuto, in materia di promozioni a scelta presso enti pubblici economici, l'esistenza del diritto del dipendente, quanto meno, all'osservanza delle regole di correttezza, con facoltà conseguente di chiedere il risarcimento del danno in caso di violazione da parte del datore di lavoro, di dette regole.

Tale decisione costituisce la prima espressione di una tendenza giurisprudenziale mirante ad ampliare la sfera della tutelabilità delle posizioni soggettive, ricomprendendosi situazioni caratterizzate proprio dalla menzionata potenzialità del pregiudizio.

Quando, ai fini dell'assunzione sono richiesti, successivamente alla procedura d'avviamento, determinati accertamenti sull'idoneità fisica e professionale del lavoratore, l'espletamento e l'esito di essi, si pone come condizione sospensiva dell'obbligo di contrarre e quest'ultimo obbligo implica quello, a carico del datore di lavoro di non impedire l'avverarsi della condizione, la violazione del quale genera il diritto al risarcimento del danno. È questa la tesi del pretore. Ma può richiamarsi anche l'art. 1337 ce. secondo il quale le parti nello svolgimento delle trattative e nella formazione 
del contratto devono comportarsi secondo buona fede.

Il contratto va interpretato ed eseguito secondo buona fede. L'attività delle parti in causa per giungere al contratto di lavoro si è arrestata nella fase preparatoria, senza dar luogo ad una stipulazione vincolativa, per l'inosservanza del dovere di comportarsi secondo buona fede da parte dell'azienda, che avendo dato, col suo originario contegno, alle controparti fondata ragione di fare affidamento sulla conclusione del contratto, ha interrotto senza giusto motivo il proseguimento della procedura di assunzione, dando luogo a responsabilità per ed. culpa in contrahendo con conseguente obbligo di risarcire il danno derivante ai lavoratori dal fatto di aver perduto l'eccezione reale di concludere con altri, lo stesso contratto mandato a monte. Non è da escludere che il preciso quantum di questo danno resti di difficile dimostrazione e si debba ricorrere all'apprezzamento equitativo del giudice, previsto dall'art. 1226 ce.

La situazione degli attuali ricorrenti - illegittimamente pretermessi nella procedura di avviamento al lavoro che veniva, invece, portata a termine per tutti gli altri « avviati » - nelle sue giuridiche conseguenze, ai fini risarcitoli, è stata oggetto di superficiale esame da parte del tribunale di Roma, che ha quasi totalmente omesso la motivazione nel respingere la richiesta di danno, com'è stato giustamente lamentato nel ricorso, che, in definitiva, dev'essere accolto.

Quanto alla liquidazione del danno, il giudice cui la causa va rimessa per il riesame trarrà elementi dalle risultanze probatorie del giudizio pretorio, e da eventuali altre circostanze che emergeranno dal giudizio di rinvio.

Pertanto, l'impugnata sentenza va cassata, con la rimessione della causa ad altro giudice d'appello che si designa nel tribunale di Viterbo, sezione lavoro. 


\title{
ANEXO F - Juchem v. Noé (1991)
}

\author{
APELAÇÃO CÍVEL No .591064837 \\ QUINTA CÂMARA CÍVEL \\ NOVO HAMBURGO/RS
}

ReSPONSAbilidade CiVil. ADVOgado. PERda DE UMA CHANCE. Age com negligencia o mandatário que sabe do extravio dos autos do processo judicial e nao comunica o fato a sua cliente nem trata de restaura-los, devendo indenizar a mandante pela perda da chance.

O DES. RUY ROSADO DE AGUIAR JÚNIOR - RELATOR - ERICA NOE propôs ação de indenização contra ERNANI ENIO JUCHEM.

A tramitação do feito em primeira instância está relatada as fls. 87-8, as quais me reporto.

Em sentença, o magistrado julgou a ação procedente para condenar o réu no pagamento dos prejuízos causados à autora face a sua negligência, prejuízos a serem apurados em liquidação de sentença. Explicou que o réu, efetivamente, fora advogado da autora, tendo ajuizado para ela ação contra o INPS, visando obter benefício de pensão do falecido cônjuge. Todavia, a ação não teve prosseguimento e, durante doze anos, o réu não tomou qualquer providência. Disse estar comprovada, através dos documentos juntados, a outorga de procuração da requerente em favor do réu e o ajuizamento da demanda contra o INPS.

Apela o vencido, arrazoando não ser o responsável pelo não prosseguimento da ação da recorrida. Seu resultado seria, de qualquer forma, o de improcedência do pedido, porque o marido da apelada, agricultor, faleceu em 1969, quando os dependentes dos trabalhadores rurais não faziam ainda jus a pensão.

Houve contra-razões.

É o relatório.

VOTO

O DES. RUY ROSADO DE AGUIAR JÚNIOR - RELATOR - Eminentes Colegas. Em 14.8.75, no Foro de Novo Hamburgo, foi distribuída uma ação promovida pela ora autora contra o INPS, objetivando o recebimento de pensão precidenciária. Pelo que consta da certidão de f. 11, o feito foi distribuído à $1^{a}$ Vara Cível daquela comarca, mas lá não chegou o processo, como se depreende da certidão de fl. 14, nem em outra qualquer das varas. Era procurador da autora o Dr. Ernani E. Juchen, ora réu, de acordo com o que está certificado à fl. 38.

Diante disso, não foram mais localizados os autos, ocorrendo o seu extravio não se sabe por culpa de quem.

Passado algum tempo, o advogado foi insistentemente procurado pela autora e seus familiares para que desse explicação sobre o andamento do feito, não obtendo dele nenhuma informação concreta. Segundo se vê do seu depoimento pessoal, até um padre interviu no sentido de recolher maiores esclarecimentos (fl. 56). As declarações testemunhais coincidem com essa narrativa (fl. 57), sendo que, em 1982, a requerente dirigiu-se diretamente ao Dr. Juiz de Direito, solicitando informes.

De tudo isso se vê que houve o fato do ajuizamento da ação e sua distribuição à $1^{\mathrm{a}}$ Vara, com o extravio do processo, do que ficou bem ciente o advogado, que não transmitiu essas informações 
esclarecedoras à parte e não providenciou a devida restauração dos autos.

2. O advogado, na condição de mandatário do cliente para a prática dos atos em juízo, assume uma obrigação de meio, para cujo cumprimento deve dedicar toda a atenção, diligência e cuidado a fim de bem desempenhar o mandato recebido, sem responsabilizar-se, porém, pela obtenção de resultado favorável ao mandante.

Para o cumprimento da sua prestação, deve empregar, a favor do cliente, os recursos permitidos pelo sistema jurídico e que estejam ao seu alcance, de acordo com as condições pessoais e as circunstâncias da causa. Entre esses deveres, decorrentes do contrato de mandato, encontram-se o de informar o cliente sobre a sua posição jurídica, possibilidade de êxito, andamento e tramitação do feito, propostas de acordo, resultados decisórios substanciais, oportunidade para recursos e suas expectativas, despesas processuais etc.

Nesse contexto, o advogado que propõe uma ação e constata o extravio dos autos entre a distribuição e o cartório para o qual foi destinado, deve, em primeiro lugar, informar a parte do incidente havido e, em seguida, diligenciar para a restauração dos autos, na forma da lei processual civil. Deixando de adotar essas diligências, o advogado cerceou até hoje o direito de a mandante ver apreciado em juízo o seu pedido de pensionamento pelo Instituto Nacional de Previdência Social, direito derivado da morte do marido.

Deixando de adotar essas diligências, o advogado cerceou até hoje o direito de a mandante ver apreciado em juízo o seu pedido de pensionamento pelo Instituto Nacional de Previdência Social, direito derivado da morte do marido. Não lhe imputo o fato do extravio, nem asseguro que a autora venceria a demanda, mas tenho por irrecusável que a omissão da informação do extravio e a não restauração dos autos causaram à autora a perda de uma chance e nisso reside o seu prejuízo. Como ensinou o Prof. François Chabas: 'Portanto, o prejuízo não é a perda da aposta (do resultado esperado), mas da chance de tentar alcançá-la ('La perte d'une chance en droit français', conferência na Faculdade de Direito da UFRGS, em 23.5.90). Por isso, não impressiona o argumento longamente expendido nas razões de recurso sobre a impossibilidade jurídica de a autora ver reconhecido seu direito à pensão previdenciária pela morte do marido, uma vez que esse não era segurado do Instituto. $\mathrm{O}$ argumento tem dois defeitos: em primeiro, mostra que o réu está agindo contra os próprios atos, isto é, tendo proposto ação fundada na alegação de um certo direito, não pode justificar sua omissão de informar e de diligenciar, lembrando a inexistência desse mesmo direito. A ninguém é dado 'venire contra factum proprium'; em segundo, porque a álea integra a responsabilidade pela perda de uma chance. Se fosse certo o resultado, não haveria a aposta e não caberia invocar este princípio específico da perda da chance, dentro do instituto da responsabilidade civil.

Isto posto, estou em negar provimento ao apelo para manter a sentença de improcedência, esclarecendo que a fixação da indenização, através de arbitramento, em liquidação de sentença, deverá atentar para o fato de que o dano corresponde apenas à perda da chance.

É o voto.

O DES. SERGIO PILLA DA SILVA - Da revisão que fiz, Sr. Presidente, resultei com idêntica convicção. Daí por que nada teria a acrescentar, a não ser que a sentença bem examinou os fatos frente às provas, aplicando com adequação o direito. Também nego provimento.

O DES. ALFREDO GHILHERME ENGLERT - Acompanho.

O SR. PRESIDENTE - DES. RUY ROSADO DE AGUIAR JÚNIOR - Apelação Cível nº 591 064 837, de Novo Hamburgo. A decisão é a seguinte: "Negaram provimento. Unânime." 